\title{
Doorbreking van de natrekking in rechtsvergelijkend perspectief
}

Citation for published version (APA):

Hoofs, K. J. H. (2013). Doorbreking van de natrekking in rechtsvergelijkend perspectief. [Doctoral Thesis, Maastricht University]. Wolf Legal Publishers. https://doi.org/10.26481/dis.20130315kh

Document status and date:

Published: 01/01/2013

DOI:

$10.26481 / \mathrm{dis} .20130315 \mathrm{kh}$

Document Version:

Publisher's PDF, also known as Version of record

\section{Please check the document version of this publication:}

- A submitted manuscript is the version of the article upon submission and before peer-review. There can be important differences between the submitted version and the official published version of record.

People interested in the research are advised to contact the author for the final version of the publication, or visit the DOI to the publisher's website.

- The final author version and the galley proof are versions of the publication after peer review.

- The final published version features the final layout of the paper including the volume, issue and page numbers.

Link to publication

\footnotetext{
General rights rights.

- You may freely distribute the URL identifying the publication in the public portal. please follow below link for the End User Agreement:

www.umlib.nl/taverne-license

Take down policy

If you believe that this document breaches copyright please contact us at:

repository@maastrichtuniversity.nl

providing details and we will investigate your claim.
}

Copyright and moral rights for the publications made accessible in the public portal are retained by the authors and/or other copyright owners and it is a condition of accessing publications that users recognise and abide by the legal requirements associated with these

- Users may download and print one copy of any publication from the public portal for the purpose of private study or research.

- You may not further distribute the material or use it for any profit-making activity or commercial gain

If the publication is distributed under the terms of Article $25 \mathrm{fa}$ of the Dutch Copyright Act, indicated by the "Taverne" license above, 


\section{Doorbreking van de natrekking}

in rechtsvergelijkend perspectief

Kim Hoofs 


\section{Doorbreking van de natrekking in rechtsvergelijkend perspectief}

Kim Hoofs

ISBN: 978-90-5850-948-2

Dit boek is een uitgave van:

Wolf Legal Publishers (WLP)

Postbus 31051

6503 CB Nijmegen

Tel: 0243551904

Fax: 0243554827

E-Mail: info@wolfpublishers.nl

www.wolfpublishers.nl

Alle rechten voorbehouden. Behoudens de door de Auteurswet 1912 gestelde uitzonderingen, mag niets uit deze uitgave worden verveelvoudigd (waaronder begrepen het opslaan in een geautomatiseerd gegevensbestand) of openbaar gemaakt, op welke wijze dan ook, zonder voorafgaande schriftelijke toestemming van de uitgever. De bij toepassing van artikel 16B en 17 Auteurswet 1912 wettelijk verschuldigde vergoedingen wegens fotokopiëren, dienen te worden voldaan aan de Stichting Reprorecht, Postbus 882, 1180 AW te Amstelveen. Voor het overnemen van een gedeelte van deze uitgave in bloemlezingen, readers en andere compilatiewerken op grond van artikel 16 Auteurswet 1912 dient men zich tevoren tot de uitgever te wenden. Hoewel aan de totstandkoming van deze uitgave de uiterste zorg is besteed, aanvaarden de auteur(s), redacteur(en) en uitgever geen aansprakelijkheid voor eventuele fouten of onvolkomenheden.

(C) WLP 2012/13 


\title{
Doorbreking van de natrekking in rechtsvergelijkend perspectief
}

\author{
PROEFSCHRIFT
}

ter verkrijging van de graad van doctor aan de Universiteit Maastricht, op gezag van de Rector Magnificus, Prof. dr. L.L.G. Soete, volgens het besluit van het College van Decanen, in het openbaar te verdedigen op vrijdag 15 maart 2013 om 14.00 uur

door

Kim Josef Henriette Hoofs 
Promotor:

Prof. dr. G.R. de Groot

Copromotor:

Dr. L.P.W. van Vliet

Beoordelingscommissie:

Prof. dr. G.E. van Maanen (voorzitter)

Prof. dr. T. Hartlief

Prof. dr. R.F.H. Mertens (Open Universiteit)

Prof. dr. H.D. Ploeger (Vrije Universiteit Amsterdam)

Prof. dr. V. Sagaert (Katholieke Universiteit Leuven) 


\section{Dankwoord}

Voor u ligt het proefschrift waar ik de afgelopen jaren met veel plezier aan heb gewerkt. Graag wil ik stilstaan bij diegenen die mij hebben gesteund, aangemoedigd en met raad en daad hebben bijgestaan.

Mijn dank gaat allereerst uit naar mijn promotor professor de Groot en copromotor dr. Lars van Vliet. Professor de Groot, mijn hartelijke dank voor de begeleiding, het vertrouwen en de fijne gesprekken. Ik heb deze altijd zeer gewaardeerd. Lars, als dagelijks begeleider hebben we vele intensieve, interessante en -voor mij- leerzame gesprekken gevoerd. Deze gesprekken zijn niet alleen van groot belang geweest voor de totstandkoming van het proefschrift, maar vormen eveneens een mooie basis voor mijn verdere carrière. Dank voor het delen van deze kennis, dank voor je vertrouwen.

Mijn dank gaat ook uit naar de leden van de leescommissie: professor Hartlief, professor van Maanen, professor Mertens, professor Ploeger en professor Sagaert. De voorzitter van de leescommissie, professor van Maanen, wil ik hierbij eveneens hartelijk danken voor de mogelijkheden die hij mij heeft geboden bij het participeren in het verzorgen van onderwijs en de daaraan gerelateerde onderwijstaken. Het werken met de studenten heb $i k$ als bijzonder plezierig en leerzaam ervaren.

Ook het opleidingstraject binnen de Ius Commune Research School heb ik als zeer leerzaam ervaren. De hartelijke en behulpzame contacten die ik via de Research School heb leren kennen, mogen in dit dankwoord niet ontbreken: Koen Swinnen, Mathieu Muylle, Sofie Bouly, Andrew Steven en Jill Robbie, hartelijk dank - thank you! Ook wil ik graag Nicole van Lierop, Pauline Kruiniger en Lotte Meurkens danken voor de motiverende, gezellige en relativerende gesprekken en mails.

Mijn familie en gezin hebben eveneens een belangrijke rol gespeeld bij de totstandkoming van het proefschrift. Mijke, dankjewel voor het ontwerpen van de boekomslag: jij kan in één afbeelding uitdrukken waar ik een heel boek voor nodig heb. Pap en mam, naast de aanmoedigende woorden hebben jullie met grote regelmaat de zorg voor Sophie en Eva op jullie genomen zodat ik zorgeloos kon werken. Een dochter kan zich geen lievere ouders wensen. Leo, dankjewel voor je eindeloze geduld en vertrouwen, en het herhaaldelijk mededelen dat 'het allemaal wel goed komt'. 
De laatste woorden zijn voor mijn lieve dochters Sophie en Eva. Zonder jullie was mijn wereld bij lange na niet zo mooi (en roze). Aan jullie draag ik mijn proefschrift op.

Het proefschrift is afgerond op 27 augustus 2012. Daarna zijn slechts incidentele wijzigingen opgenomen.

Maastricht, 27 augustus 2012 


\section{Inhoudsopgave}

Dankwoord 5

$\begin{array}{ll}\text { Inhoudsopgave } & 7\end{array}$

$\begin{array}{ll}\text { Afkortingen } & 13\end{array}$

$\begin{array}{lr}\text { Hoofdstuk 1. Inleiding } & 17\end{array}$

$\begin{array}{ll}\S 1 \text { Inleidende woorden } & 17\end{array}$

\$2. Natrekking en de wijzen waarop de natrekking kan worden $\begin{array}{ll}\text { doorbroken } & 18\end{array}$

\$3. Waarom dit proefschrift? 21

\$4. Rechtsvergelijkend onderzoek 24

§5. Plan van aanpak 26

Hoofdstuk 2. Doorbreking van de eigendomsnatrekking naar Duits recht

\$1. Inleiding 29

\$2. Bestandteile en Zubehör 31

\$2.1 Sachen $\quad 31$

\$2.2 Wesentliche bestanddelen en hun rechtsgevolgen 34

§2.2.1 Rechtsgevolgen: $§ 946$ en $§ 947$ BGB 36

$\S 2.2 .2$ Een recht als bestanddeel van een grondstuk 39

\$2.2.3 Wohnungs- en Teileigentum $\quad 40$

$\$ 2.3$ Unwesentliche bestanddelen $\quad 41$

$\$ 2.4$ Schein-bestanddelen $\quad 43$

\$2.5 Zubehör 46

\$3. Das Erbbaurecht 48

\$3.1 Kenmerken van het Erbbaurecht 48

\$3.2 Het Erbbaurechtsvertrag $\quad 52$

§3.2.1 De vertragsmäßige Inhalt 54

§3.2.2 Gegenleistung für das Erbbaurecht - der Erbbauzins $\quad 56$

§3.3 Das Bauwerk $\quad 57$

$\S 3.3 .1$ Vereisten waaraan een object dient te voldoen wil van $\begin{array}{ll}\text { een Bauwerk sprake zijn } & 57\end{array}$

\$3.3.2 Het op het Bauwerk rustende eigendomsrecht 58

\$3.4 Vestiging van een Erbbaurecht en de verschillende

Erbbau-constructies

60 
§3.4.1 Vestiging van een Erbbaurecht op het grondstuk de Belastungsgegenstand

\$3.4.2 Verschillende Erbbau-constructies

\$3.4.2.1 Erbbau-constructies ten aanzien van een grensoverschrijdend bouwwerk

§3.5 Bezwaring, overdracht en het tenietgaan van het Erbbaurecht $\quad 66$

\$3.5.1 Overdracht en bezwaring van het Erbbaurecht 66

\$3.5.1.1 Bezwaring van het Erbbaurecht met een Erbbaurecht 68

\$3.5.2 Het tenietgaan van het Erbbaurecht

\section{Hoofdstuk 3. Horizontale doorbreking van de verticale} natrekking naar Nederlands recht

$\S 1$. Inleiding

\$2. Classificatie van de goederenrechtelijke rechtsobjecten 76

\$2.1 Zaken en vermogensrechten $\quad 76$

§2.2 Het bestanddeel van artikel 3:4 BW $\quad 80$

$\$ 2.2 .1$ “...volgens verkeersopvatting ...” 80

$\$ 2.2 .2$ “... beschadiging van betekenis ..." 82

\$2.3 De onroerende zaak van artikel 3:3 BW 83

$\S 3$. Het superficies solo cedit-beginsel van artikel 5:20 lid 1 BW en de samenhang met de artikelen 3:3 en 3:4 BW 89

$\S 4$. Het recht van opstal 94

\$4.1 De karakteristieken van het recht van opstal 94

$\S 4.2$ Gebouwen, werken en beplantingen ten gunste waarvan een opstalrecht kan worden gevestigd $\quad 97$

$\$ 4.3$ Het aan het recht van opstal verbonden zijnde accessoire eigendomsrecht

§4.3.1 Kunnen de aan de opstaller toekomende bevoegdheden ten aanzien van de opstal als eigendom worden aangemerkt?

$\$ 4.4$ De retributie

§4.5 De wijzen waarop het opstalrecht kan worden beëindigd en het recht op vergoeding en wegneming van de opstallen

$\$ 4.6 .1$ Het opstalrecht in relatie tot het met het opstalrecht bezwaarde recht

$\$ 4.6 .2$ Het opstalrecht als meeromvattend recht in relatie tot zakelijke rechten

$\S 4.6 .3$ Het opstalrecht in relatie tot het recht van hypotheek 
Hoofdstuk 4. Natrekking en doorbreking van de natrekking naar Belgisch recht

§1. Inleiding

§2. De onroerend goed classificaties $\quad 130$

§2.1 Zaken en goederen $\quad 130$

\$2.2 Onroerende goederen 132

$\S 2.2 .1$ Onroerend uit zijn aard 132

\$2.2.2 Onroerend door bestemming 137

$\S 3$. De relatie tussen het recht van natrekking en objecten die uit hun aard onroerend zijn 140

$\S 4$. Het recht van opstal 143

\$4.1 Afstand van het recht van natrekking en het ontstaan van het recht van opstal 143

\$4.2 De karakteristieken van het recht van opstal $\quad 147$

$\S 4.2 .1$ Objecten ten gunste waarvan een opstalrecht kan worden gevestigd 149

\$4.2.2 Het aan de opstaller toekomende eigendomsrecht $\quad 151$

$\S 4.2 .3$ Goederen waarop een recht van opstal kan worden gevestigd 155

\$4.2.4 Duur van het opstalrecht $\quad 156$

\$4.3 Rechten en plichten van opstaller en grondeigenaar $\quad 157$

\$4.4 Vervreemding, bezwaring en verhuring van het opstalrecht

en de in eigendom verkregen opstallen 159

$\$ 4.4 .1$ Vervreemding, bezwaring en verhuring van het opstalrecht 160

§4.4.2 Verveemding, bezwaring en verhuring van de opstallen 162

$\S 4.5$ Het accessoire opstalrecht 164

\$4.5.1 De karakteristieken van het accessoire opstalrecht 164

\$4.5.2 Rechten waaraan een opstalrecht accessoir kan zijn $\quad 165$

\$4.5.2.1 Erfpacht 165

\$4.5.2.2 Vruchtgebruik 168

\$4.5.2.3 Erfdienstbaarheid $\quad 170$

\$4.5.2.4 Huur 173

$\S 4.6$ Wijzen waarop een recht van opstal teniet kan gaan en de aan het tenietgaan verbonden gevolgen 176 
Hoofdstuk 5. Kan natrekking met de grond naar Schots recht worden doorbroken?

§1. Inleiding

\$2. Things and rights 183

§2.1 Things 183

\$2.2 Ownership in relatie tot corporeal heritable property 186

\$2.2.1 De invloed van het feodale stelsel op het eigendomsrecht 186

\$2.2.2 Inhoud en reikwijdte van het eigendomsrecht met betrekking tot een grondstuk $\quad 189$

§3. Accession van een moveable met een heritable 191

\$3.1 Accession in het algemeen

$\S 3.2$ Accession van een moveable met een grondstuk vanuit

historisch perspectief

\$3.3 Accession van een moveable met een grondstuk naar huidig recht

§3.4 De rechtsgevolgen van accession $\quad 197$

§4. Right of severance 199

\$4.1 Het ontstaan respectievelijk bestaan van een right of severance 199

\$4.1.1 Landlord and tenant 201

\$4.1.2 Proper liferenter and fiar $\quad 204$

$\$ 4.1 .3$ Heritable creditors and other creditors 206

\$4.1.4 Seller and purchaser 207

\$4.2 Aard van the right of severance 208

\$4.3 Servitudes $\quad 210$

§5. Legal and conventional separate tenements 213

\$5.1 Legal separate tenements 213

\$5.2 Conventional separate tenements 214

§5.2.1 Tenements 215

Hoofdstuk 6. Samenvatting en conclusies 219

§1. Inleidende woorden 219

§2. Nadere invulling van het duurzame verenigingscriterium 222

\$2.1 Het Duitse rechtsstelsel: wesentliche Bestandteile 224

\$2.2 Het Nederlandse rechtsstelsel: een tweetal gronden voor het karakteriseren van een object als bestanddeel 225

\$2.3 Het Belgische rechtsstelsel: onroerend uit zijn aard 227

\$2.4 Het Schotse rechtsstelsel: de fixture 228

$\$ 2.5$ Het duurzame verenigingscriterium in rechtsvergelijkend perspectief

§3. Uitzonderingen op het duurzame verenigingscriterium 233

\$3.1 Het Scheinbestandteil 
\$3.2 Vervroegde roerendmaking $\quad 234$ \$3.3 Industrial fruits 234

§4. Uitzonderingen op de eigendomsnatrekking 235

\$4.1 Het recht van opstal 236

\$4.1.1 Komt aan de opstaller de eigendom van de opstallen toe? 237

\$4.1.2 De vestiging van een opstalrecht als een verkapte wijze van overdracht 242

$\S 5$. Het wegneemrecht 244

§5.1 De op grond van het wegneemrecht bevoegde wegnemer $\quad 244$

\$5.2 Onzekerheden ten aanzien van het wegneemrecht 246

$\S 6$. Enkele concluderende woorden tot besluit 249

Chapter 7. Summary and conclusions 253

§ 1. Introduction 253

§2. Further interpretation of the permanent attachment criterion $\quad 255$

\$2.1 The German legal system: wesentliche Bestandteile 257

\$2.2 The Dutch legal system: two grounds for characterising an object as a component 258

\$2.3 The Belgian legal system: immoveable by nature $\quad 260$

\$2.4 The Scottish legal system: fixtures 260

$\$ 2.5$ The permanent attachment criterion in comparative perspective 261

§3. Exceptions to the permanent attachment criterion 264

\$3.1 The Scheinbestandteil 264

\$3.2 Moveable by anticipation 265

\$3.3 Industrial fruits 266

§4. Exceptions to accession 266

\$4.1 The right of superficies 267

$\S 4.1 .1$ Does the superficiary have the right of ownership over the superficies? 268

\$4.1.2 The creation of a right of superficies as a disguised method of transfer $\quad 272$

§5. The right of removal 274

\$5.1 The competent remover under the right of removal 274

\$5.2 Uncertainties regarding the right of removal 276

§6. Some concluding words 278

Lijst van aangehaalde literatuur 281

Rechtspraakregister 303

$\begin{array}{ll}\text { Curriculum vitae } & 309\end{array}$ 



\section{Afkortingen}

aant.

Abs.

AC

AFT(S)A 2000

Arr. Cass.

art.

BBergG

BFH

BGB

BGH

BNB

Bull. Bel.

BBW

BW

Cass.

C.C.

$\mathrm{Ch}$

D

East

e.a.w.

e.d.

EU

e.v.

ErbauVO

ErbbauRG

Erfpachtwet

$\mathrm{F}$

F.J.F.

GBO

GWD

HR

Hyp.W.

Inv.

jo.

Kadw.

KB

KG

LG

LJN

LR(S)A 1979 aantekening

Absatz

Law Reports, Appeal Cases (1875 e.v.)

Abolition of Feudal Tenure etc (Scotland) Act 2000

Arresten van het Hof van Cassatie

artikel

Bundesberggesetz

Bundesfinanzhof

Bürgerliches Gesetzbuch

Bundesgerichtshof

Beslissingen in belastingzaken

Bulletin der belastingen

Belgisch Burgerlijk Wetboek

(Nederlands) Burgerlijk Wetboek

Hof van Cassatie

Code Civil

Law Reports, Chancery Division (1890 e.v.)

Dunlop's Session Cases (1838-1862)

East's King's Bench Reports (1800-1812)

en andere wetten

en dergelijke

Europese Unie

en volgende

Verordnung über das Erbbaurecht

Gesetz über das Erbbaurecht

Wet over het recht van Erfpacht van 10 januari 1824

Fraser's Session Cases (1898-1906)

Fiscale jurisprudentie

Grundbuchordnung

Greens Weekly Digest

Hoge Raad

Hypotheekwet

Invoeringswet

juncto

Kadasterwet

Law Reports, King's Bench Cases

Kort Geding

Landesgericht

Landelijk JurisprudentieNummer

Land Registration (Scotland) Act 1979 
LT

M

Macq

M.O.

M.v.A.

NJ

NJF

NJW

$\mathrm{NjW}$

NJW-RR

nr.

N.v.W.

OBW

Opstalwet

p.

par.

Parl. Gesch.

Pas.

P\&CR

r.

$\mathrm{R}$

RABG

Rec. gén. enr. not.

Res. Jur. Imm.

Rev. Fisc.

$\mathrm{Rn}$

RG

RGZ

RN

$\mathrm{rb}$

r.o.

$\mathrm{Rv}$

R.W.

RVR

$\mathrm{s}$.

SachenRBerG

SC

SES

SLC

SLT

S(S)A 1964

Stb.

T.App.
Law Times Reports (1859-1947)

MacPherson's Session Cases (1862-1873)

MacQueen's House of Lords Appeals (1851-1865)

Mondeling Overleg

Memorie van Antwoord

Nederlandse Jurisprudentie

Nederlandse Jurisprudentie Feitenrechtspraak

Neue Juristische Wochenschrift

Nieuw Juridisch Weekblad

Neu Juristische Wochenschrift-Rechtsprechungs-

Report

nummer

Nota van Wijziging

(Nederlands) Burgerlijk Wetboek van 1838

Wet over het recht van Opstal van 10 januari 1824

pagina

paragraaf

Parlementaire geschiedenis

Pasicrisie Belge

Property, Planning \& Compensation Reports

rule

Rettie's Session Cases (1873-1898)

Recueil annuel de jurisprudence Belge

Recueil général d'enregistrement et du notariat

Res et jura immobilia

Revue Fiscale

Randnote

Reichsgericht

Reichsgerichts in Zivilsachen

Rechtspraak Notariaat

rechtbank

rechtsoverweging

Wetboek van Burgerlijke Rechtsvordering

Rechtskundig Weekblad

Rechtspraak Vastgoedrecht

section

Gesetz zur Sachenrechtsbereinigung im Beitrittsgebiet

Session Cases

Schip en Schade

Scottish Law Commission

Scots Law Times

Succession (Scotland) Act 1964

Staatsblad

Tijdschrift voor appartements- en immorecht 
T.B.B.R.

TC(S)A 2003

T.F.R.

T.M.

TMS

T.Not.

T(S)A 2004

Trs

TRV

T.Vred.

VR

W.

WEG

W.H.W.

Wlb
Tijdschrift voor Belgisch burgerlijk recht Title Conditions (Scotland) Act 2003 Tijdschrift voor fiscaal recht Toelichting Meijers

Tenement Management Scheme Tijdschrift voor Notarissen Tenements (Scotland) Act 2004 Trustees

Tijdschrift voor rechtspersoon en vennootschap Tijdschrift van de vrede- en politierechters Verkeersrecht

Weekblad van het Regt

Wohnungseigentumsgesetz

Woninghuurwet

Wet op de lijkbezorging 



\section{Hoofdstuk 1. Inleiding}

\section{$\S 1$. Inleidende woorden}

Bij het lezen van de advertentie "te koop: schitterend woonhuis, gelegen te ..." zal men er in beginsel van uit mogen gaan dat de verkoop en de overdracht niet tot het woonhuis beperkt zijn. Doorgaans zal ook het grondstuk ${ }^{1}$ waarop het woonhuis is gelegen bij de verkoop als bij de overdracht zijn inbegrepen. Maatschappelijk gezien bestaat de behoefte om het woonhuis en het grondstuk waarop het woonhuis is verwezenlijkt tezamen als een eenheid te beschouwen. Ook voor het recht vormen beide objecten tezamen een eenheid en daarmee één object van recht. Aan deze juridische eenheidsvorming is een consequentie verbonden: op één rechtsobject rust één eigendomsrecht. Het eigendomsrecht dat op het grondstuk rust, strekt zich uit over het met het grondstuk verbonden woonhuis.

Ook ten aanzien van andere objecten die zich op het grondstuk bevinden kan de verwachting bestaan dat zij met het grondstuk een eenheid vormen, zoals een esdoorn die middels wortels met de grond is verenigd en de in de grond ingebouwde vijver. Van al deze objecten mag de koper er in beginsel van uitgaan dat zij in de koop en de daarop volgende overdracht zijn betrokken. Anders is het voor een op het grondstuk geparkeerde personenauto, het tuinmeubilair en de over het grondstuk kuierende labrador. Ten aanzien van laatstgenoemde objecten bestaat niet de verwachting dat zij bij de koop dan wel bij de overdracht zijn inbegrepen.

Maar zo evident als het bij een woonhuis en een auto ook is, er zijn legio voorbeelden denkbaar waarbij het niet zo eenvoudig is om te bepalen of zij al dan niet bij de koop respectievelijk de overdracht zijn inbegrepen. Een lift die met het bouwwerk is verenigd, een zich op het grondstuk bevindende havenkraan en een woonark die via een steiger en een loopplank met de kade is verbonden, zijn allemaal objecten waarvan niet zonder meer duidelijk is of zij met het grondstuk een eenheid vormen. Of van eenheidsvorming sprake is, dient in het concrete geval te worden bepaald.

Wat tot de omvang, de eenheid, van het grondstuk kan worden gerekend is niet alleen van belang voor de koper van het grondstuk. Ook voor de hypotheekhouder, zijnde de persoon ten behoeve van wie een recht van hypotheek op een onroerende zaak wordt gevestigd tot zekerheid van een

Hoewel de term 'grondstuk' in eerste instantie doet vermoeden dat hier sprake is van een Germanisme, is de term voldoende in de Nederlandse literatuur ingebed om in dit proefschrift te bezigen. Zie: Parl. Gesch. Wijziging Rv e.a.w. (Inv. 3, 5 en 6) (1992), p. 193; Van der Steur 2003, p. 31 e.v. 
geldlening, is het van belang te weten wat tot de eenheid van het grondstuk kan worden gerekend. De waarde van de eenheid van het grondstuk is voor het bepalen van de hoogte van de geldlening van belang, opdat bij het niet voldoen aan de betalingsverplichting die gekoppeld is aan de geldlening, de hypotheekhouder tot uitwinning van het grondstuk kan overgaan en verzekerd is van een opbrengst die tenminste overeenkomt met de hoogte van de verstrekte geldlening. Een object dat niet tot de eenheid van het grondstuk behoort, kan in beginsel niet met het recht van hypotheek worden bezwaard. De (over)waarde van de eenheid van het grondstuk zal overigens ook van invloed zijn op de hoogte van de over de geldlening te betalen rente.

Hoewel de eenheidsvorming van een object met een grondstuk voortkomt uit de maatschappelijke behoefte beide objecten te zien als één, leiden de objectieve maatstaven waaraan getoetst dient te worden of van eenheidsvorming sprake is niet altijd tot de maatschappelijk meest wenselijke uitkomst. De eigenaar van een schaftruimte die besluit het object te verhuren, verliest het op zijn schaftruimte rustende eigendomsrecht wanneer de schaftruimte objectief gezien een eenheid vormt met het grondstuk van een derde. En ook de eigenaar van een grafteken, de eigenaar van een zendmast en de eigenaar van een hekwerk verliezen in beginsel allen de eigendom van het object wanneer voldaan wordt aan de objectieve maatstaven van eenheidsvorming.

Om te voorkomen dat partijen in het maatschappelijk verkeer worden geremd tot het verrichten van handelingen, zoals het verhuren van schaftruimtes en het aanbrengen van graftekens, omdat de kans bestaat dat zij de eigendom van hun objecten kunnen verliezen, is het van belang dat een rechtsstelsel de mogelijkheid biedt om onder bepaalde voorwaarden of in bepaalde gevallen de eenheidsvorming te doorbreken. In dit proefschrift ligt de focus op de door de Duitse, Nederlandse, Belgische en Schotse rechtsstelsels geboden mogelijkheden deze eenheidsvorming te doorbreken.

\section{§2. Natrekking en de wijzen waarop de natrekking kan worden doorbroken}

Ieder rechtsstelsel kent zijn eigen maatstaven waaraan wordt getoetst of objecten die met elkaar zijn verenigd al dan niet een juridische eenheid vormen. Aan een juridische eenheid komt één goederenrechtelijke identiteit toe. Een object dat met het grondstuk op een zodanige wijze is verenigd dat sprake is van een juridische eenheid, wordt ingevolge het Romeinsrechtelijke superficies solo cedit-beginsel door het grondstuk in eigendom nagetrokken. Het op het grondstuk rustende eigendomsrecht strekt zich uit over het object dat als 'bestanddeel' van het grondstuk kan worden aangemerkt. ${ }^{2}$ 
De grondeigenaar wordt wanneer het met het grondstuk verenigde object niet reeds voor de vereniging aan hem in eigendom toebehoort ten gevolge van de natrekking verrijkt ${ }^{3}$, terwijl de eigenaar van het object dat met het grondstuk wordt nagetrokken zijn vóór de vereniging op het object rustende eigendomsrecht verliest. Een object waaraan een eigen goederenrechtelijke identiteit toekomt, in dit geval het grondstuk, wordt aangeduid als 'zaak'.

Een object dat met een grondstuk in eigendom wordt nagetrokken wordt geacht de goederenrechtelijke kwalificatie van het grondstuk te delen, hetgeen betekent dat het object kan worden aangemerkt als 'onroerend'. In beginsel kunnen enkel grondstukken en objecten die op een zodanige wijze met het grondstuk zijn verenigd dat voldaan wordt aan de hierna te bespreken objectieve maatstaven worden aangemerkt als onroerend; alle andere objecten zijn roerend van aard. Het onderscheid roerend-onroerend is van belang voor de rechtsregels die van toepassing zijn op het object.

Afhankelijk van het toepasselijke rechtsstelsel hoeft deze onroerendkwalificatie niet te betekenen dat het nagetrokken object zich ten opzichte van het grondstuk niet kan voortbewegen. ${ }^{4}$ De maatstaven waaraan wordt getoetst of object en grondstuk tezamen een juridische eenheid vormen verschillen per rechtsstelsel. De in dit proefschrift onderzochte rechtsstelsels hebben met elkaar gemeen dat deze maatstaven 'objectief van aard zijn. Objectief dient niet te worden verward met 'waarneembaar'. Hoewel derden doorgaans mogen vertrouwen op de waarneembare omstandigheden van het concrete geval bij het bepalen of sprake is van eenheidsvorming, kan op grond van wettelijke bepalingen van de feitelijk waarneembare situatie worden afgeweken.

Wanneer aan deze objectieve maatstaven wordt voldaan, treedt het aan het voldoen aan deze maatstaven gekoppelde rechtsgevolg, natrekking,

werken die onder het eigendomsrecht van de grond vallen in de zin van art. 5:20 lid $1 \mathrm{BW}$ altijd als bestanddeel van het grondstuk kunnen worden aangemerkt. Zie: hoofdstuk $3 \S 3$.

3 Voor het natrekken van een object met een grondstuk is het niet vereist dat het object op directe wijze met het grondstuk is verenigd. Ook objecten die op indirecte wijze met het grondstuk zijn verenigd, bijvoorbeeld doordat ze zijn verenigd met een bouwwerk dat met het grondstuk wordt nagetrokken, worden met het grondstuk in eigendom nagetrokken wanneer in de relatie object-bouwwerk aan de natrekkingsmaatstaven wordt voldaan. Afhankelijk van het rechtsstelsel dat op de feitelijke situatie van toepassing is, kunnen de objectieve maatstaven bij indirecte natrekking verschillen van de objectieve maatstaven die van toepassing zijn bij directe vereniging van een object met een grondstuk. Zie: hoofdstuk $2 \$ 2.2$ voor het Duitse rechtsstelsel en hoofdstuk 3 $\S 3$ voor het Nederlandse rechtsstelsel.

Zo kan een op een grondstuk voortbewegende havenkraan onder het Nederlandse en Belgische recht met het grondstuk in eigendom worden nagetrokken. Zie: hoofdstuk 4 \$2.2.1. 
vanzelf in. Natrekking kan in beginsel niet worden voorkomen door een tussen partijen overeengekomen obligatoire overeenkomst. Wel is het mogelijk dat een overeenkomst een aan de overeenkomst accessoir opstalrecht doet ontstaan. Ten gevolge van dit accessoir opstalrecht strekt de eigendom van het grondstuk zich niet uit over de door de gebruiker aangebrachte opstallen. Dit is bijvoorbeeld het geval bij een onder het Belgische recht tot stand gekomen huurovereenkomst; de huurder blijft in beginsel eigenaar van de door hem met het grondstuk verenigde opstallen.

De natrekking kan worden doorbroken door het object dat met het grondstuk een juridische eenheid vormt feitelijk van het grondstuk af te scheiden. Fysieke afscheiding van het object heeft tot gevolg dat de grondslag voor natrekking komt te ontvallen, waardoor aan het object een eigen goederenrechtelijke status toekomt en het object kan worden aangemerkt als roerend. Het is echter niet zonder meer aan de voormalig eigenaar van het met het grondstuk verbonden object om over te gaan tot het wegnemen van het object. Enkel wanneer hiervoor een rechtsgrond bestaat is de voormalig eigenaar van het object bevoegd tot wegname van het door hem aangebrachte object en gaat het afgescheiden object aan hem in eigendom toebehoren. Deze rechtvaardigingsgrond is gelegen in het zogenoemde 'ius tollendi', het wegneemrecht.

Het wegneemrecht kan gekoppeld zijn aan een recht op grond waarvan de voormalig eigenaar van het object bevoegd was het object aan te brengen, maar kan eveneens bestaan wanneer de bevoegd gebruiker van het grondstuk bij aanvang van het gebruik de op of in het grondstuk aanwezige objecten tegen vergoeding heeft overgenomen. Zo zijn de erfpachter en opstaller mogelijk bevoegd tot wegname van de door hen aangebrachte objecten. ${ }^{5}$ Ook de huurder die krachtens een overeenkomst bevoegd is tot gebruik van een grondstuk en de met het grondstuk verenigde woning, kan bevoegd zijn tot wegname. De huurder die op duurzame wijze een tuinornament met het gehuurde grondstuk heeft verenigd, kan zowel gedurende als bij beëindiging van de huurovereenkomst bevoegd zijn tot wegname van het tuinornament, ook als de woning reeds aan een ander is overgedragen.

De natrekking kan eveneens worden doorbroken zonder dat de feitelijke eenheid tussen object en grondstuk wordt doorbroken. Aan deze juridische doorbreking dient een rechtvaardigingsgrond ten grondslag te liggen waar derden notie van kunnen nemen. Doorbreking van de juridische eenheid zonder doorbreking van de feitelijke eenheid kan ten eerste door middel van 1) het vestigen van een zelfstandig recht van opstal, 2) het vestigen van een zakelijk recht waaraan een opstalrecht accessoir is of 3) de totstandkoming wegneemrecht uit te sluiten. 
van een overeenkomst waaraan een accessoir opstalrecht is gekoppeld ${ }^{6}$. Op grond van het opstalrecht, dat kan worden aangemerkt als een beperkt zakelijk recht, komt aan de verkriiger van het recht, de opstaller, ongeacht of het opstalrecht zelfstandig of accessoir van aard is de bevoegdheid toe om een of meerdere objecten in eigendom te hebben die met een aan een ander toebehorend grondstuk zijn of worden verenigd. ${ }^{7}$ De nadere inhoud die door partijen aan een zelfstandig recht van opstal kan worden toegekend, is afhankelijk van de wettelijke bepalingen die in het betreffende Burgerlijk Wetboek omtrent het opstalrecht zijn neergelegd. Een afhankelijk recht van opstal wordt nader 'ingevuld' door de bepalingen van het recht waaraan het opstalrecht accessoir is.

Ten tweede kan de natrekking zonder fysieke afscheiding van het object van het grondstuk worden doorbroken krachtens een wettelijke bepaling. De wetgever kan besluiten de natrekking te doorbreken ten aanzien van objecten waarbij natrekking maatschappelijk als onwenselijk wordt ervaren. Een in Nederlandse bodem neergelegd elektriciteitsnet wordt niet met het grondstuk waarin het net is gesitueerd nagetrokken, wanneer voldaan wordt aan de in de wettelijke bepaling opgenomen vereisten. Het object ten behoeve waarvan de natrekking wordt doorbroken, kan als onroerend worden gekwalificeerd.

\section{§3. Waarom dit proefschrift?}

Voor zowel de grondeigenaar als derden, zoals de voormalig eigenaar van het object dat met het grondstuk is verbonden en de hypotheekhouder, is het van belang te weten wanneer een object met het grondstuk in eigendom natrekt. Bij bespreking van de objectieve natrekkingsmaatstaven zal blijken dat het niet altijd even duidelijk is of een object al dan niet met een grondstuk wordt nagetrokken en dus als bestanddeel of juist als aparte, zelfstandige zaak dient te worden aangemerkt: het is dan aan de wetgevende of rechtsprekende macht zekerheid te verschaffen. Binnen een rechtsstelsel kan dan ook onzekerheid bestaan omtrent de exacte invulling van de objectieve maatstaven. Daarnaast kunnen de objectieve maatstaven die aan de natrekking ten grondslag liggen per rechtsstelsel verschillen en kunnen de rechtsstelsels bekend zijn met rechtsfiguren op grond waarvan de objectieve maatstaven die aan de juridische eenheidsvorming ten grondslag liggen,

$6 \mathrm{Nu}$ onder het Belgische recht een opstalrecht accessoir kan zijn aan een overeenkomst, kan ook de totstandkoming van bijvoorbeeld een huurovereenkomst doorbreking van de juridische eenheid met zich brengen. Zie: hoofdstuk $4 \$ 4.5$.

$7 \quad$ Onder het Duitse recht kan een recht van opstal eveneens ten behoeve van de eigenaar van de grond worden gevestigd. Zie: hoofdstuk 2 \$3.4.2 - noot 265. 
buitenspel wordt gezet. ${ }^{8}$ Hierdoor kan een met een grondstuk verenigd object onder het ene rechtsstelsel als bestanddeel van het grondstuk worden aangemerkt, terwijl onder het andere rechtsstelsel eenzelfde object dat op gelijke wijze met het grondstuk is verenigd als aparte zaak kan worden gekwalificeerd.

De essentie van dit proefschrift is gelegen in het in kaart brengen of en op welke wijzen de natrekking van een object met een grondstuk kan worden doorbroken naar Duits, Nederlands, Belgisch en Schots recht. ${ }^{9}$ Wanneer het mogelijk is de natrekking te doorbreken wordt ingegaan op de vereisten die gesteld worden aan de wijze van doorbreking en de rechtsonzekerheden die hierdoor kunnen ontstaan. In het hierna volgende wordt ingegaan op verschillende situaties waar doorbreking kan leiden tot rechtsonzekerheid. Ten aanzien van onderstaande situaties wordt een onderscheid gemaakt tussen die situatie waar het met het grondstuk verenigde object al dan niet op fysieke wijze van het grondstuk wordt afgescheiden.

Wanneer een derde het object ingevolge het aan hem toekomende wegneemrecht van het grondstuk afscheidt, komt aan het object een eigen goederenrechtelijke identiteit toe en gaat het object in eigendom toebehoren aan de bevoegd wegnemer. Tussen de natrekking en het wegneemrecht kan een spanningsveld bestaan, wanneer de gerechtigde tot het wegneemrecht zijn recht wenst uit te oefenen maar derden zich mogen beroepen op de tussen het grondstuk en het met het grondstuk verenigde object ingetreden natrekking. Terwijl de natrekking beoogt rechtszekerheid te bieden aan derden -derden dienen in beginsel aan de hand van de objectieve maatstaven te kunnen beoordelen of een met het grondstuk verenigd object al dan niet aan de grondeigenaar toebehoort-, heeft het wegneemrecht tot doel de bevoegd gebruiker van het grondstuk de mogelijkheid te bieden het door hem in eigendom verloren object terug te nemen zodat het eigendomsverlies wordt 'opgeheven'.

Derden hoeven van het bestaan van het wegneemrecht niet op de hoogte te zijn. De beperkt zakelijke rechten erfpacht en opstal dienen in het register te worden ingeschreven willen zij ontstaan. Dit register is openbaar en derden kunnen, wanneer zij het register hebben geraadpleegd, van het bestaan en daarmee van het mogelijk bestaan van het wegneemrecht op

8 Zo schuift het Duitse rechtsstelsel de objectieve natrekkingsmaatstaven terzijde wanneer derden uit de feitelijke omstandigheden van het geval de intentie kunnen afleiden dat het object, ondanks de verstrekkende wijze van vereniging met het grondstuk, tijdelijk met het grondstuk is verenigd. Doordat de objectieve natrekkingsmaatstaven buitenspel worden gezet, blijft het met het grondstuk verenigde object een roerende zaak. Zie: hoofdstuk 2 \$2.4. Hoofdstuk $1 \S 4$. 
de hoogte zijn. ${ }^{10}$ Welke objecten ingevolge het wegneemrecht van het grondstuk mogen worden afgescheiden volgt (uiteraard) niet uit het register. Het wegneemrecht kan eveneens worden gekoppeld aan de persoonlijke rechten huur en pacht. Deze rechten worden, anders dan de zakelijke rechten, in beginsel niet in het register ingeschreven. Derden kunnen niet van de huur- respectievelijk de pachtovereenkomst en het daaraan gekoppelde wegneemrecht op de hoogte zijn, ook als zij de registers wel hebben geraadpleegd. De hypotheekhouder zal er in beginsel van uit mogen gaan dat een op een grondstuk aanwezig gebouw samen met het grondstuk een eenheid vormt. Maar wat als de eigenaar van een grondstuk een recht van erfpacht vestigt en de erfpachter tegen een vergoeding het aanwezige gebouw overneemt na vestiging van het hypotheekrecht? En wat als de grondeigenaar ten behoeve van de hypotheekhouder een hypotheekrecht vestigt terwijl de grondeigenaar het grondstuk heeft verhuurd en de huurder het daarop aanwezige gebouw zelf heeft aangebracht? In ieder van deze gevallen dient een afweging te worden gemaakt tussen het belang van de bevoegd gebruiker van het grondstuk en dat van de hypotheekhouder.

Doorbreking van de eigendomsnatrekking zonder dat het object fysiek van het grondstuk wordt afgescheiden is mogelijk door middel van het ontstaan van een beperkt recht van opstal ${ }^{11}$; het opstalrecht kan zelfstandig dan wel accessoir van aard zijn. ${ }^{12}$ Wat exact tot de inhoud van het opstalrecht kan worden 'gemaakt' is afhankelijk van de rechtsregels die op het opstalrecht van toepassing zijn. Zo bestaan er grote verschillen tussen de rechtsstelsels ten aanzien van de objecten ten behoeve waarvan het opstalrecht kan worden gevestigd, de duur waarvoor het opstalrecht kan worden overeengekomen, alsook ten aanzien van de aan de opstaller toe te kennen rechten en plichten.

De rechtsstelsels die bekend zijn met het beperkt zakelijke recht van opstal hebben met elkaar gemeen dat zij alle, aldus de heersende leer, aan de opstaller de eigendom van de objecten toekennen ten behoeve waarvan het opstalrecht is gevestigd. Aan partijen komt een zekere mate van vrijheid toe bij het bepalen van de inhoud van de goederenrechtelijke vestigingsovereenkomst, die het opstalrecht tot stand brengt. Uitsluitend datgene wat past binnen de grenzen van de inhoud die aan het te vestigen recht door de wet wordt toegekend wordt onderdeel van het zakelijk

10 Het wegneemrecht kan niet alleen aan een erfpacht- of opstalrecht maar ook aan andere zakelijke rechten zijn gekoppeld.

11 Althans wanneer het rechtsstelsel dat van toepassing is op het grondstuk waarmee het in eigendom af te scheiden object is verenigd met het recht van opstal bekend is. Zo is het Schotse rechtsstelsel niet bekend met het recht van opstal.

12 Hoofdstuk 1 §2. In tegenstelling tot het Nederlandse en Belgische recht is het Duitse recht enkel bekend met het zelfstandige recht van opstal. 
recht. ${ }^{13}$ Andere bedingen hebben slechts obligatoire werking. Het staat partijen in beginsel vrij in de vestigingsovereenkomst de bevoegdheden die aan de opstaller toekomen ten aanzien van de in eigendom te verkrijgen opstallen te verruimen dan wel te beperken. De vraagt rijst of het recht dat de opstaller verkrijgt op grond van de vestigingsovereenkomst ten aanzien van de objecten ten behoeve waarvan het opstalrecht wordt gevestigd, de opstallen, als eigendom kan worden aangemerkt wanneer partijen de aan de opstaller toekomende bevoegdheden zodanig beperken dat deze bevoegdheden niet overeenkomen met het in het desbetreffende Burgerlijk Wetboek gedefinieerde eigendomsrecht. Wanneer deze vraag ontkennend wordt beantwoord doet de vraag zich voor of met de vestiging van een recht van opstal de natrekking wordt doorbroken.

In dit proefschrift wordt bij het bespreken van de natrekking en de doorbreking daarvan niet ingegaan op of rekening gehouden met de gevolgen die de ingenomen standpunten respectievelijk voorgestelde wijzigingen hebben voor het fiscaal recht. Dat aan bepaalde goederenrechtelijke kwalificaties fiscale gevolgen worden toegekend, mag mijns inziens geen rol spelen bij het al dan niet toekennen van deze goederenrechtelijke kwalificaties.

\section{$\S 4$. Rechtsvergelijkend onderzoek}

De Europese Unie maakt het voor burgers en ondernemers aantrekkelijker om over de grenzen van hun eigen land heen te kijken en zich elders te vestigen of te investeren. Er zijn legio voorbeelden denkbaar waarbij het van belang is notie te nemen van de rechtsfiguur natrekking en de wijzen waarop deze kan worden doorbroken. Bijvoorbeeld de Nederlandse ondernemer die voornemens is een parkeergarage te verwezenlijken onder een bestaand gebouw dat gelegen is in Edinburgh. Of de Belgische ondernemer die het plan heeft opgevat een distributiecentrum in het oosten van Duitsland te vestigen om zo Oost-Europese afnemers te kunnen bevoorraden. Beide ondernemers worden geconfronteerd met de rechtsregels van het betreffendeland waar het grondstuk zich bevindt en de investering plaatsvindt. ${ }^{14}$ Kan de Nederlandse investeerder voorkomen dat hij de eigendom van de door hem aangebrachte parkeergarage verliest wanneer deze parkeergarage in een aan een ander toebehorend grondstuk is aangebracht? Verliest de Belgische investeerder de eigendom van het gebouw dat hij voor zijn distributiecentrum aanbrengt op de door hem gehuurde grond en is hij bevoegd het gebouw bij beëindiging van zijn huurrecht weg te nemen? Deze en andere vragen dienen te worden

13 Het numerus clausus-beginsel ligt hieraan ten grondslag.

14 Krachtens het lex rei sitae-beginsel is het recht van het land waar de zaak zich bevindt van toepassing. 
beantwoord aan de hand van het rechtsstelsel van het land, in casus Schotland of Duitsland, waar het grondstuk is gelegen.

Ook met het oog op grensoverschrijdende hypothecaire financieringen is het voor de financier van belang te weten wat al dan niet met de eigendom van de grond wordt nagetrokken respectievelijk op welke wijze de natrekking met het grondstuk kan worden doorbroken. De hoogte van de geldlening als de hoogte van de over deze geldlening te betalen rente is afhankelijk van de reikwijdte van het eigendomsrecht dat op het grondstuk rust.

Het leerstuk van de natrekking en de doorbreking daarvan worden in dit proefschrift naar Duits, Nederlands, Belgisch en Schots recht uiteengezet. Volgens de cijfers van het Centraal Bureau voor de Statistiek zijn voor 'de Nederlander' de meest populaire emigratiebestemmingen de buurlanden België en Duitsland ${ }^{15}$, hetgeen een rechtsvergelijkend onderzoek naar de natrekking en de doorbreking naar Belgisch en Duits recht aantrekkelijk makkt.

Niet alleen omwille van de voornoemde emigratiebestemmingen is gekozen voor het Belgische en Duitse recht. De keuze voor het Belgische en Duitse recht is tevens gebaseerd op de grote verschillen die tussen de rechtsstelsels bestaan en de historie van deze rechtsstelsels. De keuze voor het Belgische recht komt mede voort uit de gezamenlijke geschiedenis van België en Nederland. Na de Restauratie van Europa in 1815 werd aan Willem I het Verenigd Koninkrijk der Nederlanden toegekend, waarin de Noordelijke en Zuidelijke Nederlanden (het latere België) werden verenigd. Hoewel aan deze vereniging reeds in 1830 een eind kwam, heeft deze grote invloed gehad op de Belgische rechtsfiguur van de natrekking en de doorbreking daarvan. Ten eerste ligt aan het Belgisch Burgerlijk Wetboek alsook aan het Nederlands Burgerlijk Wetboek van 1838 de Franse Code Civil ten grondslag die ten tijde van de vereniging van toepassing was in het Verenigd Koninkrijk der Nederlanden. Ten tweede is de huidige Belgische regeling omtrent de vestiging van een zelfstandig recht van opstal afkomstig uit $1824 .{ }^{16}$ Tot aan de invoer van het Burgerlijk Wetboek van 1838 is deze regeling eveneens op het zelfstandige opstalrecht naar Nederlands recht van toepassing geweest. Het Belgische en Nederlandse recht hebben dan ook een gemeenschappelijke bakermat.

Terwijl de keuze voor het Duitse recht vanuit juridisch oogpunt met name gebaseerd is op de sterke dogmatische onderbouwing van de keuzes die gemaakt zijn bij de totstandkoming van het Bürgerliches Gesetzbuch, is

15 'België en Duitsland populairste emigratiebestemmingen', website Centraal Bureau voor de Statistiek: <http://www.cbs.nl/nl-NL/menu/themas/bevolking/ publicaties/artikelen/archief/2010/2010-3080-wm.htm> (18 augustus 2012). Wet over het recht van Opstal van 10 januari 1824. 
de keuze voor het Schotse recht voornamelijk gestoeld op persoonlijke interesse. De hartelijke en inspirerende gesprekken die ik binnen de Ius Commune onderzoeksschool heb gevoerd met de tot deze onderzoeksschool behorende Schotse goederenrecht juristen hebben mij nieuwsgierig gemaakt naar dit sterker op case law gebaseerde rechtsstelsel.

Anders dan bij het Duitse, Belgische en Nederlandse rechtsstelsel ${ }^{17}$, is binnen het Schotse recht het feodale stelsel tot 2004 van grote invloed geweest op de rechten die op een grondstuk konden worden gevestigd. Onder het feodale stelsel was het niet mogelijk de eigendom van een grondstuk te hebben: de eigendom van het grondstuk kon enkel toebehoren aan de 'Kroon'. Daarnaast maakte het feodale stelsel het mogelijk bevoegdheden ten aanzien van een grondstuk aan derden toe te kennen zonder dat anderen, zoals de koper van het grondstuk, hier enige notie van konden nemen. De afschaffing van het feodale stelsel in 2004 heeft voor een belangrijke kentering in het Schotse recht gezorgd. Ten aanzien van de rechten die op een grondstuk kunnen worden gevestigd, heeft reductie plaatsgevonden en ook de inhoud die aan een recht kan worden toegekend is aan banden gelegd. ${ }^{18}$

\section{§5. Plan van aanpak}

Dit werk bestaat uit een zevental hoofdstukken. In dit eerste, inleidende hoofdstuk is beschreven waarom de behoefte bestaat nader onderzoek te doen naar de natrekking en de doorbreking van de natrekking. Ook is aangegeven dat gezien de Europese ontwikkelingen het wenselijk is dit onderzoek in rechtsvergelijkend perspectief uit te voeren. In de navolgende hoofdstukken 2, 3, 4 en 5 wordt ingegaan op het Duitse, Nederlandse, Belgische en Schotse rechtsstelsel, waarbij ieder rechtsstelsel op gelijke voet aan bod komt. Vergelijking van de rechtsstelsels vindt plaats in hoofdstuk 6. De Engelstalige samenvatting van dit proefschrift is opgenomen in hoofdstuk 7 .

Ieder van de rechtsstelsels wordt afzonderlijk in een eigen hoofdstuk uiteengezet. De volgorde van de rechtsstelsels is bewust gekozen. $\mathrm{Na}$ bestudering van de verschillende rechtsstelsels is gebleken dat het Duitse rechtsstelsel in vergelijking met de andere rechtsstelsels verreweg het

17 Zowel in het Duitse, Nederlandse en Belgische rechtsstelsel werd het feodalisme na de Franse Revolutie afgeschaft.

18 Met het van kracht worden van de Abolition of Feudal Tenure etc (Scotland) Act 2000, de Title Conditions (Scotland) Act 2003 en de Tenements Act 2004 op 28 november 2004 is een eind gemaakt aan het feodale landrecht en heeft er codificatie plaatsgevonden van rechten die ten aanzien van een grondstuk kunnen worden gevestigd. 
meest dogmatisch van opzet is. Bij de totstandkoming van het Nederlands Burgerlijk Wetboek van 1992 heeft het Bürgerliches Gesetzbuch meer dan eens als voorbeeld gediend. Vandaar de keuze het Duitse rechtsstelsel voor het Nederlandse te plaatsen. Gezien de gemeenschappelijke historie is het Belgische hoofdstuk na het Nederlandse geplaatst. Het dogmatisch minst sterk ontwikkelde rechtsstelsel maar daarmee zeker niet minder interessant, het Schotse rechtsstelsel, wordt als laatste behandeld.

Alvorens in te gaan op de wijzen waarop de juridische eenheid tussen grondstuk en object binnen het desbetreffende rechtsstelsel kan worden doorbroken, is het van belang te weten wanneer natrekking tussen grondstuk en object intreedt. Ieder hoofdstuk begint dan ook met een korte verhandeling over de objectieve maatstaven die aan de natrekking ten grondslag liggen. Natrekking treedt 'vanzelf' in wanneer aan deze maatstaven wordt voldaan. Deze maatstaven zijn voortdurend in beweging en passen zich aan de maatschappelijke behoeften aan. Bij de bespreking van deze maatstaven komt aan de jurisprudentie dan ook een belangrijke rol toe.

$\mathrm{Na}$ bespreking van de natrekking worden de verschillende wijzen van doorbreking van de natrekking besproken. Hierbij zal per rechtsstelsel in worden gegaan op die rechten die het mogelijk maken de eigendom van een met een grondstuk verenigd object af te scheiden zonder dat het object feitelijk wordt afgescheiden. Ook de rechten waaraan een wegneemrecht kan worden gekoppeld komen nader aan de orde. Echter, zoals uit de betreffende hoofdstukken zal blijken, sluit een recht op grond waarvan de eigendom van een object van het grondstuk kan worden afgescheiden zonder fysieke afscheiding van het grondstuk het bestaan van een wegneemrecht niet uit. Het is dan ook niet mogelijk een strikte scheiding van de beide wijzen van doorbreking in de hoofdstukken te maken. Reeds hier dient te worden opgemerkt dat het Schotse rechtsstelsel niet bekend is met de mogelijkheid de eigendom van een object af te scheiden zonder fysieke afscheiding van het grondstuk. 



\section{Hoofdstuk 2. Doorbreking van de eigendomsnatrekking naar Duits recht}

\section{§1. Inleiding}

\section{Bestandteile}

Objecten die met een grondstuk zijn verenigd worden ongeacht de verstrekkendheid van de vereniging als 'Bestandteil' aangemerkt. Het Sachenrecht onderscheidt wesentliche Bestandteile ${ }^{19}$, unwesentliche Bestandteile $^{20}$ en Scheinbestandteile ${ }^{21}$. Anders dan bij unwesentliche bestanddelen het geval is, zijn objecten die als wesentlich respectievelijk als Schein-bestanddeel worden aangemerkt op een vast wijze met het grondstuk verenigd. Volgens de verkeersopvatting is van een vaste vereniging sprake wanneer afscheiding van het object leidt tot beschadiging van object of grondstuk, of de afscheiding gepaard gaat met onevenredig hoge kosten. ${ }^{22}$

Wesentliche bestanddelen onderscheiden zich van Schein-bestanddelen doordat ze een juridische eenheid met het grondstuk vormen. Aan deze juridische eenheidsvorming wordt in beginsel het rechtsgevolg eigendomsnatrekking verbonden. De eigendom van het grondstuk strekt zich uit over het met het grondstuk op vaste wijze verenigde object waardoor aan het grondstuk en object, die samen één zaak vormen, één goederenrechtelijke identiteit toekomt. ${ }^{23}$ De gedachte achter eigendomsnatrekking is dat derden in beginsel uit de omstandigheden van het geval kunnen afleiden wat tot de goederenrechtelijke eenheid van een grondstuk kan worden gerekend. ${ }^{24}$ Wanneer derden uit de omstandigheden kunnen afleiden dat de vaste vereniging van het object met het grondstuk tijdelijk van aard is, vormt het object noch een juridisch noch een goederenrechtelijke eenheid met het grondstuk waarmee het is verenigd. Het vaste verbindingscriterium wordt dan terzijde geschoven en het object kan worden aangemerkt als Schein-bestanddeel. Ook objecten die ten behoeve van de uitoefening van een zakelijk recht op vaste wijze met het grondstuk

19 Hoofdstuk 2 \$2.2.

$20 \quad$ Hoofdstuk $2 \$ 2.3$.

21 Hoofdstuk $2 \$ 2.4$.

$22 \S 94$ BGB. Zie: hoofdstuk 2 \$2.2.

23 Het Romeinsrechtelijke superficies solo cedit-beginsel ligt ook aan het hedendaagse Duitse rechtsstelsel ten grondslag.

24 Hoofdstuk 2 \$2.2 en $\$ 2.2 .1$. 
zijn verenigd, vormen geen juridische eenheid met het grondstuk. Derden kunnen door raadpleging van het Grundbuch van het bestaan van een op een grondstuk rustend zakelijk recht en daarmee van het bestaan van mogelijke Schein-bestanddelen op de hoogte zijn. ${ }^{25}$

\section{Das Erbbaurecht}

Ingevolge de vestiging van het Erbbaurecht, het recht van opstal, komt aan de gerechtigde tot het opstalrecht, de opstaller, de bevoegdheid toe bouwwerken ${ }^{26}$ op of in het grondstuk van een ander in eigendom te hebben..$^{27}$ Volgens de heersende leer verkrijgt de opstaller die bouwwerken, de zogenoemde opstallen, in eigendom ten gunste waarvan het opstalrecht is gevestigd. Deze opstallen kunnen ten tijde van de vestiging reeds bestaan of gedurende het opstalrecht worden verwezenlijkt. Voor de ten tijde van de vestiging van het opstalrecht bestaande opstallen leidt vestiging van het opstalrecht tot doorbreking van de eigendomsnatrekking. Nu aan deze opstallen een eigen goederenrechtelijke identiteit toekomt, kunnen ze niet langer als wezenlijk bestanddeel van het grondstuk worden aangemerkt.

De opstallen ten gunste waarvan het opstalrecht is gevestigd, worden -ongeacht of zij ten tijde van de vestiging reeds bestaan of gedurende de bestaansduur worden verwezenlijkt- in relatie tot het grondstuk aangemerkt als Schein-bestanddeel. In relatie tot het opstalrecht worden de opstallen aangemerkt als wezenlijk bestanddeel. ${ }^{28}$ De fictie dat een opstalrecht, zijnde een onlichamelijke zaak, een fysiek object als wezenlijk bestanddeel kan hebben is een gevolg van het aanmerken van het opstalrecht als een 'grundeigentumsgleiches Recht'. ${ }^{29}$ Door de juridische gelijkstelling van het opstalrecht aan een grondstuk kan het opstalrecht worden bezwaard met rechten waarmee ook een grondstuk kan worden bezwaard. ${ }^{30}$

Naast het toekennen van het recht een of meerdere bouwwerken op of in het grondstuk van een ander in eigendom te hebben, staat het de bij de vestiging van het opstalrecht betrokken partijen vrij nadere rechten en plichten op te nemen in het Erbbaurechtsvertrag. ${ }^{31}$ Zo komt aan de opstaller doorgaans een recht van gebruik toe ten aanzien van het met het opstalrecht bezwaarde grondstuk. De reikwijdte van het gebruiksrecht is afhankelijk

25 Welke objecten als Schein-bestanddeel kunnen worden aangemerkt, is niet in het Grundbuch terug te vinden.

26 Hoofdstuk $2 \$ 3.3 .1$.

27 Hoofdstuk $2 \$ 3.3 .2$.

28 Hoofdstuk 2 \$2.2.2 en $\$ 3.3 .2$.

29 Hoofdstuk 2 \$3.1.

$30 \quad$ Hoofdstuk $2 \S 3.5$.

31 Het Erbbaurechtsvertrag is de overeenkomst die aan het opstalrecht ten grondslag ligt. Zie: hoofdstuk 2 \$3.2. 
van hetgeen de grondeigenaar en de opstaller in de vestigingsovereenkomst zijn overeengekomen. Als tegenprestatie voor de ingevolge het opstalrecht verkregen bevoegdheden kunnen partijen overeenkomen dat de opstaller een vergoeding, de Erbbauzins, betaalt. ${ }^{32}$

\section{§2. Bestandteile en Zubehör}

\section{\$2.1 Sachen}

Het Duitse goederenrecht kent als objecten in beginsel Sachen. ${ }^{33}$ Het begrip 'Sachen' is in deze niet beperkt tot objecten die aan het nader te bespreken körperlichkeit-vereiste voldoen ${ }^{34}$, maar ziet ook op vermogensrechten die op lichamelijke objecten rusten. ${ }^{35}$ Een object voldoet aan het lichamelijkheidsvereiste wanneer aan een drietal criteria wordt voldaan. Ten eerste dient het object al dan niet door middel van technische hulpmiddelen sinnlich Wahrnehmbahr te zijn. Tevens dient het object beheersbaar te zijn, hetgeen betekent dat bezit kan worden uitgeoefend en op het object zakelijke rechten rusten. Hoewel sterren waarneembare objecten zijn, kunnen zij niet als object van het goederenrecht worden aangemerkt door een gebrek aan beheersbaarheid. ${ }^{36}$ Ten derde dient te worden voldaan aan het criterium van räumliche Abgrenzung; objecten moeten van elkaar te onderscheiden zijn. ${ }^{37}$ Bij een grondstuk wordt de raümliche Abgrenzung aan de hand van de in het Grundbuch opgenomen kadastrale afmetingen bepaald. ${ }^{38}$

Met het begrip 'zaak' zal in deze en de navolgende paragrafen die objecten worden aangeduid die voldoen aan het lichamelijkheidsvereiste. Vermogensrechten die op een lichamelijke zaak rusten worden aangeduid met de term 'zakelijk recht'. ${ }^{39}$ Een zakelijk recht kenmerkt zich door zijn absolute werking. ${ }^{40}$ Deze absolute werking heeft tot gevolg dat een persoon,

Hoofdstuk $2 \S 3.2 .2$.

34 Hoewel dieren aan het lichamelijkheidsvereiste voldoen, is een dier geen zaak (§ 90a BGB). Desondanks zijn een groot aantal zakenrechtelijke bepalingen ook op dieren van toepassing. Zie: Prütting 2010, Rn 6.

35 Vermogensrechten die eveneens onder het begrip 'Sachen' in de zin van $§ 90$ BGB vallen zonder dat zij rusten op een lichamelijk object zijn Niessbrauch an Rechten en Pfandrechten an Rechten. Zie: Spyridakis 1966, p. 3.

36 Wieling 2006, p. 55.

37 MünchKommBGB/Stresemann 2012, § 90 Rn 8-9.

38 MünchKommBGB/Stresemann 2012, § 90 Rn 12.

39 In de literatuur wordt de term 'dinglich Recht' gebezigd, een term die niet in het BGB wordt gedefinieerd. Uit de Motive is af te leiden dat het gaat om een "unmittelbare Rechtsbeziehung zur Sache selbst". Zie: Motive III 2; Hk-BGB/ Dörner 2012, §90 Rn 2.

40 Zakelijke werking komt eveneens toe aan Persönlichkeitsrechte, persönliche 
de rechthebbende, ten aanzien van een specifieke zaak in een bepaalde rechtsbetrekking komt te staan..$^{41}$ Het merendeel van de zakelijke rechten zijn in het BGB opgenomen. ${ }^{42}$

Zaken kunnen worden onderscheiden in Grundstücke enerzijds en bewegliche Sachen anderzijds. ${ }^{43}$ Een grondstuk is per definitie aan te merken als een unbewegliche Sache. Bewegliche Sachen zijn alle zaken die voldoen aan het lichamelijkheidsvereiste en geen grondstuk of bestanddeel van een grondstuk zijn. ${ }^{44}$ Daarnaast kunnen zaken worden onderscheiden in einfache en zusammengesetzte zaken. Een zaak is einfach op grond van zijn natuurlijke eenheid, zoals een plant of een steen. Een zusammengesetzte zaak bestaat uit meerdere bestanddelen, zoals bij een fiets of een computer het geval is. ${ }^{45}$ Van een bestanddeel is sprake wanneer twee of meer zaken op een zodanige wijze met elkaar zijn verbonden dat zij samen een feitelijke eenheid vormen. ${ }^{46}$ Vestiging van een zakelijk recht op een verzameling van

Familienrechte en de Immaterialgüterrechte.

41 Dit aspect van de zakelijke werking wordt veelal aangeduid als 'Zuordnungsfunktion'. Uit de Zuordnungsfunktion vloeien een tweetal rechten voort die aan de rechthebbende toekomen. Ten eerste staat het de rechthebbende vrij met de zaak om te gaan zoals hem goeddunkt, het zogenoemde 'Herrschaftsrecht'. Daarnaast komt aan de rechthebbende het Zugriffsrecht toe, inhoudende dat de rechthebbende de zaak tot zijn vermogen kan rekenen. Het tweede aspect dat uit de absolute werking van het zakelijke recht vloeit is de Abwehrfunktion, inhoudende dat anderen zich hebben te weerhouden van bemoeienissen waardoor de relatie tussen zaak en rechthebbende wordt verstoord. Zie: Wieling 2006, pp. 14-15.

42 Het eigendomsrecht (§903 BGB), de Dienstbarkeiten (§ 1018 BGB, § 1030 BGB, $\$ 1068$ BGB en $§ 1090$ BGB), de Reallasten (§ 1105 BGB), de Hypothek (§ 1113 BGB), de Grundschuld (§ 1191 BGB), de Rentenschuld (§ 1199 BGB), het Pfandrecht an beweglichen Sachen (§ 1204 BGB) en het Pfandrecht an Rechten ( $\$ 1273$ BGB) zijn alle in het BGB terug te vinden. Het Erbbaurecht (§ 1 ErbbauRG), de Wohnungseigentum ( 1 WEG), het Wohnungserbbaurecht (§30 WEG), het Dauerwohnrecht ( $331 \mathrm{WEG)} \mathrm{en} \mathrm{het} \mathrm{Bergwerkseigentum} \mathrm{(§} 9$ BBergG) vinden hun grondslag in bijzondere wetgeving.

43 Een grondstuk is een ruimtelijk, afgebakend gedeelte van het aardoppervlak.

44 MünchKommBGB/Stresemann 2012, §90 Rn 13.

45 MünchKommBGB/Stresemann 2012, §90 Rn 14.

46 Objecten die samen een feitelijke eenheid vormen hoeven nog geen juridische eenheid te vormen. Zie: hoofdstuk 2 \$2.2. 
zaken is in beginsel niet mogelijk ${ }^{47}$, omdat ingevolge het Spezialitätsprinzip ${ }^{48}$ een zakelijk recht op een specifieke zaak dient te rusten.

Het Duitse recht onderscheidt bestanddelen in wesentliche $e^{49}$, unwesentliche $e^{50}$ en Schein-bestanddelen. ${ }^{51}$ Enkel wezenlijke als niet-wezenlijke bestanddelen vormen met de zaak waarmee zij zijn verenigd een zusammengesetzte zaak. Overdracht van een zusammengesetzte zaak leidt in beginsel tot overdracht van de gehele, samengestelde zaak. Anders dan bij het wezenlijke bestanddeel, komt aan een niet-wezenlijk bestanddeel een eigen goederenrechtelijke identiteit toe. ${ }^{52} \mathrm{Bij}$ een wezenlijk bestanddeel is de vereniging tussen bestanddeel en hoofdzaak zodanig verstrekkend van aard dat sprake is van een einheitliche zaak..$^{53} \mathrm{Bij}$ een eenheidszaak vormen de objecten samen een juridische eenheid. De objecten die binnen deze eenheidszaak als bestanddeel kunnen worden aangemerkt volgen de rechtspositie van de hoofdzaak, waardoor er niet alleen sprake is van een juridische maar ook van een goederenrechtelijke eenheid. ${ }^{54}$ Of een vereniging zo verstrekkend van aard is dat het bestaan van een goederenrechtelijke eenheid kan worden gerechtvaardigd, dient aan de hand van de verkeersopvatting te worden bepaald.

Een object dat als Schein-bestanddeel kan worden aangemerkt is zoals de term reeds doet vermoeden geen 'echt' bestanddeel: een Schein-bestanddeel vormt met de hoofdzaak geen zusammengesetzte zaak en gaat bij overdracht van de zaak waarmee het is verbonden niet in eigendom mee over ondanks het feit dat een Schein-bestanddeel op eenzelfde verstrekkende wijze als een wezenlijk bestanddeel met de hoofdzaak is verenigd. ${ }^{55}$ Naast voornoemde

47 Het vestigen van een zakelijk recht op bijvoorbeeld een collectie boeken of een inboedel is in beginsel niet mogelijk. Zie: MünchKommBGB/Stresemann 2012, § $90 \mathrm{Rn} 40$. Een verzameling van zaken wordt veelal met de term 'Sachgesamtheit' aangeduid. Deze term ontbreekt in het BGB en valt niet onder de definitie van $\S 90$ BGB. Desalniettemin zijn een aantal bepalingen met betrekking tot Sachen ook op een Sachgesamtheit van toepassing. Een uitzondering op het vestigen van een zakelijk recht op een verzameling van zaken wordt gemaakt door $\S 1$ Pachtkreditgesetz.

48 Hk-BGB/Dörner 2012, §90 Rn 4-7.

49 Hoofdstuk $2 \$ 2.2$.

$50 \quad$ Hoofdstuk $2 \$ 2.3$.

$51 \quad$ Hoofdstuk $2 \$ 2.4$.

$52 \quad$ Wieling 2006, p. 74.

53 MünchKommBGB/Stresemann 2012, § 90 Rn 14.

54 MünchKommBGB/Stresemann 2012, §93 Rn 3.

55 Schein-bestanddelen kunnen enkel ten aanzien van onroerende zaken bestaan. Een Schein-bestanddeel kan noch als wezenlijk, noch als niet-wezenlijk bestanddeel worden aangemerkt. Zie: Bork 2006, Rn 249. 
bestanddelen is het Duitse recht bekend met Zubehör. Zubehör hebben evenals voornoemde bestanddelen tot doel de hoofdzaak te dienen. ${ }^{56}$

\section{$\S 2.2$ Wesentliche bestanddelen en hun rechtsgevolgen}

De algemene bepaling die ziet op wezenlijke bestanddelen is neergelegd in $\S 93 \mathrm{BGB}$. Het doel van deze bepaling is tweeledig. Ten eerste biedt $\S 93$ BGB rechtszekerheid. Een object dat als wezenlijk bestanddeel wordt aangemerkt vormt met de zaak waar het bestanddeel van is een juridische eenheid. Het object volgt als wezenlijk bestanddeel de hoofdzaak in diens rechtspositie en aan de objecten die samen een eenheidszaak vormen komt één goederenrechtelijke identiteit toe. ${ }^{57}$ Het tweede doel is gelegen in behoud van de economische waarde. De eigenaar van de hoofdzaak is er niet bij gebaat het bestanddeel af te splitsen indien de samengestelde zaak meer waard is dan de waarde van de objecten los van elkaar bezien. Afscheiding zal immers leiden tot waardeverlies.

Volgens $§ 93$ BGB kan een samengestelde zaak als eenheidszaak worden aangemerkt wanneer het met de (hoofd)zaak verenigd object niet van de zaak kan worden afgescheiden zonder dat een van beide wordt beschadigd of het wezen van het bestanddeel verandert. ${ }^{58}$ Onbelangrijk voor het aanmerken van een object als wezenlijk bestanddeel is de functie die het object ten aanzien van de hoofdzaak vervult. ${ }^{59}$ Ook wanneer afscheiding zonder

57 De aan de bestanddeelvorming gekoppelde rechtsgevolgen die in $\S 946$ en $\S$ 947 BGB zijn neergelegd, komen aan bod in $\$ 2.2 .1$ van dit hoofdstuk. Zie: Baur \& Stürner 2009, § 3 Rn 10-12. Bestanddeelvorming kan leiden tot eigendomsverlies wanneer het wezenlijk bestanddeel vóór de vereniging aan een ander, niet zijnde de eigenaar van de eenheidszaak, toebehoort. De voormalig eigenaar kan geen afscheiding van het wezenlijk bestanddeel vorderen. Wel kan de voormalig eigenaar een financiële vergoeding van de begunstigde vorderen. Dit vergoedingsrecht vindt zijn grondslag in de ungerechtfertigte Bereicherung. Zie: $§ \S 812-822$ BGB.

58 §93 BGB. De Bundesgerichtshof stelt in BGH 27 juni 1973, NJW 1973, 1454: "Es gibt Bestandteile, deren Wesen in solcher Weise durch diesen Zweck bestimmt ist, daß sie, nachdem sie in das Ganze eingefügt sind, für eine allgemeine Betrachtung überhaupt kein eigenes Wesen mehr haben... Daher kann es, wirtschaftlich gesehen, richtig sein, nach der Trennung solches Bestandteile das Wesen des restlichen Hauptbestandteils mit dem Wesen der ganzen Sache gleichzusetzen”.

59 Baur \& Stürner 2009, § 3 Rn 8; MünchKommBGB/Stresemann 2012, § 93 Rn 9; Wieling 2009, p. 82. De noodzaak van het aanwezig zijn van een motor om de auto te doen voortbewegen heeft geen enkele invloed op het al dan niet kwalificeren van een motor als wezenlijk bestanddeel. Een motor kan relatief eenvoudig uit een auto worden verwijderd zonder dat de verwijdering invloed heeft op het wezen van de motor. Een motor dient dan ook als een nietwezenlijk bestanddeel te worden gekwalificeerd. Zie: BGH 8 oktober 1955, 
beschadiging mogelijk is, kan een object als wezenlijk bestanddeel worden aangemerkt wanneer de kosten voor het afscheiden van het bestanddeel onevenredig hoog zijn. ${ }^{60} \mathrm{Of}$ aan een van voornoemde criteria wordt voldaan, dient aan de hand van de verkeersopvatting te worden bezien.

In $\S 94$ BGB is een lex specialis opgenomen ten behoeve van bouwwerken ${ }^{61}$ en beplantingen ${ }^{62}$ die middels een vaste verbinding met het grondstuk zijn verenigd. ${ }^{63}$ Bouwwerken die op vaste wijze met het grondstuk zijn verenigd kunnen in beginsel als wezenlijk bestanddeel van het grondstuk worden aangemerkt. ${ }^{64}$ Volgens de verkeersopvatting is van een vaste verbinding sprake wanneer afscheiding van het object leidt tot beschadiging van bouwwerk of grondstuk, of wanneer afscheiding gepaard gaat met onevenredig hoge kosten. ${ }^{65}$ Voor het kwalificeren van een bouwwerk als wezenlijk bestanddeel is het bestaan van een fundering niet vereist; een bouwwerk kan door zijn op het grondstuk drukkend gewicht als wezenlijk bestanddeel van het grondstuk worden aangemerkt. ${ }^{66}$

Volgens het tweede lid van §94 BGB kunnen bouwwerken eveneens wezenlijke bestanddelen hebben. Objecten die volgens de verkeersopvatting

NJW 1955, 1793. In $§ 2.3$ van dit hoofdstuk wordt nader ingegaan op nietwezenlijke bestanddelen.

60 Wieling 2006, p. 83. De kosten van afscheiding worden geacht onevenredig hoog te zijn wanneer de kosten, waartoe ook de arbeidskosten dienen te worden gerekend, hoger zijn dan de waarde van het af te scheiden object.

61 Hoewel $§ 94$ Abs. 2 BGB de term 'Gebäude' (gebouw) hanteert, verdient het mijns inziens de voorkeur het begrip 'bouwwerk' te bezigen, aangezien ook muren, bruggen, leidingen en fabrieken tot het begrip 'Gebäude' worden gerekend. Zie: MünchKommBGB/Stresemann 2012, §94 Rn 17.

62 Bomen en beplantingen kunnen als wezenlijk bestanddeel worden aangemerkt wanneer zij wortelvast zijn. Ten aanzien van zaden wordt gesteld dat zij reeds als wezenlijk bestanddeel van het grondstuk kunnen worden aangemerkt vanaf het moment dat zij in de grond worden aangebracht; van wortelvorming hoeft geen sprake te zijn. Zie: Hk-BGB/Dörner 2012, § 94 Rn 3.

63 Krachtens $§ 96$ BGB kunnen ook rechten als wezenlijk bestanddeel van het grondstuk worden aangemerkt. Zie: §2.2.2 van hoofdstuk 2 .

64 Het bestaan van een vaste verbinding tussen object en grondstuk leidt niet telkens tot een wezenlijke bestanddeelkwalificatie van het object. Objecten die op vaste wijze met het grondstuk zijn verenigd maar ingevolge $§ 95$ BGB als Schein-bestanddeel worden aangemerkt, worden niet als wezenlijk bestanddeel gekwalificeerd en worden niet door het grondstuk in eigendom nagetrokken. In $\$ 2.4$ wordt nader op het Schein-bestanddeel ingegaan.

65 Hk-BGB/Dörner 2012, §94 Rn 2. Wieling voegt hieraan toe dat de kosten van de verwijdering evenals bij $§ 93$ BGB onevenredig hoog dienen te zijn, maar dat het niet vereist is dat de kosten hoger zijn dan de waarde van het afgescheiden gedeelte. Zie: Wieling 2006, p. 85.

66 BFH 4 oktober 1978, NJW 1979, 392; LG Berlin 10 november 2003, NJW-RR 2004, 635. Zie: MünchKommBGB/Stresemann 2012, § 94 Rn 4. 
nodig zijn om het bouwwerk als gereed te kunnen beschouwen zijn wezenlijke bestanddelen van het bouwwerk en daarmee wezenlijke bestanddelen van het grondstuk wanneer het bouwwerk zijnerzijds wezenlijk bestanddeel van het grondstuk is. Uit het arrest van het Landesgericht Köln van 15 juni 1979 volgt dat voor het aanmerken van een wezenlijk bestanddeel in de zin van $\$ 94$ lid 2 BGB geen vaste verbinding vereist is. In dit arrest was de in het bouwwerk neergelegde vloerbedekking op maat gesneden en gelegd, maar niet verlijmd. Het Landesgericht stelt dat de wetgever met het tweede lid van $\S 94$ BGB heeft willen bereiken dat zowel aan het bouwwerk als aan haar bestanddelen met het oog op het rechtsverkeer eenzelfde rechtspositie toekomt. In het verlengde van deze rechtszekerheid dient de rechtsverhouding tussen het bouwwerk en haar bestanddelen ruim te worden uitgelegd. Zo volgt uit de volgende zin: "In allen Fällen, in denen ein Gebäude erkennbar ausschließlich zu ganz bestimmtem Zwecke gebaut ist, gehören diejenigen Einrichtungen, die nach der jetzigen Verkehranschauung in einem. Gebäude solcher Zweckbestimmung für erforderlich gehalten werden, zu den wesentlichen Bestandteilen, soweit sie der Konsument, z.B. der Käufer oder Mieter, vorzufinden erwartet. Sie sind zur Herstellung des Gebäudes eingefügt" ${ }^{67}$ Uit deze uitspraak volgt dat voor het aanmerken van een object als wezenlijk bestanddeel van een bouwwerk in de zin van $\S 94$ lid 2 BGB niet het criterium van $§ 93$ BGB geldt. $§ 93$ BGB stelt immers dat van een wezenlijk bestanddeel enkel sprake kan zijn wanneer afscheiding leidt tot beschadiging van een van beide zaken of tot wijziging van het wezen van de afgescheiden zaak. § 94 lid 2 BGB is dan ook een zelfstandige bepaling die los staat van $§$ 93 BGB. $^{68}$

\section{§2.2.1 Rechtsgevolgen: $§ 946$ en $§ 947$ BGB}

De rechtsgevolgen die intreden wanneer twee zaken een juridische eenheid vormen, zijn neergelegd in $\S 946$ en $\S 947$ BGB. Beide bepalingen zijn van dwingend recht hetgeen betekent dat afwijking door middel van een obligatoire overeenkomst niet mogelijk is. De rechtsgevolgen treden in ongeacht de wil van partijen. ${ }^{69}$

$\S 947$ BGB ziet op de rechtsgevolgen die intreden wanneer twee of meer bewegliche zaken een eenheidszaak vormen. Hierbij kunnen een tweetal situaties worden onderscheiden. Wanneer geen van de met elkaar verenigde objecten als hoofdzaak kan worden aangewezen, worden de eigenaren

67 LG Köln v. 15 juni 1979- 11 S 385/78.

68 Of zoals Wieling stelt: "Was nach $\$ 94$ I wesentlicher Bestandteil ist, kann es auch nach $§ 93$ sein, muß es aber nicht”. Zie: Wieling 2006, p. 84.

69 Staudinger/Wiegand 2011, § 946 Rn 10. 
van de verschillende objecten mede-eigenaar. ${ }^{70}$ Kan een van de met elkaar verenigde objecten wel als hoofdzaak worden aangemerkt, dan wordt de eigenaar van de hoofdzaak eveneens eigenaar van het met de hoofdzaak verenigde object. Of een van beide zaken als hoofdzaak kan worden aangemerkt, wordt aan de hand van de verkeersopvatting bepaald. Het al dan niet aanwijzen van een object als hoofdzaak is van belang voor de rechten die vóór de bestanddeelvorming op de zaak rustten. Bij het bestaan van een hoofdzaak zullen in beginsel alle rechten die op het object rustten dat als wezenlijk bestanddeel van de hoofdzaak kan worden angemerkt, tenietgaan op het moment van vereniging met de hoofdzaak. De rechten die op de hoofdzaak rusten, strekken zich uit over het wezenlijk bestanddeel. Wanneer er geen hoofdzaak valt aan te wijzen en nà de vereniging sprake is van mede-eigendom gaan de bestaande rechten ten gevolge van het samengaan van de verschillende bewegliche zaken teniet. Krachtens de wet ontstaan dan zogenoemde substitutierechten. ${ }^{71}$

$\S 946$ BGB stelt dat de eigendom van een grondstuk zich over een bewegliche zaak uitstrekt wanneer deze ten gevolge van het bestaan van een vaste verbinding met het grondstuk als wezenlijk bestanddeel ${ }^{72}$ van het grondstuk kan worden aangemerkt. ${ }^{73}$ De eigenaar van het grondstuk verkrijgt ingevolge de natrekking de eigendom van het met het grondstuk verenigde object. Uiteraard kan zich ook de situatie voordoen dat een roerende zaak met verschillende grondstukken wordt verenigd. Wie als eigenaar kan worden aangemerkt is afhankelijk van de vraag of het grensoverschrijdende gedeelte van het bouwwerk als Überbau (verder: overbouw) kan worden aangemerkt. Van overbouw is sprake wanneer het grensoverschrijdende gedeelte een wirtschaftliche und funktionale Einheit vormt met het bouwwerk dat zich op het grondstuk van de grondeigenaar die verantwoordelijk is voor het ontstaan van het grensoverschrijdende gedeelte, bevindt. ${ }^{74}$ Is van voornoemde eenheidsvorming tussen beide objecten geen sprake dan komt het grensoverschrijdende bouwwerk toe aan de eigenaar van het grondstuk waarmee het bouwwerk is verenigd. Vormen beide objecten wel een eenheid dan kunnen er een drietal situaties worden onderscheiden. ${ }^{75}$

$70 § 947$ Abs. 1 BGB. Een mede-eigenaar heeft een eigendomsrecht dat rust op een Bruchteil van de zaak. De bepalingen omtrent mede-eigendom zijn neergelegd in $\$ \S 1008-1011$ BGB.

$71 \$ 949$ BGB.

72 Hoofdstuk $2 \$ 2.2$.

73 Het Romeinsrechtelijke superficies solo cedit-beginsel komt in § 946 BGB tot uitdrukking. Zie: Staudinger/Wiegand 2004, § 946 Rn 4.

74 Of van een 'wirtschaftliche und funktionale Einheit' sprake is dient aan de hand van de verkeersopvatting te worden bepaald. Zie: BGH 15 februari 2008, NJW 2008, 1810; BGH 23 januari 2009, NJW 2009, 1791.

75 Hk-BGB/Staudinger 2012, § 912 Rn 1-4. 
Is de overbouw met toestemming van de eigenaar van het met de overbouw belaste grondstuk verwezenlijkt, dan dient de overbouw als wezenlijk bestanddeel van het bouwwerk te worden aangemerkt. De overbouw wordt dan met het bouwwerk nagetrokken en behoort toe aan de eigenaar van het grondstuk waarop het niet-grensoverschrijdende gedeelte is gelegen. ${ }^{76}$ Gevallen waarbij de overbouw zonder toestemming van de grondeigenaar wordt verwezenlijkt, kunnen worden onderscheiden in die gevallen waarbij de overbouw al dan niet met opzet of grove nalatigheid op of in het grondstuk van de ander is aangebracht. ${ }^{77}$ Bij opzet of grove nalatigheid wordt de overbouw wezenlijk bestanddeel van het grondstuk waarop of waarin de overbouw zich bevindt. Ondanks dat de overbouw met het niet-overbouw gedeelte van het bouwwerk een eenheid vormt, vindt verticale eigendomsdeling van het bouwwerk plaats op de kadastrale grens van beide bebouwde grondstukken. ${ }^{78}$ Wordt de overbouw gerealiseerd zonder dat van opzet of grove nalatigheid sprake is, dan dient de overbouw als Schein-bestanddeel te worden aangemerkt. Het Schein-bestanddeel komt dan toe aan de eigenaar van het grondstuk waarop of waarin het bouwwerk waarmee de overbouw een eenheid vormt zich bevindt. ${ }^{79}$

Ook bij het plaatsen van een grensafscheiding is sprake van vereniging van een roerende zaak met verschillende grondstukken. Een door menselijk

76 Of aan de eigenaar van het met de overbouw belaste grondstuk een vergoedingsrecht toekomt, is afhankelijk van hetgeen partijen zijn overeengekomen. In de literatuur wordt een overbouw die met toestemming van de grondeigenaar is verwezenlijkt, aangemerkt met de term 'berechtigter Überbau'.

77 Bij opzet of grove nalatigheid wordt in de literatuur de term 'rechtswidriger unentschuldiger Überbau' gebezigd; wanneer niet van opzet of grove nalatigheid spake is van 'rechtswidriger unentschuldiger Überbau'.

78 In de literatuur wordt opgemerkt dat in die situaties waarbij een overbouw zonder toestemming wordt gerealiseerd er een afweging dient te worden gemaakt tussen twee beginselen: het superficies solo cedit-beginsel enerzijds en de Bestandteilslehre anderzijds. Terwijl krachtens het superficies solo ceditbeginsel een op vaste wijze met het grondstuk verenigd object met het grondstuk in eigendom wordt nagetrokken, kan volgens de Bestandteilslehre aan een wezenlijk bestanddeel geen eigen goederenrechtelijke identiteit toekomen. Afhankelijk van het al dan niet aanwezig zijn van opzet of grove nalatigheid dient een belangenafweging tussen beide beginselen te worden gemaakt. Zie: Hk-BGB/Staudinger 2012, § 912 Rn 15-19.

79 De overbouw wordt naar analogie van $§ 95$ Abs. 1 tweede zin BGB als Scheinbestanddeel aangemerkt. De eigenaar van het met de overbouw belaste grondstuk dient de aanwezigheid van de overbouw op zijn grondstuk te dulden (§912 BGB). Zie ook: hoofdstuk 2 §3.4.2.1. 
handelen ${ }^{80}$ en met toestemming ${ }^{81}$ aangebrachte grensafscheiding behoort in gemeenschappelijk eigendom toe aan beide grondeigenaren. ${ }^{82}$ Heeft een van beide grondeigenaren geen toestemming verleend voor het aanbrengen van de grensafscheiding dan is voornoemde Überbau-regeling van toepassing.

\section{$\S 2.2 .2$ Een recht als bestanddeel van een grondstuk}

Hoewel wezenlijke bestanddelen van een grondstuk doorgaans lichamelijk van aard zijn, kunnen ook rechten als wezenlijk bestanddeel van het grondstuk worden aangemerkt. ${ }^{83}$ Dat een recht als wezenlijk bestanddeel van een grondstuk kan worden aangemerkt ${ }^{84}$, makt dat bij uitwinning van het grondstuk het recht eveneens voor uitwinning vatbaar is. ${ }^{85}$ Rechten die als wezenlijk bestanddeel van een grondstuk worden aangemerkt volgen evenals de 'gewone' (lichamelijke) wezenlijke bestanddelen de rechtspositie van het grondstuk. Zo strekken de op het grondstuk gevestigde rechten zich uit over het recht ${ }^{86}$ en leidt overdracht van het grondstuk eveneens tot overdracht van het recht. ${ }^{87}$ De rechten die onder de werking van $§ 96$ BGB vallen worden aangemerkt met de term 'subjektiv-dingliche' rechten.

Een erfdienstbaarheid die ten behoeve van het heersend erf wordt gevestigd zal krachtens $§ 96$ BGB door bestanddeelvorming verbonden zijn aan de eigendom van het heersend erf. Overdracht van het heersend erf leidt tot overdracht van de erfdienstbaarheid. Naast de erfdienstbaarheid ${ }^{88}$ kunnen

80 Een grensafscheiding hoeft niet per definitie door menselijk handelen te zijn gerealiseerd. Zo kan een riviertje of een rij struiken dienen ter afscheiding. Zie: Hk-BGB/Staudinger 2012, §921 Rn 1.

81 Het toestemmingsvereiste dient tevens ter rechtvaardiging voor de evenredige kostenverdeling van het onderhoud van de grensafscheiding ( $922 \mathrm{BGB}$ ).

82 Zie: Motive III 274; Staudinger/Roth 2009, § 921 Rn 16-18; RG 17 januari 1903, RGZ 53, 307, 312; RG 7 december 1939, RGZ 162, 209, 222. § 921 BGB veronderstelt een Gemeinschaftliche Benutzungsberechtigung ten aanzien van de grensafscheiding, inhoudende dat beide grondeigenaren van de grensafscheiding gebruik mogen maken. Zie: Hk-BGB/Staudinger 2012, § 921 Rn 1; MünchKommBGB/Säcker 2009, § 921 Rn 1-4; Staudinger/Roth 2009, § 921 Rn 9-10.

$83 § 96 \mathrm{BGB}$.

84 Dat een recht als wezenlijk bestanddeel van een grondstuk kan worden aangemerkt, is gebaseerd op een fictie. Zie: Wieling 2006, p. 77.

85 Hk-BGB/Dörner 2012, §96 Rn 1. Met deze fictie-regeling beoogt de wetgever hetzelfde resultaat te bereiken als onder het Nederlandse en Belgische rechtsstelsels met afhankelijke rechten wordt beoogd.

86 MünchKommBGB/Stresemann 2012, § 96 Rn 7.

87 Het recht kan als wezenlijk bestanddeel niet zelfstandig van het grondstuk worden overgedragen.

88 §1018 BGB. 
ook het Recht auf Duldung eines Überbau ${ }^{89}$, Notweg $^{90}$, dingliche Vorkaufsrechte $e^{91}$ en Rechte aus einer Reallast ${ }^{92}$ gekwalificeerd worden als subjektiv-dinglich recht wanneer deze rechten zijn gevestigd ten gunste van de eigenaar van het betreffende grondstuk qualitate qua. Ook de Erbbauzins ${ }^{93}$, zijnde de in ruil voor het verkregen opstalrecht overeengekomen vergoeding, kan op grond van $§ 96 \mathrm{BGB}$ als wezenlijk bestanddeel van het met het opstalrecht bezwaarde grondstuk worden aangemerkt.

\section{§2.2.3 Wohnungs- en Teileigentum}

Op de hoofdregel dat op een wezenlijk bestanddeel van een grondstuk geen zelfstandig, zakelijk recht kan rusten ${ }^{94}$ bestaan een tweetal uitzonderingen: het Wohnungseigentum en het Teileigentum. ${ }^{95}$ Het onderscheid tussen beide eigendomsvormen is gelegen in de bestemming die aan het wezenlijk bestanddeel waarop het nader te bespreken Sondereigentum komt te rusten, wordt toegekend. Bij Wohnungseigentum is het Sondereigentum ${ }^{96}$ gelegen op een abgeschlossen gedeelte van een gebouw dat voor bewoning bestemd is. Bij Teileigentum rust het Sondereigentum eveneens op een abgeschlossen gedeelte van een gebouw, maar is dit gedeelte, zoals bij een garage of kelder het geval is, niet voor bewoning bestemd. ${ }^{97}$

Voorafgaand aan de vestiging van een Wohnungseigentum ${ }^{98}$ bestaat er ten aanzien van het grondstuk Miteigentum, die ontstaan is middels een Teilungserklärung waardoor ieder van de gerechtigden een Miteigentumsanteil in het grondstuk verkrijgt. ${ }^{99}$ De Wohnungseigentum komt tot stand doordat de verschillende grondeigenaren een Aufteilungsvertrag opstellen die in het Grundbuch wordt ingeschreven. ${ }^{100}$ De strekking van deze overeenkomst is gelegen in het beperken van de bevoegdheden van de verschillende gerechtigden door het toekennen van Sondereigentum aan één gerechtigde

$\S 913$ Abs. 1 BGB.

$90 \$ 917$ Abs. 2 BGB.

$91 \$ 1094$ Abs. 2 BGB.

$92 \S 1105$ Abs. 2 BGB.

93 Hoofdstuk 2 \$3.2.2.

94 Staudinger/Jickeli/Stieper 2012, § 93 Rn 28-29.

95 Een Wohnungs- respectievelijk Teileigentum kan ook ten behoeve van nog te realiseren bouwwerken worden gevestigd.

96 De term 'Sondereigentum' wordt nader toegelicht in hoofdstuk 2 §3.3.2.

97 MünchKommBGB/Commichau 2009, § 1 WEG Rn 12-13.

98 Al hetgeen over het Wohnungseigentum wordt opmerkt is eveneens op het Teileigentum van toepassing. Zie: MünchKommBGB/Commichau 2009, § 1 WEG Rn 44-47.

99 MünchKommBGB/Commichau 2009, § 1 WEG Rn 33-39.

100 § 2 WEG jo. § 3 WEG. 
ten aanzien van een abgeschlossen gedeelte van het gebouw. ${ }^{101} \mathrm{De}$ in het Aufteilungsvertrag opgenomen beperkingen ten aanzien van het gemeenschappelijk gebruik hebben enkel op de abgeschlossen gedeelten van het gebouw betrekking; de gemeenschappelijke gedeelten van het gebouw behoren toe aan de verschillende gerechtigden gezamenlijk. ${ }^{102}$ Sondereigentum kenmerkt zich door het Alleineigentum van $§ 903$ BGB $^{103}$ en ontstaat door inschrijving van het Aufteilungsvertrag in het Grundbuch. ${ }^{104}$ Het Sondereigentum is accessoir aan het Wohnungseigentum en kan dus niet apart van het Wohnungseigentum worden bezwaard of overgedragen. ${ }^{105}$

\section{§2.3 Unwesentliche bestanddelen}

Door het bezigen van de term 'wesentliche Bestandteile'106 onderscheidt het BGB indirect ook 'unwesentliche Bestandteile'. ${ }^{107}$ Het BGB kent geen expliciete bepaling die toegespitst is op niet-wezenlijke bestanddelen. ${ }^{108}$ Nietwezenlijke bestanddelen zijn zaken die volgens $\$ 93$ en $§ 94$ BGB niet als wezenlijk bestanddeel kunnen worden aangemerkt en dan ook zonder schade of wezensverandering van de hoofdzaak kunnen worden afgescheiden. Bij afscheiding van het niet-wezenlijk bestanddeel wordt de hoofdzaak als incompleet gezien. ${ }^{109} \mathrm{Zo}$ is de motor van een auto aan te merken als een nietwezenlijk bestanddeel. ${ }^{110}$ Een niet-wezenlijk bestanddeel onderscheidt zich van een zelfstandige zaak doordat het niet-wezenlijk bestanddeel samen

$101 \S 3$ Abs. 2 WEG. Dit abgeschlossen gedeelte kan zowel op een horizontaal als op een verticaal gedeelte van het bouwwerk betrekking hebben.

102 MünchKommBGB/Commichau 2009, § 2 WEG Rn 3.

$103 \S 13$ Abs. 1 WEG waarin de bevoegdheden van de gerechtigde tot het Wohnungseigentum worden omschreven, sluit nauw aan bij de algemene eigendomsbepaling van $\S 903$ BGB. In hoofdstuk 2 3.3.2 wordt nader op $§ 903$ BGB ingegaan.

$104 \S 3$ WEG. In hoofdstuk 2 \$3.3.2 wordt nader op het Sondereigentum ingegaan.

105 Timme 2009, §1 Rn 7.

$106 \S 93$ en $\$ 94$ BGB. Zie: hoofdstuk 2 \$2.2.

107 In de literatuur wordt eveneens de term 'einfache' bestanddelen gebezigd.

108 Wieling 2006, p. 94.

109 Staudinger/Jickeli/Stieper 2012, § 93 Rn 39.

110 Wieling 2006, p. 94. De Bundesgerichtshof was in BGH 8 oktober 1955, NJW 1955, 1793 de volgende mening toegedaan: "Der in den Schlepper eingebaute Motor hat auch im Rechtssinne durch den Einbau seine frühere Eigenschaft als selbständige Sache verloren. Zwar ist die Verbindung mit dem Fahrgestell nach den vom BerGer. getroffen Feststellungen nur lose. Der Motor kann in kurzer Zeit ohne Schwierigkeit durch lösen weniger Schrauben ausgebaut werden. Dennoch ist er Bestandteil einer einheitlichen Sache geworden. [...] Der Motor ist durch den Einbau nur einfacher und nicht wesentlicher Bestandteil des Schleppers geworden". Zie ook: BGH 27 juni 1973, NJW 1973, 1454. 
met de hoofdzaak 'slechts' een zusammengesetzte zaak vormt; van juridische eenheidsvorming is geen sprake.

Aan een niet-wezenlijk bestanddeel komt een eigen goederenrechtelijke identiteit toe. Zo blijft een op het niet-wezenlijk bestanddeel rustend eigendomsvoorbehoud ook na de vereniging met de hoofdzaak bestaan. ${ }^{111}$ Deze zelfstandigheid wordt bij niet-wezenlijke bestanddelen niet zover doorgevoerd dat bij de overdracht van de hoofdzaak een separate overdracht van de niet-wezenlijke bestanddelen dient plaats te vinden. Met de overdracht van de zusammengesetzte zaak worden in beginsel ook de met deze hoofdzaak verbonden niet-wezenlijke bestanddelen overgedragen. ${ }^{112}$ Wanneer een niet-wezenlijk bestanddeel zonder toestemming van diens eigenaar met een aan een ander toebehorende roerende zaak wordt verenigd, kan de eigenaar van het niet-wezenlijk bestanddeel in beginsel teruggave vorderen. Dit is anders wanneer de hoofdzaak die met het aan een ander toebehorend nietwezenlijke bestanddeel is verenigd aan een derde wordt overgedragen: de verkrijger van de roerende zaak verkrijgt met de overdracht van de zaak tevens de eigendom van het niet-wezenlijke bestanddeel. ${ }^{113}$ Ook rechten van derden die op een niet-wezenlijk bestanddeel rusten, gaan met de overdracht aan een verkrijger te goeder trouw teniet. ${ }^{14}$ Wanneer de verkrijger niet te goeder trouw is op het moment van levering, dan wel wanneer sprake is van grove nalatigheid aan de zijde van de verkrijger, gaat de eigendom van het niet-wezenlijke bestandeel niet over op de verkrijger en blijven ook de op het niet-wezenlijke bestanddeel rustende rechten bestaan.

Onzeker is of niet-wezenlijke bestanddelen ten aanzien van een grondstuk kunnen bestaan. Uit de jurisprudentie volgt dat Teilflächen aan een grondstuk $^{115}$, schilderijen en wandkleden die middels een houtwerk aan de wanden van een kasteel zijn bevestigd en lambrisering die eveneens aan de wanden van een kasteel zijn bevestigd ${ }^{116}$ worden aangemerkt als niet-wezenlijke bestanddelen van een grondstuk. ${ }^{117}$ Jickeli en Stieper

111 Staudinger/Jickeli/Stieper 2012, § 93 Rn 42.

112 Aldus de analoge toepassing van $§ 926$ Abs. 1 BGB. Zie: Staudinger/Pfeifer $2011, \S 926 \mathrm{Rn} 6$. In hoofdstuk 2 \$2.5 wordt hier nader op ingegaan.

$113 \S 932$ Abs. 1 BGB.

$114 \$ 936$ Abs. 1 BGB.

115 BGH 3 maart 1956, N/W 1956, 945.

116 RG 14 november 1938, RGZ 158, 362, 369. Opmerkelijk is dat gelegde, maar niet verlijmde vloerbedekking volgens LG Köln, 15 juni 1979- 11 S 385/78 als wezenlijk bestanddeel dient te wordt aangemerkt, terwijl de lambrisering die evenals de vloerbedekking dient ter aankleding van het vertrek en zelfs op verstrekkendere wijze met het bouwwerk is verenigd in de jurisprudentie als niet-wezenlijk bestanddeel wordt gekwalificeerd. Zie: hoofdstuk 2 \$2.2.

117 Ten aanzien van de schilderijen, wandkleden en lambrisering kan worden 
weerleggen de niet-wezenlijke bestanddeelkwalificatie ten aanzien van voornoemde objecten. Volgens Jickeli en Stieper kunnen Teilflächen niet als niet-wezenlijke bestanddelen worden aangemerkt, omdat de horizontale afgrenzing en daarmee de horizontale eenheid van een grondstuk niet door de verkeersopvatting wordt bepaald; de horizontale eenheid van een grondstuk is in het Grundbuch vastgelegd. Met betrekking tot de lambrisering zijn Jickeli en Stieper van mening dat deze dient te worden gekwalificeerd als wezenlijk bestanddeel ${ }^{118}$, omdat de lambrisering behoort tot de inrichting van het vertrek. Hoewel Jickeli en Stieper opmerken dat schilderijen en wandkleden noch als wezenlijke noch als niet-wezenlijke bestanddelen kunnen worden aangemerkt, gaan zij niet in op de aan deze objecten wel toekomende kwalificatie. Al met al is het aanmerken van een object als nietwezenlijk bestanddeel van een grondstuk volgens Jickeli en Stieper zeer uitzonderlijk. ${ }^{119}$ Wieling is van mening dat $\S 94$ en $§ 95$ BGB in zijn geheel geen ruimte laten voor het bestaan van niet-wezenlijke bestanddelen ten aanzien van een grondstuk. ${ }^{120}$

\section{$\S 2.4$ Schein-bestanddelen}

Een object dat door middel van een vaste verbinding met het grondstuk is verenigd, dient in beginsel als wezenlijk bestandeel van het grondstuk te worden aangemerkt. ${ }^{121}$ In een tweetal door de wet geformuleerde gevallen wordt een object dat op vaste wijze met het grondstuk is verenigd niet als wezenlijk maar als Schein-bestanddeel aangemerkt. Een op vaste wijze met het grondstuk verenigd object wordt als Schein-bestanddeel aangemerkt wanneer 1) de tussen het object en het grondstuk bestaande vaste vereniging tijdelijk van aard is ${ }^{122}$ of 2) het object in de uitoefening van een zakelijk recht met het grondstuk is verenigd. ${ }^{123}$ Schein-bestanddelen behouden hun 'eigen' goederenrechtelijke identiteit en dienen te worden aangemerkt als roerend. ${ }^{124}$

gesteld dat deze objecten niet-wezenlijke bestanddelen zijn ingevolge indirecte vereniging.

118 In de zin van §94 Abs. 2 BGB.

119 Staudinger/Jickeli/Stieper 2012, § 93 Rn 40 en § 94 Rn 36.

120 Wieling 2006, p. 94.

121 §94 Abs. 1 BGB. Zie: hoofdstuk 2 \$2.2.

122 Krachtens $\$ 95$ BGB dient sprake te zijn van een vorübergehenden Zweck.

123 Deze uitzondering op de wezenlijke bestanddeelkwalificatie is niet alleen van toepassing op zaken die direct met het grondstuk zijn verenigd ( 995 lid 1 $\mathrm{BGB})$, maar ziet ook op zaken die op indirecte wijze middels een bouwwerk met het grondstuk zijn verenigd ( $\$ 95$ lid $2 \mathrm{BGB}$ ).

124 Het doel van $§ 95$ BGB is gelegen in behoud van de eigen goederenrechtelijke identiteit van het op vaste wijze met het grondstuk verenigde object. Zie: MünchKommBGB/Stresemann 2012, § 95 Rn 1. Een op het object rustend 
Een op vaste wijze met het grondstuk verenigd object kan als Scheinbestanddeel worden aangemerkt wanneer het object met vorübergehenden Zweck is verenigd. De (beoogde) duur van de vereniging speelt bij het bepalen of er al dan niet sprake is van een vorübergehenden Zweck geen enkele rol. ${ }^{125}$ Doorslaggevend is de naar buiten toe blijkende, uit de omstandigheden van het geval af te leiden wil van de aanbrenger het object tijdelijk met het grondstuk te verenigen. ${ }^{126}$

Doordat aan een Schein-bestanddeel een eigen goederenrechtelijke identiteit toekomt, kan het object aan een ander dan de eigenaar van de grond waarmee het object is verenigd toebehoren. ${ }^{127}$ Overdracht van het Scheinbestanddeel aan de grondeigenaar leidt niet tot omzetting van het Scheinbestanddeel in een wezenlijk bestanddeel. Immers kan ook de grondeigenaar tot doel hebben het object 'slechts' tijdelijk met het grondstuk te verenigen. Pas wanneer de grondeigenaar de intentie heeft het doel van de vereniging te wijzigen van tijdelijk naar duurzaam èn deze wijziging door derden uit de naar buiten toe kenbare omstandigheden kan worden afgeleid, kan het object als wezenlijk bestanddeel van het grondstuk worden aangemerkt. ${ }^{128}$ Het is niet mogelijk door middel van een wilsverklaring of door wijziging van de Zweckbestimmung ${ }^{129}$ een wezenlijk bestanddeel om te zetten in een

125 Dat de duur van de verbinding geen rol speelt bij het aanmerken van een object als Schein-bestanddeel volgt uit de volgende passage van de Bundesgerichtshof: "Dass der Mietvertrag im Jahr 1959 auf unbestimmte Zeit abgeschlossen wurde, spielt daher für die frage, ob eine dauerhafte oder vorübergehende Verbindung mit dem Grund und Bodem gewollt war, ebenso wenig eine Rolle wie die Bauweise der Lagerhalle. Von einem auf Dauer mit dem Grundstück verbundenen Bauwerk ist in diesen Fällen vielmehr nur dann auszugehen, wenn sich aus den Vereinbarungen der Parteien oder aus den sonstigen Umständen ergibt, dass der Erbauer bei der Errichtung des Baus den Willen hat, das Bauwerk bei Beendigung des Vertragsverhältnisses in das Eigentum seines Vertragspartners übergehen zu lassen”. Zie: BGH 26 november 1999, NJW 2000, 1031. Zie ook: BGH 27 mei 1959, NJW 1959, 1487.

126 MünchKommBGB/Stresemann 2012, § 95 Rn 3.

127 BGH 12 mei 1976, NJW 1976, 1539.

128 MünchKommBGB/Stresemann 2012, § 95 Rn 13-17; Staudinger/Jickeli/Stieper 2012, § 95 Rn 14.

129 De Bundesgerichtshof stelde in BGH 11 juli 1962, NJW 1962, 1817: "Im vorliegenden Fall waren die Gas- und Wasserleitungen, soweit sie innerhalb des Ruhrschnellweges verliefen, bis zum 24.5.1949 wesentliche Bestandteile des Straßengrundstückes. Ihre Bestandteilseigenschaft ergab sich aus der festen Verbindung mit dem Grund und Boden i.S. von $\$ 94$ Abs. 1 Satz 1 BGB, ohne daß bislang einer der Ausnahmetatbestände des $\S 95$ Abs. 1 BGB vorgelegen hatte; die 
Schein-bestanddeel. ${ }^{130}$ Enkel door feitelijke afscheiding van het wezenlijke bestanddeel van het grondstuk kan aan het wezenlijke bestanddeel een eigen goederenrechtelijke identiteit toekomen. ${ }^{131}$

Bouwwerken die door een gerechtigde op of in een aan een ander toebehorend grondstuk worden aangebracht in de uitoefening van een aan hem toekomend zakelijk recht kunnen eveneens als Schein-bestanddeel worden aangemerkt. ${ }^{132} \mathrm{Bij}$ de verwezenlijking van het bouwwerk ten behoeve van de uitoefening van een beperkt zakelijk recht is een naar buiten toe kenbare intentie om het bouwwerk slechts tijdelijk met het grondstuk te verenigen niet vereist voor het aanmerken van het bouwwerk als Scheinbestanddeel. Het bestaan van het zakelijke recht rechtvaardigt het vermoeden dat het bouwwerk ten behoeve van de uitoefening van het zakelijke recht is gerealiseerd. Dit vermoeden kan worden weerlegd. ${ }^{133}$

Wanneer de gerechtigde tot het zakelijke recht ${ }^{134}$ het grondstuk dat met het zakelijke recht is bezwaard verkrijgt of, anderzijds, wanneer de eigenaar van het grondstuk tevens gerechtigde van het op zijn grondstuk rustend zakelijke recht wordt ${ }^{135}$, heeft dit geen gevolgen voor de rechtspositie van het Schein-bestanddeel. Anders dan onder het Nederlandse, Belgische en Schotse recht het geval is, treedt onder het Duitse recht geen vermenging van zakelijke rechten op. ${ }^{136}$ Ook het tenietgaan van het zakelijke recht heeft in beginsel geen invloed op de rechtspositie van het Schein-bestanddeel. ${ }^{137}$ Het Schein-bestanddeel blijft een zelfstandige zaak waarop een eigen

Bekl. war, als sie seinerzeit die Leitungen erstellte, Grundstückseigentümerin und handelte weder zu einem vorübergehenden Zweck noch in Ausübung eines Rechts am fremden Grundstück. Eine nachträgliche Änderung der Zweckbestimmung, wie sie möglicherweise in dem Übergang des Straßeneigentums auf die Kl. zu erblicken wäre, vermochte für sich allein die Bestandteilseigenschaft ebenfalls nicht aufzuheben: ...”.

131 Uit BGH 2 december 2005, NJW 2006, 990 volgt: "Eine in einem Straßengrundstück verlegte Versorgungsleitung kann nach denselben Grundsätzen zum Scheinbestandteil bestimmt und auf den neuen Versorgungsträger übereignet werden, nach denen ein Scheinbestandteil nach $\$ 951$ BGB wesentlicher Bestandteil eines Grundstücks werden kann. Hierfür bedarf es eines nach außen in Erscheinung tretenden Willens des Eigentümers des Scheinbestandteils, dass die Verbindung nunmehr auf Dauer gewollt ist".

132 Naast de zakelijke gebruiksrechten kunnen ook een Grunddienstbarkeit, een persönliche beschränkte Dienstbarkeit of een Nießbrauch aan de werking van § 95 Abs. 1 tweede zin BGB ten grondslag liggen.

133 MünchKommBGB/Stresemann 2012, § 95 Rn 22; Wieling 2006, p. 92.

134 In de zin van $\$ 95$ Abs. 1 tweede zin BGB.

135 Bijvoorbeeld door Heimfall. Zie: hoofdstuk 2 \$3.2.1.

136 Op grond van $\S 889$ BGB wordt vermenging van het eigendomsrecht met het zakelijke recht voorkomen. Zie: noot 214.

137 Staudinger/Jickeli/Stieper 2012, § 95 Rn 23. 
eigendomsrecht rust dat aan de voormalig gerechtigde tot het zakelijke recht toekomt. De voormalig gerechtigde is ingevolge het eigendomsrecht dat op het Schein-bestanddeel rust bevoegd deze weg te nemen. ${ }^{138}$

\section{$\S 2.5$ Zubehör}

Zubehör kenmerken zich door hun fysieke zelfstandigheid ${ }^{139}$ en kunnen anders dan voornoemde wezenlijke, niet-wezenlijke en Schein-bestanddelen niet als bestanddeel worden aangemerkt. Hoewel toebehoren niet als bestanddeelvan het grondstuk kunnen worden aangemerkt, gaan toebehoren bij overdracht van het grondstuk in beginsel wel over op de verkrijger van het grondstuk wanneer de toebehoren en het grondstuk aan dezelfde vervreemder in eigendom toekomen. Een aparte eigendomsoverdracht van de toebehoren is niet nodig. ${ }^{140}$ Wanneer de toebehoren niet aan de grondeigenaar in eigendom toekomen maar de verkrijger hier redelijkerwijs wel van mag uitgaan, dan gaan de toebehoren toch in eigendom mee over op de verkrijger. ${ }^{141}$

Enkel roerende zaken kunnen als toebehoor worden gekwalificeerd. ${ }^{142}$ Hoewel een grondstuk niet als toebehoor kan worden aangemerkt ${ }^{143}$, kan een grondstuk evenals roerende zaken en grundstücksgleiche rechten ${ }^{144}$ wel toebehoren hebben. ${ }^{145}$ Een object kan in zijn hoedanigheid als toebehoor meerdere zaken dienen, zoals het geval is bij landbouwmachines die ingezet worden bij de bewerking van verschillende grondstukken. Hierbij is het niet van belang of deze verschillende grondstukken toebehoren aan één of meerdere eigenaren. Anders dan onder het Belgische en Schotse recht, kunnen objecten ook als Zubehör van een grondstuk worden aangemerkt wanneer zij aan een ander dan de grondeigenaar toebehoren. ${ }^{146}$

138 Hetgeen volgt uit $§ 951$ Abs. 2 tweede zin BGB. Zie: Wieling 2006, p. 93. Wanneer het opstalrecht teniet gaat wordt het bouwwerk ten gunste waarvan het opstalrecht is gevestigd (weer) wezenlijk bestanddeel van het grondstuk ( $\S$ 12 Abs. 3 ErbbauRG). Zie: hoofdstuk 2 §3.5.2.

139 §97 BGB. Zie: MünchKommBGB/Stresemann 2012, § 97 Rn 2 en 6.

140 § 926 BGB. Zie: Staudinger/Jickeli/Stieper 2012, § 97 Rn 31; Staudinger/ Pfeifer 2011, §926 Rn 2.

141 §932 jo. §926 Abs. 2 BGB. Zie: Staudinger/Jickeli/Stieper 2012, §97 Rn 31.

142 §97 Abs. 1 BGB: "Zubehör sind bewegliche Sachen, ...".

143 Wieling 2006, p. 93.

144 Zoals das Erbbaurecht, das Wohnungseigentum of ein auf Landesrecht beruhendes Bergwerkseigentum.

145 MünchKommBGB/Stresemann 2012, § 97 Rn 8; Staudinger/Jickeli/Stieper 2012, § 97 Rn 6; Wieling 2006, p. 93.

146 Staudinger/Jickeli/Stieper 2012, § 97 Rn 6. 
Naast het gegeven dat enkel roerende zaken als toebehoor kunnen worden aangemerkt, stelt $\$ 97$ BGB nog een drietal voorwaarden aan het karakteriseren van een zaak als toebehoor. Ten eerste kan een object dat als wezenlijk bestanddeel wordt aangemerkt ten aanzien van een andere zaak niet als toebehoor worden gekwalificeerd. ${ }^{147}$ De tweede voorwaarde ziet op de relatie tussen toebehoor en hoofdzaak: de toebehoor dient "dem wirtschaftlichen Zwecke der Hauptsache zu dienen". ${ }^{148}$ Of aan deze voorwaarde wordt voldaan dient aan de hand van de verkeersopvatting te worden beoordeeld. ${ }^{149}$ Een zaak dient de hoofdzaak wanneer zij bijdraagt aan het bereiken van het doel van de hoofdzaak. ${ }^{150}$ Ook zaken die door gebruik worden verbruikt ${ }^{151}$ kunnen als toebehoor worden aangemerkt. ${ }^{152}$ Het tweede lid van $\$ 97$ BGB sluit een Zubehör-kwalificatie uit wanneer het gebruik van de zaak ten behoeve van het door de hoofdzaak dienend doel slechts tijdelijk van aard is. ${ }^{153}$ Hierin is een essentieel verschil tussen Zubehör en Schein-bestanddelen gelegen. Terwijl een object enkel als Scheinbestanddeel kan worden aangemerkt wanneer het object met vorübergehender Zweck met het grondstuk is verenigd ${ }^{154}$, althans voor zover de zaak niet ten behoeve van de uitoefening van een zakelijk recht met het grondstuk wordt verenigd, kan een object enkel als toebehoor worden aangemerkt wanneer er een dauerende Zweckbestimmung ten aanzien van de hoofdzaak bestaat. ${ }^{155}$ De laatste Zubehör-voorwaarde is gelegen in de feitelijke indienststelling van de toebehoor ten behoeve van de grond. ${ }^{156}$ Dit betekent niet dat de toebehoor zich op het grondstuk dient te bevinden of dat de daadwerkelijke indienststelling reeds dient te hebben plaatsgevonden. Voldoende is dat het object gereed is om ingezet te worden ten behoeve van de hoofdzaak wanneer het doel van de hoofdzaak dit vergt. ${ }^{157}$

147 Onzeker is of een niet-wezenlijk bestanddeel ten aanzien van een andere hoofdzaak toebehoor kan zijn. Zie: Staudinger/Jickeli/Stieper 2012, § 97 Rn 5.

$148 \S 97$ Abs. 1 BGB.

149 Wieling 2006, p. 93.

150 Uit de relatie tussen toebehoor en hoofdzaak vloeit de afhankelijkheidsverhouding tussen beide. Zie: MünchKommBGB/Stresemann 2012, § 97 Rn 15-18; Staudinger/Jickeli/Stieper 2012, § 97 Rn 14.

$151 \S 92$ Abs. 1 BGB.

152 Zoals het geval is bij kolen die verbruikt worden voor het functioneren van een fabriek. Zie: MünchKommBGB/Stresemann 2012, § 97 Rn 17-18.

153 Zo volgt uit $\S 97$ Abs. 2 BGB eerste zin. Een vorübergehende Benutzungs-intentie wordt vermoed te bestaan in het geval van huur en pacht. Zie: Staudinger/ Jickeli/Stieper 2012, § 97 Rn 19.

154 Hoofdstuk $2 \$ 2.4$.

155 Staudinger/Jickeli/Stieper 2012, § 95 Rn 27.

156 Staudinger/Jickeli/Stieper 2012, § 97 Rn 22.

157 RG 26 januari 1901, RGZ 47, 197, 200 alsook RG 15 september 1903, RGZ 55, 281, 285. Zie ook: MünchKommBGB/Stresemann 2012, § 97 Rn 20. 
Naast de hierboven besproken algemene Zubehör-bepaling, kent het BGB ook een lex specialis. ${ }^{158}$ Deze bepaling beoogt de toebehoor-kwalificatie in specifieke gevallen te waarborgen. ${ }^{159}$ "Dem wirtschaftlichen Zwecke der Hauptsache zu dienen" wordt vermoed aanwezig te zijn bij objecten die gebruikt worden voor de inrichting van een gebouw dat voor commerciële doeleinden wordt geëxploiteerd, als bij objecten die ingezet worden bij de uitoefening van een landbouw- of veebedrijf. ${ }^{160}$

\section{§3. Das Erbbaurecht}

\section{§3.1 Kenmerken van het Erbbaurecht}

Uit $\$ 1$ Abs. 1 ErbbauRG volgt dat het opstalrecht kan worden gekwalificeerd als een beperkt zakelijk recht op grond waarvan aan de gerechtigde tot het recht, de opstaller, de bevoegdheid toekomt een of meerdere bouwwerken te hebben in of op het grondstuk van een ander voor de duur waarvoor het opstalrecht is gevestigd. ${ }^{161}$ Het opstalrecht kan worden gevestigd ten gunste van bouwwerken die ten tijde van de vestiging reeds bestaan, de zogenoemde 'oude' bouwwerken, als ten aanzien van nog te verwezenlijken bouwwerken, de zogenoemde 'nieuwe' bouwwerken.

De bouwwerken ten gunste waarvan het opstalrecht wordt gevestigd, dienen met voldoende bepaalbaarheid in de vestigingsovereenkomst ${ }^{162}$ te worden omschreven. ${ }^{163}$ Hieraan wordt voldaan wanneer het aantal bouwwerken alsook de hoedanigheid van de bouwwerken in de vestigingsovereenkomst worden vermeld. ${ }^{164}$ Het staat partijen vrij te bepalen ten gunste van welke in of op het grondstuk bevindende bouwwerken het opstalrecht wordt gevestigd. Een opstalrecht kan in beginsel enkel ten aanzien van het gehele bouwwerk dat zich in of op het grondstuk bevindt of gaat bevinden, worden gevestigd. ${ }^{165}$ De bouwwerken die onderwerp

$158 \S 98 \mathrm{BGB}$.

159 MünchKommBGB/Stresemann 2012, § 98 Rn 1 en 2.

160 Aanhef $\$ 98$ BGB.

$161 \S 1$ Abs. 1 ErbbauRG. Voor het ontstaan van een opstalrecht is het vereist dat in de vestigingsovereenkomst wordt opgenomen dat aan de opstaller het recht toekomt een of meerdere bouwwerken op of in het grondstuk van een ander te hebben. Zie: MünchKommBGB/Von Oefele 2009, § 1 Rn 8; Staudinger/Rapp 2009, § 1 Rn 9.

162 In $\$ 3.2$ van dit hoofdstuk wordt nader op de vestigingsovereenkomst ingegaan.

$163 \S 53$ Abs. 1 GBO.

164 Bij invulling van de hoedanigheid van het bouwwerk kan gedacht worden aan een woonhuis, garage, etc. Zie: MünchKommBGB/Von Oefele 2009, § 1 Rn 14; Von Oefele \& Winkler 2008, Rn 2.22. Het bepaalbaarheidsvereiste wordt veelal aangeduid met de term 'Bestimmtheidserfordernisses'.

$165 \S 1$ Abs. 3 ErbbauRG. De uitzondering op deze hoofdregel wordt in $\$ 3.3 .1$ en 
van recht zijn, de opstallen, komen volgens de heersende leer in eigendom toe aan de opstaller. Het eigendomsrecht dat op deze opstallen rust wordt aangeduid met de term 'Sondereigentum'. ${ }^{166} \mathrm{Nu}$ aan deze bouwwerken een eigen goederenrechtelijke identiteit toekomt, ondanks de aanwezigheid van een vaste verbinding met het grondstuk, kunnen deze bouwwerken niet langer als wezenlijk bestanddeel van het grondstuk worden aangemerkt. ${ }^{167}$

De aan de opstaller toekomende bevoegdheden hoeven niet beperkt te zijn tot het eigendomsrecht dat volgens de heersende leer op de opstallen komt te rusten. Het staat partijen vrij in het Erbbaurechtsvertrag, de overeenkomst die aan het opstalrecht ten grondslag ligt, nadere rechten en plichten op te nemen. ${ }^{168}$ Zo kan aan de opstaller een gebruiksrecht toekomen ten aanzien van het grondstuk dat met het opstalrecht is bezwaard. ${ }^{169}$ Door aan de opstaller een gebruiksrecht toe te kennen wordt voorkomen dat naast de vestiging van het opstalrecht een erfdienstbaarheid ten behoeve van de opstaller dient te worden gevestigd. ${ }^{170}$

Een opstalrecht kan zowel tijdelijk als eeuwigdurend van aard zijn. Anders dan onder het Belgische recht het geval is, geeft het Erbbaurechtgesetz ${ }^{171}$ (verder: ErbbauRG) geen maximumtermijn waarvoor een opstalrecht kan worden gevestigd. Partijen kunnen in de vestigingsovereenkomst het voortbestaan van het opstalrecht 'koppelen' aan de in de vestigingsovereenkomst opgenomen en aan het bouwwerk toegekende bestemming. ${ }^{172}$ De duur van het opstalrecht kan eveneens aan de levensduur

\$3.4.2.1 van dit hoofdstuk besproken.

167 Von Oefele \& Winkler 2008, Rn 2.31.

168 Hoofdstuk $2 \S 3.2$.

$169 \S 1$ Abs. 2 ErbbauRG. In de literatuur wordt doorgaans de term 'Nutzungsrecht' gebezigd. Zie: hoofdstuk 2 \$3.4.1.

170 Tot aan de invoer van de Erbbaurechtsverordnung in 1919 (de voorloper van het ErbbauRG) was het noodzakelijk ten behoeve van de opstaller naast de vestiging van het opstalrecht een erfdienstbaarheid te vestigen voor het gebruik van het grondstuk. Zie: Von Oefele \& Winkler 2008, Rn 2.68.

171 Het Erbbaurecht is sinds 15 januari 1919 in de bijzondere wet 'Verordnung über das Erbbaurecht' (verder: ErbbauVO) geregeld. Deze wet is voortgekomen uit de politieke behoefte een oplossing te bieden voor de toentertijd bestaande woningnood en de stijgende grondprijzen. Met de invoering van het ErbbauVO zijn de bepalingen $\S \S 1012-1017$ van het Bürgerliches Gesetzbuch (verder: $\mathrm{BGB}$ ) komen te vervallen. Deze bepalingen blijven wel van toepassing op die opstalrechten die vóór de inwerkingtreding van de ErbbauVO tot stand zijn gekomen. Zie: $§ 38$ ErbbauRG. Sinds de invoering in 1919 is de ErbbauVO verschillende malen aangepast. Met de wijzigingen van 2008 is de benaming van de wet gewijzigd in 'Gesetz über das Erbbaurecht' (verder: ErbbauRG).

172 Partijen kunnen overeenkomen dat bij wijziging van de bestemming -aan een bouwwerk kan bijvoorbeeld de bestemming museum of school worden 
van het bouwwerk worden gekoppeld. ${ }^{173}$ Het is derhalve niet mogelijk de bestaansduur van het opstalrecht te koppelen aan het leven van grondeigenaar of opstaller. ${ }^{174}$

Doordat het opstalrecht door het ErbbauRG wordt aangemerkt als een 'grundeigentumsgleiches Recht'175 zijn op het opstalrecht in beginsel de bepalingen die betrekking hebben op grondstukken van overeenkomstige toepassing. ${ }^{176}$ Gelijkstelling van het opstalrecht aan een grondstuk heeft tot gevolg dat het opstalrecht als een onroerende zaak dient te worden benaderd, waardoor het mogelijk is subjectiv-dingliche rechten als wezenlijk bestanddeel van het opstalrecht aan te merken. ${ }^{177}$ Tevens kan een opstalrecht Zubehör hebben ${ }^{178}$ en kan een opstalrecht met beperkt zakelijke rechten worden bezwaard. ${ }^{179}$

$\S 10$ ErbbauRG stelt dat aan het opstalrecht de erste Rangstelle (vrij vertaald: eerste rang) dient toe te komen. ${ }^{180}$ Door aan het opstalrecht de eerste rang toe te kennen kan de opstaller ongestoord van zijn opstalrecht genieten. ${ }^{181}$

toegekend- het opstalrecht ophoudt te bestaan. Von Oefele \& Winkler 2008, Rn 2.42-2.49.

173 Staudinger/Rapp 2009, § 1 Rn 30.

174 Ingenstau 1987, § 1 Rn 54-55. Zie: hoofdstuk 2 §3.2.1.

$175 \S 11$ Abs. 1 ErbbauRG. Ook bepalingen die voortkomen uit 'bundes- und landesrechtlichen Vorschriften' en betrekking hebben op grondstukken zijn op het opstalrecht van toepassing. Zie: Staudinger/Rapp 2009, § 11 Rn 4. In de literatuur wordt eveneens de term 'juristisches Grundstück' gebezigd. Zie: Brehm \& Berger 2006, § 24 Rn 6 .

176 Tenzij hiervan uitdrukkelijk door het ErbbauRG wordt afgeweken. Zie: Staudinger/Rapp 2009, § 11 Rn 2.

177 Hoofdstuk 2 \$2.2.2.

178 Ingenstau 1987, § $11 \mathrm{Rn} 24$. Zie ook: hoofdstuk 2 \$2.5.

179 Volgens de heersende leer is $\$ 890$ BGB eveneens op het opstalrecht van toepassing. Krachtens het eerste lid van deze bepaling kunnen grondstukken met elkaar worden verenigd dan wel kan het ene grondstuk bestanddeel worden van het andere grondstuk. Toepassing van deze bepaling leidt ertoe dat ook opstalrechten met elkaar kunnen worden verenigd en dat het ene opstalrecht bestanddeel kan worden van het andere opstalrecht. Tevens kan een opstalrecht bestanddeel worden van een grondstuk en een grondstuk bestanddeel van een opstalrecht. Zie: Ingenstau 1987, § 11 Rn 26-27.

180 Deze bepaling is van dwingend recht. Bedingen die van $\$ 10$ ErbbauRG afwijken zijn nietig. Enkel op grond van een landesrechtliche Verordnung kan van deze erste Rangstelle worden afgeweken, aldus $§ 10$ Abs. 2 ErbbauRG. Zie: Staudinger/ Rapp 2009, § 10 Rn 1-4.

$181 \S 879 \mathrm{BGB}$ regelt de rangverhouding tussen de verschillende zakelijke rechten die op een grondstuk zijn gevestigd. De rang die aan een bepaald recht toekomt is van essentieel belang voor het bepalen van de waarde van het recht. Ook speelt deze Rangstelle een belangrijke rol bij executoriale verkoop. Zie: HkBGB/Staudinger 2012, § 879 Rn 1-2. 
Deze eerste rang dient aan het opstalrecht toe te komen op het moment van inschrijving in het Grundbuch. ${ }^{182}$ Wanneer een opstalrecht wordt gevestigd op een reeds bezwaard grondstuk dient Rangänderung plaats te vinden, zodat aan het opstalrecht alsnog de eerste rang toekomt. Rangwisseling vindt plaats ingevolge een overeenkomst strekkende tot rangwisseling welke samen met de vestigingsovereenkomst in het Grundbuch wordt ingeschreven. ${ }^{183}$ Deze overeenkomst wordt gesloten door de gerechtigde tot het reeds op het grondstuk rustend zakelijke recht ${ }^{184}$ en de toekomstig opstaller. ${ }^{185} \S 10$ ErbbauRG staat eraan in de weg dat beperkte rechten die kunnen leiden tot het verlies van de eerste rang van het opstalrecht in het Grundbuch worden ingeschreven. Mocht desondanks een zakelijk recht in het Grundbuch zijn ingeschreven waardoor de aan het opstalrecht toekomende eerste rang in het geding komt, dan dient de inschrijving ambtshalve te worden verwijderd. ${ }^{186} \mathrm{Het}$ is niet mogelijk een grondstuk met verschillende opstalrechten te bezwaren, aangezien met de vestiging van het opstalrecht het grondstuk in zijn geheel wordt belast en het niet mogelijk is aan de verschillende opstalrechten alle de eerste rang toe te kennen. ${ }^{187}$ Het 'eerste rang'-vereiste staat het bezwaren van een opstalrecht met een opstalrecht niet in de weg. ${ }^{188}$

Het zakelijke karakter van het opstalrecht brengt mee dat het recht vatbaar is voor overdracht en bezwaring. Aan een in de vestigingsovereenkomst opgenomen onvervreemdbaarheidsbeding komt geen zakelijke maar 'enkel'

182 Het is voor de vestiging niet van belang welke rang aan het opstalrecht toekomt ten tijde van de totstandkoming van de vestigingsovereenkomst. Zie: Ingenstau 1987, § 10 Rn 3; Staudinger/Rapp 2009, § 10 Rn 5.

$183 \S 873$ Abs. 2 BGB. De rang van het opstalrecht kan niet op een later moment worden bepaald. Hiermee wordt afgeweken van $§ 880$ BGB dat Rangänderung (rangwisseling) gedurende het bestaan van het beperkte recht toestaat. Zie: Staudinger/Rapp 2009, § 10 Rn 3.

184 In de literatuur wordt dit in rang wisselend recht aangeduid als 'zurücktretende Recht'.

$185 \S 880$ Abs. 2 BGB.

$186 § 53$ Abs. 1 GBO. Ook de te goeder trouw zijnde gerechtigde van het later ingeschreven beperkte recht waaraan rechtens de eerste rang toekomt, wordt niet beschermd. Zie: Staudinger/Rapp 2009, § 10 Rn 6. Volledigheidshalve dient te worden opgemerkt dat vestiging van een zakelijk recht op een grondstuk nà vestiging van een opstalrecht wel degelijk mogelijk is, zolang met de vestiging van dit zakelijk recht de eerste rang van het opstalrecht niet in gevaar wordt gebracht. Zie: Staudinger/Rapp 2009, § 10 Rn 7.

187 Het is dan ook niet mogelijk een of meerdere opstalrechten op verschillende gedeelten van het grondstuk te vestigen. Zie: MünchKommBGB/Von Oefele 2009, § 1 Rn 37; Schöner \& Stöber 2008, Rn 1700. Zie: hoofdstuk 2 §3.4.1.

188 Hoofdstuk 2 \$3.5.1.1. 
verbintenisrechtelijke werking toe. ${ }^{189}$ Aan een in de vestigingsovereenkomst opgenomen beding dat ziet op de beperking van de overdraagbaarheid respectievelijk bezwaring van het opstalrecht kan daarentegen wel zakelijke werking worden toegekend. ${ }^{190}$ Partijen kunnen in de vestigingsovereenkomst overeenkomen dat het opstalrecht enkel met toestemming van de grondeigenaar kan worden overgedragen of dat overdracht enkel kan geschieden ten gunste van een derde die zich binnen een bepaalde kring van personen bevindt. ${ }^{191}$ Een beding mag niet zo nauw worden geformuleerd dat vervreemding vrijwel onmogelijk is. Beperkingen van algemene aard alsook tijdsgebonden beperkingen zijn niet toegestaan. ${ }^{192}$

\section{$\S 3.2$ Het Erbbaurechtsvertrag}

Een opstalrecht komt tot stand door inschrijving van het Erbbaurechtsvertrag (verder: vestigingovereenkomst) in het Grundbuch. ${ }^{193}$ De vestigingsovereenkomst bestaat uit een tweetal elementen. Het eerste element kan worden aangeduid met de term 'Inhalt des Erbbaurechts', het tweede element met de term 'Gegenleistung für das Erbbaurecht'. Tot de Inhalt des Erbbaurechts behoort ten eerste het essentiële element voor het doen ontstaan van een opstalrecht ${ }^{194}$ : het recht een of meerdere bouwwerken op of in het grondstuk van een ander te hebben. ${ }^{195}$ Dit essentiële element behoort tot de gesetzliche Inhalt waaraan per definitie zakelijke werking toekomt. De in de vestigingsovereenkomst opgenomen bepalingen die zien op de nadere uitwerking van de aan de opstaller toekomende bevoegdheden ten aanzien van de opstallen, worden eveneens tot de gesetzliche Inhalt van de vestigingsovereenkomst gerekend. ${ }^{196}$ Tevens behoren de bepalingen omtrent het aan de opstaller toekomende gebruiksrecht ${ }^{197}$ alsook de bepalingen ten

189 Wanneer een opstalrecht ondanks het tussen partijen overeengekomen onoverdraagbaarheidsbeding wordt overgedragen, dan heeft dit tot gevolg dat de verveemder jegens de grondeigenaar schadeplichtig is. Zie: Böttcher 2006, Rn 68; Ingenstau 1987, § 1 Rn 46.

190 Bij het beperken van de vervreemdbaarheid en de bezwaring van het opstalrecht dienen $§ \S 5-8$ ErbbauRG in acht te worden genomen. Zie: hoofdstuk 2 \$3.2.1.

191 Staudinger/Rapp 2009, § 1 Rn 25.

192 Een tijdsgebonden beperking dient niet te worden verward met een opstalrecht dat voor bepaalde tijd wordt gevestigd.

$193 \S 14$ ErbbauRG jo. $\$ 873$ BGB.

194 Voor de totstandkoming van een opstalrecht is het vereist dat ingevolge de vestigingsovereenkomst aan de opstaller het recht wordt toegekend een of meerdere opstallen te hebben op of in het grondstuk van een ander. Zie: MünchKommBGB/Von Oefele 2009, § 1 Rn 8.

$195 \S 1$ lid 1 ErbbauRG. Uit het derde lid volgt dat het opstalrecht enkel ten gunste van het gehele bouwwerk kan worden gevestigd. Zie: hoofdstuk $2 \S 3.3$.

196 Hoofdstuk $2 \$ 3.3$.

$197 \$ 1$ lid 2 ErbbauRG. Dit gebruiksrecht dient ondergeschikt te zijn aan het recht 
aanzien van de duur waarvoor het opstalrecht wordt gevestigd ${ }^{198}$ tot de gesetzliche Inhalt.

Bepalingen die in de vestigingsovereenkomst zijn opgenomen maar niet tot voornoemde gesetzliche Inhalt kunnen worden gerekend ${ }^{199}$, zijn in beginsel enkel bindend voor de bij de totstandkoming van de vestigingsovereenkomst betrokken partijen. ${ }^{200}$ Enkel aan de rechten en plichten die onder $\S 2-8, \S 27$ Abs. 1 en $\S 32$ Abs. 1 ErbbauRG kunnen worden geschaard ${ }^{201}$, komt zakelijke werking toe ${ }^{202}$; deze rechten en plichten behoren tot de vertragsmäßige Inhalt van de vestigingsovereenkomst. Met het toekennen van zakelijke werking aan deze rechten en plichten tracht de wetgever de rechtspositie van partijen en diens rechtsopvolgers te waarborgen, aangezien het opstalrecht doorgaans voor langere duur wordt gevestigd. ${ }^{203}$ Rechten en plichten waaraan geen zakelijke werking toekomt, worden aangeduid met de term 'ergänzendeschuldrechtlicheVereinbarungen'. ${ }^{204}$

Het tweede element van de vestigingsovereenkomst, de zogenoemde 'Gegenleisting für das Erbbaurecht', heeft betrekking op de door de opstaller te leveren tegenprestatie voor het aan hem toekomende recht van opstal. Deze tegenprestatie bestaat doorgaans uit het betalen van een vergoeding, de Erbbauzins. ${ }^{205}$

bouwwerken op of in het grondstuk van een ander te hebben. Zie: hoofdstuk 2 $\$ 3.4$.

198 Hoofdstuk $2 \$ 3.1$.

199 Aan partijeen komt bij het sluiten van de vestigingsovereenkomst een zekere contractsvrijheid toe. Partijen dienen bij het bepalen van de inhoud rekening te houden met het numerus clausus-beginsel. Daarbij mogen de in de vestigingsovereenkomst opgenomen rechten en plichten niet in strijd zijn met de goede zeden en wordt de aan partijen toekomende contractsvrijheid beperkt door het verbod van de ontbindende voorwaarde van $\S 1$ Abs. 4 ErbbauRG. Zie: Von Oefele \& Winkler 2008, Rn 4.3.

200 De verkrijger die onder algemene titel het opstalrecht of het met het opstalrecht bezwaarde object verkrijgt, is eveneens gebonden aan de in de vestigingsovereenkomst neergelegde rechten en plichten. Zie: Von Oefele \& Winkler 2008, Rn 4.3-4.4.

201 Staudinger/Rapp 2009, § 2 Rn 1.

202 Staudinger/Rapp 2009, § 2 Rn 2.

203 Zie: BGH 9 juli 1954, NJW 1954, 1444; Von Oefele \& Winkler 2008, $\mathrm{Rn}$ 4.14. In $\$ 3.2 .1$ wordt ingegaan op de vertragsmäßige Inhalt van de vestigingsovereenkomst.

$204 \quad$ Hoofdstuk 2 \$3.2.1.

205 Naast de Erbbauzins kunnen ook het Vorkaufsrecht en de Vormerkung als Gegenleistung worden aangemerkt. In dit proefschrift zal enkel op de Erbbauzins nader worden ingegaan. Zie: hoofdstuk 2 §3.2.2. 


\section{§3.2.1 De vertragsmäßige Inhalt}

De rechten en plichten die tot de vertragsmäßige Inhalt van de vestigingsovereenkomst kunnen worden gerekend, worden in $\S 2-8$ ErbbauRG, § 27 Abs. 1 en § 32 Abs. 1 ErbbauRG opgesomd. § 2 ErbbauRG kan hierbij als kapstokbepaling worden angemerkt, nu deze bepaling verwijst naar de overige, hiervoor opgesomde bepalingen.

$\S 2$ ErbbauRG geeft een opsomming van een zevental Vertragliche Bestimmungen-categorieën. Tot de eerste categorie behoren de afspraken die betrekking hebben op het oprichten, het in stand houden en het gebruik van het bouwwerk. ${ }^{206}$ Hoewel uit $\S 1$ Abs. 1 ErbbauRG volgt dat aan de opstaller een recht toekomt om een of meerdere bouwwerken te hebben, vloeit hier geenszins de verplichting uit voort dat er een bouwwerk ten tijde van de vestiging op het grondstuk aanwezig dient te zijn of gedurende het opstalrecht door de opstaller verwezenlijkt dient te worden. De verplichting tot het verwezenlijken van een of meerdere opstallen kan door partijen in de vestigingsovereenkomst worden opgenomen. ${ }^{207}$

De tweede categorie is neergelegd in $\S 2 \mathrm{nr}$. 2 ErbbauRG en ziet zowel op het verzekeren als op de wederopbouw van de opstallen in het geval van vernietiging. ${ }^{208}$ De verplichting de opstallen te verzekeren is beperkt tot het afsluiten van een brandverzekering. Een tussen partijen overeengekomen beding tot het sluiten van een ander soort verzekering is mogelijk, maar aan dit beding komt geen zakelijke werking toe. Een overeengekomen verplichting tot wederopbouw hoeft niet in de vestigingsovereenkomst nader te worden gespecificeerd met betrekking tot de oorzaak van de vernietiging. Ook wanneer de opstaller geen blaam treft, kan op hem de verplichting tot wederopbouw rusten. ${ }^{209}$

De derde categorie ziet op afspraken die partijen kunnen maken ten aanzien van de draagplicht van publieke en private lasten. ${ }^{210}$ Doorgaans zullen partijen overeenkomen dat op de opstaller de verplichting rust voornoemde lasten te dragen, wanneer aan de grondeigenaar gedurende het bestaan van het opstalrecht geen gebruiksrecht toekomt ten aanzien van het met het opstalrecht bezwaarde grondstuk. ${ }^{211}$

De vierde categorie maakt het mogelijk aan de Heimfallanspruch zakelijke werking toe te kennen. ${ }^{212}$ Wanneer de opstaller nalaat aan de op hem inge-

\footnotetext{
$206 \S 2$ nr. 1 ErbbauRG.

207 Von Oefele \& Winkler 2008, Rn 4.4.

$208 \S 2$ nr. 2 ErbbauRG.

209 Staudinger/Rapp 2009, § 2 Rn 16.

$210 § 2$ nr. 3 ErbbauRG.

211 Staudinger/Rapp 2009, § 2 Rn 18.

$212 \S 2$ nr. 4 ErbbauRG.
} 
volge het opstalrecht rustende verplichtingen te voldoen ${ }^{213}$, kan de grondeigenaar op grond van de Heimfallanspruch overdracht van het opstalrecht verlangen. ${ }^{214}$ Het is niet mogelijk om in de vestigingsovereenkomst een Heimfallanspruch overeen te komen ten behoeve van een derde, niet zijnde de grondeigenaar. ${ }^{215}$ Wanneer een beroep op de Heimfallanspruch leidt tot overdracht van het opstalrecht kan op de grondeigenaar de verplichting rusten een vergoeding te betalen voor het verkregen opstalrecht; dit is afhankelijk van hetgeen partijen in de vestigingsovereenkomst zijn overeengekomen. ${ }^{216}$ Een beroep op de Heimfallanspruch kan gedurende een periode van 6 maanden vanaf het moment dat de opstaller in verzuim is. ${ }^{217}$

De vijfde categorie kent zakelijke werking toe, althans na inschrijving van de vestigingsovereenkomst in het Grundbuch, aan een beding strekkende tot betaling van een contractuele boete, de zogenoemde Vertragsstrafe ${ }^{218}$, wanneer de tot de Inhalt des Erbbaurechts behorende rechten worden geschonden. Deze contractuele boete kan zowel ten laste van de opstaller als van de grondeigenaar worden bedongen. Het is evenwel mogelijk een Vertragsstrafe in de vestigingsovereenkomst op te nemen die bij verzuim van een op de opstaller rustende verplichting leidt tot verhoging van de Erbbauzins. ${ }^{219}$ De opstaller respectievelijk de grondeigenaar kan gedurende een periode van 6 maanden vanaf het moment dat de gerechtigde tot de Vertragsstrafe kennis heeft genomen van het verzuim, aanspraak maken op deze contractuele boete. ${ }^{220}$

Tot de zesde categorie behoort het tussen partijen overeengekomen Vorrecht. Krachtens een Vorrecht komt aan de opstaller de bevoegdheid toe het opstalrecht te vernieuwen wanneer het opstalrecht door tijdsverloop eindigt. 221

De zevende en laatste door $\S 2$ ErbbauRG genoemde categorie ziet op de mogelijkheid zakelijke werking toe te kennen aan een in de vestigingsovereenkomst opgenomen kooprecht. Op grond van dit recht

213 Hetgeen bijvoorbeeld het geval is wanneer de opstaller verzuimt de overeengekomen Erbbauzins te voldoen. Zie: hoofdstuk 2 \$3.2.2.

214 Zie: Böttcher 2006, Rn 162; Staudinger/Rapp 2009, § 2 Rn 20-21. Het in één hand komen van het opstalrecht en het meeromvattende recht waaruit het opstalrecht is afgeleid, leidt op grond van $§ 889 \mathrm{BGB}$-deze bepaling ziet op de Konsolidationsausschluss- niet tot vermenging van beide rechten.

$215 \$ 3$ ErbbauRG.

$216 \$ 32$ Abs. 1 ErbbauRG. Zie: Staudinger/Rapp 2009, nr. 26.

$217 \S 4$ ErbbauRG. §32 Abs. 2, §33 en §34 ErbbauRG geven een nadere invulling aan de Heimfallanspruch.

$218 \S 2$ nr. 5 ErbbauRG.

219 Staudinger/Rapp 2009, § 2 Rn 29.

220 \$4 ErbbauRG

$221 \S 2$ nr. 6 ErbauRG jo. § 31 ErbbauRG. Zie: Böttcher 2006, Rn 203. In §3.5.2 wordt nader ingegaan op het tenietgaan van het opstalrecht door Zeitablauf. 
is de grondeigenaar verplicht het grondstuk dat met het opstalrecht is bezwaard aan de opstaller over te dragen, wanneer de opstaller gebruik wenst te maken van het kooprecht. ${ }^{222}$ De opstaller kan zich gedurende het bestaan van het opstalrecht op dit kooprecht beroepen. ${ }^{223}$

Naast het toekennen van zakelijke werking aan de in $§ 2$ ErbbauRG omschreven rechten en plichten, kent het ErbbauRG tevens zakelijke werking toe aan de rechten en plichten die in $§ 5$ en $\$ 27$ ErbbauRG zijn opgenomen. § 5 ErbbauRG ${ }^{224}$ maakt het mogelijk de aan de opstaller toekomende beschikkingsbevoegdheid met betrekking tot overdracht en bezwaring van het opstalrecht afhankelijk te maken van de toestemming van de grondeigenaar. ${ }^{225} \S 27$ ErbbauRG ziet op de mogelijkheid zakelijke werking toe te kennen aan een in de vestigingsovereenkomst bedongen vergoedingsplicht wanneer het opstalrecht door Zeitablauf teniet gaat. ${ }^{226}$ Hoewel het partijen vrij staat in de vestigingsovereenkomst een beding op te nemen waarmee aan het tenietgaan van het opstalrecht door Aufhebung een vergoedingsplicht wordt gekoppeld, kan daaraan geen zakelijke werking worden toegekend. ${ }^{227}$

\section{§3.2.2 Gegenleistung für das Erbbaurecht - der Erbbauzins}

Partijen kunnen in de vestigingsovereenkomst een beding opnemen dat strekt tot betaling van een door de opstaller te betalen vergoeding, de Erbbauzins, als tegenprestatie voor het verkregen opstalrecht. Het is gebruikelijk dat de opstaller de vergoeding geldelijk voldoet, maar het staat partijen vrij overeen te komen dat de vergoeding in natura wordt voldaan. ${ }^{228}$ De hoogte van de vergoeding zal doorgaans tussen de 4 en $8 \%$ van de waarde

$222 \$ 2$ nr. 7 ErbbauRG.

223 In de Inhalt des Erbbaurechts wordt een koopovereenkomst onder opschortende voorwaarde opgenomen die van kracht wordt op het moment dat de opstaller besluit zijn recht te willen uitoefenen en hij de grondeigenaar hiervan op de hoogte stelt. Uit de van kracht geworden koopovereenkomst vloeit vervolgens de verplichting tot overdracht. Zie: Böttcher 2006, Rn 206; Staudinger/Rapp 2009, § 2 Rn 32.

$224 \S 6,7$ en 8 ErbbauRG.

225 Böttcher 2006, Rn 232-248. Zie: hoofdstuk 2 \$3.5.1.

226 Wanneer het opstalrecht teniet gaat wordt het bouwwerk (weer) bestanddeel van het grondstuk en strekt het op het grondstuk rustende eigendomsrecht zich uit over het bouwwerk. Zie: hoofdstuk 2 \$3.5.2.

$227 \S 26$ ErbbauRG. Zie: hoofdstuk 2 \$3.5.2.

228 De verplichting tot betaling van een vergoeding kan een eenmalige dan wel een al dan niet met regelmaat terugkerende vergoeding betreffen. Wanneer sprake is van een terugkerende vergoeding zijn de bepalingen uit het BGB met betrekking tot de Reallasten, $§ 1105$ e.v. BGB, van toepassing, aldus $§ 9$ Abs. 1 ErbbauRG. Zie: Von Oefele \& Winkler 2008, Rn 6.9-6.11. 
van het grondstuk betreffen ${ }^{229}$, maar ook hier komt aan partijen een grote mate van vrijheid toe.

Aan een in de vestigingovereenkomst opgenomen Erbbauzins komt na inschrijving in het Grundbuch geen zakelijke werking toe. Voor het toekennen van zakelijke werking aan de Erbbauzins is het noodzakelijk dat een overeenkomst strekkende tot betaling van de Erbbauzins in het Grundbuch wordt ingeschreven. ${ }^{230}$ Ten gevolg van de inschrijving wordt het opstalrecht met de Erbbauzins bezwaard en wordt de Erbbauzins aangemerkt als wezenlijk bestanddeel van het grondstuk dat met het opstalrecht is bezwaard. ${ }^{231}$ Door het aanmerken van de Erbbauzins als wezenlijk bestanddeel is het niet mogelijk de Erbbauzins apart van het grondstuk te vervreemden of te bezwaren. ${ }^{232}$ Vestiging van een Erbbauzins ten behoeve van een bepaalde grondeigenaar in die zin dat de Erbbauzins niet overgaat op de opvolgend eigenaar van het grondstuk, is niet mogelijk. ${ }^{233}$

\section{§3.3 Das Bauwerk}

\section{§3.3.1 Vereisten waaraan een object dient te voldoen wil van een Bauwerk sprake zijn}

De essentie van het opstalrecht is gelegen in het hebben van een of meerdere bouwwerken op of in het grondstuk van een ander. ${ }^{234}$ Welke bouwwerken aan de opstaller toekomen is afhankelijk van hetgeen in de vestigingsovereenkomst is bepaald. Een opstalrecht kan worden gevestigd ten gunste van een of meerdere bouwwerken die zich al dan niet ten tijde van de vestiging van het opstalrecht op of in het grondstuk bevinden. Door het opstalrecht te vestigen ten gunste van nog te wezenlijken bouwwerken komt aan de opstaller (logischerwijs) de bevoegdheid toe op of in het grondstuk van een ander bouwwerken te verwezenlijken.

Het BGB noch het ErbbauRG geeft een definitie van het begrip 'bouwwerk'. Uit de literatuur volgt dat een object als bouwwerk kan worden

229 Böttcher 2006, Rn 313.

$230 § 873$ Abs. 1 BGB. In tegenstelling tot het opstalrecht zelf wordt aan de Erbbauzins geen rangvoorschrift gesteld. Zie: Böttcher, 2006 Rn 315-319. Ook is het mogelijk ten aanzien van de Erbbauzins een ontbindende voorwaarde overeen te komen; $§ 1$ Abs. 4 ErbbauRG is van toepassing op het opstalrecht, niet op de Erbbauzins. Zie: Von Oefele \& Winkler 2008, Rn 6.26-6.27.

231 §96 BGB. Zie: hoofdstuk 2 \$2.2.2.

232 §9 Abs. 2 ErbbauRG. Zie: Böttcher 2006, Rn 324.

233 Böttcher 2006, Rn 323.

234 §1 ErbbauRG. 
aangemerkt wanneer het object is ontstaan uit het samengaan van arbeid en materiaal. Woningen, fabrieken, mijnen, energie-opwekkers, golfbanen en speelplaatsen kunnen alle als bouwwerk worden aangemerkt. ${ }^{235}$ Een opstalrecht kan enkel ten gunste van die bouwwerken worden gevestigd die op een vaste wijze met het grondstuk zijn verenigd en als wezenlijk bestanddeel van het grondstuk kunnen worden aangemerkt. ${ }^{236} \mathrm{Nu}$ van een vaste vereniging sprake dient te zijn, leidt dit ertoe dat een opstalrecht enkel kan worden gevestigd ten gunste van die bouwwerken die zich op of in het grondstuk bevinden. ${ }^{237}$ Een recht van opstal kan dan ook niet worden gevestigd ten behoeve van een bouwwerk dat zich boven het grondstuk bevindt, nu iedere fysieke relatie met het onder het bouwwerk liggende grondstuk ontbreekt. In beginsel kan een opstalrecht enkel ten gunste van het gehele bouwwerk worden gevestigd. ${ }^{238}$

\section{§3.3.2 Het op het Bauwerk rustende eigendomsrecht}

Het bouwwerk ten gunste waarvan het opstalrecht is gevestigd, dient ten gevolge van de vestiging niet (langer) als wezenlijk bestanddeel van het grondstuk maar als wezenlijk bestanddeel van het opstalrecht te worden aangemerkt. ${ }^{239}$ Dat een recht een fysiek object als bestanddeel kan hebben is het gevolg van de juridische gelijkstelling van het opstalrecht aan een grondstuk. ${ }^{240}$ Een bouwwerk kan slechts ten aanzien van één goed wezenlijk bestanddeel zijn. ${ }^{241}$ Een bouwwerk dat als wezenlijk bestanddeel van het opstalrecht kan worden aangemerkt, dient in relatie tot het grondstuk waar het op vaste wijze mee is verenigd als Schein-bestanddeel te worden aangemerkt. $^{242}$

235 Von Oefele \& Winkler 2008, Rn 2.10. Een opstalrecht kan onder het Duitse recht niet ten behoeve van beplantingen worden gevestigd.

236 Hoofdstuk $2 \$ 2.2$.

237 Von Oefele \& Winkler 2008, Rn 2.7; Staudinger/Rapp 2009, § 1 Rn 11.

$238 \S 1$ Abs. 3 ErbbauRG. $\$ 1$ Abs. 3 ErbbauRG bezigt niet de term 'Bauwerk' maar de term 'Gebäude'. Onzeker is of ook bouwwerken onder voornoemde bepaling vallen. Zie: Von Oefele \& Winkler 2008, Rn 2.35; Staudinger/Rapp 2009, § 1 Rn 34. In $\$ 3.4 .2 .1$ van dit hoofdstuk wordt ingegaan op de vraag of het mogelijk is een opstalrecht te vestigen ten behoeve van een gedeelte van een bouwwerk.

$239 \S 12$ Abs. 1 ErbbauRG.

240 Uit $§ 11$ ErbbauRG volgt dat een recht van opstal kan worden aangemerkt als een 'grundeigentumsgleiches Recht'. Nu het bouwwerk wezenlijk bestanddeel is van een recht dat met een grondstuk wordt gelijkgesteld, is het bouwwerk volgens de huidige, heersende leer een unbewegliche zaak. Zie: hoofdstuk 2 $\S 3.1$.

$241 \S 12$ Abs. 2 ErbbauRG.

242 Hoofdstuk $2 \$ 2.4$. 
Het is opmerkelijk dat volgens de heersende leer op het bouwwerk als wezenlijk bestanddeel van het opstalrecht een eigen eigendomsrecht, het zogenoemde 'Sondereigentum', komt te rusten. ${ }^{243}$ Het bouwwerk kan als wezenlijk bestanddeel van het opstalrecht niet apart van het opstalrecht worden overgedragen of bezwaard. Overdracht respectievelijk bezwaring van het opstalrecht is enkel mogelijk door overdracht respectievelijk bezwaring van het opstalrecht. Nu het Sondereigentum niet apart van het opstalrecht kan worden overgedragen of bezwaard ${ }^{244}$ rijst de vraag of de bevoegdheden die ingevolge de vestigingsovereenkomst ten aanzien van de bouwwerken aan de opstaller toekomen als eigendom dienen te worden aangemerkt.

Krachtens § $903 \mathrm{BGB}$, alwaar het privaatrechtelijke eigendomsrecht is gedefinieerd, komt aan de eigenaar van een zaak de bevoegdheid toe met de zaak nach belieben zu verfahren. De eigenaar kan de zaak gebruiken, verbruiken alsook vernietigen voor zover dit niet in strijd is met de wet of de aan derden toekomende rechten. ${ }^{245}$ De verstrekkendheid van de aan de opstaller toekomende bevoegdheden is echter afhankelijk van hetgeen partijen in de vestigingsovereenkomst zijn overeengekomen. ${ }^{246}$ Wanneer aan de opstaller de eigendom van de bouwwerken in de zin van §903 BGB zou toekomen, dan zou aan de opstaller de bevoegdheid toekomen deze te mogen wegnemen gedurende het bestaan van het opstalrecht. Het is dan ook opmerkelijk dat het ErbbauRG het recht tot wegname in beginsel uitsluit. ${ }^{247}$ Enkel wanneer partijen in de vestigingsovereenkomst een wegneemrecht zijn overeengekomen is de opstaller bevoegd de opstallen weg te nemen. Aan het in de vestigingsovereenkomst opgenomen wegneemrecht komt 'slechts' verbintenisrechtelijke werking toe. ${ }^{248}$

$\mathrm{Nu}$ de opstaller niet apart van het recht van opstal over de bouwwerken kan beschikken, de opstaller ten aanzien van de door hem met betrekking tot de bouwwerken te verrichte handelingen afhankelijk is van hetgeen

$243 \S 5$ Abs. 1 WEG. MünchKommBGB/Von Oefele 2009, § 1 Rn 25. Met het tenietgaan van het opstalrecht gaat ook het op het bouwwerk rustende Sondereigentum teniet. Zie: MünchKommBGB/Von Oefele 2009, § 12 Rn 10.

244 Naar analogie van $\S 6$ Abs. 1 WEG.

245 Hemmer \& Wüst 2011, p. 6; Prütting 2010, Rn 322-323. Naast het in § 903 BGB neergelegde privaatrechtelijke eigendomsbegrip is het Duitse rechtsstelsel bekend met een publiekrechtelijke eigendomsbepaling ( $\$ 14$ Grundgetz). Zie: Wolf 2005, p. 19.

246 Zo kan de opstaller in het gebruik van het bouwwerk worden geremd door de in de vestigingsovereenkomst opgenomen en aan het bouwwerk toegekende bestemming. Hoofdstuk 2 \$3.2.1.

$247 \S 34$ ErbbauRG.

248 Hoofdstuk 2 \$3.5.2. 
in de vestigingsovereenkomst is overeengekomen en de opstaller op grond van het ErbbauRG niet bevoegd is tot wegname van de aan hem in 'eigendom' toekomende opstallen, kunnen de bevoegdheden die ten aanzien van de bouwwerken aan de opstaller toekomen mijns inziens niet als eigendom in de zin van $§ 903$ BGB worden aangemerkt. Vestiging van een recht van opstal leidt mijns inziens dan ook niet tot doorbreking van de natrekking. Zowel de bouwwerken die ten tijde van de vestiging reeds met het grondstuk zijn verenigd als de bouwwerken die gedurende de vestiging worden verwezenlijkt, worden met het grondstuk in eigendom nagetrokken. Ten gevolge van de vestiging van het opstalrecht worden aan de opstaller bevoegdheden ten aanzien van die bouwwerken overgedragen ten behoeve waarvan het opstalrecht is gevestigd. ${ }^{249}$ Deze bevoegdheden kunnen in vergaande mate overeenkomen met het eigendomsrecht zoals in § 903 BGB omschreven, maar van eigendom is geen sprake.

\section{§3.4 Vestiging van een Erbbaurecht en de verschillende Erbbau- constructies}

\section{\$3.4.1 Vestiging van een Erbbaurecht op het grondstuk - de Belastungsgegenstand}

Een opstalrecht komt per definitie op het gehele grondstuk, de Belastungsgegenstand, te rusten; het is niet mogelijk door middel van een partijafspraak hiervan af te wijken. Als de eigenaar van een grondstuk een opstalrecht wenst te vestigen op een specifiek gedeelte van het grondstuk zal hij vóór de vestiging van het opstalrecht het te bezwaren gedeelte van het grondstuk dienen af te scheiden waarna dit gedeelte als een aparte onroerende zaak kan worden aangemerkt. ${ }^{250}$

Op grond van hetgeen in de vestigingsovereenkomst ${ }^{251}$ is bepaald kan het met het opstalrecht bezwaarde grondstuk, de Belastungsgegenstand, worden

249 Volledigheidshalve dient te worden opgemerkt dat de opstaller de bevoegdheden ten aanzien van de nog te verwezenlijken opstallen ingevolge het opstalrecht verkrijgt op het moment dat de opstallen op vaste wijze met het grondstuk worden verenigd en met het grondstuk in eigendom worden nagetrokken.

$250 \S 7$ Abs. 1 GBO. Wanneer een met een opstalrecht belast grondstuk wordt uitgebreid met een aangrenzend grondstuk, een 'Fläche', zal het opstalrecht zich over het aangrenzende grondstuk uitstrekken. Zie: Staudinger/Rapp 2009, § 1 Rn 22. Het is mogelijk meerdere grondstukken tezamen met één opstalrecht te belasten. Dit opstalrecht wordt aangemerkt als 'Gesamterbbaurecht'. Zie: hoofdstuk 2 \$3.4.2.1.

251 Hoofdstuk 2 \$3.2. 
opgedeeld in 1) dat gedeelte van het grondstuk waarop het bouwwerk ${ }^{252}$ ten gunste waarvan het opstalrecht is gevestigd zich bevindt respectievelijk gaat bevinden, de zogenoemde Realfläche, en 2) in dat gedeelte van het grondstuk ten aanzien waarvan de opstaller een gebruiksrecht heeft. ${ }^{253}$ Dit gebruiksrecht kan zich over het gehele grondstuk met uitzondering van de Realfläche uitstrekken ${ }^{254}$, maar partijen kunnen in de vestigingsovereenkomst het gebruik van het grondstuk ook beperken tot een gedeelte van het met het opstalrecht belaste grondstuk. ${ }^{255}$ De grondeigenaar is bevoegdheid gebruik te maken van dat gedeelte van het grondstuk ten aanzien waarvan aan de opstaller geen gebruiksrecht toekomt. Aan de grondeigenaar blijft na vestiging van het opstalrecht de eigendom van die bouwwerken toekomen ten gunste waarvan het opstalrecht niet is gevestigd; deze bouwwerken blijven wezenlijke bestanddelen van het met het opstalrecht bezwaarde grondstuk. $^{256}$ Wanneer de grondeigenaar voor het gebruik van deze bouwwerken gebruik dient te maken van dat gedeelte van het grondstuk ten aanzien waarvan de opstaller een gebruiksrecht heeft, dan dient ten behoeve van de grondeigenaar een erfdienstbaarheid te worden gevestigd. ${ }^{257}$

252 Terwijl het bouwwerk volgens de heersende leer aan de opstaller in eigendom toekomt, blijft het grondstuk waarop of waarin het bouwwerk is gelegen toebehoren aan de eigenaar van het grondstuk. Zie: hoofdstuk 2 3.3.1.

253 Door aan de opstaller ingevolge de vestigingsovereenkomst een gebruiksrecht toe te kennen ten aanzien van een 'nicht erforderlicher Teil' van het met het opstalrecht belaste grondstuk, is het onnodig een aparte erfdienstbaarheid te vestigen om de krachtens het opstalrecht verkregen bevoegdheden te kunnen uitoefenen. Zie: Staudinger/Rapp 2009, § 1 Rn 17. Zie ook: noot 170.

254 Strikt genomen komt aan de opstaller ten aanzien van de Realfläche eveneens een gebruiksrecht toe.

255 Hoewel de opstaller niet bevoegd is tot gebruik van het voornoemde gedeelte van het grondstuk, wordt het gehele grondstuk met het opstalrecht belast. Partijen kunnen ook na de vestiging van het opstalrecht een gebruiksrecht ten aanzien van het met het opstalrecht bezwaarde grondstuk overeenkomen of de reikwijdte van het in de vestigingsovereenkomst opgenomen gebruiksrecht wijzigen door middel van een inhoudswijziging. Zie: Von Oefele \& Winkler 2008, Rn 2.72.

256 De grondeigenaar is bevoegd het gedeelte van het met het opstalrecht bezwaarde grondstuk dat niet als Realfläche kan worden aangemerkt en ten aanzien waarvan aan de opstaller geen gebruiksrecht toekomt van het grondstuk af te scheiden. Toestemming van de opstaller is hiervoor niet vereist. Ten aanzien van het afgescheiden gedeelte gaat het opstalrecht ten gevolge van de afscheiding teniet (§1026 BGB). Zie: Staudinger/Mayer 2009, § 1026 Rn 3.

257 In de literatuur wordt de term 'Grunddienstbarkeit' gebezigd. Een erfdienstbaarheid ( $\$ 1018$ e.v. BGB) kan uiteraard ook worden gevestigd ten behoeve van een derde. Het verdient dan wel de voorkeur de erfdienstbaarheid zowel op het recht van opstal als op het grondstuk te vestigen. Wanneer de erfdienstbaarheid enkel op het opstalrecht wordt gevestigd, heeft dit tot gevolg 
Het gebruiksrecht dient in verhouding tot 'het hebben van een bouwwerk op of in het grondstuk van een ander' van ondergeschikt belang te zijn. ${ }^{258}$ Of dit het geval is dient aan de hand van de verkeersopvatting te worden beoordeeld. ${ }^{259}$ Wanneer het gebruiksrecht niet ondergeschikt is aan het recht een bouwwerk te hebben, leidt dit tot partiële nietigheid van de vestigingsovereenkomst ten aanzien van het in de vestigingsovereenkomst opgenomen gebruiksrecht. ${ }^{260}$

Wanneer een opstalrecht eeuwigdurend van aard is, het aan de opstaller toekomende gebruiksrecht ten aanzien van het grondstuk onbeperkt van aard is, het gebruiksrecht zich over het gehele grondstuk uitstrekt èn aan het bestaansrecht van het opstalrecht geen enkele beperking wordt gesteld, is het aannemelijk dat beëindiging van het opstalrecht door tijdsverloop of terugval van het opstalrecht en daarmee van het op de opstallen rustende 'eigendomsrecht' vrijwel uitgesloten is. ${ }^{261}$ De vraag rijst dan of de vestiging van het opstalrecht kan worden aangemerkt als een verkapte wijze van overdracht van het grondstuk. ${ }^{262}$ De grondeigenaar heeft immers in zijn geheel geen belangen meer in zijn grondstuk. ${ }^{263}$

\section{§3.4.2 Verschillende Erbbau-constructies}

Het ErbbauRG gaat uit van de standaard opstalconstructie ${ }^{264}$ waarbij één grondstuk wordt bezwaard met één opstalrecht. De opstaller, niet zijnde de eigenaar van het grondstuk, verkrijgt met de vestiging van een 'standaard' opstalrecht naast de eigendom van een of meerdere bouwwerken die zich in hun geheel in of op het grondstuk van een ander bevinden tevens een gebruiksrecht dat zich, met uitzondering van de Realfläche, uitstrekt over het gehele grondstuk. Naast deze standaard opstalconstructie bestaan er

dat de erfdienstbaarheid samen met het opstalrecht teniet zal gaan. Door de erfdienstbaarheid eveneens op het grondstuk te vestigen, hetgeen door de eigenaar van het grondstuk dient te gebeuren, blijft het recht ook na het tenietgaan van het opstalrecht voortbestaan. Zie: Von Oefele \& Winkler 2008, Rn 5.109-5.110. Zie voor bezwaring van het opstalrecht: hoofdstuk 2 \$3.5.1.

259 Hierbij dient niet te worden uitgegaan van enkel die bouwwerken ten gunste waarvan het opstalrecht is gevestigd en die reeds op het grondstuk zijn verwezenlijkt, maar ook van de gedurende het opstalrecht nog te verwezenlijken bouwwerken zoals in de vestigingsovereenkomst omschreven.

260 Von Oefele \& Winkler 2008, Rn 2.71.

261 Hoofdstuk 2 3.3.2.

262 Von Oefele \& Winkler 2008, Rn 2.146. In \$3.3.2 wordt ingegaan op het op de opstallen rustende eigendomsrecht.

263 In hoofdstuk $6 \$ 4.2$ wordt nader op deze vraag ingegaan.

264 In de literatuur wordt deze standaard constructie aangemerkt met de term 'Normalfall'. 
ook andere constructie die afwijken van de voor de standaard constructie typerende karakteristieken. Zo kan de eigenaar van het grondstuk gerechtigde zijn tot het opstalrecht waarmee zijn grondstuk is bezwaard ${ }^{265}$, kan het ingevolge het opstalrecht verkregen gebruiksrecht beperkt zijn tot een gedeelte van het grondstuk of juist betrekking hebben op meerdere grondstukken, kan het bouwwerk ten gunste waarvan het opstalrecht wordt gevestigd zich over meerdere grondstukken uitstrekken en kunnen meerdere opstalrechten worden gevestigd ten behoeve van één bouwwerk.

In de navolgende paragraaf wordt ingegaan op die opstalconstructies die het mogelijk maken een opstalrecht te vestigen ten behoeve van een grensoverschrijdend bouwwerk en de constructie die het mogelijk maakt meerdere opstalrechten te vestigen ten gunste van één bouwwerk.

\section{§3.4.2.1 Erbbau-constructies ten aanzien van een grensoverschrijdend bouwwerk}

Hoewel bij de standaard opstalconstructie ervan uitgegaan wordt dat het bouwwerk ten gunste waarvan het opstalrecht is gevestigd zich in zijn geheel op het te bezwaren grondstuk bevindt, is het (uiteraard) ook mogelijk dat een bouwwerk zich over verschillende grondstukken uitstrekt. Wanneer een bouwwerk zich over twee of meerdere grondstukken uitstrekt en het op ieder grondstuk bevindende gedeelte van het bouwwerk als een zelfstandige eenheid kan worden aangemerkt, zoals bijvoorbeeld het geval is bij twee-onder-een-kapwoningen, kan een opstalrecht ten gunste van zo'n zelfstandige eenheid worden gevestigd; het grondstuk waarop zo'n zelfstandige eenheid zich bevindt kan met een opstalrecht worden bezwaard ${ }^{266}$ De situatie kan zich ook voordoen dat het grensoverschrijdende gedeelte van het bouwwerk niet als een zelfstandige eenheid kan worden aangemerkt. Het grensoverschrijdende gedeelte dient dan als overbouw te

265 De opstalconstructie waarbij de grondeigenaar tevens gerechtigde is tot het opstalrecht, wordt aangeduid met de term 'Eigentümererbbaurecht'. Anders dan onder het Nederlandse en Belgische recht het geval is, leidt het samenkomen van het opstalrecht en het eigendomsrecht niet tot vermenging. Zie ook: noot 214. Van een Eigentümererbbaurecht kan direct bij vestiging van het opstalrecht sprake zijn, maar het is evenwel mogelijk dat het opstalrecht naderhand als Eigentümererbbaurecht kan worden aangemerkt, bijvoorbeeld doordat het opstalrecht aan de grondeigenaar toekomt ingevolge de Heimfallanspruch. Zie: hoofdstuk $2 \S 3.2 .1$.

266 Onder bepaalde omstandigheden is het ingevolge § 39 Sachenrechtsbereinigungsgesetz (verder: SachenRBerG) mogelijk een opstalrecht te vestigen ten gunste van een onzelfstandig, verticaal gedeelte van een bouwwerk. Later in deze paragraaf zal nader worden ingegaan op $§ 39$ SachenRBerG. Zie: Hügel 2009, Rn 71-74. 
worden aangemerkt. Is de overbouw met toestemming van de eigenaar van het met de overbouw bebouwde grondstuk aangebracht dan is de overbouw wezenlijk bestandeel ${ }^{267}$ van het bouwwerk waarmee het is verenigd. Wordt de overbouw op het grondstuk van een ander aangebracht zonder dat de eigenaar van het met overbouw bebouwde grondstuk daar zijn toestemming voor heeft gegeven, dan dient de vraag te worden beantwoord of de overbouw al dan niet met opzet of grove nalatigheid is verwezenlijkt. Is er geen sprake van opzet of grove nalatigheid dan kan de overbouw in relatie tot het grondstuk als Schein-bestanddeel worden aangemerkt. ${ }^{268} \mathrm{Nu}$ een Schein-bestanddeel als roerend dient te worden gekwalificieerd, is het niet mogelijk deze te bezwaren met een recht van opstal. Bij opzet of grove nalatigheid wordt de overbouw aangemerkt als wezenlijk bestanddeel van het grondstuk waarop de overbouw is gesitueerd; de overbouw behoort toe aan de eigenaar van het met de overbouw bebouwde grondstuk. ${ }^{269}$

Een bouwwerk dat zich uitstrekt over meerdere grondstukken kan in zijn geheel aan een ander in eigendom toekomen door het vestigen van een of meerdere opstalrechten. Het Gesamterbbaurecht maakt het mogelijk één opstalrecht te vestigen ten behoeve van een bouwwerk dat zich op meerdere grondstukken bevindt. ${ }^{270} \mathrm{Bij}$ het Gesamterbbaurecht rust de Belastungsgegenstand op de verschillende grondstukken gezamenlijk. Voor het vestigen van een Gesamterbbaurecht is het niet noodzakelijk dat de bij de vestiging betrokken grondstukken toebehoren aan één grondeigenaar. De in de vestigingsovereenkomst opgenomen bepalingen die kunnen worden gerekend tot de Gesetzliche als tot de Vertragsmäßige Inhalt dienen gelijk te zijn voor ieder van de eigenaren wiens grondstuk bij de vestiging van het Gesamterbbaurecht is betrokken. ${ }^{271}$ Van de bepalingen die puur verbintenisrechtelijke van aard zijn, zoals de in de vestigingsovereenkomst opgenomen Erbbauzins ${ }^{272}$, kan daarentegen wel ten behoeve van iedere grondeigenaar wiens grondstuk met het opstalrecht wordt bezwaard, worden afgeweken. Het Gesamterbbaurecht is een einheitliches recht en kan dan ook enkel in zijn geheel worden belast. ${ }^{273}$ Bij Heimfall ${ }^{274}$ komt het

267 Hoofdstuk 2 \$2.2.

268 Naar analogie van $\$ 95$ lid 1 tweede zin BGB.

269 Hoofdstuk $2 \$ 2.2 .1$.

$270 \$ 6$ a Abs. 1 GBO.

271 \$873 BGB. Zie: hoofdstuk 2 \$3.2.

272 Aan de in de vestigingsovereenkomst opgenomen Erbbauzins komt geen zakelijke werking toe. Enkel wanneer de Erbbauzins in het Grundbuch wordt ingeschreven komt aan de Erbbauzins zakelijke werking toe. Zie: hoofdstuk 2 $\$ 3.2 .2$.

273 Von Oefele \& Winkler 2008, Rn 3.62.

274 Hoofdstuk 2 \$3.2.1. 
Gesamterbbaurecht toe aan de eigenaren van de verschillende grondstukken waarop het Gesamterbbaurecht rust. ${ }^{275}$

Een Gesamterbbaurecht kan tevens ontstaan na de vestiging van een (standaard) opstalrecht dat ten tijde van de vestiging op één grondstuk werd gevestigd, wanneer het met het opstalrecht bezwaarde grondstuk gedurende het bestaan van het opstalrecht in verschillende grondstukken wordt gesplitst. Ten gevolge van de splitsing rust het opstalrecht niet langer op één maar op meerdere grondstukken. ${ }^{276}$

Bij een Nachbarerbbaurecht wordt niet één opstalrecht gevestigd, maar wordt ieder grondstuk waarop het bouwwerk zich bevindt of gaat bevinden met een opstalrecht bezwaard. ${ }^{277}$ Dit leidt ertoe dat het opstalrecht ten gunste van een onzelfstandig, verticaal gedeelte van het bouwwerk wordt gevestigd. Hoewel de vestiging van een opstalrecht ten behoeve van een verticaal gedeelte van een bouwwerk in beginsel enkel is toegestaan wanneer dit gedeelte als een zelfstandige eenheid kan worden aangemerkt ${ }^{278}$, is de grondeigenaar krachtens $\$ 39$ SachenRBerG bevoegd het bouwwerk verticaal te splitsen ten behoeve van de vestiging van een opstalrecht ongeacht of dit leidt tot splitsing van het bouwwerk in onzelfstandige, verticale gedeelten. Het eigendomsrecht dat ten gevolge van de vestiging van het opstalrecht op een verticaal gedeelte van het bouwwerk komt te rusten strekt zich uit tot aan de kadastrale grens van het grondstuk. ${ }^{279}$

Anders dan bij het Gesamterbbaurecht, zijn er verschillende opstalrechten en daarmee ook verschillende vestigingsovereenkomsten bij het ontstaan van het Gesamterbbaurecht betrokken. Aan iedere vestigingsovereenkomst kan een eigen Gesetzliche en Vertragsmaßige Inhalt worden toegekend. ${ }^{280}$ Doordat er meerdere opstalrechten worden gevestigd ten behoeve van verschillende onzelfstandige gedeelten is het evenals bij het Gesamterbbaurecht mogelijk dat het bouwwerk aan verschillende eigenaren toebehoort. ${ }^{281}$

Uit bovenstaande volgt dat vestiging van een opstalrecht ten gunste van een verticaal gedeelte van een bouwwerk mogelijk is. Het is daarentegen niet mogelijk een opstalrecht te vestigen ten aanzien van een horizontaal gedeelte van een bouwwerk. ${ }^{282}$ Wel is het mogelijk een opstalrecht te vestigen op een horizontaal gedeelte van een bouwwerk waarop reeds een Wohnungsrespectievelijk Teileigentum rust. Het opstalrecht waarmee het Wohnungs-

\footnotetext{
275 Von Oefele \& Winkler 2008, Rn 3.4

276 Böttcher 2006, Rn 41; Von Oefele \& Winkler 2008, Rn 3.42-3.43.

277 Von Oefele \& Winkler 2008, Rn 3.70.

278 Zoals bij twee-onder-een-kapwoningen.

279 Staudinger/Rapp 2009, § 1 Rn 34.

280 Von Oefele \& Winkler 2008, Rn 3.80.

281 MünchKommBGB/Von Oefele 2009, § 1 Rn 55-57.

$282 \S 1$ Abs. 3 ErbbauRG.
} 
respectievelijk Teileigentum wordt bezwaard, wordt ten gunste van dat gedeelte van het bouwwerk gevestigd ten aanzien waarvan de Wohnungs- of Teileigentümer het Sondereigentum heeft verkregen. ${ }^{283}$

\section{$\S 3.5$ Bezwaring, overdracht en het tenietgaan van het Erbbaurecht}

\section{§3.5.1 Overdracht en bezwaring van het Erbbaurecht}

Bezwaring en overdracht van een opstalrecht vindt evenals de vestiging van een opstalrecht plaats door Einigung en Eintragung. ${ }^{284}$ Doordat het opstalrecht als een grundeigentumsgleiches Recht ${ }^{285}$ wordt aangemerkt, kan het opstalrecht worden bezwaard met rechten waarmee ook een grondstuk kan worden bezwaard. ${ }^{286}$ De aan de opstaller toekomende bevoegdheid zijn opstalrecht over te dragen of te bezwaring kan ter bescherming van de grondeigenaar worden beperkt door in de vestigingsovereenkomst een toestemmingsbeding op te nemen. ${ }^{287}$ Een verbod tot overdracht of bezwaring van het opstalrecht is nietig. ${ }^{288} \mathrm{Op}$ grond van dit toestemmingsbeding is voor overdracht of bezwaring van het opstalrecht goedkeuring van de grondeigenaar vereist. ${ }^{289}$ In beginsel is een in de vestigingsovereenkomst opgenomen toestemmingsbeding verbintenisrechtelijk van aard. Een door partijen in de vestigingsovereenkomst opgenomen toestemmingsbeding dat ziet op overdracht of bezwaring van het opstalrecht met Hypotheken, Grund- en Rentenschulden en Reallasten wordt daarentegen wel tot de vertragsmäße Inhalt van de vestigingsovereenkomst gerekend. ${ }^{290}$ De reden voor het toekennen van zakelijke werking aan een toestemmingsbeding bij

283 Hoofdstuk 2 2.2.3.

$284 \S 873$ BGB.

285 \$11 ErbbauRG. Zie: hoofdstuk 2 \$3.1.

286 Een grondstuk alsook een recht van opstal kan worden bezwaard met Dienstbarkeiten (§1018 BGB), Reallasten (§ 1105 BGB), Hypothek (§ 1113 BGB), Grundschuld (§1191 BGB), Rentenschuld (§1199 BGB), Vorkaufsrechten (§463 BGB), Nießbrauch (§1085 BGB) en het Dauerwohnungsrecht (§31 WEG). Het is evenwel mogelijk een opstalrecht met een opstalrecht te bezwaren. Zie: hoofdstuk 2 33.5.1.1.

$287 \S 5 \mathrm{t} / \mathrm{m} \S 8$ ErbbauRG. In hoofdstuk $2 \S 3.2 .1$ wordt ingegaan op de vertragsmäßige Inhalt van de vestigingsovereenkomst. Zie: Von Oefele \& Winkler 2008, Rn 4.172.

288 Von Oefele \& Winkler 2008, Rn 4.234.

289 Deze vereiste toestemming wordt angeduid met de term 'empfangsbedürftige Willenserklärung'. Een in de vestigingsovereenkomst opgenomen toestemmingsbeding ziet niet alleen op overdracht en bezwaring van het opstalrecht maar heeft ook betrekking op wijzigingen die betrekking hebben op de op het opstalrecht gevestigde rechten die leiden tot een zwaardere belasting van het opstalrecht.

290 Hoofdstuk 2 \$3.2.1. 
bezwaring van een opstalrecht met Hypotheken, Grund- en Rentenschulden en Reallasten is gelegen in de verstrekkende gevolgen die de vestiging van voornoemde rechten voor de grondeigenaar kunnen hebben. ${ }^{291}$ De op het opstalrecht rustende Hypotheken, Grund- en Rentenschulden en Reallasten blijven in beginsel voortbestaan wanneer het opstalrecht ingevolge de uitoefening van de Heimfallanspruch bij de grondeigenaar komt te rusten. ${ }^{292}$

Het al dan niet verlenen van bovengenoemde toestemming voor overdracht of bezwaring geschiedt niet willekeurig. De grondeigenaar dient toestemming te geven voor de overdracht van het opstalrecht wanneer de aan het bouwwerk toegekende en in de vestigingsovereenkomst opgenomen bestemming ten gevolge van de overdracht niet zal wijzigen ${ }^{293}$ en de verkrijger geacht wordt in staat te zijn aan de in de Erbbaurechtsinhalt ${ }^{29}$ opgenomen verplichtingen te voldoen. ${ }^{295}$ Wanneer de opstaller zijn opstalrecht wenst te bezwaren dient de grondeigenaar toestemming voor de vestiging van het recht te verlenen wanneer bezwaring van het opstalrecht "mit den Regeln einer ordnungsmäßigen Wirtschaft vereinbar sein" 296 en bezwaring niet zal leiden tot wijziging van de aan het bouwwerk toekomende bestemming. ${ }^{297}$

291 Uit $\S 8$ ErbbauRG volgt dat overeenkomsten die voortkomen uit de Zwangvollstreckung (gedwongen tenuitvoerlegging) of uit de Arrestvollziehung (tenuitvoerlegging van een vonnis) alsook de overeenkomsten die door de Insolvenzverwalter (faillissementscurator) worden gesloten nietig zijn wanneer zij afbreuk doen aan de door $\S 5$ ErbbauRG geboden bescherming van de grondeigenaar. Zie: Von Oefele \& Winkler 2008, Rn 4.172.

$292 § 5$ Abs. 2 ErbbauRG.

293 Wanneer overdracht dan wel bezwaring van het opstalrecht leidt tot wijziging van de bestemming van het opstalrecht, hetgeen bijvoorbeeld het geval zal zijn wanneer het opstalrecht overgedragen wordt met het oog op verwezenlijking van een bedrijfsgebouw terwijl in de vestigingsovereenkomst is opgenomen dat aan het door de opstaller te verkrijgen bouwwerk de bestemming 'woonhuis' toekomt, staat het de grondeigenaar vrij zijn toestemming voor overdracht respectievelijk bezwaring te weigeren.

294 Hoofdstuk 2 \$3.2.

295 §7 Abs. 1 ErbbauRG. Zie: Böttcher 2006, Rn 271-285.

296 De eigenaar van het grondstuk kan toestemming weigeren wanneer de economische waarde van het te vestigen recht waarmee het grondstuk wordt belast niet verenigbaar is met de waarde van het opstalrecht. Wanneer het recht waarmee het opstalrecht wordt bezwaard leidt tot het verschaffen van financiële middelen, hetgeen bijvoorbeeld de strekking is van een recht van hypotheek, maar deze financiële middelen niet worden aangewend voor het oprichten of het in stand houden van de opstal(len) kan de grondeigenaar weigeren zijn toestemming te geven. Zie: Von Oefele \& Winkler 2008, Rn 4.234 e.v.

297 Zie: Böttcher 2006, Rn 288-290; Von Oefele \& Winkler 2008, Rn 4.234. 
Enkel op voornoemde gronden kan de grondeigenaar weigeren zijn toestemming te geven. ${ }^{298}$ De toestemming kan vormvrij geschieden en kan zowel aan de opstaller als aan de derde aan wie het opstalrecht wordt overgedragen respectievelijk ten behoeve van wie het opstalrecht wordt bezwaard, worden gegeven. ${ }^{299}$ Voor inschrijving van de overdracht of de vestiging van het recht waarmee het opstalrecht wordt bezwaard in het Grundbuch is vereist dat de Grundbuchamte kennis neemt van de gegeven toestemming. ${ }^{300}$

\section{§3.5.1.1 Bezwaring van het Erbbaurecht met een Erbbaurecht}

$\mathrm{Nu}$ het opstalrecht als een 'grundeigentumsgleiches Recht' dient te worden aangemerkt ${ }^{301}$ is het mogelijk een opstalrecht met een opstalrecht te bezwaren. ${ }^{302} \mathrm{Bij}$ het stapelen van opstalrechten wordt het bezwaarde opstalrecht aangeduid met de term 'Obererbbaurecht', het met het Obererbbaurecht bezwaarde opstalrecht wordt aangeduid met de term 'Untererbbaurecht' ${ }^{303}$ Een Untererbbaurecht kan op zijn beurt niet met een opstalrecht worden bezwaard. ${ }^{304} \mathrm{Nu}$ aan het te vestigen opstalrecht de Erste Rangstelle dient toe te komen, kan het noodzakelijk zijn dat rangwisseling plaats dient te vinden ten aanzien van rechten die reeds op het te bezwaren opstalrecht rusten. Zo zal de grondeigenaar toestemming dienen te geven voor rangwisseling van de ten gunste van hem op het opstalrecht gevestigde Erbbauzins. ${ }^{305}$

Bij bezwaring van een opstalrecht met een opstalrecht mag de Belastungsgegenstand ${ }^{306}$ van het Untererbbaurecht niet gelijk zijn aan de Belastungsgegenstand van het Obererbbaurecht. Gelijkstelling zou betekenen dat aan de gerechtigde tot het Obererbbaurecht niet langer de bevoegdheid toekomt een bouwwerk te hebben in of op het aan een

298 Wanneer de grondeigenaar desondanks weigert zijn toestemming te geven, kan de opstaller de rechter om een vervangende toestemming verzoeken (§ 29 Abs. 1 GBO). Zie: Böttcher 2006, Rn 294.

$299 \S 182$ Abs. 1 BGB. Zie: Von Oefele \& Winkler 2008, Rn 4.183.

$300 \$ 15$ ErbbauRG.

301 §11 ErbbauRG. Zie: hoofdstuk 2 §3.1.

302 Hoofdstuk $2 \$ 3.5 .1$.

303 Ingenstau 1987, § $11 \mathrm{Rn}$ 14. Met de invoer van $\S 6$ a Abs. 1 GBO kent het Untererbbaurecht een wettelijke grondslag. Het is niet mogelijk een opstalrecht te vestigen dat zowel op een recht van opstal als op een grondstuk rust, aldus $\S$ 6a Abs. 2 GBO.

304 Dit zou immers tot rechtsonzekerheid kunnen leiden. Zie: Schubert 1995, p. 204.

305 Hoofdstuk 2 \$3.2.2.

306 Hoofdstuk 2 \$3.4.1. 
ander toekomende grondstuk, hetgeen vereist is voor het bestaan van een opstalrecht. ${ }^{307}$ Wanneer de Belastungsgegenstand van het Untererbbaurecht wel met de Belastungsgegenstand van het Obererbbaurecht samenvalt, leidt dit niet tot bezwaring maar tot overdracht van het opstalrecht. De bevoegdheden die de gerechtigde tot het Untererbbaurecht aan zijn recht ontleent zijn afkomstig uit het Obererbaurecht. ${ }^{308}$

Anders dan bij de gerechtigde tot het Obererbbaurecht het geval is, komt de gerechtigde tot het Untererbbaurecht bij het tenietgaan van het Untererbbaurecht in beginsel niet in aanmerking voor vergoeding van de door hem aangebrachte opstallen. De grondeigenaar is immers geen partij ten aanzien van het gevestigde Untererbbaurecht. Dit is slechts anders wanneer de gerechtigde tot het Untererbbaurecht met de grondeigenaar een recht op vergoeding is overeengekomen. ${ }^{309}$

\section{§3.5.2 Het tenietgaan van het Erbbaurecht}

Wanneer het recht van opstal teniet gaat worden de wezenlijke bestanddelen van het opstalrecht (weer) wezenlijke bestanddelen van het grondstuk dat met het tenietgegane opstalrecht is bezwaard. ${ }^{310}$ Deze wezenlijke bestanddelen gaan krachtens natrekking aan de eigenaar van het grondstuk toebehoren. Een opstalrecht kan tenietgaan door Aufhebung (verder: opzegging) als door Zeitablauf (verder: tijdsverloop). ${ }^{311}$ De opstaller kan het opstalrecht opzeggen door middel van een Aufgabeerklärung. ${ }^{312}$ Aan deze verklaring worden geen vormvereisten gesteld. Voor het tenietgaan van het opstalrecht is vereist dat de grondeigenaar en derden die een recht hebben dat ten gevolge van de opzegging teniet gaat, met de verklaring instemmen ${ }^{313}$; zij dienen de opstaller alsook het Grundbuchamt van hun instemming op de hoogte te stellen. ${ }^{314}$ De opzegging kan vervolgens in het

307 Hoofdstuk 2 \$3.1.

308 De reikwijdte van de aan gerechtigde tot het Untererbbaurecht toekomende bevoegdheden kan dan ook niet ruimer zijn dan de bevoegdheden die de gerechtigde tot het Obererbbaurecht aan zijn recht ontleent. Zie: Ingenstau 1987, § 11 Rn 18; Von Oefele \& Winkler 2008, Rn 3.20.

309 Staudinger/Rapp 2009, § 1 Rn 13.

$310 \$ 12$ Abs. 3 ErbbauRG. Zie: Von Oefele \& Winkler 2008, Rn 5.256. Zie ook: hoofdstuk 2 \$2.2.1.

311 Een recht van opstal gaat niet teniet door het tenietgaan van het bouwwerk (§ 13 ErbbauRG).

312 §11 Abs. 1 ErbbauRG jo. § 875 Abs. 1 BGB.

313 Deze instemming kan worden aangeduid als een 'einseitige, abstrakte, empganungsbedürftige Willenserklärung'.

$314 \S 26$ ErbbauRG, § 11 ErbbauRG jo. § 876 BGB. Zie: Von Oefele \& Winkler 2008, Rn 5.198-200. 
Grundbuch worden ingeschreven ${ }^{315}$ waarna het opstalrecht teniet gaat. ${ }^{316}$ Of aan de opstaller een recht tot wegname òf een recht op vergoeding toekomt voor de door hem aangebrachte opstallen is afhankelijk van hetgeen partijen in de vestigingsovereenkomst zijn overeengekomen. ${ }^{317}$

Het opstalrecht kan ook door Zeitablauf (verder: tijdsverloop) eindigen. $\mathrm{Na}$ verloop van de in de vestigingsovereenkomst opgenomen termijn, gaan zowel het opstalrecht als de op het opstalrecht rustende beperkte rechten teniet. ${ }^{318}$ Aan de opstaller komt op grond van het ErbbauRG niet het recht toe de opstallen weg te nemen. Het recht tot wegname van de door de opstaller verwezenlijkte opstallen kan door partijen wel in de vestigingsovereenkomst worden opgenomen; aan dit wegneemrecht komt 'slechts' verbintenisrechtelijke werking toe. ${ }^{319}$ Het ErbbauRG kent aan de opstaller wel een vergoedingrecht toe ten gunste van de door de opstaller verwezenlijkte opstallen. ${ }^{320}$ Deze vergoeding dient als subrogatie van de opstallen $^{321}$ en betreft ten minste $2 / 3$ van de waarde van de opstallen op het moment van het tenietgaan van het opstalrecht. Van deze waardebepaling kan niet ten nadele van de opstaller worden afgeweken. ${ }^{322}$ De grondeigenaar kan onder deze vergoedingsplicht uitkomen door vóór het aflopen van de termijn waarvoor het opstalrecht is gevestigd, het opstalrecht te verlengen voor de voraussichtliche Standdarddauer. ${ }^{323}$ Wanneer de opstaller geen gebruik wil maken van deze verlenging gaat zijn recht op vergoeding tezamen met het opstalrecht teniet op het moment dat de duur waarvoor het opstalrecht is gevestigd verstrijkt. ${ }^{324}$ Wanneer de opstaller akkoord gaat met de verlenging

315 §11 Abs. 1 ErbbauRG jo. $\$ 875$ Abs. 1 BGB.

316 §16 ErbbauRG. Zie: Böttcher 2006, Rn 565-570.

317 Aan de in de vestigingsovereenkomst opgenomen bedingen omtrent wegname en vergoeding komt enkel verbintenisrechtelijke werking toe. Zie: Böttcher 2006, Rn 572; Von Oefele \& Winkler 2008, Rn 5.197.

$318 § 27$ Abs. 1 ErbbauRG. Zie: Böttcher 2006, Rn 598. Anders dan bij opzegging is voor het tenietgaan van het opstalrecht (uiteraard) geen toestemming van de grondeigenaar of derden vereist.

$319 \S 34$ ErbbauRG.

$320 \$ 27$ Abs. 1 ErbbauRG.

321 Von Oefele \& Winkler 2008, Rn 5.239.

$322 \S 27$ Abs. 2 ErbbauRG.

$323 \S 27$ Abs. 3 ErbbauRG. Met deze bepaling wordt voorkomen dat de grondeigenaar in financiële problemen belandt. Wanneer de standaardduur van het aangebrachte bouwwerk 50 jaar betreft en het opstalrecht verloopt op het moment dat het bouwwerk zich 35 jaar op het grondstuk bevindt, dan kan de grondeigenaar aan de opstaller een verlenging van het opstalrecht aanbieden voor een periode van 15 jaar. Zie: Von Oefele \& Winkler 2008, Rn 5.224.

$324 \$ 27$ Abs. 3 ErbbauRG. 
zal dit leiden tot wijziging van het opstalrecht. Deze wijziging dient in het Grundbuch te worden ingeschreven. ${ }^{325}$

$325 \S 877 \mathrm{BGB}$. 



\section{Hoofdstuk 3. Horizontale doorbreking van de verticale natrekking naar Nederlands recht}

\section{§1. Inleiding}

\section{Bestanddelen en natrekking}

Het Burgerlijk Wetboek (verder: BW) geeft een tweetal wijzen waarop een object een juridische eenheid met een grondstuk kan vormen. ${ }^{326}$ De eerste wijze is gelegen in art. 3:4 BW. Dit artikel geeft een tweetal criteria op grond waarvan een object als bestanddeel kan worden aangemerkt: 1) het 'verkeersopvatting'-criterium ${ }^{327}$ en 2) het 'beschadiging van betekenis'criterium. ${ }^{328}$ Wordt voldaan aan een van beide criteria dan kan het object als bestanddeel worden aangemerkt en vormt het object dat op indirecte wijze met het grondstuk is verenigd een juridische eenheid met het grondstuk. Het eigendomsrecht van het grondstuk waarmee het object (indirect) is verenigd, strekt zich ingevolge art. 5:3 BW uit over het bestanddeel.

Naast de twee criteria van art. 3:4 BW geeft art. 5:20 lid 1 BW een opsomming van objecten die geacht worden tot de eigendom van de grond te behoren. ${ }^{329} \mathrm{Bij}$ de totstandkoming van art. 5:20 lid $1 \mathrm{BW}$ heeft de wetgever aansluiting gezocht bij de definitie voor onroerende zaken en de opsomming van art. 5:20 lid $1 \mathrm{BW}$ is dan ook vrijwel identiek aan de objecten die krachtens art. 3:3 lid $1 \mathrm{BW}$ als onroerend worden gekwalificeerd. Een object dat ingevolge art. 3:3 lid 1 BW wordt aangemerkt als onroerend vormt met de grond een juridische eenheid en wordt met de grond in eigendom

326 In het 'graftekens'-arrest heeft de Hoge Raad het naast elkaar bestaan van beide wijzen van bestanddeelvorming impliciet erkend door te stellen dat een grafteken onroerend is en tot de eigendom van de grond behoort, maar niet als bestanddeel in de zin van art. 3:4 BW kan worden aangemerkt. Zie: r.o. 3.4 en 3.8 bij HR 25 oktober 2002, NJ 2003, 241. In hoofdstuk 3 §3 wordt ingegaan op de verhouding tussen beide wijzen van eigendomsnatrekking.

327 Hoofdstuk $3 \$ 2.2 .1$.

328 Hoofdstuk $3 \$ 2.2 .2$.

329 De in art. 5:20 lid 1 BW opgesomde objecten zijn mijns inziens als bestanddeel van het grondstuk aan te merken. Over het aanmerken van de in art. 5:20 lid 1 $\mathrm{BW}$ opgesomde objecten als bestanddeel bestaat in de literatuur discussie. Zie: hoofdstuk $3 \S 3$. 
nagetrokken. ${ }^{330}$ Voor het karakteriseren van een gebouw of werk $^{331}$ als onroerend is niet de fysieke verbondenheid met de grond doorslaggevend, maar de bestemming van het bouwwerk om duurzaam met de grond te zijn verenigd. ${ }^{332}$

\section{Doorbreking van de natrekking}

Uit de aanhef van art. 5:20 lid $1 \mathrm{BW}$ volgt dat een met de grond verenigd object niet in eigendom natrekt wanneer de wet anders bepaalt. De wijzen waarop de natrekking kan worden doorbroken, kunnen in een drietal categorieën worden onderverdeeld. Ten eerste wordt een object niet met de grond nagetrokken wanneer het object als bestanddeel van eens anders onroerende zaak kan worden aangemerkt. ${ }^{333}$ De tweede categorie ziet op wettelijke bepalingen die leiden tot doorbreking van de natrekking ten aanzien van specifieke objecten. Zo worden netten van kabels en leidingen en grafbedekkingen ondanks de duurzame vereniging met de grond in beginsel niet met de grond nagetrokken. Zowel aan de netten als de grafbedekkingen komt ondanks het feit dat ze krachtens art. 3:3 lid 1 BW als onroerend kunnen worden aangemerkt een 'eigen' goederenrechtelijke identiteit toe. ${ }^{334}$ De derde categorie ziet op de vestiging van een beperkt zakelijk recht van opstal.

330 In de relatie grondstuk-object dient het grondstuk als zaak te worden aangemerkt. Het Romeinsrechtelijke superficies solo cedit-beginsel komt in art. 5:20 lid $1 \mathrm{BW}$ tot uitdrukking.

331 Gebouwen en werken worden in de literatuur veelal aangeduid met de term 'bouwwerk'.

332 Hoofdstuk $3 \S 2.3$. Uiteraard kunnen ook beplantingen als onroerend worden aangemerkt wanneer zij met het grondstuk zijn verenigd. Anders dan bij bouwwerken speelt bij het aanmerken van beplantingen als onroerend de bestemming geen rol. Zie: noot 403 .

333 Art. 5:20 lid 1 sub e BW. Wanneer een gedeelte van een woning gerealiseerd is op het grondstuk van een ander, dan wordt dit gedeelte, de overbouw, niet met het grondstuk waarop of waarin de overbouw zich bevindt in eigendom nagetrokken wanneer de overbouw als bestanddeel van de woning kan worden aangemerkt. De overbouw wordt nagetrokken met het grondstuk waarop of waarin de woning zich bevindt.

334 De netten behoren toe aan de bevoegd aanlegger, aldus art. 5:20 lid 2 BW. De grafbedekkingen komen ingevolge art. 32a Wet op de lijkbezorging (verder: Wlb) in eigendom toe aan de nabestaanden die verantwoordelijk zijn voor het aanbrengen van de grafbedekkingen. Met het van kracht worden van art. 32a Wlb op 1 januari 2010 worden graftekens -deze objecten kunnen immers onder de noemer 'grafbedekkingen' worden geschaard- geacht niet langer met het grondstuk te worden nagetrokken. 
Door het vestigen van een recht van opstal komt aan de gerechtigde tot het opstalrecht, de opstaller, de bevoegdheid toe "in, op of boven een onroerende zaak van een ander gebouwen, werken of beplantingen in eigendom te hebben of te verkrijgen". ${ }^{335}$ De bouwwerken en beplantingen ten gunste waarvan het opstalrecht wordt gevestigd, de zogenoemde opstallen, kunnen ten tijde van de vestiging van het opstalrecht reeds bestaan, maar kunnen ook gedurende het bestaan van het opstalrecht met het grondstuk worden verenigd. Ten gevolge van de vestiging van het opstalrecht rust op de opstallen een 'eigen' eigendomsrecht; de opstallen worden niet (langer) met het grondstuk in eigendom nagetrokken. ${ }^{336}$ Het op de opstallen rustende eigendomsrecht is accessoir aan het opstalrecht, hetgeen betekent dat het eigendomsrecht noch kan worden overgedragen noch kan worden bezwaard zonder overdracht of bezwaring van het opstalrecht. Als tegenprestatie voor het hebben van een opstal op het aan een ander toebehorend grondstuk kan op de opstaller de verplichting rusten een geldsom te betalen. ${ }^{337}$

Naast het hebben of verkrijgen van een opstal kan aan de opstaller op grond van het opstalrecht een gebruiksrecht toekomen ten aanzien van de onroerende zaak waarop de opstal zich bevindt. Of de opstaller aan het opstalrecht een gebruiksrecht ontleent is afhankelijk van hetgeen in de vestigingsovereenkomst is overeengekomen en de aard van het opstalrecht, waarbij een onderscheid dient te worden gemaakt tussen zelfstandige en afhankelijke opstalrechten. ${ }^{338}$ Is het opstalrecht zelfstandig van aard dan komt aan de opstaller op grond van het opstalrecht een gebruiksrecht toe; bij een afhankelijk opstalrecht vloeit dit gebruiksrecht voort uit het recht ${ }^{339}$ waaraan het opstalrecht accessoir is.

Bij de beëindiging van het opstalrecht komen aan de opstaller in beginsel een tweetal, elkaar uitsluitende rechten toe. Het eerste recht betreft het recht op vergoeding van de waarde van de opstallen die door de opstaller of zijn

335 Art. 5:101 BW. Ploeger geeft in zijn proefschrift een zeer beeldende omschrijving van het opstalrecht: "Het recht van opstal als beperkt recht dat de hoofdzaak bezwaart, fungeert in ons recht als het werktuig om de juridische band tussen opstal en grond te verbreken. Het opstalrecht is de steeksleutel waarmee men de bouten los draait die de machine verbinden met de werkvloer. Het afzonderlijke eigendomsrecht op de opstal bestaat aldus bij de gratie van het opstalrecht”. Zie: Ploeger 1997, nr. 187.

336 Althans volgens de heersende leer. Mijns inziens komt aan de opstaller geen eigendom van de opstal(len) toe, maar 'enkel' bevoegdheden die uit een meeromvattend recht afkomstig zijn. Zie: hoofdstuk 3 §4.3.1.

337 Of op de opstaller de verplichting rust een geldsom, de zogenoemde retributie, te betalen is afhankelijk van hetgeen partijen in de vestigingsovereenkomst zijn overeengekomen. Zie: hoofdstuk $3 \S 4.4$.

338 Hoofdstuk 3 \$4.1.

339 Uit art. 5:101 lid 2 BW volgt dat dit een zakelijk recht kan betreffen alsook een recht van huur of pacht. 
rechtsvoorganger onverplicht zijn aangebracht. Ook de opstallen die bij aanvang van het opstalrecht tegen vergoeding der waarde zijn overgenomen komen voor vergoeding in aanmerking. Het tweede recht kent aan de opstaller de bevoegdheid toe voornoemde opstallen weg te nemen. De bevoegdheid gebouwen, werken of beplantingen weg te nemen kan eveneens toekomen aan de gerechtigde tot een recht van erfpacht, de erfpachter. ${ }^{340}$ $\mathrm{Nu}$ aan de gerechtigde tot een erfpachtrecht zowel een gebruiksrecht ten aanzien van een onroerende zaak toekomt als een wegneemrecht met betrekking tot de door de erfpachter aangebrachte en de bij aanvang van het erfpachtrecht in waarde vergoede opstallen, rijst de vraag of het opstal- en erfpachtrecht voldoende van elkaar verschillen om het naast elkaar bestaan van beide rechten te rechtvaardigen. ${ }^{341}$

\section{§2. Classificatie van de goederenrechtelijke rechtsobjecten}

\section{$\S 2.1$ Zaken en vermogensrechten}

Het rechtsobject van het Nederlandse goederenrecht is een 'goed', hetgeen een genusbegrip is voor alle vermogensbestanddelen waarvan zaken en vermogensrechten de species vormen. ${ }^{342}$ In het Burgerlijk Wetboek is een ruime omschrijving opgenomen van rechten die als vermogensrecht kunnen worden aangemerkt. Vermogensrechten zijn die rechten die afzonderlijk dan wel tezamen met andere overdraagbaar zijn, dan wel rechten die een stoffelijk voordeel verschaffen, of rechten die in ruil voor een (in het vooruitzicht gesteld) stoffelijk voordeel zijn verkregen. ${ }^{343}$ Een recht is een vermogensrecht wanneer het enige economische waarde vertegenwoordigt. Een belofte om te gaan winkelen is geen vermogensrecht. ${ }^{344}$

Een zaak is, anders dan een vermogensrecht, een voor menselijke beheersing vatbaar stoffelijk object ${ }^{345}$, zoals auto's en dieren. ${ }^{346}$ Het stoffelijk en

340 Ook aan de gerechtigde tot een recht van vruchtgebruik of erfdienstbaarheid als aan de huurder, pachter en hypotheekgever kan een wegneemrecht toekomen. Zie: hoofdstuk $3 \S 4.5$.

341 Hoofdstuk $3 \$ 4.3 .1$.

342 Art. 3:1 BW. Zie: M.v.A. II bij art. 3:1 BW, Parl. Gesch. Boek 3 (1981), p. 64.

343 Art. 3:6 BW.

344 Pitlo/Reehuis \& Heisterkamp 2012, Goederenrecht, nr. 7.

345 Art. 3:2 BW.

346 Of elektriciteit als een zaak in de zin van art. 3:2 BW moet worden aangemerkt, is onduidelijk. Uit de T.M. bij art. 3:2 BW volgt dat energie geen zaak is in de zin van het ontwerp, terwijl art. 7:5 lid $1 \mathrm{BW}$ stelt dat het bij consumentenkoop gaat om “een roerende zaak, elektriciteit daaronder begrepen ...”. Zie: Parl. Gesch. Boek 3 (1981), p. 64. Volgens Van der Steur dient de stoffelijkheid van een object niet op functionele, maar louter op formele, natuurkundige wijze te 
daarmee tastbaar zijn van een object maakt een object nog niet tot een zaak. Het object dient tevens vatbaar te zijn voor bezit: uitoefening van enige zeggenschap is noodzakelijk. ${ }^{347} \mathrm{Zo}$ is de maan wel stoffelijk en met enige moeite tastbaar, maar is de maan geen zaak in goederenrechtelijke zin omdat zeggenschap over de maan niet mogelijk is. Daarnaast dient aan het object ook enig 'belang' toe te komen, hetgeen wordt beoordeeld aan de hand van de algemene, objectieve opvatting. ${ }^{348}$ Wanneer aan voornoemde vereisten wordt voldaan kan een object worden aangemerkt als zaak of bestanddeel. ${ }^{349}$ Een zaak is een op zichzelf staand, geïndividualiseerd object, terwijl een bestanddeel deel uitmaakt van een groter geheel, de zaak. ${ }^{350}$

Anders dan bij een bestanddeel, komt aan een zaak een eigen goederenrechtelijk identiteit toe. ${ }^{351}$ De op de zaak rustende goederen-

worden bepaald. Doordat elektriciteit bestaat uit elektronen en daarmee enige massa kent, kenmerkt elektriciteit zich door een stoffelijk karakter, aldus Van der Steur. Zie: Van der Steur 2003, pp. 170-171.

348 Aan dit vereiste zal worden voldaan wanneer het object op geld waardeerbaar is. Ook objecten die niet op geld waardeerbaar zijn kunnen als zaak worden gekwalificeerd. Aan een 'gewone' kindertekening zal doorgaans geen enkel belang worden toegekend, hoewel het voor de ouders van de kleine creatieveling wel enige affectieve waarde heeft. Daarentegen zal aan een kindertekening van bijvoorbeeld een staatshoofd volgens de algemene opvatting wel enig 'belang' worden toegekend. Zie: Ploeger 1997, nrs. 16-19.

349 Tot aan de invoer van het BW in 1992 was het Nederlandse recht, naast het bestanddeel en de zaak, bekend met de zogenoemde 'hulpzaak'. Een hulpzaak is een uit zijn aard roerende zaak die op grond van zijn bestemming werd gekwalificeerd als onroerend, aldus art. 563 OBW (OBW staat voor het Burgerlijk Wetboek van 1838). Volledigheidshalve dient te worden opgemerkt dat een object dat onroerend door bestemming is onder het Belgische recht niet met de term 'hulpzaak', maar met de term 'bijzaak' wordt aangeduid. Zie: hoofdstuk $4 \$ 2.2$.2. Het belang van de hulpzaak kwam met name tot uitdrukking bij een op de hoofdzaak gevestigd recht van hypotheek. Het hypotheekrecht strekte zich tevens uit over de aan de hoofdzaak toebehorende hulpzaak. Hoewel de hulpzaak in het BW van 1992 niet is opgenomen, biedt art. 3:254 BW de mogelijkheid een (stil) pandrecht te vestigen ten aanzien van zaken die volgens de verkeersopvatting bestemd zijn een onroerende zaak duurzaam te dienen. Ten aanzien van dit pandrecht kan worden bedongen dat de schuldeiser bevoegd is de verpande zaken èn de verhypothekeerde goederen samen te executeren. Zie: Heyman \& Bartels 2012, nr. 11; Kortmann 1990, pp. 710-715; Ploeger 1997, nrs. 51-52; Stein 1991, pp. 880-882.

350 Voor het karakteriseren van een object als bestanddeel is het niet van belang of er tussen het object en de zaak een fysieke band bestaat. Zie de arresten 'sleepboot Egbertha'(HR 26 maart 1936, NJ 1936, 757), 'stafmateriaal' (HR 11 december 1953, NJ 1954, 115) en 'Radio Holland' (HR 16 maart 1979, NJ 1980, 600).

351 "Eigendom op deelen eener zaak is onbestaanbaar", aldus Land 1901, p. 124. Zie ook: Van Maanen 1998, p. 554. 
rechtelijke rechten strekken zich uit over de bestanddelen van de zaak ${ }^{352}$, terwijl de op de bestanddelen rustende goederenrechtelijke rechten tenietgaan. Een bestanddeel volgt de goederenrechtelijke status van de zaak waar het bestanddeel van is. ${ }^{353}$ Zo gaan bij overdracht van de zaak ook de tot de zaak behorende bestanddelen mee over op de vervreemder en leidt bezwaring van de zaak tot bezwaring van al diens bestanddelen. De rechtvaardiging voor het verloren gaan van de op het bestanddeel rustende goederenrechtelijke rechten is gelegen in het eenheidsbeginsel dat strekt tot behoud van de economische waarde van de zaak. ${ }^{354}$ Een object kan slechts van één zaak bestanddeel zijn. ${ }^{355}$

Ten aanzien van objecten die uit een massief lichaam bestaan, zoals bij een diamant of dier het geval is, zal geen discussie worden gevoerd over de individualiseerbaarheid van het object. ${ }^{356} \mathrm{Bij}$ een samengestelde $\mathrm{zaak}^{357} \mathrm{zal}$ het daarentegen niet altijd duidelijk zijn of de verschillende objecten waaruit de zaak is samengesteld alle als bestanddeel van de zaak kunnen worden aangemerkt. ${ }^{358}$ De wetgever heeft met het neerleggen van een tweetal criteria in art. 3:4 BW beoogd handvatten te bieden. ${ }^{359}$ Naast de criteria van art. 3:4 BW geeft de wetgever in art. 5:20 lid $1 \mathrm{BW}$ een opsomming van objecten

352 Wanneer twee of meerdere roerende zaken met elkaar worden nagetrokken en geen van deze zaken als hoofdzaak kan worden aangemerkt, worden de eigenaren van de nagetrokken zaken mede-eigenaar voor een aandeel evenredig aan de waarde van de zaak (art. 5:14 lid 2 BW). Zie: Asser/Mijnssen, Van Velten \& Bartels 5* 2008, nr. 69.

353 De goederenrechtelijke onzelfstandigheid van het bestanddeel belemmert een derde niet het bestanddeel weg te nemen wanneer aan deze het recht toekomt het bestanddeel weg te nemen ingevolge het ius tollendi. Het ius tollendi komt aan bod in $\$ 4.5$ van dit hoofdstuk.

354 Kortmann 1990, p. 714; Ploeger 1997, pp. 42-46.

355 Hetgeen tot uitdrukking komt in art. 5:20 lid 1 sub e BW: “... voor zover ze geen bestanddeel zijn van eens anders onroerende zaak".

356 Een uit een massief lichaam bestaande zaak wordt veelal met de term 'eenheidszaak' aangeduid.

357 Een samengestelde zaak dient niet te worden verward met een verzameling van zaken, zoals een collectie boeken. Bij overdracht of bezwaring van een collectie wordt iedere tot de collectie behorende zaak afzonderlijk overgedragen of bezwaard. Zie: Ploeger 1997, nr. 24.

358 Het samengaan van twee of meerdere zaken tot één zaak kan volgens de wet op verschillende wijzen geschieden. Roerende zaken kunnen middels natrekking (art 5:14 BW), vermenging (art. 5:15 BW) en zaaksvorming (art. 5:16 BW) een eenheid vormen. Onroerende zaken kunnen 'slechts' samengaan door middel van natrekking. Vóór het samengaan van de verschillende zaken komt aan iedere zaak een eigen goederenrechtelijke identiteit toe. Voornoemde verenigingswijzen hebben alle tot gevolg dat aan de samengevoegde objecten tezamen één goederenrechtelijke identiteit toekomt.

359 Asser/Mijnssen, Van Velten \& Bartels 5*2008, nr. 96. 
die tot de eigendom van de grond behoren. ${ }^{360} \mathrm{Nu}$ de eigendom van de grond zich uitstrekt over deze objecten ${ }^{361}$ kunnen deze als bestanddeel van de grond worden aangemerkt. ${ }^{362}$ De wetgever heeft de artikelen 3:3 lid $1 \mathrm{BW}$, waarin de definitie voor onroerende zaken is neergelegd, en 5:20 lid $1 \mathrm{BW}$ bewust op elkaar afgestemd: objecten die ingevolge art. 3:3 lid $1 \mathrm{BW}$ geacht worden onroerend te zijn, gaan in beginsel tot de eigendom van de grond behoren. ${ }^{363}$ Onroerend zijn “ ... de grond ${ }^{364}$, de nog niet gewonnen delfstoffen ${ }^{365}$, de met de grond verenigde beplantingen, alsmede de gebouwen en werken die duurzaam met de grond zijn verenigd, hetzij rechtstreeks, hetzij door vereniging

360 Tevens kent de wet bepalingen waarin specifieke objecten als bestanddeel worden aangemerkt. Zo zijn voortbewegingswerktuigen en andere machinerieën na inbouw in het schip als bestanddeel van het schip aan te merken, aldus art. 8:1 lid 3 BW. Zie ook: art. 1 lid 1 Wet toeboekgestelde Luchtvaartuigen.

361 Art. 5:20 aanhef lid 1 BW: "De eigendom van de grond omvat, ...”.

362 In het proefschrift wordt niet ingegaan op de natrekking van grondstukken onderling. Noch het BW noch het OBW kent bepalingen omtrent de natrekking van grondstukken onderling. Van eigendomsnatrekking was onder het OBW wel sprake wanneer een rivier haar bedding verlegde. De eigenaar van de rivier verkreeg de grond waarover de rivier na verlegging stroomde. Zie: noot 429. Onder het OBW strekte het eigendomsrecht van het grondstuk zich uit over de aanwas, wanneer de aanwas niet was verkregen middels een door de grondeigenaar aangelegde kunstgreep. Zie: Hof Arnhem 1877 (datum van zitting is niet opgegeven), W. 4081; HR 8 februari 1878, W. 4207. Uit de Parlementaire geschiedenis volgt dat bij aanwas onder het $\mathrm{BW}$ geen sprake is van natrekking, maar van een 'automatische grenswijziging' tussen het perceel land en het perceel water. Zie: T.M. bij art. 5:29 BW, Parl. Gesch. Boek 5 (1981), pp. 146-147. Het aan de automatische grenswijziging gekoppelde rechtsgevolg is desondanks gelijk aan dat van natrekking: de op het grondstuk rustende rechten strekken zich uit over de aanwas. Zie: M.v.A. bij art. 3:227 BW, Parl. Gesch. Boek 3 (1981), p. 734.

363 Over het aanmerken van de in art. 5:20 lid $1 \mathrm{BW}$ opgesomde objecten als bestanddeel bestaat in de literatuur discussie. Zie: hoofdstuk $3 \S 3$.

364 De 'grond' wordt in de Parlementaire geschiedenis omschreven als "het uiterste vlak van de aardkorst en de onder dat vlak zich bevindende vaste lagen”. Zie: T.M. bij art. 3:3 BW, Parl. Gesch. Boek 3 (1981), p. 66.

365 Delfstoffen zijn de in de ondergrond aanwezige mineralen of substanties van organische oorsprong en behoren in beginsel, althans zolang zij niet zijn gewonnen, toe aan de Staat. De in de grond bevindende delfstoffen gaan pas aan een derde in eigendom over wanneer de delfstoffen mèt gebruikmaking van een winningsvergunning worden gewonnen. Zie: art. 3 Mijnwet 2002. Dit is anders wanneer de Staat vóór 1 januari 2003 een concessie onder de Mijnwet van 1810 heeft verleend. De nog niet gewonnen delfstoffen behoren dan reeds op het moment dat de concessie is verleend aan de concessionaris in eigendom toe, aldus art. 7 jo. 19 Mijnwet 1810. Zie: Dankers-Hagenaars 2000, p. 287; Roggenkamp 2006, p. 213-225. 
met andere gebouwen of werken" ${ }^{366}$ Het onderscheid tussen roerende en onroerende zaken is van essentieel belang voor de rechtsgevolgen die aan beide kwalificaties zijn verbonden. Zo dient de levering van een onroerende zaak te geschieden door een in de openbare registers ingeschreven notariële akte $^{367}$, terwijl de levering van een roerende zaak in beginsel plaatsvindt door bezitsverschaffing ${ }^{368}$. Ook verschillen de verkrijgende verjaringstermijnen voor roerende en onroerende zaken. ${ }^{369}$ Een definitie van de roerende zaak ontbreekt in het BW. De wet stelt enkel dat roerende zaken alle zaken zijn die niet onroerend zijn. ${ }^{370}$

\section{$\S 2.2$ Het bestanddeel van artikel 3:4 BW}

\section{\$2.2.1 “...volgens verkeersopvatting ...”"}

Anders dan bij het karakteriseren van een zaak als onroerend ${ }^{371}$, komt aan de verkeersopvatting bij het aanmerken van een object als bestanddeel een zelfstandige rol toe. Het aanwenden van de verkeersopvatting als een zelfstandig criterium heeft tot de nodige discussie geleid. ${ }^{372}$ Enerzijds heeft de verkeersopvatting tot voordeel dat het flexibel van aard is en met de tijd mee kan bewegen, anderzijds is het criterium vaag en kan het leiden tot rechtsonzekerheid. ${ }^{373}$ Het verkeersopvatting-criterium is in het 'sleepboot Egbertha'-arrest ${ }^{374}$ als volgt geformuleerd: "Dat bij twijfel, of een voorwerp door verbinding een wezenlijk $k^{375}$ bestanddeel van een andere roerende zaak is geworden voor alles betekenis moet worden toegekend aan de opvattingen, welke in het maatschappelijk verkeer omtrent die soort van roerende zaken bestaan, terwijl aan den afwijkenden wil van de betrokken personen in een bepaald geval

366 Art. 3:3 lid 1 BW.

367 Art. 3:89 lid 1 BW.

368 Art. 3:90 BW.

369 Zie voor een uitvoerige uiteenzetting van de verschillende rechtsgevolgen die aan de kwalificatie van een zaak als roerend respectievelijk onroerend zijn verbonden: Memelink 2005, pp. 66-67.

$370 \quad$ Art. 3:3 lid 2 BW.

371 Hoofdstuk $3 \$ 2.3$.

372 Zo ook bij de totstandkoming van het BW. Zie: M.O. bij art. 3:4 BW, Parl. Gesch. Boek 3 (1981), pp. 77-80.

373 Rogmans 2007, nr. 29.

$374 \quad$ HR 26 maart 1936, NJ 1936, 757.

375 Meijers heeft in zijn ontwerp van art. 3:4 lid 1 BW de term 'wezenlijk' uit het 'sleepboot Egbertha'-arrest overgenomen. Zie: HR 26 maart 1936, NJ 1936, 757. In de definitieve versie van art. 3:4 BW is deze term weggelaten, nu het onwenselijk is een object alleen dan als bestanddeel aan te merken wanneer het object mede het wezen van de zaak bepaalt. Zie: M.v.A. II bij art. 3:4 BW, Parl. Gesch. Boek 3 (1981), p. 74. 
geen betekenis kan worden toegekend, nu het te doen is om de vaststelling van de zakenrechtelijke ten opzichte van een ieder intredende gevolgen van een dergelijke verbinding". Of een object in de concrete situatie als bestanddeel dient te worden aangemerkt is niet per definitie afhankelijk van de opvatting van de 'gemiddelde' Nederlander. De verkeersopvatting kan ook voortkomen uit een bepaalde kring van personen waarbinnen het object wordt gebruik. ${ }^{376}$

In zijn jurisprudentie geeft de Hoge Raad aanwijzingen voor het invullen van de verkeersopvatting. Deze aanwijzingen hebben slechts een sturende rol. In het arrest Dépex/Curatoren Bergel c.s. ${ }^{377}$ rijst de vraag of een waterdistillatieinrichting bestanddeel is van het gebouw waarin de inrichting is geplaatst. De Hoge Raad geeft bij het beantwoorden van deze vraag een tweetal aanwijzingen. De eerste aanwijzing is gelegen in de constructieve afstemming tussen gebouw en machine. De tweede aanwijzing kan worden gevonden in de mogelijke incompleetheid van het gebouw bij het ontbreken van de inrichting. ${ }^{378}$ Wichers geeft in haar dissertatie een uitvoerige opsomming van aanwijzingen op grond waarvan een object mogelijkerwijs als bestanddeel kan worden aangemerkt. Zo kunnen aanwijzingen worden gevonden in de naamgeving van de zaak, in de organische samenhang van de verschillende delen waaruit de zaak bestaat, in de economische meerwaarde van het geheel en in de duurzame samenhang tussen bestanddeel en hoofdzaak. Een aanwijzing kan volgens Wichers tevens worden gevonden in de objectief tijdelijke bedoeling van de vereniging, waarbij Wichers zich beroept op een uitspraak van rechtbank Leeuwarden. ${ }^{379}$ In dit vonnis oordeelt de rechter dat in de kring van bouwers van race-auto's en coureurs de verkeersopvatting heerst dat de voor race-auto's gebruikte motoren zodanig uitwisselbaar zijn dat zij ook na montage geen deel uitmaken van de auto. ${ }^{380}$ De tijdelijkheid van de vereniging alsook de eenvoudige verwisselbaarheid van de motoren leidde tot het oordeel dat de motor niet als bestanddeel van de auto kan worden aangemerkt. Een tijdelijk met de auto verenigde autoband welke is geleend of gehuurd, is volgens Wichers

376 Pitlo/Reehuis \& Heisterkamp 2012, Goederenrecht, nr. 12.

$377 \quad$ HR 15 november 1991, NJ 1993, 316.

378 Deze incompleetheidsmaatstaf wordt zowel in het arrest HR 27 november 1992, NJ 1993, 317 (Ontvanger Delft/Rabobank) als in het arrest HR 28 juni 1996, NJ 1997, 397 (Hendriks/Slot) herhaald.

379 Rechtbank Leeuwarden 20 december 1994, KG 1995, 61.

380 Ten aanzien van vliegtuigmotoren stelt het hof's-Hertogenbosch dat: “... naar Nederlands recht van natrekking geen sprake is. Noch door verkeersopvattingen, zoals uit het vorenstaande voldoende blijkt, noch door hechte verbinding wordt de vliegtuigmotor bestanddeel van het vliegtuig”. Zie: r.o. 4.14 bij hof 's-Hertogenbosch 15 augustus 2002, SES 2003, 56. Ook op grond van de Cape Town Convention wordt een vliegtuigmotor gezien als een aparte zaak, aangezien het mogelijk is een pandrecht op een vliegtuigmotor te vestigen. 
wel bestanddeel van de auto omdat de tijdelijkheid van de vereniging in dit geval subjectief is. ${ }^{381}$ Maar wat als het nu voor eenieder duidelijk is dat de vereniging van de geleende autoband tijdelijk is? Bijvoorbeeld doordat er op de velg van deze band met neonletters staat 'geleend' of 'slechts tijdelijk met de auto verenigd'? Of wanneer er een tijdelijke verwarmingsketel in een gebouw wordt bevestigd waarop duidelijk staat vermeld dat de ketel gehuurd is? Zowel ten aanzien van de motor in de race-auto, de geleende autoband als de gehuurde verwarmingsketel is het onjuist om de bestanddeelvorming afhankelijk te maken van de objectief tijdelijke bedoeling van vereniging, omdat het discutabel is wanneer van zo'n voldoende objectief tijdelijke bedoeling sprake is.

\section{$\$ 2.2 .2$ “... beschadiging van betekenis ...”}

Naast het verkeersopvatting-criterium kan ook an het verbondenheidscriterium worden getoetst of een object als bestanddeel kan worden aangemerkt. ${ }^{382}$ Aan dit criterium wordt voldaan wanneer het object niet van de zaak kan worden afgescheiden ${ }^{383}$ zonder dat er een beschadiging van betekenis wordt toegebracht aan de zaak of het af te scheiden object. ${ }^{384}$ Het moet gaan om een forse, aanzienlijke schade die objectief gezien van betekenis is. ${ }^{385}$ Onvoldoende is dat de hoofdzaak of het bestanddeel niet geheel gaaf meer is. ${ }^{386}$ Of de beschadiging van betekenis is, is afhankelijk van de vergelijking tussen de omvang van de door de afscheiding veroorzaakte schade en de waarde van de betrokken objecten. Wanneer de hoogte van de schade de waarde van de zaak overtreft is de beschadiging van betekenis. Afscheiding van een object waarbij geen schade ontstaat, kan onder het verbondenheidscriterium worden geschaard wanneer de afscheiding met onevenredig hoge kosten of arbeid gepaard gaat. Hoewel de fysieke schade ontbreekt kunnen de met de afscheiding gepaard gaande onevenredige kosten respectievelijk arbeid vanuit economisch perspectief als een beschadiging van betekenis worden beschouwd. ${ }^{387}$

Uit de volgende, uit de Parlementaire geschiedenis afkomstige passage volgt dat het verbondenheidscriterium meer is dan een aanwijzing voor het intreden van bestanddeelvorming: "Het tweede lid stelt buiten twijfel dat

Wichers 2002, pp. 83-95.

383 Anders dan bij het verkeersopvatting-criterium, dient bij het aannemen van bestanddeelvorming op grond van het verbondenheidscriterium een materiële verbinding tussen object en zaak te bestaan. M.v.A. II bij art 3:4 BW, Parl. Gesch. Boek 3 (1981), p. 75. Onbelangrijk is de waarde die partijen aan de schade toekennen. 
hetgeen op de daar aangegeven wijze aan een (hoofd)zaak is verbonden, steeds bestanddeel van die (hoofd)zaak is. Hier wordt de ruimte welke het eerste lid aan de verkeersopvattingen toestaat, dus niet verleend. Deze ruimte zou voor aard- of nagelvaste onderdelen ongewenst zijn. De regel geldt van de oudste tijden af en de ondergetekende ziet geen aanleiding hem te wijzigen". ${ }^{388} \mathrm{Bij}$ een aard- of nagelvaste verbinding wordt aangenomen dat bestanddeelvorming plaatsvindt, omdat dit in het maatschappelijk verkeer sinds jaar en dag gebruikelijk is. Echter is het niet de aard- of nagelvaste verbinding die de bestanddeelvorming doet intreden, maar de maatschappelijke opvatting dat bij een aard- of nagelvaste verbinding sprake is van een bestanddeel. Ook bij het beoordelen van de beschadiging zullen partijen terugvallen op de verkeersopvatting: zowel de hoogte van de schade als de waarde die aan de betrokken objecten wordt toegekend alsook de vergelijking tussen de hoogte van de schade en de waarde van de objecten zijn alle gebaseerd op de daaraan in het maatschappelijk verkeer toegekende 'getallen'. Het verbondenheidscriterium kan dan ook worden gezien als een nadere invulling van het verkeersopvatting-criterium. ${ }^{389}$ Met het formuleren van het verbondenheidscriterium geeft de wetgever een concrete situatie waar een object als bestanddeel moet worden aangemerkt. Een specifieke benoeming van het verbondenheidscriterium in het tweede lid is noodzakelijk, nu het criterium dwingend van aard is. ${ }^{390}$

\section{§2.3 De onroerende zaak van artikel 3:3 BW}

Uit de 'onroerende zaak'-definitie volgt dat gebouwen en werken onroerend zijn wanneer zij duurzaam met de grond zijn verenigd. ${ }^{391}$ Dit 'onroerend'criterium voor gebouwen en werken wordt in de literatuur aangeduid met het 'bestemmingscriterium' waarvan de grondslag is gelegen in

388 M.v.A. II bij art 3:4 BW, Parl. Gesch. Boek 3 (1981), p. 75.

389 Bartels is daarentegen van mening dat het verbindingscriterium van art. 3:4 lid $2 \mathrm{BW}$ een zelfstandige maatstaf betreft "en niet alleen maar een vermoeden dat een andere maatstaf, de verkeersopvatting, geldt”. Zie: Heyman \& Bartels 2006, p. 273. Volgens Heyman en Bartels is de meest praktische werkwijze bij het beoordelen of een object als bestanddeel van een bouwwerk kan worden aangemerkt om eerst aan lid 2 te toetsen. Pas wanneer deze toets negatief uitvalt, dient aan het eerste lid, de verkeersopvatting, te worden getoetst. Zie: Heyman \& Bartels 2012, nr. 19.

390 Kortmann 1990, pp. 710-715; Wolfert 2003b, pp. 279-285.

391 Uit art. 3:3 lid $1 \mathrm{BW}$ volgt dat bouwwerken zowel op directe als op indirecte wijze met de grond verenigd kunnen zijn. Van directe vereniging is sprake wanneer het bouwwerk in of op de grond is geplaatst zonder tussenkomst van een ander bouwwerk. Bij indirecte vereniging is het bouwwerk middels een ander bouwwerk met de grond verenigd. 
het zogenoemde 'Amercentrale'-arrest. ${ }^{392}$ Ten aanzien van deze uit het aansprakelijkheidsrecht afkomstige casus stelt de Hoge Raad dat het hof blijk heeft gegeven van de juiste opvatting dat de eigenaar van een opengescheurde olietanker aansprakelijk is voor de hierdoor ontstane schade ingevolge art. $1405 \mathrm{OBW}^{393}$ : “... dat het hof, door op de grondslag van voormelde vaststellingen te oordelen dat de tank moet worden aangemerkt als een gebouw in de zin van art. 1405, niet heeft blijk gegeven van een onjuiste opvatting van gemeld artikel; dat toch in een en ander ligt besloten dat de onderhavige constructie een bouwsel was dat naar aard en inrichting bestemd was om duurzaam ter plaatse te blijven, waarbij niet van belang is of technisch de mogelijkheid zou hebben bestaan om het te verplaatsen". Het bestemmingscriterium is geformuleerd ter verruiming van de risicoaansprakelijkheid van art. 1405 OBW, aangezien de risicoaansprakelijkheid van art. 1405 OBW in beginsel beperkt was tot ingestorte ${ }^{394}$ gebouwen $^{395}$. De wetgever heeft bij het formuleren van de 'onroerend zaak'-definitie -ten behoeve van het in 1992 ingevoerde BW- aansluiting gezocht bij voornoemde uitspraak van de Hoge Raad. ${ }^{396}$ Met het van kracht worden van het BW heeft de wetgever het tot dan geldende fysieke verbondenheidscriterium ${ }^{397}$ voor onroerende zaken vervangen door het bestemmingscriterium. ${ }^{398}$

In de jurisprudentie is de toepassing van het bestemmingscriterium voor het definiëren van zaken als onroerend door de Hoge Raad bevestigd en nader uitgewerkt in het zogenoemde 'portacabin'-arrest. ${ }^{399}$ In dit arrest diende de

$392 \quad$ HR 13 juni 1975, NJ 1975, 509.

393 Art. 1405 OBW is de voorloper van art. 6:174 BW. In art. 6:174 lid 4 BW worden opstallen gedefinieerd als "gebouwen en werken, die duurzaam met de grond zijn verenigd, hetzij rechtstreeks, hetzij door vereniging met andere gebouwen of werken".

394 De eigenaar van een gebouw is ingevolge art. 1405 OBW zowel bij gehele als bij gedeeltelijke instorting van het gebouw aansprakelijk wanneer de instorting veroorzaakt is door verzuim van onderhoud of door een gebrek in de bouwing of inrichting. Zie: Asser/Hartkamp \& Sieburgh 6-IV* 2011, nr. 235.

395 Het begrip 'gebouw' in art. 1405 OBW dient ruim te worden uitgelegd. De Hoge Raad stelt in HR 29 mei 1925, NJ 1925, 750 ten aanzien van de door eiseres ingenomen stelling dat met het begrip 'gebouw' in de zin van artikel 1405 OBW een geheel voltooid gebouw wordt bedoeld, dat: “... echter voormelde uitdrukking, als in het algemeen te kennen gevende al wat door bouwing wordt gevormd, eene zoodanige beperkte uitlegging niet veroorlooft, terwijl aard en strekking van het voorschrift daartoe evenmin eenige aanleiding geven". Zie ook: HR 6 december 1963, NJ 1965, 9.

396 M.O. en N.v.W. bij art. 3:3 BW, Parl. Gesch. Boek 3 (1981), p. 70.

397 Krachtens art. 562 OBW wordt een zaak als onroerend aangemerkt wanneer er sprake is van een aard- en nagelvaste verbinding met een onroerende zaak.

398 Heyman 2000a, p. 118.

399 HR 31 oktober 1997, NJ 1998, 97. 
Hoge Raad te beoordelen of het hof de juiste maatstaven had toegepast bij het kwalificeren van een portacabin als een onroerende zaak. ${ }^{400}$ De Hoge Raad komt in dit arrest met een aantal maatstaven ter uitwerking van het bestemmingscriterium. "Een gebouw kan duurzaam met de grond verenigd zijn in de zin van art. $3: 3 \mathrm{BW}$, doordat het naar aard en inrichting bestemd is om duurzaam ter plaatse te blijven; ... . Niet van belang is dan meer dat technisch de mogelijkheid bestaat om het bouwsel te verplaatsen". ${ }^{401}$ De eerste maatstaf (aard en inrichting) ziet op het bouwwerk zelf. Met de aard van het bouwwerk wordt gedoeld op de objectieve aard van het bouwwerk, terwijl bij de inrichting wordt gekeken naar de toepassing van het bouwwerk in de gegeven situatie. In het later gewezen 'woonark'-arrest benadrukt de Hoge Raad dat het gaat om de aard en inrichting van het bouwwerk zelf: de omstandigheden die betrekking hebben op de omgeving hebben geen invloed op de aard en inrichting van het bouwwerk. ${ }^{402}$

De tweede maatstaf ziet op de naar buiten kenbare bestemming van het bouwwerk om duurzaam met het grondstuk te zijn verenigd. ${ }^{403}$ Met de term

$400 \quad$ In deze casus gaat het om een portcabin die zich op een aan Buys toekomend grondstuk bevindt. Wanneer Buys verzuimt aan zijn betalingsverplichtingen te voldoen rijst de vraag of de aanwezige portacabin roerend dan wel onroerend van aard is, hetgeen van belang is voor de vraag of de portacabin valt onder het door de 'Ontvanger' gelegde beslag of onder het verhaalsrecht van de hypotheekverstrekker. De portacabin was als kantoorruimte in gebruik genomen en op een zodanige wijze met de grond verenigd dat deze daarmee één geheel vormde. De portacabin had een aparte ingang die middels een tegelpad bereikbaar was en werd omgeven door een goed onderhouden tuin. Ook kon men in de portacabin beschikken over gas, water en elektriciteit, en was er zowel een telefoon- als een rioolaansluiting.

401 R.o. 3.3 HR 31 oktober 1997, NJ 1998, 97.

402 “... de in 4.4 .1 vermelde omstandigheden betrekking hebben op de omgeving van de woonark, en niet zijn aan te merken als naar buiten kenbare bijzonderheden van aard en inrichting van de woonark zelf", r.o. 4.4.2 bij HR 15 januari 2010, LJN: BK9136. Zie ook: HR 17 november 2006, BNB 2007, 50.

403 “... de bestemming van een gebouw of werk om duurzaam ter plaatse te blijven dient naar buiten kenbaar te zijn. Dit vereiste vloeit voort uit het belang dat de zakenrechtelijke verhoudingen voor derden kenbaar dienen te zijn”, r.o. 3.3 bij HR 31 oktober 1997, NJ 1998, 97. Bij het aanmerken van beplantingen als onroerend speelt de bestemming geen rol. Beplantingen zijn op een zodanige wijze met het grondstuk verenigd dat sprake is van bestanddeelvorming wanneer "door het uitlopen van wortels een organisch verband is gelegd" met de grond. Zie: T.M. bij art. 3:3 BW, Parl. Gesch. Boek 3 (1981), p. 67. Zie ook: HR 10 december 1937, NJ 1938, 335. Toepassing van het bestemmingscriterium op beplantingen kan leiden tot rechtsonzekerheid. Een boom die ten behoeve van economische exploitatie tijdelijk met de grond is verenigd zou bij toepassing van de duurzaamheidsmaatstaf roerend zijn, terwijl eenzelfde boom die met de intentie langdurig met de grond te zijn verenigd onroerend is. Zie: M.v.A. II bij art. 3:3 BW, Parl. Gesch. Boek 3 (1981), p. 69. 
'bestemming' wordt gedoeld op de bedoeling van de bouwer. Onder bouwer moet mede worden verstaan diegene in wiens opdracht het bouwwerk wordt aangebracht. ${ }^{404}$ In het 'zeecontainer'-arrest worden tot de bouwer en de aanbrenger ook de belanghebbenden tot het bouwwerk gerekend. ${ }^{405}$ Voorgaande heeft in de literatuur tot de nodige kritiek geleid. De bedoeling van de bouwer is een subjectieve maatstaf ook al is deze naar buiten kenbaar, terwijl het goederenrecht juist ten behoeve van de bescherming van derden gestoeld is op objectieve maatstaven. ${ }^{406}$ Volgens Heyman is het onduidelijk hoe de bestemming van de zaak moet worden vastgesteld en op welke wijze de bedoeling van de bouwer kenbaar moet worden gemaakt. ${ }^{407}$ Heyman is daarom van mening dat enkel de "fysieke onverplaatsbaarheid in maatschappelijk opzicht" doorslaggevend zou moeten zijn bij het kwalificeren van een zaak als onroerend. De bestemming kan op zijn best als correctie dienen, aldus Heyman. ${ }^{408}$ Ploeger is van mening dat het begrip 'duurzaam' uitgelegd dient te worden als 'permanent', waarmee hij benadrukt dat de zaak niet gebonden is aan de persoon van de gebruiker maar aan de grond waarmee de zaak is verenigd. ${ }^{409}$

De Hoge Raad stelt dat het niet van belang is of de technische mogelijkheid bestaat het bouwwerk te verplaatsen ${ }^{410}$, om vervolgens in het 'graftekens'arrest hieraan toe te voegen dat een beperkte fundering of zelfs het ontbreken daarvan niet onverenigbaar is met het bestaan van een duurzame bestemming. ${ }^{411}$ Van een duurzame vereniging met de grond kan eveneens

404 R.o. 3.3 bij HR 31 oktober 1997, NJ 1998, 97.

405 R.o. 3.2 bij HR 5 januari 2000, BNB 2000, 83.

406 Zie: Wichers 2002, p. 108; Heyman 2000b, p. 198. Zowel de bedoeling van de bouwer als die van de opdrachtgever kan tot een onbevredigend resultaat leiden bij het bepalen of een zaak al dan niet onroerend van aard is, omdat de bedoeling sterk kan afwijken van de bedoeling van de gebruiker. Zie: Janssen 2006, pp. 855-867.

$407 \quad$ Heyman 2005, p. 114.

408 Heyman 2000a, pp. 92-98.

$409 \quad$ Ploeger 1998, p. 472; Ploeger 2002, p. 521.

410 R.o. 3.3 bij HR 31 oktober 1997, NJ 1998, 97.

411 Zie r.o. 3.4.2 bij HR 25 oktober 2002, NJ 2003, 241, waarin de Hoge Raad stelt dat het hof de vraag of graftekens als die van het Aartsbidom Utrecht duurzaam met de grond zijn verenigd, naar de juiste door de Hoge Raad in het 'portacabin'arrest aanvaarde maatstaven heeft beoordeeld. Het hof heeft dan ook tot het oordeel kunnen komen dat de graftekens onroerend van aard zijn. Ploeger is van mening dat de graftekens roerend zijn, ondanks het feit dat er tussen de graftekens en het grondstuk een verbinding bestaat. Zie: Ploeger 1999, p. 425. Met het van kracht worden van art. 32a Wlb wordt de eigendomsnatrekking van de grafbedekking met de grond doorbroken en blijven de nabestaanden die verantwoordelijk zijn voor het aanbrengen van de grafbedekking in beginsel eigenaar van de grafbedekking. 
sprake zijn wanneer het werk zich op de grond voortbeweegt. De Hoge Raad oordeelde ten aanzien van havenkranen ${ }^{412}$ dat het hof zonder schending van enige rechtsregel heeft kunnen aannemen dat deze kranen ondanks hun beweegbaarheid over rails ingevolge art. 3:3 BW met de grond waren verenigd. ${ }^{413}$

Terwijl een over rails voortbewegende havenkraan als onroerend wordt aangemerkt, stelt de Hoge Raad ten aanzien van een woonark die met meerpalen aan de onder de woonark gelegen bodem is verenigd ${ }^{414}$ : "Het gaat hier om een zaak die blijkens zijn constructie bestemd is om te drijven en drifft, zodat sprake is van een schip in de zin van artikel 8:1 BW. Een schip is in het algemeen een roerende zaak. Een verbinding tussen een schip en de onder dat schip gelegen bodem ${ }^{415}$ die toelaat dat het schip met de waterstand mee beweegt, kan niet leiden tot het oordeel dat het schip met de bodem is verenigd in de zin van art. 3:3 lid $1 \mathrm{BW}$. Klaarblijkelijk is in het onderhavige geval sprake van een dergelijke verbinding, zodat de woonark niet met de onder die ark gelegen bodem is verenigd in de zojuist bedoelde zin". ${ }^{416}$ De Hoge Raad komt tot het oordeel dat er geen sprake is van een duurzame vereniging van de woonark met de onder de woonark gelegen bodem. Het hof waar de zaak door de Hoge Raad naar is doorverwezen, komt tot de conclusie dat de vereniging tussen de woonark en de oever evenmin als duurzaam kan worden aangemerkt. ${ }^{417}$

412 Zie: HR 8 juli 1997, BNB 1997, 294; HR 24 december 2010, LJN: BO3644.

413 Uit r.o. 3.3.4 bij HR 24 december 2010, LJN: BO3644 volgt: "De stukken van het geding laten geen andere conclusie toe dan dat de onderhavige havenkranen blijkens hun constructie bestemd zijn om zich op het land te bevinden en dat zij, zij het indirect via rails, ook feitelijk in voortdurende verbinding staan met de onder de kranen gelegen grond”. Zie ook: Van der Plank 2010, p. 140. Ploeger is daarentegen van mening dat havenkranen roerend zijn: "De 'aard' van de zaak blijkt aan belang in te boeten ten gunste van de 'bestemming'. Een bestemming die m.i. te snel wordt aangenomen. Dit wordt waarschijnlijk in de hand gewerkt door een te grote nadruk op het begrip 'duurzaam'... het feit dat dergelijke zaken de grens van het perceel niet verlaten doet hen niet in hun aard veranderen". Zie: Ploeger 1998, p. 472.

$414 \quad$ HR 15 januari 2010, BNB 2010, 80.

415 In deze casus bestaat de verbinding uit twee beugels die om een meerpaal zitten. De meerpaal is in de bodem van de waterkavel verankerd.

416 R.o. 4.2 bij HR 15 januari 2010, BNB 2010, 80, hetgeen in het zogenoemde 'marina'-arrest, HR 9 maart 2012, LJN: BV8198, wordt bevestigd. Anders oordeelde de Hoge Raad ten aanzien van drijvende steigers: “... de drijvende steigers moeten worden aangemerkt als werken die naar hun aard en inrichting bestemd zijn om duurzaam ter plaatse te blijven, en dus als gebouwde eigendommen in de zin van artikel 16 van de Wet waardering onroerende zaken". Zie: HR 20 september 2002, BNB 2002, 374.

417 R.o. 4.6 bij hof 's-Hertogenbosch 30 december 2010, LJN: BQ0443. Van der Plank werpt de vraag op waarom een woonark die middels beugels aan een meerpaal is bevestigd roerend van aard is, terwijl havenkranen die middels rails met het grondstuk zijn verenigd geacht worden duurzaam met de grond 
In het 'marina'-arrest bevestigt de Hoge Raad dat "een zaak die blijkens zijn constructie bestemd is om te drijven en drijft, moet worden aangemerkt als een schip in de zin van artikel 8:1 BW" in het algemeen een roerende zaak is. ${ }^{418}$ Anders dan bij het 'woonark'-arrest wordt de verbinding tussen de marina en de onder de marina gelegen bodem alsook de verbinding van de marina met de oever ernaast niet bekeken in het licht van art. 3:3 BW maar in de zin van art. 3:4 $\mathrm{BW}^{419}$ : kan de verbinding van de marina met de bodem dan wel met de oever ingevolge de verkeersopvatting leiden tot het aanmerken van de Marina als een bestanddeel van de grond die onder en naast de Marina ligt? De Hoge Raad merkt vervolgens op dat: “... de verkeersopvatting alleen in aanmerking [kan] worden genomen in de gevallen dat onzekerheid bestaat of die marina kan worden beschouwd als duurzaam met de grond verenigd (zie HR 31 oktober 1997,....)". Hoewel uitdrukkelijk naar het 'portacabin'-arrest wordt verwezen, stelt de Hoge Raad in het 'marina'-arrest iets anders. Bij beantwoording van de vraag of de marina bestanddeel is geworden in de zin van art. 3:4 BW -een vraag die niet aan de orde was in het 'portacabin'arrest- komt aan de verkeersopvatting geen zelfstandige betekenis meer toe wanneer vaststaat dat ingevolge art. 3:3 BW geen sprake is van een duurzame verbinding tussen de marina en de grond. De Hoge Raad lijkt in die gevallen waarin art. 3:3 BW een duidelijke uitkomst geeft art. 3:4 BW buitenspel te zetten.

De laatste maatstaf die de Hoge Raad in het 'portacabin'-arrest geeft is de verkeersopvatting. De verkeersopvatting kan, anders dan bij de bestanddeelvorming van art. 3:4 $\mathrm{BW}^{420}$, niet als een zelfstandige maatstaf worden aangemerkt, maar "kan echter wel in aanmerking worden genomen in de gevallen dat in het kader van de beantwoording van die vragen onzekerheid blijkt te bestaan of een object kan worden beschouwd als duurzaam met de grond verenigd, en voor de toepassing van die maatstaf nader moet worden bepaald wat in een gegeven geval als "duurzaam", onderscheidenlijk "verenigd" en in verband daarmee als "bestemming" en als "naar buiten kenbaar" heeft te gelden". ${ }^{421}$

te zijn verenigd. Zie: Van der Plank 2011, p. 205. Mijns inziens is een essentieel onderscheid gelegen in de meerwaarde die de wijze waarop het object met de grond is verenigd heeft voor het object zelf; de havenkraan kan niet voortbewegen zonder de met de grond verenigde rails, terwijl de woonboot ook zonder met de meerpaal te zijn verenigd, blijft drijven.

418 R.o. 3.3 bij HR 9 maart 2012, LJN: BV8198.

419 "Bij de beantwoording van de vraag of de marina's bestanddeel in de zin van artikel 3:4 BW van een onroerende zaak zijn, dient niet het recreatiepark als mogelijke hoofdzaak in aanmerking te worden genomen, maar - voor iedere afzonderlijke marina-de grond onder en naast die marina”. R.o. 3.4. bij HR 9 maart 2012, LJN: BV8198.

420 Hoofdstuk $3 \$ 2.2 .1$.

421 R.o. 3.3 bij HR 31 oktober 1997, NJ 1998, 97. 


\section{§3. Het superficies solo cedit-beginsel van artikel 5:20 lid $1 \mathrm{BW}$ en de samenhang met de artikelen $3: 3$ en $3: 4 \mathrm{BW}$}

In dit hoofdstuk is reeds verschillende malen gesteld dat bestanddeelvorming op twee verschillende wijzen kan geschieden: enerzijds volgens art. 3:4 jo. 5:3 BW en anderzijds middels art. 5:20 lid 1 jo. 3:3 lid $1 \mathrm{BW}$. Met het erkennen van deze twee wijzen van bestanddeelvorming worden naar mijn mening de argumenten tegen het aanmerken van een bouwwerk als bestanddeel van de grond in de zin van art. 3:4 BW ondervangen. ${ }^{422}$ Veel gehoorde argumenten die worden aangevoerd tegen het aanmerken van een bouwwerk als bestanddeel krachtens art. 3:4 BW zijn dat een bouwwerk geen deel uitmaakt van de grond, een bouwwerk zonder beschadiging van de grond kan worden verwijderd, en dat ten gevolge van de vestiging van een opstalrecht een eigen eigendomsrecht op het bouwwerk komt te rusten ondanks het feit dat de bestanddeelvorming niet wordt doorbroken. Ongeacht waarop het argument tegen het aanmerken van een bouwwerk als bestanddeel in de zin van art. 3:4 BW ook is gestoeld, de verschillende auteurs die deze argumentatie volgen komen tot eenzelfde conclusie: een bouwwerk is een aparte zaak. ${ }^{423}$ Uit onderstaande zal naar voren komen dat ik van mening ben dat een bouwwerk ingevolge de criteria van art. 3:4 BW niet als bestanddeel kan worden aangemerkt, maar evenmin als een zelfstandige zaak kan worden gekarakteriseerd.

Wil een met een grondstuk duurzaam verenigd bouwwerk als zaak worden aangemerkt dan dient het in art. 5:20 lid $1 \mathrm{BW}$ neergelegde Romeinsrechtelijke superficies solo cedit-beginsel te worden doorbroken. Ten gevolge van de doorbreking van art. 5:20 lid 1 BW ontstaan twee verschillende zaken, de grond enerzijds en het bouwwerk anderzijds, met ieder een eigen goederenrechtelijke identiteit. Voor het bewerkstelligen van een algemene uitzondering op de eigendomsnatrekking ten behoeve van bouwwerken is een aanpassing van het BW vereist. In het BW dient dan een bepaling te worden opgenomen die strekt tot doorbreking van de

422 In de literatuur bestaat de nodige discussie over het aanmerken van een bouwwerk als een bestanddeel van de grond in de zin van art. 3:4 BW. Zie: Van den Bos 2004, p. 588; Van Maanen 2006, pp. 228-230; Ploeger 1997, pp. 105127; Wolfert 2003a en 2003b, pp. 191-197 en pp. 279-285; Wichers 2002, pp. 106-107.

423 Van Maanen 2006, p. 229; Wolfert 2003b, p. 280. Ploeger stelt dat een object dat vreemd blijft aan de grond, zoals een gebouw, kan worden aangemerkt als zaak of bijzaak. "De bijzaak is door de (duurzame) verbinding met de grond onroerend, maar daarmee geen bestanddeel geworden van de grond. ... De eigendom van de bijzaak volgt in de regel die van de hoofdzaak (de grond, of een andere opstal)....”. Zie: Ploeger 1997, p. 127. 
eigendomsnatrekking ten behoeve van bouwwerken. ${ }^{424}$ Het opnemen van zo'n algemene uitzondering op de eigendomsnatrekking is niet onoverkomelijk, maar het is de vraag of het maatschappelijk als wenselijk wordt ervaren om aan een bouwwerk een eigen goederenrechtelijke identiteit toe te kennen. De lezer van een advertentie waarin een 'landelijk gelegen woonhuis' wordt aangeboden zal ervan uitgaan dat de grond waarop het woonhuis is gelegen eveneens tot de koop en de daarop volgende overdracht behoort; volgens de in de maatschappij heersende opvatting vormen de grond en het bouwwerk een juridische eenheid. Waarom een aanpassing van datgene wat maatschappelijk gebruikelijk is omwille van een bepaling welke ten aanzien van bouwwerken leidt tot een onbevredigende uitkomst? Hieronder zal worden bepleit dat art. 3:4 BW niet de enige grondslag is waarop een object kan worden aangemerkt als bestanddeel; art. 5:20 lid 1 BW biedt eveneens een zelfstandige grondslag ingevolge bouwwerken bestanddeel kunnen zijn van de grond waarop of waarin zij zijn verwezenlijkt.

Artikel 5:20 lid $1 \mathrm{BW}$ geeft een opsomming van objecten die met de grond in eigendom worden nagetrokken "voor zover de wet niet anders bepaalt". ${ }^{425} \mathrm{Nu}$ het eigendomsrecht van de grond zich uitstrekt over de opgesomde objecten en een eigen goederenrechtelijke identiteit ten aanzien van deze objecten ontbreekt, kan worden aangenomen dat deze objecten bestanddeel zijn van de grond. De opgesomde objecten betreffen de bovengrond, de zich onder de bovengrond bevindende aardlagen, het grondwater dat door een bron, put of pomp aan de oppervlakte is gekomen, het water dat zich op de grond bevindt en niet in open gemeenschap met water op een anders erf staat, gebouwen en werken die duurzaam met de grond zijn verenigd, hetzij rechtstreeks, hetzij door vereniging met andere gebouwen en werken -althans voor zover ze geen bestanddeel zijn van eens anders onroerende zaak ${ }^{426}$ - en de met de grond verenigde beplantingen. Deze opsomming komt in vergaande mate overeen met de objecten die krachtens art. 3:3 lid $1 \mathrm{BW}$ als onroerend worden aangeduid ${ }^{427}$, zij het dat er enige verschillen bestaan. Zo noemt art.

424 Zo is in art. 5:20 lid $2 \mathrm{BW}$ ten behoeve van netten een algemene uitzondering op de eigendomsnatrekking opgenomen.

425 Art. 5:20 lid 1 aanhef BW: "De eigendom van de grond omvat, voor zover de wet niet anders bepaalt: ...”. Deze zinsnede stelt buiten twijfel dat de grond het gebouw natrekt en de grond als hoofdzaak kan worden aangemerkt. Zie: T.M. bij art. 5:20 BW, Parl. Gesch. Boek 5 (1981), p. 120.

426 Art. 5:20 lid 1 sub e BW.

427 "Beplantingen en opstallen zijn meestal wegens hun organische of mechanische verbinding met de grond als een bestanddeel van de grond aan te merken. Om verschillende redenen is het echter wenselijk hen afzonderlijk te noemen. In de eerste plaats wegens hun grote economische betekenis; in de tweede plaats omdat opstallen en beplantingen zelfstandig voorwerp van recht kunnen zijn; en in de derde plaats omdat tegenwoordig vele gebouwen worden geplaatst zonder dat enig mechanisch 
5:20 lid $1 \mathrm{BW}$, anders dan art. 3:3 lid $1 \mathrm{BW}$, het grondwater dat door een bron, put of pomp aan de oppervlakte is gekomen en het water dat zich op de grond bevindt en niet in openbare gemeenschap met water op eens ander erf staat. In beide gevallen is het water voldoende individualiseerbaar doordat het niet meer kan circuleren naar andere erven en de eigenaar van de grond als enige zeggenschap heeft over het water. Hoewel het eigendomsrecht van de grond zich uitstrekt over het water en daarmee als bestanddeel van de grond kan worden aangemerkt ${ }^{428}$, is het water roerend van aard, aldus de Parlementaire geschiedenis. ${ }^{429}$ Mijns inziens is het kwalificeren van water als een roerende zaak strijdig met de structuur van het goederenrecht, omdat een bestanddeel de goederenrechtelijke kwalificatie van de zaak volgt waarvan zij bestanddeel is. ${ }^{430}$ Het aanmerken van water als een roerende zaak is dan ook niet verdedigbaar.

De wetgever heeft de artikelen 3:3 en 5:20 lid 1 BW bewust op elkaar afgestemd. De ruime toepassing van art. 3:3 $\mathrm{BW}^{431}$ heeft tot gevolg dat een object relatief snel met de grond in eigendom wordt nagetrokken. De in art. 5:20 lid $1 \mathrm{BW}$ opgesomde objecten zijn alle bestanddeel van de grond, maar niet ingevolge de door art. 3:4 BW gestelde criteria, zo blijkt uit de volgende uit de Parlementaire geschiedenis afkomstige passage: "Het is immers de vraag of alles wat het onderhavige artikel noemt, wel naar de definitie van art. 3.1.1.3 [KH: art. 3:4 BW] als bestanddeel van de grond moet worden aangemerkt. Het

verband met de grond wordt gelegd, en het dan twijfelachtig is of het gebouw als een bestanddeel van de grond kan worden beschouwd (...). In het algemeen kan men zeggen, dat een constructie enige stabiliteit moet vertonen, wil zij als opstal aan te merken zijn". Zie: T.M. bij art. 3:3 BW, Parl. Gesch. Boek 3 (1981), pp. 66-67.

28 Asser/Mijnssen-Van Dam-Van Velten 2002, nr. 85. Een op de grond gevestigd recht van hypotheek strekt zich uit over het water. Zie: Asser/Mijnssen, Van Velten \& Bartels 5* 2008, nr. 85.

429 T.M. bij art. 3:3 BW, Parl. Gesch. Boek 3 (1981), p. 66. Onder het huidige BW wordt water, wanneer individualiseerbaar, nagetrokken door de eigendom van de grond. Bij stromend water ontbreekt deze individualiseerbaarheid en kan het water niet als zaak worden gekwalificeerd. Zie: Asser/Mijnssen, Van Velten \& Bartels 5* 2008, nrs. 96-97. Dit was anders onder het BW van 1838. Art. 646 OBW stelt: "De eigendom van stroomen en rivieren brengt mede den eigendom van den grond, waarover het water loopt". Ten gevolge van deze bepaling was het mogelijk eigendom te hebben van een stromend water, zijnde een nietindividualiseerbaar object en trok het op het water van de rivier rustend eigendomsrecht de grond na. Of zoals Diephuis het formuleert: "Maar bij stroomen en rivieren is het loopend water de hoofdzaak, de bedding van ondergeschikt belang, en was daarom billijk, het mindere aan het meerdere te laten volgen”. Zie: Diephuis 1857, nr. 378. Zie ook: hof's-Hertogenbosch 4 december 1888, W. 5650; HR 14 november 1904, W. 8142; Hofmann 1944, p. 139; Land 1901, p. 15; Suijling 1940, nr. 225.

430 M.v.A. II bij art. 3:3 BW, Parl. Gesch. Boek 3 (1981), p. 69.

$431 \quad$ Hoofdstuk $3 \S 2.3$. 
onderhavige artikel maakt voor de vraag van de omvang van het eigendomsrecht op de grond overbodig een onderzoek naar hetgeen volgens verkeersopvatting als een wezenlijk onderdeel van de grond geldt" ${ }^{432}$ Deze passage doet vermoeden dat de bestanddeelvorming van art. 3:4 BW niet uitputtend is. ${ }^{433}$

De Hoge Raad lijkt in het 'graftekens'-arrest eenzelfde mening toegedaan: "Enerzijds kan immers niet worden aangenomen dat graftekens volgens verkeersopvatting onderdeel uitmaken van de grond van de begraafplaats en dat die grond zonder graftekens incompleet zou zijn en anderzijds zijn graftekens in het algemeen niet zodanig met de grond verbonden dat zij daarvan niet kunnen worden afgescheiden zonder dat beschadiging van betekenis wordt toegebracht. Van een bestanddeel in de zin van genoemd wetsartikel [art. 3:4 BW] kan derhalve geen sprake zijn. ... onderhavige graftekens, als door gedaagden betoogd, worden aangemerkt als werken die duurzaam met de grond zijn verenigd. Van onzekerheid dienaangaande kan geen sprake zijn. Het vorenoverwogene leidt tot de conclusie dat de graftekens in eigendom toebehoren aan St. Barbara als eigenares van de begraafplaats". ${ }^{434}$ De zinsnede "van een bestanddeel in de zin van genoemd wetsartikel [art. 3:4 BW] kan derhalve geen sprake zijn' kan de indruk wekken dat volgens de Hoge Raad de graftekens in het geheel geen bestanddeel zijn. Ik vermoed echter dat de Hoge Raad heeft bedoeld dat de graftekens geen bestanddeel zijn naar de criteria van art. 3:4 BW. Nu de eigendom van de grond zich uitstrekt over de graftekens, dient ingevolge de structuur van het goederenrecht te worden aangenomen dat er naast art. 3:4 BW een tweede wijze van bestanddeelvorming in de artikelen 5:20 lid 1 jo. 3:3 lid $1 \mathrm{BW}$ is opgenomen. De graftekens zijn op grond van deze tweede wijze van bestanddeelvorming aan te merken als bestanddeel -in de zin van art. 3:4 BW-van het grondstuk volgens het 'duurzame verenigingscriterium' zoals in de artikelen 5:20 lid 1 jo. 3:3 lid 1 BW geformuleerd.

Dat een object krachtens art. 5:20 lid 1 jo. 3:3 lid 1 BW als bestanddeel kan worden gekwalificeerd wordt bekrachtigd door de uitzonderingen die de wet op art. 5:20 lid $1 \mathrm{BW}$ maakt. Doorbreking van de eigendomsnatrekking met de grond dient ertoe te leiden dat het betreffende object waarop de eigendomsdoorbreking van toepassing is als een zelfstandige zaak kan worden aangemerkt. Op deze zaak rust een eigen eigendomsrecht ondanks het feit dat de zaak duurzaam met de grond is verenigd. Wanneer gebouwen en werken op grond van art. 3:4 BW als bestanddeel worden gekwalificeerd leidt doorbreking van de eigendomsnatrekking van art. 5:20 lid $1 \mathrm{BW}$ niet

432 T.M. bij art. 5:20 lid 1 BW, Parl. Gesch. Boek 5 (1981), p. 120.

433 Heyman en Bartels zijn van mening dat de artikelen 3:3 en 5:20 BW geen betrekking hebben op bestanddeelvorming. De functie van beide artikelen is gelegen in het garanderen van de belangrijkste gevolgen van bestanddeelvorming in het geval dat van bestanddeelvorming zelf geen sprake mocht zijn. Zie: Heyman \& Bartels 2012, nr. 32.

434 R.o. 3.8, 3.13 en 3.14 bij HR 25 oktober 2002, NJ 2003, 241. 
automatisch tot doorbreking van de bestanddeelkwalificatie van art. 3:4 BW. Dit heeft tot gevolg dat aan een bestanddeel een eigen eigendomsrecht wordt toegekend. Op grond van de bestanddeelvorming van art. 5:20 lid 1 jo. 3:3 lid 1 BW wordt met de doorbreking van de eigendomsnatrekking eveneens de bestanddeelkwalificatie doorbroken. ${ }^{435}$

Ten aanzien van bouwwerken geschiedt bestanddeelvorming met de grond krachtens art. 5:20 lid 1 jo. 3:3 lid $1 \mathrm{BW}$ niet alleen wanneer het bouwwerk rechtstreeks met de grond is verenigd, maar ook wanneer sprake is van indirecte vereniging. Bij indirecte vereniging wordt een bouwwerk middels een ander bouwwerk met de grond verenigd. ${ }^{436}$ Met het onderscheid tussen rechtstreekse en indirecte vereniging met de grond wordt de fysieke relatie tussen het bouwwerk en de grond tot uiting gebracht. Wat het rechtsgevolg betreft bestaat er geen onderscheid tussen een bouwwerk dat direct dan wel indirect met de grond is verenigd; in beide gevallen is het bouwwerk bestanddeel van de grond.

Niet kan worden gesteld dat aan de bestanddeelvorming van art. 3:4 BW geheel geen rol toekomt in relatie tot de in art. 5:20 lid 1 sub e BW opgesomde gebouwen en werken. In de tweede zinsnede van art. 5:20 lid 1 sub e BW ${ }^{437}$ wordt een uitzondering op de bestanddeelvorming van art. 5:20 lid 1 jo. art. 3:3 lid $1 \mathrm{BW}$ gemaakt ten aanzien van gebouwen en werken die aangemerkt kunnen worden als bestanddeel van eens anders onroerende zaak. Een object dat als bestanddeel kan worden gekarakteriseerd kan slechts bestanddeel zijn van één zaak. Zo zal het gedeelte van een bouwwerk dat over de kadastrale grenzen van het grondstuk is verwezenlijkt, de zogenoemde overbouw, niet met het grondstuk worden nagetrokken waarop of waarin de overbouw zich bevindt wanneer de overbouw kan worden aangemerkt als bestanddeel van het bouwwerk. De overbouw wordt ingevolge horizontale natrekking met het bouwwerk nagetrokken en behoort toe aan de eigenaar van het grondstuk waarop het bouwwerk waarvan de overbouw deel uitmaakt, zich bevindt. ${ }^{438}$

$435 \quad$ Kortmann 1998, p. 103: "Persoonlijk zou ik de wettelijke regeling aldus willen uitleggen dat artikel 3:4 BW de algemene maatstaven geeft voor bestanddeelvorming en dat artikel 5:20 BW een nadere invulling van deze algemene maatstaven geeft voor wat betreft zaken die door de grond worden nagetrokken".

436 Art. 5:20 lid 1 sub e BW.

437 “..., voor zover ze geen bestanddeel zijn van eens anders onroerende zaak".

438 Ten aanzien van een gangenstelsel in een mergelgroeve oordeelde de rechtbank dat: “... de eigenaar van het perceel waarop de ingang is gelegen, door natrekking eigenaar is van de daardoor te betreden en daarmee verbonden Sibbegroeve, nu het immers voor de eigenaren van de boven de groeve gelegen percelen niet mogelijk is de onder hun percelen gelegen gang(en) te betreden". Zie: r.o. 3.2.4 bij rechtbank Maastricht 13 juni 1996, NJ 1997, 299. Het gangenstelsel trekt horizontaal na met de ingang van de groeve. Zie ook: hof 's-Hertogenbosch 26 mei 1997, NJ 1998, 93; Rechtbank Maastricht 6 april 2000, LJN: AA5402; hof 's-Hertogenbosch 5 december 2000, NJ 2001, 626. 
De vraag wat als bestanddeel van een bouwwerk kan worden aangemerkt, wordt beantwoord aan de hand van de door art. 3:4 BW gegeven criteria; art. 3:4 BW 'helpt' in de afbakening van de omvang van een bouwwerk. Ook bij het beantwoorden van de vraag of een zich in het bouwwerk bevindend object als bestanddeel van het bouwwerk kan worden aangemerkt, wordt getoetst aan de criteria van art. 3:4 BW. ${ }^{439}$ Art. 5:20 lid $1 \mathrm{BW}$ kan geen uitkomst bieden nu dit artikel een opsomming geeft van objecten, zoals gebouwen en werken, die als bestanddeel van de grond worden gezien.

\section{$\S 4$. Het recht van opstal}

\section{$\S 4.1$ De karakteristieken van het recht van opstal}

Aan de gerechtigde tot het recht van opstal, de opstaller, komt het recht toe "om in, op of boven een onroerende zaak van een ander gebouwen, werken of beplantingen in eigendom te hebben of te verkrijgen" ${ }^{440}$ Het object ten behoeve waarvan het opstalrecht wordt gevestigd, wordt angeduid met de term 'opstal' ${ }^{441}$ Het opstalrecht kan worden gevestigd ten gunste van opstallen die zich ten tijde van de vestiging van het opstalrecht reeds in of $\mathrm{op}^{442}$ het grondstuk bevinden, de zogenoemde 'oude' opstallen, als ten behoeve van opstallen die gedurende de bestaansduur van het opstalrecht worden verwezenlijkt, de zogenoemde 'nieuwe' opstallen. ${ }^{43}$ Ondanks de duurzame vereniging van de opstallen met het grondstuk komt ten gevolge van de vestiging van het

439 In het in §2.2.1 van dit hoofdstuk aangehaalde arrest Dépex/Curatoren Bergel c.s. staat de vraag centraal of een waterdistillatie-inrichting bestanddeel is van het gebouw waar de inrichting is gehuisvest. "Het gaat in gevallen als het onderhavige om beantwoording van de vraag of apparatuur en gebouw naar verkeersopvatting te zamen als een zaak moeten worden gezien", aldus de Hoge Raad. De verkeersopvatting ziet hier op de verkeersopvatting van art. 3:4 BW. Zie: r.o. 3.7 bij HR 15 november 1991, NJ 1993, 316. Deze stellingname wordt in HR 28 juni 1996, NJ 1997, 397 bevestigd.

440 Art. 5:101 lid 1 BW.

441 De term opstal wordt in het BW ook in een andere context gebezigd. Art. 6:174 BW legt een risicoaansprakelijkheid op de bezitter van een opstal, waarbij onder het begrip opstal die gebouwen en werken worden geschaard die als onroerend kunnen aangemerkt (art. 6:74 lid 4 jo. art. 3:3 BW). Beplantingen vallen niet onder de term opstal in de zin van art. 6:174 BW. Zie: hof's-Hertogenbosch 16 november 2004, NJF 2005, 355. De term opstal zal in dit proefschrift worden gebezigd ten aanzien van die objecten ten gunste waarvan een opstalrecht is gevestigd, tenzij uit de tekst anders blijkt.

442 Mijns inziens is het niet mogelijk een opstalrecht te vestigen ten gunste van objecten die zich 'enkel' boven het grondstuk van een ander bevinden. Zie: $§ 4.2$ van hoofdstuk 3.

443 De opstaller verkrijgt de eigendom van de nog te verwezenlijken opstallen pas op het moment dat de opstallen zijn gerealiseerd. 
opstalrecht aan deze opstallen een eigen goederenrechtelijke identiteit toe. Zo rust, hetgeen uit de opstaldefinitie kan worden afgeleid, op de opstallen een 'eigen' eigendomsrecht. Aangezien het volgens de systematiek van de wet niet mogelijk is dat meerdere eigendomsrechten op één zaak rusten, heeft vestiging van een opstalrecht tot gevolg dat de eigendom van het grondstuk zich niet (langer) over de opstallen uitstrekt. Volgens mij dient de heersende leer zo te worden uitgelegd dat ten gevolge van de vestiging van het recht van opstal de eigendomsnatrekking ten aanzien van de 'oude' opstallen wordt doorbroken, en de eigendomsnatrekking ten aanzien van de 'nieuwe' opstallen terzijde wordt geschoven. ${ }^{444} \mathrm{Nu}$ volgens de wetgever de essentie van het opstalrecht gelegen is in het verkrijgen van eigendom, is hiermee het substantiële onderscheid met het erfpachtrecht ${ }^{445}$ gegeven. ${ }^{446}$

Wanneer het opstalrecht eindigt ${ }^{447}$ strekt het op het grondstuk rustende eigendomsrecht zich (wederom) uit over de objecten die op duurzame wijze met het grondstuk zijn verenigd, en daarmee ook over de objecten ten behoeve waarvan het tenietgegane opstalrecht was gevestigd. Om te voorkomen dat de opstaller de eigendom van de opstallen verliest, staat het de opstaller in beginsel vrij de opstallen weg te nemen die door de opstaller of zijn rechtsvoorganger onverplicht zijn aangebracht of bij vestiging van het opstalrecht tegen vergoeding van de waarde zijn overgenomen. De opstaller kan eveneens besluiten de opstallen op het grondstuk achter te laten; aan de opstaller komt dan in beginsel een recht op vergoeding van de waarde van de opstallen toe. ${ }^{448}$

Naast het op de opstallen rustende eigendomsrecht kan aan de opstaller ingevolge het opstalrecht een gebruiksrecht toekomen ten aanzien van

$444 \quad$ Hoofdstuk 3 \$4.3.1.

445 Het erfpachtrecht komt aan bod in $\$ 4.6 .1$ en $\$ 4.6 .2$ van dit hoofdstuk.

446 Parl. Gesch. Boek 5 (1981), p. 356: "Het in titel 5.8 geregelde recht van opstal voor welks totstandkoming volgens artikel 3.4.2.11 lid 1 juncto artikel 3.4.2.4 lid 1 inschrijving van de akte van vestiging in de openbare registers vereist is - dient $n u$ juist om te voorzien in deze behoefte aan een splitsing tussen de eigendom van de grond en die van de opstallen. Het erfpachtsrecht zoals dit in het huidige B.W. en in titel 5.7 van het ontwerp is geregeld, zou in deze behoefte niet kunnen voorzien, aangezien de erfpachter niet eigenaar van de opstallen wordt". Volgens Heyman is de essentie van het opstalrecht niet gelegen in het toekennen van eigendom aan de opstaller, maar in de doorbreking van de verticale natrekking van art. 5:20 BW. Zie: Heyman 1999, pp. 52-56.

447 In $\$ 4.5$ wordt nader ingegaan op de duur waarvoor een opstalrecht kan worden gevestigd en de verschillende wijzen waarop een opstalrecht teniet kan gaan.

448 Art. 5:105 lid 2 BW alsook art. 5:105 lid 3 jo. 5:99 BW. Zie: hoofdstuk 3 §4.5. 
de onroerende $z^{2}{ }^{449}$ die met het opstalrecht is bezwaard. ${ }^{450}$ Of dit gebruiksrecht voortvloeit uit het opstalrecht is afhankelijk van de aard van het opstalrecht, waarbij een onderscheid kan worden gemaakt tussen zelfstandige en afhankelijke opstalrechten. Bij een zelfstandig opstalrecht komt het recht tot gebruik voort uit het opstalrecht, terwijl bij een afhankelijk opstalrecht de opstaller dit gebruiksrecht ontleent aan het recht, het hoofdrecht, waaraan het opstalrecht accessoir is. Wanneer het hoofdrecht een persoonlijk recht betreft ${ }^{451}$, zoals huur of pacht, is het gebruiksrecht persoonlijk van aard: de vestiging van een afhankelijk opstalrecht doet daar niets aan af. ${ }^{452}$ Ingevolge het gebruiksrecht komen aan de gerechtigde tot een zelfstandig opstalrecht in beginsel die bevoegdheden toe die voor het volle genot van het aan hem toekomende opstalrecht nodig zijn. ${ }^{453}$ Het staat partijen vrij het gebruiksrecht in de vestigingsovereenkomst te beperken dan wel te verruimen. ${ }^{454}$

449 Het opstalrecht kan volgens de opstaldefinitie, artikel 5:101 lid 1 BW, worden gevestigd op een onroerende zaak. Wanneer de werking van het opstalrecht louter op een specifiek gedeelte van een grondstuk betrekking heeft, staat het partijen vrij het opstalrecht te vestigen op dit specifieke gedeelte. Bij inschrijving van de vestigingsovereenkomst wordt het oorspronkelijke grondstuk verticaal gesplitst. "Wanneer op gedeelten van één perceel een verschillende rechtstoestand komt te heersen of heerst, worden deze gedeelten van een nieuwe kadastrale aanduiding voorzien”, aldus de M.v.T. bij art. 73 Kadasterwet, Parl. Gesch. Kadasterwet (1990), p. 255. Of andere zakelijke rechten dan het eigendomsrecht met een opstalrecht kunnen worden bezwaard, komt in $§ 4.6 .1$ van dit hoofdstuk aan de orde.

450 Parl. Gesch. Boek 5 (1981), p. 356: "Een bevoegdheid om de grond te gebruiken, is in de wettelijke omschrijving niet opgenomen omdat deze bevoegdheid-anders dan bij de erfpacht - slechts secundair is". Een recht van opstal hoeft niet per definitie het gebruik van de grond met zich te brengen. Zie: HR 7 maart 1979, NJ 1980, 116.

451 Een recht van opstal kan afhankelijk zijn van een ander zakelijk recht of van een recht van huur of pacht (art. 5:101 lid 2 BW). Een opstalrecht ter aanvulling van een persoonlijk recht, bijvoorbeeld een huurovereenkomst, wordt evenals een zelfstandig opstalrecht gevestigd op de onroerende zaak. In de vestigingsovereenkomst wordt verwezen naar het recht waarmee het verbonden is. Het afhankelijke opstalrecht wordt met deze verbondenheid aan het persoonlijke recht een 'gemengd' recht. Het opstalrecht wordt zowel door de bepalingen van het goederenrecht als de verbintenisrechtelijke bepalingen van het (hoofd)recht nader ingevuld. Zo is de duur van het opstalrecht afhankelijk van het hoofdrecht en de verbintenisrechtelijke bepalingen die hierop van toepassing zijn.

452 Of zoals Snoijink het in de noot bij HR 5 februari 2010, BNB 2010, 106 verwoordt: "De huurder heeft immers 'slechts' genot krachtens een persoonlijk recht. Dit kan niet 'zakelijker' worden door het aanvullende opstalrecht”. Zie ook: HR 7 maart 1979, NJ 1980, 116; HR 14 september 1994, BNB 1994, 322.

453 Art. 5:103 BW.

$454 \quad$ “..., mits die bevoegdheden in zodanig verband staan met die welke de opstaller 
Het onderscheid tussen het afhankelijke en het zelfstandige recht van opstal is eveneens van belang voor de duur waarvoor het opstalrecht kan worden gevestigd. Een afhankelijk opstalrecht kan niet zonder het recht waaraan het accessoir is, het hoofdrecht, voortbestaan; een afhankelijk opstalrecht eindigt samen met het hoofdrecht. Het is wel mogelijk het opstalrecht voor een kortere duur te vestigen dan de duur waarvoor het hoofdrecht is gevestigd. ${ }^{455}$ De BW geeft, anders dan voor het afhankelijke opstalrecht het geval is, bepalingen omtrent de duur van het zelfstandige opstalrecht. ${ }^{456}$ Deze bepalingen geven echter geen minimale of maximale termijn waarvoor het opstalrecht kan worden gevestigd. ${ }^{457}$ Het is dan ook mogelijk een eeuwigdurend opstalrecht te vestigen.

Als tegenprestatie voor het verkregen opstalrecht kan, hetgeen afhankelijk is van wat partijen in de vestigingsovereenkomst zijn overeengekomen, op de opstaller de verplichting rusten een vergoeding, de retributie, te betalen. Door deze verplichting in de vestigingsovereenkomst op te nemen komt hieraan -althans na inschrijving van de vestigingsakte in de registerskwalitatieve werking toe. ${ }^{458}$

\section{$\S 4.2$ Gebouwen, werken en beplantingen ten gunste waarvan een opstalrecht kan worden gevestigd}

Een recht van opstal kan worden gevestigd ten gunste van gebouwen, werken en beplantingen die ten tijde van de vestiging reeds bestaan of gedurende het bestaan van het opstalrecht worden verwezenlijkt. ${ }^{459}$ Het is niet noodzakelijk dat het opstalrecht wordt gevestigd ten behoeve van alle

naar de aard van dat recht toekomen dat het gerechtvaardigd is die bevoegdheden als onderdeel van dat recht te behandelen", aldus HR 11 maart 1981, NJ 1982, 76.

De Parlementaire geschiedenis geeft als voorbeeld het trekken van natuurlijke vruchten van een grondstuk dat met een opstalrecht is bezwaard ten gunste van een zomerhuis. Zie: Parl. Gesch. Boek 5 (1981), p. 361. Zie ook: Asser/ Mijnssen, Van Velten \& Bartels 5*2008, nr. 254.

455 Parl. Gesch. Boek 5 BW (1981), p. 360.

456 Schakelbepaling 5:104 lid 2 BW bepaalt dat de erfpacht-'duur'-bepalingen, artt. 5:86, 5:87 en 5:88 BW, van overeenkomstige toepassing zijn op het zelfstandige recht van opstal.

457 Met de codificatie van het opstalrecht in de Wet over het recht van Opstal in 1824 waren partijen gebonden aan de maximale vestigingsduur van 50 jaar (art. 4 Opstalwet). Deze maximale vestigingsduur is met de inwerkingtreding van het BW van 1838 komen te vervallen.

458 Hoofdstuk $3 \$ 4.4$.

459 Art. 5:101 lid 1 jo. 3:3 lid 1 BW. Zie ook: Parl. Gesch. Boek 5 (1981), p. 355. Anders dan bij bouwwerken is het voor het aanmerken van beplantingen als onroerend niet vereist dat de vereniging met het grondstuk duurzaam van aard is. Zie: noot 403. 
objecten die zich op en in de met het opstalrecht te bezwaren onroerende zaak bevinden. ${ }^{460}$ Partijen kunnen de werking van het opstalrecht beperken tot die objecten die in de vestigingsovereenkomst worden vermeld. ${ }^{461}$ Voor het aanmerken van een object als gebouw of werk is menselijk ingrijpen vereist dat "heeft bijgedragen aan de (duurzame) bestemming of functie van dat werk. De mate waarin of de wijze waarop dit menselijk ingrijpen daaraan moet hebben bijgedragen, kan niet bij voorbaat worden bepaald en is mede afhankelijk van het soort van werk en de bestemming of functie ervan" ${ }^{462}$ Tevens dient het object voldoende individualiseerbaar te zijn. In de literatuur wordt dit individualiteitsvereiste ook wel aangeduid als het zelfstandigheidsvereiste. Ploeger geeft als voorbeeld een op het erf aangebrachte aardlaag ten behoeve van het verhogen van het erf. Deze laag aarde heeft onvoldoende individualiteit, terwijl een uit aarde opgebouwde dijk daarentegen wel voldoende individualiseerbaar is en als bouwwerk kan worden aangemerkt. ${ }^{463}$ Op grond van dit zelfstandigheidsvereiste kan een dak op een woning niet, maar een op het dak geplaatste antenne wel als werk worden aangemerkt, aldus Van Velten. ${ }^{464}$ Volgens Van Maanen mist een vertrek in een gebouw de vereiste zelfstandigheid voor het aanmerken van een vertrek als bouwwerk en is het niet mogelijk een (onder)opstalrecht te vestigen ten behoeve van een vertrek. ${ }^{465}$ Daarbij stellen Van Maanen en Bartels zich op het standpunt dat het zeer twijfelachtig is of een feitelijke situatie die onder de werking van het appartementsrecht -zoals in art. 5:106 e.v. BW opgenomen- kan worden geschaard, zich leent voor de vestiging van een recht van opstal. ${ }^{466}$ Bartels stelt in navolging van Ploeger dat in die situaties waar sprake is van een stapeling van bouwwerken die in bouwkundig opzicht èn in de exploitatiesfeer zo goed als niets met elkaar van doen hebben, het wel mogelijk is een opstalrecht te vestigen ten gunste van een of meerdere bouwwerken. ${ }^{467}$

460 Asser/Mijnssen, Van Velten \& Bartels 5*2008, nr. 252.

461 Parl. Gesch. Boek 5 (1981), p. 361.

462 R.o. 4.3.2 bij HR 17 december 2010, NJ 2012, 155.

463 Ploeger 1997, nrs. 54 en 169d. Zie ook: Ploeger \& Stolker 1994, pp. 641643. In het arrest van de Hoge Raad van 17 december 2010 betoogt het Hoogheemraadschap in onderdeel 3 dat de in de casus ter discussie staande veendijk geen opstal is, "omdat de veendijk hoofdzakelijk een natuurlijke kade is". De Hoge Raad stelt, in navolging van het hof, dat de veendijk wèl een opstal in de zin van art. 6:174 BW is, nu "het dijklichaam is ontstaan door uitgraving en drooglegging, is gevormd naar de inzichten in de waterkering, in stand is gehouden overeenkomstig de door TAW ontwikkelde richtlijnen en is voorzien van een in de grond aangebrachte beschoeiing”. Zie: r.o. 4.3.2 bij HR 17 december 2010, NJ 2012, 155.

$464 \quad$ Van Velten 2012, p. 59.

465 Pitlo/Reehuis \& Heisterkamp 2012, Goederenrecht, nr. 708.

466 Asser/Mijnssen, Van Velten \& Bartels* 2008, nr. 362.

467 Ploeger geeft als voorbeeld een ondergronds metrostation waarop een parkeergarage wordt aangebracht. Op deze parkeergarage wordt vervolgens 
Een nadere invulling van de begrippen gebouwen, werken en beplantingen in relatie tot het opstalrecht ontbreekt zowel in de wet als in de Parlementaire geschiedenis. ${ }^{468} \mathrm{Nu}$ uit de Parlementaire geschiedenis volgt dat de wetgever voor een bewuste afstemming tussen de artikelen 5:101 en 6:176 BW heeft gekozen, biedt de jurisprudentie omtrent opstallen in het aansprakelijkheidsrecht hier enige houvast. Een rampaaltje ${ }^{469}$, een betonnen drempel $^{470}$, een gemetselde pilaar ${ }^{471}$ alsook een hekwerk ${ }^{472}$ worden alle aangemerkt als werk. Aan de onderscheidenlijke begrippen 'gebouwen' en 'werken' worden gelijke rechtsgevolgen toegekend: het is dan ook om het even of een object wordt aangemerkt als gebouw of werk.

Uit de opstaldefinitie volgt dat de opstal zich in, op of boven de onroerende zaak van een ander ${ }^{473}$ kan bevinden. Met deze definitie heeft de wetgever het toepassingsbereik van het opstalrecht in verhouding tot het opstalrecht zoals in het OBW gedefinieerd ${ }^{474}$, op tweeërlei wijzen willen verruimen.

een tramviaduct met bijbehorend tramstation verwezenlijkt. Ploeger 1997, nr. 228.

468 Het ontbreken van een nadere precisering leidde reeds onder het OBW bij verschillende auteurs tot de nodige vragen en discussies. Hofmann omschrijft de opstalobjecten als volgt: "Bij 'een gebouw' kan men ook aan een gedeelte van een gebouw -een verdieping b.v. - denken ( ... ), terwijl bij 'werken' aan muren e.d. moet worden gedacht. Wat 'beplantingen' betreft, daaronder zal men alleen mogen verstaan boomen en andere planten, die duurzaam op den grond aanwezig blijven. Gewassen, welke na korten tijd van den grond worden verwijderd en als vruchten van den grond zijn te beschouwen kunnen niet onder de beplantingen, ..., worden gebracht, ...”. Zie: Hofmann 1944, p. 322. Opzoomer en Diephuis werpen de vraag op of het begrip gebouw enkel ziet op huizen dienende ter bewoning of dat het begrip gebouw ruimer dient te worden genomen, zodat ook magazijnen, schuren en verdere inrichtingen die onroerend van aard zijn hieronder kunnen worden geschaard. Land stelt dat het onduidelijk is wat onder het begrip werken moet worden verstaan, "maar de wetgever schijnt daarmede bedoeld te hebben alles wat door' 's menschen daad met den grond vereenigd is, 'tzij door bouwen 't zij door planten”. Zie: Opzoomer 1876, p. 480; Diephuis 1857, nr. 892; Land 1901, p. 313.

469 Hof's-Hertogenbosch 3 maart 2009, NJF 2010, 343.

$470 \quad$ Rechtbank's-Hertogenbosch 8 april 2009, RVR 2009, 76.

$471 \quad$ HR 8 oktober 2010, RN 2011, 2.

472 Rechtbank Maastricht 21 januari 2004, VR 2005, 35.

473 Een recht van opstal kan niet worden gevestigd ten behoeve van de eigenaar van de met het opstalrecht te bezwaren onroerende zaak. Wanneer het meer omvattend recht waaruit het opstalrecht is afgeleid alsook het daaruit afgeleide opstalrecht bij dezelfde persoon komen te rusten, heeft dit tot gevolg dat het beperkte recht door vermenging ingevolge art. 3:81 lid 2 aanhef en onder sub e BW teniet gaat. Zie ook: noot 553 .

474 Art. 758 OBW: "Het regt van opstal is een zakelijk regt om gebouwen, werken of beplantingen op eens anders grond te hebben". 
Ten eerste is het niet langer noodzakelijk dat de opstal zich bevindt op de grond, maar in, op of boven de onroerende zaak van een ander. ${ }^{475}$ De verruiming ziet op die situaties waarbij het gebouw waarin de machine of waarop de zendmast zich bevindt door de vestiging van een opstalrecht reeds aan een ander dan de grondeigenaar toebehoort; door verruiming van de opstaldefinitie kan ten behoeve van de machine als van de zendmast een opstalrecht worden gevestigd. ${ }^{476}$

Ten tweede hoeft de opstal zich niet op de onroerende zaak te bevinden, maar mag de opstal zich ook in of boven de onroerende zaak van een ander bevinden. De keuze voor het hebben van een recht van opstal in de onroerende zaak is gebaseerd op de wens van de wetgever ook een recht van opstal te kunnen vestigen op leidingen en kabels die zich in de grond bevinden. ${ }^{477}$ Vestiging van een opstalrecht ten gunste van een object dat zich in de onroerende zaak bevindt, geschiedt bijvoorbeeld ten behoeve van ondergrondse parkeergarages en machines die zich in een bouwerk bevinden. Door het vestigen van een opstalrecht ten gunste van een machine die zich in een bouwwerk bevindt, kan de leverancier voorkomen dat de machine met het grondstuk wordt nagetrokken; de eigendom van de machine blijft ten gevolge van de vestiging van het opstalrecht bij de leverancier liggen. ${ }^{478}$ Doorgaans zal in de vestigingsovereenkomst worden opgenomen dat het recht van opstal eindigt wanneer de opstalgever de waarde van de machine aan de opstaller, de leverancier van de machine, heeft voldaan. Het opstalrecht kan dan ook als een alternatief zekerheidsrecht worden gebruikt. ${ }^{479}$

Mijns inziens is het maar zeer de vraag of een opstalrecht kan worden gevestigd ten gunste van een object dat zich boven de grond bevindt. Een

475 Parl. Gesch. Boek 5 (1981), p. 359. In §4.6.1 van dit hoofdstuk wordt de vraag beantwoord of deze verruiming meebrengt dat ook andere zakelijke rechten dan het eigendomsrecht met een opstalrecht kunnen worden bezwaard.

476 Het 'stapelen' van opstalrechten is dan ook mogelijk. Zie: hoofdstuk 3 §4.6.

477 Met de invoer van art. 5:20 lid $2 \mathrm{BW}$ is het niet langer noodzakelijk een recht van opstal te vestigen ten behoeve van netten van kabels of leidingen wanneer deze zijn aangelegd door een bevoegd aanlegger. De netten worden niet met de grond waarin zij zijn gelegen nagetrokken, maar behoren toe aan de bevoegd aanlegger.

478 Een ten behoeve van de leverancier overeengekomen eigendomsvoorbehoud (art. 3:92 BW) gaat ten gevolge van de duurzame vereniging met de grond teniet.

479 Volgens de heersende leer is het gebruik van het opstalrecht als zekerheidsrecht niet in strijd met het fiduciaverbod zoals in art. 3:84 lid 3 BW verwoord. Uit het zogenoemde 'Sogelease'-arrest volgt dat art. 3:84 lid 3 BW terughoudend dient te worden uitgelegd. Zie: HR 19 mei 1995, NJ 1996, 119. Zie ook: Asser/ Mijnssen, Van Velten \& Bartels 5* 2008, nr. 249; Kortmann 1997, pp. 34-37; Pitlo/Reehuis \& Heisterkamp 2012, Goederenrecht, nr. 668. 
verbinding met de onroerende zaak ontbreekt, omdat er anders geen sprake is van een opstal boven maar op de onroerende zaak. Bij een object dat zich boven de onroerende zaak van een ander bevindt, kan worden gedacht aan een op de tweede verdieping van een gebouw bevindend en overstekend appartement of een brug die zich boven de onroerende zaak van een ander bevindt zonder dat op deze onroerende zaak ten behoeve van de brug een brugpijler rust. Maar kan een recht van opstal worden gevestigd ten gunste van een object dat zich 'slechts' boven het te bezwaren grondstuk bevindt? Volgens de heersende leer heeft het opstalrecht tot doel de eigendomsnatrekking te doorbreken. Maar bij een object dat op geen enkele wijze met de te bezwaren onroerende zaak is verbonden en zich 'slechts' boven het te bezwaren grondstuk bevindt, kan natrekking zich simpelweg niet voordoen omdat een duurzame vereniging met het grondstuk ontbreekt. Zo gaat het overstekende appartement middels horizontale natrekking ${ }^{480}$ in eigendom toebehoren aan de eigenaar van het bouwwerk waartoe het appartement behoort. Ik ben dan ook van mening dat alleen de eigenaar van het bouwwerk bevoegd is een recht van opstal te vestigen ten behoeve van het appartement, en niet de eigenaar van het grondstuk waarboven het appartement zich bevindt. ${ }^{481}$

\section{$\S 4.3$ Het aan het recht van opstal verbonden zijnde accessoire eigendomsrecht}

Met de invoering van de Wet over het recht van Opstal van 10 januari 1824 (verder: de Opstalwet) werd een wettelijke grondslag voor het doorbreken van de natrekking middels de vestiging van een beperkt recht geboden. ${ }^{482}$ De wet is tot aan de invoer van het Burgerlijk Wetboek van 1838 voor het Koninkrijk Nederland van kracht geweest, waarna het recht van opstal in het $\mathrm{OBW}$ is opgenomen.

Terwijl uit art. 758 OBW naar voren komt dat het recht van opstal kan worden gekwalificeerd als een zakelijk recht, volgt uit $19^{\text {de }}$ eeuwse rechtspraak dat doorbreking van de natrekking eveneens mogelijk was middels een persoonlijke verbintenis: "Daaromtrent, dat die beschouwing van

480 Art. 5:20 lid 1 sub e BW. In $§ 3$ van dit hoofdstuk wordt ingegaan op de horizontale natrekking.

481 Zie: Asser/Mijnssen, Van Velten \& Bartels 5*2008, nr. 249; Ploeger 1997, nr. $169 \mathrm{c}$.

482 De Wet over het recht van Opstal is gelijktijdig met de Wet over het recht van Erfpacht in 1824 ingevoerd in het Verenigd Koninkrijk der Nederlanden, dat zowel uit de Noordelijke als de Zuidelijke Nederlanden bestond. Beide wetten zijn op Nederlands grondgebied tot aan de invoer van het OBW van kracht geweest. Op Belgisch grondgebied zijn de wetten tegenwoordig nog van kracht. Zie: hoofdstuk 4 §4. 
de Rechtbank alleszins juist is, daar er geen de minste grond is om aan te nemen, dat het beginsel, uitgedrukt in artt. 626 en 656 B.W., tot de openbare orde zou behooren, zoodat daarvan bij overeenkomst niet zou mogen worden afgeweken, maar dat het integendeel den grondeigenaar volkomen vrij staat om aan een ander vergunning te verleenen om op zijn grond te bouwen of te planten, met dat gevolg, dat die andere eigenaar wordt van het door hem gebouwde of geplante, zoodat noch de genoemde wetsartikelen, noch een der overige aangehaalde artikelen, zijn geschonden of verkeerd toegepast". ${ }^{43}$ Bij arrest van 4 december 1903 heeft de Hoge Raad gesteld dat doorbreking van de natrekking enkel mogelijk wordt geacht door het vestigen van een zakelijk recht, zoals het recht van opstal ${ }^{484}$ : "Dat alleen dan, wanneer bleek dat de gefailleerde had wat zij blijkt te missenn.l. een zakelijk recht, als dat van opstal, door hetwelk eene uitzondering op den rechtsregel van art. 656 voormeld kan worden geschapen - het eigendomsrecht van den grondeigenaar op hetgeen hij Arena had veroorloofd te bouwen zou zijn uitgesloten geworden". ${ }^{45}$ Uit deze passage volgt niet alleen dat enkel door het vestigen van een zakelijk recht de natrekking kan worden doorbroken, maar ook dat ten gevolge van de vestiging van het zakelijke recht aan de gerechtigde het eigendomsrecht van de betreffende opstal(len) toekomt. Dat de vestiging van een opstalrecht een eigendomsrecht ten aanzien van één of meerdere opstallen aan de opstaller doet toekomen wordt ook onder het huidige recht algemeen aanvaard; de vestiging van een recht van opstal kan dan ook worden aangemerkt als een wijze van eigendomsverkrijging. ${ }^{486}$

$483 \quad$ HR 16 mei 1884,W. 5035.

484 Zowel in het ontwerp van 1898 als in de rechtspraak werd aangenomen dat de erfpachter de eigendom van de opstallen verkreeg. Uit de toelichting bij art. 54 'ontwerp-1898' volgt: "Eene afwijking van dien regel, waardoor de een eigenaar zou zijn van den grond, de ander van den boom of van het huis, of de een van de benedenverdieping, de ander van de daarboven gelegen verdieping, zou alleen dàn te rechtvaardigen zijn, indien zulke toestanden ten onzent inheemsch waren. Dergelijke verdeelingen van den grond en hetgeen daarmede één geheel uitmaakt komen in ons land zelden of nooit voor, tenzij als gevolg van de eene of andere erfdienstbaarheid of van eenig ander zakelijk recht als opstal, erfpacht, beklemming enz., zoodat men dan ook kon volstaan met het bestaan van zulke toestanden aan de gevolgen dier zakelijke rechten over te laten". Zie: rechtbank Middelburg 11 oktober 1882, W. 4833.

485 HR 4 december 1903, W. 8004. Hetgeen in HR 22 december 1911, W. 9290 en HR 11 april 1913, W. 9499 wordt bevestigd.

486 Zie: Mon. BW B28 (De Jong/Ploeger), nr. 54; Ploeger 1997, nr. 189; Pitlo/ Reehuis \& Heisterkamp 2012, Goederenrecht, nr. 667; Scheltema 2003, p. 356. Volgens Ploeger ontstaat door de vestiging van het opstalrecht een nieuw eigendomsrecht en kan de eigendomsverkrijging als originair worden aangemerkt ongeacht of het opstalrecht wordt gevestigd ten gunste van opstallen die ten tijde van de vestiging reeds bestaan of gedurende het opstalrecht worden verwezenlijkt. 
Tussen het eigendomsrecht en het opstalrecht bestaat een accessoire relatie. $^{487}$

De eigendomstoekenning van de opstal(len) aan de opstaller door de Hoge $\mathrm{Raad}^{488}$ is in het begin van de $20^{\text {ste }}$ eeuw aanleiding geweest tot een uitvoerige discussie tussen de verschillende rechtsgeleerden, waarbij de vraag centraal stond of aan de opstaller eigenlijk wel de eigendom van de opstallen toekomt. Diephuis stelt dat het verkrijgen van eigendom afhankelijk is van het al dan niet betalen van een vergoeding voor de opstallen ten gunste waarvan het opstalrecht wordt gevestigd ${ }^{489}$, een mening die door Opzoomer allerminst wordt gedeeld: "Het is hier toch geen verkooping der gebouwen, die, door overschrijving van den titel gevolgd, den eigendom zou doen overgaan; indien de opsteller eigenaar wordt, kan hij dit alleen door zijn zakelijk recht van opstal, en dat recht is bij het niet betalen van den prijs der gebouwen zeker niet minder aanwezig, dan wanneer die prijs betaald is" ${ }^{490}$ Land alsook Suijling betwisten dat aan de opstaller ingevolge de vestiging van een opstalrecht de eigendom van de opstallen toekomt. ${ }^{491}$ Een antwoord op de rechtsvraag of de bevoegdheden die aan de opstaller ingevolge het opstalrecht toekomen als eigendom kunnen worden aangemerkt, mag naar huidig recht dan ook niet ontbreken.

\section{\$4.3.1 Kunnen de aan de opstaller toekomende bevoegdheden ten aanzien van de opstal als eigendom worden aangemerkt?}

Aan de opstaller komt het recht toe gebouwen, werken en beplantingen te hebben in of op het grondstuk van een ander. Wanneer de objecten ten gunste

487 Parl. Gesch. Boek 5 (1981), pp. 355-356: "In de omschrijving van artikel 1 ligt opgesloten, dat het recht van opstal en het eigendomsrecht op de opstallen onverbrekelijk met elkaar verbonden zijn. Dit brengt enerzijds mede, dat, wanneer het opstalrecht door overdracht of op andere wijze aan een ander overgaat, de nieuwe gerechtigde van rechtswege de eigendom van de opstallen verwerft, anderzijds dat de opstaller geen beschikkingen kan treffen over het eigendomsrecht op de opstallen los van het opstalrecht”. Zie ook: Asser/Van Heusde 1890, p. 166; Hofmann 1944, p. 325.

$488 \quad$ HR 4 december 1903, W. 8004.

489 Diephuis 1857, p. 371. Een discussie die eveneens onder het Belgische recht wordt gevoerd. Zie: hoofdstuk 4 §4.2.2.

$490 \quad$ Opzoomer 1876, p. 494.

491 Land 1901, pp. 314, 317-318; Suijling 1940, nr. 360. Anders: Hofmann 1944, p. 323: "En nu zegt ons art. 758 ook wel niet meer uitdrukkelijk, dat de opsteller gebouwen en beplantingen als eigenaar op eens anders grond mag hebben, doch uit de tegenstelling 'eigenaar van het gebouw en eigenaar van den grond' in de artt. 761 en 763 en uit art. 762 (treedt in den eigendom) kan - toch vooral in verband met den oorsprong dezer bepalingen - niet anders worden geconcludeerd". Ook Beekhuis is van mening "dat de opsteller inderdaad als de eigenaar van den opstal beschouwd moet worden...”. Zie: Beekhuis 1940, p. 42. 
waarvan het opstalrecht is gevestigd reeds ten tijde van de vestiging op of in het grondstuk aanwezig zijn, de zogenoemde 'oude' opstallen, leidt vestiging van een opstalrecht naar de heersende leer tot eigendomsverkrijging van deze opstallen. Met de vestiging van het opstalrecht wordt de eigendomsnatrekking ten aanzien van de oude opstallen doorbroken; op een onroerende zaak kan 'slechts' één eigendomsrecht rusten. ${ }^{492}$ Met betrekking tot de opstallen diegedurende de bestaansduur van het opstalrecht door de opstaller bevoegd worden verwezenlijkt, de zogenoemde 'nieuwe' opstallen, leidt vestiging van het opstalrecht -althans volgens de mij aan de heersende leer toe te kennen uitleg- tot het buitenspel zetten van de eigendomsnatrekking. $\mathrm{Nu}$ het eigendomsrecht op de nieuwe opstallen pas ontstaat met de realisatie van deze opstallen en dus ontstaat ná de vestiging van het opstalrecht, is het niet mogelijk dat dit eigendomsrecht reeds met de vestiging van het opstalrecht aan de opstaller wordt toegekend. Nu ten gevolge van de vestiging van het opstalrecht de eigendomsnatrekking terzijde wordt geschoven -nieuwe opstallen worden immers niet met het grondstuk in eigendom nagetrokkenkan worden gesteld dat het eigendomsrecht dat reeds vóór de vereniging met het grondstuk op de opstallen rust blijft voortbestaan. De vestiging van een opstalrecht hoeft niet te leiden tot eigendomsverkrijging: wanneer het opstalrecht wordt gevestigd ten behoeve van nieuwe opstallen, verkrijgt de opstaller geen eigendom maar behoudt hij de eigendom van de opstallen die duurzaam met het grondstuk zijn verenigd.

De juridische gevolgen van de vestiging van een opstalrecht kunnen mijns inziens als volgt worden onderscheiden: 1) de opstaller krijgt het recht bouwwerken en/of beplantingen te hebben op het grondstuk van een ander en eventuele andere gebruiksbevoegdheden ten aanzien van het grondstuk en 2) de opstaller verkrijgt of behoudt het eigendomsrecht met betrekking tot de oude respectievelijk de nieuwe opstallen en 3) er ontstaat een accessoire relatie tussen het recht van opstal en het eigendomsrecht van de opstallen.

Het BW definieert eigendom als "het meest omvattende recht dat een persoon op een zaak kan hebben" ${ }^{493}$, hetgeen betekent dat aan de opstaller een 'compleet'

492 Hoofdstuk $3 \S 3$. Onduidelijk is of het eigendomsrecht dat op de 'oude' opstallen komt te rusten op originaire of op derivatieve wijze wordt verkregen. Een verkrijging is, in tegenstelling tot de zogenoemde 'derivatieve' verkrijging, originair van aard wanneer de verkrijger zijn recht niet aan een rechtsvoorganger ontleent. Zie: Pitlo/Reehuis \& Heisterkamp 2012, Goederenrecht, nr. 94. Volgens Ploeger wordt het eigendomsrecht dat aan de opstaller krachtens het opstalrecht toekomt op originaire wijze verkregen; de op het meeromvattende recht rustende rechten strekken zich niet uit over het verkregen eigendomsrecht. Zie: Ploeger 1997, nr. 189.

493 Art. 5:1 lid 1 BW. 
dan wel 'volledig' recht toekomt. ${ }^{494} \mathrm{Nu}$ het opstalrecht volgens het BW afkomstig is uit een meeromvattend recht ${ }^{495}$ ontstaat de opmerkelijke situatie dat het eigendomsrecht dat op de oude opstallen rust uit een meeromvattend recht wordt afgeleid. Dit meeromvattend recht kan een eigendomsrecht betreffen, maar zoals later in dit hoofdstuk zal blijken, kunnen naast het eigendomsrecht ook andere rechten zoals een recht van vruchtgebruik met een opstalrecht worden bezwaard. Is het opstalrecht en daarmee het eigendomsrecht afgeleid uit een recht niet zijnde een eigendomsrecht, dan rijst de vraag hoe het mogelijk is verstrekkendere bevoegdheden af te leiden uit een minder verstrekkend recht. Het systeem van de wet lijkt eraan in de weg te staan de aan de opstaller ten aanzien van de bestaande opstallen toekomende bevoegdheden als eigendom aan te merken. ${ }^{496}$

Het eigendomsrecht zoals in art. 5:1 BW gedefinieerd is zelfstandig en eeuwigdurend van aard en gaat in beginsel enkel teniet wanneer de onroerende zaak waarop het eigendomsrecht rust teniet gaat. Het eigendomsrecht dat op de opstallen rust is, ongeacht of dit recht op oude of nieuwe opstallen rust, niet zelfstandig van aard, maar accessoir aan het opstalrecht. Deze accessoire relatie leidt ertoe dat vervreemding noch bezwaring van de opstallen separaat van het opstalrecht, mogelijk is. ${ }^{497}$ Het eigendomsrecht op de opstallen gaat teniet wanneer de opstallen tenietgaan of het opstalrecht waaraan het eigendomsrecht accessoir is, ophoudt te bestaan. De accessoriteit brengt mee dat het op de opstallen rustende eigendomsrecht op enig moment kan terugvallen aan de eigenaar van de onroerende zaak ${ }^{498}$ die met het opstalrecht is bezwaard en het op de opstallen rustende eigendomsrecht eveneens tijdelijk van aard kan zijn.

Het tijdelijk van aard zijn van het eigendomsrecht dat op de opstallen rust, staat op gespannen voet met art. 3:85 BW. Volgens deze bepaling dient een verbintenis strekkende tot overdracht van een goed voor een bepaalde tijd te worden aangemerkt als een verbintenis tot vestiging van

494 De eigenaar van een zaak kan enkel in zijn gebruik worden beperkt door rechten van anderen en de op wettelijke voorschriften en regels van ongeschreven recht gegronde beperkingen (art. 5:1 lid $2 \mathrm{BW}$ ).

495 "Een beperkt recht is een recht dat afgeleid is uit een meer omvattend recht, hetwelk met het beperkt recht is bezwaard", aldus art. 3:8 BW.

$496 \quad$ Hoofdstuk 3 §4.6.1.

497 "De opstaller daarentegen is weliswaar juridisch eigenaar van de opstal maar kan niet over zijn eigendom beschikken los van het recht waaruit dit voortvloeit", aldus Ploeger 1997, p. 176. Vervreemding dan wel bezwaring van het opstalrecht leidt tot vervreemding respectievelijk bezwaring van de opstal.

498 Ook opstalrechten die eeuwigdurend van aard zijn kunnen tenietgaan. Wanneer het opstalrecht eeuwigdurend van aard is èn de kans op terugval vrijwel nihil is, rijst de vraag of de vestiging van het opstalrecht dient te worden aangemerkt als een verkapte wijze van eigendomsoverdracht. Zie: hoofdstuk 6 \$4.1.2. 
een vruchtgebruik. ${ }^{499}$ Als aan de opstaller ten aanzien van de opstallen daadwerkelijk eigendom zou toekomen dan zou de opstaller ingevolge art. 3:85 BW niet bevoegd zijn het opstalrecht te verveemden, nu vervreemding van het opstalrecht tevens leidt tot vervreemding van de opstallen waarop een eigendomsrecht rust dat tijdelijk van aard kan zijn.

In de vestigingsovereenkomst kunnen de bevoegdheden ten aanzien van het gebruik, als het aanbrengen en wegnemen van de oude en nieuwe opstallen worden beperkt. ${ }^{500}$ Wanneer deze bevoegdheidsbeperkingen in de vestigingsovereenkomst worden opgenomen komt hieraan zakelijke werking toe op het moment van inschrijving van de vestigingsakte in de registers. Ten aanzien van de heersende leer betekent dit dat de inhoud van een goederenrechtelijk recht, nota bene het eigendomsrecht, nader ingevuld wordt door een door partijen gemaakte overeenkomst. Dit werpt de vraag op hoe volgens de heersende leer van een eigendomsrecht sprake kan zijn, wanneer op voorhand de bevoegdheden zodanig uitgehold worden dat van het 'meest omvattende recht' in de zin van artikel 5:1 BW geheel geen sprake kan zijn. Let wel: beperking van het eigendomsrecht op grond van rechten toekomende aan anderen is mogelijk. ${ }^{501}$ Echter wordt in deze situatie niet het met opstalrecht bezwaarde eigendomsrecht beperkt door de rechten van anderen, maar de bevoegdheden die ten gevolge van het vestigen van het opstalrecht aan de opstaller toekomen en als eigendom worden aangemerkt. Hier is dus niet sprake van beperking van een eigendomsrecht op grond van een beperkt recht, maar wordt het volgens de heersende leer 'gecreëerde' eigendomsrecht direct beperkt middels de vestigingsovereenkomst die aan

499 Asser/Mijnssen, Van Velten \& Bartels 5* 2008, nr. 19.

500 Partijen kunnen op grond van art. 5:102 BW het gebruiksrecht ten aanzien van de opstallen inperken door de bestemming van de opstallen in de vestigingsovereenkomst vast te leggen. Hiermee wordt het in de Memorie van Antwoord gegeven argument ontkracht waarom het onwenselijk is het opstalrecht af te schaffen en op te laten gaan in het erfpachtrecht. Uit de Memorie van Antwoord volgt: "Zo mag een opstaller aan de hem toebehorende zaak de bestemming geven die hem goeddunkt, terwijl de erfpachter die niet tevens een recht van opstal heeft bedongen, de bestemming van de zaak zonder de toestemming van de grondeigenaar niet mag wijzigen (artikel 5.7.1.3 lid 2). Zie: M.v.A. II, Parl. Gesch. Boek 5 (1981), p. 358.

501 Het eigendomsrecht is in beginsel exclusief van aard zo volgt uit art. 5:102 BW, hetgeen betekent dat de eigenaar een inbreuk op diens eigendomsrecht niet hoeft te dulden, tenzij het gebruik in strijd is met de rechten van anderen waarbij de op wettelijke voorschriften en regels van ongeschreven recht gegronde beperkingen in acht dienen te worden genomen. Het in art. 5:1 lid 2 BW gebezigde 'gebruik' dient ruim te worden opgevat: verbruik, verandering alsook vernietiging van de zaak kunnen onder de term 'gebruik' worden geschaard. Zie: Parl. Gesch. Boek 5 (1981), p. 19; Pitlo/Reehuis \& Heisterkamp 2012, Goederenrecht, nr. 470. 
het opstalrecht ten grondslag ligt. Het ten gevolge van de vestiging van het opstalrecht gecreëerde zakelijke recht kan -ondanks de 'noemer' eigendommiddels de vergaande uithollingbepaling van art. 5:102 BW inhoudelijk naar eigen inzicht worden ingevuld. Mijns inziens is dit in strijd met het gesloten stelsel van zakelijke rechten. ${ }^{502}$

Terwijl de bevoegdheden ten aanzien van de opstallen in de vestigingsovereenkomst van het opstalrecht kunnen worden beperkt, is het onder het erfpachtrecht ${ }^{503}$ mogelijk de bevoegdheden van de erfpachter ten aanzien van de opstallen, die bestanddeel zijn en ook na de vestiging van het erfpachtrecht bestanddeel blijven van de onroerende zaak waarop het erfpachtrecht is gevestigd, uit te breiden. Zo komt aan de erfpachter krachtens de wet in beginsel het recht tot vergoeding toe voor de door hem aangebrachte opstallen ${ }^{504}$, staat het de erfpachter in beginsel vrij de door hem aangebrachte opstallen weg te nemen bij het einde van het erfpachtrecht ${ }^{505}$ en kan de erfpachter aanspraak maken op de tijdens de duur van het erfpachtrecht afgescheiden en opeisbaar geworden vruchten ${ }^{506} .{ }^{507}$ Naast deze door de wet gegeven bevoegdheden kunnen partijen rechten en plichten in de vestigingsovereenkomst opnemen die niet direct betrekking hebben op het volle genot van de zaak, maar zodanig met het recht zijn verbonden dat opname in de vestigingsovereenkomst toelaatbaar is; bij het bestaan van een voldoende verband met het aard van het erfpachtrecht komt aan deze bevoegdheden goederenrechtelijke werking toe. ${ }^{508}$

Voorgaande laat zien dat er ten aanzien van de opstallen onder het erfpachtrecht een dusdanige elasticiteit bestaat, dat de bevoegdheden die ten aanzien van de opstallen onder het erfpachtrecht kunnen worden verkregen vrijwel identiek kunnen zijn aan de bevoegdheden van de opstaller. Het is bevreemdend dat gelijke bevoegdheden, beide voortkomend uit een beperkt zakelijk recht, in het geval van een erfpachtrecht enkel 'bevoegdheden' zijn,

502 Ten gevolge van het gesloten stelsel van beperkte rechten is het niet mogelijk zakelijke rechten te vestigen die niet in de wet zijn opgenomen. Daarnaast is het niet mogelijk aan de door de wet erkende zakelijke rechten een andere dan in de wet opgenomen inhoud toe te kennen. Struycken gaat in zijn dissertatie 'De numerus clausus in het goederenrecht' uitvoerig in op het gesloten stelsel van beperkte rechten.

503 Het erfpachtrecht komt aan bod in \$4.6.1 en \$4.6.2 van dit hoofdstuk.

504 Art. 5:99 BW.

505 Art. 5:89 lid 3 BW.

506 Art. 5:90 lid 1 BW.

507 De vermelde bevoegdheden komen enkel dan aan de erfpachter toe wanneer in de vestigingsovereenkomst hier niet van wordt afgeweken.

508 Op deze wijze is het mogelijk aan het opstalrecht een recht van vruchttrekking te koppelen. Zie: Parl. Gesch. Boek 5 (1981), p. 361 alsook Asser/Mijnssen, Van Velten \& Bartels 5* 2008, nr. 253. 
terwijl deze bevoegdheden onder het opstalrecht worden aangemerkt als 'eigendom'.

Concluderend: Het eigendomsrecht toekomende aan de opstaller is mijns inziens niets meer of minder dan het benoemen van bevoegdheden die aan de opstaller met betrekking tot de opstallen toekomen krachtens de vestigingsovereenkomst. De verschillen tussen deze bevoegdheden en het juridisch eigendomsrecht zoals in art. 5:1 BW gedefinieerd is dermate groot, immers ontbreken de essentiële elementen wil er sprake zijn van eigendom zoals de mogelijkheid de eigendom te bezwaren dan wel over te dragen, dat van eigendom in de zin van art. 5:1 BW geen sprake kan zijn. Gelijkstelling van de uit het meeromvattend recht ten aanzien van de opstal(len) voortvloeiende bevoegdheden aan het eigendomsrecht is dan ook gebaseerd op een fictie.

\section{$\$ 4.4$ De retributie}

Als tegenprestatie voor de aan de opstaller toekomende bevoegdheden kunnen partijen in de vestigingsovereenkomst opnemen dat de opstaller verplicht is om op al dan niet regelmatig terugkerende tijdstippen een geldsom, de zogenaamde retributie ${ }^{509}$, te betalen. ${ }^{510}$ Door deze verplichting in de vestigingsovereenkomst op te nemen komt hieraan, althans na inschrijving van de vestigingsakte in de openbare registers, kwalitatieve werking toe waardoor ook een verkrijger onder bijzondere titel aan de retributie gehouden is.

Partijen kunnen ook een betalingsverplichting overeenkomen zonder dat deze in de vestigingsovereenkomst wordt opgenomen. De verplichting tot betaling kan dan worden aangemerkt als een persoonlijke verbintenis die bij overdracht van het opstalrecht niet op de derdeverkrijger overgaat. Het niet kwalitatief van aard zijn van de retributieverplichting heeft ook gevolgen voor de op de retributie van toepassing zijnde bepalingen. Zo kan de opstalgever geen beroep doen op de hoofdelijke aansprakelijkheidsregel inhoudende dat de nog aan de opstalgever verschuldigde retributie, welke

509 De term 'retributie' wordt in het BW eveneens gebruikt voor de op de gerechtigde tot een erfdienstbaarheid rustende verplichting tot betaling van een geldsom. Zie: art. 5:70 lid 2 BW.

510 "Er moet sprake zijn van een geldsom, niet van andere vermogenswaarden ...", aldus Parl. Gesch. Boek 5 (1981), p. 359. Lid 3 van art. 5:101 BW wijkt af van art. 1 van het 'ontwerp-Meijers' dat stelt dat betaling van de retributie op regelmatig terugkerende tijdstippen dient te geschieden. Zie: Meijers 1955, p. 200. In het Voorlopig Verslag, Parl. Gesch. Boek 5 (1981), p. 358 wordt gesteld dat deze regeling te strak is en dat ook een overeengekomen vergoeding die niet op terugkerende tijdstippen wordt betaald alsook een som in eens onder de retributie kunnen worden geschaard. 
in de voorafgaande vijf jaren opeisbaar is geworden, zowel op de derdeverkrijger als zijn rechtsvoorganger(s) kan worden verhaald. ${ }^{511}$ Ook een beroep op de door de wet geboden mogelijkheid het opstalrecht op te zeggen wanneer de opstaller in verzuim is de retributie over twee achtereenvolgende jaren te betalen, staat niet open wanneer de retributie niet kwalitatief van aard is. ${ }^{512}$

Het toekennen van kwalitatieve werking aan de retributie is volgens de wet enkel mogelijk door deze verplichting in de vestigingsovereenkomst op te nemen; grammaticale uitleg van art. 5:101 lid 3 BW staat eraan in de weg dat aan een naderhand geïntroduceerde retributieverplichting kwalitatieve werking toekomt. ${ }^{513}$ Aan de retributieregeling ligt de gedachte ten grondslag dat aan partijen een grote mate van vrijheid dient toe te komen bij het al dan niet vaststellen van de retributie. ${ }^{514}$ Wanneer aan art. 5:101 lid $3 \mathrm{BW}$ een ruime werking zou worden toegekend, inhoudende dat de retributie 'in een akte' in plaats van 'in de akte van vestiging' kan worden opgelegd, worden partijen in staat gesteld ook ná de vestiging van het opstalrecht een retributie overeen te komen waaraan kwalitatieve werking kan worden toegekend. Evenals het geval is bij de vestigingsovereenkomst zal voor het bewerkstelligen van goederenrechtelijke werking de akte tot wijziging van de retributie in de openbare registers dienen te worden ingeschreven.

\section{§4.5 De wijzen waarop het opstalrecht kan worden beëindigd en het recht op vergoeding en wegneming van de opstallen}

Ingevolge de erfpachtbepalingen die van overeenkomstige toepassing worden verklaard voor het opstalrecht, biedt de wet zowel aan de opstaller als aan de opstalgever de mogelijkheid het opstalrecht op te zeggen. ${ }^{515} \mathrm{De}$ opstaller is bevoegd tot opzegging, tenzij in de akte van vestiging anders is bepaald. ${ }^{516}$ De opstalgever kan het recht opzeggen wanneer de opstaller in

511 Art. 5:104 lid 2 jo. 5:87 lid 2 BW.

$512 \mathrm{Nu}$ de overeengekomen retributie als een kwalitatieve verplichting dient te worden aangemerkt, rijst de vraag of de bepalingen van Boek 6 BW op de kwalitatieve verplichting van toepassing zijn aangezien de kwalitatieve verplichting in wezen een verbintenis is. Over het antwoord op deze vraag bestaat geen consensus. Zie: Van Velten 2012, pp. 549-551; Struycken 2007, pp. 435-438.

513 Art. 5:101 lid 3 BW.

514 Zie: Parl. Gesch. Boek 5 (1981), p. 294. Zie ook: Schoordijk 1992, pp. 12021206; Vonck 2007, pp. 598-603.

515 Art. 3:81 lid 2 aanhef en onder sub d BW jo. art. 5:104 lid 2 BW jo. art. 5:87 BW.

516 Art. 5:104 lid 2 jo. art. 5:87 lid 1 BW. 
verzuim is de retributie over twee achtereenvolgende jaren te betalen ${ }^{517}$ of de opstaller in ernstige mate tekortschiet in de nakoming van zijn andere verplichtingen. ${ }^{518}$

Naast beëindiging van het opstalrecht door opzegging kan het opstalrecht tenietgaan krachtens de algemene wijzen van tenietgaan van beperkte rechten zoals in Boek $3 \mathrm{BW}$ omschreven. ${ }^{519}$ Zo eindigt een opstalrecht automatisch wanneer de in de vestigingsovereenkomst opgenomen duur van het opstalrecht is verstreken. ${ }^{20}$ Een opstalrecht kan ook vóór de overeengekomen vestigingsduur eindigen. Dit zal het geval zijn wanneer de opstaller afstand doet van zijn recht ${ }^{521}$ of het recht waaruit het opstalrecht is afgeleid teniet gaat. ${ }^{522}$ Het tenietgaan van de opstal ten behoeve waarvan het opstalrecht is gevestigd leidt in beginsel niet tot het tenietgaan van het opstalrecht. Wanneer het opstalrecht in één hand komt met het met het opstalrecht bezwaarde goed, eindigt het opstalrecht door vermenging. ${ }^{523}$

Wanneer een recht van opstal eindigt gaat het op de opstallen rustende eigendomsrecht van rechtswege over op de eigenaar van de onroerende zaak die met het opstalrecht is bezwaard. ${ }^{524}$ Om te voorkomen dat aan de zijde van de eigenaar van de bezwaarde onroerende zaak sprake is van ongerechtvaardigde verrijking komen aan de opstaller een tweetal, elkaar uitsluitende rechten toe: het recht van wegneming ${ }^{525}$ en het recht op

$517 \quad$ Hoofdstuk $3 \$ 4.4$.

518 Opzegging dient door middel van een deurwaardersexploit te geschieden, "omdat er ... met het oog op eventuele rechten van derden geen onzekerheid dient te bestaan over de vraag of het recht geëindigd is”. Zie: Parl. Gesch. Boek 5 (1981), p. 304. De opzegging dient tenminste een jaar voor het tijdstip waartegen wordt opgezegd te geschieden, tenzij de opstalgever zich beroept op verzuim tot betaling van de retributie gedurende twee onafgebroken jaren of de opstaller in ernstige mate tekortschiet in de nakoming van zijn andere verplichtingen. Opzegging kan ten aanzien van voornoemde omstandigheden een maand voor het tijdstip waartegen wordt opgezegd geschieden. Zie: art. 5:104 lid 2 jo. 5:87 BW jo. 5:88 lid $1 \mathrm{BW}$.

519 Art. 3:81 lid 2 BW.

520 Art. 3:81 lid 2 aanhef en onder sub b BW.

521 Art. 3:81 lid 2 aanhef en onder sub c BW.

522 Art. 3:81 lid 2 aanhef en onder sub a BW. Of zoals Opzoomer het verwoordt: "De grond is het, waarop het recht wordt uitgeoefend. Zonder dien grond is het recht dus niet langer denkbaar". Zie: Opzoomer 1876, p. 487.

523 Art. 3:81 lid 2 aanhef en onder sub e BW.

524 Art. 5:105 BW.

525 Het recht van wegneming wordt veelal aangeduid met de term 'ius tollendi'. Dit wegneemrecht kan eveneens toekomen aan de vruchtgebruiker (art. 3:208 lid $2 \mathrm{BW}$ ), de hypotheekgever (art. 3:266 BW), de gerechtigde tot een erfdienstbaarheid (art. 5:75 lid 3 BW), de erfpachter (art. 5:89 lid 3 BW), de huurder (art. 7:216 BW) en de pachter (art. 7:349 lid $1 \mathrm{BW}$ ) bij beëindiging van het recht. 
vergoeding. ${ }^{526}$ Aan de opstaller komt in beginsel het recht toe de nieuwe opstallen die door hemzelf of een rechtsvoorganger onverplicht ${ }^{527}$ zijn aangebracht of de oude opstallen die van de eigenaar tegen vergoeding der waarde zijn overgenomen bij het einde van het opstalrecht weg te nemen, voor zover in de vestigingsovereenkomst niet anders is bepaald. Bij wegneming van de opstallen rust op de opstaller de verplichting de onroerende zaak waarop of waarin het opstalrecht rustte in de oude toestand terug te brengen. ${ }^{528}$ Het wegneemrecht is gebaseerd "op de gedachte te voorkomen dat iemand ongegrond wordt verarmd, en een ander dientengevolge wordt verrijkt, doordat op of aan de zaak van deze ander verbeteringen worden aangebracht" ${ }^{529}$

In eerste instantie lijkt het aan de opstaller toegekende wegneemrecht overbodig, nu volgens de heersende leer aan de opstaller de eigendom van de opstallen toekomt. Aan de eigenaar komt krachtens het eigendomsrecht de bevoegdheid toe "vrij van de zaak gebruik te maken" 530 hetgeen betekent "dat de eigenaar in beginsel vrij is met de zaak te doen wat hij wil, ...". ${ }^{331} \mathrm{De}$ opstaller is als eigenaar van de opstallen mijns inziens dan ook zonder het in art. 5:105 BW toegekende wegneemrecht bevoegd de opstallen weg te nemen. Hoewel volgens art. 5:105 BW het wegneemrecht aan de opstaller

526 Art. 5:99 jo. 5:105 lid 3 BW (vergoedingsrecht) en art. 5:105 lid 2 (wegneemrecht). Naast de regeling van Boek 5 BW, geeft Boek 3 BW (art. 3:120 $\mathrm{t} / \mathrm{m}$ 3:124 BW) een algemene regeling ten aanzien van het vergoeden en het wegnemen van opstallen. Deze algemene regeling kan door de opstaller enkel worden ingeroepen wanneer een derde, zijnde de daadwerkelijke eigenaar van de met het opstalrecht bezwaarde onroerende zaak, de zaak van de gerechtigde opeist èn de opstaller heeft verkregen van een beschikkingsonbevoegde. Zie ook: Van Velten 2012, pp. 48-52.

527 Wanneer ingevolge de vestigingsovereenkomst op de opstaller de verplichting rust gebouwen, werken of beplantingen aan te brengen, is de opstaller in beginsel verplicht deze objecten op het grondstuk achter te laten bij beëindiging van het opstalrecht. Zie: Parl. Gesch. Boek 5 (1981), p. 308.

528 Art. 5:105 lid 2 BW. Aan het wegneemrecht is volgens Opzoomer de 'natuurlijke voorwaarde' verbonden de zaak in oude toestand terug te brengen. De eigenaar van de bezwaarde, onroerende zaak dient ten gevolge van het wegnemen van de opstallen geen schade te lijden. "Daarom kan zijn wegnemen hem dan alleen vrij staan, wanneer hij hetgeen hij wegnemen wil óf zelf op den grond heeft aangebracht of de waarde er van aan den eigenaar heeft betaald, en dit wel of toen het recht van opstal door hem verkregen werd, ó later mits ten gevolge van een toen getroffen schikking. Daarenboven moet hij in ieder geval den grond in dien toestand herstellen, waarin die vór het bouwen of planten zich bevond”. Zie: Opzoomer 1876, p. 487.

529 Wichers 2002, p. 274.

$530 \quad$ Art. 5:1 lid 2 BW.

531 Parl. Gesch. Boek 5 (1981), p. 19. “... mits dit gebruik niet strijdt met rechten van anderen en de op wettelijke voorschriften en regels van ongeschreven recht gegronde beperkingen daarbij in acht worden genomen", aldus art. 5:1 lid $2 \mathrm{BW}$. 
toekomt "bij het einde van zijn recht", ben ik van mening dat de bevoegdheid tot wegname reeds bestaat op het moment dat de opstaller de eigendom van de opstallen verkrijgt. Krachtens het eigendomsrecht is de opstaller bevoegd alle opstallen weg te nemen ten gunste waarvan het opstalrecht is gevestigd $\mathrm{d}^{532}$, terwijl bij het einde van het opstalrecht de reikwijdte van het wegneemrecht ingevolge art. 5:105 lid $2 \mathrm{BW}$ beperkt is tot de ten tijde van de vestiging bestaande en in waarde vergoede opstallen en de door de opstaller onverplicht aangebrachte opstallen. ${ }^{533}$ Wanneer de opstaller de oude opstallen die door de opstaller niet in waarde zijn vergoed wegneemt, leidt dit tot financiële benadeling van de opstalgever. Ik betwijfel ten zeerste of dit de bedoeling van de wetgever is geweest. ${ }^{534}$

De meerwaarde van het in art. 5:105 BW opgenomen wegneemrecht is gelegen in de bevoegdheid van de opstaller de opstallen gedurende een bepaalde periode $n a$ beëindiging van het opstalrecht weg te mogen nemen. ${ }^{535} \mathrm{Na}$ beëindiging van het opstalrecht worden de opstallen ten gunste waarvan het opstalrecht is gevestigd met het grondstuk nagetrokken, althans voor zover de opstaller de opstallen niet reeds van het grondstuk heeft afgescheiden, waardoor de opstaller de bevoegdheid de opstallen weg te mogen nemen niet langer kan ontlenen aan het op de opstallen rustende eigendomsrecht.

Wanneer -zoals in \$4.3.1 door mij beargumenteerd- de aan de opstaller ten aanzien van de opstallen toekomende bevoegdheden niet als eigendom kunnen worden aangemerkt, dient de wettekst van art. 5:105 lid $1 \mathrm{BW}$ te worden aangepast. $\mathrm{Nu}$ van eigendom geen sprake is, kan de opstaller de bevoegdheid de opstallen weg te mogen nemen gedurende het opstalrecht niet ontlenen aan het op de opstallen rustende eigendomsrecht. De wettekst van art. 5:105 lid $1 \mathrm{BW}$ dient zo te worden geformuleerd dat aan de opstaller de bevoegdheid toekomt, zowel tijdens de duur van het opstalrecht als bij het einde daarvan, de opstallen weg te mogen nemen die door hemzelf of zijn rechtsvoorganger onverplicht zijn aangebracht of van de eigenaar tegen

532 Aan de opstaller komt de eigendom van de opstallen toe ongeacht of de opstallen bij de vestiging van het opstalrecht zijn vergoed of door de opstaller gedurende het opstalrecht verplicht zijn aangebracht.

533 Althans voor zover in de vestigingsovereenkomst niet anders is bepaald, aldus art. 5:105 lid 2 BW.

534 Een oplossing voor deze conflictueuze situatie tussen het uit het eigendomsrecht voorvloeiende wegneemrecht enerzijds en het aan de opstaller op grond van art. 5:105 lid 2 BW toegekende wegneemrecht anderzijds kan worden gevonden in het niet langer kwalificeren van de aan de opstaller toekomende bevoegdheden ten aanzien van de opstallen als eigendom. Zie: hoofdstuk 3 \$4.3.1 en hoofdstuk 6 \$4.1.1.

535 Parl. Gesch. Boek 5 (1981), p. 365. 
vergoeding der waarde zijn overgenomen, mits hij de met opstal bezwaarde zaak in oude toestand terugbrengt. ${ }^{536}$

Aan de opstaller kan in beginsel een recht op vergoeding toekomen wanneer de opstaller besluit de door hem onverplicht aangebrachte opstallen en de tegen vergoeding der waarde overgenomen opstallen niet weg te nemen. ${ }^{537}$ Van dit recht op vergoeding kan in de vestigingsovereenkomst worden afgeweken, maar alleen in die vier gevallen die bij wet zijn geregeld. ${ }^{538}$ Uitsluiting van het vergoedingsrecht laat het recht de opstallen weg te nemen ongemoeid.

Het eerste geval waarbij van het vergoedingsrecht kan worden afgeweken, doet zich voor wanneer aan de in opstal gegeven grond een andere bestemming toekomt dan woningbouw. ${ }^{539}$ Van Velten is van mening dat deze regel niet beperkt is tot woningen die als hoofdverblijf van de opstaller kunnen worden aangemerkt, maar eveneens ziet op woningen in de recreatie sfeer, zoals vakantiewoningen. ${ }^{540}$ Het recht op vergoeding kan in de vestigingsovereenkomst eveneens worden uitgesloten wanneer de opstaller de opstallen niet zelf heeft bekostigd zoals het geval is bij een woningwetwoning ${ }^{541}$, of het opstalrecht eindigt doordat de opstaller het opstalrecht opzegt. ${ }^{52}$ De laatste vergoedingsuitsluitingsgrond ziet op de opstallen die door de opstaller onverplicht zijn aangebracht en ten aanzien waarvan aan de opstaller het recht toekomt ze weg te mogen nemen. De gedachte achter deze vergoedingsuitsluitingsgrond is dat de eigenaar niet gehouden kan worden tot het vergoeden van opstallen die hij niet heeft gewenst. Opstallen die door de opstaller verplicht zijn aangebracht, mogen door de opstaller in beginsel niet worden weggenomen. Ten aanzien van deze opstallen komt aan de opstaller een recht op vergoeding toe. ${ }^{543}$

De opstalgever is bevoegd de kosten die hij uit hoofde van het opstalrecht van de opstaller heeft te vorderen te verrekenen met de door hem aan de

536 In plaats van wijziging van art. 5:105 lid 2 BW, kan verwijzing naar art. 5:89 lid 3 BW door de in Titel 8 van Boek 5 BW -deze titel ziet op de bepalingen omtrent het opstalrecht- opgenomen schakelbepaling, art. 5:104 BW, uitkomst bieden.

537 Art. 5:105 lid 3 jo. 5:99.

538 Art. 5:105 lid 3 jo. 5:99 lid 2 BW. Zie: Asser/Mijnssen, Van Velten \& Bartels 5* 2008, nr. 257.

539 Met andere woorden: indien de in opstal gegeven grond de bestemming woningbouw heeft, komt aan de opstaller een recht op vergoeding van de opstallen toe, tenzij sprake is van een andere in art. 5:99 lid 2 BW gegeven vergoedingsuitsluitingsgrond.

$540 \quad$ Van Velten 1995, p. 54.

$541 \quad$ Parl. Gesch. Boek 5 (1981), p. 348.

542 Hoofdstuk $3 \S 4.5$.

543 Parl. Gesch. Boek 5 (1981), p. 343. 
opstaller te betalen vergoeding. ${ }^{544}$ De opstaller is bevoegd tot uitoefening van een retentierecht ${ }^{545}$ totdat de verschuldigde vergoeding is betaald. ${ }^{546}$ Dit retentierecht kan de opstaller enkel uitoefenen ten aanzien van de opstallen. ${ }^{547}$ Ook aan de opstalgever kan een retentierecht toekomen met betrekking tot hetgeen hij uit hoofde van het opstalrecht heeft te vorderen. De opstalgever kan dit recht uitoefenen op hetgeen reeds door de opstaller is afgebroken. ${ }^{548}$

\section{$\S 4.6$ Het recht van opstal in relatie tot andere rechten}

Met het vestigen van het opstalrecht worden bevoegdheden die afkomstig zijn uit het recht dat met het opstalrecht wordt bezwaard, het meeromvattende recht, aan de opstaller overgedragen. Uit de opstaldefinitie kan worden afgeleid dat dit meeromvattende recht het op een onroerende zaak rustend eigendomsrecht betreft. Uit de navolgende paragaaf zal blijken dat ook andere zakelijke rechten met een opstalrecht kunnen worden bezwaard. ${ }^{549}$

In $§ 4.6 .2$ wordt ingegaan op de zakelijke rechten die door de opstaller kunnen worden gevestigd. Binnen deze relatie opstalrecht-zakelijk recht kan het opstalrecht als meeromvattend recht worden aangemerkt. Naast het vestigen van beperkt zakelijke rechten kan de opstaller het recht van opstal met een recht van hypotheek bezwaren. ${ }^{550}$ Tevens staat het de opstaller vrij zijn recht te verhuren of te verpachten. ${ }^{551}$

\section{\$4.6.1 Het opstalrecht in relatie tot het met het opstalrecht bezwaarde recht}

Een opstalrecht wordt afgeleid uit een meeromvattend recht dat met het opstalrecht wordt bezwaard. ${ }^{552}$ Het opstalrecht kan als afgeleid recht worden aangemerkt als 'dochterrecht', het meeromvattende recht als 'moederrecht'. ${ }^{553}$ Wil een recht als moederrecht worden aangemerkt,

$544 \quad$ Art. 5:105 lid 3 jo. 5:99 lid 3 BW.

545 Art. 3:290 BW e.v.

546 Van het retentierecht kan in de vestigingsovereenkomst niet ten nadele van de opstaller worden afgeweken (art. 5:105 lid 3 jo. 5:100 lid 2 BW).

$547 \quad$ Art. 5:105 lid 3 jo. art. 5:100 lid 1 BW.

$548 \quad$ Art. 5:105 lid 3 jo. art. 5:100 lid 3 BW.

549 Hoofdstuk $3 \$ 4.6 .1$.

$550 \quad$ Hoofdstuk 3 §4.6.3.

551 Tenzij in de vestigingsovereenkomst anders is overeengekomen. Zie: hoofdstuk $3 \S 4.6 .4$.

552 Art. 5:101 jo. 3:8 BW.

553 Pitlo/Reehuis \& Heisterkamp 2012, Goederenrecht, nr. 588. Wanneer moeder- en dochterrecht aan dezelfde persoon toekomen, gaat het beperkte recht in beginsel teniet door vermenging (art. 3:81 lid 2 aanhef en onder 
dan dient zij niet alleen 'meeromvattend' te zijn op grond van het nog te bespreken nemo-plus-beginsel ${ }^{554}$, maar dient zij eveneens overdraagbaar en zelfstandig van aard te zijn. ${ }^{555}$ De verhouding tussen het meeromvattende recht en het daaruit voortkomend beperkte recht kan niet worden gekarakteriseerd als ondergeschikt. ${ }^{556}$

Volgens de opstaldefinitie wordt het opstalrecht gevestigd op een onroerende zaak; het opstalrecht wordt dan ook aangemerkt als een beperkt zakelijk recht. ${ }^{557} \mathrm{Nu}$ ingevolge art. 3:1 BW het begrip 'zaak' vereenzelvigd wordt met het eigendomsrecht dat op de zaak rust, wordt het opstalrecht strikt gezien gevestigd op het eigendomsrecht dat op de te bezwaren onroerende zaak rust. Een beperkt zakelijk recht wordt daarentegen niet met de zaak waarop het beperkt zakelijke recht rust vereenzelvigd. Nu een beperkt recht niet als zaak kan worden aangemerkt, heeft dit tot gevolg dat

sub e BW). Hierbij dienen een tweetal kanttekeningen te worden gemaakt. Ten eerste werken afstand en vermenging niet ten nadele van hen die op het tenietgaande beperkte recht een beperkt recht hebben (art. 3:81 lid $3 \mathrm{BW}$ ). Het tenietgaan van het beperkte recht heeft dan ook 'relatieve werking'. Zo zal bij het niet-betalen van een vordering die met een hypotheekrecht is verzekerd en op een beperkt recht is gevestigd de hypotheekhouder gerechtigd zijn tot uitwinning van het hypotheekrecht waardoor het hypotheekrecht herleeft. Ten tweede maakt art. 3:81 lid $1 \mathrm{BW}$ overdracht onder voorbehoud van een beperkt recht mogelijk. Nog voor het zakelijke recht wordt overgedragen vestigt de gerechtigde tot het zakelijke recht een beperkt recht ten behoeve van zichzelf, waarna hij het bezwaarde, zakelijke recht overdraagt. Hoewel de vestiging van het beperkte recht en de overdracht van het te bezwaren hoofdrecht geschieden middels dezelfde akte komen beide rechten, zij het voor een zeer korte, zo goed als verwaarloosbare periode, toe aan dezelfde persoon. Zie: HR 4 december 1998, NJ 1999, 594; Pitlo/Reehuis \& Heisterkamp 2012, Goederenrecht, nr. 597.

554 Ingevolge het nemo-plus-beginsel kan niemand meer bevoegdheden overdragen dan hij zelf heeft.

555 Art. 3:81 lid 2 BW. Zie: Parl. Gesch. Boek 3 (1981), p. 309.

556 Meijers omschrijft de relatie tussen het eigendomsrecht en de beperkte rechten als volgt: "Ik voor mij zie het nut der gansche vraag of er een quantitatief of een qualitatief verschil tusschen het begrip eigendom en de overige zakelijke rechten bestaat, niet in. Dat de overige zakelijke rechten van den eigendom zijn afgeleid, zal niemand betwisten, maar dat er een principieel verschil is in de omschrijving der bevoegdheden van den eigendom eenerzijds en de omschrijving van de overige zakelijke rechten anderzijds, is onjuist”. Zie: Meijers 1910, pp. 205-206. De stellingname van Meijers wordt ook door de huidige doctrine onderschreven. Zie: De Jong 2006, nr. 176.

557 De erfdienstbaarheid (art. 5:70 BW) en het erfpachtrecht (art. 5:85 BW) worden eveneens op een onroerende zaak gevestigd. Het recht van vruchtgebruik is een bijzondere 'eend in de bijt'; dit beperkte recht kan zowel op rechten als op zaken rusten. Bij bezwaring van een zaak met een recht van vruchtgebruik (art. 3:201 BW) dient het vruchtgebruik als een beperkt zakelijk recht te worden gekwalificeerd. 
het vestigen ${ }^{558}$ van een opstalrecht op een beperkt recht volgens de letter van de wet niet mogelijk is. ${ }^{559}$

Reeds tijdens het wetgevingsproces werd duidelijk dat het door Meijers opgezette systeem niet voldeed aan de in de praktijk bestaande behoefte beperkt zakelijke rechten te stapelen. ${ }^{560}$ Beekhuis is met de volgende oplossing gekomen: het te stapelen beperkte recht wordt niet op het reeds gevestigde beperkt zakelijke recht gevestigd, maar wordt gevestigd op het eigendomsrecht van de onderliggende zaak. Doordat het beperkt zakelijke recht wordt gevestigd op de zaak, leidt dit tot de vestiging van een tweede beperkt zakelijk recht naast het reeds bestaande beperkte recht. Hierdoor wordt het op de onroerende zaak rustende eigendomsrecht door beide rechten afzonderlijk en in zijn geheel bezwaard. Strikt genomen is van stapeling van beperkte rechten dan ook geen sprake.

Of de beperkt gerechtigde bevoegd is het grondstuk dat met het aan hem toekomende beperkte recht is belast te bezwaren met een opstalrecht, is afhankelijk van de vraag of de gerechtigde hiertoe beschikkingsbevoegd is. De beschikkingsbevoegdheid van de beperkt gerechtigde is beperkt tot die bevoegdheden die aan hem krachtens het aan hem toekomende beperkte recht toekomen. ${ }^{561} \mathrm{Nu}$ art. 5:104 lid $2 \mathrm{BW}$ als schakelbepaling art. 5:93 lid 1 BW van overeenkomstige toepassing verklaart, is de opstaller krachtens de wet bevoegd tot het vestigen van een recht van opstal. ${ }^{562}$

Of de erfpachter bevoegd is tot het vestigen van een recht van opstal is afhankelijk van de vraag of de aan de opstaller toekomende bevoegdheden als eigendom dienen te worden aangemerkt. ${ }^{563}$ De erfpachter is bevoegdheid de aan een ander toebehorende onroerende zaak te houden en te gebruiken. ${ }^{564}$ Anders dan bij het opstalrecht, komt aan de erfpachter ten aanzien van de onroerende zaak 'enkel' een gebruiksrecht toe. Terwijl de opstaller volgens de heersende leer de eigendom van de opstallen verkrijgt ten gunste waarvan

558 Het bezwaren van een beperkt recht met een beperkt recht wordt in de literatuur veelal aangemerkt met de term 'stapelen'. Zie: Struycken 2007, p. 367.

559 Zie: Asser/Mijnssen, Van Velten \& Bartels 5*2008, nr. 9a; Van Velten 2005, pp. 283-286. Hoewel het volgens de letter van de wet niet mogelijk een beperkt zakelijk recht met een dito recht te bezwaren is het wel mogelijk een zakelijk recht te bezwaren met de uit Boek 3 BW afkomstige beperkt zakelijke rechten hypotheek, pand en vruchtgebruik.

$560 \quad$ Heyman 1999, pp. 52-56.

$561 \quad$ Heyman 2003, p. 81.

562 Ofschoon de meningen hierover verdeeld zijn. In $\$ 4.6 .2$ van dit hoofdstuk wordt nader ingegaan op het bezwaren van een opstalrecht met een opstalrecht.

563 Hoofdstuk $3 \$ 4.3 .1$.

564 Art. 5:85 BW. In $§ 4.6 .2$ wordt nader ingegaan op het recht van erfpacht. 
het opstalrecht is gevestigd, staat het nemo-plus-beginsel er volgens de heersende leer aan in de weg dat de erfpachter een recht van opstal vestigt. ${ }^{565}$ Mijns inziens kan de erfpachter wel een recht van opstal vestigen wanneer de bevoegdheden die de opstaller ten aanzien van de opstallen verkrijgt niet verder strekken dan de bevoegdheden die aan de erfpachter toekomen krachtens het erfpachtrecht. Reeds in $\$ 4.3 .1$ van dit hoofdstuk is opgemerkt dat de aan de erfpachter toekomende bevoegdheden verstrekkender van aard kunnen zijn dan de aan de opstaller toekomende bevoegdheden en het dus maar zeer de vraag is of het wenselijk is deze aan de opstaller toekomende bevoegdheden als eigendom aan te merken..$^{566}$

Volgens de heersende leer is de vruchtgebruiker eveneens onbevoegd tot het vestigen van een opstalrecht nu evenals bij het erfpachtrecht aan de vruchtgebruiker geen eigendom, maar 'enkel' een gebruiksrecht ten aanzien van de onroerende zaak toekomt ${ }^{567}{ }^{568}$ Mijns inziens kan ook de vruchtgebruiker een opstalrecht vestigen voor zover de bevoegdheden die aan de opstaller worden toegekend niet verstrekkender van aard zijn dan de aan de vruchtgebruiker toekomende bevoegdheden.

Alvorens in te gaan op de vraag of een appartementsrecht ${ }^{569}$ met een opstalrecht kan worden bezwaard dient te worden opgemerkt dat het

566 Heyman is in navolging van Kleyn eveneens van mening dat "het nemo-plusprobleem kan worden uitgeschakeld als men aanvaardt dat een opstalrecht verkregen van een erfpachter alleen die eigenaarsbevoegdheden omvat - Kleyn spreekt van dominale rechten - die in het erfpachtrecht besloten liggen ...”. Zie: Heyman 1999, p. 541; Kleyn 1997, p. 14. Zie ook: Struycken 2007, p. 379. Ploegers argument tegen het vestigen van een recht van opstal op een erfpachtrecht is hierin gelegen dat de erfpachter "niet ten nadele van de bloot-eigenaar van de onroerende zaak en ten gunste van een derde [kan] ingrijpen in de gevolgen van de superficiesregel”. Zie: Ploeger 1997, nr. 192.

567 Art. 3:201 BW.

568 Struycken 2007, pp. 379-380. Volgens Bartels kan een op een onroerende zaak rustend recht van vruchtgebruik met een recht van hypotheek of met een recht van vruchtgebruik worden bezwaard. Zie: Asser/Mijnssen, Van Velten \& Bartels* 2008, nr. 262. Vereist is, wil van bezwaring en niet van overdracht van het vruchtgebruik sprake zijn, dat aan de vruchtgebruiker van het gestapelde vruchtgebruik minder bevoegdheden worden toegekend dan aan de vruchtgebruiker van het bezwaarde recht van vruchtgebruik toekomen.

569 Het Nederlandse appartementsrecht is gebaseerd op het monistisch stelsel dat gekenmerkt wordt door mede-eigendom. De appartementseigenaar verkrijgt ten aanzien van het appartementsrecht geen exclusief eigendomsrecht, maar enkel een exclusief gebruiksrecht. Krachtens het dualistische stelsel komt aan de appartementseigenaar ten aanzien van het appartement wèl een exclusief eigendomsrecht toe alsook mede-eigendom ten aanzien van de overige gedeelten van de onroerende zaak. Zie: Mon. BW B29 (Mertens), nr. 5; Timmermans 2003a, pp. 501-205; Timmermans 2003b, pp. 525-530. 
appartementsrecht verschilt van voornoemde zakelijke rechten, doordat het recht niet uit een meeromvattend recht is afgeleid en dan ook niet als 'beperkt recht' kan worden aangemerkt. Volgens art. 5:106 BW is de eigenaar ${ }^{570}$ van een gebouw ${ }^{571}$ en/of de daarbij behorende grond bevoegd het op deze zaak rustende eigendomsrecht te splitsen in appartementsrechten. ${ }^{572}$ Aan de gerechtigde tot het appartementsrecht, de appartementseigenaar ${ }^{573}$, komt een aandeel in de goederen toe die in de splitsing zijn betrokken. ${ }^{574}$ Ingevolge dit aandeel verkrijgt de appartementseigenaar mede-eigendom van de in de splitsing betrokken onroerende zaken. ${ }^{575}$ Aan de appartementseigenaar komt een exclusief gebruiksrecht toe ten aanzien van het privé-gedeelte en een algemeen gebruiksrecht ten aanzien van de gemeenschappelijke ruimtes. ${ }^{576}$

$\mathrm{Nu}$ de gerechtigde tot een appartementsrecht een aandeel in de eigendom van een onroerende zaak en daarmee een onroerende zaak verkrijgt ${ }^{577}$, kan het appartementsrecht volgens de heersende leer met een recht van opstal worden bezwaard ${ }^{578}$, althans voor zover in de akte van splitsing niet anders

570 Uit art. 5:106 lid 1 BW volgt dat naast de eigenaar ook de erfpachter en de opstaller bevoegd zijn het erfpacht- respectievelijk het opstalrecht te splitsen in appartementsrechten, mits dit recht op een gebouw of grond rust. Zie: Asser/ Mijnssen, Van Velten \& Bartels* 2008, nr. 343a.

571 Het begrip 'gebouw' dient ruim te worden uitgelegd. Woon-, kantoor-, winkelen andere ruimtes als een groep van (nog te realiseren) gebouwen (art. 5:106 lid $6 \mathrm{BW})$ kunnen onder dit begrip worden geschaard.

572 Het is eveneens mogelijk onbebouwde grond in appartementsrechten te splitsen. Zie: Mon. BW B29 (Mertens), nr. 8.

573 Art. 5:106 lid 5 BW. De term 'appartementseigenaar' kan tot verwarring leiden aangezien de gerechtigde tot het appartementsrecht ten aanzien van het appartement geen eigendom in de zin van art. 5:1 BW verkrijgt.

574 Het appartementsrecht is een aandeel in de eigendom van een onroerende zaak, waardoor het appartementsrecht zelf ook is aan te merken als een onroerende zaak. Zie: Venemans 1997, p. 51.

575 Het splitsen van een eigendomsrecht in appartementsrechten kan niet gelijk worden gesteld met horizontale splitsing van de onroerende zaak, daar de crux van het appartementsrecht gelegen is in deelgenootschap. Eenieder die een appartementsrecht heeft met betrekking tot een bepaalde zaak is medeeigenaar van de gehele onroerende zaak.

576 Art. 5:106 lid 4 BW. De appartementseigenaar wordt met het verkrijgen van het appartementsrecht tevens lid van de Vereniging van Appartementseigenaren. Het doel van deze vereniging is gelegen in "het behartigen van gemeenschappelijke belangen van appartementseigenaren” (art. 5:112 lid 1 sub e BW). Zie: Pitlo/ Reehuis \& Heisterkamp 2012, Goederenrecht, nr. 707; Mon. BW. B29 (Mertens), nr. 21.

577 Venemans 1997, p. 51.

578 Een appartementsrecht kan eveneens met een recht van vruchtgebruik, erfdienstbaarheid of erfpacht worden bezwaard. Het appartementsrecht kan ook in verschillende appartementsrechten worden (onder)gesplitst. 
is bepaald. ${ }^{579}$ Het opstalrecht komt daarbij op het privé-gedeelte van het appartementsrecht te rusten; een opmerkelijke constructie omdat het privégedeelte niet kan worden aangemerkt als een goed en volgens de systematiek van de wet dan ook niet vatbaar is voor beschikkingshandelingen. ${ }^{580}$ Daarbij dient de kanttekening te worden gemaakt dat hoewel de wet het vestigen van een opstalrecht op een appartementsrecht mogelijk maakt door te stellen dat het privé-gedeelte met het opstalrecht kan worden bezwaard, het nemo-plusbeginsel hier strikt genomen aan in de weg staat; de appartementseigenaar heeft immers 'enkel' mede-eigendom en geen volledige eigendom van het privé-gedeelte. ${ }^{581}$

\section{$\S 4.6 .2$ Het opstalrecht als meeromvattend recht in relatie tot zakelijke rechten}

Of de opstaller bevoegd is tot het vestigen van een zakelijk recht is afhankelijk van de aan de opstaller toekomende bevoegdheden. ${ }^{52}$ Het nemo-plus-beginsel staat eraan in de weg dat de opstaller met de vestiging van een zakelijk recht meer bevoegdheden aan een derde overdraagt dan aan de opstaller ingevolge het opstalrecht toekomen. Een door de opstaller gevestigd beperkt zakelijk recht komt volgens de 'constructie-Beekhuis' niet op het opstalrecht te rusten, maar op de onroerende zaak die met het opstalrecht is bezwaard. ${ }^{583}$

$579 \quad$ Art. 5:118a BW.

580 Asser/Mijnssen, Van Velten \& Bartels 5*2008, nr. 215.

581 Zie: Heyman 1999, p. 53; Venemans 1999, p. 387.

582 Het zelfstandige opstalrecht is een overdraagbaar recht (art. 3:81 lid 1 BW), tenzij -zo volgt uit art. 3:83 lid $1 \mathrm{BW}$ - de wet of de aard van het recht zich tegen een overdracht verzet. Een in de vestigingsovereenkomst opgenomen onvervreemdbaarheids- of bezwaringsbeding laat de overdraagbaarheid respectievelijk de mogelijkheid het opstalrecht te bezwaren onverlet. Wel kan ingevolge art. 5:91 lid $1 \mathrm{BW}$-deze bepaling wordt krachtens schakelbepaling 5:104 BW van overeenkomstige toepassing verklaard- de overdracht respectievelijk de bezwaring van het beperkte recht afhankelijk worden gemaakt van de toestemming van de eigenaar van de belaste onroerende zaak. Zie ook: Parl. Gesch. Boek 5 (1981), p. 310.

583 Hoofdstuk 4 \$4.6.1. Een door de opstaller gevestigd beperkt zakelijk recht komt op de onroerende zaak te rusten die reeds met het opstalrecht is bezwaard. Van Velten werpt de vraag op of de opstaller meer bevoegdheden kan overdragen dan aan de opstaller toekomen, wanneer de eigenaar van de onroerende zaak hiermee instemt. Zie: Van Velten 2005, p. 285. 
In de voorgaande paragraaf is reeds opgemerkt dat de opstaller bevoegd is tot het vestigen van een onderopstalrecht ${ }^{584}{ }^{585}$ Wanneer de opstaller een onderopstalrecht vestigt, komt aan de onderopstaller het recht toe 1) bouwwerken of beplantingen te hebben in of op de onroerende zaak van een ander, en 2) een gebruiksrecht dat kan zien op zowel de onroerende zaak die met het opstalrecht is bezwaard als op de opstal(len) ten gunste waarvan het opstalrecht is gevestigd. ${ }^{586}$ Het object ten gunste waarvan het onderopstalrecht is gevestigd kan betrekking hebben op reeds aan de opstaller toekomende opstallen alsook op nog te realiseren opstallen waartoe de opstaller krachtens de vestigingsovereenkomst bevoegd is deze te verwezenlijken.

Uit de wet volgt dat de opstaller ${ }^{587}$ bevoegd is zowel ten laste als ten behoeve van de onroerende zaak die met het opstalrecht is bezwaard een erfdienstbaarheid te vestigen respectievelijk te bedingen. ${ }^{588}$ De erfdienstbaarheid is een beperkt zakelijk recht dat kan worden gedefinieerd als een last, waarmee een onroerende zaak, het dienend $\operatorname{erf}^{589}$, ten behoeve van een andere onroerende zaak, het heersende erf, is bezwaard. ${ }^{590}$ Volgens de 'constructie-Beekhuis'591 komt een erfdienstbaarheid die door de opstaller wordt gevestigd niet op het opstalrecht te rusten, maar op het erf, het dienend erf, dat reeds met het opstalrecht is bezwaard. ${ }^{592}$ De gevestigde

584 Doordat het onderopstalrecht niet op het opstalrecht komt te rusten, maar op de onroerende zaak die met het opstalrecht is bezwaard, is de term 'onderopstal' strikt gezien niet correct. Zie: Van Velten 2005, p. 284.

585 Art. 5:104 lid 2 jo. 5:93 BW. Volgens de wetgever bestaat er in "de praktijk de behoefte aan de figuur van een recht van ,onderstal”, hierin bestaande dat de opstaller op de roerende zaak op zijn beurt ten behoeve van een ander een recht van opstal vestigt. Men denke aan een projectontwikkelaar die zelf een recht van opstal op een hoeveelheid grond heeft en nu delen daarvan aan andere uitgeeft, die daarop dan krachtens eigen recht kunnen bouwen zonder dat de ontwikkelaar zijn recht ten aanzien van de grond verliest”. Zie: Parl. Gesch. Boek 5 (Inv. 3, 5 en 6) (1990), p. 1084.

586 Zie: hoofdstuk $3 \S 4$.1. Een recht van opstal hoeft niet per definitie het gebruik van de grond met zich te brengen. Zie: HR 7 maart 1979, NJ 1980, 116. Zie: noot 450 .

587 De opstaller wordt door de wet, art. 5:84 lid 4 BW, in relatie tot de te vestigen respectievelijk te bedingen erfdienstbaarheid als eigenaar van het heersende dan wel dienende erf aangemerkt. Zie: Asser/Mijnssen, Van Velten \& Bartels* 2008, nr. 207.

588 Art. 5:84 lid 1 BW. Uit deze bepaling volgt dat de erfpachter alsook de vruchtgebruiker bevoegd zijn tot het vestigen van een erfdienstbaarheid.

$589 \quad$ Met de term 'erf' wordt een onroerende zaak bedoeld.

590 Voor het vestigen van een erfdienstbaarheid is het niet noodzakelijk dat beide erven aan elkaar grenzen.

$591 \quad$ Hoofdstuk 3 §4.6.1.

592 Berger 2001, p. 226. 
erfdienstbaarheid gaat in beginsel teniet wanneer het opstalrecht teniet gaat. ${ }^{593}$ De opstaller ${ }^{594}$ is evenwel bevoegd ten behoeve van het erf waarop zijn opstalrecht is gevestigd, het heersend erf, een erfdienstbaarheid te bedingen. Deze erfdienstbaarheid strekt tot voordeel van het heersend erf en gaat bij beëindiging van het opstalrecht in beginsel niet teniet, tenzij partijen dit in de vestigingsovereenkomst zijn overeengekomen. ${ }^{595}$

De opstaller is eveneens bevoegd een erfdienstbaarheid te vestigen ten behoeve als ten laste van de opstallen ten gunste waarvan het opstalrecht is gevestigd ${ }^{596}$ Het is gezien de accessoire relatie tussen het opstalrecht en de opstallen ten behoeve waarvan het opstalrecht is gevestigd zeer opmerkelijk dat enkel de opstallen, los van het opstalrecht, met een erfdienstbaarheid kunnen worden bezwaard. Een erfdienstbaarheid gevestigd door de opstaller ten laste van de opstallen gaat in beginsel tezamen met het opstalrecht teniet $^{597}$, terwijl de door de opstaller ten behoeve van de opstallen bedongen erfdienstbaarheid in beginsel het opstalrecht 'overleeft' ${ }^{598}$

In $\$ 4.6 .1$ is opgemerkt dat de erfpachter volgens de heersende leer niet bevoegd is tot het vestigen van een recht van opstal: het nemo-plus-beginsel staat hieraan in de weg. In deze paragraaf rijst de vraag of de opstaller bevoegd is tot het vestigen van een erfpachtrecht. Uit de erfpachtdefinitie volgt dat de gerechtigde tot een erfpachtrecht bevoegd is eens anders onroerende zaak te houden en te gebruiken. ${ }^{599}$ De bevoegdheid tot gebruik biedt aan de erfpachter in beginsel een genot van de met het erfpachtrecht bezwaarde onroerende zaak dat overeenstemt met het aan de eigenaar van de onroerende zaak toekomende genot wanneer de onroerende zaak onbelast is. ${ }^{600}$ Of aan

593 Een erfdienstbaarheid kan het opstalrecht 'overleven' wanneer het opstalrecht eindigt door vermenging of afstand, aldus art. 3:81 lid 3 BW. Zie: noot 553. Uit art. 5:84 lid $2 \mathrm{BW}$ volgt dat de erfdienstbaarheid evenmin teniet gaat wanneer de eigenaar van de zaak waarop het beperkte recht rustte door middel van een in de openbare registers ingeschreven akte heeft verklaard met de vestiging van de erfdienstbaarheid in te stemmen. Zie: Asser/Mijnssen, Van Velten \& Bartels* 2008, nr. 207; Mon. BW B27 (Wibbens-De Jong), nr. 26.

594 Ook de erfpachter en de vruchtgebruiker zijn bevoegd een erfdienstbaarheid te bedingen, zo volgt uit art. 5:84 lid $1 \mathrm{BW}$.

595 Art. 5:84 lid 2 BW.

$596 \mathrm{Nu}$ de aan de opstaller toekomende opstallen worden aangemerkt als onroerende zaken, is het mogelijk ten behoeve als ten laste van deze opstallen een erfdienstbaarheid te bedingen respectievelijk te vestigen, aldus art. 5:70 lid 1 BW. Zie: Berger 2001, p. 266; Parl. Gesch. Boek 5 (1981), p. 291; Ploeger 1997, p. 198.

597 Art. 5:84 lid 3 BW.

598 Art. 5:84 lid 2 BW.

599 Art. 5:85 lid 1 BW.

600 Althans "voor zover niet in de akte van vestiging anders is bepaald" (art. 5:89 lid 1 BW). Zie: Asser/Mijnssen, Van Velten \& Bartels 5*2008, nr. 223; Land 1901, 
de opstaller de bevoegdheid toekomt een erfpachtrecht te vestigen zijn de meningen verdeeld. Zo acht Bartels de vestiging van een erfpachtrecht door de opstaller onmogelijk $k^{601}$, terwijl volgens De Jong en Ploeger de opstaller hiertoe wel bevoegd is. ${ }^{602}$ Uit de Toelichting bij het Ontwerp Meijers volgt dat de bevoegdheid van de opstaller een erfpachtrecht te vestigen voortkomt uit het aan de opstaller toekomende eigendomsrecht. ${ }^{603}$ Volgens mij is de opstaller bevoegd een erfpachtrecht te vestigen, voor zover de opstaller niet meer bevoegdheden met de vestiging van het erfpachtrecht aan de erfpachter overgedraagt dan aan de opstaller zelf ingevolge het opstalrecht toekomen.

Uit de wet volgt dat naast de eigenaar ook de opstaller ${ }^{604}$ bevoegd is zijn recht op een gebouw en op de daarbij behorende grond te splitsen in appartementsrechten, wanneer de grondeigenaar hiervoor zijn toestemming heeft gegeven. ${ }^{605}$ Anders dan bij het onderopstalrecht, de erfdienstbaarheid en het erfpachtrecht kan bij splitsing van het opstalrecht in appartementsrechten het opstalrecht niet als meeromvattend recht worden aangemerkt. Het voortbestaan van de appartementsrechten is in beginsel afhankelijk van het voortbestaan van het in appartementsrechten gesplitste opstalrecht. Het appartementsrecht gaat niet teniet wanneer bij het eindigen van het opstalrecht een nieuw opstalrecht wordt gevestigd. ${ }^{606}$

p. 322; Parl. Gesch. Boek 5 (1981), p. 308; Reepmakers 1931, p. 79. Van een erfpachtrecht is geen sprake wanneer het genot van de zaak ontbreekt. Zie: Mon. BW B28 (De Jong/Ploeger), nr. 54. Het genot dient binnen het kader van de bestemming te passen die partijen in de vestigingsovereenkomst aan de onroerende zaak hebben toegekend. De erfpachter is enkel bevoegd de zaak voor andere doeleinden te gebruiken wanneer de eigenaar van de onroerende zaak instemt met wijziging van de bestemming. Zie: art. 5:89 lid 2 BW.

602 Zie: Mon. BW B28 (De Jong/Ploeger), nr. 63. Zie anders: Van Velten 2012, p. 27.

603 Parl. Gesch. Boek 5 (1981), p. 300.

604 Het is evenwel mogelijk een erfpachtrecht of meerdere zakelijke rechten gezamenlijk, bijvoorbeeld een opstal- èn een erfpachtrecht, in appartementsrechten te splitsen. Het splitsen van meerdere zakelijke rechten in appartementsrechten wordt in de literatuur aangeduid als een 'meerzijdige splitsing'.

605 Art. 5:106 lid 1 BW jo. 5:106 lid 7 BW. Weigert de grondeigenaar zonder redelijke grond toestemming te geven of zich te verklaren, dan kan de opstaller de kantonrechter om een machtiging verzoeken waarmee de vereiste toestemming van de grondeigenaar wordt vervangen. Zie: Asser/Mijnssen, Van Velten \& Bartels* 2008, nr. 248; Pitlo/Reehuis \& Heisterkamp 2012, Goederenrecht, nr. 712; Venemans 1997, p. 46.

606 Art. 5:143 lid 1 sub a BW. Door het vestigen van een nieuw opstalrecht blijven de op de appartementsrechten gevestigde rechten, zoals het recht van hypotheek, voortbestaan. Zie: Asser/Van Mierlo \& Van Velten 3-VI* 2010, nr. 276. 


\section{\$4.6.3 Het opstalrecht in relatie tot het recht van hypotheek}

Het recht van hypotheek is een beperkt recht, strekkende om op de daaraan onderworpen registergoederen een vordering tot voldoening van een geldsom bij voorrang boven andere schuldeisers te verhalen. ${ }^{607}$ Een zelfstandig recht van opstal kan worden aangemerkt als een registergoed en is dan ook vatbaar voor bezwaring met een recht van hypotheek. ${ }^{608}$ Een afhankelijk opstalrecht kan daarentegen niet, separaat van het recht waaraan het opstalrecht accessoir is, met een recht van hypotheek worden bezwaard. ${ }^{609}$

Wanneer het recht van opstal eindigt, eindigt in beginsel ook het recht van hypotheek dat op het opstalrecht rust. Gaat het recht van opstal teniet door vermenging of afstand dan komt aan het tenietgaan van het hypotheekrecht 'slechts' relatieve werking toe; het hypotheekrecht herleeft wanneer de hypotheekgever verzuimt aan zijn verplichtingen te voldoen. ${ }^{610} \mathrm{Bij}$ opzegging van het opstalrecht verkrijgt de hypotheekhouder een pandrecht op alle aan de opstaller toekomende en door de opstalgever te verstrekken vorderingen tot vergoeding. ${ }^{611}$

De situatie kan zich voordoen dat een met een opstalrecht te bezwaren recht reeds vóór de vestiging van het opstalrecht met een recht van hypotheek is bezwaard. Bij executie van het hypotheekrecht kan dan een conflictueuze situatie ontstaan tussen de belangen van de hypotheekhouder enerzijds en die van de opstaller anderzijds. ${ }^{612}$ Terwijl de hypotheekhouder bij executie

607 Art. 3:227 jo. 3:228 BW. Zie: Mon. BW B12b (Huijgen), nr. 6.

608 De accessoire relatie tussen het opstalrecht en het op de opstallen rustende eigendomsrecht staat eraan in de weg dat enkel de opstallen met een recht van hypotheek kunnen worden bezwaard. Zie: hoofdstuk $3 \S 4.3 .1$.

609 Een op het hoofdrecht gevestigd hypotheekrecht strekt zich uit over het afhankelijke recht van opstal. Zie: Asser/Van Mierlo \& Van Velten 3-VI* 2010, nr. 275; Ploeger 1997, nr. 209. Een afhankelijk recht is noch voor overdracht noch voor de vestiging van een beperkt recht vatbaar. Zie: hoofdstuk $3 \S 4.1$. Onder het OBW werd het bezwaren van een afhankelijk opstalrecht met een hypotheekrecht ondanks het afhankelijke karakter toch mogelijk geacht, omdat het opstalrecht in de artikelen 759 en 1210 OBW wordt aangemerkt als een recht dat vatbaar is voor hypotheek. Zie: Ploeger 1997, nr. 209. Zie ook: noot Kleyn bij HR 7 maart 1979, NJ 1980, 116; Stein 2004, p. 44.

610 Het staat de hypotheekhouder vrij over te gaan tot executie van zijn hypotheekrecht. Zie: Gerver 2001, pp. 94-95. Zie ook: noot 553.

611 Art. 3:229 BW.

612 Ten gevolge van de executie van het recht van hypotheek komt het opstalrecht te vervallen (art. 3:273 BW) en komt aan de opstaller een bevoorrechte vordering toe op de opbrengst. De hoogte van de vergoeding wordt gesteld op het bedrag van de waarde die het vervallen opstalrecht ten tijde van de executie zou hebben gehad wanneer het opstalrecht in stand zou zijn gebleven (art. 3:282 BW). Zie: Stein 2004, p. 26. 
het later gevestigde zakelijke recht mag negeren ${ }^{613}$ en het hypotheekrecht op de zaak zich uitstrekt over al hetgeen de eigendom van de zaak omvat ${ }^{614}$, komt aan de opstaller krachtens art. 5:105 lid 2 BW in beginsel het recht toe die opstallen weg te nemen die door de opstaller of zijn rechtsvoorganger onverplicht zijn aangebracht of door de opstaller of zijn rechtsvoorganger tegen vergoeding der waarde zijn overgenomen. ${ }^{615}$ Aangezien de hypotheekgever op grond van art. 3:266 BW in beginsel bevoegd is die opstallen weg te nemen die door hem na de vestiging van het hypotheekrecht op of in het grondstuk zijn aangebracht ${ }^{616}$, komt mijns inziens aan de opstaller eveneens de bevoegdheid toe de door hem gerealiseerde opstallen weg te nemen. ${ }^{617}$ De hypotheekhouder heeft bij het verstrekken van de geldlening geen rekening gehouden met de eventuele, na de vestiging aangebrachte opstallen, en hij wordt dan ook niet benadeeld wanneer deze opstallen worden weggenomen. Ten aanzien van de opstallen die reeds ten tijde van de vestiging van het hypotheekrecht met het grondstuk zijn verenigd, bestaat de bevoegdheid tot wegname mijn inziens niet ook al zijn deze opstallen aan de opstalgever in waarde vergoed. De hypotheekhouder mag erop vertrouwen dat de bouwwerken die zich ten tijde van de vestiging van het hypotheekrecht op het grondstuk bevinden, voor uitwinning in aanmerking komen.

Uit bovenstaande kan worden geconcludeerd dat hoewel de hypotheekhouder op grond van het prioriteitsbeginsel het opstalrecht mag negeren, de opstaller krachtens het aan hem toekomende wegneemrecht bevoegd is de opstallen weg te nemen die door de opstaller of zijn rechtsvoorganger gedurende de uitoefening van zijn recht zijn aangebracht. Ondersteuning van deze conclusie kan worden gevonden in het door de Hoge Raad gewezen 'Christenhusz/Brunsveld'-arrest ${ }^{618}$, waarin de Hoge Raad stelt dat de huurder bevoegd is het aan hem toekomende wegneemrecht ${ }^{619}$

613 Ten aanzien van een en hetzelfde goed kunnen verschillende beperkte rechten worden gevestigd. Wanneer er een conflict ontstaat gaat het oudere recht krachtens het prioriteitsbeginsel voor op het jongere recht. De rangorde van beperkte rechten wordt bepaald door de volgorde van hun ontstaan (art. 3:21 lid 1 BW). Zie: Pitlo/Reehuis \& Heisterkamp 2012, Goederenrecht, nrs. 64-65; Ploeger 1997, nr. 189.

614 Art. 3:227 lid 2 BW.

615 Hoofdstuk $3 \$ 4.5$.

$616 \mathrm{Bij}$ het recht de opstallen te mogen wegnemen dienen een tweetal kanttekeningen te worden gemaakt. Ten eerste kan het wegneemrecht in de vestigingsovereenkomst worden uitgesloten. Ten tweede bestaat dit wegneemrecht enkel voor zover op de hypotheekgever niet de verplichting rust de opstallen mede tot onderpand van de vordering te doen strekken.

617 Pitlo/Reehuis \& Heisterkamp 2012, Goederenrecht, nr. 866.

618 HR 2 juni 1989, NJ 1990, 253.

619 Art. 7:216 BW. 
te effectueren ondanks het feit dat dit recht is ontstaan nà de vestiging van het hypotheekrecht en de huurovereenkomst in strijd met het in de hypotheekakte opgenomen huurbeding tot stand is gekomen.

\section{§4.6.4 Verhuur en verpachting van het opstalrecht}

De opstaller is bevoegd de met het opstalrecht bezwaarde zaak ${ }^{620}$ te verhuren $^{621}$ of te verpachten ${ }^{622}$, althans voor zover in de vestigingsovereenkomst niet anders is bepaald. ${ }^{623}$ Partijen kunnen in de vestigingsovereenkomst opnemen dat verhuur of verpachting van de met het opstalrecht bezwaarde zaak door de opstaller enkel is toegestaan wanneer de opstalgever hiervoor zijn toestemming geeft. Bij het in strijd handelen met deze bepaling is de opstalgever niet gehouden tot voortzetting van de huurrespectievelijk de pachtovereenkomst bij beëindiging van het opstalrecht.

De eigenaar ${ }^{624}$ van de met het opstalrecht bezwaarde onroerende zaak zal de opstaller bij beëindiging van het opstalrecht in beginsel opvolgen in de hoedanigheid van verhuurder respectievelijk verpachter, wanneer de overeengekomen huur- of pachtovereenkomst na beëindiging van het opstalrecht voortduurt. ${ }^{625}$ Art. 5:94 lid 2 BW noemt een tweetal omstandigheden waaronder de opvolgend verhuurder respectievelijk verpachter voortzetting van de bestaande overeenkomst kan weigeren: 1) wanneer de tijdsduur van de overeenkomst langer is dan met het plaatselijk gebruik overeenstemt, of 2) verhuur respectievelijk verpachting geschiedt onder ongewone bezwarende omstandigheden. De opvolgend verhuurder dan wel verpachter dient de overeenkomst voort te zetten, maar is daarbij enkel gebonden aan een normale duur en normale omstandigheden; hij is niet gebonden aan het ongebruikelijke deel van de duur of de ongebruikelijke omstandigheden. ${ }^{626}$

620 Parl. Gesch. Boek 5 (1981), p. 318. Verhuur respectievelijk verpachting van het opstalrecht is niet mogelijk.

621 Art. 5:101 lid 2 jo. 7:201 BW.

622 Art. 5:101 lid 2 jo. 7:311 BW. Pacht komt uitvoerig aan bod in: Rodrigues Lopes 2007 en Asser/Snijders 7-III* 2009.

623 Uit art. 5:104 lid 2 BW volgt dat art. 5:94 BW enkel van overeenkomstige toepassing is op zelfstandige opstalrechten. Of de gerechtigde tot een afhankelijk opstalrecht bevoegd is tot verhuur of verpachting, dient te worden beantwoord aan de hand van het hoofdrecht waaraan het opstalrecht accessoir is. Zie: Rossel 2007, p. 48.

624 Of de gerechtigde tot het meeromvattende recht waaruit het opstalrecht is afgeleid.

625 Art. 5:104 lid 2 BW jo. 5:94 lid 2 BW.

626 HR 25 november 2005, NJ 2006, 338. De opvolgend verhuurder respectievelijk verpachter dient zich binnen de door de huurder of pachter gestelde redelijke 
Hoofdstuk 3

termijn uit te spreken over de voortzetting van de overeenkomst ten aanzien van de ongewone duur en de ongewone, bezwarende omstandigheden zoals in de overeenkomst opgenomen. Zie: art. 5:94 lid 3 BW. Laat de opvolgend verhuurder of verpachter dit na dan is hij evenwel gebonden aan het ongebruikelijke deel van de duur of de ongebruikelijke omstandigheden. Zie: Rossel 2007, pp. 49-52. 


\title{
Hoofdstuk 4. Natrekking en doorbreking van de natrekking naar Belgisch recht
}

\author{
§1. Inleiding
}

\section{Onroerende zaken}

Het Belgisch Burgerlijk Wetboek (verder: BBW) onderscheidt onroerende zaken in zaken die uit hun aard onroerend zijn en zaken die door hun bestemming onroerend zijn. ${ }^{627}$ "Onroerend uit hun aard zijn gronderven alsmede de gebouwen waarmee moeten worden gelijkgesteld de voorwerpen die duurzaam en gewoonlijk ermee verbonden zijn of erin vastzitten". ${ }^{628}$ Het vereiste van duurzaam en gewoonlijk verbonden zijn met het gronderf staat er niet aan in de weg dat een object dat zich beperkt functioneel kan voortbewegen ${ }^{629}$ aan te merken is als onroerend uit zijn aard. Objecten die op een zodanige wijze met het gronderf zijn verenigd dat zij geacht worden duurzaam en gewoonlijk met het gronderf verbonden te zijn, vormen een juridische eenheid met het gronderf. Ten gevolge van deze juridische eenheidsvorming gaat de eigendom van het gronderf de eigendom van de geïncorporeerde objecten bevatten, waardoor deze objecten als bestanddeel van het gronderf kunnen worden aangemerkt. ${ }^{630}$

Uit hun aard roerende objecten kunnen als onroerend worden aangemerkt omwille van de relatie die zij met een onroerende zaak hebben; zij zijn op grond van hun bestemming onroerend. Hierbij kan een onderscheid worden gemaakt tussen zaken die tot doel hebben de uit haar aard onroerende zaak te dienen en zaken die dienen ter verfraaiing van de uit haar aard onroerende zaak. Zaken die door hun bestemming onroerend zijn, zijn niet als bestanddeel maar als bijzaak van de onroerende zaak aan te merken; zij behouden hun eigen goederenrechtelijke identiteit. ${ }^{631}$ Volledigheidshalve dient te worden opgemerkt dat objecten die onder het Nederlands BW van 1838 konden worden aangemerkt als onroerend door bestemming niet met de term 'bijzaak', maar met de term 'hulpzaak' werden aangeduid. ${ }^{632}$

\footnotetext{
$627 \quad$ Art. 517 BBW. Zie: hoofdstuk 4 \$2.1.

628 Cass. 15 september 1988, T.B.B.R. 1990, 211. Zie: art. 518 BBW jo. 525 lid 1 BBW.

629 Cass. 14 februari 2008, R.W. 2008-09, 458; hof Gent 11 januari 2011, T.F.R. $2011 / 42,607$.

$630 \quad$ Hoofdstuk 4 \$2.2.1.

631 Hoofdstuk $4 \$ 2.2 .2$.

632 Hoofdstuk 3 \$2.1 - noot 349 .
} 
Het op een gronderf rustend eigendomsrecht geeft recht op al wat door het gronderf wordt voortgebracht en op hetgeen met het gronderf wordt verenigd. Dit recht wordt aangeduid als 'het recht van natrekking' ${ }^{633}$ In de literatuur bestaat discussie over het karakter van het recht van natrekking: is het een recht of dient de natrekking te worden gezien als een feitelijke situatie waaraan rechtsgevolgen worden verbonden? ${ }^{634}$ Ingevolge het recht van natrekking komt aan de eigenaar van de grond de eigendom van de met het gronderf geïncorporeerde objecten toe. ${ }^{635}$ Uit deze tot voordeel van de grondeigenaar strekkende eigendomstoekenning kunnen een tweetal vermoedens worden afgeleid: 1) de objecten die met het gronderf zijn geïncorporeerd zijn door de grondeigenaar op eigen kosten aangebracht en 2) de objecten behoren toe aan de eigenaar van het gronderf. ${ }^{636}$ Wordt aangetoond dat de objecten door een ander zijn gefinancierd, dan kan de grondeigenaar afhankelijk van de omstandigheden van het geval afbraak van deze objecten vorderen. Besluit de grondeigenaar de aangebrachte objecten te behouden dan rust op de grondeigenaar in beginsel de verplichting de in eigendom verkregen opstallen te vergoeden. ${ }^{637}$ Wanneer kan worden aangetoond dat het duurzaam en gewoonlijk met het gronderf verenigde object aan een ander dan de grondeigenaar toebehoort, kan worden gesteld dat de natrekking door het ontstaan van een recht van opstal is doorbroken. ${ }^{638}$

\section{Het recht van opstal}

Iedere doorbreking van de natrekking leidt tot de vestiging van een recht van opstal. Ten gevolge van de vestiging van het beperkt zakelijke recht van opstal komt aan de gerechtigde tot het opstalrecht, de opstaller, het recht toe gebouwen, werken en beplantingen te hebben op een gronderf dat toebehoort aan een ander. De objecten ten gunste waarvan het opstalrecht is gevestigd, de opstallen, komen volgens de heersende leer aan de opstaller in eigendom toe. ${ }^{639}$ In de literatuur bestaat zowel discussie over de vraag of het mogelijk is een opstalrecht te vestigen ten gunste van een verdieping van een gebouw ${ }^{640}$ als over de vraag of andere uit hun aard onroerende objecten dan een gronderf met een recht van opstal kunnen worden bezwaard. ${ }^{641}$

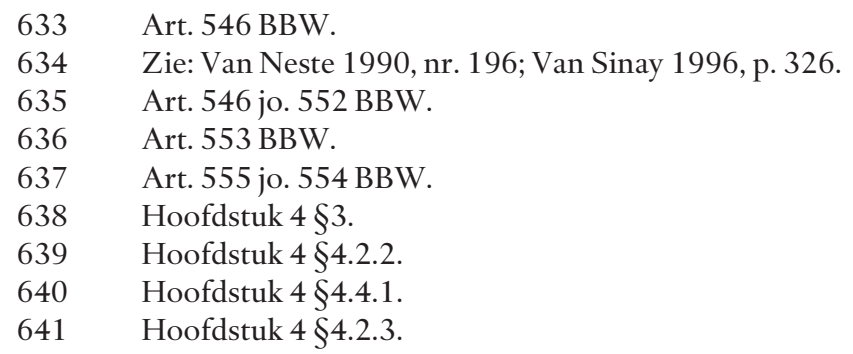


Opstalrechten kunnen worden onderscheiden in zelfstandige en accessoire opstalrechten. Een zelfstandig opstalrecht is een vermogensrecht dat, in tegenstelling tot een afhankelijk opstalrecht, zelfstandig overdraagbaar is. Een accessoir opstalrecht kenmerkt zich door zijn afhankelijke relatie met het recht, het hoofdrecht, waaraan het accessoir is. Terwijl de wettelijke bepalingen omtrent het zelfstandige opstalrecht zijn neergelegd in de Wet over het recht van Opstal van 24 januari 1824 (verder: Opstalwet), wordt het accessoire opstalrecht nader ingevuld door de rechtsregels die van toepassing zijn op het hoofdrecht. ${ }^{642}$ Een opstalrecht kan zowel aan de beperkte rechten van erfpacht, vruchtgebruik en erfdienstbaarheid als aan een huur-, samenlevings- of huwelijksovereenkomst accessoir zijn ${ }^{643}$

Wanneer in de vestigingsovereenkomst niet anders is overeengekomen, staat het de opstaller van een zelfstandig opstalrecht vrij, zijn opstalrecht te vervreemden, te bezwaren en te verhuren. ${ }^{644}$ De opstaller kan bevoegd zijn de opstallen separaat van het opstalrecht te bezwaren en/of te verhuren. De relatie tussen het opstalrecht en de opstallen ten gunste waarvan het opstalrecht is gevestigd is dan ook 'beperkt accessoir' van aard. ${ }^{645}$ De gerechtigde tot een accessoir opstalrecht is niet bevoegd zijn opstalrecht separaat van het hoofdrecht te vervreemden; de accessoire relatie tussen het hoofdrecht en het opstalrecht staat hieraan in de weg. Bezwaring en verhuring van de opstallen is daarentegen in beginsel wel mogelijk.

De Opstalwet is, met uitzondering van de bepaling omtrent de maximale vestigingsduur ${ }^{646}$, aanvullend van aard. Of aan de opstaller het recht toekomt de opstallen ten gunste waarvan het opstalrecht is gevestigd weg te nemen, kan doorgaans aan de hand van hetgeen partijen in de vestigingsovereenkomst hebben opgenomen worden bepaald. Zwijgt de vestigingsovereenkomst dan wordt aangenomen dat de door de opstaller ten tijde van het opstalrecht aangebrachte objecten mogen worden weggenomen evenals de objecten die gedurende de vestiging van het opstalrecht reeds op het gronderf aanwezig waren en in waarde aan de grondeigenaar zijn vergoed ${ }^{647}$

$642 \quad$ Hoofdstuk 4 \$4.1.

643 Hoofdstuk 4 \$ 4.5 .

$644 \quad$ Hoofdstuk 4 \$4.4.1.

645 Hoofdstuk 4 \$4.4.2.

646 Hoofdstuk $4 \$ 4.2 .4$.

647 Hoofdstuk 4 \$ 4.6 . 


\section{$\S 2$. De onroerend goed classificaties}

\section{$\S 2.1$ Zaken en goederen}

In de literatuur worden aan de term 'zaak' verschillende betekenissen toegekend. Ten eerste kan de term 'zaak' worden gebezigd voor al hetgeen bestaat met uitzondering van de mens. Binnen deze context zijn hemellichamen, huizen, dieren en rechten aan te merken als zaken. ${ }^{648}$ Zaken die van nut zijn voor de samenleving en door de mens kunnen worden toegeëigend, worden aangeduid met de term 'goed'. Een goed is een vermogensbestanddeel en kan zowel lichamelijk als onlichamelijk van aard zijn. Een goed dat lichamelijk van aard is, wordt eveneens aangeduid met de term 'zaak'. ${ }^{649}$ Om verwarring te voorkomen wordt de term 'zaak' in het hierna volgende louter in deze beperkte context gebezigd. ${ }^{650}$

Naast het onderscheid lichamelijke en onlichamelijke goederen, kunnen goederen worden onderscheiden in roerende en onroerende goederen. ${ }^{651}$ Goederen kunnen uit hun aard, door vervroegde roerendmaking ${ }^{652}$ of door wetsbepaling ${ }^{653}$ als roerend worden aangemerkt. Goederen die uit hun

$648 \quad K$ Kluyskens 1940, nr. 1: "Door zaken (les choses) verstaat men alles wat in de natuur bestaat, de mensch alleen uitgezonderd, terwijl men slechts goederen noemt de zaken die vatbaar zijn voor privaat of openbaar bezit, anders gezegd de zaken die de mensch of een rechtspersoon zich, bij uitsluiting van alle anderen, toeëigenen kan, alles dus wat een voorwerp van recht kan uitmaken". Zie ook: De Corte \& de Groote 2005, nr. 502.

649 Het eigendomsrecht wordt eveneens als 'zaak' gekwalificeerd. Zie: Delva 1982, p. 98; Kluyskens 1940, nr. 2; Van Neste 1990, nr. 16A.

650 Hoewel een zaak in beginsel lichamelijk van aard is, brengt dit lichamelijkheidsvereiste niet met zich dat een object tastbaar dient te zijn. Ook objecten die op andere zintuiglijke wijze waarneembaar zijn, kunnen als zaak worden aangemerkt. Zo kan men gas (mogelijkerwijs) ruiken en is elektriciteit met het oog waarneembaar, aldus Dekkers en Dirix. Zie: Dekkers/Dirix 2005, nr. 16; Van Neste 1990, nr. 70.

651 Art. 516 BBW. Of een onlichamelijk goed als roerend dan wel als onroerend dient te worden gekwalificeerd is afhankelijk van de aard van het object waar het goed betrekking op heeft. Terwijl bij zakelijke rechten en rechtsvorderingen deze kwalificatie eenvoudig kan worden bepaald aan de hand van het object waarop het zakelijke recht of de rechtsvordering betrekking heeft, is dit bij een schuldvordering niet mogelijk. Bij een schuldvordering is sprake van een vordering van de ene persoon op de andere persoon waarbij het voorwerp van recht een verschuldigde prestatie betreft die bestaat uit een verplichting iets te doen of te laten. Zie: Dekkers/Dirix 2005, nrs. 46-54. Van Neste stelt dat het wenselijk is de roerend respectievelijk onroerend-kwalificatie enkel ten aanzien van lichamelijke zaken te maken. Zie: Van Neste 1990, nr. 22.

652 Hoofdstuk 4 §2.2.1.

653 Art. 527 jo. 529 BBW. Verbintenissen en vorderingen die opeisbare geld- 
aard roerend zijn, zijn zaken die uit eigener beweging of door toedoen van anderen verplaatsbaar zijn. ${ }^{654}$ Dit verplaatsbaarheidscriterium is echter niet sluitend. Ten eerste is het Belgische recht bekend met een tweetal rechtsficties waarbij de kwalificatie die aan een zaak wordt toegekend afwijkt van de aard van de zaak. Een zaak die van nature roerend is, kan als onroerend worden angemerkt wanneer de zaak bestemd is de onroerende zaak te dienen of te verfraaien. Deze zaken zijn krachtens hun bestemming onroerend. ${ }^{655}$ Tevens kan een van nature onroerende zaak als roerend worden aangemerkt ingevolge vervroegde roerendmaking. ${ }^{656} \mathrm{Bij}$ vervroegde roerendmaking worden objecten die uit hun aard onroerend zijn reeds vóór de feitelijke afscheiding van het gronderf op grond van een tussen partijen gesloten overeenkomst aangemerkt als roerend. ${ }^{657}$ Ten tweede leidt ook de ruime invulling van het incorporatie-criterium, het criterium waaraan dient te worden getoetst of een object al dan niet uit zijn aard onroerend is, ertoe dat bepaalde beweegbare objecten geacht worden onroerend uit hun aard te zijn. ${ }^{658}$

Onroerende goederen kunnen worden onderscheiden in zaken die uit hun aard onroerend zijn, zaken die uit hun aard roerend zijn maar ten gevolge van hun bestemming als onroerend kunnen worden aangemerkt en goederen die door het voorwerp waarop zij betrekking hebben onroerend zijn. ${ }^{659}$ In de navolgende paragraaf wordt nader ingegaan op zaken die uit hun aard ${ }^{660}$ of ingevolge hun bestemming als onroerend kunnen worden aangemerkt. ${ }^{661}$

654 Danau, Dom \& Roodhooft 2010, nr. 15. Het BBW kent (uiteraard) geen limitatieve opsomming van zaken die uit hun aard roerend zijn. De in de artt. 531 en 532 BBW gegeven opsomming ziet op roerende zaken waarbij het roerend karakter mogelijkerwijs in twijfel zou kunnen worden getrokken. Zie: Vandenberghe 2005, nr. 88.

655 Zo is een tractor die wordt gebruikt ter exploitatie van het erf onroerend door bestemming. Zie: Tilleman 2005, nr. 12. In hoofdstuk 4 \$2.2.2 wordt ingegaan op zaken die op grond van hun bestemming onroerend zijn.

656 Hoofdstuk 4 \$2.2.1.

657 De Corte \& de Groote 2005, nr. 533.

658 Zo kan een op een gronderf bewegende havenkraan worden aangemerkt als onroerend. Zie: hoofdstuk 4 §2.2.1.

659 Art. 526 BBW. Onroerende zakelijke rechten zijn alle vermogensrechten die als onroerend kunnen worden gekwalificeerd door het voorwerp waarop zij betrekking hebben. Zie: Danau, Dom \& Roodhooft 2010, nr. 17; Van Neste 1990, nrs. 65-68.

660 Hoofdstuk 4 \$2.2.1.

661 Hoofdstuk 4 \$2.2.2. 


\section{$\S 2.2$ Onroerende goederen}

\section{\$2.2.1 Onroerend uit zijn aard}

Het BBW is niet bekend met een definitie aan de hand waarvan kan worden bepaald of een object al dan niet onroerend uit zijn aard is. Wel geeft het BBW een niet-limitatieve opsomming van objecten die geacht worden onroerend te zijn. Gronderven en gebouwen ${ }^{662}$, wind- en watermolens die op palen staan en van het gebouw deel uitmaken ${ }^{663}$, wortelvaste veldvruchten en onafgeplukte boomvruchten ${ }^{664}$, schaarbossen en hoogstammige bomen ${ }^{665}$ alsook de buizen dienende voor de waterleiding in een huis of op een ander erf ${ }^{666}$ worden door het BBW aangemerkt als onroerend uit hun aard. ${ }^{667}$ Deze objecten hebben alle met elkaar gemeen dat zij op een zodanige wijze met het gronderf ${ }^{668}$ zijn verbonden dat zij geacht worden onroerend uit hun aard te zijn. Een uit zijn aard onroerend object vormt een juridische eenheid met het gronderf en wordt in beginsel met het gronderf in eigendom nagetrokken. Anders gezegd: de eigendom van het gronderf strekt zich uit over het met het gronderf verenigde object. ${ }^{669}$

Niet iedere verbinding tussen object en gronderf leidt tot een onroerendkwalificatie van het object. De vereiste mate van vereniging is afhankelijk van

662 Art. 518 BBW. Ook tunnels, putten, dijken, bruggen e.d. zijn 'gebouwen' in de zin van art. $518 \mathrm{BBW}$ wanneer zij met de grond zijn geïncorporeerd. Het is dan ook wenselijk niet de term 'gebouw', maar de term 'bouwwerk' te bezigen. Zie: Dekkers/Dirix 2005, nr. 28; Van Neste 1990, nr. 43; De Page \& Dekkers 1975, nrs. 602-603; Sagaert, Tilleman \& Verbeke 2010, nr. 42; Vandenberghe 2005, nr. 32 .

663 Art. 519 BBW.

664 Art. 520 BBW.

665 Art. $521 \mathrm{BBW}$.

666 Art. 523 BBW.

667 Hoewel het BBW een uitgebreide regeling omtrent waterbronnen (art. 641 e.v. BBW) en waterlopen (art. 644 e.v. BBW) bevat, ontbreekt een regeling ten aanzien van grondwater. In de literatuur wordt aangenomen dat het water dat zich in de bovenlagen van de ondergrond bevindt krachtens natrekking (art. 546 jo. $551 \mathrm{BBW}$ ) aan de grondeigenaar toebehoort. Het water wordt niet met de grond nagetrokken wanneer het water niet door de grond wordt 'vastgehouden' maar stroomt. Het water wordt dan als 'res nullius' aangemerkt. Zie: Dekkers/Dirix 2005, nr. 197; Goedertier 1953-1954, p. 1659.

668 Een gronderf is een begrensd deel van het aardoppervlak waartoe ook de zich daaronder bevindende aardlagen behoren. Zie: Kokelenberg 2009a, p. 343; Van Neste 1990, nr. 40. Het BBW is niet consistent in de terminologie die gebruikt wordt voor het aanduiden van een gronderf. Terwijl in art. $518 \mathrm{BBW}$ de term 'gronderf' wordt gebezigd, worden in de artikelen 522, 524 en 525 BBW de termen 'grond' en 'erf gebruikt.

669 Hoofdstuk $4 \S 3$. 
het 'soort' object dat met het gronderf is verbonden. Beplantingen kunnen als onroerend worden aangemerkt wanneer sprake is van een wortelvaste verbinding met het gronderf ${ }^{670}$, terwijl delfstoffen onroerend zijn wanneer en voor zolang zij deel uitmaken van de ondergrond. ${ }^{671} \mathrm{Bij}$ beplantingen en delfstoffen wordt de vereiste wijze van vereniging met het gronderf louter objectief ingevuld. Aan het karakteriseren van een bouwwerk als onroerend uit zijn aard ligt een meer subjectieve benadering ten grondslag.

Aan de hand van het incorporatie-criterium dient te worden bepaald of een bouwwerk al dan niet als onroerend kan worden aangemerkt. De inhoud van het incorporatie-criterium heeft de afgelopen decennia in de literatuur veelvuldig ter discussie gestaan. Volgens De Page en Dekkers voldoet aan het incorporatie-criterium "tout ouvrage d'art fixé au sol, de telle sorte qu'il ne puisse être déplacé ou retiré sans détérioration”. ${ }^{672}$ Van schade is sprake wanneer wegname of verplaatsing van het bouwwerk aanleiding geeft tot herstellingswerken. ${ }^{673}$ Met het arrest van 15 september $1988^{674}$ kent het Hof van Cassatie aan het incorporatie-criterium een ruimere invulling toe. ${ }^{675}$ Doorslaggevend is niet langer het bestaan van een hechte materiële verbinding, maar of het bouwwerk duurzaam en gewoonlijk met het gronderf, direct dan wel middels een bouwwerk ${ }^{676}$, is verbonden

670 Dekkers/Dirix 2005, nr. 27; Sagaert, Tilleman \& Verbeke 2010, nr. 47.

671 Vandenberghe 2005, nr. 48.

672 De Page \& Dekkers 1975, nr. 640.

673 Art. 518 jo. 525 lid 1 BBW. Zie: hof Gent 17 mei 1966, Rev. Fisc. 1967, 322.

674 Cass. 15 september 1988, T.B.B.R. 1990, 211. De rechtsvraag in onderhavig arrest ziet op het al dan niet karakteriseren van een installatie bestaande uit boven de grond aanwezige benzinepompen en een onder de grond gelegen opslagtank als onroerend. Deze benzinepompen zijn met bouten aan de grond bevestigd en kunnen na het losdraaien van deze bouten zonder beschadiging worden verwijderd. De tank is in de grond ingegraven en kan zonder schade worden weggenomen.

675 Deze verruiming van het incorporatie-criterium staat niet op zichzelf, maar komt voort uit de technologische ontwikkelingen van de bouwtechniek. Deze ontwikkelingen maken het mogelijk bouwwerken te construeren die, ondanks het feit dat ze duurzaam en gewoonlijk met het gronderf zijn verbonden, zonder schade van het gronderf kunnen worden afgescheiden. Zie: Tilleman 2005, nr. 9.

676 Een object kan zowel op directe als op indirecte met het gronderf worden verenigd. Bij indirecte vereniging wordt het object door middel van een bouwwerk met het gronderf verenging. "Dat overeenkomstig artikel 523 [BBW] onroerend uit hun aard worden geacht, alle zaken die éen geheel vormen met het gebouw, die men kan beschouwen als onderdeel van een bepaald gebouw; ...”, aldus het hof van Antwerpen. Zie: hof Antwerpen 2 juni 1994, Bull. Bel. 1996, 1090. Het Hof van Cassatie stelt: “... de onroerende slaat op alle delen van het gebouw, alle apparaten of onderdelen die daarmee een geheel vormen en gelet op de bestemming ervan normaal noodzakelijk zijn om er een volledig en voltooid bouwwerk van te 
of erin vastzit. ${ }^{677}$ De bestemming van het bouwwerk om duurzaam en gewoonlijk ter plaatse te blijven kan volgen uit het bestaan van een hechte materiële verbinding tussen gronderf en bouwwerk, maar kan eveneens uit andere omstandigheden worden afgeleid. Zo kan een op een gronderf rustend bouwwerk waarbij de aanwezigheid van een fundering ontbreekt als onroerend worden bestempeld wanneer uit de omstandigheden van het geval blijkt, bijvoorbeeld doordat bij het bouwwerk een tuin en terras zijn aangelegd en het bouwwerk aangesloten is op alle nutsvoorzieningen, dat het bouwwerk bestemd is duurzaam ter plaatse te blijven. ${ }^{678}$ De oorspronkelijke aan het incorporatie-criterium toegekende invulling ${ }^{679}$, wordt dan ook niet terzijde geschoven, maar is vervat in de door het Hof van Cassatie gegeven ruimere invulling. ${ }^{600}$ Ten gevolge van deze ruimere invulling zullen

677 Met deze ruimere invulling van het incorporatie-criterium sluit het Hof van Cassatie aan bij de in het publiekrecht gehanteerde definitie voor 'bouwen' zoals gebezigd in art. 44 van de Stedenbouwwet (deze wet is in 1999 omgezet in het Decreet Ruimtelijke Ordening waar de voornoemde definitie is opgenomen in artikel 99). Uit deze definitie volgt dat uit de wijze waarop het object met het gronderf is verbonden, dient te volgen dat het bouwwerk "bestemd is om ter plaatse te blijven staan". In de literatuur heeft de nodige discussie bestaan over de vraag of de publiekrechtelijke invulling van het begrip 'bouwen' kan worden gebruikt voor het privaatrechtelijke begrip 'gebouwen' zoals in art. $518 \mathrm{BBW}$ gebezigd. Zie: Tilleman 2005, nr. 10.

678 In 1988 is het hof van Bergen nog van mening dat stacaravans roerend van aard zijn. Het hof stoelt haar mening op een tweetal argumenten. Ten eerste kunnen stacaravans zonder beschadiging worden verplaatst en ten tweede is de verkoop van stacaravans niet onderworpen aan de registratierechten zoals bij onroerende goederen gebruikelijk is. Zie: hof Bergen 27 juli 1988, Bull. Bel. 1989, 2171. Zie ook: hof Gent 17 mei 1966, Rev. Fisc. 1967, 322. In 2000 stelt het hof van Gent: "Stacaravans die bedoeld zijn om gedurende meerdere jaren te blijven staan op percelen die afgebakend zijn met afsluiting of haag, geplaatst zijn op stutten of betondallen, dikwijls omgeven van platen in PVC of hout en waarvan ongeveer $85 \%$ met terras, vertonen alle kenmerken van onroerende goederen uit hun aard, mede gelet op het feit dat ze aangesloten zijn op alle nutsvoorzieningen en geschikt zijn om de gebruikers voortdurend onderdak te verlenen". Zie: hof Gent 16 maart 2000, T.F.R. 2000, 650. Uit het arrest van het hof van Luik 13 november 1990, Rec. gén. enr. not. 1991, nr. 24050 volgt dat de huidige prefabtechnieken er niet aan in de weg staan dat deze gebouwen, die in zijn geheel of in aparte elementen kunnen worden getransporteerd, aan te merken zijn als onroerend. Zie ook: Tilleman 2005, nr. 9; Sagaert, Tilleman \& Verbeke 2010, nr. 44.

679 Zoals in art. 525 lid 1 BBW omschreven.

680 Sagaert, Tilleman \& Verbeke 2010, nr. 44. Zie ook: Sagaert 2008-2009b, p. 458. 
objecten die met een gronderf zijn verbonden eerder als onroerend worden aangemerkt.

Onder het Nederlandse recht wordt een over de kadastrale grens heen gebouwd gedeelte van een bouwwerk -de overbouw- geacht met het bouwwerk in eigendom na te trekken wanneer de overbouw als bestanddeel van het bouwwerk kan worden aangemerkt. ${ }^{681}$ Onder het Belgische recht prevaleert de eenheid van overbouw en bouwwerk daarentegen niet boven de eenheid van overbouw en gronderf. De overbouw wordt in beginsel met het gronderf nagetrokken waarmee het duurzaam en gewoonlijk is verbonden. Door het vestigen van een erfdienstbaarheid van steun verkrijgt de gerechtigde tot het bouwwerk waarmee de overbouw is verenigd, het recht deze overbouw op het gronderf van een ander te hebben. ${ }^{682}$ Het gronderf waarop de overbouw rust kan als dienend erf worden aangemerkt, het gronderf waarop het bouwwerk rust als heersend erf. Op grond van deze erfdienstbaarheid kan de gerechtigde tot de erfdienstbaarheid zich mogelijkerwijs beroepen op een aan de erfdienstbaarheid accessoir opstalrecht ten gevolge waarvan hij als eigenaar van de overbouw kan worden aangemerkt. ${ }^{683}$

In het arrest van 2008 oordeelt het Hof van Cassatie dat ook bouwwerken die zich ten opzichte van het gronderf beperkt functioneel kunnen voortbewegen aan het incorporatie-criterium kunnen voldoen: "De beperkte functionele bewegingen van een voorwerp dat duurzaam op een bepaalde plaats blijft, en aldaar verbonden is met de grond, ontnemen aan dat voorwerp niet zijn aard van onroerend goed". ${ }^{684}$ De casus in het gewezen arrest ziet op een havenkraan die over rails verplaatsbaar is ten behoeve van het laden en lossen van vrachtschepen. ${ }^{655}$ In het 'rolkraan'-arrest van 2011 volgt het Gentse hof van beroep voornoemde uitspraak van het Hof van Cassatie door te stellen dat "de rolkranen in kwestie bestemd zijn om ter plaatse te blijven op de kade en

681 Art. 5:20 lid 1 sub e BW. Zie: hoofdstuk 3 \$3.

682 Blockx, Lens \& Wynant 2006, p. 170.

683 Het accessoire opstalrecht komt nader aan bod in $\$ 4.5$ van dit hoofdstuk.

684 Cass. 14 februari 2008, R.W. 2008-09, 456. In 2002 overweegt het hof van Antwerpen, 5 februari 2002, T.F.R. 2002, 890, nog anders: "Dat het feit dat hun werking [KH: de werking van de rolkranen] effectief geschiedt door middel van met de grond verbonden spoorstaven, niet van aard is te stellen dat deze kranen zelf met de grond duurzaam zijn verbonden, dat bovendien uit hun werking zelf blijkt dat zij effectief bestemd zijn om verplaatsingen uit te voeren, en zodoende geenszins met de grond zijn verbonden en zeker niet erin gewoonlijk vastzitten".

685 Kokelenberg stelt ten aanzien van dit arrest terecht de vraag: "Moeten we dan vermoeden dat het Hof van Cassatie gemeend heeft dat er relevante maatschappelijke wijzigingen zijn opgetreden die meebrengen dat men zich niet aan de aldus geïnterpreteerde teksten kan houden omdat dit anders tot onbillijkheid zou leiden of meebrengen dat de wet haar doel mist? Is dat onwenselijke resultaat dan dat de fiscus in een aantal gevallen inkomsten zou missen?”. Zie: Kokelenberg 2009a, p. 342. 
zich op die kade slechts voor de noden van hun functie beperkt bewegen”, waarmee de rolkranen dus "duurzaam en gewoonlijk verbonden zijn met de grond en te beschouwen zijn als onroerend uit hun aard" ${ }^{686}$ Volgens Sagaert heeft het Hof van Cassatie een onderscheid willen maken tussen de beweegbaarheid van de zaak enerzijds en de verplaatsbaarheid anderzijds, maar heeft het Hof nagelaten de vraag te beantwoorden wat de reikwijdte is van het 'beperkt functioneel bewegen' van zaken. ${ }^{687}$ Anders geformuleerd: wanneer gaat de beweegbaarheid van een zaak over in de verplaatsbaarheid van een zaak?

Een zaak die zich kenmerkt door zijn verplaatsbaarheid is in beginsel roerend van aard. ${ }^{688}$ Een verplaatsbare zaak is beweegbaar, maar een beweegbaar object is niet per definitie een verplaatsbare zaak. Met de term 'beweegbaar' wordt niet gedoeld op de mogelijkheid het object van het gronderf af te scheiden ${ }^{689}$, maar op de functionele beweegbaarheid van het object zelf. Een object is functioneel beweegbaar wanneer het object deze beweegbaarheid 'nodig heeft' voor de uitoefening van zijn functie. ${ }^{690}$ Het functioneel beweegbaar zijn van een object staat een onroerend-kwalificatie niet in de weg, mits het object bestemd is duurzaam ter plaatse te blijven. ${ }^{691}$

Een uit zijn aard onroerend object zal als roerend worden aangemerkt wanneer niet langer aan het incorporatie-criterium wordt voldaan. ${ }^{692}$ Hiervan zal in beginsel sprake zijn wanneer het object fysiek van het gronderf wordt afgescheiden. ${ }^{693}$ Een object kan ook zonder fysieke afscheiding als roerend worden aangemerkt wanneer het object voorwerp uitmaakt van een rechtshandeling die tot doel heeft het nog niet van het gronderf afgescheiden object in eigendom te doen overgaan aan een ander. ${ }^{694}$ Op grond van deze rechtshandeling vindt een afzonderlijke behandeling van het object, los van het gronderf, plaats. Hierdoor kunnen de vruchten aan een boom, de grondstoffen die zich in de grond bevinden en de bouwmaterialen die worden gewonnen uit een op het gronderf bevindend bouwwerk in eigendom worden overgedragen, zonder dat afscheiding van

$686 \quad$ Hof Gent 11 januari 2011, T.F.R. 2011, 603.

687 Sagaert 2008-2009b, pp. 456-459. Zie ook: Sagaert 2008-2009a, p. 23.

688 Art. 528 BBW.

689 Immers is het mogelijk, al dan niet met gebruik van hulpmiddelen, ieder willekeurig object van een gronderf af te scheiden.

$690 \quad$ Kokelenberg 2009a, p. 345.

691 Hof Gent 19 december 2006, T.F.R. 2007, 324. Zie ook: Apers 2011, p. 607.

692 Art. 532 BBW.

693 Tenzij de bouwwerken "slechts gedeeltelijk en tijdelijk worden losgemaakt, bijvoorbeeld met het oog op herstelling, om nadien opnieuw verankerd te worden in het gebouw of de grond of er blijvend aan verbonden te worden, ..."; zij verliezen hun onroerend karakter dan niet. Zie: Sagaert, Tilleman \& Verbeke 2010, nr. 46; Vandenberghe 2005, nr. 42.

694 Vandenberghe 2005, nr. 101. 
het gronderf heeft plaatsgevonden. Deze constructie wordt aangemerkt met de term 'vervroegde roerendmaking' ${ }^{695}$ Objecten die voorwerp zijn van een rechtshandeling die ziet op vervroegde roerendmaking, strekken niet tot verhaal van de hypothecaire schuldeisers; zij kunnen hun verhaalsrechten uitoefenen op de koopprijs. ${ }^{696}$

\section{$\S 2.2 .2$ Onroerend door bestemming}

Zaken die uit hun aard roerend zijn ${ }^{697}$ kunnen omwille van de relatie die ze met een onroerende zaak hebben, worden aangemerkt als onroerend door bestemming. Deze zaken zijn bestemd om de onroerende zaak te dienen ${ }^{698}$ of te verfraaien ${ }^{699}$ en kunnen als bijzaak van de onroerende zaak worden aangemerkt. De rechtvaardiging voor het kwalificeren van een van nature roerende zaak als onroerend is gelegen in waardebehoud; aan de zaken samen komt een hogere economische waarde toe dan de waarde van ieder der zaken apart bezien. ${ }^{700}$ Een bijzaak is bestemd de hoofdzaak in haar rechtstoestand en rechtsovergang te volgen krachtens het accessorium sequitur principale-beginsel. Bij verkoop van het gronderf rust op de vervreemder in beginsel de verplichting om bij overdracht van het gronderf ook de tot het gronderf behorende bijzaken mee over te dragen. ${ }^{701}$ Een op de hoofdzaak gevestigd recht van hypotheek ${ }^{702}$ of beperkt zakelijk gebruiksrecht strekt zich uit over de bijzaken. ${ }^{703}$

Een roerende zaak wordt niet enkel op grond van haar relatie met het gronderf onroerend. De roerende zaak dient door de eigenaar te worden 'omgezet ${ }^{\text {' } 04}$ in een onroerende zaak. Omzetting is enkel mogelijk wanneer

695 Of met de term 'roerend door anticipatie'. Zie: Danau, Dom \& Roodhooft 2010, nr. 19; Kluyskens 1940, nr. 12; Van Neste 1990, nrs. 80-82.

696 Art. 45 lid 3 Hypotheekwet (verder: Hyp.W.). Zie: Sagaert, Tilleman \& Verbeke 2010, nr. 57.

697 Art. 528 BBW.

698 Art. 524 BBW.

699 Art. 525 leden $2 \mathrm{t} / \mathrm{m} 4$ BBW.

700 "De waardevermindering is geen criterium, het is de grondslag voor de redenering dat goederen die samen een waardevol economisch geheel vormen doch juridisch een verschillend statuut hebben, via fictie best juridisch aan dezelfde regels onderworpen worden en als een geheel beschouwd worden ...", aldus Kokelenberg, Van Sinay \& Vuye 1989, p. 1696. Zie ook: Dekkers/Dirix 2005, nr. 33; Kluyskens 1940, nr. 22; Sagaert, Tilleman \& Verbeke 2010, nr. 48.

701 Art. 1615 BBW.

702 Art. 45 lid 2 Hyp.W.

703 De Corte \& de Groote 2005, nr. 522; Delva 1982, p. 100; Van Neste 1990, nr. 61.

704 In de literatuur wordt ook wel gesproken van 'immobilisatie'. 
zowel de onroerende als de roerende zaak aan dezelfde persoon toekomen ${ }^{705}$ èn de intentie van de eigenaar om de roerende zaak met de onroerende zaak te verbinden ${ }^{706}$ objectief naar buiten toe kenbaar is. ${ }^{707}$ De wijze waarop de intentie kenbaar dient te zijn, is afhankelijk van de rol die de roerende zaak in relatie tot de onroerende zaak vervult, waarbij een onderscheid kan worden gemaakt tussen roerende zaken die ten dienste staan van de onroerende zaak en roerende zaken die dienen ter verfraaiing van de onroerende zaak.

Een zaak ${ }^{708}$ die ten dienste staat van een onroerende zaak dient voor de onroerende zaak van nut te zijn. ${ }^{709}$ Het bestaan van deze op nut gebaseerde ideële relatie dient voor derden uit de feitelijke omstandigheden afleidbaar te zijn. ${ }^{710}$ Art. 524 BBW geeft een niet-limitatieve opsomming van objecten die geacht worden onroerend door bestemming te zijn. ${ }^{711} \mathrm{Zo}$ is de vrachtwagen

705 Art. 522, 524 lid 1 en 525 lid 1 BBW. Volgens de heersende leer is een beperkt gerechtigde of huurder niet in staat om een roerende zaak in een onroerende zaak om te zetten. Ook de opstaller, aan wie de eigendom van een opstal toekomt op grond van een ten gunste van hem gevestigd opstalrecht, is niet in staat een roerende zaak om te zetten in een bijzaak. "Een blote eigenaar die tevens huurder is van de vruchtgebruiker kan de bijzaak niet onroerend maken", aldus Vandenberghe 2005, nr. 53. Zie ook: hof Gent 22 oktober 1958, R.W. 19561960, 1951; rb. Leuven 16 februari 1982, T.Not. 1982, 143; Sagaert 2011 2012, p. 178. Anders: Kluyskens 1940, nr. 14: “... dat de regel der immobilisatie door bestemming, tijdelijk ten minste, toepasselijk is op de voorwerpen die de vruchtgebruiker voor den dienst en de exploitatie van het erf daarop plaats heeft.... De vruchtgebruiker ... heeft eigenlijk het recht om van het goed evenals de eigenaar te genieten, zoodat ze zoolang dat genot duurt wat de toepassing van artikel 524 en 525 met den eigenaar dienen gelijkgesteld te worden". Het is niet vereist dat de eigenaar zelf beide zaken exploiteert. Exploitatie kan eveneens geschieden door een beperkt gerechtigde of een huurder zonder dat de bijzaak weer roerend wordt. Zie: Tilleman 2005, nrs. 13-14.

706 Deze verbinding bestaat anders dan bij een zaak die naar zijn aard onroerend is niet uit een materiële verbinding die voldoet aan het incorporatie-criterium. Zou dit namelijk wel het geval zijn dan wordt de roerende zaak ten gevolge van de verbinding niet onroerend naar bestemming, maar onroerend uit zijn aard.

707 Zie: Dekkers/Dirix 2005, nr. 38; Kokelenberg, Van Sinay \& Vuye 1989, nr. 4; Van Neste 1990, nr. 50B; Vandenberghe 2005, nr. 54.

708 Verbruikbare zaken en grondstoffen die in een productieproces worden ingebracht, kunnen niet als onroerend worden gekwalificeerd. Zie: Van Neste 1990, nr. 51A.

709 Het is niet vereist dat de zaak, zoals onder het Franse recht het geval is, noodzakelijk is voor de exploitatie van het gronderf. Voldoende is dat de zaak van nut is voor het gronderf. Zie: Cass. 11 september 1980, R.W. 1980-1981, 1663; rb. Bergen 22 maart 1989, T.B.B.R. 1990, 331. Omzetting vindt niet plaats wanneer de roerende zaak enkel van nut is voor de persoonlijke doeleinden van de eigenaar van de onroerende zaak. Zie: Sagaert, Tilleman \& Verbeke 2010, nr. 49.

710 De Corte \& de Groote 2005, nr. 529.

711 Deze opsomming ziet met name op zaken die ten dienste staan van de 
die de op het gronderf vervaardigde gewassen naar een afnemer vervoert onroerend door bestemming. ${ }^{712}$

Bij zaken die dienen ter verfraaiing kan de intentie van de omzetting niet uit het objectieve nut van de roerende zaak worden afgeleid, maar dient de intentie afleidbaar te zijn uit de uitwendige tekenen van de verbinding tussen de roerende en de onroerende zaak. ${ }^{713}$ De leden 2, 3 en 4 van art. 525 BBW geven verschillende voorbeelden van uitwendige tekenen waarbij het vermoeden bestaat dat de eigenaar de intentie heeft de verfraaiende zaak met het gronderf te verbinden. ${ }^{714}$ Spiegels, schilderijen en andere sierraden worden vermoed met de onroerende zaak te zijn verbonden wanneer het houtwerk waarmee de objecten zijn verbonden deel uitmaakt van het beschot. ${ }^{715}$ Beelden die in een opzettelijk daarvoor gemaakte nis worden gezet, worden eveneens vermoed onroerend door bestemming te zijn. ${ }^{716}$

Wanneer de intentie voor de omzetting objectief gezien niet langer waarneembaar is, hetgeen het geval is wanneer de ideële $e^{717}$ of materiële verbinding ophoudt te bestaan of wanneer een van beide zaken aan een ander gaat toebehoren, bijvoorbeeld door afzonderlijke verkoop of gift, komt

exploitatie van landbouw. Ook zaken die ten dienste staan van andere wijzen van exploitatie van de onroerende zaak, kunnen worden aangemerkt als onroerend door bestemming, zoals het meubilair van een school, schouwburg of kerk. Zie: Dekkers/Dirix 2005, nr. 40; Kluyskens 1940, nrs. 13-16; Van Neste 1990, nrs. 56-59. Vandenberghe 2005, nr. 59.

713 Art. 525 leden 2 t/m 4 BBW. Anders dan art. 525 lid 1 BBW doet vermoeden heeft dit lid geen betrekking op zaken die onroerend door bestemming zijn op grond van hun materiële verbinding. Zie: Van Neste 1990, nr. 53C. Art. 525 lid $1 \mathrm{BBW}$ geeft een nadere invulling van het incorporatie-criterium zoals gebezigd vóór het toonaangevende arrest van 15 september 1988 voor het kwalificeren van objecten die onroerend uit hun aard zijn. Zie: Cass. 15 september 1988, T.B.B.R. 1990, 211. Zie ook: De Corte \& de Groote 2005, nr. 529; Van Neste 1990, nr. 53B.

714 De 'omzetting' kan ook blijken uit andere materiële verbindingswijzen. Bij andere materiële verbindingswijzen dan die in art. 525 BBW zijn opgenomen, ontbreekt het bestaan van het wettelijk vermoeden dat de zaak kan worden aangemerkt als onroerend door bestemming. Zie: Van Neste 1990, nr. 53B.

715 Reeds in 1900 oordeelde de rechter dat het zeldzaam is wanden op zulke wijze te bekleden. De leden 2 en 3 van art. 525 BBW dienen ruim te worden uitgelegd: iedere wijze van aankleving waaruit blijkt dat de eigenaar de intentie heeft de roerende zaken blijvend met de onroerende zaak te verbinden, kan onder de werking van de leden 2 en 3 worden geschaard. Zie: hof Brussel 20 juli 1900, Pas. 1901, II, 142.

716 Kluyskens 1940, nrs. 18-19.

717 De ideële verbinding houdt op te bestaan wanneer de onroerende zaak niet langer gebruikt wordt voor de exploitatie van de onroerende zaak waaraan de roerende zaak ten dienste staat. 
aan de 'onroerend door bestemming'-kwalificatie een eind. ${ }^{718}$ Het staat de eigenaar vrij een zaak die ten tijde van de vestiging van het hypotheekrecht als onroerend door bestemming wordt gekwalificeerd gedurende het bestaan van het hypotheekrecht als roerend te benaderen. De eigenaar is in beginsel bevoegd de zaak die ingevolge zijn bestemming onroerend is aan een ander over te dragen. Als hierdoor de waarde van de tot zekerheid strekkende onroerende zaak voor verhaal ontoereikend wordt, staat het de hypotheekhouder vrij terugbetaling van zijn schuldvordering te eisen. ${ }^{719}$

\section{$\S 3$. De relatie tussen het recht van natrekking ${ }^{720}$ en objecten die uit hun aard onroerend zijn}

Objecten die op een zodanige wijze met het gronderf worden verenigd dat zij met het gronderf één lichaam vormen komen in beginsel in eigendom toe aan de eigenaar van het gronderf. ${ }^{721}$ De grondslag voor deze eigendomstoekenning is gelegen in het recht van natrekking dat voortkomt uit het eigendomsrecht dat op het gronderf rust. ${ }^{722} \mathrm{Nu}$ op een gronderf

718 In de literatuur wordt deze omzetting ook wel aangeduid met de term 'desimmobilisatie'. Zie: Dekkers/Dirix 2005, nrs. 32-45; Kluyskens 1940, nr. 22; Van Neste 1990, nrs. 48 en 64.

719 Art. 79 Hyp.W.

720 Zoals in $\$ 1$ van dit hoofdstuk reeds is aangegeven, bestaat er in de literatuur discussie over het karakter van het recht van natrekking. Onduidelijk is of het recht van natrekking zoals in art. $546 \mathrm{BBW}$ geformuleerd als een recht dient te worden beschouwd of dat de natrekking dient te worden gezien als een feitelijke situatie waaraan rechtsgevolgen worden verbonden. Zie: Van Neste 1990, nr. 196; Van Sinay 1996, p. 326.

721 Art. 551 BBW. De reikwijdte van het recht van natrekking is niet beperkt tot objecten die ten gevolge van de vereniging met het gronderf één lichaam vormen. Ook de voortbrengselen die door het gronderf worden voortgebracht, worden ingevolge het recht van natrekking tot de eigendom van het gronderf gerekend. Tot de voortbrengselen behoren vruchten en buitengewone voortbrengselen (art. 547 jo. 582 BBW). Zie: Kluyskens 1940, nr. 119.

722 Art. 546 BBW. Het recht van natrekking raakt de openbare orde niet. Met het recht van natrekking worden enkel die conflicten beslecht die zien op private eigendomsrechten. Zaken die tot het publiek domein behoren zijn uit hun aard of op grond van een overheidsbeslissing tot het nut van eenieder gesteld. Deze zaken zoals openbare wegen en bruggen zijn niet vatbaar voor individuele eigendomsverkrijging en worden dan ook niet met het gronderf in eigendom nagetrokken. Dit betekent echter niet dat alle aan de overheid toebehorende zaken buiten de handel vallen. Aan de overheid kunnen ook zaken toekomen die behoren tot het privaat domein. Deze zaken worden door de overheid op eenzelfde wijze behandeld, ook vanuit goederenrechtelijk oogpunt, als bij particulieren het geval is. Zie: De Corte \& de Groote 2005, nrs. 510-511; Dekkers/Dirix 2005, nrs. 389 en 392c; Derine, Van Neste \& Vandenberghe 1984b, nr. 697; Kokelenberg 2009b, p. 1150. 
slechts één eigendomsrecht rust, dient het met het gronderf verenigde object als bestanddeel van het gronderf te worden aangemerkt. ${ }^{723}$

Vereniging van een object met een gronderf kan zowel op natuurlijke als op kunstmatige wijze geschieden. Bij natuurlijke vereniging is de vereniging een gevolg van het toedoen van de natuur. Het BBW geeft een opsomming van objecten die op een natuurlijke wijze met de hoofdzaak worden verenigd. ${ }^{724}$ Kunstmatige vereniging geschiedt daarentegen door tussenkomst van menselijk handelen. Aan de eigenaar van het gronderf komt een recht van natrekking toe ten aanzien van een op kunstmatige wijze met het gronderf verenigd object, wanneer het object ingevolge het incorporatiecriterium $^{725}$ als onroerend kan worden aangemerkt.

Ingevolge het recht van natrekking kan aan de grondeigenaar de eigendom toekomen van de met het gronderf geïncorporeerde objecten, hetgeen gebaseerd is op een tweetal vermoedens die in art. $553 \mathrm{BBW}$ worden verwoord. Op grond van het eerste vermoeden mag men ervan uitgaan dat de grondeigenaar het met het gronderf geïncorporeerde object op eigen kosten heeft aangebracht. Dit vermoeden kan feitelijk worden weerlegd door het aandragen van bewijs waaruit blijkt dat een derde ${ }^{726}$ op eigen kosten en met eigen materialen het object met het gronderf heeft geïncorporeerd of de grondeigenaar op het aan hem toebehorende gronderf beplantingen of bouwwerken heeft aangebracht die toebehoorden aan een ander. ${ }^{727}$ Met

723 De term 'bijzaak' in art. 546 BBW schept verwarring ten aanzien van objecten die met een onroerende zaak zijn verenigd, omdat de term 'bijzaak' ook wordt gebruikt voor zaken die door hun bestemming onroerend zijn. Mijns inziens verdient het de voorkeur om de met de onroerende zaak geïncorporeerde objecten aan te merken als bestanddeel. Bij vereniging van een object met een gronderf geldt dat het gronderf in beginsel als hoofdzaak dient te worden aangemerkt, nu ook aan het Belgische recht het superficies solo cedit-beginsel ten grondslag ligt. Zie: Van Neste 1990, nr. 194B; De Page 1942, nr. 41.

724 Ten eerste kan een gronderf door aanslijkingen van stromen en rivieren worden uitgebreid (artt. $556 \mathrm{t} / \mathrm{m} 563 \mathrm{BBW}$ ). Ook kan het recht van natrekking zich uitstrekken over dieren die zich op het erf hebben gevestigd (art. 564 BBW, artt. 14 en 90 Veldwetboek) en over schatten die zich in de aardlagen onder het gronderf bevinden (art. 716 BBW). Zie: Kluyskens 1940, nr. 124.

$725 \quad$ Hoofdstuk 4 \$2.2.1.

726 Art. $555 \mathrm{BBW}$ is niet van toepassing wanneer een bijzondere wet het eigendomsconflict tussen grondeigenaar en derde regelt. Zie: Van Neste 1990, nrs. 205 en 213.

727 Art. 554 BBW wordt in zijn reikwijdte beperkt door art. 2279 BBW. Wanneer de grondeigenaar op zijn gronderf objecten aanbrengt ten aanzien waarvan hij als bezitter te goeder trouw kan worden aangemerkt, dan wordt op grond van art. $2279 \mathrm{BBW}$ vermoed dat de bouwer reeds eigenaar van de bouwmaterialen is geworden, nog voordat deze materialen met de grond zijn geïncorporeerd. Dit vermoeden wordt geacht te bestaan wanneer het bezit reëel is, de bouwer de materialen voor zichzelf houdt en het bezit deugdelijk is. Van natrekking is 
het begrip 'derde' in de zin van art. 555 BBW wordt eenieder aangemerkt die onbevoegd is objecten met het gronderf te incorporeren. Heeft een derde op eigen kosten en met eigen materialen het object met het gronderf geïncorporeerd, dan komt aan de eigenaar van het gronderf de keuze toe het geïncorporeerde object ${ }^{728}$ te behouden dan wel de derde te verplichten tot wegname van het object. Wegname dient te geschieden op kosten van de aanbrenger van het object. ${ }^{729}$ De grondeigenaar kan de aanbrenger niet verplichten tot wegname wanneer de aanbrenger kan worden aangemerkt als bezitter te goeder trouw. ${ }^{730} \mathrm{Op}$ de grondeigenaar rust de verplichting tot schadeloosstelling ${ }^{731}$, waarbij aan de grondeigenaar de keuze toekomt de onkosten die bestaan uit de waarde van de materialen en het arbeidsloon ò de door het gronderf geboekte meerwaarde te vergoeden. Wanneer de aanbrenger bezitter te kwader trouw is en de grondeigenaar de keuze heeft gemaakt het geïncorporeerde object te willen behouden, dan rust op de grondeigenaar de verplichting tot vergoeding van de onkosten. Is de

728 Art. 555 BBW ziet niet op verbeterings- of veranderingswerken aan reeds bestaande bouwwerken, maar is enkel van toepassing op aangebrachte bouwwerken en beplantingen. Hoewel bij grensoverschrijdend bouwen het doorgaans het geval is dat een derde met eigen materialen ten dele op de grond van een ander heeft gebouwd, is het onzeker of art. 555 BBW op 'overbouw' situaties van toepassing is. Een tweetal argumenten die worden aangevoerd waarom art. $555 \mathrm{BW}$ niet van toepassing wordt geacht op die situaties waar sprake is van grensoverschrijdend bouwen zijn te vinden in het vonnis van Rechtbank Brugge 8 maart 1999, R.W. 2001-2002, 248: 1) de bouwer heeft op zijn grond gebouwd, maar is bij het bouwen enkel de grenzen van zijn eigendom te buiten gegaan en 2) afbraak kan niet worden gevorderd omdat na afbraak aan de eigenaren van de aangrenzende percelen een beroep op art. 663 BBW toekomt, op grond waarvan de aanbreng van een nieuwe muur op gemene kosten kan worden gevorderd. Zie: Kluyskens 1940, nr. 131; Van Neste 1990, nr. 208; Kokelenberg 2009b, p. 1165.

729 Art. 555 BBW.

730 De goede trouw dient te bestaan op het moment dat het object met het gronderf wordt verenigd.

731 De rechtvaardiging voor deze schadeloosstelling is gelegen in de ongerechtvaardigde verrijking. 
aanbrenger van het met het gronderf verenigde object houder ${ }^{732}$ van het gronderf waarop het object is aangebracht, dan staat het de grondeigenaar vrij afbraak te vorderen van het object dan wel het object te behouden in ruil voor een onkostenvergoeding. ${ }^{733}$

Heeft de grondeigenaar objecten met het aan hem toekomende gronderf geïncorporeerd die vóór de incorporatie aan een derde toebehoorden dan rust op de grondeigenaar de verplichting de waarde van de geïncorporeerde objecten te vergoeden. ${ }^{734}$ De voormalig eigenaar van de geïncorporeerde objecten is niet bevoegd tot wegname van de materialen. ${ }^{735}$

Op grond van het tweede vermoeden mag men ervan uitgaan dat de met het gronderf geïncorporeerde objecten aan de grondeigenaar toebehoren. ${ }^{736}$ Dit vermoeden kan juridisch worden weerlegd door te bewijzen dat de geïncorporeerde zaak aan een ander toebehoort. ${ }^{737} \mathrm{Bij}$ weerlegging van het tweede vermoeden komt de eigendom van de geïncorporeerde zaak toe aan een ander dan de grondeigenaar. Weerlegging leidt dan ook tot doorbreking van de eigendomsnatrekking zonder dat het object feitelijk van het gronderf wordt afgescheiden. Doorbreking van de eigendomsnatrekking leidt telkens tot de vestiging van een recht van opstal. ${ }^{738}$

\section{$\S 4$. Het recht van opstal}

\section{§4.1 Afstand van het recht van natrekking en het ontstaan van het recht van opstal}

Een met een gronderf geïncorporeerd object wordt niet met het gronderf in eigendom nagetrokken wanneer het vermoeden wordt weerlegd dat het object toebehoort aan de eigenaar van het gronderf. ${ }^{739}$ Het vermoeden van eigendom wordt weerlegd wanneer kan worden aangetoond dat de eigenaar van het gronderf afstand heeft gedaan van het aan hem op grond van zijn eigendomsrecht toekomende recht van natrekking. Het doen van afstand

732 Art. 2236 BBW.

733 Bij wet kan van de aan de grondeigenaar geboden keuzemogelijkheid worden afgeweken. Zie: Dekkers/Dirix 2005, nrs. 385-392c; Michiels 2007, p. 215.

734 De grondeigenaar kan worden veroordeeld tot betaling van schadevergoeding.

735 Art. 554 BBW. Degene die de zaak heeft aangebracht, kan worden veroordeeld tot betaling van schadevergoeding indien daarvoor een reden is, bijvoorbeeld doordat de grondeigenaar door de aanbrenging wordt gehinderd in het verhuren of verpachten van het gronderf. Zie: Dekkers/Dirix 2005, nr. 385.

736 Art. 553 BBW.

737 Van Neste 1990, nr. 203.

738 Hoofdstuk $4 \$ 4.1$.

739 Art. 553 BBW. Hoofdstuk 4 §3. 
kan zowel uitdrukkelijk als stilzwijgend geschieden. ${ }^{740}$ Het Hof van Cassatie heeft geoordeeld dat afstand van het recht van natrekking ${ }^{741}$ telkens leidt tot de vestiging van een recht van opstal. ${ }^{742}$ Ten gevolge van de vestiging van een opstalrecht komt op het met het gronderf geïncorporeerde object een 'eigen' eigendomsrecht te rusten, dat toekomt aan de gerechtigde tot het opstalrecht, de opstaller. ${ }^{743}$ De vestiging van een opstalrecht kan niet worden voorkomen door het opmaken van een akte waarin wordt gesteld dat afstand niet leidt tot het ontstaan van een opstalrecht. ${ }^{74}$

Opstalrechten kunnen worden onderscheiden in zelfstandige opstalrechten enerzijds en accessoire opstalrechten anderzijds. ${ }^{75}$ Een zelfstandig opstalrecht is een vermogensrecht dat zelfstandig overdraagbaar is en volgens artikel 4 Opstalwet kan worden gevestigd voor een maximale duur van 50 jaar, behoudens de bevoegdheid het recht te vernieuwen. ${ }^{746}$ De wettelijke bepalingen omtrent het zelfstandige recht van opstal zijn neergelegd in de Opstalwet. ${ }^{747}$ De in deze regeling neergelegde bepalingen zijn met uitzondering van de bepaling over de maximale duur van 50 jaar alle aanvullend van aard. ${ }^{748}$ In deze en volgende paragrafen zal met het gebruik van de term 'opstalrecht' of 'recht van opstal' worden gedoeld op een opstalrecht dat zelfstandig van aard is.

740 Het gedogen van een opstal kan niet als een daad van afstand worden beschouwd. Zie: Van Muylder \& Verstappen 1992, nr. 7; Vandenberghe \& Viaene 2006, p. 47.

741 In de literatuur wordt ook wel gesproken van 'verzaking aan het recht van natrekking'.

742 Cass. 19 mei 1988, R.W. 1988-1989, 572: “De eigenaar van een grond doet, door afstand te doen van de natrekking van de door een derde op de grond opgerichte gebouwen, ten voordele van die derde een recht van opstal ontstaan en blijft alleen eigenaar van het gedeelte van de grond waarop die gebouwen staan". Het recht van opstal kan dan ook als een correctie op de in de artikelen 552 jo. 553 BBW geformuleerde natrekking worden aangemerkt. Zie: Van Oevelen, Van Poucke \& Van de Velde 1989, nr. 24. Afstand van natrekking dient te allen tijde worden gekwalificeerd als een recht van opstal, hetgeen nauw samenhangt met het numerus clausus-beginsel. Zie: Storme 2010-2011, p. 34; Timmermans 2009, p. 41; Sagaert 2005, pp. 1041-1042.

743 Hoofdstuk 4 §3.

744 Sagaert, Tilleman \& Verbeke 2010, nr. 999.

745 Het accessoire opstalrecht komt nader aan bod in hoofdstuk 4 §.

746 In hoofdstuk $4 \$ 4.2 .4$ wordt ingegaan op de duurbeperkingen van zelfstandige opstalrechten. Zie: Storme 2010-2011, pp. 29 en 36; Vandenberghe \& Viaene 2006, p. 35.

747 Tot aan de invoer van het Nederlands Burgerlijk Wetboek van 1838 was de Opstalwet van 1824 eveneens op het Nederlandse grondgebied van toepassing. Zie: hoofdstuk $3 \$ 4.3$.

748 Art. 4 jo. 8 Opstalwet. 
Een accessoir opstalrecht ${ }^{749}$ kenmerkt zich door zijn afhankelijkheid; het bestaansrecht van een accessoir opstalrecht is afhankelijk van het bestaan van het recht, het hoofdrecht, ten behoeve waarvan het opstalrecht is gecreëerd. Rechtshandelingen die ten aanzien van het hoofdrecht worden verricht hebben eveneens betrekking op het accessoire opstalrecht. Wordt het betreffende hoofdrecht overgedragen, bezwaard of beëindigd dan wordt daarmee ook het accessoire opstalrecht overgedragen, bezwaard of beëindigd. De bepalingen van de Opstalwet zijn niet op het accessoire opstalrecht van toepassing. Het accessoire opstalrecht wordt beheerst door de bepalingen van het hoofdrecht waaraan het opstalrecht accessoir is. ${ }^{750}$ Zo kan een aan een erfdienstbaarheid gekoppeld accessoir opstalrecht in tegenstelling tot een zelfstandig opstalrecht eeuwigdurend van aard zijn. ${ }^{751}$

Een recht van opstal kan worden gevestigd bij titel, door verjaring of bij wet $^{752}$. De titel die aan een opstalrecht ten grondslag ligt kan een overeenkomst of een testament ${ }^{753}$ betreffen. $^{754} \mathrm{Op}$ grond van een overeenkomst kan een opstalrecht zowel rechtstreeks als onrechtstreeks worden gevestigd. ${ }^{755} \mathrm{Bij}$ rechtstreekse vestiging wordt de vestiging van het opstalrecht uitdrukkelijk in de vestigingsovereenkomst opgenomen. ${ }^{756}$ De vestiging van een zelfstandig opstalrecht geschiedt rechtstreeks, terwijl accessoire opstalrechten zowel op rechtstreekse als op onrechtstreekse wijze kunnen worden gevestigd. Bij onrechtstreekse vestiging ${ }^{757}$ van een accessoir opstalrecht vloeit het opstalrecht voort uit de tussen partijen

749 Accessoire opstalrechten worden ook wel aangeduid als 'afhankelijke' of 'onzelfstandige opstalrechten'.

$750 \quad$ Hoofdstuk 4 \$4.5.

$751 \quad$ Hoofdstuk 4 §4.5.2.3.

752 Een zelfstandig opstalrecht kan onder andere ontstaan op grond van art. 97 van de Wet van 21 maart 1991 betreffende de hervorming van sommige economische overheidsbedrijven als op grond van art. 15 Wet van 10 maart 1925 elektriciteitsvoorziening. Zie: Sagaert, Tilleman \& Verbeke 2010, nr. 1001; Storme 2010-2011, pp. 44-45.

753 De vestiging van een opstalrecht door middel van een testament dient niet te worden verward met een reeds vóór het openvallen van de erfenis gevestigd recht van opstal. $\mathrm{Nu}$ de vestiging van een opstalrecht door middel van een testament slechts zeer sporadisch voorkomt, zal in dit proefschrift hier niet verder op worden ingegaan. Zie: Deli 1998, nr. 48.

754 Deli 1998, nr. 48; Van Oevelen, Van Poucke \& Van de Velde 1989, nr. 26; Storme 2010-2011, p. 31.

755 Blockx, Lens \& Wynant 2006, p. 78.

756 Voor de rechtstreekse vestiging van een opstalrecht is het niet vereist dat de term 'opstalrecht' of 'recht van opstal' in de vestigingsovereenkomst wordt vermeld.

757 In de literatuur ook wel aangeduid als 'indirecte' vestiging. 
opgemaakte overeenkomst die aan het hoofdrecht ten grondslag ligt. ${ }^{758}$ Ook buiten de partijen gelegen, uitwendige aspecten kunnen van invloed zijn op het ontstaan van een accessoir opstalrecht. Zo kan een aan de erfpachter of huurder toegekende bouwvergunning een accessoir opstalrecht doen ontstaan. ${ }^{759}$

Vestiging van een opstalrecht kan tevens geschieden door middel van verjaring. Hierbij kan een onderscheid worden gemaakt tussen de 10- en 20 -jarige verjaringstermijnen enerzijds en de 30 -jarige verjaringstermijn anderzijds. De 10 - en 20-jarige verjaringstermijnen ${ }^{760}$ treden in wanneer de gebruiker van de onroerende zaak te goeder trouw ${ }^{761}$ is en de gebruiker zich op een wettige titel ${ }^{762}$ kan beroepen. Tevens dient de gebruiker van de onroerende zaak de bevoegdheden die aan een opstaller ${ }^{763}$ toekomen feitelijk te hebben uitgeoefend. ${ }^{764}$ Wanneer de gebruiker niet te goeder trouw is verjaren alle zakelijke rechtsvorderingen ${ }^{765}$ door verloop van 30 jaar. ${ }^{766}$ Het opstalrecht ontstaat op het moment dat de duur van de verjaringstermijn is verstreken. ${ }^{767}$

758 Overeenkomsten die een accessoir opstalrecht kunnen doen ontstaan, kunnen worden onderscheiden in overeenkomsten die aan een derde een gebruiksrecht ten aanzien van het gronderf toekennen enerzijds en in samenlevings- en huwelijksovereenkomsten anderzijds. In $\$ 4.5$ wordt nader op het accessoire opstalrecht ingegaan. Zie: Deli 1998, nr. 52; Kluyskens 1940, nr. 246; Sagaert, Tilleman \& Verbeke 2010, nr. 992.

759 Zie: Blockx, Lens \& Wynant 2006, p. 65; Timmermans 2009, p. 36. Zie ook: rb. Brussel 26 oktober 2001, T.F.R. 2002, 421.

760 Art. 2265 BBW. Het onderscheid tussen de 10- en 20-jarige verjaringstermijn is gelegen in het al dan niet woonachtig zijn van de eigenaar binnen het rechtsgebied van het hof van beroep waar de onroerende zaak is gelegen.

761 De goede trouw dient aanwezig te zijn op het moment van de overdracht. Zie: Van Neste 1990, nr. 185C.

762 Van een wettige titel is sprake wanneer de aan de titel ten grondslag liggende rechtshandeling tot doel heeft de eigendom of het beperkte recht te doen overgaan of te vestigen. Een wettige titel dient werkelijk te bestaan; een putatieve titel volstaat niet. Zie: Van Neste 1990, nr. 185D.

763 Voor de gerechtigde tot een opstalrecht wordt in de Belgische literatuur zowel de term 'opstaller' als 'opstalhouder' gebezigd.

764 Art. 2229 BBW. Zie: Sagaert, Tilleman \& Verbeke 2010, nrs. 665-666 en 1000.

765 Hiertoe behoren alle rechtsvorderingen tot erkenning, wijziging en opheffing van het beperkt zakelijke recht.

766 Art. 2262 BBW. Zie: Dekkers/Dirix 2005, nrs. 1342 e.v.

767 Van Oevelen, Van Poucke \& Van de Velde 1989, nr. 26; Sagaert, Tilleman \& Verbeke 2010, nr. 1000. Zie ook: Vred. Eeklo 19 april 1973, R.W. 1973-1974, 1830. 


\section{§4.2 De karakteristieken van het recht van opstal}

De Opstalwet definieert het recht van opstal als "een zakelijk recht om gebouwen, werken of beplantingen op eens anders grond te hebben" ${ }^{768}$ Uit deze definitie volgt dat een opstalrecht kan bestaan ten gunste van gebouwen, werken of beplantingen die zich op het gronderf van een ander bevinden. ${ }^{769}$ Hierbij dienen een tweetal kanttekeningen te worden gemaakt. Ten eerste kan een opstalrecht eveneens worden gevestigd ten behoeve van een of meerdere opstallen die zich in de grond bevinden. ${ }^{770}$ Hierdoor is het mogelijk ten gunste van een kelder of een ondergrondse parkeergarage een opstalrecht te vestigen. ${ }^{771}$ Ten tweede kan een recht van opstal worden gevestigd ten behoeve van opstallen die op indirecte wijze met het gronderf zijn verenigd. Hierdoor is het mogelijk een opstalrecht te vestigen ten gunste van een zendmast die

768 Art. 1 Opstalwet. Volgens Laurent wordt in artikel 1 Opstalwet niet het opstalrecht gedefinieerd, maar wordt het gevolg van het opstalrecht omschreven: "Ce n'est pas là le véritable droit de superficie, mais du moins la séparation entre le sol et la superficie est consacrée par la loi”. Zie: Laurant 1878 , nr. 410. Op grond van het zakelijke karakter van het opstalrecht komt aan de opstaller een volgrecht, een recht van voorrang en de bevoegdheid toe om bezitsvordering in te stellen. Een recht van opstal kan worden overgedragen en bezwaard en is voor beslag vatbaar. Wil aan het opstalrecht derdenwerking toekomen, dan is inschrijving van het opstalrecht in de registers van de hypotheekbewaarder van het arrondissement waar de onroerende zaak is gelegen noodzakelijk (art. 1 Hyp.W.). Zie: Dekkers/Dirix 2005, nrs. 123-124; Deli 1998, nrs. 12-13; Goeminne 2007, XV.B-37; Van Neste 1990, nr. 32; Van Oevelen, Van Poucke \& Van de Velde 1989, nr. 26.

769 De begrippen 'gebouw' en 'werk' worden in de literatuur doorgaans aangeduid met de term 'bouwwerk'.

770 Uit Cass. 1969, Arr. Cass. 1969-1970, 314 volgt dat: "artikel 552 BW [KH: $B B W]$ niet verhindert dat een persoon eigenaar is van de ondergrond zonder eigenaar te zijn van de bovengrond". Parkeergarages, opslagplaatsen, verkeerstunnels en netwerkinfrastructuren zijn alle objecten die zich in de grond bevinden en ten gunste waarvan een opstalrecht kan worden gevestigd. Hierbij dient de kanttekening te worden gemaakt dat de vestiging van een opstalrecht op een infrastructuur die tot het openbaar domein behoort, enkel mogelijk is "voor zover evenwel een privaat recht van opstal voormelde bestemming [KH: de bestemming tot het gebruik van allen] niet verhindert". Zie ook: Cass. 18 mei 2007, R.W. 2007-08, 736.Zie: Blockx, Lens \& Wynant 2006, p. 67; Derine, Van Neste \& Vandenberghe 1984b, nr. 1019; Van Oevelen 1992, p. 372; Timmermans 2009, pp. 37-38; Sagaert 2008, pp. 11-13.

771 Nu reeds is opgemerkt dat tot een gronderf ook de zich daaronder bevindende aardlagen behoren (noot 668) is het maar zeer de vraag of er eigenlijk wel een onderscheid kan worden gemaakt tussen bouwwerken die zich op of in het gronderf bevinden. Een bouwwerk dat zich in het gronderf bevindt rust ook op grond, namelijk de onder het gronderf bevindende aardlagen. Zie: Muylle 2012, nr. 443. 
middels een bouwwerk met het gronderf is verenigd. ${ }^{72}$ In de literatuur bestaat discussie over de vraag of een recht van opstal enkel kan worden gevestigd op het eigendomsrecht dat op het gronderf rust of dat ook andere zakelijke rechten met een recht van opstal kunnen worden bezwaard. ${ }^{773}$

Het opstalrecht kan worden gevestigd ten gunste van een of meerdere reeds bestaande of nog te verwezenlijken opstallen. ${ }^{.74}$ De ten tijde van de vestiging bestaande opstallen, de zogenoemde 'oude' opstallen, komen aan de opstaller in eigendom toe op het moment dat het opstalrecht wordt gevestigd. Door aan de opstaller de eigendom van deze opstallen toe te kennen, leidt vestiging van een opstalrecht tot doorbreking van het Romeinsrechtelijke superficies solo cedit-beginsel dat aan het Belgische recht ten grondslag ligt. ${ }^{775}$ Ten aanzien van de nog te verwezenlijken opstallen, de zogenoemde 'nieuwe' opstallen, leidt vestiging van het opstalrecht -althans volgens de mij aan de heersende leer toe te kennen uitleg-niet tot doorbreking van de natrekking; de natrekking wordt terzijde geschoven en de opstaller behoudt het eigendomsrecht dat op de opstallen rust. ${ }^{776}$ Door het vestigen van een opstalrecht rusten er in beginsel meerdere eigendomsrechten op één juridische eenheid; de opstallen ten gunste waarvan het opstalrecht is gevestigd trekken niet (langer) met het gronderf in eigendom na. Het doorbreken respectievelijk het buitenspel zetten van de natrekking is 'slechts' tijdelijk van aard ${ }^{777}$, althans wanneer een zelfstandig opstalrecht hieraan ten grondslag ligt. Volgens de Opstalwet kan een zelfstandig opstalrecht voor een maximale duur van 50 jaar worden gevestigd. ${ }^{778}$ Een afhankelijk recht van opstal kan daarentegen wel eeuwigdurend zijn. ${ }^{779}$

772 In de literatuur wordt ook wel van een 'indirecte vereniging' met het gronderf gesproken.

773 Hoofdstuk 4 \$4.2.1.

774 In $§ 4.2 .1$ van dit hoofdstuk wordt ingegaan op de objecten ten gunste waarvan een opstalrecht kan worden gevestigd.

775 Het superficies solo cedit-beginsel komt tot uitdrukking in art. 552 BBW. Zie: hoofdstuk 4 §3.

776 Het op de opstallen rustende eigendomsrecht komt nader aan bod in $\$ 4.2 .2$ van dit hoofdstuk.

777 Zie: Van Muylder \& Verstappen 1992, nr. 10; Storme 2010-2011, pp. 32-33. In $\$ 4.5$ wordt nader ingegaan op het accessoire opstalrecht.

778 Behoudens vernieuwing van het opstalrecht. Art. 4 Opstalwet wordt geacht van openbare orde te zijn en het is dan ook niet mogelijk in tegenstelling tot de andere bepalingen van de Opstalwet hiervan af te wijken. Zie: De Corte \& de Groote 2005, nr. 1498.

779 Hoofdstuk 4 \$4.5. 


\section{\$4.2.1 Objecten ten gunste waarvan een opstalrecht kan worden gevestigd}

Zoals reeds in de voorgaande paragraaf is opgemerkt kan een recht van opstal worden gevestigd ten gunste van gebouwen, werken en beplantingen die ten tijde van de vestiging reeds met het gronderf zijn geïncorporeerd of die gedurende de bestaansduur van het opstalrecht worden verwezenlijkt. ${ }^{780}$ Het is niet noodzakelijk dat het opstalrecht wordt gevestigd ten behoeve van alle op of in het gronderf bevindende objecten. ${ }^{781}$ Partijen kunnen in de vestigingsovereenkomst overeenkomen ten gunste van welke objecten het opstalrecht wordt gevestigd. Vereist is dat aan het betreffende object een zelfstandig bestaan toekomt. Veranderingen, verbouwingen en restauraties kunnen niet separaat van het bouwwerk waaraan voornoemde wijzigingen hebben plaatsgevonden als opstal worden aangemerkt. ${ }^{782}$

Over de vraag of een recht van opstal kan worden gevestigd ten gunste van een bestaand of nog te verwezenlijken gedeelte van een bouwwerk, zoals een verdieping of appartement bestaat discussie. In 2007 diende het hof van beroep te Gent te oordelen of een vijftig jaar voordien opgestelde vestigingsovereenkomst had geleid tot de vestiging van een opstalrecht. Het object ten behoeve waarvan de overeenkomst was opgesteld betrof een zolderkamer die gesitueerd was boven een aan een ander toekomende garage. Deze zolderkamer was door middel van een aan de buitenzijde bevestigde trap bereikbaar en het was dan ook niet noodzakelijk de garage te betreden voor het bereiken van de zolderkamer. Het hof oordeelde in tegenstelling tot de rechtbank ${ }^{783}$ dat de overeenkomst waarmee de eigendom van de zolder aan een derde was overgedragen niet leidde tot de vestiging van een recht van opstal, maar dat de juridische consequenties die aan de overeenkomst waren verbonden aan de hand van de bepalingen van het appartementsrecht dienden te worden vastgesteld. ${ }^{784}$

In 2010 oordeelde de rechtbank van Brugge ten aanzien van een casus die in vergaande mate gelijk is aan de voornoemde 'zolderkamer'-casus, dat de opgestelde overeenkomst eveneens had geleid tot de vestiging van een appartementsrecht. In deze casus verkocht de eigenaar van een gebouw dat uit verschillende verdiepingen bestaat de winkel, de woonvertrekken en de

780 Vandenberghe 2005, nrs. 958-959.

781 Wanneer niet alle op of in het gronderf bevindende objecten als object van het opstalrecht kunnen worden aangemerkt, wordt het opstalrecht aangemerkt als 'onvolledig'. Zie: Derine, Van Neste \& Vandenberghe 1984b, nr. 1024.

782 Zie: Derine, Van Neste \& Vandenberghe 1984b, nr. 1024; Van Muylder \& Verstappen 1992, nr. 21; Sagaert, Tilleman \& Verbeke 2010, nr. 994.

783 Rb. Ieper 18 februari 2005, R.A.B.G. 2006, 756.

784 Hof Gent 25 april 2007, T.App. 2008, 16. 
garage met magazijn. De eigenaar was voornemens de overige verdiepingen van het bouwwerk in eigendom te behouden. ${ }^{785}$

Hoewel de voornoemde uitspraken doen vermoeden dat de eigendom van een verdieping van een bouwwerk enkel kan worden verkregen middels een appartementsrecht ${ }^{786}$, bestaat in de literatuur geen eenduidig antwoord op de vraag of een recht van opstal ten gunste van een verdieping kan worden gevestigd. Bij bespreking van deze rechtsvraag maken Van Muylder en Verstappen een onderscheid tussen de meer klassieke auteurs enerzijds en de meer moderne auteurs anderzijds. ${ }^{787}$

Het argument van de meer klassieke auteurs ${ }^{788}$ voor hun afwijzende stellingname is gelegen in de puur tekstuele uitleg van art. 1 Opstalwet. Volgens de auteurs vereist het recht van opstal een rechtstreekse incorporatie van het object ten gunste waarvan het opstalrecht wordt gevestigd met het gronderf. Volgens deze auteurs kan een recht van opstal dan ook enkel ten gunste van het gehele bouwwerk worden gevestigd, ten gevolge waarvan het gehele gebouw in eigendom aan de opstaller toekomt. $\mathrm{Nu}$ het volgens de heersende leer mogelijk is een recht van opstal te vestigen ten gunste van een bouwwerk dat zich in de grond bevindt ${ }^{789}$, staat buiten kijf dat art. 1 Opstalwet ruim kan worden geïnterpreteerd wanneer dit volgens de verkeersopvatting wenselijk is. Daarbij rijst de vraag waarin een rechtstreekse incorporatie verschilt van een niet-rechtstreekse incorporatie. Het recht van natrekking maakt geen onderscheid tussen bouwwerken die al dan niet op een directe wijze met het gronderf worden geïncorporeerd; een met het bouwwerk geïncorporeerde gevellamp wordt evenals de met het gronderf geïncorporeerde lantaarnpaal met het gronderf in eigendom nagetrokken. Waarom dient bij de doorbreking van de natrekking dan wel een onderscheid tussen directe en indirecte incorporatie te worden gemaakt?

De meer moderne auteurs bevestigen de mogelijkheid een recht van opstal te vestigen op een gronderf ten gunste van een verdieping van een bouwwerk. De verdieping dient dan wel als een zelfstandige eenheid te worden aangemerkt, aldus Timmermans. ${ }^{790}$ Timmermans laat na in te gaan

785 Rb. Brugge 26 mei 2010, T.App. 2010, 28. Zie: Sagaert 2010-2011, pp. 7-8.

786 Aan de appartementseigenaar komen een tweetal rechten toe: 1) het recht op eigendom van een privégedeelte en 2) een recht van mede-eigendom ten aanzien van de voor gemeenschappelijk gebruik bestemde zaken. Deze twee rechten zijn onlosmakelijk met elkaar verbonden. Het Belgische recht is anders dan het Nederlandse rechtsstelsel bekend met een dualistisch systeem. Zie: Timmermans 2008b. Zie ook: noot 569.

787 Van Muylder \& Verstappen 2005, p. 294.

788 Van Muylders en Verstappen verwijzen hierbij naar Carton de Tournai, Mertens de Wilmars en Renard.

789 Hoofdstuk 4 \$4.2.3.

790 Timmermans 2008a, pp. 4-5. Zie ook: Storme 2010-2011, p. 35. 
op dit zelfstandigheidsvereiste. De in art. 1 Opstalwet opgesomde objecten -gebouwen, werken en beplantingen- hebben alle met elkaar gemeen dat zij volgens de verkeersopvatting een eenheid vormen. Ik denk dan ook te kunnen stellen dat een object aan het zelfstandigheidsvereiste voldoet wanneer het betreffende object volgens de verkeersopvatting een zelfstandige eenheid vormt.

\section{\$4.2.2 Het aan de opstaller toekomende eigendomsrecht}

De opstaller verkrijgt de oude opstallen op het moment dat het opstalrecht wordt gevestigd. Doordat volgens de heersende leer aan de opstaller de eigendom van deze opstallen toekomt, leidt vestiging van een opstalrecht tot doorbreking van de natrekking. ${ }^{791}$ Ten aanzien van de nog te verwezenlijken opstallen is er -althans volgens de mij aan de heersende leer toe te kennen uitleg- geen sprake van verkrijging maar van behoud van het op de opstallen rustende eigendomsrecht. De opstallen blijven ondanks het feit dat zij duurzaam en gewoonlijk met het gronderf worden verenigd ten gevolge van de vestiging van het opstalrecht aan de opstaller toebehoren. Vestiging van het opstalrecht leidt ten aanzien van de nieuwe opstallen tot het buitenspel zetten van de natrekking.

Vandenberghe doet een opmerkelijke stellingname ten aanzien van oude opstallen die niet in waarde aan de opstalgever zijn vergoed: "Bij nietbetaling van de bestaande opstallen heeft de opstalhouder ten aanzien daarvan geen beschikkingsrecht in de zin van vervreemding, enkel een genotsrecht, dat hij evenwel kan verhuren of in vruchtgebruik kan geven". 792 Deze stellingname roept een drietal vragen op. Heeft Vandenberghe met deze stellingname willen impliceren dat de opstallen apart van het opstalrecht kunnen worden overgedragen wanneer de gerechtigde tot het opstalrecht een vergoeding betaalt voor de objecten ten gunste waarvan het opstalrecht is gevestigd? Kan het zijn dat Vandenberghe in voornoemde stellingname het opstalrecht met de opstallen vereenzelvigt en het niet vergoeden van de opstallen leidt tot onoverdraagbaarheid van het opstalrecht? Of volgt uit voornoemde stellingname dat bij het niet vergoeden van de opstallen de eigendom van de opstallen ten gunste waarvan het opstalrecht is gevestigd bij de eigenaar van het gronderf blijft liggen?

$\mathrm{Nu}$ de verkregen opstallen accessoir zijn aan het opstalrecht is een separate overdracht van de opstallen niet mogelijk en lijkt het onwaarschijnlijk dat Vandenberghe met zijn stellingname een overdracht van de opstallen -apart

791 Het tweede in art. 553 BBW gegeven vermoeden wordt krachtens de vestiging van het opstalrecht weerlegd. Zie: hoofdstuk $4 \$ 3$.

792 Vandenberghe 2005, nr. 967. 
van het opstalrecht-heeft bedoeld. ${ }^{793}$ Aannemelijker is dat Vandenberghe het opstalrecht met het op de opstallen rustende eigendomsrecht vereenzelvigt, en hij heeft bedoeld dat de opstaller zijn opstalrecht ten gevolge van het niet vergoeden van de opstallen niet kan vervreemden. Hierbij wil ik een tweetal opmerkingen maken. Ten eerste is het niet juist het opstalrecht met (het eigendomsrecht op) de opstallen te vereenzelvigen. Het eigendomsrecht dat op de opstallen komt te rusten is een gevolg van het effectueren van het recht 'een of meerdere opstallen in of op het gronderf van een ander hebben'; een recht dat de opstaller aan het opstalrecht ontleent. Ten aanzien van de oude opstallen ten behoeve waarvan het opstalrecht is gevestigd zal de vestiging direct leiden tot effectuering van het recht. Met de vestiging van het opstalrecht wordt afstand gedaan van het recht van natrekking waardoor met betrekking tot de oude opstallen de eigendomsnatrekking wordt doorbroken en op de opstallen een eigen eigendomsrecht komt te rusten. Is een recht van opstal ten behoeve van nieuwe opstallen gevestigd, en realiseert de opstaller deze opstallen dan behoudt de opstaller de eigendom van de nieuwe opstallen. Het eigendomsrecht dat op de opstallen rust is -ongeacht of het eigendomsrecht op oude of nieuwe opstallen rustaccessoir aan het recht van opstal. ${ }^{794}$ Besluit de opstaller zijn recht om een of meerdere opstallen in of op het gronderf van een ander te hebben niet te effectueren, dan kan van vereenzelviging van het opstalrecht met het eigendomsrecht geen sprake zijn, omdat er simpelweg geen opstal is waarop een eigendomsrecht rust.

Ten tweede kan worden gesteld dat de stellingname niet te mogen beschikken -in de zin van vervreemding- over de niet-vergoede opstallen leidt tot het onvervreemdbaar zijn van het opstalrecht. Tussen het opstalrecht en de opstallen ten gunste waarvan het opstalrecht is gevestigd, bestaat immers een (beperkt) accessoire relatie. Hoewel de overdraagbaarheid van een opstalrecht ingevolge een in de vestigingsovereenkomst opgenomen beding kan worden uitgesloten ${ }^{795}$, is het mijns inziens onwenselijk het al dan niet vergoeden van de opstallen gelijk te stellen aan een onvervreemdbaarheidsbeding. Ten eerste kan dit tot rechtsonzekerheid leiden wanneer partijen omtrent het vergoeden van de opstallen geen beding in de vestigingsovereenkomst hebben opgenomen. Ten tweede is het vergoeden van de opstallen een puur feitelijke handeling waar derden in beginsel niet van op de hoogte hoeven te zijn. Wat als de opstaller bij het ontbreken van een in de vestigingsovereenkomst opgenomen beding

793 Uit §4.4.2 van dit hoofdstuk volgt dat de opstaller in beginsel over de opstallen -apart van het opstalrecht- kan beschikken door de opstallen te bezwaren dan wel te verhuren. Vervreemding van de opstallen is daarentegen niet mogelijk. De relatie tussen opstalrecht en opstallen is dan ook 'beperkt accessoir' van aard.

$794 \quad$ Hoofdstuk 4 \$4.4.2.

795 Hoofdstuk $4 \$ 4.4$. 
de opstallen in waarde aan de opstalgever vergoedt? Of de opstallen ingevolge de vestigingsovereenkomst zouden worden vergoed, maar de opstaller dit heeft nagelaten? Is de opstaller krachtens het voor derden kenbare vergoedingsbeding toch eigenaar geworden, of wordt hij dit pas op het moment van het daadwerkelijk vergoeden van de opstallen? Wanneer partijen overeenkomen dat de oude opstallen niet in waarde worden vergoed en daaraan het rechtsgevolg van onvervreemdbaarheid wensen te koppelen dan is het in het belang van de rechtszekerheid dat dit uitdrukkelijk in de vestigingsovereenkomst wordt opgenomen. Het 'enkel' in de vestigingsovereenkomst opnemen dat de opstallen niet in waarde zullen worden vergoed, kan mijns inziens niet gelijk worden gesteld met een onoverdraagbaarheidsbeding. Immers staat het de opstalgever vrij ook zonder het ontvangen van een vergoeding de opstallen in eigendom aan de opstaller toe te kennen.

De derde vraag ziet op het al dan niet benoemen van de op de oude opstallen rustende bevoegdheden als eigendom wanneer deze opstallen niet in waarde aan de opstalgever zijn vergoed. Mijns inziens kan het niet vergoeden van de opstallen -althans volgens de heersende leer- niet leiden tot het verkrijgen van een 'ander' recht dan een eigendomsrecht. Nu volgens de heersende leer de essentie van het opstalrecht is gelegen in het hebben van (de eigendom van) opstallen die zich in of op het gronderf van een ander bevinden, is het niet aan partijen deze eigendomsverkrijging uit te sluiten. Dit is in strijd met het numerus clausus-beginsel.

Ook de Opstalwet lijkt er niet van uit te gaan dat een ander recht dan het eigendomsrecht op de oude opstallen komt te rusten, ook wanneer deze niet in waarde zijn vergoed. Uit art. 7 Opstalwet volgt dat de grondeigenaar bij beëindiging van het opstalrecht de niet aan hem vergoede opstallen mag terugnemen. Volgens Van Muylder \& Verstappen kan uit deze bepaling worden afgeleid dat de grondeigenaar wederom eigenaar wordt van de opstallen. ${ }^{796}$

Volgens art. 544 BBW komt aan de eigenaar van een zaak het recht toe om op de meest volstrekte wijze van de zaak het genot te hebben en over de zaak te beschikken. ${ }^{797}$ Het eigendomsrecht dat op de opstallen rust kan van voornoemde eigendomsdefinitie sterk afwijken. Ten eerste kunnen krachtens de vestigingsovereenkomst de aan de opstaller ten aanzien van de opstallen toekomende gebruiksbevoegdheden worden ingeperkt. Zo kan de bevoegdheid de opstallen te mogen wegnemen ingevolge de vestigingsovereenkomst worden uitgesloten, ook wanneer de opstallen wèl

796 Van Muylder \& Verstappen 1992, nr. 15.

797 Mits het gebruik van de zaak niet in strijd is met wetten of verordeningen (art. 544 BBW). 
in waarde aan de opstalgever zijn vergoed. Als aan de opstaller daadwerkelijk de eigendom van de opstallen toekomt, dan is de opstaller mijns inziens krachtens het eigendomsrecht gedurende de bestaansduur van het opstalrecht bevoegd de opstallen van het gronderf af te scheiden ongeacht of deze opstallen zijn aan te merken als oude of nieuwe opstallen en ongeacht of de oude opstallen ten gunste waarvan het opstalrecht is gevestigd al dan niet in waarde zijn vergoed. Ook kan in de vestigingsovereenkomst worden overeengekomen dat de opstaller niet bevoegd is bepaalde wijzigingen aan de opstallen aan te brengen, of dat het gebruik van de opstallen dient overeen te stemmen met de in de vestigingsovereenkomst aan de opstallen toegekende bestemming.

Ten tweede is het niet mogelijk de opstallen apart van het opstalrecht te vervreemden, terwijl krachtens het eigendomsrecht van art. $544 \mathrm{BW}$ de eigenaar bevoegd is over de zaak te beschikken zoals het hem goeddunkt. Ten derde is het eigendomsrecht zoals in art. 544 BBW gedefinieerd, eeuwigdurend van aard. ${ }^{798}$ Het eigendomsrecht dat op de opstallen komt te rusten is daarentegen tijdelijk van aard. Dat volgens de heersende leer de tijdelijkheid van het eigendomsrecht niet voortvloeit uit het karakter van het eigendomsrecht dat op de opstallen rust, maar uit de door art. 4 Opstalwet gestelde beperking die dwingendrechtelijk van aard is, doet aan het 'tijdelijk zijn' van het eigendomsrecht dat op de opstallen rust niets af. Krachtens art. 4 Opstalwet kan een opstalrecht voor de maximale termijn van 50 jaar worden gevestigd, behoudens vernieuwing van het recht. Het bestaan van het eigendomsrecht op de opstallen is niet alleen afhankelijk van het bestaan van de opstallen waarop het eigendomsrecht rust, maar ook van het opstalrecht; met het tenietgaan van het opstalrecht gaat het op de opstallen rustende eigendomsrecht eveneens teniet. ${ }^{799}$

Op grond van voornoemde betwijfel ik ten zeerste of de bevoegdheden die ingevolge de vestiging van een opstalrecht op de opstallen (komen te) rusten als eigendom kunnen worden aangemerkt. $\mathrm{Nu}$ de reikwijdte van de op de opstallen rustende bevoegdheden in vergaande mate wordt bepaald door hetgeen partijen in de vestigingsovereenkomst zijn overeenkomen, is het mijns inziens wenselijk het 'hebben' van opstallen op of in het gronderf van

$798 \quad$ Kluyskens 1940, nr. 88: "Eigendom is naar aard een voortdurende recht, maar het is zulks niet naar zijn wezen, altijd en noodzakelijk. Het is inderdaad mogelijk dat het eigendomsrecht tengevolge van de wijze waarop het is verkregen, slechts tijdelijk is... De voornaamste voorbeelden van tijdelijken eigendom zijn: 1 . Het recht van opstal. Dat recht [KH: het opstalrecht] heeft noodzakelijk een tijdelijk karakter .... ." Zie ook: De Page \& Dekkers 1975, nr. 1255 B. In $§ 4.2 .4$ van dit hoofdstuk wordt ingegaan op de duur waarvoor een opstalrecht kan worden gevestigd.

799 Dit is niet anders dan wanneer bijvoorbeeld een gronderf of een fiets teniet gaat. Met het tenietgaan van het gronderf respectievelijk de fiets gaat ook het eigendomsrecht dat op de betreffende zaak rust teniet. 
een ander ${ }^{800}$ niet langer te vertalen met het hebben van de eigendom van de opstallen ten behoeve waarvan het opstalrecht is gevestigd. Partijen kunnen krachtens de vestigingsovereenkomst immers vrijwel iedere wenselijke inhoud aan het 'eigendomsrecht' toekennen. Het verdient dan ook de voorkeur het opstalrecht te benaderen als ieder ander beperkt zakelijk recht. De duurzaam en gewoonlijk met het gronderf verenigde bouwwerken worden met het gronderf in eigendom nagetrokken en de opstaller verkrijgt krachtens de vestiging van het opstalrecht die bevoegdheden die ingevolge de vestigingsovereenkomst aan hem worden toegekend. De aan de opstaller ten aanzien van de opstallen toekomende bevoegdheden kunnen in vergaande mate overeenkomen met de bevoegdheden die uit een eigendomsrecht voortvloeien, maar van eigendom in de zin van art. 544 $\mathrm{BBW}$ is geen sprake. ${ }^{801}$

$\mathrm{Nu}$ op de opstallen mijns inziens geen eigendomsrecht rust, rijst de vraag wat de meerwaarde is van het naast elkaar bestaan van opstalen erfpachtrecht. ${ }^{802}$ Zowel de bevoegdheden van de erfpachter als de aan de opstaller toekomende bevoegdheden kunnen in vergaande mate overeenkomen met de bevoegdheden die aan de eigenaar van de onroerende zaak toekomen. ${ }^{803}$

\section{$\S 4.2 .3$ Goederen waarop een recht van opstal kan worden gevestigd}

Uit de definitie van het opstalrecht ${ }^{804}$ volgt dat het opstalrecht op een gronderf kan worden gevestigd. ${ }^{805}$ In de literatuur bestaat discussie of het recht van opstal eveneens op andere onroerende goederen kan worden gevestigd, waarbij een onderscheid kan worden gemaakt tussen het vestigen van een recht van opstal op onlichamelijke goederen, vermogensrechten, zoals een recht van erfpacht of vruchtgebruik, en onroerende zaken niet zijnde een gronderf.

Volgens verschillende auteurs is het niet mogelijk een opstalrecht te vestigen op andere zakelijke rechten dan het eigendomsrecht dat op een gronderf rust, nu de wettekst van art. 1 Opstalwet de term 'grond' bezigt en dus geen ruimte laat voor een ruime interpretatie. ${ }^{806}$ Sagaert, Tilleman en Verbeke stellen zich op het standpunt dat deze vraag niet aan de hand

800 Art. 1 Opstalwet.

$801 \quad$ Hoofdstuk $6 \$ 4.1 .1$.

802 Art. 1 Wet over het recht van Erfpacht van 10 januari 1824 (verder: Erfpachtwet).

803 Hoofdstuk $4 \$ 4.5 .2 .1$.

804 Art. 1 Opstalwet.

805 Artikel 1 Opstalwet stelt dat het recht van opstal kan worden gevestigd “ ... op eens anders grond".

806 Vandenberghe \& Viaene 2006, p. 44. 
van een $19^{\text {de }}$ eeuwse wettekst dient te worden beantwoord, maar benaderd dient te worden vanuit het nemo plus-beginsel ${ }^{807}$. Nu de aan de erfpachter en de vruchtgebruiker toekomende bevoegdheden zodanig verstrekkend van aard zijn dat deze bevoegdheden in vergaande mate overeenkomen met die van de eigenaar, kan worden verdedigd dat zowel de erfpachter als de vruchtgebruiker binnen de grenzen van het erfpachtrecht respectievelijk vruchtgebruik bevoegd zijn tot het vestigen van een opstalrecht. ${ }^{808}$

De vestiging van een recht van opstal op een onroerende zaak niet zijnde een gronderf is in beginsel enkel mogelijk wanneer aan de zaak een eigen goederenrechtelijke identiteit toekomt. $\mathrm{Nu}$ volgens de heersende leer de opstallen ten behoeve waarvan een opstalrecht is gevestigd met een opstalrecht kunnen worden bezwaard, kan worden gesteld dat ook een onroerende zaak, niet zijnde een gronderf, met een opstalrecht kan worden bezwaard. ${ }^{809}$

\section{§4.2.4 Duur van het opstalrecht}

Volgens art. 4 Opstalwet kan een opstalrecht voor een maximale duur van 50 jaar worden gevestigd, behoudens vernieuwing van het opstalrecht. Wanneer een opstalrecht voor een periode langer dan 50 jaar of voor onbepaalde tijd wordt gevestigd, leidt dit niet tot nietigheid van het opstalrecht, maar wordt de termijn waarvoor het opstalrecht is gevestigd, herleid tot de wettelijke maximumtermijn van 50 jaar. ${ }^{810}$ "De noodzaak van het tijdelijk karakter wordt afgeleid uit de overweging dat een eeuwigdurend opstalrecht erg nadelig kan zijn voor de grondeigenaar". ${ }^{11}$ De Opstalwet geeft geen minimumtermijn waarvoor het opstalrecht dient te worden gevestigd. ${ }^{812}$

807 Ingevolge het nemo-plus-beginsel kan men niet meer rechten aan een ander overdragen dan men zelf bezit.

808 Sagaert, Tilleman \& Verbeke 2010, nr. 994. Zie ook: Deli 1998, nr. 74; Storme 2010-2011, p. 30.

809 Vandenberghe \& Viaene 2006, p. 44. In hoofdstuk 4 \$4.4 wordt nader ingegaan op de rechten waarmee het opstalrecht en de opstallen ten gunste waarvan het opstalrecht is gevestigd, kunnen worden bezwaard.

810 Cass. 15 december 2006, R.W. 2007-2008, 104. Zie: Storme 2010-2011, pp. 36-37.

811 Aldus Derine, Van Neste \& Vandenberghe 1984b, nr. 1021. Zie ook: Blockx, Lens \& Wynant 2006, p. 72; Deli 1998, nr. 33; Van Oevelen, Van Poucke \& Van de Velde 1989, nr. 25. Mijns inziens hoeft de vestiging van een opstalrecht voor en langere periode dan 50 jaar voor de grondeigenaar niet nadelig te zijn wanneer de opstaller periodiek een behoorlijke vergoeding betaalt, dan wel aan de opstalgever de bevoegdheid toekomt het opstalrecht na het verstrijken van een bepaalde periode, bijvoorbeeld na 50 jaar, te mogen beëindigen.

812 Hoewel de wet geen vereiste stelt ten aanzien van de minimumtermijn 
De duur waarvoor een opstalrecht wordt gevestigd, zegt niets over de bestaansduur van het opstalrecht. Enerzijds is het mogelijk het opstalrecht vroegtijdig te beëindigen ${ }^{813}$, terwijl anderzijds de Opstalwet het mogelijk maakt het opstalrecht te vernieuwen. Er worden geen beperkingen gesteld aan het aantal keren dat een opstalrecht kan worden vernieuwd ${ }^{814}$, maar het is volgens de heersende leer niet mogelijk een automatische vernieuwingsclausule in de vestigingsovereenkomst op te nemen. Dit zou in strijd zijn met het tijdelijke karakter van het opstalrecht. ${ }^{815}$ Vernieuwing dient te geschieden vóór beëindiging van de overeengekomen termijn waarvoor het opstalrecht is gevestigd. ${ }^{816}$ Vereist is dat de grondeigenaar beschikkingsbevoegd is het opstalrecht te vernieuwen. Het louter in bezit blijven en het blijven gebruiken van de opstallen doet geen hernieuwing van het opstalrecht ontstaan. ${ }^{817}$ Het is niet noodzakelijk dat de vernieuwing uitdrukkelijk geschiedt. Vernieuwing van het opstalrecht kan eveneens stilzwijgend gebeuren, maar of de vernieuwing nu uitdrukkelijk of stilzwiigend heeft plaatsgevonden, het vernieuwde opstalrecht kan pas aan derden worden tegengeworpen wanneer de vernieuwing in de registers is ingeschreven. ${ }^{818}$

\section{$\S 4.3$ Rechten en plichten van opstaller en grondeigenaar}

Aan opstaller en grondeigenaar komen ten gevolge van het bestaan van het opstalrecht verschillende rechten en plichten toe. De rechten en plichten die voortvloeien uit de Opstalwet zijn niet-limitatief en regelend van aard, hetgeen betekent dat het partijen vrij staat in de vestigingsovereenkomst van de in de Opstalwet opgenomen rechten en plichten af te wijken. Het recht van opstal is een beperkt zakelijk recht ${ }^{819}$ dat ingevolge art. 2 Opstalwet door de opstaller kan worden vervreemd en bezwaard. ${ }^{820}$ Op de opstaller kan de verplichting rusten om bij aanvang van het opstalrecht de opstallen

waarvoor een opstalrecht kan worden gevestigd, is de fiscus wantrouwig ten aanzien van opstalrechten die voor een kortere duur dan 10 jaar zijn gevestigd. Zie: Storme 2010-2011, p. 38.

813 Hoofdstuk 4 §4.6.

814 Blockx, Lens \& Wynant 2006, p. 72.

815 Zie: Deli 1998, nr. 34; Goeminne 2007, XV.B-34.

816 Timmermans stelt: "Wanneer immers de vernieuwing gebeurt na het verstrijken van de eindtermijn, dan zou men kunnen argumenteren dat de gebouwen reeds eigendom geworden zijn van de grondeigenaar ingevolge het recht van natrekking, ...”. Zie: Timmermans 2009, nr. 11.

817 Rb. Gent 30 april 2009, F.J.F. 2010, p. 635.

818 Art. 1 Hyp.W. Zie: Van Muylder \& Verstappen 1992, nr. 10; Storme 20102011, p. 36.

819 Art. 1 Opstalwet.

820 Art. 2 Opstalwet. Zie: hoofdstuk 4 §4.4.1. 
die hij in eigendom verkrijgt aan de grondeigenaar te vergoeden. ${ }^{821}$ Wanneer de opstaller deze opstallen vergoedt, kan hij aan deze vergoeding het recht ontlenen de opstallen weg te nemen zowel gedurende als bij beëindiging van het opstalrecht. ${ }^{822}$ Het staat de opstaller in beginsel vrij de bestemming van de opstallen te bepalen. ${ }^{823}$

Bij de beëindiging van het recht van opstal verkrijgt de grondeigenaar volgens de heersende leer (wederom) de eigendom van de met het gronderf geïncorporeerde opstallen ingevolge het recht van natrekking. ${ }^{824}$ Het vorderen van afbraak van de opstallen die door de opstaller zijn aangebracht is niet mogelijk wanneer partijen dit niet uitdrukkelijk in de vestigingsovereenkomst zijn overeengekomen. De grondeigenaar is doorgaans dan ook verplicht tot overname van de op het gronderf aanwezige opstallen. ${ }^{825}$ De verplichting tot overname ziet niet alleen op het accepteren van de aanwezigheid van de opstallen in of op het gronderf, maar de opstaller dient de opstallen die bij aanvang van het opstalrecht door de opstaller zijn vergoed alsook de opstallen die ten tijde van het opstalrecht door de opstaller zijn verwezenlijkt aan de opstaller in waarde te vergoeden. ${ }^{826}$ Zolang de grondeigenaar verzuimt de opstallen te vergoeden, komt aan de opstaller een retentierecht ten aanzien van deze niet-vergoede opstallen toe. ${ }^{827}$ Ingevolge het retentierecht is de voormalig opstaller bevoegdheid de nog niet-vergoede opstallen onder zich te houden en van deze opstallen gebruik te maken. ${ }^{828}$

Naast de voornoemde rechten en plichten die in de Opstalwet tot uitdrukking komen en waarvan partijen in de vestigingsovereenkomst kunnen afwijken, kunnen aan de opstaller en grondeigenaar ook rechten en plichten toekomen die niet in de Opstalwet hun grondslag vinden. Een gebruiksrecht ten aanzien van het gronderf waarop of waarin de opstallen zijn gelegen is zo'n niet in de Opstalwet opgenomen recht. Het staat de opstaller in beginsel ${ }^{829}$ vrij het gronderf te gebruiken voor zover dit noodzakelijk is voor

821 Art. 5, 6 en 7 Opstalwet.

822 Van Oevelen, Van Poucke \& Van de Velde 1989, nr. 40. Zie: hoofdstuk 4 §4.2.2 en $§ 4.6$.

823 Derine, Van Neste \& Vandenberghe 1984b, nr. 1027.

824 Bracke 2007, p. 553.

825 Danau, Dom \& Roodhooft 2010, p. 184; Delva 1982, p. 128.

826 Deze vergoedingsplicht betreft een schuldvordering uit ongerechtvaardigde verrijking. Wanneer de opstaller de in eigendom verkregen opstallen bij aanvang van het opstalrecht niet heeft vergoed, kan de grondeigenaar deze in beginsel zonder betaling van enige schadeloosstelling terugnemen (art. 7 Opstalwet).

827 Art. 6 Opstalwet.

828 Van Muylder \& Verstappen 1992, nr. 16; Timmermans 2009, p. 42. Zie ook: hoofdstuk $4 \$ 4.6$.

829 Althans voor zover partijen geen andere afspraken omtrent het gebruik van het 
het hebben van het volle genot van de aan hem in eigendom toekomende opstallen. ${ }^{830}$ Daarnaast kunnen op de opstaller een tweetal financiële verplichtingen rusten, die evenals het gebruiksrecht niet in de Opstalwet tot uitdrukking komen. Partijen kunnen ${ }^{831}$ overeenkomen dat de opstaller aan de grondeigenaar een vergoeding, een solarium ${ }^{832}$, betaalt als tegenprestatie voor het verkregen opstalrecht. ${ }^{833}$ Deze vergoeding kan eenmalig of periodiek van aard zijn. ${ }^{83}$ De tweede financiële verplichting die op de opstaller rust, althans voor zover partijen niet anders zijn overeengekomen, is het betalen van de belastingen ten aanzien van het gronderf waarmee de opstallen zijn verenigd alsook ten aanzien van de opstallen ten gunste waarvan het opstalrecht is gevestigd. ${ }^{835}$

Aangenomen wordt dat op de opstaller een herstel- en onderhoudsplicht rust ten aanzien van de op en in het gronderf rustende opstallen die door de opstaller bij vestiging van het opstalrecht niet in waarde zijn vergoed. ${ }^{836}$ Omtrent de reikwijdte van deze herstel- en onderhoudsplicht bestaat enige onduidelijkheid. ${ }^{837}$ Doorgaans gaat men ervan uit dat de erfpachtregeling hierop analoog van toepassing is ${ }^{838}$, op grond waarvan de opstaller verplicht is de niet-vergoede opstallen te onderhouden en daaraan de gewone repaties te verrichten. ${ }^{839}$

\section{$\S 4.4$ Vervreemding, bezwaring en verhuring van het opstalrecht en de in eigendom verkregen opstallen}

De aan de opstaller bij vestiging van het opstalrecht toekomende bevoegdheden kunnen worden gesplitst in bevoegdheden die betrekking hebben op het opstalrecht enerzijds en bevoegdheden die betrekking

gronderf hebben gemaakt. Zie: Verbeke \& Snaet 2007, p. 387.

831 Het staat partijen vrij een recht van opstal te vestigen om niet.

832 In de jurisprudentie wordt deze betalingsverplichting ook wel aangemerkt met de term 'canon'. Zie: hof Gent 12 mei 2005, T.B.B.R. 2007, 541.

833 Deli 1998, nr. 48. Anders dan bij het recht van erfpacht is het overeenkomen van een vergoedingsplicht voor de totstandkoming van het opstalrecht niet vereist, aldus art. 1 lid 1 Erfpachtwet.

834 Goeminne 2007, XV.B-35; Vandenberghe 2005, nr. 960.

835 Blockx, Lens \& Wynant 2006, p. 87; Kluyskens 1940, nr. 248; Storme 20102011, p. 41; Vandenberghe 2005, nr. 975.

836 Blockx, Lens \& Wynant 2006, p. 87; Sagaert, Tilleman \& Verbeke 2010, nr. 1003.

837 Vandenberghe 2005, nr. 974.

838 Van Oevelen, Van Poucke \& Van de Velde 1989, nr. 30; Van Oevelen 1992, p. 361.

839 Art. 5 lid 2 Erfpachtwet. 
hebben op de opstallen anderzijds. ${ }^{840}$ Dat de opstaller zowel ten aanzien van het opstalrecht als ten aanzien van de opstallen -apart van het opstalrechtbeschikkingsbevoegd is, komt tot uitdrukking in art. 2 Opstalwet. Volgens deze bepaling kan het opstalrecht worden vervreemd en bezwaard met een recht van hypotheek en kunnen de opstallen met een erfdienstbaarheid worden bezwaard. Zoals uit de hierna volgende paragrafen zal blijken, is de door art. 2 Opstalwet gegeven opsomming van rechten waarmee het opstalrecht respectievelijk de opstallen kunnen worden bezwaard nietlimitatief. ${ }^{841}$ De mogelijkheid tot vervreemding en bezwaring van een opstalrecht bestaat enkel voor zover het opstalrecht zelfstandig van aard is. Afhankelijke opstalrechten kunnen niet separaat van het hoofdrecht worden vervreemd of bezwaard. Bezwaring van het hoofdrecht waaraan het opstalrecht accessoir is, leidt eveneens tot bezwaring van het opstalrecht. De opstallen ten gunste waarvan het accessoire opstalrecht is gevestigd, kunnen daarentegen wel apart worden bezwaard of verhuurd. ${ }^{842}$

Partijen kunnen de bevoegdheid tot het verrichten van rechtshandelingen in de vestigingsovereenkomst inperken. Zo kunnen partijen overeenkomen dat vervreemding en bezwaring van het opstalrecht enkel is toegestaan wanneer de grondeigenaar hiervoor zijn toestemming verleent. ${ }^{843}$ Een in de vestigingsovereenkomst opgenomen verbod tot het uitoefenen van een bepaalde rechtshandeling ten aanzien van het opstalrecht, is niet van toepassing op de ten aanzien van de opstallen te verrichten rechtshandelingen. Dit geldt vice versa ook voor een in de vestigingsovereenkomst opgenomen bezwarings- of verhuringsverbod ten aanzien van de opstallen. ${ }^{84}$

\section{\$4.4.1 Vervreemding, bezwaring en verhuring van het opstalrecht}

De opstaller is bevoegd, althans voor zover dit in de vestigingsovereenkomst niet is uitgesloten, zijn opstalrecht te vervreemden, te bezwaren en te verhuren. Bij vervreemding van het opstalrecht gaan de opstallen ten gunste waarvan het opstalrecht is gevestigd mee over op de verkrijger. ${ }^{845}$ Naast de bevoegdheid het opstalrecht te bezwaren met een recht van hypotheek ${ }^{846}$,

$840 \quad$ Van Oevelen 1992, pp. 358-359.

$841 \quad$ Hoofdstuk $4 \$ 4.4 .1$ en $\$ 4.4 .2$.

842 Vandenberghe \& Viaene 2006, p. 46.

843 Van Oevelen, Van Poucke \& Van de Velde 1989, nr. 40.

844 Derine, Van Neste \& Vandenberghe 1984b, nr. 1005.

845 Derine, Van Neste \& Vandenberghe 1984b, nr. 1005. De opstaller is 'slechts' bevoegd de opstallen te bezwaren en te verhuren; aan de opstaller komt niet de bevoegdheid toe de opstallen -separaat van het opstalrecht- te vervreemden. De (beperkt) accessoire relatie staat hieraan in de weg. Zie: hoofdstuk 4 \$4.4.2.

846 Art. 2 lid 1 Opstalwet en art. 45 lid 1 Hyp.W. 
is de opstaller eveneens bevoegd zijn opstalrecht te bezwaren met een recht van vruchtgebruik ${ }^{847}$ alsook het opstalrecht te verhuren ${ }^{848} .{ }^{849}$ Onzeker is of een recht van opstal met een erfpachtrecht kan worden bezwaard nu aan de opstaller ten aanzien van de met het opstalrecht bezwaarde onroerende zaak 'slechts' een gebruiksrecht toekomt. ${ }^{850}$ De opstaller is bevoegd een erfdienstbaarheid te vestigen ten gunste als ten laste van de met het opstalrecht belaste onroerende zaak. De erfdienstbaarheid komt daarbij op de belaste onroerende zaak te rusten. ${ }^{851}$

In beginsel kan een opstalrecht enkel voor de duur waarvoor het recht is gevestigd, worden vervreemd, bezwaard of verhuurd. ${ }^{852}$ Wanneer het recht van opstal teniet gaat, gaan in beginsel eveneens de op het opstalrecht rustende beperkt zakelijke en persoonlijke rechten teniet. ${ }^{853}$ Op deze hoofdregel bestaan een tweetal uitzonderingen. Wanneer een recht van opstal teniet gaat ten gevolge van een abnormale, vrijwillige beëindigingswijze, zoals het geval is bij vermenging en afstand, eindigen de op het opstalrecht gevestigde rechten niet. ${ }^{854}$ Gaat het opstalrecht ten gevolge van een vrijwillige gedraging van de opstaller teniet, dan heeft de beëindigingswijze slechts relatieve werking. Hierdoor kan de hypotheekhouder wanneer de opstaller niet aan zijn betalingsverplichting voldoet het opstalrecht uitwinnen. ${ }^{855}$

De tweede uitzondering wordt gemaakt ten behoeve van het recht van hypotheek dat voor een langere periode wordt gevestigd dan de (te verwachten) bestaansduur van het opstalrecht. Wanneer een recht van hypotheek voor een periode van bijvoorbeeld 30 jaar wordt gevestigd, maar het recht van opstal 15 jaar na vestiging van het hypotheekrecht door verloop van tijd eindigt, dan rust het hypotheekrecht niet langer op het opstalrecht

847 Derine, Van Neste \& Vandenberghe 1984b, nr. 1027; Verbeke \& Snaet 2007 , p. 367. In $§ 4.5 .2 .2$ van dit hoofdstuk wordt ingegaan op het recht van vruchtgebruik.

848 Voor huur zie: hoofdstuk 4 \$4.5.2.4.

849 Zie: Blockx, Lens \& Wynant 2006, p. 85; Van Oevelen 1992, p. 360; Sagaert, Tilleman \& Verbeke 2010, nr. 1004.

850 Vandenberghe en Viaene alsook Verbeke en Snaet zijn van mening dat het niet mogelijk is een opstalrecht met een erfpachtrecht te bezwaren. Zie: Vandenberghe \& Viaene 2006, p. 43; Verbeke \& Snaet 2007, p. 379 . Mijns inziens is bezwaring van het opstalrecht met een erfpachtrecht mogelijk wanneer aan de erfpachter ingevolge het gevestigde erfpachtrecht niet meer bevoegdheden worden toegekend dan aan de opstaller krachtens het aan hem toekomende opstalrecht toekomen. Zie ook: Sagaert 2004, p. 246.

851 Art. 2 lid 2 Opstalwet. Zie: Deli 1998, nr. 85; Storme 2010-2011, pp. 38-39.

852 Delva 1973, p. 118.

853 In hoofdstuk $4 \$ 4.6$ wordt ingegaan op de verschillende wijzen waarop een recht van opstal teniet kan gaan.

854 Vandenberghe \& Viaene 2006, p. 54.

855 Sagaert 2003, nr. 629. 
maar vindt zakelijke subrogatie plaats. Ten gevolge van het tenietgaan van het opstalrecht komt het hypotheekrecht te rusten op het aan de opstaller toekomende vergoedingsrecht. ${ }^{856}$ Komt aan de opstaller geen recht op vergoeding toe, bijvoorbeeld omdat hij de opstallen bij aanvang niet heeft vergoed en/of geen opstallen op het gronderf heeft verwezenlijkt, dan gaat het recht van hypotheek met het tenietgaan van het opstalrecht eveneens definitief teniet. ${ }^{85}$

\section{\$4.4.2 Verveemding, bezwaring en verhuring van de opstallen}

Het staat de opstaller vrij de aan hem in eigendom toekomende opstallen te bezwaren en te verhuren. De zakelijke rechten waarmee de opstal wordt bezwaard en de ten aanzien van de opstal overeengekomen huurovereenkomst bestaan in beginsel enkel voor de duur van het opstalrecht. De door de opstaller gevestigde rechten dienen binnen de grenzen van de aan de opstaller toekomende bevoegdheden te worden gevestigd.

Niet iedere opstal ten gunste waarvan het opstalrecht is gevestigd, kan worden bezwaard respectievelijk verhuurd. Ten eerste kan in de vestigingsovereenkomst een beding zijn opgenomen dat aan het bezwaren dan wel het verhuren van de opstal in de weg staat. Ten tweede is het beschikkingsrecht ten aanzien van de opstallen volgens de heersende leer gelimiteerd wanneer de ten tijde van de vestiging bestaande opstallen niet in waarde aan de opstalgever zijn vergoed. De opstaller is volgens de heersende leer ten aanzien van deze niet-vergoede opstallen enkel bevoegd deze te verhuren en in vruchtgebruik te geven. ${ }^{858} \mathrm{Nu}$ het partijen vrij staat in de vestigingsovereenkomst nadere afspraken te maken over de beschikkingsbevoegdheid, hetgeen meebrengt dat partijen kunnen overeenkomen dat de opstaller ook kan beschikken over opstallen die niet door de opstaller zijn vergoed, ben ik van mening dat van een beperking van de beschikkingsbevoegdheid ten aanzien van de in eigendom verkregen opstallen enkel sprake kan zijn voor zover partijen dit in de vestigingsovereenkomst uitdrukkelijk zijn overeengekomen. Immers zal het voor derden doorgaans onduidelijk zijn of de opstallen al dan niet in waarde zijn vergoed. ${ }^{859}$

Wanneer de opstaller niet in zijn beschikkingsbevoegdheid wordt beperkt is de opstaller bevoegd de opstallen te bezwaren met een erfdienstbaarheid ${ }^{860}$,

$856 \quad$ Hoofdstuk $4 \$ 4.6$.

857 Byttebier 2005, nr. 656; Sagaert 2003, nrs. 626-627.

858 Vandenberghe \& Viaene 2006, pp. 44 en 49.

859 Hoofdstuk 4 \$4.2.2.

860 Art. 2 Opstalwet. Een erfdienstbaarheid kan zowel ten gunste als ten laste van 
een recht van vruchtgebruik, een recht van erfpacht ${ }^{861} \mathrm{en}$, maar hier zijn de meningen over verdeeld, met een recht van opstal. Daarnaast komt aan de opstaller de bevoegdheid toe de opstallen te verhuren. ${ }^{862} \mathrm{Nu}$ aan de opstaller de bevoegdheid toekomt de opstallen apart van het opstalrecht te bezwaren en te verhuren kan de relatie tussen het opstalrecht en de ten gevolge van het opstalrecht verkregen opstallen worden aangemerkt als 'beperkt' accessoir.

Zoals opgemerkt zijn de meningen verdeeld over het antwoord op de vraag of een opstal met een opstalrecht kan worden bezwaard. Het antwoord op deze vraag is afhankelijk van de wijze waarop art. 1 Opstalwet door de betreffende auteur wordt geïnterpreteerd. Uit de wettekst van art. 1 Opstalwet volgt dat een recht van opstal enkel kan worden gevestigd op de aan een ander toekomende grond; een ruime interpretatie van het begrip 'grond', als in de zin van onroerende zaak, biedt aan de opstaller de mogelijkheid de aan hem toekomende opstal met een opstalrecht te bezwaren. ${ }^{863}$ Door de vestiging van een opstalrecht op de opstal kan aan de gerechtigde tot het opstalrecht de bevoegdheid toekomen een of meerdere bouwwerken op het bestaande bouwwerk te verwezenlijken. ${ }^{864}$

In de literatuur wordt eveneens betoogd dat de opstallen met een recht van hypotheek ${ }^{865}$ kunnen worden bezwaard. $\mathrm{Nu}$ uitwinning van het

de opstal worden gevestigd Zie: Deli 1998, nr. 85; Van Oevelen 1991, p. 73. In \$4.5.2.3 van dit hoofdstuk wordt ingegaan op de erfdienstbaarheid.

861 Bij de vestiging van een erfpachtrecht op een opstal dient rekening te worden gehouden met de in art. 2 Erfpachtwet opgenomen minimumtermijn van 27 jaar. Met een minimale vestigingsduur van 27 jaar, betekent dit dat ten tijde van de vestiging van het erfpachtrecht de bestaansduur van het opstalrecht volgens de vestigingsovereenkomst van het opstalrecht nog minimaal 27 jaar dient te bedragen. Een erfpachtrecht dat voor een kortere termijn dan voor 27 jaar wordt gevestigd, wordt aangemerkt als huur. Is het erfpachtrecht voor een termijn van 27 jaar of langer gevestigd, maar komt het erfpachtrecht desalniettemin vroegtijdig tot zijn eind, dan wordt het recht alsnog aangemerkt als huur. Zie: Deli 1998, nr. 88; Vandenberghe 2005, nr. 922; Vandenberghe \& Viaene 2006, nr. 32; Verbeke \& Snaet 2007, p. 388.

862 Zie: Derine, Van Neste \& Vandenberghe 1984b, nr. 1027; Kluyskens 1940, nr. 248; Van Oevelen 1991, p. 73; Van Oevelen, Van Poucke \& Van de Velde 1989, nr. 28; Vandenberghe 2005, nr. 970.

863 In $§ 4.2 .3$ van dit hoofdstuk is reeds ingegaan op de wijze waarop het begrip 'grond' zoals in art. 1 Opstalwet gebezigd, dient te worden geïnterpreteerd. Zie: Sagaert 2004, p. 263; Vandenberghe \& Viaene 2006, nr. 35.

864 Of een recht van opstal kan worden gevestigd ten gunste van een nog te realiseren verdieping op een bestaand bouwwerk is onzeker. Zie: hoofdstuk 4 $\S 4.2 .1$.

865 Art. 2 Opstalwet en art. 45bis Hyp.W. Voor het verhypothekeren van opstallen is het niet noodzakelijk dat de opstallen ten tijde van de vestiging van het hypotheekrecht reeds op het gronderf zijn gerealiseerd. Vereist is dat reeds begonnen is met de realisatie van de opstallen dan wel dat de opstallen reeds zijn 
hypotheekrecht door de hypotheekhouder leidt tot doorbreking van de beperkt accessoire relatie tussen het opstalrecht en de opstallen, kan een recht van hypotheek volgens mij enkel worden gevestigd ten aanzien van de opstallen èn het opstalrecht samen.

\section{$\S 4.5$ Het accessoire opstalrecht}

\section{§4.5.1 De karakteristieken van het accessoire opstalrecht}

Een accessoir opstalrecht ${ }^{866}$ wordt beheerst door de regels van het recht, het hoofdrecht, waaraan het opstalrecht accessoir is ${ }^{867}$ Een accessoir opstalrecht kan uitdrukkelijk in de vestigingsovereenkomst van het hoofdrecht worden opgenomen, maar kan eveneens voortvloeien uit de bevoegdheden die aan de gerechtigde krachtens het hoofdrecht toekomen. ${ }^{868}$ Op grond van het accessoire opstalrecht behoudt de gerechtigde tot het hoofdrecht de eigendom ${ }^{869}$ van de opstallen die door de gerechtigde in de uitoefening van zijn hoofdrecht zijn verwezenlijkt. De accessoire relatie tussen het opstalrecht en het hoofdrecht brengt mee dat vervreemding, bezwaring en het tenietgaan van het hoofdrecht eveneens leidt tot vervreemding, bezwaring en het tenietgaan van het opstalrecht. Het opstalrecht kan niet apart van het hoofdrecht worden overgedragen of vervreemd. De opstallen kunnen daarentegen in beginsel wel met een zakelijk recht worden bezwaard, of worden verhuurd. ${ }^{870}$ Hoewel het opstalrecht doorgaans tezamen met het hoofdrecht teniet zal gaan, leidt het tenietgaan van 'enkel' het opstalrecht niet tot het tenietgaan van het hoofdrecht. Het opstalrecht kan accessoir zijn aan het beperkte recht van erfpacht, vruchtgebruik en erfdienstbaarheid als aan een huurovereenkomst en een samenlevings- respectievelijk huwelijksovereenkomst. ${ }^{871}$

Ten aanzien van de samenlevings- en huwelijksovereenkomst wordt aangenomen dat een opstalrecht bestaat dat accessoir is aan de overeen-

ontworpen en de opstaller op grond van zijn opstalrecht het recht verkregen heeft deze opstallen te verwezenlijken. Zie: Van Muylder \& Verstappen 1992, p. 300.

866 In de literatuur wordt eveneens de term 'onzelfstandig opstalrecht' gebezigd.

867 De bepalingen van de Opstalwet zijn dan ook niet van toepassing op het accessoire opstalrecht. Zie: Truyen 2009, nr. 6.

868 Hoofdstuk $4 \$ 4.1$.

869 Hoofdstuk $4 \$ 4.2 .2$.

870 Tenzij de opstallen verkregen zijn ten gevolge van de uitoefening van een opstalrecht dat accessoir is aan een erfdienstbaarheid. Zie: hoofdstuk 4 \$4.5.2.3.

871 Hof Antwerpen 6 maart 2002, NjW 2002, 25. Zie: Dambre 2006, nr. 1050; Goeminne 2007, XV.B-36; Michiels 2007, p. 218; Sagaert 2004, p. 260; Verschelden e.a. 2007, nr. 422 
komst in die gevallen dat een gezamenlijk gefinancierd bouwwerk wordt verwezenlijkt op een gronderf dat enkel aan een van beide partners toebehoort. Ten gevolge van het accessoire opstalrecht wordt de natrekking met het gronderf doorbroken, waardoor beide partners als eigenaar van het door hen beide gefinancierde bouwwerk worden aangemerkt. ${ }^{872}$

\section{§4.5.2 Rechten waaraan een opstalrecht accessoir kan zijn}

\section{\$4.5.2.1 Erfpacht}

Het erfpachtrecht ${ }^{873}$ is een zakelijk recht om het volledige genot te hebben "van een aan een ander toebehorend onroerend goed". ${ }^{74}$ De bevoegdheden die de erfpachter aan zijn erfpachtrecht ontleent komen in vergaande mate overeen met de bevoegdheden die aan de eigenaar inzake zijn eigendomsrecht toekomen. ${ }^{875}$ Zo staat het de erfpachter in beginsel vrij de bestemming van de in erfpacht gegeven onroerende zaak te wijzigen en de onroerende zaak te bezwaren met een erfdienstbaarheid voor de duur van het erfpachtrecht. ${ }^{876}$ Sagaert, Tilleman en Verbeke zijn van mening dat de erfpachter ingevolge de aan hem toekomende bevoegdheden in beginsel bevoegd is tot het vestigen van een recht van vruchtgebruik of opstal voor zover het te vestigen beperkte recht "binnen de grenzen van de aan de erfpachter toegestane bevoegdheden (nl. de duurtijd van de erfpacht) blijft". ${ }^{877}$

872 Door een opstalrecht te koppelen aan een samenlevings- respectievelijk huwelijksovereenkomst wordt voorkomen dat de financierende maar nieteigenaar van het gronderf zijnde partner het door hem of haar ingebrachte kapitaal verliest en daar 'slechts' een schuldvordering voor in de plaats krijgt. Het verdient de voorkeur dat partijen in de overeenkomst een duidelijke vergoedingsregeling opnemen voor het geval de overeenkomst wordt beëindigd. Zie: Gits \& Devos 2007, p. 225; Michiels 2007, p. 255; Van Sinay 1996, nr. 98. In dit proefschrift wordt niet nader ingegaan op opstalrechten die accessoir zijn aan een samenlevings- of huwelijksovereenkomst.

873 Deze bepalingen van de Erfpachtwet zijn met uitzondering van artikel 2, welke ziet op de minimum- en maximumduur waarvoor het erfpachtrecht kan worden gevestigd, aanvullend van aard. Het staat partijen dan ook vrij in de vestigingsovereenkomst van deze aanvullende bepalingen af te wijken. Zie: art. 17 Erfpachtwet.

874 Art. 1 Erfpachtwet.

875 Hierbij dient de kanttekening te worden gemaakt dat de erfpachter niet bevoegd is de met het erfpachtrecht bezwaarde zaak te vervreemden. De erfpachter mag in beginsel geen handelingen verrichten die leiden tot waardevermindering van de grond (art. 3 Erfpachtwet). Zie: Blockx, Lens \& Wynant 2006, p. 31; Deli 1998, nr. 17; Goeminne 2007, XV.B-23; Vandenberghe 2005, nr. 921.

876 Art. 6 Erfpachtwet.

877 Sagaert, Tilleman \& Verbeke 2010, nr. 982. 
In ruil voor het verkrijgen van het volle genot van de zaak dient de erfpachter een vergoeding, pacht, te betalen. ${ }^{878}$ Anders dan bij het recht van opstal, is de verplichting tot het betalen van pacht een vestigingsvereiste voor het ontstaan van het erfpachtrecht. Door het betalen van een vergoeding erkent de erfpachter het aan de eigenaar toekomende eigendomsrecht dat op de bezwaarde zaak rust. ${ }^{879}$ De pacht mag een louter symbolisch bedrag betreffen ${ }^{880}$ en kan zowel in geld als in natura worden voldaan. ${ }^{881}$

De Erfpachtwet stelt zowel een minimum- als een maximumduur waarvoor het recht kan worden gevestigd; een erfpachtrecht is dan ook per definitie tijdelijk van aard. De minimale duur waarvoor het erfpachtrecht kan worden gevestigd, bedraagt 27 jaar, de maximale vestigingsduur 99 jaar. Een erfpachtrecht dat voor een kortere termijn dan 27 jaar wordt gevestigd, wordt aangeduid als huur ${ }^{882}$. Erfpachtrechten die voor een langere termijn dan 99 jaar worden gevestigd, worden teruggebracht tot de wettelijke maximumduur van 99 jaar. ${ }^{883}$ Vernieuwing van het erfpachtrecht is mogelijk, mits ten gevolge van de vernieuwing de termijn van 99 jaar niet wordt overschreden. ${ }^{884}$ Zo kan een erfpachtrecht dat is gevestigd voor een termijn van 50 jaar met maximaal 49 jaar worden verlengd. ${ }^{885}$

Uit de Erfpachtwet volgt dat de erfpachter bevoegd is tot het aanbrengen van bouwwerken en beplantingen, althans voor zover in de vestigingsovereenkomst niet anders is bepaald. ${ }^{886}$ De door de erfpachter aangebrachte opstallen blijven krachtens een accessoir opstalrecht toebehoren aan de erfpachter. ${ }^{87}$ Het onderscheid tussen bouwwerken die al dan niet in eigendom aan de erfpachter toekomen, is doorgaans van belang voor het al dan niet bestaan van een onderhoudsplicht en de mate

878 In de literatuur wordt tevens de term 'canon' gebezigd. Hoewel art. 1 Erfpachtwet stelt dat er een jaarlijkse pacht dient te worden betaald, volgt uit de heersende leer dat een erfpachtrecht eveneens tegen een eenmalige vergoeding kan worden gevestigd. De heersende leer betwist evenmin de geldigheid van erfpachtrechten waarbij overeengekomen wordt dat de pacht maandelijks of volgens contractueel vastgestelde termijnen wordt betaald. Zie: Deli 1998, nr. 50; Goeminne 2007, XV.B-22; Vandenberghe 2005, nr. 935.

879 Art. 1 Erfpachtwet stelt: “... als een erkentenis van deszelfs eigendom, ...”.

$880 \quad$ Verbeke \& Snaet 2007, p. 383.

881 Vandenberghe 2005, nr. 935.

882 Derine, Van Neste \& Vandenberghe, 1984b, nr. 1001. Zie ook: hoofdstuk 4 $\$ 4.5 .2$.

883 Deli 1998, nr. 23.

$884 \quad$ Hof Gent 21 april 1977, Res. Jur. Imm. 1978, 103, nr. 5658.

885 Hetgeen niet gelijk gesteld dient te worden met een stilzwijgende vernieuwing van het erfpachtrecht (art. 14 Erfpachtwet). Zie: Deli 1998, nr. 24.

886 Art. 4, 5, 7 en 8 Erfpachtwet.

887 Werdefroy 1994, p. 5. Zie ook: Vandenberghe \& Viaene, p. 49. 
waarin de erfpachter bevoegd is over de bouwwerken te beschikken. ${ }^{888}$ In beginsel rust op de erfpachter de verplichting de bezwaarde zaak te onderhouden, met uitzondering van de bouwwerken die aan de erfpachter in eigendom toebehoren. Dit onderhoud ziet op de gewone herstellingen van de belaste zaak. ${ }^{89}$ De erfpachter is in beginsel bevoegdheid zijn recht ${ }^{890}$ te vervreemden, te bezwaren ${ }^{891}$ alsook te verhuren. ${ }^{892}$ Bij vervreemding van het erfpachtrecht gaan de opstallen in eigendom mee over op de verkrijger van het erfpachtrecht. ${ }^{893}$ De erfpachter is bevoegd de door hem aangebrachte opstallen te bezwaren en te verhuren. ${ }^{894}$

Bij beëindiging van het erfpachtrecht komt aan de erfpachter de bevoegdheid toe de opstallen weg te nemen die hij bij aanvang van het erfpachtrecht in waarde heeft vergoed of die hij ten tijde van het erfpachtrecht heeft verwezenlijkt, tenzij ingevolge de vestigingsovereenkomst op de erfpachter de verplichting rustte de opstallen in of op het gronderf te verwezenlijken. Dit wegneemrecht bestaat evenmin wanneer partijen in de vestigingsovereenkomst ten aanzien van de in waarde vergoede opstallen anders zijn overeengekomen. Op de erfpachter rust de verplichting de schade te vergoeden welke veroorzaakt wordt door het wegnemen van de opstallen. ${ }^{895}$ Het niet wegnemen van de opstallen doet de opstallen na beëindiging van het erfpachtrecht ${ }^{896}$ aan de eigenaar van de belaste zaak in

888 Hoofdstuk 4 §4.4 en $§ 4.4 .2$.

889 Volgens de heersende leer worden met de gewone herstellingen die herstellingen bedoeld waartoe een vruchtgebruiker is gehouden (artikel 605 e.v. BBW). Zware of grove herstellingen komen ten laste van de grondeigenaar, tenzij de oorzaak voor het doen van deze herstellingen gelegen is in het nalaten van het door de erfpachter te verrichten gewone onderhoud. Zie: Derine, Van Neste \& Vandenberghe, 1984b, nr. 1007; Vandenberghe 2005, nr. 936.

890 Hoewel aan de erfpachter op grond van zijn erfpachtrecht die bevoegdheden toekomen die kunnen worden gelijkgesteld met het eigendomsrecht dat op de grond rust, is de erfpachter niet bevoegd de onroerende zaak waarop het erfpachtrecht rust te vervreemden of te bezwaren. Zie: Vandenberghe \& Viaene 2006, p. 49.

891 Art. 6 Erfpachtwet.

892 Tenzij partijen de bevoegdheid tot het vervreemden, verhuren en/of bezwaren van het erfpachtrecht in de vestigingsovereenkomst hebben uitgesloten.

893 Het erfpachtrecht kan met een recht van hypotheek of vruchtgebruik worden bezwaard. Onzeker is of het erfpachtrecht met een erfpachtrecht kan worden bezwaard. Volgens Vandenberghe en Viaene kan een erfpachtrecht met een onderfpacht worden bezwaard, mits het ondererfpachtrecht rechtstreeks op het gronderf wordt gevestigd. Zie: Deli 1998, nr. 72; Vandenberghe 2005, nr. 933; Vandenberghe \& Viaene 2006, p. 42; Verbeke \& Snaet 2007, p. 367.

894 Hoofdstuk 4 \$4.4.2.

895 Art. 7 lid 1 Erfpachtwet.

896 Met de beëindiging van het erfpachtrecht komt eveneens het accessoire opstalrecht tot zijn eind. 
eigendom overgaan aangezien met het tenietgaan van het erfpachtrecht ook het accessoire opstalrecht teniet gaat. De grondeigenaar is niet verplicht de in eigendom verkregen opstallen te vergoeden ${ }^{897}$, tenzij partijen in de vestigingsovereenkomst anders zijn overeengekomen. ${ }^{898}$ De wetgever achtte een vergoedingsplicht onnodig nu een erfpachtrecht doorgaans voor een aanzienlijke duur wordt gevestigd. ${ }^{899}$

\section{\$4.5.2.2 Vruchtgebruik}

De vruchtgebruiker "geniet alle rechten waarvan de eigenaar het genot kan hebben, en hij heeft dit genot zoals de eigenaar zelf, maar onder verplichting de zaak zelf in stand te houden" ${ }^{900}$ Dit genot komt aan de vruchtgebruiker toe ten aanzien van de zaak waarop het vruchtgebruik is gevestigd alsook met betrekking tot de vruchten die de zaak voortbrengt. ${ }^{901}$ De vruchtgebruiker is verplicht de zaak in stand te houden en dient aan de in vruchtgebruik gegeven zaak herstellingen tot onderhoud te plegen. ${ }^{902}$ De vruchtgebruiker is in beginsel bevoegd zijn recht te vervreemden, met een erfdienstbaarheid

897 Art. 8 Erfpachtwet.

898 Michiels 2007, p. 219.

899 Art. $555 \mathrm{BBW}$ is dan ook niet van toepassing. Voor een nader bespreking van art. 555 BBW zie: hoofdstuk 4 §3.

900 Art. 578 BBW. Een recht van vruchtgebruik kan worden gevestigd ten behoeve van zaken, zakelijke rechten, persoonlijke genotsrechten zoals huur of pacht, schuldvorderingen, vorderingsrechten en onlichamelijke eigendommen. Zie: De Corte \& de Groote 2005, nr. 1507; Goeminne XV.B-46.

901 Art. 582 BBW e.v. Zie: De Corte \& de Groote 2005, nr. 1510.

902 Art. 605 BBW. Uit art. 605 jo. 606 BBW volgt dat grove herstellingen ten lasten komen van de bloot eigenaar. De term 'grove herstellingen' dient te worden uitgelegd als "grove vernieuwings- en verbouwingswerken met het oog op de algemene stevigheid en de instandhouding van het gehele gebouw die werkelijk een uitzondering zijn in het bestaan zelf van de eigendom en waarvan de kosten normaal van het kapitaal worden genomen", aldus het Hof van Cassatie 22 januari 1970, Arr. Cass. 1970, 460. De kosten die gemaakt worden bij het schilderen van de muren worden evenals de kosten voor het leggen van tapijt beschouwd als 'herstellingen tot onderhoud' en komen ten laste van de vruchtgebruiker. Het plaatsen van een centrale verwarming wordt gezien als een werk van algemene stevigheid en de instandhouding van het gehele gebouw. Zie: rb. Leuven 14 februari 2003, F.J.F. 2003/251. 
of hypotheek te bezwaren of te verhuren ${ }^{903} \cdot{ }^{904}$ Over de vraag of het recht van vruchtgebruik met een recht van erfpacht kan worden belast, zijn de meningen verdeeld. ${ }^{905}$

Een ten behoeve van een natuurlijke persoon gevestigd recht van vruchtgebruik kan voor een bepaalde duur worden overeengekomen, maar kan ook worden gekoppeld aan de duur van het leven van de vruchtgebruiker. ${ }^{906}$ Wanneer de vruchtgebruiker overlijdt vóór het verstrijken van de overeengekomen vestigingsduur, eindigt het recht van vruchtgebruik met het overlijden van de vruchtgebruiker. Dat de termijn waarvoor het vruchtgebruik is gevestigd niet is verstreken doet hier niets aan af. Een ten behoeve van een rechtspersoon gevestigd recht van vruchtgebruik kan voor een maximale duur van 30 jaar worden gevestigd. ${ }^{907}$

De vruchtgebruiker is in beginsel ${ }^{908}$ bevoegd tot het aanbrengen van opstallen op het in vruchtgebruik gegeven gronderf, althans wanneer de verwezenlijking van de opstallen kan worden aangemerkt als "een

903 Nu het voortbestaan van het recht van vruchtgebruik doorgaans is gekoppeld aan de levensduur van de vruchtgebruiker, kan onzekerheid bestaan omtrent de duur van de overeengekomen huurovereenkomst. Vandaar dat in het BBW een regeling is opgenomen op grond waarvan de eigenaar van de door de vruchtgebruiker verhuurde zaak gehouden is de huurovereenkomst voor een maximale periode van negen jaar, ingaande vanaf het moment dat het recht van vruchtgebruik ophoudt te bestaan, te eerbiedigen (art. 595 BBW). Zie: Dekkers/Dirix 2005, nr. 522; Sagaert, Tilleman \& Verbeke 2010, nrs. 946-948.

904 Althans voor zover partijen in de vestigingsovereenkomst niet anders zijn overeengekomen. Zie: De Corte \& de Groote 2005, nr. 1505; Verbeke \& Vanhove 2005, nr. 26.

905 Deze onzekerheid komt voort uit de erfpachtdefinitie (art. 1 Erfpachtwet) ingevolge een erfpachtrecht dient te worden gevestigd op een lichamelijk onroerend goed. Volgens de heersende leer is het dan ook niet mogelijk een erfpachtrecht te vestigen op een recht van vruchtgebruik. Zie: Derine, Van Neste \& Vandenberghe 1984b, nr. 1000; Van Oevelen 1991, p. 60. Sagaert, Tilleman, Verbeke en Snaet zijn van mening dat ook onlichamelijke onroerende goederen met een erfpachtrecht kunnen worden bezwaard, voor zover de aan de erfpachter toekomende bevoegdheden niet verstrekkender van aard zijn dan de bevoegdheden die aan de vruchtgebruiker toekomen. Zie: Sagaert, Tilleman \& Verbeke 2010, nrs. 941; Verbeke \& Snaet 2007, pp. 398-369.

906 Art. 580 BBW. Zie: Meulemans 1998, nr. 73.

907 Art. 619 BBW. Naast het tenietgaan door tijdsverloop of overlijden, kan een recht van vruchtgebruik tenietgaan door vermenging, het niet uitoefenen van het vruchtgebruik voor een periode van 30 jaar, het tenietgaan van het goed waarop het vruchtgebruik is gevestigd en door misbruik van het recht door de vruchtgebruiker (artt. 617-618 BBW). Zie: De Corte \& de Groote 2005, nr. 1514.

908 Partijen kunnen het recht tot het aanbrengen van opstallen op het in vruchtgebruik gekregen gronderf in de vestigingsovereenkomst uitsluiten. 
handeling van een goede huisvader" $"{ }^{\prime 09}$ èn de te verwezenlijken opstallen in overeenstemming zijn met de bestemming van de zaak. ${ }^{910}$ De vruchtgebruiker behoudt de eigendom van de door hem aangebrachte opstallen, nu aan het recht van vruchtgebruik in beginsel een accessoir opstalrecht is gekoppeld. ${ }^{911}$ Het staat de vruchtgebruiker vrij de door hem angebrachte opstallen te bezwaren en te verhuren. ${ }^{912}$

Bij beëindiging van het vruchtgebruik komt aan de grondeigenaar de bevoegdheid toe afbraak van de opstallen te vorderen, althans voor zover de vruchtgebruiker de door hem aangebrachte opstallen niet reeds heeft weggenomen. De grondeigenaar kan er eveneens voor kiezen de door de vruchtgebruiker aangebrachte opstallen te handhaven; aan de vruchtgebruiker komt dan een recht op vergoeding toe ingevolge artikel $555 \mathrm{BBW} .{ }^{913}$ Ten aanzien van de verbeteringen die de vruchtgebruiker aan de opstallen heeft aangebracht, kan de vruchtgebruiker geen vergoeding vorderen noch staat het de vruchtgebruiker vrij deze verbeteringen weg te nemen.

\section{\$4.5.2.3 Erfdienstbaarheid}

Een erfdienstbaarheid ziet op de rechtsverhouding tussen twee of meer erven die gekwalificeerd kunnen worden als lijdend respectievelijk heersend erf. Het lijdend erf draagt een 'last'. Deze last dient te strekken tot gebruik en nut van het heersend erf. ${ }^{914}$ De last dient het nut van het heersend erf te vergroten ${ }^{915}$ en mag niet louter strekken tot persoonlijk voordeel van de eigenaar van het heersend erf. ${ }^{916}$ De eigenaar van het heersend erf mag enkel "binnen de grenzen van de noodwendigheden voor dewelke zij gevestigd werd" van de erfdienstbaarheid gebruik maken. ${ }^{917}$ Ten gevolge van deze last, wordt de eigenaar ${ }^{918}$ van het lijdend erf beperkt in het gebruik van zijn gronderf. ${ }^{919}$

909 Van Sinay 1996, nr. 76.

910 De vruchtgebruiker is niet bevoegd de bestemming van het gronderf en daarmee van de met het gronderf verenigde opstallen te wijzigen. Zie: Goeminne 2007, XV.B-43.

911 Sagaert 2004, p. 260.

912 Van Sinay 1996, nr. 77. Zie: hoofdstuk 4 \$4.4.2.

913 Van Sinay 1996, nr. 78. In $§ 3$ van dit hoofdstuk wordt ingegaan op art. 555 BBW.

914 Art. 637 BBW.

915 Derine, Van Neste \& Vandenberghe 1984b, nr. 921.

916 Art. 686 BBW. Zie: Kluyskens 1940, nr. 251.

917 Kluyskens 1940, nr. 392.

918 De gebruiker van het lijdend erf wordt in het genot van zijn gebruiksrecht eveneens beperkt door de gevestigde erfdienstbaarheid.

919 Delva 1982, p. 128; Derine, Van Neste \& Vandenberghe 1984b, nr. 918. Derine, Van Neste en Vandenberghe omschrijven de inbreuk op het eigendomsrecht aan de zijde van de eigenaar van het lijdend erf als volgt: "Een erfdienstbaarheid 
De erfdienstbaarheid onderscheidt zich van het zelfstandige recht van opstal, de erfpacht en het vruchtgebruik doordat de erfdienstbaarheid afhankelijk van aard is. Een erfdienstbaarheid kan niet separaat van het heersende erf worden overgedragen of bezwaard. ${ }^{920}$ Vervreemding en bezwaring van het heersend erf leidt eveneens tot vervreemding en bezwaring van de erfdienstbaarheid. ${ }^{921}$

Voor de uitoefening van de erfdienstbaarheid kan het noodzakelijk zijn dat er opstallen op of in het lijdend erf worden aangebracht. ${ }^{922}$ Hierbij kan gedacht worden aan het aanleggen van een weg ten behoeve van een recht van overpad of een brug voor een recht van overgang. Wanneer deze opstallen door de eigenaar van het lijdend erf worden aangebracht en deze opstallen met het gronderf worden geïncorporeerd, dan worden deze opstallen met het gronderf waarmee zij zijn verenigd in eigendom nagetrokken. ${ }^{923}$ Opstallen die door de eigenaar van het heersend erf op het lijdend erf worden aangebracht gaan toebehoren aan de eigenaar van het heersend erf ingevolge het aan de erfdienstbaarheid accessoire opstalrecht. ${ }^{924}$ De kosten voor de te verwezenlijken bouwwerken zijn in beginsel

920 "Het doorslaggevende argument hiervoor ligt in het feit dat erfdienstbaarheden slechts bijkomstige rechten zijn, die niet op zichzelf kunnen bestaan", aldus Verbeke en Snaet. Zie: Verbeke \& Snaet 2007, p. 367.

921 Derine, Van Neste \& Vandenberghe 1984a, nr. 846.

922 Art. 697 BBW. Erfdienstbaarheden kunnen worden onderscheiden in positieve en negatieve erfdienstbaarheden. Op grond van een positieve erfdienstbaarheid komt aan de eigenaar van het heersend erf, dan wel de gerechtigde tot een gebruiksrecht dat op het heersend erf rust, de bevoegdheid toe 'iets te doen'. Ingevolge een negatieve erfdienstbaarheid wordt de eigenaar van het lijdend erf geremd in de uitoefening van zijn genot doordat hij 'iets niet mag doen'. In beginsel kan een erfdienstbaarheid aan de eigenaar van het lijdend erf niet de verplichting opleggen 'iets te doen', tenzij deze 'doen'-verplichting noodzakelijk is voor de uitoefening van de erfdienstbaarheid. Zo kan het voor de uitoefening van een erfdienstbaarheid noodzakelijk zijn dat op het lijdende erf bepaalde bouwwerken worden aangebracht. Deze 'doen'-verplichting kan als nevenverplichting van de erfdienstbaarheid worden aangemerkt. Zie: Derine, Van Neste \& Vandenberghe 1984b, nr. 919; Kluyskens 1940, nr. 256.

923 Hoofdstuk 4 \$2.2.1.

924 De bevoegdheidstoekenning aan de gerechtigde van het heersend erf tot het aanbrengen van de voor de uitoefening van de erfdienstbaarheid noodzakelijke bouwwerken is gelegen in de gedachte dat het geen zin heeft een erfdienstbaarheid te vestigen wanneer dit recht niet daadwerkelijk kan worden uitgeoefend, omdat de voor de uitoefening van het recht benodigde bouwwerken ontbreken. Zie: Derine, Van Neste \& Vandenberghe 1984b, nr. 968; Kluyskens 1940, nr. 391. 
voor de eigenaar van het heersend erf, tenzij in de vestigingsovereenkomst anders is overeengekomen. ${ }^{925} \mathrm{Nu}$ een erfdienstbaarheid eeuwigdurend van aard is ${ }^{926}$ en een accessoir opstalrecht aan de hand van de bepalingen van het hoofdrecht nader worden 'ingevuld' ${ }^{927}$, is het opstalrecht dat aan de gerechtigde tot de erfdienstbaarheid toekomt eveneens eeuwigdurend van aard. ${ }^{928}$

Of de opstallen die ten behoeve van de uitoefening van de erfdienstbaarheid op het gronderf zijn aangebracht, kunnen worden bezwaard of verhuurd, zwijgt de literatuur. Nu de aangebrachte opstallen noodzakelijk zijn voor de uitoefening van de erfdienstbaarheid ${ }^{929}$, vermoed ik dat het niet mogelijk is de opstallen met een gebruiksrecht te vervreemden dan wel te verhuren. De literatuur alsook de bepalingen omtrent het recht van erfdienstbaarheid zwijgen eveneens ten aanzien van de vraag of de gerechtigde tot de erfdienstbaarheid bevoegd is de door hem aangebrachte opstallen weg te nemen. Deze vraag zal primair aan de hand van de vestigingsovereenkomst dienen te worden beantwoord. Zwijgt ook de vestigingsovereenkomst dan komt aan de gerechtigde tot de erfdienstbaarheid de bevoegdheid toe de aangebrachte opstallen weg te nemen; de gerechtigde is krachtens het accessoire opstalrecht immers als eigenaar van de door hem aangebrachte opstallen aan te merken.

Kiest de gerechtigde ervoor de door hem verwezenlijkte opstallen op het gronderf achter te laten, dan is het antwoord op de vraag of de eigenaar van het gronderf bevoegd is tot het vorderen van afbraak mijns inziens afhankelijk van de duur waarvoor de erfdienstbaarheid is gevestigd. Is de gevestigde erfdienstbaarheid in beginsel eeuwigdurend van aard dan is de grondeigenaar bij de vestiging uitgegaan van een eeuwigdurende belasting van zijn gronderf en lijkt mij dat het vorderen van afbraak niet redelijk is. Bij een 'tijdelijke' erfdienstbaarheid zal het recht tot afbraak wel bestaan. Wanneer de opstallen niet door de gerechtigde tot de erfdienstbaarheid worden weggenomen en de eigenaar van het gronderf geen afbraak vordert

925 Art. 698 BBW.

926 Derine, Van Neste \& Vandenberghe 1984b, nr. 931.

927 Hoofdstuk 4 \$4.6.

928 Kluyskens 1940, nr. 390: "Merk nochtans wel op dat deze accessoire rechten slechts aan den eigenaar van het heerschend erf kunnen verleend worden inzoover zij er noodzakelijk bijhooren: het eene moet het gevolg zijn van het ander". Volledigheidshalve dient te worden opgemerkt dat een recht van erfdienstbaarheid wel degelijk teniet kan gaan. Het tenietgaan van een erfdienstbaarheid wordt niet veroorzaakt door onafhankelijke of onvermijdelijke oorzaken. De grondslag voor het tenietgaan is accidenteel van aard dan wel afhankelijk van de wil van partijen. Zie: Derine, Van Neste \& Vandenberghe 1984b, nr. 980.

929 Art. 696 BBW. 
van de opstallen -voor zover dit recht van afbraak aan de grondeigenaar toekomt-, dan rust op de grondeigenaar de verplichting deze opstallen te vergoeden ingevolge de leer van de ongerechtvaardigde verrijking.

\section{$\$$ 4.5.2.4 Huur}

Een huurrecht $\mathrm{t}^{930}$ komt tot stand door een consensuele overeenkomst. De wilsovereenstemming die aan de huurovereenkomst ten grondslag ligt kan zowel schriftelijk als mondeling geschieden. ${ }^{931}$ De huurder is verplicht de gehuurde zaak in overeenstemming met de aan de zaak toegekende bestemming te gebruiken "als een goed huisvader". In ruil voor het gebruik en genot van de zaak dient de huurder aan de verhuurder de overeengekomen huurprijs te voldoen. ${ }^{932}$ Een huurrecht kan voor een periode van ten hoogste 99 jaar worden overeengekomen. ${ }^{933}$

De huurder is in beginsel bevoegd, althans wanneer niet anders in de wet of in de overeenkomst is overeengekomen ${ }^{934}$, het huurrecht over te dragen respectievelijk de gehuurde zaak onder te verhuren. Een huurrecht dat onder de Woninghuurwet ${ }^{935}$ valt, kan niet worden overgedragen. ${ }^{936}$ Een

930 De algemene huurregeling komt aan bod in het art. $1708-1762$ bis BBW. Van de in het BBW opgenomen huurbepalingen wordt afgeweken ten behoeve van woninghuur, handelshuur en pacht. Deze drie specifieke vormen van huur worden in de Woninghuurwet, de Handelshuurwet en de Pachtwet nader geregeld. De bepalingen uit voornoemde wetten zijn dwingendrechtelijk van aard. In deze paragraaf zal de algemene huurregeling worden besproken en daar waar nodig worden aangevuld met de van de algemene regeling afwijkende woninghuur-, handelshuur- en pachtbepalingen. Terwijl bij woninghuur de huur ziet op de verhuur van een woning aan een particulier die de woning als zijn hoofdverblijfplaats aanmerkt, wordt bij handelshuur een onroerende zaak verhuurd ten behoeve van het voeren van handel. Pacht ziet op de huur van landeigendommen. Als landeigendommen kunnen worden aangemerkt: bouwland, weiden, hoevegebouwen, landgebouwen, hoevewoningen, schuren en loodsen. Zie voor een uitvoerige bespreken van de voornoemde wetten: Van Oevelen 2009 (woninghuur); Stassijns 1998 (pacht); Vanhove 2012 (handelshuur).

931 Art. 1714 BBW. Huurovereenkomsten die onder de Woninghuurwet vallen dienen alle aan het schriftelijkheidsvereiste te voldoen wanneer zij tot stand zijn gekomen na 14 juni 2007. (art. $1 \S 1$ bis Woninghuurwet). Zie: Vanhove 2009, nr. 49; De Boeck 2009, nrs. 262-263; Meulemans 1998, nr. 33.

932 Art. 1728 BBW.

933 Ten aanzien van de duur van handelshuur kent de wet een minimum termijn van 9 jaar. Zie: Meulemans 1998, nr. 37.

934 Art. 1717 BBW. Zie: Meulemans 1998, nr. 106.

935 In de literatuur doorgaans afgekort als W.H.W.

936 Overdracht van een huurovereenkomst die valt onder de Woninghuurwet is verboden (art. 4 § 1 W.H.W.). 
huurrecht ressorteert onder de Woninghuurwet wanneer de overeenkomst die aan het huurrecht ten grondslag ligt, ziet -zoals uit de benaming van de wet reeds kan worden afgeleid- op het verhuren van een woning ${ }^{937}$ aan een natuurlijke persoon die de woning als zijn hoofdverblijfplaats aanmerkt. ${ }^{938}$ Het onderverhuren van een woning die onder de Woninghuurwet valt, is enkel toegestaan wanneer het een gedeeltelijke onderverhuring ${ }^{939}$ betreft en de eigenaar van de onroerende zaak hiervoor zijn toestemming verleent. ${ }^{940}$ Tevens dient het gedeelte van de woning dat door de huurder niet wordt onderverhuurd door de huurder als hoofverblijfplaats te worden aangemerkt. ${ }^{941}$ De pachter is in beginsel evenmin bevoegd zijn pachtrecht over te dragen of in onderpacht uit te geven. ${ }^{942}$

In beginsel is de huurder bevoegd om bouwwerken ${ }^{943}$ en aanpassingen aan de gehuurde zaak aan te brengen die noodzakelijk of nuttig zijn voor het genot van de zaak. ${ }^{944}$ De huurder dient daarbij de bestemming die aan de verhuurde zaak is toegekend, te eerbiedigen. ${ }^{945}$ Het aanbrengen van bouwwerken en aanpassingen die leiden tot wijziging van de aard van het verhuurde, zijn in strijd met de bestemming van de zaak. ${ }^{946}$ Bij strijdigheid

937 Art. $1 \S 1$ Woninghuurwet definieert het begrip 'woning' als: “... elk roerend of onroerend goed of een deel ervan dat tot hoofdverblijfplaats van de huurder is bestemd".

938 Meulemans 1998, nr. 104.

939 Volledige onderverhuring is bij wet verboden (art. 4 § 2 eerste lid W.H.W.).

$940 \quad$ Art. 4 § 2 tweede lid W.H.W.

941 Meulemans 1998, nr. 108.

942 Art. 30 Pachtwet e.v. Op dit verbod bestaan verschillende uitzonderingen. Zie: Stassijns 1998, nr. 5.

943 Bij pacht bestaat er in beginsel een verbod tot aanplanting, tenzij het aanbrengen van de beplantingen noodzakelijk is voor het in stand houden van de gepachte zaak of de verpachter voor het aanbrengen van de beplantingen zijn toestemming heeft verleend. Zie: art. 28 Pachtwet. Het aanbrengen van beplantingen dient te worden onderscheiden van normale bebouwing van de gronden. Zie: Stassijns 1998, nr. 576.

944 Gits \& Devos 2007, p. 223. Wanneer sprake is van handelshuur komt aan de huurder het recht toe "elke verbouwing uit te voeren die dienstig is voor zijn onderneming en waarvan de kosten 3 jaar huur niet te boven gaan, mits daardoor noch de veiligheid, noch de salubriteit, noch de esthetische waarde van het gebouw in het gedrang komen, en mits hij vooraf de verhuurder bij ter post aangetekende brief in kennis stelt van al de voorgenomen veranderingen, met overlegging van de plans en bestekken, zodat de huurder in voorkomend geval zich om wettige redenen ertegen kan verzetten" (art. 7 Handelshuurwet). Op grond van art. 25 Pachtwet staat het de pachter vrij die bouwwerken op te richten die nuttig zijn voor de exploitatie van de verhuurde zaak, voor zover de bouwwerken niet leiden tot strijdigheid met de aan de zaak toegekende bestemming.

945 Art. 1728 BBW.

946 Van Sinay 1996, nr. 80. 
met de bestemming komt aan de verhuurder het recht toe afbraak te vorderen van de aangebrachte bouwwerken en aanpassingen. Tevens komt aan de verhuurder het recht toe de huurovereenkomst te beëindigen. Wanneer de verhuurder geen afbraak vordert dient hij de bouwwerken en aanpassingen bij beëindiging van het huurrecht te vergoeden. ${ }^{947}$

De door de huurder op de verhuurde zaak aangebrachte bouwwerken behoren in eigendom toe aan de huurder ${ }^{948}$ op grond van het aan de huurovereenkomst accessoire recht van opstal. ${ }^{949}$ De huurder kan over de aan hem toekomende bouwwerken beschikken door ze te bezwaren of te verhuren. Tevens staat het de huurder vrij de door hem aangebrachte objecten, voor zover verwijdering mogelijk is, weg te nemen ingevolge het op de opstallen rustende eigendomsrecht. ${ }^{950}$

De verhuurder kan krachtens art. $555 \mathrm{BW}^{951}$ na beëindiging van het huurrecht afbraak vorderen van de door de huurder aangebrachte en wegneembare objecten. ${ }^{952}$ Weigert de huurder hieraan gehoor te geven dan staat het de verhuurder vrij deze objecten op kosten van de huurder te verwijderen. ${ }^{953} \mathrm{Bij}$ behoud van de opstallen rust op de verhuurder de

947 Michiels 2007, p. 222.

948 Althans voor zover de huurovereenkomst niet anders bepaalt.

949 Kluyskens 1940, nr. 88. Het is voor het ontstaan van een opstalrecht niet noodzakelijk dat partijen in de huurovereenkomst uitdrukkelijk een opstalrecht zijn overeenkomen. Zie: rb. Brussel 14 mei 2004, trv 2004, pp. 612-618.

950 Voorbeelden van niet-verwijderbare objecten zijn elektriciteitsbekabeling, centrale verwarming en de in de badkamer aangebrachte tegeltjes.

$951 \quad$ Hoofdstuk $4 \$ 3$.

952 Michiels 2007, p. 222.

953 Wanneer sprake is van handelshuur kan de verhuurder bij beëindiging van de overeenkomst geen afbraak vorderen van de aangebrachte bouwwerken en aanpassingen wanneer de verhuurder uitdrukkelijk of stilzwijgend toestemming heeft gegeven voor het aanbrengen van deze bouwwerken en aanpassingen. Zijn de bouwwerken en aanpassingen zonder toestemming van de verhuurder aangebracht, dan kan de verhuurder herstel van de verhuurde zaak vorderen. De zaak dient dan in de toestand te worden teruggebracht waarin deze zich bevond ten tijde van het ontstaan van het huurrecht. Wanneer de verhuurder kiest voor behoud van het door de huurder aangebrachte dan bestaat in beginsel geen verplichting tot vergoeding van de bouwwerken en aanpassingen (art. 9 Handelshuurwet). De pachter is in beginsel bevoegd die bouwwerken en aanpassingen aan te brengen die nuttig zijn voor de bewoning of voor de exploitatie van de verpachte zaak. Het staat de pachter vrij deze bouwwerken weg te nemen. Wanneer de pachter besluit de aangebrachte bouwwerken niet weg te nemen, rust op de verpachter een vergoedingsplicht ten aanzien van deze opstallen. Bij het bepalen van de hoogte van de vergoeding speelt de vraag of de verpachter toestemming heeft gegeven voor het aanbrengen een rol (artikelen 25 en 26 Pachtwet). Zie: Stassijns 1997, nr. 564 e.v. 
verplichting tot vergoeding van de ten gevolge van de natrekking verkregen opstallen. ${ }^{954}$ De hoogte van de vergoeding wordt bepaald aan de hand van de door de aangebrachte objecten gerealiseerde meerwaarde van de verhuurde zaak. ${ }^{955}$ In beginsel komt aan de huurder die niet-verwijderbare objecten heeft aangebracht geen recht op vergoeding toe wanneer de verhuurder geen toestemming heeft gegeven voor het aanbrengen van deze objecten. Bij het ontbreken van toestemming handelt de huurder in strijd met de overeengekomen huurovereenkomst nu de verhuurde zaak ten gevolge van het aanbrengen van niet-verwijderbare objecten niet in de staat kan worden teruggebracht waarin de verhuurde zaak zich ten tijde van aanvang van de huurovereenkomst bevond; de huurder is immers in beginsel verplicht tot herstel van de verhuurde zaak in de oorspronkelijke staat. ${ }^{956}$ Desalniettemin komt aan de huurder een vergoedingsrecht toe ten aanzien van de niet-verwijderbare objecten die noodzakelijk of nuttig zijn voor de onroerende zaak. ${ }^{957}$ De grondslag voor dit vergoedingsrecht is gelegen in de zogenoemde leer van de onkosten. ${ }^{958}$ Dit is anders wanneer de verhuurder geen toestemming heeft gegeven voor het aanbrengen van de niet-wegneembare objecten en partijen de vergoedingsplicht in de huurovereenkomst hebben uitgesloten. De verhuurder kan dan in beginsel niet gehouden zijn tot betaling van een vergoeding. ${ }^{959}$

\section{\$4.6 Wijzen waarop een recht van opstal teniet kan gaan en de aan het tenietgaan verbonden gevolgen}

Ten gevolge van het tenietgaan van het opstalrecht worden de opstallen ten gunste waarvan het opstalrecht is gevestigd (weer) met het gronderf

954 Cass. 31 mei 2012, c.10.0647.n.

955 Dambre 2006, nrs. 1081-1084; Michiels 2007, p. 222; Van Sinay 1996, nr. 82.

956 Art. 1731 BBW.

957 Objecten die puur 'voor de luxe' zijn aangebracht komen niet voor vergoeding in aanmerking.

958 De rechtvaardiging voor deze vergoeding is gelegen in de gedachte dat de huurder noodzakelijke of nuttige objecten heeft aangebracht met het oog op het bewerkstelligen van een objectieve meerwaarde aan het gehuurde en zich dan ook als een goed huisvader heeft gedragen. Zie: Neut 2000, p. 1029.

959 Michiels 2007, p. 222; Tilleman \& Verbeke 2005, nr. 548; Van Oevelen 2003, p. 9. Maar ook wanneer de verhuurder wel zijn goedkeuring heeft verleend aan de huurder voor het aanbrengen van de objecten hoeft er geen recht op vergoeding bestaan. Zo oordeelde de rechtbank van Brussel dat aan de huurder geen vergoedingsrecht toekomt, omdat de huurder 16 jaar lang voor een symbolische huurprijs heeft mogen genieten van de gehuurde zaak. De rechtbank is van mening dat de aangebrachte werken tezamen met de symbolische vergoeding de tegenprestatie vormen voor het genot van de gehuurde zaak. Zie: Rechtbank Brussel 1 september 1998, R.W. 1999-2000, 1026. 
nagetrokken, waardoor de grondeigenaar (weer) eigenaar wordt van de opstallen die met het gronderf zijn geïncorporeerd. ${ }^{960}$ Natrekking kan niet worden voorkomen door een tussen grondeigenaar en opstaller overeengekomen beding dat de opstaller ook na het tenietgaan van het opstalrecht eigenaar blijft van de opstallen. ${ }^{961}$ Een zelfstandig opstalrecht ${ }^{962}$ kan op verschillende wijzen tenietgaan. Volgens de Opstalwet kan een opstalrecht tenietgaan door vermenging, door het tenietgaan van het gronderf dat met het opstalrecht is bezwaard en door verjaring. ${ }^{963}$

Van vermenging is sprake wanneer het opstalrecht en het moederrecht in één hand komen. Vandenberghe is van mening dat vermenging niet dient te worden aangemerkt als een wijze van tenietgaan, maar als een onmogelijkheid om het opstalrecht uit te oefenen; het opstalrecht herleeft wanneer de onmogelijkheid om het opstalrecht uit te oefenen ophoudt te bestaan. ${ }^{964}$ Rechten die door derden zijn verkregen blijven ondanks de vermenging 'voortbestaan'965, omdat derden tegen eenzijdig optreden van de opstaller dienen te worden beschermd. ${ }^{966}$ Wanneer het object dat met het recht van opstal is bezwaard teniet gaat, leidt dit in beginsel tot het tenietgaan van het opstalrecht. Zo gaat het opstalrecht teniet wanneer de met opstal bezwaarde grond door een aardverschuiving teniet gaat. Het tenietgaan van de opstallen ten gunste waarvan het opstalrecht is gevestigd, leidt in beginsel niet tot het tenietgaan van het opstalrecht, tenzij het opstalrecht beperkt is tot de bestaande bouwwerken en de opstaller onbevoegd is nieuwe opstallen te verwezenlijken. ${ }^{967}$ Wanneer de opstaller gedurende een onafgebroken periode van 30 jaar geen gebruik heeft gemaakt van zijn opstalrecht gaat het recht teniet door (bevrijdende) verjaring. ${ }^{968}$

$960 \quad$ Hoofdstuk $4 \$ 3$.

961 Vandenberghe \& Viaene 2006, p. 54.

962 Een accessoir opstalrecht gaat in beginsel teniet wanneer het hoofdrecht waaraan het opstalrecht accessoir is teniet gaat.

963 Art. 9 Opstalwet. Deze opsomming is niet-limitatief; het recht van opstal gaat eveneens teniet door de algemene wijzen van tenietgaan van zakelijke rechten.

964 Van Oevelen 1992, nr. 33. In dit verlengde stellen Derine, Van Neste en Vandenberghe dat beëindiging door vermenging dan ook slechts relatief van aard is. Zie: Derine, Van Neste \& Vandenberghe 1984b, nr. 1029.

$965 \quad$ Kluyskens 1940, nr. 249.

966 Derine, Van Neste \& Vandenberghe 1984b, nr. 1011.

967 Wanneer de grondeigenaar verantwoordelijk is voor het tenietgaan van de grond eindigt het opstalrecht derhalve niet. Zie: Derine, Van Neste \& Vandenberghe 1984b, nr. 1030; Kluyskens 1940, nr. 249; Van Oevelen 1992, nr. 33; Vandenberghe 2005, nr. 983.

968 Art. 2262 BBW. Kluyskens stelt dat het niet gebruiken van een opstalrecht gedurende 30 jaar, 'non-usus', gelijk staat aan verwaarlozing van het recht. Zie: Kluyskens 1940, nr. 249. Nu volgens Sagaeert, Tilleman en Verbeke het recht van opstal beschouwd kan worden als een tijdelijk eigendomsrecht dat op de opstallen rust, dient een rechtvaardigingsgrond te worden gevonden voor het 
Het opstalrecht kan eveneens tenietgaan volgens de algemene wijzen van het tenietgaan van zakelijke rechten zoals door het BBW gegeven. ${ }^{969} \mathrm{Zo}$ gaat het opstalrecht teniet door het verstrijken van de termijn waarvoor het recht is gevestigd $\mathrm{d}^{970}$ en staat het partijen vrij in samenspraak met elkaar het opstalrecht vervroegd, nog vóór het verstrijken van de termijn waarvoor het opstalrecht is gevestigd, te beëindigen. ${ }^{971}$ De opstaller kan ook middels een eenzijdige akte, vervroegd afstand doen van zijn recht. ${ }^{972}$ Daarnaast kan de grondeigenaar de vestigingsovereenkomst die aan het opstalrecht ten grondslag ligt ontbinden wanneer sprake is van wanprestatie aan de zijde van de opstaller, hetgeen leidt tot vernietiging van de vestigingstitel. ${ }^{973}$ Van wanprestatie kan in beginsel enkel sprake zijn wanneer een opstalrecht onder bezwarende titel is gevestigd en de opstaller verzuimt de overeengekomen vergoeding te betalen. ${ }^{974}$

Naast de algemene wijzen van tenietgaan voorziet art. 2 Wet van 14 mei 1955 betreffende Erfpachten uitdrukkelijk in de mogelijkheid het opstalrecht vervallen te doen verklaren wanneer de opstaller de in het eerste artikel van voornoemde wet opgenomen indexering van de bedongen vergoedingen niet betaalt. Daarnaast kan het opstalrecht worden beëindigd door onteigening van de grond ten algemene nutte. De onteigeningsprocedure dient te worden ingesteld tegen de grondeigenaar, die op zijn beurt de opstaller in het geding dient te betrekken zodat ook de opstaller aanspraak kan maken op de vergoeding van zijn recht en opstallen. ${ }^{975}$

Reeds hiervoor is opgemerkt dat aan de opstaller bij beëindiging van het opstalrecht in beginsel een recht op vergoeding toekomt ten aanzien van

tenietgaan van het eigendomsrecht dat zich kenmerkt door het onverjaarbaar zijn. Zij vinden de rechtvaardiging in het tijdelijke karakter van het opstalrecht alsook in het voordeel dat de grondeigenaar geniet van het tenietgaan van het opstalrecht. Zie: Sagaert, Tilleman \& Verbeke 2010, nr. 1008. Mijns inziens kan het opstalrecht niet worden gelijkgesteld aan een tijdelijk eigendomsrecht; het ontstaan van het eigendomsrecht, als de aan de opstaller toekomende bevoegdheden ten aanzien van de opstallen al als eigendom kunnen worden aangemerkt, kàn een gevolg zijn van de vestiging van een opstalrecht. Zie: hoofdstuk 4 \$4.2.1.

969 Sagaert, Tilleman \& Verbeke 2010, nr. 1007.

970 Behoudens vernieuwing van het opstalrecht. Zie: hoofdstuk 4 \$4.2.4.

971 Truyen 2009, nr. 17.

972 Van Muylder \& Verstappen 1992, nr. 19. "De mogelijkheid om een zakelijk recht uit te doven door er afstand van te doen, wordt verklaard door de omstandigheid dat het zakelijk recht uiting geeft aan een verband tussen een persoon en een zaak", aldus Truyen 2009, nr. 7.

973 Art. 1183 en 1184 BBW. Zie: Van Oevelen 1992, nr. 34.

974 Bracke 2007, pp. 547-548.

975 Van Oevelen 1992, nr. 33. 
de opstallen die de opstaller ten tijde van het opstalrecht op het gronderf heeft aangebracht, als ten aanzien van de opstallen die bij aanvang van het opstalrecht in waarde zijn vergoed. ${ }^{976}$ De hoogte van de vergoeding ziet op de economische waarde van de opstallen op het moment van verkrijging van deze opstallen door de grondeigenaar. ${ }^{977}$ Aan de opstaller komt geen recht op vergoeding toe ten aanzien van verbeteringen die de opstaller aan de oude opstallen heeft aangebracht. ${ }^{978}$

De opstaller kan in plaats van vergoeding van de opstallen er ook voor kiezen de opstallen die bij aanvang van het opstalrecht zijn vergoed en de opstallen die gedurende het opstalrecht met het gronderf zijn geïncorporeerd, fysiek van het gronderf af te scheiden. Het staat partijen vrij het wegneemrecht in de vestigingsovereenkomst uit te sluiten of uit te breiden. Op de opstaller rust in beginsel de verplichting het gronderf na wegname van de opstallen te herstellen "in den staat waarin dezelve zich vóór het opbouwen of beplanten bevond". ${ }^{979}$

Tenzij anders in de vestigingsovereenkomst is overeengekomen, komt aan de grondeigenaar bij het tenietgaan van het opstalrecht niet de bevoegdheid toe afbraak van de door de opstaller aangebrachte opstallen te vorderen. ${ }^{980}$ Wanneer het opstalrecht met terugwerkende kracht geacht wordt nooit te hebben bestaan, zoals het geval is bij ontbinding van de vestigingstitel, zijn op de nieuwe opstallen niet de bepalingen van de Opstalwet van toepassing maar dient art. $555 \mathrm{BBW}$ uitkomst te bieden. ${ }^{981}$ Zolang de grondeigenaar niet tot vergoeding is overgegaan, komt aan de voormalig eigenaar van de opstallen het recht van terughouding, retentie, toe. ${ }^{982}$

976 Art. 6 Opstalwet. Opstallen die zich bij aanvang van het opstalrecht op het gronderf bevinden, maar door de opstaller niet in waarde aan de grondeigenaar zijn vergoed, komen bij beëindiging van het opstalrecht niet voor vergoeding in aanmerking (art. 7 Opstalwet). Zie: Vandenberghe 2005, nr. 977.

977 Goeminne 2007, XV.B-42. Het recht op vergoeding kan worden angeduid als een schuldvordering uit ongegronde verrijking; de grondeigenaar wordt immers eigenaar van de met het gronderf geïncorporeerde objecten.

978 Vandenberghe 2005, nr. 977.

979 Art. 5 Opstalwet. Zie: Van Oevelen, Van Poucke \& Van de Velde 1989, nr. 25.

980 Art. 555 BW. Zie: Danau, Dom \& Roodhooft 2010, p. 184; Vandenberghe 2005, nr. 976.

981 Sagaert, Tilleman \& Verbeke 2010, nr. 1011; Vandenberghe 2005, nr. 976.

982 Artikel 6 Opstalwet. 



\section{Hoofdstuk 5. Kan natrekking met de grond naar Schots recht worden doorbroken?}

\section{§1. Inleiding}

\section{Feudalism}

Tot voor kort werden in het Schotse recht de rechten die men ten aanzien van land kon hebben sterk beïnvloed door het feodale stelsel dat in de $12^{\text {de }}$ eeuw na Christus zijn intrede heeft gedaan in het Schotse recht. Krachtens het feodale stelsel kwamen zowel aan de Kroon als aan de vazal bevoegdheden toe ten aanzien van hetzelfde grondstuk. Aangenomen werd dat in beginsel alle grondstukken die tot het Schotse Koninkrijk konden worden gerekend aan de Kroon in eigendom ${ }^{983}$ toekwamen. De Kroon kon besluiten het aan het eigendomsrecht te ontlenen gebruiksrecht ten aanzien van een grondstuk aan een ander, de vazal, toe te kennen in ruil voor persoonlijke diensten. Na toekenning van voornoemde bevoegdheden kon de vazal als houder van de toegekende bevoegdheden worden aangemerkt. De middeleeuwse glossatoren poogden de ten aanzien van een grondstuk bestaande bevoegdheden van Kroon en vazal in te passen in het Romeinsrechtelijke absolute eigendomsbegrip, waardoor er een tweetal 'eigendomsbegrippen' werden geïntroduceerd: de aan de Kroon toekomende bevoegdheden werden aangemerkt als dominium directum, de aan de vazal toekomende bevoegdheden als dominium utile. Door de introductie van deze twee eigendomsbegrippen werd onder het feodale stelsel aangenomen dat ten aanzien van grond sprake was van een duaal eigendomsbegrip. ${ }^{984}$

Commercialisering van de door de vazal te leveren persoonlijke diensten in de $14^{\text {de }}$ eeuw, waarbij deze diensten werden vervangen door financiële verplichtingen, leidde tot wijziging van het persoonlijke karakter van de feodale rechtsfiguur. Het recht van de vazal ten aanzien van de grond leek in grote mate op dat van het absolute eigendomsrecht, aangezien de vazal zijn recht kon overdragen en bezwaren. Maar hoe men het ook wendde of keerde, de eigendom van de grond bleef bij de Kroon liggen. Op 28 november 2004 werd met het van kracht worden van een drietal acts $^{985}$ een eind gemaakt aan

983 Gretton \& Steven 2008, p. 458. Met het Romeinsrechtelijke begrip 'eigendom' wordt niet de exacte lading van de ingevolge de feodale relatie aan de Kroon toekomende bevoegdheden gedekt, nu het begrip 'eigendom' een typisch Romeinsrechtelijk begrip is dat niet in het feodale stelsel voorkwam.

984 Carey Miller 2000, p. 273; Heirbaut 1999, p. 106; Reid 1996, pars. 47-49; Watkin 1999, p. 227.

985 De Abolition of Feudal Tenure etc (Scotland) Act 2000, de Title Conditions 
het feodale stelsel en het daaruit voortvloeiende duale eigendomsbegrip; met de afschaffing van het feodale stelsel is aan de voormalig vazal een absoluut eigendomsrecht toegekend. ${ }^{986}$

\section{Eigendom van een onroerende zaak}

Het eigendomsrecht dat op een grondstuk rust strekt zich uit over de ruimtes die zich onder alsook boven het aardoppervlak bevinden. Het eigendomsrecht brengt mee dat aan de eigenaar een gebruiksrecht ten aanzien van deze ruimtes toekomt. Hoewel het in beginsel een exclusief gebruiksrecht betreft, kan niet iedere inbreuk op dit gebruiksrecht worden aangemerkt als onrechtmatig. Dit zou immers tot maatschappelijk onwenselijke uitkomsten leiden. ${ }^{987}$

Het exclusief gebruiksrecht van de ruimtes boven en onder het aardoppervlak brengt niet mee dat alle objecten die zich binnen deze ruimtes bevinden tot de eigendom van het grondstuk kunnen worden gerekend. Zo gaat een op het grondstuk van een ander geparkeerde auto niet louter door zijn anwezigheid toebehoren aan de eigenaar van de grond. Enkel die objecten die op fysieke wijze duurzaam met het grondstuk zijn verenigd worden door het op het grondstuk rustende eigendomsrecht nagetrokken. ${ }^{988}$ Objecten die middels een bouwwerk met het grondstuk zijn verenigd worden met het grondstuk nagetrokken wanneer de fysieke vereniging duurzaam van aard is èn de vereniging tussen object en bouwwerk ten gunst van het bouwwerk geschiedt. ${ }^{989}$

De vraagstelling die in dit hoofdstuk centraal staat is op welke wijzen de eigendomsnatrekking kan worden doorbroken. Hierbij kan een onderscheid worden gemaakt tussen het wegneemrecht ${ }^{990}$ enerzijds en de separate

986

987 Zo hoeft de piloot van een vliegtuig geen toestemming te vragen aan de eigenaren van de te passeren grondstukken. De eigenaar van een grondstuk kan aan een derde de bevoegdheid toekennen op een bepaalde wijze gebruik te maken van het aan de eigenaar toekomende grondstuk door de vestiging van een servitude (hoofdstuk 5 \$4.3) of een lease (hoofdstuk $5 \S 4.1 .1$ ).

988 In de literatuur worden de natrekkingscriteria aangeduid met de termen 'physical attachment' en 'perpetual use'. Zie: Van der Merwe 2000, p. 247. In hoofdstuk $5 \S 3$ wordt nader op deze criteria ingegaan.

989 Dit criterium, in de Schotse literatuur aangeduid met de term 'functional subordination', heeft zich aan het eind van de $19^{\text {de }}$ eeuw in de jurisprudentie ontplooid en lag voordien 'verscholen' in het duurzaamheidscriterium. Zie: hoofdstuk $5 \S 3$.

990 Het wegneemrecht wordt in de Schotse literatuur aangeduid met de term 'right of severance'. Zie: hoofdstuk 5 \$4. 
tenement ${ }^{991}$ respectievelijk de tenement ${ }^{992}$ anderzijds. Anders dan de overige in dit proefschrift te vergelijken rechtsstelsels is het Schotse recht niet bekend met het zakelijke recht van opstal. Aan de gebruiker ${ }^{993}$ van een onroerende zaak kan de bevoegdheid toekomen een door hem aangebracht object dat door natrekking bestanddeel van de onroerende zaak is geworden weg te nemen. Ten gevolge van de fysieke afscheiding komt aan het afgescheiden object een eigen goederenrechtelijke identiteit toe. Bij de separate tenement en de tenement wordt de natrekking eveneens doorbroken, maar vindt er geen fysieke afscheiding van het object plaats.

\section{§2. Things and rights}

\section{\$2.1 Things}

Het object van the law of property is een thing. ${ }^{994}$ Met het begrip thing kan zowel een lichamelijk object, een zaak, worden aangeduid alsook een recht. Things kunnen in een verschillende categorieën worden onderverdeeld ${ }^{995}$ : een goed is corporeal dan wel incorporeal, heritable dan wel moveable. ${ }^{996}$ Van een corporeal property (verder: lichamelijk goed) is sprake wanneer de thing tastbaar, fysiek van aard is, zoals het geval is bij huizen en fietsen. ${ }^{997}$ Al hetgeen niet lichamelijk van aard is, is incorporeal (verder: onlichamelijk)

$991 \quad$ Hoofdstuk $5 \$ 5.1$.

$992 \quad$ Hoofdstuk $5 \$ 5.2$.

993 Uit $\$ 4.1 .3$ en $\$ 4.1 .4$ van dit hoofdstuk zal blijken dat het wegneemrecht ook kan toekomen aan een niet-gebruiker van de onroerende zaak.

994 Het Schotse privaatrecht maakt een onderscheid tussen the law of persons, the law of things en the law of actions. De grondslag voor dit onderscheid is gelegen in het Romeinse recht. The law of things kan nader worden verdeeld in the law of obligations enerzijds en the law of property anderzijds. Het object van the law of obligations is eveneens een thing. Zie: Gretton \& Steven 2009, nr. 1.13; Reid 1996, par. 16.

995 De onderverdeling van things heeft betrekking op zowel verbintenisrechtelijke als goederenrechtelijke rechtsobjecten.

996 Daarnaast kan een thing fungible dan wel non-fungible zijn. Een fungible property wordt door gebruik verbruikt, zoals het geval is bij geld en granen. Een nonfungible property wordt daarentegen niet door gebruik verbruikt. Een schilderij is een voorbeeld van een non-fungible property. Het onderscheid fungible-nonfungible is binnen het huidige Schotse recht van ondergeschikt belang. Aan dit onderscheid komt nog slechts een kleine rol toe bij de rechtsfiguur liferent. In het kader van dit proefschrift zal niet verder op dit onderscheid worden ingegaan. Liferent komt nader aan bod in \$4.1.2 van dit hoofdstuk. Zie: Bankton 1751, I, III, 17. Miller \& Robson 1991, p. 15.

997 Gretton \& Steven 2009, nr. 1.19; Reid 1996, par. 11. Gas wordt onder het Schotse recht aangemerkt als een lichamelijk goed. Ten aanzien van elektriciteit is het Schotse recht minder duidelijk. Zie: Gretton \& Steven 2009, nr. 3.3. 
van aard. ${ }^{998}$ Het onderscheid tussen heritable property (verder: onroerende goederen) en moveable property (verder: roerende goederen) heeft volgens Bell tot gevolg dat er een tweedeling in het recht is ontstaan: "A double system of jurisprudence, in relation to the subjects of property, has thus arisen in Scotland, as in most European nations; - the one regulating land and arrangements of the feudal system; the other regulating the rights to moveables according to the principles of Roman jurisprudence which prevailed before the establishment of feus" ${ }^{999}$ Onroerende goederen zijn objecten welke immoveable van aard zijn, zoals een grondstuk en de objecten die met het grondstuk op fysieke wijze duurzaam met het grondstuk zijn verenigd. ${ }^{1000}$ Roerend zijn alle goederen die niet onroerend zijn. ${ }^{1001}$ Een roerend goed is in tegenstelling tot een onroerend goed verplaatsbaar, dan wel door anderen dan wel door zichzelf. ${ }^{1002}$ Het recht ten aanzien van roerende goederen is historisch gezien lange tijd ondergeschikt geweest aan het recht van onroerende goederen. ${ }^{1003}$

Het onderscheid onroerend-roerend wordt niet alleen gemaakt ten aanzien van lichamelijke goederen, maar ook met betrekking tot onlichamelijke goederen. Een recht kan, ongeacht of dit een goederenrechtelijk recht dan wel een persoonlijk recht betreft, worden gekwalificeerd als 'incorporeal heritable property' dan wel als 'incorporeal moveable property', hetgeen afhankelijk is van het goed waar het recht betrekking op heeft. ${ }^{1004}$ Het enige recht dat niet vatbaar is voor de onderverdeling roerend-onroerend is ownership, eigendom. Reid onderbouwt dit als volgt: "Ownership,..., is not itself a thing capable of being owned. Thus ownership, alone among the real

998 In de zaak Burghead Harbour Co. v George wordt het onderscheid tussen lichamelijke en onlichamelijke goederen als volgt omschreven: "Res corporales are according to the legal definition physical things which can be touched; and res incorporales are things which do not admit of being handled, but consist in jure, and so are more properly rights than subjects.... All rights, therefore, are incorporeal; and the distinction really is not between two kinds of right, but between things which are object of right and the legal conception of the right itself". Zie: Burghead Harbour Co. v George (1906) 8 F 982 at 996.

999 Bell 1839, §636.

1000 Guthrie 2005, nr. 1.9.

1001 Gretton \& Steven 2009, nr. 1.20.

1002 Bell 1839, $\$ 1472$ omschrijft een moveable als: "Whatever moves, or is capable of being moved from place to place without injury or change of nature in itself, or in the subject with which it is connected, is moveable".

1003 Bell 1839, §1283: "Moveables were of little consideration under our early law.... Moveables unaffected by any of the rules of the feudal law, remained under the rules of a jurisprudence immediately derived from the Civilians; in many of its doctrines modified, and in some respects improved, by the Canonists".

1004 De navolgende rechten worden eveneens als incorporeal heritable property aangemerkt: incompleted real rights in land, personal rights to real rights in land, personal bonds, rights with a tract of future time, goodwill and titles of honours. Zie: Reid 1996, pars. 13-14. 
rights, is not incorporeal property". ${ }^{1005}$ Volledigheidshalve dient te worden opgemerkt dat het mogelijk is eigendom te hebben van onlichamelijke goederen. Op een recht rust een eigendomsrecht en de gerechtigde tot dit recht kan als eigenaar van dit recht worden aangemerkt. ${ }^{1006}$

Het Schotse recht kent op voornoemd onderscheid roerend-onroerend verschillende uitzonderingen. Zo worden onafgescheiden vruchten die worden voortgebracht door beplantingen die duurzaam met het grondstuk zijn verenigd gekwalificeerd als roerend ${ }^{1007}$, wanneer deze vruchten zijn aan te merken als 'industrial fruits'. ${ }^{1008}$ Naast het aanmerken van een uit zijn aard onroerende zaak als roerend, is het evenwel mogelijk een naar zijn aard roerende zaak te benaderen als een onroerende zaak. Hierbij kan een onderscheid worden gemaakt tussen naar hun aard roerende objecten die onroerend zijn op grond van hun bestemming en naar hun aard roerende objecten die enkel in het licht van the law of succession als onroerend worden aangemerkt. ${ }^{1009}$ Een roerende zaak is onroerend door bestemming wanneer de zaak tot doel heeft de onroerende zaak te dienen èn de roerende zaak in constructief opzicht op de onroerende zaak is afgestemd. Zo zijn de 'losse' onderdelen van een met een onroerende zaak verenigde machine en de sleutels van een woning onroerend door bestemming. Objecten die krachtens hun bestemming onroerend zijn, worden met de term 'constructive fixtures' aangeduid. ${ }^{1010}$ Een roerende zaak kan eveneens als onroerend

1005 Het is dan ook niet mogelijk een eigendomsrecht ten aanzien van een eigendomsrecht te hebben. Zie: Reid 1996, par. 14 - noot 3; Gretton \& Steven 2009, nrs. 3.3-3.5.

1006 Dat het hebben van eigendom niet beperkt is tot corporeal property is sterk beïnvloed door het Romeinse recht. Volgens het Romeinse recht was het gebruikelijk dominium te hebben ten aanzien van incorporeal property.

1007 De eigendom van de vruchten komt in beginsel toe aan de grondeigenaar ingevolge natural accession. Van natural accession is sprake wanneer de vruchten zonder menselijk handelen zijn ontstaan. De vruchten kunnen worden aangemerkt als bestanddeel van het grondstuk. Zie: hoofdstuk 5 §3. Zie: Gordon \& Wortley 2009, nrs. 4-38; Stair 1693, II, I, 34; Paul v Cuthbertson (1840) 2 D 1286.

1008 Tot de industrial fruits behoren niet alleen de jaarlijkse vruchten die aan de bomen groeien en die voor de handel zijn bestemd, maar ook gewassen die ten behoeve van derden worden gepland of gezaaid. Deze constructie maakt het mogelijk de vruchten aan derden in eigendom over te dragen, terwijl zij nog met het grondstuk zijn verbonden. De bomen waaraan de vruchten groeien kunnen niet als industrial fruits worden aangemerkt. Zie: Erskine II, II, 4. Het is opmerkelijk dat bomen die gekweekt worden ten behoeve van de handel evenmin als industrial fruits kunnen worden aangemerkt. Zie: Paul v Cuthbertson (1840) 2 D 1286.

1009 In de literatuur wordt deze omzetting met de term 'implied destinaton' aangeduid.

1010 Reid 1996, nr. 576. 
worden bestempeld wanneer de erflater de wil heeft geuit de zaak te willen 'omzetten'. De erflater is niet aan enig vormvereiste gebonden bij het wijzigen van de aard van het object; de intentie van de eigenaar kan zowel impliciet als expliciet blijken. De 'omgezette' zaak is enkel en alleen in het licht van the law of succession te kwalificeren als onroerend. Ten aanzien van alle andere rechtsgebieden blijft de betreffende zaak roerend van aard. ${ }^{1011}$

In dit hoofdstuk ligt de nadruk op de real rights ${ }^{1012}$ die op een heritable corporeal property kunnen rusten en die (mogelijkerwijs) leiden tot doorbreking van de eigendomsnatrekking met het grondstuk.

\section{\$2.2 Ownership in relatie tot corporeal heritable property}

\section{§2.2.1 De invloed van het feodale stelsel op het eigendomsrecht}

Tot aan de afschaffing van het feodale stelsel in 2004 was het in beginsel ${ }^{1013}$ niet mogelijk als 'gewone man' eigendom van een grondstuk te hebben. ${ }^{1014}$

1011 Lange tijd werd het maatschappelijk wenselijk geacht vele naar hun aard roerende zaken aan te merken als onroerend. Deze behoefte kwam voort uit de gedachte dat bij het overlijden van de erflater een zo groot mogelijke heritable estate aan de heir, zijnde de mannelijke sole representative of the family, toe diende te komen. De overige erfgenamen, de executors, “... must be contented with that part of the succession which is of a more perishable nature, and which in value bears generally but a small proportion to the share falling to the heir", aldus Erskine. Zie: Erskine 1773, II, II, 2. Zo werden paarden, meubels, boeken en sierraden tot de heritable property gerekend. Tot aan de invoer van de Succession (Scotland) Act 1964 kwamen, wanneer er geen testament door de erflater was opgemaakt, alle onroerende goederen toe aan de heir en alle roerende goederen aan de executor. Zie: Bell 1839, §1475; Guthrie 2005, nr. 1.13; Carey Miller \& Irvine 2005, nrs. 3.17-3.18; Van der Merwe 2000, pp. 248-249; Reid 1996, pars. 15 en 576. Zie ook: Fairlie's Trustees v Fairlie's Curator Bonis (1932) SC 216.

1012 Met de term 'real right' worden rechten bedoeld die de relatie tussen een persoon en een zaak weerspiegelen. Een personal right geeft de relatie tussen twee of meerdere personen weer. Het meest omvattende real right is eigendom. Naast eigendom erkent het Schotse recht de volgende zakelijke rechten: possession, right in security, proper liferent, servitude, real burdens, lease, rights held by public en exclusive privileges. Zie: Reid 1996, par. 5; Paisley 2005, pp. 268269. Gretton en Steven stellen ter discussie of rights held by public, exclusive privilege en possession als real right dienen te worden aangemerkt. Zie: Gretton \& Steven 2009, nr. 2.10.

1013 Ten aanzien van zowel allodial-als anomalies property was het mogelijk absolute eigendom te hebben. Zie: Reid 1999, par. 47. Bij allodial property kan gedacht worden aan kerken en begraafplaatsen, maar ook aan de Orkney en de Shetland eilanden aangezien zij evenmin aan de Kroon toebehoorden. Allodial land betrof ongeveer 20\% van het Schotse grondoppervlak. Zie: Gordon 1999, nrs. 3-02 tot 3-12; Miller \& Robson 1991, pp. 39-40.

1014 Reid 1996, par. 42. 
Het feodale stelsel is gebaseerd op de gedachte dat alleen de Kroon als eigenaar van een grondstuk kan worden aangemerkt. Hoewel de oorsprong van het feodale stelsel in de $8^{\text {ste }}$ eeuw na Christus ligt ${ }^{1015}$, heeft het tot de $12^{\text {de }}$ eeuw geduurd voordat zij haar entree maakte in het Schotse rechtsstelsel. Op grond van deze feodale rechtsverhouding kende de Kroon de gebruiksbevoegdheden die voortkomen uit het aan de Kroon toekomende en op het grondstuk rustende eigendomsrecht toe aan een onderdaan, de vazal, door middel van een grant $^{1016}$ in ruil voor het verlenen van diensten ${ }^{1017}$, zoals militaire en kerkelijke diensten. ${ }^{1018}$ De Kroon was bevoegd de overeenkomst te herroepen wanneer zij dit beliefde, ten gevolge waarvan de door de vazal verworven bevoegdheden weer bij de Kroon kwamen te liggen. ${ }^{1019}$ De relatie tussen Kroon en vazal was aanvankelijk persoonlijk van aard, waarbij de Kroon werd aangeduid met de term 'feudal superior' of 'grantor' en de onderdaan als 'feudal vassal' of 'grantee'. De middeleeuwse glossatoren en commentatoren en latere generaties juristen poogden de ten aanzien van een grondstuk bestaande bevoegdheden in te passen in het Romeinsrechtelijke absolute eigendomsbegrip, waardoor er een tweetal 'eigendomsbegrippen' werden geïntroduceerd: de bevoegdheden van de Kroon werden aangemerkt als het 'dominium directum' en de aan de vazal toekomende bevoegdheden als het 'dominium utile'. ${ }^{1020}$ In beginsel was de

1015 Het feodale recht heeft zich gedurende de $8^{\text {ste }}$ eeuw in het Frankische recht, onafhankelijk van zowel het Romeinse als Germaanse recht, tot een zelfstandig rechtsstelsel ontwikkeld dat gebaseerd is op het gewoonterecht. De feodale rechtsfiguur is ontstaan door het samengaan van een tweetal reeds bestaande rechtsfiguren: benefice en vassalage. Benefice is in grote lijnen gelijk te stellen met het van Romeinse oorsprong zijnde ususfructus. Aan de houder van een benefice kwam het gebruiksrecht met betrekking tot een bepaald grondstuk toe. In ruil voor dit gebruiksrecht lag er aan de zijde van de houder een verplichting tot het betalen van een kleine vergoeding. Met de rechtsfiguur vassalage werd een verbond tussen twee heren aangeduid, waarin ze elkaar over en weer verplichtten voor elkander te zorgen en elkaar te beschermen. Deze verplichting was wederkerig ongeacht het verschil in stand. Het samengaan van beide rechtsfiguren leidde tot het ontstaan van het feodale rechtsstelsel waarbij in ruil voor het gebruiksrecht van de grond op de gerechtigde tot dit gebruiksrecht de verplichting kwam te rusten militaire bijstand te verlenen. Zie: Ganshof 1996, p. 15 e.v.; Reid 1996, par. 43.

1016 Een grant is een schriftelijke overeenkomst.

1017 Stair 1693, II, 3, 8: "There is necessarily implied in fees, some rent or return to the superior, for the fee, which may be either service, money, or other fungible, or prayers and supplications, as in fees mortified to the kirk, or other performance, or at least the vassal's fidelity to the superior, implying, not only negative, that he may not wrong the superior, but positive, that he must reveal to his superior any design against his life or fame".

1018 Gordon 1999, nrs. 2-08 en 2-11.

1019 Miller \& Robson 1991, p. 36.

1020 Stair 1693, II, 3, 7: "There must remain a right in the superior, which is called 
vazal op zijn beurt vrij de door hem verworven bevoegdheden ten aanzien van het grondstuk aan een derde toe te kennen in ruil voor diensten. ${ }^{1021}$

Gedurende de late middeleeuwen onderging het feodale stelsel onder invloed van economische belangen een verstrekkende wijziging. Hoewel de feodale rechtsverhouding tussen superior en vazal bleef bestaan waarbij aan devazal een gebruiksrechtvan de grond toekwam, bestond de wederkerigheid niet langer uit het verlenen van diensten ${ }^{1022}$, maar uit het betalen van een jaarlijks terugkerende vergoeding, de feuduty. ${ }^{1023}$ Doordat aan de feuduty in de regel geen inflatiecorrectie was gekoppeld verminderde de waarde van de feuduty in de loop der tijd dusdanig dat de superior doorgaans geen aanspraak meer maakte op de feuduty. ${ }^{1024}$

dominium directum; and withal, a right in the vassal, called dominium utile: the reason of the distinction and terms thereof is, because it can hardly be determined, whether the right of property is in the superior or vassal alone, so that the other should only have a servitude upon it; though some have thought superiority but a servitude, the property being in the vassal, and others have thought the fee itself to be but a servitude, to wit, the perpetual use and fruit; yet the reconciliation and satisfaction of both, have been well found out in this distinction, whereby neither's interest is called a servitude". Zie: Rüfner 2010, p. 129; Carey Miller 2000, p. 273; Coing 1953, pp. 348-371.

1021 Het toekennen van gebruiksbevoegdheden aan een ander wordt veelal aangeduid met het begrip 'subinfeudation'. De bevoegdheden verlenende vazal werd in de relatie tot de derde aangeduid als 'midsuperior' en de derde als 'vassal'. Deze toekenning van bevoegdheden dient uitdrukkelijk niet als een overdracht van bevoegdheden te worden aangemerkt; de op de vassal/midsuperior rustende verplichtingen ten aanzien van de Kroon bleven ondanks de subinfeudation voortbestaan. Zie: Carey Miller 2000, p. 277; Gordon 1999, nr. 2-02.

1022 Militaire diensten werden op grond van de Tenures Abolition Act 1746 uitdrukkelijk verboden en vervangen door de verplichting tot betaling van een financiële vergoeding.

1023 Met de invoer van Land Tenure Reform (Scotland) Act 1974, s. 1(1) is het niet langer toegestaan nieuwe feuduties te doen ontstaan: "No deed executed after the commencement of this Act shall impose feuduty; but a deed executed after that date which contains a grant of land in feu shall have effect otherwise as if the grant were subject to a feuduty". Afspraken omtrent reeds bestaande feuduties dienen te worden beëindigd, waarbij aan de superior het recht toekomt een afkoopsom te vragen, zo volgt uit s. 4(1) van voornoemde Act: "Subject to the provisions of this section and of any agreement in relation to the redemption of feuduty made before the commencement of this Act, and without prejudice to any existing method of redemption, any proprietor of a feu may, at any term of Whitsunday or Martinmas, redeem the feuduty which, as at the date of the notice aftermentioned, is exigible in respect thereof". Zie ook: Reid 2003, p. 153.

1024 Zie: Gordon 1999, nrs. 22-3 tot 22-28; SLC 1999, par. 3.1. Zie voor een uitvoerige verhandeling over de feuduty: Reid 2003 chapter 10. 
Bij de afschaffing van het feodale stelsel op 28 november $2004^{1025}$ is er voor gekozen aan de vazal het absolute eigendomsrecht van het grondstuk toe te kennen. ${ }^{1026}$ Met de afschaffing van het feodale stelsel werd dan ook het duaal eigendomsbegrip afgeschaft en deed ook in het Schotse recht het absolute eigendomsbegrip van onroerende zaken zijn intreden.

\section{$\S 2.2 .2$ Inhoud en reikwijdte van het eigendomsrecht met betrekking tot een grondstuk}

Erskine definieert ownership als: "... the right of using and disposing of a subject as our own, except in so far as we are restrained by law of paction. This right necessarily excludes every other person but the proprietor; for if another had a right to dispose of the subject, or so much as to use it, without this consent, it would not be his property, but common to him with that other. Property therefore implies a prohibition that no person shall encroach upon this right of the proprietor". ${ }^{1027}$ De bevoegdheden die aan de eigenaar toekomen lijken in de afgelopen 200 jaar nauwelijks te zijn veranderd, hetgeen blijkt uit de definitie van ownership zoals door Reid en Van der Merwe opgesteld: “... it embraces the power to use, to enjoy the fruits, to consume, to possess, to dispose, to reclaim, and to resist any unlawful invasion". ${ }^{1028} \mathrm{Al}$ deze bevoegdheden tezamen kunnen worden vervat in the right to exclusive use and enjoyment dat aan de eigenaar ten aanzien van zijn grondstuk toekomt. Dit recht is niet beperkt tot de grenzen van het grondstuk in het horizontale vlak ${ }^{1029}$, maar strekt zich eveneens uit

1025 Met het van kracht worden van de AFT(S)A 2000 zijn op 28 november 2004 alle eeuwigdurende tenures komen te vervallen. De gekozen datum van 28 november 2004 is alles behalve willekeurig; de op dat moment wèl nog van kracht zijnde feuduties dienden namelijk jaarlijks op 28 mei dan wel op 28 november te worden voldaan.

1026 AFT(S)A 2000, s. 2: "An estate of dominium utile of land shall, on the appointed day, cease to exist as a feudal estate but shall forthwith become the ownership of the land and, in so far as is consistent with the provisions of this Act, the land shall be subject to the same subordinate real rights and other encumbrances as was the estate of dominium utile". Derden die door de afschaffing van het feodale stelsel rechten verloren, werden in staat gesteld compensatie te vorderen. Zie: AFT(S)A 2000, s. 10 .

1027 Erskine 1773, II, I, 1. Zie ook: Bankton 1751, II, I, 6.

1028 Reid \& Van der Merwe 2004, pp. 659-660.

1029 Hetgeen als grens kan worden aangemerkt volgt uit de uitleg en de context van de title. Sinds 1617 is een grondeigenaar verplicht zijn grondstuk te registreren. Registratie geschiedde van oudsher in het Register of Sasines. Dit register kenmerkt zich door een negatief stelsel; een nietige titel kan door registratie niet worden 'gerepareerd'. Het Register of Sasines is met het van kracht worden van de Land Registration (Scotland) Act 1979 (verder: LR(S) A 1979) vervangen door de Land Register. Ander dan de Register of Sasines kan de Land Register worden aangemerkt als een positief stelsel; inschrijving 
over de ruimtes die zich zowel boven als onder het aardoppervlak van het grondstuk bevinden. ${ }^{1030}$

Op grond van the right to exclusive use and enjoyment is de eigenaar bevoegd het gebruik dan wel het genot geheel of gedeeltelijk aan een ander over te dragen. Dit kan door middel van overdracht van het eigendomsrecht dan wel door vestiging van een beperkt recht. Overdracht van een op een grondstuk rustend eigendomsrecht geschiedt door registratie van de deed of de conveyance in het register ${ }^{1031}$, waarbij de naam van de vervreemder wordt doorgehaald en de naam van de verkrijger wordt ingeschreven. ${ }^{1032} \mathrm{Bij}$ vestiging van een beperkt recht verkrijgt een derde de bevoegdheid gebruik te maken van het grondstuk ${ }^{1033}$; de eigenaar dient de overeengekomen beperking op zijn right to exclusive use and enjoyment te eerbiedigen. Naast het vestigen van een beperkt recht, kan de rechtvaardigingsgrond voor het beperking van the right to exclusive use and enjoy gelegen zijn in case law en wettelijke bepalingen. ${ }^{1034}$

van een nietige titel leidt tot een geldige titel. Het bepalen van de horizontale grenzen van een grondstuk is zeer eenvoudig, omdat registratie geschiedt op basis van een map-based system. Deze map, de Ordnance Survey map, geeft de grenzen van ieder perceel nauwkeurig weer. Zie: Paisley 2000, pp. 135-137 als ook de website van the Land Registry, <http://www.landregistry.gov.uk> (18 augustus 2012).

1030 Aan het Schotse eigendomsrecht ligt het Romeinsrechtelijke cuius est solum eius est usque ad coelum et ad inferos-beginsel ten grondslag; de eigenaar van het aardoppervlak is tevens eigenaar van de ruimtes die zich boven als onder het aardoppervlak bevinden. Dit beginsel is in de zaak Glasgow City and District Rly Co v Macbrayne (1883) 10 R 894 at 899 bevestigd: "A conveyance of any land in unqualified terms gives a right of property in the substance or solid contents of the land without any assignable limit. This is what is meant by a conveyance being a coelo ad centrum'. There are no limits in the vertical direction except such as physical conditions impose”. Zie: Gretton \& Steven 2009, nr. 14.13.

1031 In het Land Register.

1032 Gretton \& Steven 2009, nr. 1.24 alsook de nrs. 6.30-6.34.

1033 Hetgeen zowel bij vestiging van een lease als bij een servitude het geval zal zijn. Zie: hoofdstuk $5 \$ 4.1 .1$ en $\$ 6.1$.

1034 Paisley geeft een opsomming van de algemeen aanvaarde beperkingen: Limitations on geographic extent; limitations arising because of extent of legal share; limitations arising from agreement; statutory limitations; and common law limitations such as nuisance. Zie verder: Paisley 2000, pp. 125-135. 


\section{§3. Accession van een moveable met een heritable}

\section{$\S 3.1$ Accession in het algemeen}

Het eigendomsrecht van een grondstuk is niet beperkt tot het aardoppervlak, maar strekt zich uit over de ruimtes die zich boven en onder het aardoppervlak bevinden. De objecten die zich binnen deze ruimtes bevinden, behoren niet per definitie in eigendom toe aan de grondeigenaar. Het vliegtuig dat door het luchtruim boven een grondstuk vliegt alsook het wild konijn dat over het grondstuk huppelt ${ }^{1035}$ zijn beide voorbeelden van objecten die zich wel boven of op het aardoppervlak van het grondstuk bevinden, maar niet aan de grondeigenaar toebehoren. Of de eigenaar van een grondstuk kan worden aangemerkt als eigenaar van de op of in het grondstuk bevindende objecten, wordt bepaald aan de hand van het leerstuk accession (verder: natrekking). ${ }^{1036}$ Natrekking treedt op wanneer verschillende objecten op een zodanige wijze met elkaar zijn verbonden dat er sprake is van een intimate connection die het rechtvaardigt dat de rechten rustende op de hoofdzaak zich uitstrekken over het met de hoofdzaak verenigde object. Natrekking heeft tot gevolg dat aan het met de hoofdzaak verenigde object niet langer een eigen goederenrechtelijke identiteit toekomt ${ }^{1037}$; het object dient als bestanddeel van de hoofdzaak te worden aangemerkt.

In de Schotse literatuur worden een tweetal vormen van natrekking onderscheiden: natural accession enerzijds en industrial accession anderzijds. ${ }^{1038}$ Bell omschrijft natural accession als: “... increase or augmentation which proceeds from the production of fruits, ...; or from the propagation of animals". ${ }^{1039}$ De vruchten kunnen als bestanddeel worden aangemerkt

1035 Carey Miller 1986, pp. 3-5.

1036 Natrekking ziet op het samengaan van corporeal property. Zie: Paisley 2000, par. 3.6.

1037 Erskine 1773, II, I, 14.

1038 Bankton 1751, II, 1, 10; Bell 1839, §1297.

1039 Bell 1839, §1297. Anders dan Bell geeft Bankton een ruimere inhoud aan het begrip natural accession. Bij uitbreiding van een grondstuk door middel van aanwas, Romeinsrechtelijk aangeduid met de term 'alluvio', doet zich volgens Bankton eveneens natural accession voor. Zie: Bankton 1751, II, 1, 10. Van alluvion is alleen dan sprake wanneer het toegevoegde gedeelte geleidelijk is ontstaan, blijvend van aard is en de toevoeging niet door menselijk handelen is bewerkstelligd. Bij uitbreiding van een grondstuk ten gevolge van het wijzigen van de waterloop door het bouwen van een dam, is geen sprake van alluvion maar van avulsion. Zie: Stirling v Bartlett (1993) SLT 763. Terwijl bij alluvion de grondeigenaar tevens als eigenaar van het toegevoegde gedeelte kan worden aangemerkt, zal bij avulsion de oorspronkelijk eigenaar van het toegevoegde gedeelte ook na de 'herplaatsing' eigenaar blijven. Zie: Erskine 1773, II, I, 14; Gretton \& Steven 2009, nr. 8.15. 
en gaan krachtens natural accession toebehoren aan de eigenaar van het voortbrengende object, de hoofdzaak. ${ }^{1040}$ Anders dan bij natural accession is er voor het bewerkstelligen van industrial accession menselijk handelen vereist. "Industrial accession is produced by the art or industry of man", aldus Bell. ${ }^{1041}$ Voor het doen intreden van industrial accession is het niet vereist dat met de handeling de natrekking wordt beoogd. Industrial accession kan optreden tussen twee of meer roerende objecten ${ }^{1042}$, tussen grondstukken onderling als tussen een roerend object en een heritable. In de hierop volgende paragrafen zal nader worden ingegaan op de industrial accession van een corporeal moveable property met een corporeal heritable property. ${ }^{1043}$

\section{$\S 3.2$ Accession van een moveable met een grondstuk vanuit historisch perspectief}

"Things, by their own nature moveable, might become immoveable, by their being fixed or united to an immoveable subject for its perpetual use, as stone, marble, wood, used either in building any edifice, or for additional ornaments to it after it is built”. ${ }^{1044}$ Uit dit citaat van Erskine volgt dat een roerende zaak als onroerend kan worden aangemerkt wanneer er tussen het grondstuk en de zaak een physical attachment bestaat voor perpetual use. ${ }^{1045}$ Deze twee criteria vormen de basis voor het leerstuk natrekking. De nadere invulling die aan deze criteria wordt gegeven is afhankelijk van de maatschappelijke behoeften. Objecten die op een zodanige wijze met het grondstuk worden verenigd dat ze met het grondstuk in eigendom worden nagetrokken, worden aangeduid met de term 'fixture'. ${ }^{1046}$

Bij de opkomst van de industriële revolutie oordeelde de Court of Session in de zaak Fisher v Dixon ${ }^{1047}$ dat machines die zijn geleased met het oog op de

1040 Bell 1839, §1297; Paisley 2000, par. 3.12.

1041 Bankton 1751, II, I, 15; Bell 1839, \$1298.

1042 Volgens de Institutionele schrijvers dienen vermenging, 'commixtion', en zaaksvorming, 'specification', als vormen van natrekking te worden aangemerkt. Zie: Bankton 1751, II, I, 12-15; Bell 1839, §§1296-1298. De moderne schrijvers erkennen de relatie tussen de natrekking enerzijds en vermenging respectievelijk zaaksvorming anderzijds, maar zien vermenging en zaaksvorming niet als vormen van natrekking maar als separate rechtsfiguren. Zie: Reid 1996, nrs. 539 en 588.

1043 Natrekking van een roerende zaak met een grondstuk wordt in het Romeinse recht aangeduid met de term 'inaedificatio'.

1044 Erskine 1773, II, II, 2. Zie ook: Stair 1693, II, I, 2.

1045 Van der Merwe 2000, p. 247.

1046 Is een object met een onroerende zaak verenigd, maar leidt de vereniging niet tot natrekking van het object met de onroerende zaak dan wordt het object aangeduid met de term 'fitting'. Zie: Paisley 2000, par. 3.7; Reid 1996, par. 578.

1047 Fisherv Dixon (1843) 5 D 775. 
handel roerend van aard zijn. Deze machines, zogenaamde 'trade fixtures'1048, dienen als moveable property te worden aangemerkt ${ }^{1049} \mathrm{nu}$ zij 'enkel' zijn aangebracht in het belang van de handel. In de zaak Syme v Harvey voegde de Court of Session hieraan toe dat ook dient te worden gekeken naar de relatie die de aanbrenger van de objecten heeft met het grondstuk. ${ }^{1050}$ Wanneer de relatie van de aanbrenger van het object met het grondstuk tijdelijk van aard is, zoals in het geval van lease, wordt niet voldaan aan het perpetual use-criterium; het object wordt dan niet aangebracht in het belang respectievelijk voordeel van de grond, maar in het belang van de handel die de aanbrenger drijft. ${ }^{1051}$

Door bij de invulling van de natrekkingscriteria zowel rekening te houden met het doel waarmee het object met het grondstuk is verenigd als met de relatie waartoe de aanbrenger van het object tot het grondstuk staat, worden de natrekkingscriteria op subjectieve wijze ingevuld, hetgeen tot grote rechtsonzekerheid kan leiden. Met het wijzen van de zaak Brand's Trs v Brand's Trs ${ }^{1052}$ heeft de House of Lords aan deze rechtsonzekerheid een eind gemaakt. Gezien de grote invloed die dit arrest heeft gehad op het Schotse goederenrecht mag een uitvoerige bespreking ervan niet ontbreken.

Robert Brand sr. is gerechtigde, tenant, tot een lease welke hij is aangegaan voor de duur van 19 jaar ten aanzien van een grondstuk waarop hij een kolenmijn heeft verwezenlijkt. Bij Robert's overlijden in 1873 zijn pas 8 van de 19 lease-jaren verstreken. Alle goederen van Robert gaan over op zijn zoon Robert Brand jr. die een aantal maanden na zijn vader sterft. Robert jr. heeft op zijn beurt al zijn goederen bij testament toegewezen aan zijn trustees. Echter op het moment dat Robert jr. sterft heeft hij de leeftijd van 21 jaar nog niet bereikt, en was hij volgens het toen geldende recht niet bevoegd testamentair over zijn onroerende goederen te beschikken. Dit heeft tot gevolg dat enkel de aan Robert jr. toebehorende roerende goederen overgaan aan de door Robert jr. aangewezen trustees; de onroerende goederen komen toe aan Robert jr.'s erfgenaam Alexander Brand. Maar ook Alexander is geen lang leven beschoren en hij overlijdt niet veel later. Bij testament heeft Alexander bepaald dat al zijn roerende en onroerende goederen toekomen aan zijn trustees. De trustees van zowel Robert jr. en Alexander komen met elkaar overeen dat alle onroerende goederen inclusief de lease overgaan op Alexander's trustees; alle roerende goederen komen toe aan de trustees

1048 Hoewel het gebruik van de term 'fixtures' doet vermoeden dat deze machines als bestanddeel van het grondstuk dienen te worden gekwalificeerd, wordt de term 'fixture' hier in oneigenlijke zin gebruikt. Uit het arrest volgt dat de machines als zelfstandige, roerende zaken dienen te worden aangemerkt.

1049 Van der Merwe 2000, p. 252.

1050 Syme v Harvey (1861) 24 D 202 at 210.

1051 Van der Merwe 2000, pp. 254-255.

1052 Brand's Trs v Brand's Trs (1876) 3 R 16. 
van Robert jr. Onduidelijk is of de kolenmijn, bestaande uit een fabriek en machines, te kwalificeren is als roerend dan wel als onroerend. Partijen besluiten deze rechtsvraag aan de rechter voor te leggen. Ze komen overeen dat wanneer de rechter besluit dat de objecten roerend van aard zijn, de zaken desalniettemin bij Alexander's trustees blijven, maar op hen de verplichting komt te rusten de waarde van de roerende objecten te vergoeden.

Lord Shand, rechter in eerste aanleg, bepaalde dat: “... the machinery and plant, and those parts thereof, are heritable, and belong to the trustees of the late Alexander Brand ...”. In dit verlengde stelde Lord Shand dat alle machines, zowel direct als indirect verbonden met de grond, alsook die zaken die niet physically attached zijn maar wel ten dienste staan tot een specifieke machine, onroerend zijn en toekomen aan Alexander's trustees. Buitengewoon opmerkelijk is diens stellingname dat de machines evenals de fabriek gezien moeten worden als een bestanddeel van het incorporeal right, de lease. Lord Gifford, rechter in tweede instantie, reageerde afwijzend op de eerste uitspraak: "A lease is an incorporeal right, and it is difficult to follow what is meant by fixture to a lease. Fixture to the subject of a lease is not the same as fixture to or incorporation with the lease itself" 1053.1054 "Now, it humbly appears to me that if trade fixtures do not go to the landlord, they must of necessity remain the moveable property of the tenant and must remain moveable quoad omnia. The only thing that can make them heritable is their fixture, - their annexation to the soil; but that would carry them to the landlord to whom alone the soil belongs. If the fixtures have not this effect, and this is conceded, it is difficult to see how it can make them heritable to any effect at all. The tenant could remove the fixtures at pleasure. He could convey them by assignation ... . The tenant could bequeath them by will or testament, separate from the mineral lease ..." ${ }^{1055}$ Lord Gifford schuift het oordeel van Lord Shand dan ook terzijde en stelt dat zowel de fabriek alsook de machines als trade fixtures zijn aan te merken en op grond van deze kwalificatie roerend van aard zijn ${ }^{1056}$; een oordeel dat aansluit bij de zaken Fisher v Dixon ${ }^{1057}$ en Syme v Harvey ${ }^{1058}$.

1053 Brand's Trs v Brand's Trs (1874) 2 R 258 at 270.

1054 In het arrest Brand's Trs v Brand's Trs (1874) 2 R 258 at 270 reageert Lord Chelmsford hier als volgt op: "If the argument was as represented it was certainly incorrect, for the machinery was not fixed to the lease, but to the subject of it, the colliery; nor do I comprehend what it meant by a lease being an incorporeal right. Leases may be of incorporeal as well as of corporeal hereditaments, but a lease itself is neither corporeal nor incorporeal".

1055 Brand's Trs v Brand's Trs (1874) 2 R 258 at 269-270.

1056 Brand's Trs v Brand's Trs (1874) 2 R 258 at 270.

1057 Fisher v Dixon (1843) 5 D 775.

1058 Syme v Harvey (1861) 24 D 202. 
Lord Cairns, lid van the House of Lords komt vervolgens met een geheel eigen insteek:"... there are with regard to matters of this kind, which are included under the comprehensive term of "fixtures", two general rules,... . My Lords, one of those rules is the general well-known rule that whatever is fixed to the freehold of land becomes part of the freehold or the inheritance. The other is quite a different and separate rule. Whatever once becomes part of the inheritance cannot be severed by a limited owner, whether he be owner for life or for years, ... . But to the second rule, namely, the irremovability of things fixed to the inheritance, there is undoubtedly ground for a very important exception. That exception has been established in favour of the fixtures which have been attached to the inheritance for the purpose of trade, and perhaps in a minor degree for the purpose of agriculture. But,..., the exception is not to the first of these rules, but the exception is to the second. Under that exception a tenant who has fixed to the inheritance things for the purpose of trade has a certain power of severance and removal during the tenancy". ${ }^{1059}$ Uit dit citaat volgt dat de natrekking en het wegneemrecht twee verschillende rechtsfiguren zijn. Tevens introduceert de House of Lords met dit citaat het wegneemrecht in het Schotse recht. In beginsel komt aan de gebruiker ${ }^{1060}$ van een grondstuk niet de bevoegdheid toe de door hem aangebrachte objecten ${ }^{1061}$ die met het grondstuk op een zodanige wijze zijn verenigd dat van natrekking sprake is, af te scheiden. De bevoegdheid deze objecten van het grondstuk af te scheiden ${ }^{1062}$ kan bestaan wanneer het gaat om trade fixtures of agricultural fixtures.

\section{$\S 3.3$ Accession van een moveable met een grondstuk naar huidig recht}

Volgens het huidige recht is van natrekking ${ }^{1063}$ sprake wanneer voldaan wordt aan de objectieve criteria van physical attachment, subordination en permanency. ${ }^{1064}$ Deze criteria zijn objectief van aard: derden mogen

1059 Brand's Trs v Brand's Trs (1876) 3 R 16 Lord Chancellor at 20.

1060 Niet zijnde de eigenaar van het grondstuk.

1061 Waartoe ook die objecten kunnen worden gerekend die in opdracht van de gebruiker door een derde met het grondstuk zijn verenigd.

1062 Hoofdstuk 5 \$.

1063 Natrekking van een roerende met een onroerende zaak kan zowel direct als indirect. Van directe natrekking is sprake wanneer tussen het grondstuk en de roerende zaak een directe fysieke verbinding bestaat. Bij indirecte natrekking is de onroerende zaak middels een andere zaak met het grondstuk verbonden. Een voorbeeld van indirecte natrekking is de elektriciteitsbedrading in een bouwwerk.De draden zijn niet direct verbonden met het grondstuk maar worden middels het bouwwerk waarmee zij zijn verbonden deel van de heritable property. Zie: Erskine 1773, II, II, 2; Gordon 1999, nrs. 5-07.

1064 Reid 1996, pars. 579-582. 
vertrouwen op de naar buiten toe kenbare situatie. ${ }^{1065}$ Deze objectieve beoordeling brengt mee dat partijen niet kunnen voorkomen of overeenkomen dat natrekking plaatsvindt. ${ }^{1066}$ Het is voor het optreden van natrekking niet noodzakelijk dat aan alle drie de criteria wordt voldaan. Zo kan het physical attachment-criterium op zichzelf al doorslaggevend zijn voor het aannemen van natrekking wanneer afscheiding van het object tot ernstige beschadiging leidt. ${ }^{1067}$ Wanneer dit het geval is wordt veelal gesproken van physical union in plaats van physical attachment. ${ }^{1068}$

Naast de reeds in de voorgaande paragraaf genoemde criteria van physical attachment en permanency wordt in de recente literatuur nog een criterium genoemd, het zogenoemde functional subordination-criterium. Hoewel dit criterium op het eerste oog een nieuwkomer lijkt, is de grondslag voor dit criterium reeds te vinden in het volgende citaat van Erskine: “... fixed or united to an immoveable subject for its perpetual use”. ${ }^{1069}$ Het subordinationcriterium ligt verscholen in de woorden "for its... use", inhoudende dat de samenvoeging dient te geschieden ten gunste van de onroerende zaak. Het zal niet altijd even duidelijk zijn of de samenvoeging ten gunste van het ene of het andere object is. Veelal is de samenvoeging in beider voordeel. In dat geval dient de vraag te worden beantwoord welk van beide objecten het grootste voordeel geniet van de samenvoeging. Het functional subordinationcriterium speelt met name een rol bij indirecte natrekking en wordt niet toegepast bij bouwwerken en technische installaties van aanzienlijke omvang in relatie tot het grondstuk, omdat toepassing van het criterium kan leiden tot een tegenstrijdige uitkomst. Een woning die op een grondstuk wordt verwezenlijkt, zal niet zozeer ten gunste van het grondstuk worden aangebracht, maar ten gunste van de woning zelf. Wanneer het functional subordination-criterium hierop wordt toegepast zal men tot de conclusie komen dat er van natrekking ten gunste van het grondstuk geen sprake

1065 Shetland Islands Council v BP Petroleum Development Ltd (1990) SLT 82.

1066 Tot aan het arrest Brand's Trs v Brand's Trs (1876) 3 R 16 werd aangenomen dat natrekking contractueel kon worden uitgesloten. Zie: Gretton \& Steven 2009, par. 8.4; Reid 1996, pars. 579-582. In het arrest Scottish Discount Co Ltd v Blin (1985) SC 216 at 240 bevestigt Lord Cameron de in de zaak Brand's Trs v Brand's Trs ingeslagen koers: "It is clear enough that parties by private agreement cannot change the legal character of what the law regards and holds to be heritable in character so as to be effectual, in a question with third parties who are strangers to and ignorant of such an agreement, to affect the right of such third parties”. Zie ook: Shetland Islands Council v BP Petroleum Development Ltd (1990) SLT 82.

1067 Aanname van natrekking op grond van het physical attachment-criterium past binnen het stelsel van de wet, dat gericht is op behoud en niet op vernieling van things. Zie: Reid 1996, pars. 579-580.

1068 Reid 1996, pars. 579-580.

1069 Erskine 1773, II, II, 2. 
is; dit staat haaks op de uitkomst van het physical attachment-criterium dat daarentegen wel naar natrekking zal neigen.

Wil van natrekking sprake zijn dan dient uit de fysieke verbinding tussen grondstuk en object te volgen dat het object langdurig ter plaatse blijft. Een viertal aspecten spelen bij het invullen van het permanence-criterium een rol. Ten eerste is de wijze waarop en de mate waarin de objecten met elkaar worden verbonden van belang. Wanneer een aangebracht object op een ingrijpendere wijze wordt verbonden dan doorgaans gebruikelijk is, mag men ervan uitgaan dat het object aangebracht is om langdurig ter plaatse te blijven. ${ }^{1070}$ Een ander aspect dat op een duurzame verbinding kan duiden, is te vinden in de aanpassing van een of beide samengevoegde objecten ten behoeve van de fysieke verbinding. Bij het derde aspect wordt aan de verkeersopvatting een doorslaggevende rol toegekend: is het volgens de verkeersopvatting gebruikelijk het met de onroerende zaak verenigde object achter te laten of mee te nemen wanneer de onroerende zaak van eigenaar wisselt. Zo zal het volgens de verkeersopvatting gebruikelijk zijn dat bij een verhuizing huishoudelijke apparaten, zoals een wasmachine, door de vervreemder worden meeverhuisd. Wat volgens de verkeersopvatting gebruikelijk is kan in de loop der tijd veranderen. ${ }^{1071}$ Het vierde aspect ziet op de tijdspanne die nodig is om een object aan te brengen of te verwijderen. Objecten waarbij het aanbrengen respectievelijk het verwijderen langere tijd in beslag neemt, worden eerder vermoed duurzaam met de onroerende zaak verbonden te zijn. ${ }^{1072}$

\section{$\S 3.4$ De rechtsgevolgen van accession}

Ten gevolge van de natrekking kan het met de hoofdzaak verenigde object als bestanddeel van de hoofdzaak worden aangemerkt. Door de nieuw ontstane eenheid verliest het object dat als bestanddeel kan worden gekwalificeerd haar zelfstandig bestaansrecht. Hierdoor gaan de op het bestanddeel rustende rechten teniet, terwijl de rechten die op de hoofdzaak rusten zich over het bestanddeel uitstrekken. Wanneer een roerende zaak met een onroerende zaak wordt nagetrokken, verandert de aard van het bestanddeel van roerend in onroerend. ${ }^{1073}$ Wanneer hoofdzaak en bestanddeel aan verschillende eigenaren toebehoren heeft natrekking zowel eigendomsverlies aan de zijde van de (voormalig) eigenaar van het met de hoofdzaak verenigde object als

1070 Leigh v Taylor (1902) AC 157.

1071 Howie's Trs v MacLay (1902) 5 F 214 at 220.

1072 TSB Scotland plc v James Mills (Montrose) Ltd 1991 GWD 39-2406.

1073 Erskine 1773, II, II, 2. 
eigendomsverkrijging aan de zijde van de eigenaar van de hoofdzaak tot gevolg. ${ }^{1074}$

Wanneer een bouwwerk gedeeltelijk over de kadastrale grens van het grondstuk is gerealiseerd rijst de vraag of dat gedeelte van het bouwwerk dat over de kadastrale grens is heen gebouwd, de zogenoemde overbouw, met het grondstuk waarmee het is verenigd in eigendom (verticaal) natrekt of dat de overbouw met het bouwwerk waarmee het is verenigd (horizontaal) natrekt. Evenals onder het Belgische recht ${ }^{1075}$, prevaleert onder het Schotse recht de verticale natrekking en wordt de overbouw met het grondstuk waarmee het is verenigd nagetrokken. ${ }^{1076}$

Aan de voormalig eigenaar van het bestanddeel kan een recht op financiële compensatie ${ }^{1077}$ toekomen. Of een recht op compensatie ${ }^{1078}$ bestaat is afhankelijk van de vraag wie verantwoordelijk is voor de handeling die de natrekking tot gevolg had. Is de eigenaar van de hoofdzaak verantwoordelijk voor de vereniging van het object met het bouwwerk, dan heeft de voormalig eigenaar van het bestanddeel in beginsel recht op vergoeding van de waarde van het bestanddeel. De eigenaar van de hoofdzaak kan zich hier niet tegen verweren door zich te beroepen op goede trouw. ${ }^{1079}$ Wanneer niet de eigenaar van de hoofdzaak maar de (voormalig) eigenaar van het bestanddeel verantwoordelijk is voor de natrekking bestaat het recht op compensatie niet, tenzij de voormalig eigenaar van het bestanddeel handelde in the reasonable but mistaken belief dat hij bevoegd was het object met het grondstuk te verenigen. ${ }^{1080}$ Een derde kan eveneens verantwoordelijk zijn voor het verrichten van de handeling die natrekking tot gevolg heeft. Deze

1074 In de zaak Miller v Muirhead (1894) 21 R 658 at 660 stelt Lord Rutherfurd Clark: "No language could be clearer. The trade fixture, by being attached to the ground, becomes "a part of the inheritance", "a part of the freehold". So long as it is so attached it must belong to the owner of the soil, for he is necessarily owner of everything which is part of it. The tenant possesses it as a part of the subject of the lease, but in no other character. He has a right to make it his own by severing it from the soil, but until that right is exercised, he can have no right of property". Zie ook: Brand's Trs v Brand's Trs (1876) 3 R 16 Lord Chelmsford at 22-23; Scottish Discount Co Ltd v Blin (1985) SC 216.

1075 Hoofdstuk 4 §2.2.1.

1076 Reid 1996, par. 179.

1077 Chambers stelt dat wanneer de natrekking geschiedt ten gevolge van de uitoefening van een gebruiksrecht, het partijen vrij staat overeen te komen dat de gebruiker van de heritable afstand doet van zijn recht op financiële compensatie in ruil voor verlenging van het gebruiksrecht. Zie: Chambers 1823 , p. 349.

1078 Het recht op compensatie is gebaseerd op het leerstuk van de ongerechtvaardigde verrijking. Zie: Reid 1996, par. 577.

1079 Reid 1996, par. 577.

1080 Reid 1996. par. 577. Zie ook: Stair 1693, II, I, 39-40. 
derde is alleen dan vergoedingsplichtig wanneer hij te kwader trouw was op het moment van het verrichten van de handeling. De voormalig eigenaar van het bestanddeel kan er in dit geval ook voor kiezen de eigenaar van het grondstuk aan te spreken op grond van ongerechtvaardigde verrijking in plaats van de derde. ${ }^{1081}$

Wanneer het bestanddeel een trade, agricultural, ornamental of domestic fixture betreft kan de voormalig eigenaar van deze objecten -zijnde de gebruiker van de onroerende zaak- in plaats van het vorderen van financiële compensatie, besluiten gebruik te maken van het (mogelijk) aan hem toekomende wegneemrecht. ${ }^{1082}$ De mogelijkheid tot wegname van de aangebrachte objecten kan eveneens bestaan wanneer partijen het wegneemrecht uitdrukkelijk zijn overeengekomen. Op grond van het wegneemrecht kunnen de aangebrachte bestanddelen van de onroerende zaak worden afgescheiden. ${ }^{1083}$ Het wegneemrecht voorkomt noch doorbreekt de natrekking; de fysieke afscheiding van de onroerende zaak leidt tot doorbreking van de natrekking.

\section{§4. Right of severance}

\section{\$4.1 Het ontstaan respectievelijk bestaan van een right of severance}

Doordat het Schotse recht niet bekend is met een real right op grond waarvan een ander dan de eigenaar van het grondstuk eigenaar kan zijn van de met het grondstuk duurzaam verenigde objecten, en ook een eigendomsvoorbehoud de natrekking tussen een object met een onroerende zaak niet kan voorkomen, komt in het Schotse recht een belangrijke rol toe aan the right of severance (verder: wegneemrecht). ${ }^{1084}$ Aan het wegneemrecht ligt de gedachte ten grondslag dat de gebruiker van de onroerende zaak ${ }^{1085}$

1081 Shilliday v Smith (1998) SLT 976.

1082 "There is no doubt, ex hypothesi, a right to remove these fixtures as against the landlord; ... It is not a right in gross; it is not a right collateral to the ownership of the subject; it is a right which of necessity must be annexed to the ownership of the subject, and must be exercised by him who is the owner of the subject". Zie: Brand's Trs v Brand's Trs (1876) 3 R 16 at 21.

1083 De grondslag van het wegneemrecht is gelegen in het Romeinsrechtelijke ius tollendi. Zie: hoofdstuk 5 §4.

1084 Naast de term 'right of severance' worden in de literatuur eveneens de termen 'right of removal' en 'the right to disannex' gebezigd.

1085 Het wegneemrecht ontstaat niet ten aanzien van objecten die door de eigenaar met de aan hem toekomende onroerende zaak duurzaam worden verenigd. De bevoegdheid tot afscheiding van de aangebrachte objecten komt aan de eigenaar van de onroerende zaak reeds toe ingevolge het eigendomsrecht dat op de onroerende zaak rust. Gordon \& Wortley 2009, par. 4-17. 
niet geremd mag worden in diens gebruik van de zaak, doordat het door hem aangebrachte object ook na beëindiging van het gebruiksrecht tot het vermogen van de eigenaar van de onroerende zaak behoort. Na (fysieke) afscheiding van het bestanddeel komt het object in eigendom toe aan de (voormalig) gebruiker van de onroerende zaak. ${ }^{1086}$

Met het invoeren van het wegneemrecht heeft de House of Lords in de zaak Brand's Trsv Brand's Trs aansluiting gezocht bij het Engelse recht, aldus Lord Chelmsford: "The law as to fixtures is the same in Scotland as in England". ${ }^{1087}$ De Court of Sessions wees in de zaak Syme v Harvey het afscheiden van bestanddelen op basis van het doel van aanbrenging nog resoluut af: "The attempted proof of usage in the trade is irrelevant, as usage has not been pleaded in the inferior Court before proof was allowed. The rule in Scotland is well fixed inaedificatum solo cedit solo, and the attempt to show that an exception has been introduced by the English cases has been unsuccessful.... and even if it did, it could not control the law of Scotland where the fundamental principle has always been considered more firmly fixed than it has been in England". 1088

In het voornoemde arrest Brand's Trs v Brand's Trs ${ }^{1089}$ is door de House of Lords gesteld dat een wegneemrecht kan voortvloeien uit een lease: de relatie tenant-landlord. ${ }^{1090}$ Maar ook uit een proper liferent (verder: recht van vruchtgebruik) waarbij aan de liferenter (verder: vruchtgebruiker) een gebruiksrecht toekomt, kan een wegneemrecht voortvloeien. ${ }^{1091}$ Ten aanzien van zowel de lease als het recht van vruchtgebruik kan worden gesteld dat het wegneemrecht accessoir is aan het gebruiksrecht dat aan de tenant respectievelijk de vruchtgebruiker toekomt. Naast de relatie tenantlandlord en liferenter-fiar worden in de literatuur nog een drietal relaties genoemd waarbij aan de gerechtigde een wegneemrecht kan toekomen: de relatie tussen heritable creditors en andere crediteuren, de relatie tussen verkoper en koper en de verhouding heir en executor. Deze opsomming van relaties waarbinnen een wegneemrecht kan bestaan is derhalve nietlimitatief. ${ }^{1092}$ Anders dan bij de lease en het recht van vruchtgebruik, kan het wegneemrecht binnen de relatie heritable creditors and other creditors, seller and purchaser en heir and executor ${ }^{1093}$ enkel bestaan wanneer partijen dit recht uitdrukkelijk zijn overeengekomen.

1086 Reid 1996, par. 586.

1087 Brand's Trs v Brand's Trs (1876) 3 R 16 at 23.

1088 Syme v Harvey (1861) 24 D 202 at 209.

1089 Brand's Trs v Brand's Trs (1876) 3 R 16.

1090 Hoofdstuk 5 §4.1.1.

1091 Hoofdstuk 5 \$4.1.2.

1092 Gordon \& Wortley 2009, nr. 4-18.

$1093 \mathrm{Nu}$ het wegneemrecht binnen de relatie heir-executor enkel een rol speelt ten aanzien van nalatenschappen welke zijn opengevallen vóór 10 september 
In de navolgende paragrafen zal nader worden ingegaan op de voornoemde relaties waarbinnen een wegneemrecht wordt aangenomen. ${ }^{1094}$ Vervolgens zullen de karakteristieken en de reikwijdte van het wegneemrecht worden besproken. ${ }^{1095}$ In $\$ 4.3$ zal worden ingegaan op de servitude (verder: erfdienstbaarheid). $\mathrm{Nu}$ aan de gerechtigde tot een erfdienstbaarheid een gebruiksrecht toekomt ten aanzien van een onroerende zaak, zoals ook bij de lease en het recht van vruchtgebruik het geval is, rijst de vraag of ook aan de gerechtigde tot een erfdienstbaarheid een wegneemrecht toekomt.

\section{\$4.1.1 Landlord and tenant}

De relatie landlord-tenant vindt zijn grondslag in de lease. Op grond van een lease komt aan de tenant ten aanzien van een onroerende zaak een exclusief gebruiksrecht ${ }^{1096}$ toe voor bepaalde duur. ${ }^{1097}$ Op de tenant rust de verplichting een bepaalde vergoeding, rent, te betalen. ${ }^{1098}$ Hoewel de lease een overeenkomst betreft, kan deze rechtsfiguur worden aangemerkt als een real right wanneer aan de in de Leases Act 1449 opgesomde voorwaarden wordt voldaan. ${ }^{1099}$ Zo dient een lease die overeengekomen is

1964, wordt met uitzondering van de in deze noot gegeven informatie in dit proefschrift niet nader ingegaan op het wegneemrecht binnen voornoemde relatie. Bij de verdeling van een vóór 10 september 1964 opengevallen nalatenschap werd een onderscheid gemakt tussen roerende goederen die aan de executor toe werden gekend en onroerende goederen die toekwamen aan de heir. Zie: noot 1011. Het toekennen van een wegneemrecht aan de executor binnen de relatie heir-executor was uiterst zeldzaam, en bestond enkel wanneer het recht tot wegname uitdrukkelijk door de erflater aan de executor was toegekend. Nu met de invoer van de Succession (Scotland) Act 1964 een nalatenschap niet langer aan de hand van het onderscheid roerende en onroerende goederen wordt verdeeld, speelt het wegneemrecht binnen de relatie heir-executor geen rol meer. Zie: Gordon \& Wortley 2009, nr. 4-19; Paisley 2000, pp. 504-505. Zie voor een uitvoerige verhandeling over de Succession (Scotland) Act 1964: Meston 1993.

1094 Hoofdstuk 5 §4.1.1-\$4.1.4.

1095 Hoofdstuk 5 \$4.2.

1096 Dit exclusief gebruiksrecht kan worden omschreven als the use and enjoyment of the property en is afdwingbaar ten opzichte van eenieder, ook ten opzichte van de grondeigenaar.

1097 Een vóór 9 juni 2000 tot stand gekomen lease kende geen beperkingen omtrent de duur waarvoor de lease kon worden gevestigd. Een 999 jaar durende of eeuwigdurende lease is veel voorkomend. Een lease die tot stand is gekomen op of ná 9 juni 2000 kan voor een maximale periode van 175 jaar worden gevestigd. Zie: AFT(S)A 2000, s. 67 alsook McAllister 2002, pars. 1.2-1.5 en 7.43 e.v.

1098 McAllister 2002, par. 1.1.

1099 Hoewel de lease als een real right kan worden gekwalificeerd, is hier geen sprake van een beperkt zakelijk recht. Zie: hoofdstuk 5 §6.1. 
voor de duur van één jaar of langer op schrift worden gesteld. ${ }^{1100}$ Tevens dient de lease betrekking te hebben op een onroerende zaak die door de tenant ook daadwerkelijk in possession moet worden genomen èn ten aanzien waarvan de tenant een exclusief gebruiksrecht toekomt tegen een voldoende gespecificeerde en regelmatig te betalen vergoeding. De termijn waarvoor de lease is overeengekomen en de beëindigingsdatum dienen eveneens in de schriftelijke overeenkomst te zijn opgenomen. ${ }^{1101}$ Een lease die overeengekomen is voor de duur van 20 jaar $^{1102}$ of langer dient in het register te worden ingeschreven ${ }^{1103}$ wil de lease als een real right worden aangemerkt. ${ }^{1104}$

Krachtens het aan de tenant toekomende exclusieve gebruiksrecht is de tenant in beginsel bevoegd wijzigingen aan de onroerende zaak aan te brengen. Deze wijzigingen kunnen eenvoudige aanpassingen betreffen, zoals vloeren raambekleding, maar kunnen ook zien op het verwezenlijken van bouwwerken op of in het in lease gekregen grondstuk. Ongeacht de omvang van de wijziging geldt dat wanneer voldaan wordt aan de voorwaarden van natrekking ${ }^{1105}$ de door de tenant aangebrachte objecten in eigendom overgaan op de eigenaar van de onroerende zaak.

Wanneer de lease eindigt, wordt het maatschappelijk als wenselijk ervaren de tenant financieel te compenseren voor de door hem duurzaam met het grondstuk verenigde objecten dan wel de tenant in de gelegenheid te stellen de aangebrachte objecten weg te nemen. ${ }^{1106} \mathrm{Nu}$ de House of Lords in de zaak Brand's Trs v Brand's Trs ${ }^{1107}$ van mening is dat the law of fixtures onder het Schotse recht overeenkomt met het Engelse recht, kan worden gesteld dat een wegneemrecht kan bestaan ten aanzien van trade, agricultural, ornamental en domestic fixtures. ${ }^{108}$ De bevoegdheid tot wegname van voornoemde bestanddelen bestaat in beginsel alleen wanneer afscheiding van het bestanddeel niet leidt tot vernietiging van het bestanddeel ${ }^{1109}$ èn de ten gevolge van de afscheiding aan het

1100 Tot een jaar kan een lease in beginsel vormvrij tot stand komen. Zie: Shetland Islands Council v BP Petroleum Development Ltd (1990) SLT 82; Requirements of Writing (Scotland) Act 1995, s. 1.

1101 Guthrie 2005, nr. 12.3; McAllister 2002, pars. 2.23-2.27.

1102 Een lease die voor minder dan 20 jaar wordt overeengekomen, kan ook in het register worden ingeschreven wanneer in de overeenkomst is opgenomen dat de duur van de lease kan worden verlengd en met de verlenging de duur van minimaal 20 jaar wordt behaald. Zie: McAllister 2001, par. 7.12.

1103 Registration of Leases (Scotland) Act 1857, s. 1.

1104 LR(S)A 1979, s. 3.

1105 Hoofdstuk $5 \$ 3.3$.

1106 McAllister 2002, par. 1.9; Miller \& Robson 1991, p. 49.

1107 Brand's Trs v Brand's Trs (1876) 3 R 16 Lord Chancellor at 23.

1108 Reid 1996, nr. 586. Zie ook: hoofdstuk 5 \$3.2.

1109 Zolang het object niet van de onroerende zaak is afgescheiden, komt aan de 
grondstuk veroorzaakte schade aan de eigenaar van de onroerende zaak wordt vergoed of de onroerende zaak in de staat wordt teruggebracht waar deze zich in bevond vóór het aanbrengen van de objecten. ${ }^{1110}$

Trade fixtures ${ }^{111}$ zijn objecten die ten behoeve van de handel met de onroerende zaak zijn verenigd. De mogelijkheid tot het wegnemen van deze fixtures is geïntroduceerd in de Engelse zaak Elwes v Maw. ${ }^{112}$ Hierbij hebben economisch maatschappelijke belangen een grote rol gespeeld; de gebruiker van de onroerende zaak, niet zijnde de grondeigenaar, mag niet worden geremd in het gebruik van de onroerende zaak bij het voeren van handel. Wanneer de bevoegdheid tot het wegnemen van de objecten niet zou bestaan, dan zou dit tot gevolg hebben dat de met de onroerende zaak verenigde objecten blijvend aan de eigenaar van de onroerende zaak toekomen. ${ }^{1113} \mathrm{Bij}$ het al dan niet aanmerken van een bestanddeel als trade fixture kan de plaatselijke gewoonte een rol spelen. ${ }^{114}$

Ook ten aanzien van agricultural fixtures kan een wegneemrecht bestaan. Waarom de House of Lords van mening is dat ten aanzien van agricultural fixtures minder snel een wegneemrecht bestaat is onduidelijk. ${ }^{1115}$ Daar waar landbouw plaatsvindt met het oogmerk handel te drijven -hetgeen doorgaans het geval zal zijn- lijkt het aannemelijk dat de daarvoor aangebrachte objecten voor afscheiding in aanmerking komen. Nu duidelijkheid omtrent agricultural fixtures in de jurisprudentie achterwege is gebleven, heeft de wetgever op grond van de Agricultural Holdings (Scotland) Act 1991 aan de tenant de bevoegdheid toegekende agricultural fixtures weg te nemen. ${ }^{1116}$

De bevoegdheid tot fysieke afscheiding van ornamental en domestic fixtures van een onroerende zaak is gebaseerd op rechtspraak en komt voort uit de gedachte dat de gebruiker van de onroerende zaak niet mag worden geremd in het veraangenamen van zijn verblijf. ${ }^{1117}$ Anders dan onder het

tenant niet de bevoegdheid toe het door hem aangebrachte object te vernietiging. $\mathrm{Na}$ afscheiding komt op het object een 'eigen' eigendomsrecht te rusten en is de eigenaar krachtens dit eigendomsrecht bevoegd tot vernietiging van het object. Syme v Harvey (1861) 24 D 202. Wanneer het object ten behoeve van de afscheiding uit elkaar dient te worden genomen, is afscheiding enkel toegestaan als het object na afscheiding weer in elkaar kan worden gezet.

1111 In het Engelse recht worden deze bestanddelen aangemerkt met de term 'fixtures for trade and manufacturing'. Zie: Bronson 1904, p. 18 e.v.

1112 Elwes v Maw (1802) 3 East 38.

1113 Bronson 1904, p. 21.

1114 Gordon \& Wortley 2009, nr. 4-30.

1115 Brand's Trs v Brand's Trs (1876) 3 R 16 Lord Chancellor at 20: "That exception has been established in favour of the fixtures which have been attached to the inheritance for the purpose of trade, and perhaps in a minor degree for the purpose of agriculture".

1116 Agricultural Holdings (Scotland) Act 1991, s. 18(1).

1117 Uit de Engelse zaak Botham v TSB Bank plc(1996) 73 P\&CR D1 volgt dat 
Engelse recht het geval is, wordt in de Schotse literatuur doorgaans geen onderscheid gemaakt tussen ornamental fixtures enerzijds en domestic fixtures anderzijds: beide type bestanddelen worden in de Schotse literatuur aangemerkt als ornamental. In de Engelse literatuur wordt de term ornamental fixtures gebruikt voor objecten die met de onroerende zaak zijn verbonden voor decoratieve doeleinden, zoals vloerbedekking en raambekleding. ${ }^{1118}$ Domestic fixture zijn die objecten welke dienen ter vergemakkelijking van het gebruik van de onroerende zaak. ${ }^{1119}$

Het wegneemrecht dient in beginsel te worden uitgeoefend gedurende de duur van de lease, maar ook na afloop van de lease wordt aan de tenant een redelijke termijn toegekend voor de uitoefening van zijn recht. ${ }^{1120}$ In het arrest Houldsworth v Brand's $\operatorname{Trs}^{1121}$ is aangenomen dat aan de tenant een wegneemrecht toekomt ondanks het verlopen van de leasetermijn, omdat de tenant de onroerende zaak nog steeds in possession had. Een tenant die geen gebruik maakt van zijn wegneemrecht, wordt geacht zijn recht vrijwillig op te geven ten gunste van de landlord. ${ }^{1122}$

\section{\$4.1.2 Proper liferenter and fiar}

Op grond van de proper liferent ${ }^{1123}$ (verder: vruchtgebruik) komt aan de gerechtigde, de liferenter (verder: vruchtgebruiker), het gebruiksrecht van de met vruchtgebruik bezwaarde onroerende zaak en de uit de onroerende zaak vloeiende vruchten toe. Anders dan bij de lease, rust op de vruchtgebruiker niet de verplichting tot betaling van een periodieke vergoeding. ${ }^{1124} \mathrm{De}$ duur van het recht van vruchtgebruik is veelal gekoppeld aan de duur van

keukens, baden en de daartoe behorende kranen evenals witgoed, zoals koelkasten en afwasmachines, in beginsel niet als bestanddeel van de onroerende zaak worden aangemerkt.

1118 Smith 2011, p. 86.

1119 Bronson 1904, p. 30; Ewell 1905, p. 127.

1120 Gordon \& Wortley 2009, nr. 4-28; Paisley 2000, pp. 505-506. De Agricultural Holdings (Scotland) Act 1991, s. 18(1) stelt ten aanzien van agricultural fixtures dat zij: “... shall be removable by the tenant at any time during the continuance of the tenancy or before the expiry of 6 months, or such longer period as may be agreed, after the termination of the tenancy and shall remain his property so long as he may remove it by virtue of this subsection".

1121 Houldsworth v Brand's Trs (1877) 4 R 369.

1122 Amos \& Ferard 1827, pp. 72-73.

1123 In de literatuur kunnen twee typen liferent worden onderscheiden: proper liferent en improper liferent. Het onderscheid tussen beide is gelegen in de kwalificatie van het recht. Proper liferent is een real right in land terwijl improper liferent voortkomt uit een trust. In dit proefschrift zal enkel worden ingegaan op de proper liferent.

1124 Gordon \& Wortley 2009, nr. 4-24. 
het leven van de vruchtgebruiker, maar het staat partijen vrij een kortere termijn overeen te komen. ${ }^{1125}$ De bevoegdheid tot gebruik strekt niet tot vernielen van de onroerende zaak. ${ }^{1126}$ Een recht van vruchtgebruik kan enkel door de eigenaar van de met vruchtgebruik te bezwaren zaak, de fiar, worden gevestigd middels een geregistreerde deed. ${ }^{1127}$ Het vruchtgebruik kan worden gekarakteriseerd als een subordinate real right. ${ }^{1128}$ Op grond van het recht van vruchtgebruik komen aan de vruchtgebruiker bevoegdheden toe die in vergaande mate overeenkomen met het op de onroerende zaak rustende eigendomsrecht. ${ }^{1129}$ Het vruchtgebruik kan worden bezwaard met een lease of met een zekerheidsrecht, maar beide rechten eindigen bij het tenietgaan van het vruchtgebruik. ${ }^{1130}$

Op de vruchtgebruiker rust de verplichting zorg te dragen voor het onderhoud en de gebruikelijke en noodzakelijke reparatiewerkzaamheden van de in vruchtgebruik gegeven zaak. ${ }^{1131}$ Wijzigingen respectievelijk toevoegingen aan de in vruchtgebruik gekregen zaak die op eigen initiatief door de vruchtgebruiker zijn aangebracht gaan, wanneer voldaan wordt aan de vereisten van natrekking ${ }^{1132}$, toebehoren aan de fiar. Bij beëindiging van het vruchtgebruik bestaat in beginsel geen recht op financiële vergoeding aangezien de vruchtgebruiker bekend is met de tijdelijkheid van zijn recht ${ }^{1133}$ en van de vruchtgebruiker mag worden verwacht dat hij met deze tijdelijkheid rekening houdt. Aan de vruchtgebruiker kan een wegneemrecht toekomen dat accessoir is aan het vruchtgebruik. Voor toekenning van een

1125 Het is sinds de invoer van de Succession (Scotland) Act 1964 niet meer mogelijk een recht van vruchtgebruik te vestigen bij testament.

1126 Dobie 1941, p. 1; Rankine 1891, p. 630; Gretton \& Steven 2009, nr. 21.9.

1127 Bezwaring van het recht van vruchtgebruik met een recht van vruchtgebruik is dan ook uitgesloten.

1128 Gretton \& Steven 2009, nrs. 21.2 en 21.4.

1129 Hoewel aan de vruchtgebruiker bevoegdheden toekomen die in vergaande mate overeenkomen met het eigendomsrecht, dient nadrukkelijk te worden gesteld dat van eigendom geen sprake is. Zoals Gretton \& Steven stellen: "What a liferenter has is not interim ownership but a subordinate real right. Ownership is vested exclusively in the fiar". Zie: Gretton \& Steven 2009, nr. 21.6.

1130 Gordon \& Wortley 2009, nrs. 17-62 e.v.; Gretton \& Steven 2009, nr. 21.6.

1131 De vruchtgebruiker mag daarbij gebruik maken van de materialen die op het grondstuk aanwezig zijn, zoals hout en stenen. De vruchtgebruiker is aansprakelijk voor vernielingen veroorzaakt door eigen handelen. Een bouwwerk dat door zijn toedoen tot op de grond toe afbrandt, zal door de vruchtgebruiker dienen te worden gereconstrueerd en gefinancierd. Zie: Rankine 1891, p. 650.

1132 Hoofdstuk 5 \$3.3.

1133 Opmerkelijk is dat dit niet van toepassing is op leases die na 9 juni 2000 tot stand zijn gekomen, aangezien een na 9 juni 2000 tot stand gekomen lease evenals het recht van vruchtgebruik tijdelijk van aard is. Zie: noot 1097. 
wegneemrecht aan de vruchtgebruiker is het niet vereist dat de bevoegdheid tot wegname van trade, agricultural, ornamental en domestic fixtures uitdrukkelijk in de vestigingsovereenkomst is opgenomen. ${ }^{1134}$

In de literatuur is geen eenduidig antwoord te vinden op de vraag welke door de vruchtgebruiker aangebrachte objecten, die als bestanddeel van de bezwaarde onroerende zaak kunnen worden aangemerkt, van de onroerende zaak mogen worden afgescheiden. Volgens Gordon en Wortley komen trade fixtures in aanmerking voor afscheiding, hetgeen in de jurisprudentie wordt bevestigd. ${ }^{1135}$ Het wegneemrecht ten aanzien van andere type bestanddelen wordt aangenomen minder sterk te zijn, omdat de vruchtgebruiker anders dan de tenant geen (periodieke) vergoeding betaalt. ${ }^{1136}$ Wat het Engelse recht betreft delen Harpum, Bridge en Dixon deze stellingname niet. Volgens hen speelt het al dan niet betalen van een vergoeding geen enkele rol bij de vraag welke bestanddelen voor afscheiding in aanmerking komen; trade, ornamental en domestic fixtures die door de vruchtgebruiker zijn aangebracht kunnen volgens hen alle van de onroerende zaak worden afgescheiden. ${ }^{1137}$ Afscheiding van agricultural fixtures kan niet op grond van de Agricultural Holdings (Scotland) Act $1991^{1138}$ geschieden nu deze Act enkel ziet op het afscheiden van agricultural fixtures die gedurende een lease zijn aangebracht. ${ }^{139}$

\section{\$4.1.3 Heritable creditors and other creditors}

Het recht van de heritable creditor ${ }^{1140}$ beperkt zich niet tot de fysieke omvang van de heritable zoals deze bestaat op het moment van vestiging van het zekerheidsrecht. Het zekerheidsrecht strekt zich uit over de onroerende zaak zoals deze ten tijde van de uitwinning door de heritable creditor wordt aangetroffen. Hierbij wordt geen onderscheid gemaakt tussen de objecten die vóór de natrekking toebehoorden aan de zekerheidsgever of aan derden. Een gehuurde boiler zal eveneens voor uitwinning in aanmerking komen

1134 Aan de vruchtgebruiker komt geen wegneemrecht toe wanneer partijen in de overeenkomst de bevoegdheid tot wegname van de door de vruchtgebruiker aangebrachte objecten hebben uitgesloten. Zie: hoofdstuk $5 \S 4.2$.

1135 Ward v Countess of Dudley (1887) 57 LT 20. De mogelijkheid tot afscheiding van trade fixtures wordt door Dobie bevestigd. Zie: Dobie 1941, pp. 81-82.

1136 Gordon \& Wortley 2009, nr. 4-24; Paisley 2000, p. 506.

1137 Harpum, Bridge \& Dixon 2008, nr. 23-017.

1138 Agricultural Holdings (Scotland) Act 1991, s. 18(1).

1139 Het staat partijen vrij in de overeenkomst die aan het recht van vruchtgebruik ten grondslag ligt een wegneemrecht overeen te komen ten aanzien van agricultural fixtures.

1140 De heritable creditor is de gerechtigde tot het zekerheidsrecht dat op het onroerend goed rust. 
wanneer de boiler als bestanddeel van de onroerende zaak kan worden aangemerkt. ${ }^{1141}$

Een beding tussen de eigenaar van de onroerende zaak en een derde, bijvoorbeeld de verhuurder van de voornoemde boiler, strekkende tot het toekennen van een wegneemrecht aan deze derde zal in beginsel niet tegen de heritable creditor kunnen worden ingeroepen. Dit is slechts anders wanneer de heritable creditor bij de vestiging van het zekerheidsrecht op de hoogte is van dit beding en hij het bestaan van dit wegneemrecht eerbiedigt. ${ }^{1142}$ Het is onduidelijk of het tussen partijen overeengekomen beding strekkende tot wegname van de door derden aangebrachte objecten in het register kan worden ingeschreven. Wanneer inschrijving van het beding mogelijk is, betekent dit dat de gerechtigde tot het zekerheidsrecht op de hoogte kan zijn van die bedingen strekkende tot wegname die vóór de vestiging van het zekerheidsrecht zijn overeengekomen. In dat geval dient de gerechtigde tot het zekerheidsrecht deze in het register ingeschreven bedingen te eerbiedigen.

\section{\$4.1.4 Seller and purchaser}

Alle objecten die bestanddeel zijn van een onroerende zaak gaan bij overdracht van de zaak mee over op de verkrijger. ${ }^{1143}$ Partijen kunnen overeenkomen dat specifieke bestanddelen van de onroerende zaak van de koop worden uitgesloten. Het kan voorkomen dat onduidelijkheid bestaat over wat al dan niet in de koop is betrokken, bijvoorbeeld omdat het bestanddeel dat van de koop is uitgesloten niet of niet met voldoende bepaaldheid in de overeenkomst is opgenomen. Wanneer hieromtrent een geschil bestaat dient dit binnen alle redelijkheid te worden beslecht. ${ }^{1144}$ Wanneer na de overdracht van de onroerende zaak het van de koop uitgesloten bestanddeel niet van de zaak is afgescheiden, staat het de vervreemder vrij het bestanddeel af te scheiden zich beroepend op zijn wegneemrecht. ${ }^{1145}$

1141 Gordon \& Wortley 2009, nrs. 4-22 en 4-23. Zie ook: Cliffpland Ltd v Kinnaird (1981) SC 9; Scottish Discount Co Ltd v Blin (1985) SC 216.

1142 Gordon \& Wortley 2009, nr. 4-36; Smith 2011, pp. 88-89. Zie ook: Hobson v Gorringe (1897) 1 Ch 182; Reynolds v Ashby (1904) AC 466; Ellis v Glover and Hobson (1908) $1 \mathrm{~KB} 388$.

1143 Jamieson v Welsh (1900) 3 F 176.

1144 Christie v Smith's Exrx (1949) SC 572.

1145 Gordon \& Wortley 2009, nr. 4-20; Rankine 1891, p. 128; Paisley 2000, p. 505. 


\section{$\S 4.2$ Aard van the right of severance}

Aan de gerechtigde tot het wegneemrecht komt de bevoegdheid toe een door hem met de onroerende zaak verenigd object af te scheiden. ${ }^{1146}$ Ten gevolge van de fysieke afscheiding kan het afgescheiden object niet langer als bestanddeel van de zaak worden gekwalificeerd, maar is het afgescheiden object aan te merken als een zelfstandige zaak waaraan een eigen goederenrechtelijke identiteit toekomt. De grondslag voor deze eigendomsverkrijging aan de zijde van de aanbrenger van het nadien afgescheiden object is gelegen in de tussen partijen overeengekomen afspraken.

Aan de hand van de in de voorgaande paragraaf gegeven niet-limitatieve opsomming van relaties waarbinnen een wegneemrecht kan bestaan ${ }^{1147}$, kan een onderscheid worden gemaakt tussen wegneemrechten die accessoir zijn aan een real right ${ }^{1148}$, zoals het geval is bij de lease en het recht van vruchtgebruik, en wegneemrechten die tot stand komen middels een door partijen overeengekomen beding zonder de vestiging van een real right. Objecten die op grond van een aan een real right accessoir wegneemrecht van een onroerende zaak kunnen worden afgescheiden, zijn beperkt tot trade, agricultural, ornamental en domestic fixtures. Volgens Reid kan het aan een lease accessoir wegneemrecht gezien worden als "an implied term of the contract of the lease" 1149 , hetgeen meebrengt dat aan de tenant een wegneemrecht toekomt ook als dit recht niet uitdrukkelijk in de vestigingsovereenkomst is overeengekomen. Aan het wegneemrecht komt, ongeacht of dit recht impliciet tot stand komt dan wel expliciet in de vestigingsovereenkomst wordt opgenomen, derdenwerking toe. Een expliciet in de vestigingsovereenkomst opgenomen wegneemrecht hoeft niet te worden beperkt tot de voornoemde fixtures; partijen kunnen in de vestigingsovereenkomst opnemen op welke objecten die door de tenant met het grondstuk worden verenigd het wegneemrecht betrekking heeft. Het staat partijen (uiteraard) vrij het bestaan van het accessoire wegneemrecht

1146 De gerechtigde tot het wegneemrecht is niet alleen bevoegdheid tot wegname van de objecten die door de gerechtigde zelf met het grondstuk zijn verenigd, maar ziet ook op objecten die door derden in opdracht van de gerechtigde zijn aangebracht. Onduidelijk is of de door de gerechtigde ingevolge de effectuering van het wegneemrecht verkregen eigendom als een vorm van derivatieve of originaire verkrijging dient te worden aangemerkt. Reid 1996, par. 586 - noot 2.

1147 Gordon \& Wortley 2009, nr. 4-18.

1148 Een real right waaraan een wegneemrecht accessoir is, wordt eveneens middels een partijafspraak gevestigd.

1149 Reid 1996, nr. 586 - noot 8. Hetgeen eveneens van toepassing zal zijn op het aan het vruchtgebruik accessoire wegneemrecht. 
in de vestigingsovereenkomst van het real right uit te sluiten. ${ }^{1150}$ Derden kunnen via de openbare registers kennisnemen van het bestaan van het real right waaraan een wegneemrecht accessoir is en dus van het mogelijk bestaan van het wegneemrecht op de hoogte zijn.

Een niet-accessoir wegneemrecht kan in beginsel ten opzichte van ieder object dat door de gerechtigde met het grondstuk wordt verenigd, worden overeengekomen. Dat de natrekking wordt doorbroken ingevolge de effectuering van een 'louter' door partijen gesloten overeenkomst waarin het wegneemrecht zijn grondslag vindt, staat haaks op het uitgangspunt van de natrekking, de rechtszekerheid. Het is in beginsel niet mogelijk op grond van een afspraak tussen partijen het intreden van natrekking te voorkomen, tenzij de wet een grondslag biedt voor de doorbreking van de natrekking en derden door inschrijving van deze grondslag in de openbare registers van de doorbreking op de hoogte kunnen zijn. Anders dan bij het wegneemrecht dat accessoir is aan een real right, kunnen derden in de registers waarschijnlijk geen enkel aanknopingspunt vinden voor het bestaan van niet-accessoire wegneemrechten. Het is immers onduidelijk of het mogelijk is een nietaccessoir wegneemrecht in de registers in te schrijven. ${ }^{1151}$

Uit de literatuur volgt dat het wegneemrecht met een zekerheidsrecht kan worden bezwaard. ${ }^{152}$ Hierbij dient een onderscheid te worden gemaakt tussen het accessoire wegneemrecht enerzijds en het niet-accessoire wegneemrecht anderzijds. Een accessoir wegneemrecht kan niet 'apart' van het gebruiksrecht worden bezwaard. Bezwaring van het accessoire wegneemrecht is enkel mogelijk door het gebruiksrecht waaraan het wegneemrecht accessoir is, te bezwaren met een zekerheidsrecht. ${ }^{1153}$ Het zekerheidsrecht blijft op het gebruiksrecht rusten ook als het wegneemrecht door effectuering teniet gaat. Dit is echter anders bij niet-accessoire wegneemrechten. Bij bezwaring van een niet-accessoir wegneemrecht met een zekerheidsrecht komt het zekerheidsrecht 'enkel' op het wegneemrecht te rusten. Effectuering van het wegneemrecht leidt tot het tenietgaan van het wegneemrecht en daarmee tot het tenietgaan van het op het wegneemrecht rustende zekerheidsrecht. Aangenomen wordt dat, ongeacht of het wegneemrecht al dan niet accessoir van aard is, het van de onroerende zaak afgescheiden object vrij is van zekerheidsrechten.

1150 Volgens Reid komt het zelden voor dat een wegneemrecht uitdrukkelijk door partijen wordt overeengekomen. Zie: Reid 1996, par. 586; Amos \& Ferard 1827 , pp. $81-87$.

1151 Het niet-accessoire wegneemrecht kan worden gekarakteriseerd als een personal right. Zie: Gordon 1999, nr. 5-35; Reid 1996, par. 586.

1152 Gordon 2009, nr. 4-23.

1153 Deze situatie wijkt af van de in $\$ 4.1 .3$ van dit hoofdstuk besproken situatie nu in $§ 4.1 .3$ geen sprake is van een accessoir wegneemrecht. 


\section{$\S 4.3$ Servitudes}

Op grond van een praedial servitude (verder: erfdienstbaarheid) komt aan de gerechtigde tot de het grondstuk ten gunste waarvan de erfdienstbaarheid is gevestigd, het heersende erf, de bevoegdheid toe het grondstuk dat met de erfdienstbaarheid wordt bezwaard, het lijdend erf, op een bepaalde wijze te gebruiken. ${ }^{1154}$ Een erfdienstbaarheid is accessoir aan het op het heersend erf rustende eigendomsrecht. ${ }^{1155}$ Een erfdienstbaarheid is een beperkt zakelijk recht dat tijdelijk dan wel eeuwigdurend van aard is. Tevens kan een erfdienstbaarheid worden gevestigd met het oog op een bepaald doel; partijen kunnen in de vestigingsovereenkomst overeenkomen dat de erfdienstbaarheid ophoudt te bestaan wanneer het betreffende doel is verwezenlijkt. ${ }^{1156}$

Door het vestigen van een erfdienstbaarheid wordt de gerechtigde tot het lijdend erf zowel in juridische als in materiële zin in zijn gebruiksbevoegdheid beperkt. ${ }^{1157}$ In juridische zin dient de gerechtigde bij de door hem te verrichten rechtshandelingen rekening te houden met de op het grondstuk rustende erfdienstbaarheid. De verstrekkendheid van de door de gerechtigde tot het lijdend erf te dulden materiële beperking hangt af van de exacte inhoud die aan een erfdienstbaarheid is toegekend. Partijen kunnen niet ieder willekeurige inhoud aan de erfdienstbaarheid toekennen; partijen zijn gebonden aan een relatief gesloten lijst. ${ }^{158}$ De gebondenheid aan een

1154 Bell 1839, §979; Erskine 1773, II, IX, 5; Gordon 1999, nr. 24-18; Guthrie 2005, nr. 13.1.

1155 Cusine en Paisley omschrijven de erfdienstbaarheid in relatie tot het grondstuk ten behoeve waarvan de erfdienstbaarheid is gevestigd als: “... an inseparable pertinent of the dominant tenement”. Zie: Cusine \& Paisley 1998, nr. 1.67. Het is dan ook niet mogelijk de erfdienstbaarheid zelfstandig, los van het heersend erf, over te dragen. Zie: Cusine \& Paisley 1998, nrs. 1.45-46 en 1.63.

1156 Reid 1996, par. 446.

1157 De aan de gerechtigde toekomende gebruiksbevoegdheid wordt uit het op het lijdend erf rustende eigendomsrecht afgeleid en de erfdienstbaarheid kan dan ook worden aangemerkt als een derivative right. Een derivative right en het recht waaruit het derivative right is afgeleid kunnen niet aan een en dezelfde eigenaar toebehoren. Wanneer beide rechten toekomen aan een en dezelfde persoon treedt confusio op. Zie: Cusine \& Paisley 1997, nrs. 1.64 en 1.69. Dat de eigenaar van een grondstuk geen erfdienstbaarheid kan hebben ten aanzien van het aan hem toebehorende grondstuk komt tot uitdrukking in het Romeinse beginsel nulli res sua servit. Dit beginsel heeft in het Schotse recht zijn intreden gedaan in de $16^{\text {de }}$ eeuw. Zie: Gordon 1999, nr. 24-09; Gretton \& Steven 2009, nr. 12.47; TC(S)A 2003, s. 75(2).

1158 Tot de lijst van te vestigen erfdienstbaarheden behoren: Aquaduct, bleaching, building materials, fuel, feal and divot, passage, pasturage, thirlage, wrack and ware, light or prospect, stillicide, support en the access for a railway line (North British Rly Co v Park Yard Co Ltd (1898) 25 R 47). Zie: Gordon 1999, nrs. 24-22 en 
relatief gesloten lijst van erfdienstbaarheden dient ter bescherming van de eigenaar van het lijdend erf, omdat lange tijd de verplichting tot inschrijving van erfdienstbaarheden ontbrak..$^{1159}$

Het 'gesloten' zijn van voornoemde lijst van erfdienstbaarheden is relatief. In de zaak Dyce v Hay stelde de Lord Chancellor: "The category of servitudes and easements must alter and expand with the changes that take place in the circumstances of mankind". ${ }^{1160}$ Deze stellingname is in het recente arrest Luigi Romano v Standard Commercial Property Securities Ltd and Atlas Investments Ltd bevestigd, waarbij voor het aannemen van het bestaan van een nieuwe erfdienstbaarheid het van belang is dat dit recht similar in nature is in relatie tot de reeds bestaande erfdienstbaarheden. De reden voor deze toevoeging is gelegen in de volgende zinsnede: “... the principle is to prevent purchasers from being taken by surprise by a claim of some unusual and unwritten burden affecting their property". ${ }^{1161}$ Zo erkent de House of Lords in het recent gewezen arrest Moncrieff $\mathrm{v}$ Jamieson het bestaan van de erfdienstbaarheid 'right to park'. In deze zaak stond de rechtsvraag centraal of een servitude of access, gevestigd in het begin van de $20^{\text {ste }}$ eeuw, kan worden opgerekt tot the right of parking a car. De House of Lords stelde dat bij het beantwoorden van deze vraag de omstandigheden van het geval doorslaggevend zijn. Ten aanzien van de onderhavige casus ${ }^{1162}$ oordeelde de House of Lords dat het

24-23. Zie ook: Bankton 1751, II, VII, 38; Bell 1839, §979; Erskine 1773, II, IX, 18-32.

1159 Doordat er grote onzekerheid kon bestaan aan de zijde van de eigenaar van het lijdend erf over mogelijke, op zijn grondstuk rustende erfdienstbaarheden, werd het als wenselijk ervaren dat de eigenaar van het lijdend erf enkel kon worden 'verrast' met de door de wet erkende erfdienstbaarheden. Met het van kracht worden van de TC(S)A 2003 bestaat een verplichting tot registratie van erfdienstbaarheden die tot stand zijn gekomen ná 28 november 2004. De erfdienstbaarheid dient zowel ten aanzien van het heersend als van het lijdend erf te worden ingeschreven; er wordt dan ook gesproken van dual registration. Wanneer registratie uitblijft ontstaat er geen real right, maar bestaat er tussen partijen enkel een overeenkomst (TC(S)A 2003, s. 75(1)). Een uitzondering op het dual registration requirement wordt gemaakt ten aanzien van cable and pipeline servitudes. Registratie ten aanzien van de servient property is voldoende (TC(S)A 2003, s. 75(3)(b) en s. 77(1)). Zie: Gordon \& De Waal 2004, p. 742; Gretton \& Steven 2009, nr. 12.19; SLC 2000, par. 12.18.

1160 Dyce v Hay (1852) 1 Macq 304 at 312-313. Zie ook: Alexander v Butchart (1875) 3R 156.

1161 Luigi Romano v Standard Commercial Property Securities Ltd and Atlas Investments Ltd (2008) SLT 859 at 24.

1162 De servitude of access is in het begin van de $20^{\text {ste }}$ eeuw gevestigd ten gunste van 'Da Store', een woning gelegen aan de voet van een klif bij zee. De enige wijze waarop de woning is te bereiken, is middels een steil voetpad bestaande uit 30 treden. Een directe verbinding met de openbare weg ontbreekt vandaar de noodzaak gebruik te maken van het aangrenzende perceel dat tijdens de conflictsituatie toebehoort aan Jamieson. Wanneer Jamieson in 1998 een 
parkeren van een auto op het lijdend erf gewenst was voor "the comfortable use en enjoyment of the expressly granted servitude in question". ${ }^{1163}$

Op grond van een erfdienstbaarheid komt aan de gerechtigde tot de erfdienstbaarheid een gebruiksrecht toe ten aanzien van een grondstuk, het lijdend erf. Een bouwwerk dat voor de uitoefening van dit gebruiksrecht noodzakelijk is, mag op het lijdend erf worden aangebracht. ${ }^{164}$ Zo zal het bij een servitude of parking veelal onvermijdelijk zijn dat een gedeelte van het lijdend erf wordt bestraat of dat er ten behoeve van de te parkeren voertuigen een garage wordt aangebracht. Ongeacht wie deze aanpassingen verwezenlijkt respectievelijk de materialen voor deze aanpassingen aanlevert of financiert, de materialen zullen wanneer voldaan wordt aan de vereisten van natrekking met het grondstuk natrekken en tot de eigendom van het dienend erf gaan behoren. ${ }^{165}$ Wanneer deze aanpassingen door de gerechtigde tot de erfdienstbaarheid worden gerealiseerd, heeft dit tot gevolg dat de gerechtigde de eigendom van de met het lijdend erf verenigde objecten -die noodzakelijk zijn voor de aanpassingen- verliest. Het is nadrukkelijk niet toegestaan een erfdienstbaarheid te vestigen enkel omwille van het aanbrengen van een bouwwerk. ${ }^{1166}$

Opmerkelijk is dat in de literatuur noch in de jurisprudentie wordt gerept over het toekennen van een wegneemrecht aan de gerechtigde tot een erfdienstbaarheid. Ik ben de mening toegedaan dat op grond van hetgeen in $\$ 4.2$ van dit hoofdstuk omtrent het wegneemrecht is beschreven, kan worden aangenomen dat ook aan de gerechtigde tot een erfdienstbaarheid

omheining rondom zijn perceel plaatst, kan de gerechtigde tot het heersend erf, Moncrieff, 'Da Store' enkel nog te voet bereiken.

1163 Anders oordeelde de Court of Session in de zaak Luigi Romano v Standard Commercial Property Securities Limited and Atlas Investments Ltd. In dezezaak diende de vraag te worden beantwoord of aan de eigenaar van de begane grond, Luigi Romano, de bevoegdheid toekomt krachtens een erfdienstbaarheid 'right of signage' aan de voorgevel een reclamebord te bevestigen. Romano beroept zich voor het ontstaan van de erfdienstbaarheid primair op verjaring, secundair op (indirecte) vestiging door de in 1962 opgestelde overeenkomst. De Court of Session is van mening dat een erfdienstbaarheid 'right of signage' niet door het recht wordt erkend, omdat iedere verwantschap met de reeds erkende erfdienstbaarheden ontbreekt. Zie: Luigi Romano v Standard Commercial Property Securities Limited and Atlas investments Ltd (2008) SLT 859.

1164 McLellan v Hunter (1987) GWD 21-799; Todd v Scoular (1988) GWD 241041.

1165 Hoofdstuk 5 \$3.

1166 Tenzij de erfdienstbaarheid betrekking heeft op de overbouw van een bouwwerk. Scottish Temperance Life Assurance Co. v Law Union and Rock Insurance Co. (1917) SC 175; Cf. Spafford v Bryden (1991) SLT 49. 
een wegneemrecht toekomt. Evenals bij de lease ${ }^{167}$ en het recht van vruchtgebruik ${ }^{1168}$ komt ook aan de gerechtigde tot een erfdienstbaarheid een gebruiksrecht toe ten aanzien van het grondstuk dat met het recht is bezwaard. Net als bij de vestiging van een lease zal de grondeigenaar van het lijdend erf zich er terdege van bewust zijn dat, wil de gerechtigde tot een erfdienstbaarheid zijn recht kunnen uitoefenen, aanpassingen aan het lijdend erf noodzakelijk kunnen zijn. Hoewel een essentieel verschil tussen de lease en het vruchtgebruik enerzijds en de erfdienstbaarheid anderzijds is gelegen in de duur waarvoor het recht kan worden gevestigd, ben ik van mening dat de maximale vestigingsduur niet van invloed is op het al dan niet bestaan van een wegneemrecht. De jurisprudentie omtrent het wegneemrecht in relatie tot de lease ziet op leases die eeuwigdurend van aard zijn. Enkel leases die op of na 9 juni 2000 tot stand zijn gekomen kunnen voor een maximale duur van 175 jaar worden gevestigd; leases die voor 9 juni 2000 zijn gevestigd kunnen wel eeuwigdurend van aard zijn. ${ }^{1169}$

Naast het accessoire wegneemrecht dat dus 'spontaan' met de vestiging van de erfdienstbaarheid ontstaat, staat het partijen vrij in de vestigingsovereenkomst van de erfdienstbaarheid uitdrukkelijk te bedingen dat ook andere objecten dan trade, agricultural, ornamental en domestic fixtures voor afscheiding van het grondstuk in aanmerking komen. ${ }^{1170}$

\section{§5. Legal and conventional separate tenements}

Op grond van een legal separate tenement ${ }^{1171}$ respectievelijk een conventional separate tenement $t^{172}$ is het mogelijk een gedeelte van de onroerende zaak dan wel rechten ten aanzien van een onroerende zaak in eigendom ${ }^{1173}$ aan een derde toe te kennen. ${ }^{1174}$

\section{$\S 5.1$ Legal separate tenements}

Legal separate tenements vinden hun grondslag in het feodale rechtsstelsel. ${ }^{1175}$ Hoewel bij de afschaffing van het feodale rechtsstelsel aan de vazal het

1167 Hoofdstuk 5 \$4.1.1.

1168 Hoofdstuk 5 \$4.1.2. Een recht van vruchtgebruik kan worden aangemerkt als een 'personal servitude'.

1169 Zie: noot 1097.

$1170 \quad$ Hoofdstuk 5 \$4.2.

$1171 \quad$ Hoofdstuk 5 \$5.1.

1172 Hoofdstuk 5 \$5.2.

1173 Eigendom kan bestaan ten aanzien van corporeal property en incorporeal property. Zie: hoofdstuk 5 §2.1.

1174 Beide rechten kunnen als real right worden gekwalificeerd. Zie: Reid 1996, par. 208.

1175 Hoofdstuk 5 §2.2.1. 
absolute eigendomsrecht ten aanzien van een grondstuk werd toekend, zijn er specifieke objecten en rechten die ingevolge de legal separate tenementrechtsfiguur toekomen aan een ander dan de grondeigenaar. Hierbij kan een onderscheid worden gemaakt tussen rechten respectievelijk objecten die aan de Kroon dan wel aan derden worden toegekend. Wie als begunstigde kan worden aangemerkt volgt, evenals het ontstaan van de legal separate tenement zelf, uit het recht. ${ }^{1176}$ Tot de belangrijkste rechten ${ }^{1177}$ respectievelijk objecten die in beginsel worden toegekend aan de Kroon ${ }^{1178}$ behoort het visrecht op zalm, oesters en mosselen. Het betreft hier het recht op vangst van de zalm, oester of mossel; deze zeebewoners zijn res nullius tot aan het moment van de vangst.

\section{§5.2 Conventional separate tenements}

Conventional separate tenements ontstaan, anders dan legal separate tenements, niet van rechtswege maar door vestiging. De conventional separate tenement is een rechtsfiguur die in het leven is geroepen ten gevolge van een tweetal sociaal-economische gebeurtenissen: 1) de ontdekking van grote hoeveelheden mineralen in Schotse bodem en 2) de maatschappelijke behoefte tot verwezenlijking van hoogbouw ten gevolge van de urbanisering. Ten aanzien van beide gebeurtenissen ontstond de behoefte een gedeelte van de onroerende zaak in eigendom aan een ander toe te kennen. ${ }^{1179}$ Mineralen alsook appartementen ${ }^{1180}$ kunnen tot object van een conventional separate tenement worden gemaakt, maar ten aanzien van andere things bestaat onduidelijkheid. ${ }^{1181}$ Duidelijkheid bestaat wel over de aard van het object van de conventional separate tenement; het object dient, met uitzondering van the right of sporting ${ }^{1182}$, stoffelijk van aard te zijn. ${ }^{1183}$

1176 Reid 1996, par. 209.

1177 Een uitvoerige opsomming en bespreking van alle legal separate tenements gaat aan het doel van dit proefschrift voorbij. Naast de hierboven opgesomde rechten komen aan de Kroon de volgende legal separate tenements toe: port and harbour on free port, public ferry, treasure and lost property, wreck, fairs and markets, forest and customary rights. Zie voor een uitvoerige omschrijving van deze legal separate tenements: Gordon \& Wortley 2009, hoofdstuk 7.

1178 Dit type legal separate tenement wordt veelal aangeduid met de term 'regalia minora' of 'regalia'. Zie: Gretton \& Steven 2009, par. 14.16; Reid 1996, par. 210.

1179 Reid 1996, par. 212.

1180 Hoofdstuk 5 \$5.2.

1181 Reid 1996, nr. 212: "But in most other respects the law is neither clear nor coherent". 1182 AFT(S)A 2000, s. 65A.

1183 Gretton \& Steven 2009, par. 14.15. 
Bij het beantwoorden van de vraag of een object kan worden aangemerkt als een conventional separate tenement is de plaats van het object ten aanzien van het grondstuk van belang. Ten aanzien van objecten die zich onder het aardoppervlak bevinden, lijken vrijwel geen beperkingen te bestaan bij het creëren van conventional separate tenements; kelders, tunnels en mineralen ${ }^{1184}$ kunnen object zijn van een conventional separate tenement, aldus Gretton en Steven. ${ }^{1185}$ Ook Reid erkent de mogelijkheid tot het aanmerken van ondergrondse objecten als conventional separate tenements. Anders dan Gretton en Steven benadert Reid deze objecten niet vanuit het profiel, de contouren van het object, maar vanuit de toekenning van een bepaalde laag onder het aardoppervlak aan de gerechtigde. ${ }^{1186}$ Boven het aardoppervlak lijken de objecten die als object van een conventional separate tenement kunnen worden aangemerkt, beperkt tot tenements ${ }^{187}$ (appartementen) en molens ${ }^{1188}$. Bomen, water en leidingen worden in de jurisprudentie als object van een conventional separate tenement afgewezen. ${ }^{189}$ Anders dan onder het aardoppervlak lijkt het niet mogelijk een laag boven het aardoppervlak, een ruimtelaag, aan te merken als object van een conventional separate tenement; de jurisprudentie geeft hiervoor geen aanwijzing. ${ }^{1190}$

\section{§5.2.1 Tenements}

Natrekking treedt niet op tussen de verschillende in een bouwwerk aanwezige appartementen. ${ }^{191}$ Van een tenement is sprake wanneer een gebouw of een gedeelte hiervan uit twee of meer appartementen bestaat. Het fysieke bestaan van de appartementen is onvoldoende om deze als tenement te kunnen betitelen. Minimaal één van de appartementen dient aan een ander in eigendom toe te komen. ${ }^{1192}$ Tevens is vereist dat splitsing van een bouwwerk in appartementen horizontaal geschiedt ${ }^{1193}$ en de grond

1184 Niet het recht tot winning van de mineralen is hier object van de conventional separate tenement, maar de mineralen zelf. Zie: Graham v Duke of Hamilton (1871) 9 M 98.

1185 Gretton \& Steven 2009, par. 14.14.

1186 Reid 1996, par. 212.

1187 Hoofdstuk 5 \$5.2.1.

1188 Zie: Bankton 1751, II, III, 94; Bell 1839, §743; Erskine 1773, II, VI, 5; Stair 1693, II, III, 71.

1189 Paul v Cuthbertson (1840) 2 D 1286; Crichton v Turnbull (1946) SC 52.

1190 Reid 1996, par. 212; Gretton \& Steven 2009, par. 14.14.

1191 Reid \& Zimmermann 2000, p. 219; SLC 1998b, par. 2.14. Binnen het appartement zelf treedt natrekking daarentegen wel op. De plavuizen op de vloer van een appartement worden bestanddeel van het appartement wanneer wordt voldaan aan de vereisten van natrekking.

1192 SLC 1998b, par. 4.6.

1193 Het horizontale splitsingsvereiste is historisch van aard. Bij het opstellen van de T(S)A 2004 heeft de Scottish Law Commission overwogen om ook verticaal 
waarop de appartementen zijn verwezenlijkt eveneens object is van het appartementsrecht. ${ }^{1194}$

Op ieder appartement rust een zelfstandig eigendomsrecht dat zijn grondslag vindt in de Tenements (Scotland) Act 2004 (verder: T(S) A 2004). ${ }^{1195}$ De reikwijdte van het eigendomsrecht rustende op een appartement is afhankelijk van de positie waar het appartement zich binnen het bouwwerk bevindt. ${ }^{1196}$ Wanneer het appartement wordt verwoest

gescheiden wooneenheden zoals twee-onder-een-kapwoningen' onder the T(S)A 2004 te laten vallen. De Commissie heeft echter besloten de historische tweedeling in horizontale en verticale wooneenheden te handhaven. De verticale scheiding van een bouwwerk in twee of meer wooneenheden wordt aangeduid met de term 'terraced property'. Zie: SLC 1998b, par. 4.8.

1195 The law of tenement is lange tijd beheerst door common law. Met de invoer van de T(S)A 2004, die sinds 28 november 2004 van kracht is, is het appartementsrecht gecodificeerd waarmee beoogd is meer duidelijkheid te bieden ten aanzien van de toen bestaande vraagstukken. Zo bestond onder andere onduidelijkheid over de reikwijdte van de appartementseigendom en het gebrekkig aanwezig zijn van case law omtrent het onderhoud en de herstelwerkzaamheden van de gemeenschappelijke eigendom. De T(S)A 2004 is van toepassing op zowel oude als nieuwe tenements. Zie: Gordon \& Wortley 2009, nr. 15-47; Guthrie 2005, nr. 11.2; SLC 1998b, par. 2.13.

1196 Voor ieder appartement geldt dat het eigendomsrecht zich uitstrekt tot het middelpunt van de buitenste muren van het appartement, tenzij het de buitenmuren van het gebouw betreffen. In dit laatste geval behoort de buitenmuur, tevens zijnde de buitenste muur van het appartement in zijn geheel toe aan de appartementseigenaar (T(S)A, s. 2(1)(b)). Zie: Girdwood v Paterson (1873) 11 M 647; McArly v French's Trs (1883) 10 R 574. Daar waar de eigendom zich uitstrekt tot het middelpunt van een muur is geen sprake van gemeenschappelijk eigendom, maar is ieder eigenaar van de helft van de muur. Zie: SLC 1998b, par. 2.10. Het grondstuk waarop het gebouw is aangebracht behoort toe aan de eigenaar wiens appartement op directe wijze met het grondstuk is verenigd. Zie: T(S)A 2004, s. 2(4); Sanderson's Trs v Yule (1897) 25 R 211. De fundering van het bouwwerk alsook de kelderruimtes behoren in eigendom toe aan de eigenaar van het appartement dat verbonden is met het grondstuk. Zie: Johnston v White (1877) $4 \mathrm{R}$ 721.Wanneer de omvang van het grondstuk waarop het bouwwerk is verwezenlijkt niet beperkt is tot enkel het grondstuk dat nodig is voor het bouwwerk zelf, behoort deze additionele grond toe aan de appartementseigenaar waar de additionele grond aan grenst. De eigenaar van het appartement dat op directe wijze met het grondstuk is verenigd, is tevens eigenaar van het boven het appartement bevindende luchtruim. Dit beperkt de eigenaar van het bovenste appartement bij het in verticale zin uitbreiden van zijn appartement. Zie: Watt v Burgess' Tr (1891) 18 R 766. Het dak behoort daarentegen wel toe aan de eigenaar van het bovenste appartement (T(S)A 2004, s. 2(6)). Zie: Taylor v Dunlop (1872) 11 M 25. 
gaat daarmee het eigendomsrecht niet teniet. De appartementseigenaar blijft eigenaar van de ruimte waar het appartement zich bevond. ${ }^{1197}$ Ten aanzien van objecten die gemeenschappelijk worden gebruikt, bestaat gemeenschappelijk eigendom. ${ }^{1198}$

Aan de appartementseigenaar komt in beginsel een exclusief gebruiksrecht toe ten aanzien van het appartement. Een belangrijke uitzondering op dit gebruiksrecht wordt gemaakt ten aanzien van de common interest. Op alle appartementseigenaren rust de verplichting zich te onthouden van handelingen die een negatieve invloed hebben op het bouwwerk. ${ }^{1199}$ Naast deze negatieve verplichting rust op de appartementseigenaren ook een positieve verplichting ${ }^{1200}$ ten aanzien van scheme property. Onder het begrip scheme property vallen die objecten die kunnen worden aangemerkt als strategische objecten, zoals het grondstuk, de fundering en de buitenmuren. Ook objecten waar een gemeenschappelijk eigendomsrecht op rust, kunnen als scheme property worden aangemerkt. ${ }^{1201}$ Ten aanzien van de tot de scheme property te rekenen objecten bestaat een onderhoudsverplichting. De tussen partijen overeengekomen bepalingen omtrent onderhoud, kosten ${ }^{1202}$ en beheer ten aanzien van scheme property worden in de akte opgenomen en ingeschreven in het register. ${ }^{1203}$

1197 Guthrie 2005, nr. 11.5.

1198 De gemeenschappelijke passages en de trappen die zich in het gebouw bevinden, behoren toe aan alle appartementseigenaren gezamenlijk evenals het dak, de grond en het luchtruim boven de gemeenschappelijke delen. De appartementseigenaren die een appartement op de begane grond hebben en voor het gebruik van hun appartement niet afhankelijk zijn van een in het gebouw aanwezige, gemeenschappelijke trap, delen niet mee in de gemeenschappelijke eigendom van de trap. Zie: T(S)A 2004, s. 3(1) en (2); T(S) A 2004, s. 2(5). Tot de gemeenschappelijke delen kunnen ook objecten zoals brandblusser, brandtrappen, rookkanalen, verwarmingspijpen etc. worden gerekend. De appartementseigenaren hebben ten aanzien van deze delen gemeenschappelijk eigendom. Zie: Gordon \& Wortley 2009, nrs. 15-53 - 1565; Gretton \& Steven 2009, nrs. 15.7-15.11; Guthrie 2005, nrs. 11.6-11.7; SLC 1998b, pars. 2.6-2.10.

1199 T(S)A 2004, s. 9.

1200 T(S)A 2004, s. 8.

1201 T(S)A 2004, TMS, r. 1.2.

1202 Hieronder vallen zowel de kosten van het onderhoud als de verzekeringskosten.

1203 De Tenements Management Scheme (verder: TMS) is ook van toepassing op tenements die vóór de invoer van de T(S)A 2004 zijn gecreëerd en waarbij in de title deed bepalingen ontbreken ten aanzien van onderhoud, kosten en beheer. $\mathrm{Bij}$ het ontbreken van deze bepalingen is de TMS zoals gegeven in 'Schedule 1' bij de T(S)A 2004 van toepassing. 



\section{Hoofdstuk 6. Samenvatting en conclusies}

\section{$\S 1$. Inleidende woorden}

De gehuurde schaftkeet die op een grondstuk is aangebracht voor de duur van een bouwproject, het in de tuin geplaatst en onder eigendomsvoorbehoud gekocht bronzen beeld en de in het grondstuk aangebrachte bekabeling ten behoeve van de elektriciteitsvoorziening, zijn allemaal voorbeelden van objecten die direct dan wel indirect met een grondstuk zijn verenigd. Deze vereniging kan verstrekkende gevolgen hebben voor de goederenrechtelijke rechten die op het met het grondstuk verenigde object rusten wanneer het object volgens objectieve maatstaven duurzaam met het grondstuk is verenigd. Wordt aan het duurzame verenigingscriterium voldaan dan vormen object en grondstuk een juridische eenheid, hetgeen in beginsel tot gevolg heeft dat de op het grondstuk rustende goederenrechtelijke rechten zich uitstrekken over het met het grondstuk verenigde object en de goederenrechtelijke rechten die vóór de vereniging op het object rustten tenietgaan. ${ }^{1204}$ Het object vormt dan niet alleen een juridische maar ook een goederenrechtelijke eenheid met het grondstuk. Het object dat met het grondstuk een juridische eenheid vormt volgt de goederenrechtelijke kwalificatie van het grondstuk; het object is evenals het grondstuk te kwalificeren als 'onroerend'.

Hoewel ieder van de in dit proefschrift onderzochte rechtsstelsels ${ }^{1205}$ bekend is met het duurzame verenigingscriterium verschillen de objectieve maatstaven die aan dit criterium ten grondslag liggen per rechtsstelsel. ${ }^{1206}$ Hierdoor bestaan er verschillen in de reikwijdte van het duurzame verenigingscriterium waardoor het mogelijk is dat onder het ene rechtsstelsel een met het grondstuk verenigd object wel een juridische eenheid

1204 Het Romeinsrechtelijke superficies solo cedit-beginsel stelt buiten twijfel dat het grondstuk als hoofdzaak dient te worden aangemerkt ongeacht het object dat met het grondstuk wordt verenigd. Een 110 verdiepingen tellend flatgebouw alsook een met goud beklede fontein worden beide nagetrokken met het grondstuk waarop zij zijn verwezenlijkt. Aan alle in dit proefschrift onderzochte rechtsstelsels ligt het superficies solo cedit-beginsel ten grondslag.

1205 In dit proefschrift worden de natrekking en de doorbreking van de natrekking naar Duits (hoofdstuk 2), Nederlands (hoofdstuk 3), Belgisch (hoofdstuk 4) en Schots recht (hoofdstuk 5) beschreven. Het rechtsstelsel dat op de concrete situatie van toepassing is, is het rechtsstelsel dat in het betreffende land waar het grondstuk zich bevindt van kracht is.

1206 Hoofdstuk $6 \$ 2.2$ voor het Duitse rechtsstelsel, $\$ 2.3$ voor het Nederlandse rechtsstelsel, \$2.2.1 voor het Belgische rechtsstelsel en §3.3 voor het Schotse rechtsstelsel. 
vormt met het grondstuk waarmee het is verenigd, terwijl dit onder een ander rechtsstelsel niet het geval hoeft te zijn.

De reden voor het aannemen van een goederenrechtelijke eenheid tussen een grondstuk en een met het grondstuk verenigd object is gelegen in de meerwaarde die aan een samengestelde zaak toekomt en het daaraan gekoppelde waardebehoud alsmede in de rechtszekerheid. Volgens de in het maatschappelijk verkeer geldende opvatting komt een zekere meerwaarde toe aan objecten die samen een samengestelde zaak vormen. Terwijl de waarde van een enkele baksteen vrijwel nihil is, wordt aan een uit baksteen opgetrokken bouwwerk een waarde toegekend die boven de opgetelde waarde van alle afzonderlijke bakstenen ligt die nodig zijn voor de verwezenlijking van het bouwwerk. Vormt het uit bakstenen opgetrokken bouwwerk een goederenrechtelijk eenheid met het grondstuk dan heeft de aan het bouwwerk toekomende meerwaarde een positief effect op de waarde van het grondstuk. De aanwezigheid van het bouwwerk doet de waarde van het grondstuk stijgen. Het samenvoegen van verschillende zelfstandige zaken tot één samengestelde zaak vergroot de maatschappelijke waarde, het nut, van ieder van de samengevoegde objecten waardoor de economische waarde van het geheel hoger is. Door deze hogere economische waarde, zal de eigenaar van de samengestelde zaak minder snel geneigd zijn objecten die deel uitmaken van de samengestelde zaak af te scheiden. De aan de samengestelde zaak toekomende meerwaarde leidt dan ook tot waardebehoud.

Naast waardebehoud kan de rechtszekerheid worden gegeven als reden voor het aannemen van een goederenrechtelijke eenheid. Wanneer een object geacht wordt duurzaam met het grondstuk te zijn verenigd dan vormen het grondstuk en het daarmee verenigde object een juridische eenheid waaraan in beginsel één goederenrechtelijke identiteit toekomt. Het uitgangspunt is dat derden uit de waarneembare situatie moeten kunnen afleiden welke objecten aan het duurzame verenigingscriterium voldoen en dus tot de eigendom van het grondstuk kunnen worden gerekend. Dit is bijvoorbeeld van belang voor de hypotheekhouder die overeenkomstig de waarde van het grondstuk de hoogte van de aan de hypotheekgever te verstrekken lening bepaalt.

De rechtszekerheid kan in het geding zijn wanneer derden op grond van de feitelijke situatie tot de conclusie komen dat een met het grondstuk verenigd object bestemd is om duurzaam met het grondstuk te zijn verenigd, maar ingevolge wettelijke bepalingen of een door partijen gesloten overeenkomst het duurzame verenigingscriterium terzijde wordt geschoven. Nu niet aan het duurzame verenigingscriterium kan worden voldaan omdat het criterium simpelweg niet op de betreffende situatie van toepassing is, dient het object 
als een roerende zaak te worden aangemerkt. ${ }^{1207}$ Het is evenwel mogelijk dat niet het duurzame verenigingscriterium terzijde wordt geschoven, maar het rechtsgevolg -de eigendomsnatrekking- niet intreedt bij het voldoen aan voornoemd criterium. Op grond van wettelijke bepalingen ${ }^{1208}$ alsook door het vestigen van een beperkt zakelijk recht van opstal ${ }^{1209}$ wordt voorkomen dat natrekking intreedt. De duurzaam met het grondstuk verenigde maar niet in eigendom nagetrokken objecten worden beheerst door de rechtsregels die van toepassing zijn op onroerende zaken.

Rechtsonzekerheid kan eveneens bestaan ten aanzien van objecten die met het grondstuk in eigendom worden nagetrokken, maar die door een ander dan de grondeigenaar met het grondstuk zijn verenigd. Aan deze derde kan de bevoegdheid toekomen de door hem aangebrachte objecten weg te nemen krachtens het aan hem toekomende wegneemrecht. De rechtsonzekerheid is daarin gelegen dat derden zoals de koper of de hypotheekhouder die bij het bepalen van de koopprijs of de hoogte van de te verstrekken geldlening uitgaan van de feitelijke situatie, op enig moment geconfronteerd kunnen worden met een derde die bevoegd is een of meerdere objecten van het grondstuk af te scheiden. Uitoefening van het wegneemrecht leidt tot fysieke afscheiding van het met het grondstuk verenigd object, waarna het object als roerende zaak toekomt aan de derde.

In dit hoofdstuk wordt nader ingegaan op bovengenoemde, rechtsonzekerheid scheppende situaties. In $\$ 3$ wordt ingegaan op de wijzen waarop wordt voorkomen dat een volgens de feitelijke situatie duurzaam met het grondstuk verenigd object (nog langer) een juridische eenheid vormt met het grondstuk waarmee het is verenigd. Ten aanzien van het doorbreken van de goederenrechtelijke eenheid kan een onderscheid worden gemaakt tussen die situaties waarbij het object al dan niet van het grondstuk wordt afgescheiden. Bij doorbreking zonder fysieke afscheiding van het object ligt de nadruk op het beperkt zakelijke recht van opstal. Met betrekking tot het recht van opstal wordt met name ingegaan op de vraag of de bevoegdheden die de opstaller verkrijgt ten aanzien van de objecten ten gunste waarvan het opstalrecht is gevestigd, de opstallen, als eigendom kunnen worden aangemerkt. Een ontkennend antwoord op deze vraag heeft tot gevolg

1207 Zowel het Duitse, Belgische alsook het Schotse rechtsstelsel zijn bekend met wettelijke bepalingen respectievelijke rechtsfiguren op grond waarvan het duurzame verenigingscriterium buitenspel wordt of kan worden gezet. Zie: hoofdstuk $6 \S 3$.

1208 Zo komen onder het Nederlandse recht grafbedekkingen krachtens art. 32a Wet op de lijkbezorging (verder: Wlb) in eigendom toe aan de nabestaanden die verantwoordelijk zijn voor het aanbrengen van deze grafbedekkingen, ondanks het feit dat de grafbedekkingen duurzaam met het grondstuk zijn verenigd.

1209 Het Schotse recht is in tegenstelling tot de andere in dit proefschrift onderzochte rechtsstelsels niet bekend met het beperkt zakelijke recht van opstal. 
dat de vestiging van het recht van opstal niet leidt tot doorbreking van de natrekking. De eigenaar van het grondstuk blijft dan ondanks de vestiging van het opstalrecht eigenaar van de opstallen. ${ }^{1210}$ In $§ 5$ wordt ingegaan op de doorbreking van de natrekking mèt fysieke afscheiding van het object krachtens het wegneemrecht.

Alvorens in te gaan op de wijzen waarop het duurzame verenigingscriterium en de natrekking terzijde kunnen worden geschoven, wordt in de navolgende paragraaf ingegaan op de objectieve maatstaven die aan het duurzame verenigingscriterium ten grondslag liggen. Deze objectieve maatstaven verschillen per rechtsstelsel waardoor de reikwijdte van het duurzame verenigingscriterium per rechtsstelsel verschilt. ${ }^{1211}$

\section{§2. Nadere invulling van het duurzame verenigingscriterium}

Voor een goed begrip van deze en navolgende paragrafen is het wenselijk dat de kwalificaties die aan een zich op een grondstuk bevindend object kunnen worden toegekend, nader worden toegelicht. Een object dat zich op een grondstuk bevindt, kan worden aangemerkt als zaak, bestanddeel of bijzaak. Reeds hier dient te worden opgemerkt dat niet ieder van de in dit proefschrift onderzochte rechtsstelsels bekend is met de 'bijzaak'kwalificatie. ${ }^{1212}$

Met het goederenrechtelijke begrip 'zaak' wordt gedoeld op een fysiek tastbaar object dat voor menselijke beheersing vatbaar is en waarover machtsuitoefening mogelijk is. Hoewel de maan een tastbaar object is, is de maan geen zaak in goederenrechtelijke zin, omdat het niet mogelijk is over de maan te beschikken. Aan een zaak komt een eigen goederenrechtelijke identiteit toe, hetgeen betekent dat op het object goederenrechtelijke rechten zoals het eigendomsrecht kunnen rusten.

Een zaak kan bestaan uit een massief lichaam, zoals bij een edelsteen het geval is, maar een zaak kan eveneens uit verschillende objecten zijn samengesteld. Voorbeelden van samengestelde zaken zijn auto's en machines. Het is niet altijd even duidelijk of de verschillende objecten die met elkaar zijn verbonden deel uitmaken van één en dezelfde zaak of dat deze objecten zelfstandige objecten zijn. De trappers van een fiets maken evenals het zadel en het stuur deel uit van de fiets. Maar hoe dienen fietslampjes te worden gekwalificeerd die met een eenvoudige 'klik' op de fiets kunnen

1210 Hoofdstuk $6 \S 4$.

1211 Hoofdstuk $6 \$ 2$.

1212 Het Nederlandse rechtsstelsel kent sinds de invoering van het Burgerlijk Wetboek in 1992 niet langer de 'bijzaak'-kwalificatie. Hierbij dient te worden opgemerkt dat in het Nederlandse recht een object dat onroerend door bestemming is niet als 'bijzaak', maar met de term 'hulpzaak' werd aangeduid. 
worden bevestigd en ook voor andere doeleinden kunnen worden gebruikt? Maken deze lampjes deel uit van de fiets en zijn zij daarmee als bestanddeel van de zaak aan te merken of zijn zulke fietslampjes zelfstandige zaken? Deze vraag dient aan de hand van de verkeersopvatting te worden beantwoord. Wanneer de lampjes als bestanddeel van de fiets kunnen worden aangemerkt, heeft dit tot gevolg dat aan de lampjes geen eigen goederenrechtelijke identiteit toekomt; bij overdracht of bezwaring van de fiets worden ook de lampjes in eigendom mee overgedragen respectievelijk bezwaard.

Een met een grondstuk verenigd bouwwerk kan als bestanddeel van het grondstuk worden aangemerkt, wanneer het bouwwerk en het grondstuk waarmee het bouwwerk is verenigd een juridische eenheid vormen. Van een juridisch eenheid is sprake wanneer de vereniging van het bouwwerk met het grondstuk duurzaam van aard is, hetgeen aan de hand van objectieve maatstaven dient te worden bepaald. ${ }^{1213} \mathrm{Nu}$ volgens het Romeinsrechtelijke superficies solo cedit-beginsel het grondstuk in de relatie tot het bouwwerk als hoofdzaak dient te worden aangemerkt, kan volgens de in dit proefschrift te vergelijken rechtsstelsels -die alle bekend zijn met voornoemd beginselniet anders worden geconcludeerd dan dat het bouwwerk als bestanddeel dient te worden aangemerkt. ${ }^{1214}$ Aan het vormen van een juridische eenheid is het rechtsgevolg natrekking gekoppeld; de goederenrechtelijke rechten die vóór het ontstaan van de duurzame vereniging op het bouwwerk rustten gaan teniet en de goederenrechtelijke rechten die op het grondstuk rusten strekken zich uit over het bouwwerk. Aan het bouwwerk komt niet langer een 'eigen' goederenrechtelijke identiteit toe. Zo gaat een vóór de eigendomsnatrekking op een zendmast rustend eigendomsrecht ten gevolge van de natrekking teniet en strekt het op het grondstuk rustende eigendomsrecht zich uit over de zendmast.

Naast de begrippen 'zaak' en 'bestanddeel' kunnen onder het Duitse, Belgische en Schotse recht roerende zaken die in een bepaalde relatie tot het grondstuk staan als bijzaak worden aangemerkt. ${ }^{1215}$ Een roerende

1213 Uiteraard kunnen ook beplantingen als bestanddeel van het grondstuk worden aangemerkt, wanneer zij met het grondstuk zijn verenigd. Afhankelijk van het rechtsstelsel dat van toepassing is, dient voor het aanmerken van beplantingen als bestanddeel de vereniging al dan niet duurzaam van aard te zijn.

1214 In de Nederlandse literatuur bestaat discussie over het aanmerken van een duurzaam met het grondstuk verenigd bouwwerk als bestanddeel van het grondstuk. Zie: hoofdstuk $3 \S 3$.

1215 Onder het Belgische recht worden deze objecten aangeduid als 'zaken die onroerend door bestemming zijn' (hoofdstuk 4 \$2.2.2), terwijl in de Duitse literatuur deze roerende zaken worden aangemerkt als 'Zubehör' (hoofdstuk 2 §2.5). Een uit zijn aard roerende zaak wordt onder het Schotse recht als bijzaak en daarmee als onroerend aangemerkt wanneer sprake is van implied destination 
zaak kan als bijzaak worden aangemerkt wanneer het object ten dienste staat van het grondstuk. De nadere, vereiste invulling van het 'ten dienste staan van' voor het aanmerken van een roerende zaak als bijzaak verschilt per rechtsstelsel. Terwijl onder het Belgische en Duitse recht een ruime invulling aan dit criterium wordt toegekend, waardoor bijvoorbeeld een vrachtwagen als bijzaak van een grondstuk kan worden aangemerkt wanneer deze vrachtwagen de op het grondstuk verbouwde producten transporteert, kan onder het Schotse recht een roerende zaak enkel als bijzaak worden aangemerkt wanneer de roerende zaak in constructief opzicht op het grondstuk is afgestemd. ${ }^{1216}$ Onder het Belgische recht kan een roerende zaak eveneens als bijzaak worden aangemerkt wanneer deze zaak dient ter verfraaiing van het grondstuk of van het met het grondstuk duurzaam verenigde bouwwerk. Voor het aanmerken van een uit zijn aard roerende zaak als bijzaak is het onder het Belgische en Schotse recht tevens vereist dat de roerende zaak toebehoort aan de eigenaar van het grondstuk.

Een object dat als bijzaak kan worden gekwalificeerd behoudt zijn eigen goederenrechtelijke identiteit. Het object wordt niet in eigendom met het grondstuk nagetrokken en de goederenrechtelijke rechten die op het object rusten blijven dan ook na het voldoen aan het bijzaak-vereiste op het object rusten. Zo blijft een op het object rustend recht van pand of vruchtgebruik ondanks het kwalificeren van het object als bijzaak voortbestaan. De bijzaak gaat bij overdracht van het grondstuk met de hoofdzaak in eigendom mee over.

\section{§2.1 Het Duitse rechtsstelsel: wesentliche Bestandteile}

Onder het Duitse recht kunnen objecten wordt onderscheiden in Sachen, wesentliche Bestandteile, unwesentliche Bestandteile, Scheinbestandteile en Zubehör. De Duitse term 'Bestandteil' is niet gelijk aan het hiervoor beschreven bestanddeel-begrip. De term Bestandteil wordt gebezigd ten aanzien van objecten die op enigerlei wijze in relatie tot het grondstuk staan; van een juridische eenheid hoeft geen sprake te zijn. Enkel bij een wesentlich Bestandteil (verder: wezenlijk bestanddeel) vormen grondstuk en object een juridische eenheid.

Bouwwerken en beplantingen kunnen als wezenlijk bestanddeel van het grondstuk worden aangemerkt wanneer zij op vaste wijze met het grondstuk zijn verenigd ${ }^{1217}$ en zij niet als Schein-bestanddeel ${ }^{1218}$ kunnen worden aangemerkt. Volgens de verkeersopvatting wordt aan het vaste 
verbindingscriterium voldaan wanneer afscheiding van bouwwerk of beplanting leidt tot beschadiging van het grondstuk of van het met het grondstuk verenigd object, of de afscheiding gepaard gaat met onevenredig hoge kosten. ${ }^{1219}$ Aangenomen wordt dat ook aan het vaste verbindingscriterium wordt voldaan wanneer het bouwwerk op grond van zijn gewicht niet of moeilijk verplaatsbaar is. ${ }^{1220} \mathrm{Wordt}$ voldaan aan het vaste verbindingscriterium, dan kan het object worden aangemerkt als wezenlijk bestanddeel en trekt het grondstuk het object in eigendom na; het object is niet langer roerend, maar onroerend van aard.

Ook objecten die op indirecte wijze met het grondstuk worden verenigd, hetgeen zich voordoet wanneer een object met een wezenlijk bestanddeel van het grondstuk wordt verenigd, kunnen als wezenlijk bestanddeel worden aangemerkt. ${ }^{1221} \mathrm{Bij}$ een indirecte vereniging van het object met het grondstuk hoeft niet te worden voldaan aan het vaste verbindingscriterium. Wel is vereist dat het aangebrachte object volgens de verkeersopvatting nodig is om het bouwwerk als gereed te kunnen beschouwen. Gelegde maar niet verlijmde vloerbedekking, rolluiken en ook een eenvoudig te verwijderen verwarmingsketel zijn alle wezenlijk bestanddeel van het bouwwerk. ${ }^{1222}$

\section{§2.2 Het Nederlandse rechtsstelsel: een tweetal gronden voor het karakteriseren van een object als bestanddeel}

Onder het Nederlandse rechtsstelsel kan een object op een tweetal wijzen een juridische eenheid met een grondstuk vormen: enerzijds krachtens artikel 3:4 BW jo. 5:3 BW en anderzijds krachtens artikel 5:20 lid $1 \mathrm{BW}$ jo. 3:3 lid $1 \mathrm{BW}$. Ongeacht op welke wijze de eenheidsvorming tot stand komt, de rechtsgevolgen zijn gelijk: het object wordt met het grondstuk in eigendom nagetrokken. ${ }^{1223}$

De eerste wijze van juridische eenheidsvorming is gelegen in artikel 3:4 jo. 5:3 BW. Artikel 3:4 BW geeft een tweetal criteria: de verkeersopvatting en het verbondenheidscriterium. De sleutel van een fietsslot, de van een woning afgewaaide dakpan en de reserveonderdelen van een machine maken volgens

1219 In de vereiste, verstrekkende wijze waarop een object met het grondstuk dient te zijn verenigd voor het aanmerken van het object als wezenlijk bestanddeel, is het duurzaamheidscriterium van de vereniging gelegen.

1220 BFH 4 oktober 1978, NJW 1979, 392; LG Berlin 10 november 2003, NJW-RR 2004, 635 .

$1221 \S 94$ Abs. 2 BGB.

1222 Hoofdstuk 2 \$2.2.

1223 Een object dat krachtens art. 3:4 BW een juridische eenheid met de zaak vormt, wordt ingevolge art. 5:3 BW met de zaak in eigendom nagetrokken. Bouwwerken en beplantingen die volgens art. 3:3 BW een juridische eenheid met het grondstuk vormen, worden ingevolge 5:20 lid $1 \mathrm{BW}$ met het grondstuk in eigendom nagetrokken. 
de verkeersopvatting alle onderdeel uit van de fiets, woning of machine. Deze objecten kunnen als bestanddeel van de zaak worden aangemerkt. ${ }^{1224}$ In het tweede lid van artikel 3:4 BW is het verbondenheidscriterium neergelegd. Op grond van dit criterium is van juridische eenheidsvorming sprake wanneer het object niet zonder beschadiging kan worden afgescheiden èn de beschadiging van betekenis is. Afscheiding van een object waarbij geen beschadiging aan een van beide objecten ontstaat, kan eveneens onder het verbondenheidscriterium worden geschaard wanneer de afscheiding met onevenredige kosten of arbeid gepaard gaat. Het verbondenheidscriterium kan als een nadere invulling van de verkeersopvatting worden gezien. ${ }^{1225}$

Op grond van de in art. 3:4 lid $1 \mathrm{BW}$ gebezigde criteria kan een bouwwerk niet als bestanddeel van een grondstuk worden aangemerkt: het bouwwerk maakt volgens de verkeersopvatting geen deel uit van het grondstuk en het bouwwerk kan (mogelijkerwijs) zonder beschadiging van betekenis van het grondstuk worden afgescheiden. Nu ook aan het Nederlandse rechtsstelsel het Romeinsrechtelijke superficies solo cedit-beginsel ten grondslag ligt ${ }^{1226}$, op grond waarvan alle objecten die op duurzame wijze met het grondstuk zijn verenigd met het grondstuk in eigendom worden nagetrokken, dient er in het Burgerlijk Wetboek een tweede grondslag te zijn op basis waarvan een object een juridische eenheid met het grondstuk vormt. Deze tweede grondslag is gelegen in artikel 5:20 lid 1 jo. 3:3 BW. ${ }^{1227}$ Artikel 5:20 lid 1 BW geeft een opsomming van objecten die met het grondstuk worden nagetrokken en daarmee als bestanddeel van het grondstuk kunnen worden aangemerkt, althans "voor zover de wet niet anders bepaalt". Deze opsomming komt in vergaande mate overeen met de objecten die krachtens artikel 3:3 lid $1 \mathrm{BW}$ als onroerend kunnen worden bestempeld.

Volgens artikel 3:3 BW kan een bouwwerk als onroerend worden aangemerkt wanneer het duurzaam met de grond is verenigd, hetzij rechtstreeks, hetzij door vereniging met andere bouwwerken. In het toonaangevende 'portacabin'-arrest komt de Hoge Raad met een nadere uitwerking van 'het duurzaam met de grond verenigd zijn': "Een gebouw kan duurzaam met de grond verenigd zijn in de zin van art. $3: 3 \mathrm{BW}$, doordat het naar aard en inrichting bestemd is om duurzaam ter plaatse te blijven". ${ }^{1228}$ Van een duurzame vereniging is sprake wanneer de aanbrenger van het object de intentie heeft het object duurzaam met het grondstuk te verenigen. Deze intentie van duurzaamheid dient objectief uit de vereniging tussen

1226 In het Nederlandse rechtsstelsel komt het superficies solo cedit-beginsel tot uitdrukking in artikel 5:20 lid $1 \mathrm{BW}$.

1227 Hoofdstuk 3 §3.

1228 HR 31 oktober 1997, NJ 1998, 97. 
bouwwerk en grondstuk te zijn af te leiden. Het bestaan van een fundering is niet vereist voor het kwalificeren van een vereniging als duurzaam. ${ }^{1229}$ Een object kan ook op andere wijze zodanig met het grondstuk zijn verenigd dat voor derden duidelijk is dat de vereniging duurzaam van aard is. Zo kunnen ook objecten die zich over het grondstuk voortbewegen, zoals bij een havenkraan het geval is ${ }^{1230}$, krachtens artikel 3:3 BW als onroerend worden bestempeld wanneer derden uit de vereniging kunnen afleiden dat deze duurzaam van aard is. Ingevolge artikel 5:20 lid 1 jo. 3:3 lid $1 \mathrm{BW}$ vormt voornoemde havenkraan een juridische alsook een goederenrechtelijke eenheid met het grondstuk. ${ }^{1231}$

Uit bovenstaande kan niet worden geconcludeerd dat aan de juridische eenheidsvorming van artikel 3:4 BW ten aanzien van bouwwerken geheel geen rol toekomt. De vraag wat als bestanddeel van een bouwwerk kan worden aangemerkt wordt beantwoord aan de hand van de in artikel 3:4 BW neergelegde criteria. Artikel 5:20 lid 1 BW kan hier geen uitkomst bieden, aangezien dit artikel enkel een opsomming geeft van objecten die als bestanddeel van de grond kunnen worden aangemerkt. Artikel 3:4 BW ziet op de afbakening van de omvang van het bouwwerk. ${ }^{1232}$

\section{\$2.3 Het Belgische rechtsstelsel: onroerend uit zijn aard}

Het Belgische rechtsstelsel onderscheidt onroerende zaken in zaken die uit hun aard onroerend zijn ${ }^{1233}$ en zaken die op grond van hun bestemming onroerend zijn ${ }^{1234}$. Objecten die onroerend uit hun aard zijn kunnen worden onderverdeeld in grondstukken enerzijds en objecten die middels het incorporatie-criterium als onroerend worden aangemerkt anderzijds. Enkel de objecten die krachtens het incorporatie-criterium als onroerend worden gekwalificeerd vormen een juridische eenheid met het grondstuk. Aan het incorporatie-criterium wordt voldaan wanneer een bouwwerk duurzaam en gewoonlijk, direct dan wel middels een bouwwerk, met het grondstuk is verbonden of erin vastzit. ${ }^{1235}$

De bestemming van het bouwwerk om duurzaam en gewoonlijk ter plaatse te blijven kan volgen uit het bestaan van een hechte materiële verbinding tussen grondstuk en bouwwerk, maar kan bij het ontbreken van

HR 25 oktober 2002, NJ 2003, 241.

Hoofdstuk $3 \$ 2.3$.

1233 Art. 518 jo. 525 lid 1 BBW. Zie: hoofdstuk 4 §2.2.1.

1234 Een zaak die op grond van zijn bestemming onroerend is, kan als bijzaak worden aangemerkt. Zie: hoofdstuk 4 \$2.2.2 alsook hoofdstuk 6 \$2.

1235 Cass. 15 september 1988, T.B.B.R. 1990, 211. 
een hechte materiële verbinding eveneens uit de overige omstandigheden van het geval worden afgeleid. Zo kan een zich op het grondstuk voortbewegende havenkraan ${ }^{1236}$ uit zijn aard onroerend zijn wanneer uit de omstandigheden van het geval kan worden afgeleid dat de relatie tussen grondstuk en havenkraan duurzaam van aard is. Wanneer een object wordt gekwalificeerd als onroerend uit zijn aard dan volgt uit artikel 552 BBW dat de eigendom van de grond de eigendom van het onroerende object in zich bevat. ${ }^{1237}$

\section{$\S 2.4$ Het Schotse rechtsstelsel: de fixture}

Anders dan onder het Duitse, Nederlandse en Belgische rechtsstelsel kan onder het Schotse recht geen onderscheid worden gemaakt tussen juridische en goederenrechtelijke eenheidsvorming. Het vereiste dat een object op fysieke wijze duurzaam met het grondstuk is verenigd ligt aan de natrekking -en daarmee aan de goederenrechtelijke eenheidsvorming- ten grondslag. De in de literatuur opgesomde vereisten voor natrekking zijn: physical attachment, permanency en functional subordination. Voor natrekking is vereist dat de onroerende zaak en het in of op de onroerende zaak bevindend object fysiek met elkaar zijn verenigd en dat de vereniging kan worden aangemerkt als duurzaam. Deze duurzaamheid kan uit verschillende aspecten naar voren komen. Uit de wijze waarop het object met het grondstuk is verenigd en de verstrekkendheid van deze vereniging kan naar voren komen dat de vereniging duurzaam van aard is. Ook in het gegeven dat aanpassingen aan object en/of grondstuk zijn gemaakt alvorens tot vereniging over te gaan, kan de duurzaamheid tot uitdrukking komen. De verkeersopvatting kan bij het bepalen van het al dan niet duurzaam zijn van de vereniging een rol spelen: wordt het met de onroerende zaak verenigde object achtergelaten of meegenomen wanneer de onroerende zaak van eigenaar wisselt? Het laatste aspect ziet op de tijdspanne die nodig is om het object met de onroerende zaak te verenigen of van het grondstuk te verwijderen. Objecten waarbij het aanbrengen of het verwijderen langere tijd in beslag neemt, worden vermoed duurzaam met het grondstuk te zijn verenigd.

Wil aan het functional subordination-vereiste worden voldaan dan dient de vereniging van het object met het grondstuk ten gunste van de onroerende zaak te geschieden. Aan dit vereiste komt enkel een rol toe bij indirecte vereniging van een object met een grondstuk, omdat toepassing van het functional subordination-vereiste op een directe vereniging strijdig kan zijn met het physical attachment-vereiste. De vereniging van een fabrieksgebouw

1236 Cass. 14 februari 2008, R.W. 2008-2009, 456; hof Gent 11 februari 2011, T.F.R. 2011/42, 603.

1237 In art. 552 BBW komt het superficies solo cedit-beginsel tot uitdrukking. Zie: hoofdstuk 4 §3. 
met een grondstuk geschiedt niet ten gunste van het grondstuk, maar ten dienste van het fabrieksgebouw. ${ }^{1238}$

Ten gevolge van de natrekking verliest het met de onroerende zaak nagetrokken object zijn zelfstandigheid en komen de rechten die ten aanzien van de onroerende zaak bestaan ook op het met de onroerende zaak verenigde object te rusten. ${ }^{1239} \mathrm{Nu}$ het object niet langer zelfstandig van aard is, dient het object als fixture te worden aangemerkt.

\section{$\S 2.5$ Het duurzame verenigingscriterium in rechtsvergelijkend perspectief}

Zowel het wesentliche Bestandteil, het bestanddeel, de uit zijn aard onroerende zaak als de fixture hebben gemeen dat zij ten gevolge van de duurzame vereniging met het grondstuk een juridische eenheid met het grondstuk vormen en, althans in beginsel, door het grondstuk in eigendom worden nagetrokken. Ieder van de onderzochte rechtsstelsels geeft, zoals uit voorgaande paragrafen is gebleken, een eigen invulling aan het duurzame verenigingscriterium. ${ }^{1240}$ De objectieve maatstaven waaraan dient te worden voldaan wil sprake zijn van een duurzame vereniging, zijn tot stand gekomen aan de hand van de in de maatschappij heersende opvatting over wanneer een eenheid tussen object en grondstuk geacht wordt te bestaan. Doordat de maatstaven per rechtsstelsel verschillen bestaat er ten aanzien van de rechtsstelsels een verschil in de reikwijdte van het duurzame verenigingscriterium. Zo vormt onder het ene rechtsstelsel een object onder bepaalde omstandigheden wel een juridische eenheid met het grondstuk, terwijl onder het andere rechtsstelsel het object onder diezelfde omstandigheden geen juridische eenheid met het grondstuk vormt. Een zich over rails voortbewegende havenkraan kan onder het Nederlandse en Belgische rechtsstelsel een juridische eenheid vormen met het grondstuk waarmee de havenkraan is verenigd, terwijl onder het Duitse en Schotse recht diezelfde havenkraan zal worden aangemerkt als een zelfstandige zaak nu ingevolge laatstgenoemde rechtsstelsels de vereniging tussen grondstuk en havenkraan niet als 'vast' respectievelijk 'duurzaam' kan worden aangemerkt. ${ }^{1241}$

1238 Hoofdstuk $5 \$ 3.3$.

1239 Hoofdstuk $5 \$ 3.4$.

$1240 \quad$ Hoofdstuk $6 \$ 2.1 \mathrm{t} / \mathrm{m} \S 2.4$.

1241 Zowel de Hoge Raad (HR 24 december 2010, LJN: BO3644) als het Hof van Cassatie (Cass. 14 februari 2008, R.W. 2008-09, 456) zijn van mening dat de beweegbaarheid van een object een duurzame vereniging met het grondstuk niet in de weg staat. Zie: hoofdstuk $3 \$ 2.3$ (Nederlands recht) en hoofdstuk 4 $\S 2.2 .1$ (Belgische recht). 
De in de maatschappij heersende opvatting is niet statisch van aard, maar beweegt mee met de veranderende maatschappelijke behoeften van de samenleving. Dit betekent dat de maatstaven waaraan voldaan dient te worden wil van een duurzame vereniging sprake zijn eveneens aan verandering onderhevig zijn. Een veranderende verkeersopvatting komt doorgaans in de jurisprudentie tot uiting, wat kan leiden tot het herformuleren van bestaande maatstaven, het formuleren van nieuwe maatstaven of een tegenovergesteld oordeel gebaseerd op dezelfde maatstaven. Een voorbeeld van deze veranderende verkeersopvatting is in de jurisprudentie waar te nemen ten aanzienvan 'kant-en-klare' bouwwerken, zoals een blokhut of een portacabin, die met een grondstuk zijn verenigd. De vereniging van zo'n 'kant-en-klaar' bouwwerk met een grondstuk kenmerkt zich doorgaans door het ontbreken van een fundering, waardoor de vereniging van het bouwwerk met het grondstuk puur door het gewicht van het bouwwerk op het grondstuk wordt bewerkstelligd. Terwijl onder het Duitse, Nederlandse en Belgische rechtsstelsel lange tijd werd aangenomen dat voor een duurzame vereniging het bestaan van een fundering noodzakelijk was, zijn zowel de Duitse $^{1242}$, de Nederlandse ${ }^{1243}$ als de Belgische ${ }^{1244}$ rechtsprekende macht tot het oordeel gekomen dat veranderende bouwtechnieken ertoe leiden dat ook 'kant-en-klare' bouwwerken -ondanks het ontbreken van een funderingkunnen worden aangemerkt als bestanddeel van het grondstuk. ${ }^{1245}$

In beginsel dient de duurzaamheid van de vereniging te zijn af te leiden uit de omstandigheden die betrekking hebben op de vereniging zelf. De Hoge Raad stelt in een recent arrest dat bij het beantwoorden van de vraag of een object naar aard en inrichting bestemd is om duurzaam met het grondstuk te zijn verenigd enkel naar de aard en inrichting van het met het grondstuk verenigd object dient te worden gekeken. ${ }^{1246}$ De casus die aan de uitspraak van de Hoge Raad ten grondslag ligt, heeft betrekking op een woonark die enkel in een woonwijk kon worden geplaatst door middel van het tijdelijk doorbreken van een dijk. Na plaatsing wordt de woonark omgeven door lage bruggen waardoor de woonark niet in zijn geheel naar een andere locatie kan worden gesleept. ${ }^{1247}$ De Hoge Raad is van mening dat enkel naar de aard en inrichting van de woonark zelf dient te worden gekeken bij het bepalen of sprake is van een duurzame vereniging. Noch uit de vereniging tussen de onderhavige woonark en de onder de woonark

1242 BFH 4 oktober 1978, NJW 1979, 392; LG Berlin 10 november 2003, NJW-RR 2004, 635.

1243 HR 31 oktober 1997, NJ 1998, 97.

1244 Hof Gent 16 maart 2000, T.F.R. 2000, 650.

1245 Onzeker is of onder het Schotse recht een 'kant-en-klare' woning als bestanddeel van een grondstuk kan worden aangemerkt.

1246 HR 15 januari 2010, LJN: BK9136. Zie: hoofdstuk 3 \$2.3.

1247 R.o. 4.4.1 bij HR 15 januari 2010, LJN: BK9136. 
gelegen bodem ${ }^{1248}$ noch uit de vereniging tussen de woonark en de oever ${ }^{1249}$ kan worden afgeleid dat de woonark bestemd is om duurzaam met het grondstuk te zijn verenigd. ${ }^{1250}$ Uit de Belgische literatuur volgt daarentegen dat de bestemming van een bouwwerk om duurzaam met een grondstuk te zijn verenigd behalve uit de vereniging tussen bouwwerk en grondstuk ook uit de overige omstandigheden van het geval kan worden afgeleid. ${ }^{1251}$ Het is aannemelijk dat onder het Belgische recht voornoemde woonark geacht wordt duurzaam met het grondstuk te zijn verenigd.

Wanneer een object op directe wijze met het grondstuk is verenigd, mogen naar Nederlands recht bij het bepalen of een object een juridische eenheid vormt met het grondstuk enkel die omstandigheden worden meegewogen die betrekking hebben op de vereniging tussen object en grondstuk zelf. ${ }^{1252}$ Dit is anders wanneer een object op indirecte wijze met het grondstuk wordt verenigd. Bij een indirecte vereniging dient aan de hand van de verkeersopvatting waarbij alle omstandigheden van het geval worden meegenomen, te worden bepaald of het object als bestanddeel van een bouwwerk kan worden aangemerkt. ${ }^{1253}$

Vergelijking van het duurzame verenigingscriterium zoals in de verschillende rechtsstelsels gebezigd, leidt tot een glijdende schaal. Het Duitse rechtsstelsel kenmerkt zich door de kleinste groep van objecten die geacht worden duurzaam met het grondstuk te zijn verenigd. Dit komt niet alleen door de in vergelijking met de overige rechtsstelsels strenge maatstaven die aan het 'duurzaam met het grondstuk zijn verenigd' worden gesteld, maar ook door het nog te bespreken Scheinbestandteil. ${ }^{1254}$

Het Schotse recht kent evenals het Duitse recht in vergelijking tot het Nederlandse en het Belgische rechtsstelsel een relatief kleine groep van objecten die geacht worden een juridische eenheid met het grondstuk te vormen. Anders dan onder het Duitse recht, kent het Schotse recht aan de verkeersopvatting een grotere rol toe bij het invullen van het permanencycriterium. Het Nederlandse en het Belgische recht kenmerken zich in

1248 R.o. 4.2 bij HR 15 januari 2010, LJN: BK9136.

1249 R.o. 4.6 bij hof Đs-Hertogenbosch 30 december 2010, LJN: BQ0443.

1250 In de zin van art. 3:3 lid $1 \mathrm{BW}$.

1251 Hoofdstuk $4 \$ 2.2 .1$.

1252 Hoofdstuk $3 \$ 2.3$.

1253 Later in deze paragraaf wordt ingegaan op het aanmerken van een object als bestanddeel ingevolge de verkeersopvatting van artikel 3:4 BW.

1254 Wanneer een object als Scheinbestandteil kan worden gekwalificeerd, heeft dit tot gevolg dat het object ondanks de duurzame vereniging met het grondstuk als een roerende zaak kan worden aangemerkt. In $§ 3$ van dit hoofdstuk wordt ingegaan op de uitzonderingen die de verschillende, in dit proefschrift besproken rechtsstelsels maken ten aanzien van het duurzame verenigingscriterium. Het Scheinbestandteil komt nader aan bod in $§ 3.1$. 
vergelijking tot het Duitse en Schotse recht door een grotere groep objecten die met het grondstuk een juridische eenheid vormen. Ook objecten die zich op het grondstuk kunnen voortbewegen kunnen, zoals hiervoor reeds is opgemerkt, een juridische eenheid met het grondstuk vormen. Deze ruime uitleg van het duurzaamheidscriterium kan tot rechtsonzekerheid leiden: vormt het op het grondstuk voortbewegende object een juridische eenheid met het grondstuk of is het object aan te merken als een roerende zaak? Kwalificatie van het object is afhankelijk van de omstandigheden van het concrete geval.

In het Nederlandse recht is een andere bron van rechtsonzekerheid gelegen in het dubbele criterium dat het Nederlandse rechtsstelsel bezigt voor het vormen van een jurdische eenheid tussen object en grondstuk. Naast het duurzame verenigingscriterium dat van toepassing is op die gevallen waarbij een bouwwerk rechtstreeks dan wel middels een ander bouwwerk met het grondstuk wordt verenigd, kan een object, niet zijnde een bouwwerk, een juridische eenheid met het grondstuk vormen wanneer het object volgens de verkeersopvatting deel uitmaakt van het bouwwerk. ${ }^{1255}$ Deze tweede wijze van juridische eenheidsvorming ziet op de afbakening van de omvang van het bouwwerk. ${ }^{1256}$ Aanwijzingen voor wat volgens het maatschappelijk verkeer als onderdeel van een bouwwerk dient te worden aangemerkt kunnen worden gevonden in de wet ${ }^{1257}$ en in de jurisprudentie. Zo geeft de Hoge Raad in het arrest Dépex/Curatoren Bergel c.s. ${ }^{1258}$ voor de beantwoording van de vraag wanneer apparatuur als bestanddeel van een fabrieksgebouw moet worden angemerkt twee criteria: 1) is het gebouw onvolledig wanneer de apparatuur ontbreekt, en 2) zijn gebouw en apparaat in constructief opzicht op elkaar afgestemd. ${ }^{1259}$ Het aanmerken van een object als bestanddeel van het bouwwerk wordt dan ook niet puur aan de hand van de feitelijke verbinding tussen bouwwerk en object beoordeeld.

$\mathrm{Nu}$ de invulling van de verkeersopvatting in vergelijking tot het duurzame verenigingscriterium in mindere mate is omlijnd ${ }^{1260}$, kan dit tot gevolg hebben dat een met een bouwwerk verbonden object onder het ene rechtsstelsel wel en onder het andere rechtsstelsel geen juridische eenheid vormt.

Art. 3:4 lid 1 BW.

1256 Hoofdstuk $3 \S 3$.

1257 De wet stelt dat een object als bestanddeel kan worden aangemerkt wanneer afscheiding van het object leidt tot beschadiging van betekenis aan object of bouwwerk. Zie: art. 3:4 lid 2 BW.

1258 HR 15 november 1991, NJ 1993, 316.

1259 Hoofdstuk 3 \$2.2.1.

1260 Behalve voor het zo juist beschreven belangrijke geval van apparatuur in een fabrieksgebouw. 


\section{$\S 3$. Uitzonderingen op het duurzame verenigingscriterium}

Niet ieder object dat duurzaam met het grondstuk is verenigd vormt met het grondstuk een juridische eenheid. Het Duitse ${ }^{1261}$, Belgische ${ }^{1262}$ alsook het Schotse rechtsstelsel ${ }^{1263}$ zijn bekend met rechtsfiguren op grond waarvan het duurzame verenigingscriterium buitenspel wordt gezet. Ondanks het bestaan van een duurzame vereniging met het grondstuk zijn de objecten waarop deze rechtsfiguren betrekking hebben aan te merken als roerende zaken.

\section{\$3.1 Het Scheinbestandteil}

Onder het Duitse recht komt aan een duurzaam met het grondstuk ${ }^{1264}$ verenigd object een eigen goederenrechtelijke identiteit toe wanneer het object kan worden gekwalificeerd als 'Scheinbestandteil' (verder: Scheinbestanddeel). ${ }^{1265}$ Een object dient als Schein-bestanddeel te worden aangemerkt wanneer het object duurzaam met het grondstuk is verenigd, maar uit de feitelijke omstandigheden van het geval de intentie kan worden afgeleid dat de duurzame vereniging van het object met het grondstuk tijdelijk van aard is of de duurzame vereniging heeft plaatsgevonden ten behoeve van de uitoefening van een zakelijk recht. ${ }^{1266}$

Als aan de hand van de verkeersopvatting kan worden gesteld dat uit de omstandigheden van het geval de intentie kan worden afgeleid dat het object 'slechts' tijdelijk met het grondstuk is verenigd, dient het object als Scheinbestanddeel te worden gekwalificeerd; het object vormt dan geen juridische eenheid met het grondstuk. Wanneer een tribune op duurzame wijze met een grondstuk is verenigd om aan de bezoekers van een zomerfestival een zitplek te bieden, zal het voor eenieder duidelijk zijn dat de aanbrenger voornemens is het object tijdelijk met het grondstuk te verenigen. Ten aanzien van een door de huurder met het grondstuk verenigd object zal het veelal niet zo eenvoudig zijn om te bepalen of het object als wezenlijk of als Schein-bestanddeel dient te worden aangemerkt. Is de tijdelijkheid van de vereniging niet uit de omstandigheden af te leiden, dan vormt het object een juridische eenheid met het grondstuk en kan het object worden aangemerkt als wezenlijk bestanddeel. Aan de huurder kan het recht toekomen de door

1261 Hoofdstuk $6 \S 3.1$.

1262 Hoofdstuk $6 \$ 3.2$.

1263 Hoofdstuk $6 \$ 3.3$.

1264 Objecten die op indirecte wijze duurzaam met het grondstuk zijn verenigd, bijvoorbeeld door vereniging met een bouwwerk, kunnen eveneens als 'Scheinbestanddeel' worden aangemerkt.

1265 Hoofdstuk 2 §2.4.

$1266 \S 95 \mathrm{BGB}$. 
hem aangebrachte en ten gevolge van de vereniging in eigendom met het grondstuk nagetrokken objecten weg te nemen. ${ }^{1267}$

Objecten die door een zakelijk gerechtigde met het grondstuk worden verenigd, worden vermoed ten behoeve van de uitoefening van het zakelijk recht met het grondstuk te zijn verenigd. Derden kunnen door raadpleging van het Grundbuch kennisnemen van het bestaan van het zakelijk recht en daarmee op de hoogte zijn van het mogelijk bestaan van Schein-bestanddelen. Welke objecten als Schein-bestanddeel kunnen worden aangemerkt, is (uiteraard) niet in het Grundbuch terug te vinden. De intentie het object enkel voor de duur van het zakelijke recht met het grondstuk te verenigen hoeft niet uit de omstandigheden te kunnen worden afgeleid voor het aanmerken van het object als Schein-bestanddeel.

\section{$\S 3.2$ Vervroegde roerendmaking}

Onder het Belgische recht is het mogelijk door middel van vervroegde roerendmaking ${ }^{1268}$ een duurzaam met het grondstuk verenigd object als een roerende zaak te kwalificeren. ${ }^{1269}$ Een object wordt gekwalificeerd als een roerende zaak wanneer het object voorwerp uitmaakt van een rechtshandeling die tot doel heeft het nog niet van het grondstuk afgescheiden object in eigendom te doen overgaan aan een ander. Nu de overdracht betrekking heeft op roerende zaken is inschrijving van de overdracht, evenals inschrijving van de overeenkomst strekkende tot vervroegde roerendmaking in de registers, niet vereist. Zo kunnen de aan een boom groeiende vruchten, de grondstoffen die zich in de grond bevinden en de bouwmaterialen die afkomstig zijn van een op het grondstuk bevindend bouwwerk aan een derde in eigendom worden overgedragen zonder dat fysieke afscheiding reeds dient te hebben plaatsgevonden. Objecten die voorwerp zijn van een rechtshandeling die ziet op vervroegde roerendmaking, strekken niet tot verhaal van de hypothecaire schuldeisers; zij kunnen hun verhaalsrechten uitoefenen op de koopprijs. ${ }^{1270}$

\section{$\S 3.3$ Industrial fruits}

Onder het Schotse recht kunnen duurzaam met het grondstuk verenigde vruchten als moveable worden aangemerkt, wanneer deze vruchten worden verbouwd ten behoeve van het voeren van handel. ${ }^{1271}$ Deze vruchten, die

$1267 \S 539$ Abs. 2 BGB. In hoofdstuk $6 \S 5$ wordt nader op het wegneemrecht ingegaan.

1268 In de literatuur wordt eveneens de term 'roerend door anticipatie' gebezigd.

1269 Hoofdstuk 4 §2.2.1.

1270 Art. 45 lid 3 Hypotheekwet (verder: Hyp.W.).

1271 Hoofdstuk 5 §2.1. 
met term 'industrial fruits' worden aangeduid, zijn vanaf het moment dat de zaden of planten met het grondstuk worden verenigd of de vruchten aan de bomen zich beginnen te ontwikkelen roerend van aard. ${ }^{1272}$ Doordat aan deze vruchten een eigen goederenrechtelijke identiteit toekomt, kunnen de vruchten gedurende hun vereniging met het grondstuk aan een ander worden overgedragen. Omdat de objecten moveable van aard zijn, vindt er geen inschrijving van de eigendomsoverdracht in het register plaats.

Ook de zaden en planten die door de tenant op het grondstuk van een ander worden aangebracht ten behoeve van het voeren van handel zijn roerend van aard; de planten en zaden behoren ondanks de duurzame vereniging met het grondstuk toe aan de tenant. Terwijl de planten en zaden aan de tenant in eigendom toekomen, vormen duurzaam met het grondstuk verenigde machines die nodig zijn voor het vervaardigen van producten ten behoeve van het voeren van handel, zogenoemde 'trade fixtures', wel een juridische eenheid met het grondstuk. ${ }^{1273}$ Aan de tenant komt ten aanzien van deze trade fixtures in beginsel de bevoegdheid toe ze van het grondstuk af te scheiden. Een verklaring voor het verschil in goederenrechtelijke benadering van industrial fruits enerzijds en trade fixtures anderzijds wordt in de Schotse literatuur niet gegeven.

\section{§4. Uitzonderingen op de eigendomsnatrekking}

Niet ieder object dat duurzaam met het grondstuk is verenigd, wordt met het grondstuk in eigendom nagetrokken. Wanneer natrekking van een bepaald object met het grondstuk maatschappelijk als onwenselijk wordt ervaren, kan de wetgever besluiten de natrekking terzijde te schuiven door het opnemen van een wettelijke bepaling. Zo'n wettelijke bepaling kan, hetgeen afhankelijk is van het rechtsstelsel èn het object waarop de wettelijke bepaling van toepassing is, leiden tot de vestiging van een wettelijk recht van opstal. ${ }^{1274}$ Naast wettelijke bepalingen als instrument tot maatschappelijk

1272 De boom waaraan de vruchten groeien kan daarentegen niet als een industrial fruit worden aangemerkt; de boom is bestanddeel van het grondstuk. Opmerkelijk is dat bomen die gekweekt worden met het oog op exploitatie evenmin als industrial fruits kunnen worden aangemerkt. Zie: Paulv Cuthbertson (1840) 2 D 1286.

1273 Hoofdstuk 5 \$4.1.1.

1274 Zo komt aan de aanbrenger van een elektriciteitsnet dat in Belgische grond is gesitueerd ten behoeve van het algemeen nut de eigendom van het net toe krachtens een wettelijke opstalrecht. Zie: art. 15 Wet van 10 maart 1925 elektriciteitsvoorziening; hoofdstuk 4 \$4.1. Aan de bevoegd aanlegger van een in Nederlandse grond aangebracht elektriciteitsnet komt eveneens de eigendom van het net toe, maar anders dan onder het Belgische recht vindt de doorbreking niet plaats door een wettelijk recht van opstal. Het Nederlandse 
ingrijpen, staat het de grondeigenaar vrij een beperkt zakelijk recht van opstal te vestigen. Vestiging heeft tot gevolg dat aan de gerechtigde tot het opstalrecht een of meerdere objecten die duurzaam met het grondstuk zijn verenigd in eigendom toekomen. Zowel onder het Duitse, Nederlandse als het Belgische rechtsstelsel kan de natrekking door middel van de vestiging van een opstalrecht terzijde worden geschoven. ${ }^{1275}$

\section{$\S 4.1$ Het recht van opstal}

Op grond van het beperkt zakelijke recht van opstal komt aan de gerechtigde tot dit recht, de opstaller, het recht toe een of meerdere objecten, opstallen, te hebben op of in het grondstuk van een ander. Zowel onder het Nederlandse als onder het Belgische recht kunnen deze objecten gebouwen, werken en beplantingen betreffen. ${ }^{1276}$ Onder het Duitse recht kan een recht van opstal enkel worden gevestigd ten behoeve van gebouwen en werken. ${ }^{1277}$ In de vestigingsovereenkomst worden de objecten vermeld ten gunste waarvan het opstalrecht wordt gevestigd. Het recht van opstal kan worden gevestigd ten gunste van een of meerdere objecten die ten tijde van de vestiging reeds met het grondstuk duurzaam zijn verenigd, de zogenoemde 'oude' opstallen, of gedurende de bestaansduur van het opstalrecht worden verwezenlijkt, de zogenoemde 'nieuwe' opstallen. ${ }^{1278} \mathrm{Nu}$ volgens de heersende leer ${ }^{1279}$ aan de opstaller de eigendom toekomt van die objecten ten gunste waarvan het opstalrecht is gevestigd, dient te worden gesteld dat vestiging van een recht van opstal leidt tot doorbreking van de natrekking ten aanzien van de 'oude' opstallen. Mijns inziens dient de heersende leer zo te worden uitgelegd dat met betrekking tot de 'nieuwe' opstallen de natrekking niet wordt doorbroken, maar terzijde wordt geschoven.

Zowel onder het Nederlandse als onder het Belgische recht kan de relatie tussen het recht van opstal enerzijds en het eigendomsrecht op de opstallen

recht is niet bekend met het wettelijke recht van opstal. Krachtens art. 5:20 lid $2 \mathrm{BW}$ komt de eigendom van een net toe aan de bevoegd aanlegger. Zie: hoofdstuk $3 \S 4.2$.

1275 Het opstalrecht komt aan bod in hoofdstuk $2 \S 3$ met betrekking tot het Duitse rechtsstelsel, hoofdstuk $3 \S 4$ ten aanzien van het Nederlandse rechtsstelsel en in hoofdstuk $4 \S 4$ aangaande het Belgische rechtsstelsel. Hoofdstuk $3 \S 4.2$ (Nederlands recht) en hoofdstuk $4 \S 4.4 .1$ (Belgisch recht). Hoofdstuk 2 §3.3.

1278 Objecten die gedurende het opstalrecht door de opstaller met het grondstuk duurzaam zijn verenigd, worden met het grondstuk in eigendom nagetrokken wanneer uit de vestigingsovereenkomst blijkt dat het opstalrecht niet ten gunste van deze door de opstaller aangebrachte objecten is gevestigd.

1279 Hoofdstuk $2 \S 3.3 .2$ (Duits); hoofdstuk $3 \S 4.3 .1$ (Nederlands); hoofdstuk 4 $\$ 4.2 .2$ (Belgisch). 
anderzijds als afhankelijk worden aangemerkt. Het is niet mogelijk het op de opstallen rustende eigendomsrecht separaat van het recht van opstal over te dragen. Vervreemding van het opstalrecht leidt tot vervreemding van de opstallen. Onder het Nederlandse recht leidt bezwaring en verhuring van het opstalrecht eveneens tot bezwaring en verhuring van de opstallen. ${ }^{1280}$ Anders dan bij het Nederlandse recht is het onder het Belgische recht wel mogelijk de opstallen apart van het opstalrecht te bezwaren en te verhuren. Vervreemding van de opstallen separaat van het opstalrecht is daarentegen niet mogelijk. ${ }^{1281}$ De relatie tussen het recht van opstal enerzijds en de opstallen ten gunste waarvan het opstalrecht is gevestigd anderzijds kan onder het Belgische recht dan ook worden aangeduid als 'beperkt accessoir'. ${ }^{1282}$

Onder het Duitse recht wordt het object ten gunste waarvan het opstalrecht is gevestigd als wezenlijk bestanddeel van het opstalrecht aangemerkt, hetgeen mogelijk is doordat het opstalrecht door het ErbbauRG als een grundeigentumsgleiches Recht wordt angemerkt. ${ }^{1283} \mathrm{Als}$ wezenlijk bestanddeel van het opstalrecht is de opstal afhankelijk van het opstalrecht. De opstal kan dan ook niet separaat van het opstalrecht worden vervreemd of bezwaard. ${ }^{1284}$ In relatie tot het grondstuk dient de opstal als Schein-bestanddeel te worden aangemerkt. ${ }^{1285}$

\section{$\S 4.1 .1$ Komt aan de opstaller de eigendom van de opstallen toe?}

De in dit proefschrift te vergelijken rechtsstelsels die bekend zijn met het beperkt zakelijke recht van opstal hebben met elkaar gemeen dat volgens de heersende leer op de opstallen een eigen eigendomsrecht komt te rusten. Zowel uit $\S 903 \mathrm{BGB}$, art. 5:1 BW en art. $544 \mathrm{BBW}$ volgt dat het eigendomsrecht een recht betreft dat met uitsluiting van een ieder kan worden uitgeoefend. De eigenaar mag de zaak waarop het eigendomsrecht rust gebruiken zoals hij wenst, tenzij dit gebruik in strijd is met wettelijke bepalingen of rechten van anderen. Het gebruik van de zaak ziet eveneens op handelingen die overdracht, bezwaring en het tenietgaan van de zaak tot gevolg hebben. Het eigendomsrecht zoals in voornoemde bepalingen gedefinieerd, kan worden aangemerkt als het meest omvattende recht dat men ten aanzien van een object kan hebben. Ik betwijfel echter of het recht

$1280 \quad$ Hoofdstuk $3 \$ 4.6$.

1281 Hoofdstuk 4 \$4.4.

1282 Voor overdracht en bezwaring van het opstalrecht respectievelijk de opstallen kan toestemming van de opstalgever vereist zijn wanneer partijen dit in de vestigingsovereenkomst zijn overeengekomen.

$1283 \S 11$ ErbbauRG jo. §96 BGB. Zie: hoofdstuk 2 2.2.2 en §3.3.2.

1284 Hoofdstuk $2 \S 3.5$.

1285 Hoofdstuk 2 \$3.3.2. 
dat ten gevolge van de vestiging van het opstalrecht op de opstallen komt te rusten als eigendom dient te worden aangemerkt.

De reikwijdte van het eigendomsrecht dat op de opstallen komt te rusten wordt niet alleen beperkt door de in voornoemde paragraaf beschreven (beperkt) afhankelijke relatie tussen het opstalrecht enerzijds en het op de opstallen rustende eigendomsrecht anderzijds. De reikwijdte wordt eveneens beperkt door de wettelijke bepalingen die betrekking hebben op het opstalrecht en de overeenkomst die aan de vestiging van het opstalrecht ten grondslag ligt. Dat de reikwijdte van het eigendomsrecht door de vestigingsovereenkomst kan worden beperkt is opmerkelijk, omdat de mogelijkheid tot beperking van het eigendomsrecht op grond van een (vestigings)overeenkomst door de reeds hiervoor aangehaalde bepalingen $\S 903 \mathrm{BGB}$, art. 5:1 BW en art. $544 \mathrm{BBW}$ niet wordt genoemd. Het staat partijen vrij in de vestigingsovereenkomst afspraken te maken omtrent het gebruik van het opstalrecht ${ }^{1286}$, het grondstuk en de daarmee verenigde opstallen. Door afspraken in de vestigingsovereenkomst op te nemen ten aanzien van het gebruik van de opstallen, wordt de inhoud van het op de opstallen rustend eigendomsrecht door partijen contractueel bepaald. $\mathrm{Nu}$ partijen het eigendomsrecht in beginsel naar believen kunnen vormgeven kan aan het eigendomsrecht vrijwel iedere willekeurige inhoud worden toegekend, hetgeen mijns inziens in strijd is met het numerus clausus-beginsel. Zowel onder het Nederlandse als onder het Belgische rechtsstelsel is het mogelijk de aan de opstaller toekomende bevoegdheden ten aanzien van de in eigendom verkregen opstallen zodanig in te perken dat aan de erfpachter, aan wie enkel het gebruik van het grondstuk en de daarmee verenigde opstallen toekomt, meer bevoegdheden kunnen toekomen dan aan de opstaller aan wie de eigendom van de opstallen toekomt. Hoewel de aan de erfpachter toekomende bevoegdheden verstrekkender van aard kunnen zijn, zullen deze bevoegdheden niet als eigendom worden gekwalificeerd. ${ }^{1287}$

Terwijl het bestaan van het op een zaak rustend eigendomsrecht ${ }^{1288}$ afhankelijk is van het bestaan van de zaak, is het bestaan van het op de opstallen rustend eigendomsrecht niet alleen afhankelijk van het (voort) bestaan van de opstallen maar eveneens afhankelijk van de bestaansduur van het opstalrecht. ${ }^{1289}$ Het tenietgaan van de opstallen heeft in beginsel

1286 Het begrip 'gebruik' ziet niet enkel op het feitelijk gebruik, maar ook op de mogelijk te verrichten rechtshandelingen.

1287 Hoofdstuk $3 \S 4.3 .1$ (Nederlands); hoofdstuk 4 \$4.2.2 (Belgisch).

1288 Zoals in $§ 903 \mathrm{BGB}$, art. 5:1 BW en art. 544 BBW gebezigd.

1289 De opstallen worden voor de duur van het opstalrecht zowel onder het Nederlandse als onder het Belgische recht als zaak aangemerkt. Zie: hoofdstuk $3 \S 4.1$ en hoofdstuk $4 \$ 4.2$. Onder het Duitse recht worden de opstallen aangemerkt als wezenlijk bestanddeel van het opstalrecht. Zie: hoofdstuk 
geen consequenties voor het voortbestaan van het opstalrecht. Afhankelijk van het rechtsstelsel kan een recht van opstal tijdelijk of eeuwigdurend van aard zijn. Terwijl het eigendomsrecht zoals in $§ 903$ BGB, art. 5:1 BW en art. 544 BBW gebezigd in beginsel eeuwigdurend van aard is, is het onder het Belgische recht niet mogelijk een eeuwigdurend zelfstandig recht van opstal te vestigen. Een zelfstandig recht van opstal kan voor een maximale duur van 50 jaar worden gevestigd. ${ }^{1290}$

Volgens het Nederlandse recht is het niet mogelijk eigendom voor bepaalde tijd over te doen gaan in het vermogen van een ander. Artikel 3:85 lid $1 \mathrm{BW}$ stelt dat een verbintenis strekkende tot overdracht van een goed voor bepaalde tijd wordt aangemerkt als een verbintenis tot vestiging van een recht van vruchtgebruik. Nu de vestiging van een opstalrecht volgens de heersende leer leidt tot eigendomsverkrijging, dient mijns inziens te worden geconcludeerd dat de vestiging van een tijdelijk recht van opstal onder het Nederlandse recht in strijd is met artikel 3:85 BW of dat vestiging van het opstalrecht niet leidt tot eigendomsverkrijging. $\mathrm{Nu}$ een zinsnede met de strekking 'tenzij de wet anders bepaalt' in artikel 3:85 BW ontbreekt en het (uiteraard) mogelijk is een opstalrecht te vestigen dat tijdelijk van aard is, sterkt dit mijn vermoeden dat met de vestiging van het recht van opstal geen eigendom aan de opstaller toekomt. ${ }^{1291}$

$\mathrm{Nu}$ volgens de heersende leer aan de opstaller de eigendom toekomt van de opstallen ten gunste waarvan het opstalrecht is gevestigd, betekent dit dat de vestiging van een opstalrecht niet kan worden afgedaan als het 'enkel' vestigen van een beperkt zakelijk gebruiksrecht: de vestiging van een opstalrecht dient eveneens te worden beschouwd als een wijze waarop eigendom kan worden verkregen. Onduidelijk is of het door vestiging van het opstalrecht verkregen eigendomsrecht een wijze van originaire of derivatieve verkrijging is. Volgens de heersende leer dient de vestiging van een beperkt recht te worden aangemerkt als een vorm van derivatieve verkrijging. Hoewel met de vestiging van het beperkte recht een nieuw (beperkt) recht ontstaat zijn de aan de beperkt gerechtigde toekomende bevoegdheden afkomstig

1290 De Opstalwet maakt het mogelijk het zelfstandige recht van opstal te vernieuwen (art. 4 Opstalwet). Zie: hoofdstuk $4 \$ 4$.2.4. Een opstalrecht dat accessoir is aan een erfdienstbaarheid kan daarentegen wel eeuwigdurend van aard zijn. Zie: hoofdstuk 5 \$4.5.2.3. De tijdelijkheid van het eigendomsrecht komt niet voort uit het karakter van het eigendomsrecht dat op de opstallen komt te rusten, maar uit de door art. 4 Opstalwet gestelde beperking die dwingendrechtelijk van aard is. Zie: hoofdstuk 4 §4.2.4.

1291 Hoofdstuk 3 \$4.3.1. 
uit een reeds bestaand moederrecht; de bevoegdheden worden ten gevolge van de vestiging overgedragen aan de beperkt gerechtigde. De moeilijkheid ten aanzien van het opstalrecht in vergelijking tot andere beperkte rechten is daarin gelegen dat de opstaller niet alleen gebruiksbevoegdheden heeft maar ook eigendom van de opstallen ten behoeve waarvan zijn recht is gevestigd. Wat de vraag van verkrijging betreft dient een onderscheid te worden gemaakt al naar gelang de opstallen reeds aanwezig zijn bij de vestiging van het opstalrecht of zij na vestiging worden aangebracht door de opstaller.

Volgens de heersende leer dient de vestiging van het opstalrecht mede als een wijze van eigendomsverkrijging te worden aangemerkt ten aanzien van 'oude' opstallen. Met de vestiging van het opstalrecht ontstaat niet alleen een recht van opstal maar ook een aan het opstalrecht accessoir eigendomsrecht ten aanzien van de 'oude' opstallen. ${ }^{1292}$ Of het eigendomsrecht op de 'oude' opstallen op originaire of derivatieve wijze wordt verkregen is onduidelijk. Een kenmerk van originaire verkrijging is dat in beginsel een op het verkregen goed rustend beperkt recht komt te vervallen. Dat zou bij het opstalrecht betekenen dat een vóór de vestiging van het opstalrecht op het moederrecht gevestigd beperkt recht niet langer op de opstal rust die in eigendom overgaat op de opstaller. Maar die beschrijving zou misleidend zijn. Een vóór de vestiging van het opstalrecht gevestigd beperkt recht kan wel degelijk invloed hebben op het eigendomsrecht. ${ }^{1293}$ Krachtens het prioriteitsbeginsel is de gerechtigde tot een ouder recht, zoals hypotheek of erfdienstbaarheid, bevoegd zijn recht uit te oefenen zonder daarbij rekening te houden met een later gevestigd recht. Wanneer een opstalrecht wordt gevestigd op een met een recht van hypotheek bezwaard grondstuk, staat het opstalrecht er niet aan in de weg dat de hypotheekhouder het grondstuk vrij van opstalrecht executeert. Ook de opstallen ten aanzien waarvan het opstalrecht is gevestigd zijn dus in de executie betrokken. Hierdoor is het vraagstuk of de opstaller op originaire of derivatieve wijze verkrijgt van geen enkel praktisch belang.

Het eigendomsrecht op de 'nieuwe' opstallen is eveneens accessoir aan het opstalrecht, maar vloeit mijns inziens niet voort uit het beperkte recht van opstal. Het reeds op deze opstallen rustende eigendomsrecht blijft voortbestaan doordat de opstallen niet met het grondstuk in eigendom zijn nagetrokken. De opstaller verkrijgt geen eigendomsrecht maar behoudt het eigendomsrecht dat reeds op de opstallen rust, nu mijns inziens ten gevolge van de vestiging van het opstalrecht de natrekking terzijde wordt geschoven. De vraag of hier sprake is van originaire of derivatieve verkrijging rijst dus niet.

1292 Vestiging van het opstalrecht leidt tot doorbreking van de natrekking.

1293 Pitlo/Reehuis \& Heisterkamp 2012, Goederenrecht, nr. 94. 
Wanneer krachtens de in deze paragraaf aangevoerde argumenten kan worden gesteld dat de aan de opstaller ten aanzien van de opstallen toekomende bevoegdheden niet als eigendom kunnen worden aangemerkt, maar de aan de opstaller toekomende bevoegdheden evenals bij andere beperkt zakelijke rechten het geval is 'gewoon' afkomstig zijn uit het meeromvattend moederrecht dan kan simpelweg geen sprake zijn van een nieuw of reeds bestaand 'eigendomsrecht'. ${ }^{1294}$ Zowel ten aanzien van 'oude' als 'nieuwe' opstallen kan worden gesproken van derivatieve verkrijging van het recht van opstal. In die opvatting rust noch op 'oude' noch op 'nieuwe' opstallen een eigendomsrecht. De opstallen worden na verwezenlijking met het grondstuk in eigendom nagetrokken en gaan in eigendom toebehoren aan de grondeigenaar; de opstaller verkrijgt krachtens het opstalrecht de in de vestigingsovereenkomst opgenomen bevoegdheden.

Reeds in $\S 2$ van dit hoofdstuk is opgemerkt dat aan een bestanddeel geen eigen goederenrechtelijke identiteit toekomt. ${ }^{1295}$ Het is dan ook zeer opmerkelijk dat onder het Duitse recht op de opstallen die als wezenlijk bestanddeel van het opstalrecht worden aangemerkt een eigendomsrecht rust. Doordat de Duitse wetgever het eigendomsrecht dat op de opstallen komt te rusten als 'Sondereigentum' kwalificeert ${ }^{1296}$, lijkt de Duitse wetgever zich er terdege van bewust te zijn dat het recht dat op de opstallen komt te rusten niet gelijk kan worden gesteld aan het eigendomsrecht zoals in $§ 903$ BGB gedefinieerd. De vraag rijst of daarmee een tweede privaatrechtelijke eigendomsvorm ${ }^{1297}$ naast het eigendomsbegrip van $\S 903$ BGB bestaat. $\mathrm{Nu}$ de in dit proefschrift onderzochte rechtsstelsels alle bekend zijn met een uniform eigendomsrecht dat zijn intrede heeft gedaan mede ten behoeve van de rechtszekerheid, is het niet wenselijk een tweede privaatrechtelijk eigendomsbegrip aan te nemen.

Naar aanleiding van bovenstaande ben ik van mening dat het de voorkeur verdient de vestiging van een opstalrecht te benaderen als de vestiging van ieder ander beperkt zakelijk gebruiksrecht. Ten gevolge van de vestiging wordt aan de opstaller een bundel van bevoegdheden overgedragen die betrekking hebben op het met het opstalrecht bezwaarde grondstuk enerzijds en de opstallen anderzijds. De ten aanzien van de opstallen verkregen bevoegdheden kunnen -hetgeen afhankelijk is van hetgeen in de vestigingsovereenkomst is opgenomen- in vergaande mate overeenkomen

1294 De vestiging van het opstalrecht kan dan worden aangemerkt als een overdracht van bevoegdheden.

1295 Hoofdstuk $6 \S 2$.

1296 §3 WEG. Zie: hoofdstuk 2 3.3.2.

1297 Naast het in $\S 903$ BGB neergelegde privaatrechtelijke eigendomsbegrip is het Duitse rechtsstelsel bekend met een publiekrechtelijke eigendomsbepaling ( $\S$ 14 Grundgesetz). Zie: hoofdstuk 2 §3.3.2. 
met het eigendomsrecht zoals in $\$ 903$ BGB, art. 5:1 BW en art. 544 BBW omschreven, maar van een op de opstallen rustend en aan de opstaller toekomend eigendomsrecht is geen sprake.

\section{\$4.1.2 De vestiging van een opstalrecht als een verkapte wijze van overdracht}

Onder het Duitse recht wordt het bezwaren van een opstalrecht met een opstalrecht niet als de vestiging van een opstalrecht aangemerkt wanneer aan de opstaller wiens recht met een opstalrecht wordt bezwaard niet langer de bevoegdheid toekomt een bouwwerk te hebben op het grondstuk van een ander. De vestiging van het opstalrecht dient dan als de overdracht van het opstalrecht te worden aangemerkt. ${ }^{1298}$ Deze overdracht ziet niet alleen op de opstallen ten gunste waarvan het opstalrecht is gevestigd -deze komen immers volgens de heersende leer reeds aan de opstaller in de eigendom toe krachtens het gevestigde recht van opstal- maar ziet ook op dat gedeelte van het grondstuk en de daarmee duurzaam verenigde objecten ten aanzien waarvan de opstaller 'slechts' een gebruiksrecht heeft.

Het vermoeden van overdracht van het grondstuk kan mijns inziens bestaan wanneer de aan de opstaller toekomende bevoegdheden ${ }^{1299}$ dusdanig verstrekkend van aard zijn dat ten gevolge van de vestiging van een eeuwigdurend opstalrecht ${ }^{1300}$ aan de eigenaar van het grondstuk (vrijwel) geen bevoegdheden meer toekomen ten aanzien van het grondstuk en dit, zoals uit de vestigingsovereenkomst zal blijken, ook in de toekomst niet het geval zal zijn. ${ }^{1301}$ Naast de vestigingsduur en de verstrekkendheid van de inhoud die aan het opstalrecht wordt toegekend spelen de volgende factoren bij het aanmerken van een eeuwigdurend recht van opstal als een (verkapte) wijze van overdracht mijns inziens ook een rol: 1) de mogelijkheid van terugval van het opstalrecht aan de grondeigenaar ${ }^{1302}$ en 2) de op de opstaller

1298 Hoofdstuk 2 \$3.4.1 en $§ 3.5 .1 .1$.

1299 Volledigheidshalve dient hier te worden opgemerkt dat de opstaller deze bevoegdheden ontleent aan het aan hem toekomende opstalrecht.

1300 Ten aanzien van de in dit proefschrift te vergelijken rechtsstelsels is het enkel onder het Duitse en Nederlandse recht mogelijk een eeuwigdurend opstalrecht te vestigen.

1301 Hoofdstuk 2 \$3.4.1.

1302 Hier wordt bewust de term 'terugval' gebezigd. Terwijl onder het Nederlandse recht terugval van het opstalrecht leidt tot vermenging en daarmee tot het tenietgaan van het opstalrecht, leidt het in één hand komen van het opstalrecht en het eigendomsrecht dat met het opstalrecht is bezwaard onder het Duitse rechtsstelsel niet tot vermenging. Zie: hoofdstuk $2 \$ 3.2 .1 \mathrm{~m} . n$. noot 214 (Duits recht), hoofdstuk $3 \$ 4.5$ (Nederlands recht) en hoofdstuk $4 \$ 4.6$ (Belgisch recht). 
rustende verplichting tot het al dan niet betalen van een terugkerende vergoeding. ${ }^{1303}$

Wanneer het bestaan van het opstalrecht is gekoppeld aan bepaalde voorwaarden kan worden gesteld dat de mogelijkheid bestaat dat de aan de opstaller toekomende bevoegdheden op enig moment bij de eigenaar van het grondstuk terugkomen. Zo kan de bestaansduur van een opstalrecht afhankelijk zijn van de bestemming die ingevolge de vestigingsovereenkomst aan de opstallen wordt toegekend. Bestaat volgens de verkeersopvatting de reële kans dat de aan de opstaller toekomende bevoegdheden terugvallen aan de grondeigenaar of diens rechtsopvolger dan is het niet aannemelijk het gevestigde recht van opstal aan te merken als de overdracht van het grondstuk.

Naast de al dan niet reële kans van terugval van het eeuwigdurend opstalrecht aan de grondeigenaar speelt ook het al dan niet betalen van een eenmalige vergoeding door de opstaller voor het verkregen recht van opstal een rol bij het aanmerken van de vestiging van het opstalrecht als de overdracht van het grondstuk. ${ }^{1304}$ Een eeuwigdurend recht van opstal dat om niet wordt gevestigd kan evenals de vestiging van een eeuwigdurend opstalrecht waarbij een eenmalige vergoeding is bedongen leiden tot overdracht. Wanneer partijen in de vestigingsovereenkomst een terugkerende vergoedingsverplichting zijn overeenkomen, wordt met de terugkerende betaling het bestaan van de aan de grondeigenaar toekomend eigendomsrecht bevestigd; van overdracht kan dan geen sprake zijn. De hoogte van de vergoeding speelt mijns inziens geen doorslaggevende rol bij het aanmerken van de vestiging als een wijze van overdracht, maar de hoogte kan wel het vermoeden van overdacht bevestigen. Een overeengekomen eenmalige vergoeding die de waarde van het grondstuk benadert, zal het vermoeden van overdracht bevestigen.

Door de vestiging van een eeuwigdurend opstalrecht in bepaalde gevallen gelijk te stellen aan de overdracht van het grondstuk, wordt aangesloten bij de feitelijke situatie. ${ }^{1305}$ Ten gevolge van de vestiging van een eeuwigdurend

1303 De op de opstaller rustende verplichting tot het betalen van een vergoeding voor het verkregen opstalrecht, de Erbbauzins, dient niet te worden verward met de Reallast ( $\$ 1105$ BGB e.v.). Hoewel $\S 9$ ErbbauRG de bepalingen omtrent de Reallast op de Erbbauzins van toepassing verklaart, is het bestaan van de Erbbauzins in vergelijking tot de Reallast afhankelijk van het bestaan van het opstalrecht. Zie: hoofdstuk 2 §3.2.2.

1304 Het opnemen van een op de opstaller rustende vergoedingsplicht in de vestigingsovereenkomst voor het verkregen opstalrecht is niet vereist voor het ontstaan van een opstalrecht. Hoofdstuk $2 \S 3.2 .2$ (Duits); hoofdstuk $3 \S 4.4$ (Nederlands); hoofdstuk 4 \$4.3 (Belgisch).

1305 Hetgeen bij de overdrachtsbelasting reeds op ruimere schaal wordt gedaan. 
opstalrecht waarbij de kans op terugval zeer klein of niet aanwezig is en waarbij op de opstaller geen of een eenmalige vergoedingsverplichting rust, vermindert het grondstuk dusdanig in waarde dat, evenals bij het tenietgaan van de feodale rechtsfiguur dominium directum, aangenomen mag worden dat het aan de grondeigenaar toekomende eigendomsrecht zodanig is uitgekleed dat aan de zijde van de grondeigenaar geen sprake meer kan zijn van eigendom.

\section{§5. Het wegneemrecht}

Aan de gerechtigde tot het wegneemrecht ${ }^{1306}$ komt de bevoegdheid toe een of meerdere objecten fysiek van het grondstuk af te scheiden. Door aan de gebruiker van het grondstuk een wegneemrecht toe te kennen, wordt voorkomen dat de gebruiker geremd wordt in de uitoefening van de aan hem toekomende gebruiksbevoegdheden. Naast het wegneemrecht kunnen partijen in de vestigingsovereenkomst een vergoedingsregeling opnemen op grond waarvan aan de gebruiker een recht op vergoeding toekomt ten aanzien van de opstallen die door de gebruiker gedurende het opstalrecht zijn aangebracht of bij aanvang van het opstalrecht aan de grondeigenaar zijn vergoed. ${ }^{1307}$ In deze paragraaf zal louter op het wegneemrecht worden ingegaan; enkel door effectuering van het wegneemrecht wordt de natrekking doorbroken.

\section{§5.1 De op grond van het wegneemrecht bevoegde wegnemer}

Het wegneemrecht kan aan alle Duitse, Nederlandse en Belgische zakelijk gebruiksgerechtigden toekomen. ${ }^{1308}$ Dit betekent dat onder het Duitse, Nederlandse en Belgische recht de opstaller bevoegd kan zijn de door hem aangebrachte opstallen weg te nemen. Door het duurzaam met het grondstuk verenigd object fysiek van het grondstuk af te scheiden, komt aan het object een eigen goederenrechtelijke identiteit toe. Het wegneemrecht ziet in beginsel op die objecten die door de gebruiker duurzaam met het grondstuk zijn verenigd. Daarnaast kan onder het Nederlandse en Belgische recht aan de gebruiker een wegneemrecht toekomen ten aanzien van 'oude' opstallen die door de gebruiker in waarde aan de grondeigenaar zijn

1306 In de literatuur wordt ook wel de term 'ius tollendi' gebezigd.

1307 Hoofdstuk $2 \$ 3.5 .2$ (Duitse recht); hoofdstuk $3 \$ 4.5$ (Nederlands recht); hoofdstuk $4 \$ 4.6$ (Belgische recht).

1308 De gerechtigden tot een opstalrecht, erfpachtrecht, erfdienstbaarheid of vruchtgebruik zijn allen bevoegd tot wegname van de door hen aangebrachte objecten. Zoals uit deze paragraaf zal blijken kan een wegneemrecht eveneens worden toegekend aan de huurder en pachter. Deze opsomming van rechten waaraan een wegneemrecht kan worden gekoppeld is niet-limitatief. 
vergoed. Met betrekking tot de objecten die de gerechtigde op grond van de vestigingsovereenkomst gehouden is aan te brengen, bestaat de bevoegdheid tot wegname in beginsel niet tenzij in de vestigingsovereenkomst anders is bepaald. Het staat partijen vrij het wegneemrecht in de vestigingsovereenkomst op te nemen of uit te sluiten. Wanneer in de vestigingsovereenkomst hieromtrent geen beding is opgenomen geven de wettelijke bepalingen ten aanzien van het gebruiksrecht waaraan het wegneemrecht is gekoppeld uitsluitsel.

Zowel onder het Nederlandse als onder Belgische recht komt aan de opstaller krachtens de wettelijke bepalingen die op het opstalrecht van toepassing zijn een wegneemrecht toe waaraan zakelijke werking toekomt. Dit wettelijke wegneemt kan in de vestigingsovereenkomst uitdrukkelijk worden uitgesloten. ${ }^{1309} \mathrm{Op}$ grond van de wettelijke bepalingen van het ErbbauRG komt aan de opstaller geen wegneemrecht toe. Onder het Duitse recht is de opstaller enkel bevoegd de door hem aangebrachte opstallen weg te nemen wanneer partijen dit in de vestigingsovereenkomst zijn overeengekomen. Dit overeengekomen wegneemrecht is slechts verbintenisrechtelijk van aard en opvolgers onder bijzondere titel zijn hier dan ook niet aan gebonden. ${ }^{1310}$

Een wegneemrecht kan naar Nederlands, Belgisch en Duits recht onder andere ook toekomen aan de huurder en de pachter. Onder het Nederlandse recht is het wegneemrecht opgenomen in de wettelijke bepalingen omtrent huur en pacht. ${ }^{1311}$ Door aan de huurder een wegneemrecht toe te kennen ontstaat de situatie dat aan een verbintenisrechtelijk rechtsfiguur zakelijke werking kan toekomen. ${ }^{1312}$ De Hoge Raad oordeelde in het 'Christenhusz/ Brunsveld'-arrest dat de huurder bevoegd is het aan hem toekomende wegneemrecht te effectueren ondanks het feit dat dit recht ontstaan is ná de vestiging van het hypotheekrecht en de huurovereenkomst in strijd met het in de hypotheekakte opgenomen huurbeding tot stand is gekomen. ${ }^{1313}$ Ook onder het Duitse recht komt aan de huurder een wegneemrecht toe ${ }^{1314}$, echter zal een beroep op dit recht enkel noodzakelijk zijn als het door de huurder aangebrachte object geacht wordt duurzaam met het grondstuk te zijn verenigd. Is het voor derden duidelijk dat de duurzame vereniging

1309 Hoofdstuk $3 \$ 4.5$ (Nederlands recht) en hoofdstuk 4 \$4.6 (Belgisch recht).

1310 Dat aan de opstaller naar Duits recht in beginsel geen wegneemrecht toekomt ten aanzien van de door hem verwezenlijkte objecten, bevestigt mijns inziens dat de aan de opstaller toekomende bevoegdheden die betrekking hebben op de opstallen niet als eigendom kunnen worden aangemerkt. Zie: hoofdstuk 6 $\S 4.1 .1$ en hoofdstuk 2 3.3.2 en $\S 3.5 .2$.

1311 Art. 7:216 BW (huur), art. 7:349 BW (pacht).

1312 Hoofdstuk 3 §4.5 en $§ 4.6 .3$.

1313 HR 2 juni 1989, NJ 1990, 253. Zie: hoofdstuk 3 \$4.6.3.

$1314 \S 539$ Abs. 2 BGB. 
van het object met het grondstuk tijdelijk van aard is, dan kan het object worden aangemerkt als Schein-bestanddeel en blijft het object roerend van aard; ten aanzien van objecten die als Schein-bestanddeel kunnen worden aangemerkt wordt het vaste verbindingscriterium ${ }^{1315}$ terzijde geschoven. ${ }^{1316}$ Het wegneemrecht bij huur en pacht onder het Belgische rechtsstelsel komt voort uit het accessoire, zakelijke recht van opstal. Aangenomen wordt dat een door de huurder of pachter aangebracht object in beginsel in eigendom toekomt aan de huurder of de pachter. ${ }^{1317}$

Uit de Schotse literatuur volgt dat zowel aan de lease ${ }^{1318}$ als aan de liferent $^{1319}$ een wegneemrecht kan worden gekoppeld. Deze opsomming is niet-limitatief; ook ten aanzien van andere (gebruiks)relaties kan een wegneemrecht ${ }^{1320}$ bestaan. ${ }^{1321}$ Een aan een gebruiksrecht gekoppeld wegneemrecht ziet 'enkel' op die objecten die door de tenant duurzaam met het grondstuk zijn verenigd, de zogenoemde fixtures, en gekwalificeerd kunnen worden als trade, agricultural, ornamental of domestic fixture. Aangenomen wordt dat een wegneemrecht onder het Schotse recht niet per definitie afhankelijk hoeft te zijn van een ander (gebruiks)recht. Het is mogelijk een overeenkomst te sluiten met als hoofdverbintenis een wegneemrecht. Onzeker is in hoeverre derdenwerking aan deze overeenkomst kan worden toegekend en of het mogelijk is deze overeenkomst in het register in te schrijven. Een uitdrukkelijk door partijen bedongen wegneemrecht is niet beperkt tot voornoemde fixtures, maar kan worden overeengekomen ten gunste van ieder willekeurig object dat duurzaam met het grondstuk is verenigd. ${ }^{1322}$

\section{\$5.2 Onzekerheden ten aanzien van het wegneemrecht ${ }^{1323}$}

In beginsel kan het wegneemrecht worden uitgeoefend gedurende het bestaan van het gebruiksrecht waaraan het wegneemrecht is gekoppeld; het wegneemrecht is immers afhankelijk van het gebruiksrecht. Opmerkelijk is dan ook dat volgens het Nederlandse rechtsstelsel het wegneemrecht niet alleen gedurende maar ook enige tijd na beëindiging van het gebruiksrecht

1315 Zoals in $\$ 2.2$ van hoofdstuk 2 beschreven.

1316 Hoofdstuk 2 $\$ 2.4$ en hoofdstuk $6 \$ 3.1$.

1317 Hoofdstuk 4 §4.5 m.n. $§ 4.5 .2 .3$.

1318 Hoofdstuk 5 \$4.1.1.

1319 Hoofdstuk 5 \$4.1.2.

1320 In de literatuur wordt doorgaans de term 'right of severance' gebezigd.

$1321 \quad$ Hoofdstuk 5 \$

1322 Hoofdstuk $5 \$ 4.2$.

1323 Al wat in deze paragraaf over het wegneemrecht wordt gesteld ziet niet alleen op het wegneemrecht in relatie tot het opstalrecht, maar heeft eveneens betrekking op het wegneemrecht in relatie tot andere gebruiksrechten zoals erfpacht, huur en pacht. 
kan worden uitgeoefend. ${ }^{1324}$ Dit kan mijns inziens tot grote rechtsonzekerheid leiden wanneer ná beëindiging van het gebruiksrecht het grondstuk aan een derde wordt overgedragen. ${ }^{1325}$

De nieuwe eigenaar van het grondstuk zal, wanneer hij niet op de hoogte is gebracht van het nog voortdurende wegneemrecht, ervan uit mogen gaan dat alle objecten die duurzaam met het grondstuk zijn verenigd aan hem toebehoren ingevolge eigendomsnatrekking. Daarentegen zal de gerechtigde tot het nog te effectueren wegneemrecht van mening zijn dat hij niet mag worden benadeeld door een rechtshandeling, in casu de overdracht van het grondstuk, waar hij geen invloed op heeft. Op de vervreemder van het grondstuk rust de verplichting de verkrijger van het grondstuk op de hoogte te stellen van het bestaan van het nog te effectueren wegneemrecht. Laat de vervreemder dit na dan is het de vervreemder die de geleden schade van de verkrijger respectievelijk de gerechtigde tot het wegneemrecht dient te vergoeden. ${ }^{1326}$ Of de gerechtigde tot het wegneemrecht daadwerkelijk bevoegd is de door hem aangebrachte opstallen weg te nemen, dient mijns inziens te worden benaderd aan de hand van het type object dat door de gerechtigde met het grondstuk is verenigd. Wanneer het een authentiek, niet-vervangbaar object betreft lijkt het aannemelijk dat de belangen van de gerechtigde tot het wegneemrecht voorgaan op die van de verkrijger van het grondstuk. De verkriiger van het grondstuk kan dan de geleden schade bestaande uit de waarde van het weggenomen object verhalen op de vervreemder van het grondstuk. ${ }^{1327}$

Ook de hypotheekhouder die ná beëindiging van het gebruiksrecht zijn recht van hypotheek verkrijgt kan worden benadeeld, wanneer blijkt dat aan de voormalig gebruiksgerechtigde van het grondstuk dat met het hypotheekrecht is bezwaard de bevoegdheid toekomt objecten weg te nemen die duurzaam met het grondstuk zijn verenigd en de hypotheekhouder van het bestaan van het wegneemrecht niet op de hoogte is gesteld. Het recht van hypotheek strekt zich in beginsel uit over alle objecten die met het grondstuk zijn verenigd. Wanneer de gerechtigde tot het wegneemrecht besluit zijn recht uit te oefenen, betekent dit dat daarmee de waarde van het object waarop de hypotheekhouder zich kan verhalen vermindert. De

1324 Hoofdstuk $3 \S 4.5$. Onder het Schotse recht kan een aan een lease gekoppeld wegneemrecht ook nog na het verlopen van de leasetermijn worden uitgeoefend wanneer de tenant de onroerende zaak nog steeds in possession heeft. Zie: hoofdstuk 5 \$4.1.1.

1325 In hoofdstuk $3 \S 4.5$ wordt ingegaan op de relatie tussen het wegneemrecht en het eigendomsrecht dat op de opstallen komt te rusten ten gevolge van de vestiging van een opstalrecht.

1326 Dit is een verbintenisrechtelijk probleem dat opgelost wordt aan de hand van het leerstuk van de niet-nakoming.

1327 Ook hier zijn de bepalingen omtrent het leerstuk van de niet-nakoming van toepassing. 
hypotheekhouder kan de hypotheekgever dan verzoeken aanvullende goederen in zekerheid te geven, zodat voldoening van het krediet veilig kan worden gesteld. Wanneer de hypotheekgever dit weigert staat het de hypotheekhouder vrij het door hem verstrekte krediet op te zeggen. ${ }^{1328}$

Een situatie die zich in alle in dit proefschrift onderzochte rechtsstelsels kan voordoen en kan leiden tot rechtsonzekerheid is de volgende: een reeds met een recht van hypotheek bezwaard grondstuk wordt belast met een gebruiksrecht ${ }^{1329}$ waaraan ten behoeve van de gerechtigde tot het gebruiksrecht een wegneemrecht is gekoppeld. Het staat buiten twijfel dat het recht van hypotheek zich uitstrekt over objecten die duurzaam met het grondstuk zijn verenigd, ongeacht of deze zijn aangebracht door de grondeigenaar of de gebruiker en ongeacht of de objecten voor of na de vestiging van het hypotheekrecht zijn aangebracht. Dit betekent dat bij executie van het recht van hypotheek ook de door de gebruiker aangebrachte objecten voor executie in aanmerking komen, terwijl aan de gebruiker ten aanzien van de door hem aangebrachte objecten een wegneemrecht toekomt. Onduidelijk is of de gebruiker zijn wegneemrecht kan uitoefenen. Als argument voor de bevoegdheid tot wegname zou kunnen worden aangedragen dat het hypotheekrecht gevestigd is zonder de aanwezigheid van de later aangebrachte objecten en de hypotheekhouder dan ook niet in zijn verhaalsrecht benadeeld wordt wanneer de objecten door de gebruiker worden weggenomen. Anderzijds kan worden gesteld dat de gebruiker van het bestaan van het recht van hypotheek op de hoogte kan zijn door raadpleging van de registers en aan de gebruiker enkel een wegneemrecht toekomt wanneer de hypotheekhouder heeft ingestemd met de vestiging van het gebruiksrecht waaraan het wegneemrecht is gekoppeld.

De situatie kan ook zo zijn dat er ten aanzien van het grondstuk reeds een gebruiksrecht bestond en het recht van hypotheek nà het gebruiksrecht is gevestigd. De grondeigenaar blijft, ook als het gebruiksrecht zakelijk van aard is, gerechtigd tot het verhypothekeren van zijn grondstuk. Wanneer het gebruiksrecht zakelijk van aard is, kan de hypotheekhouder van het bestaan van het gebruiksrecht op de hoogte zijn door raadpleging van de registers. Op grond van deze wetenschap kan de (toekomstig) hypotheekhouder nader onderzoek doen naar de objecten die met het grondstuk zijn verenigd, de vestigingsovereenkomst die aan het gebruiksrecht ten grondslag ligt bestuderen en eventueel navraag doen bij de gebruiksgerechtigde, waarna hij kan besluiten al dan niet de hoogte van de aan de hypotheekgever te verstrekken geldlening hieraan aan te passen. Mijns inziens staat het de zakelijk gerechtigde te allen tijde vrij, alleen al vanwege het

1329 Dit gebruiksrecht kan zowel verbintenisrechtelijk- als goederenrechtelijk van aard zijn. 
prioriteitsbeginsel, de door hem aangebrachte opstallen weg te nemen. Wanneer het wegneemrecht afhankelijk is van een verbintenisrechtelijk gebruiksrecht zal raadpleging van de registers geen uitkomst bieden. Het is dan aan de hypotheekgever om de (toekomstig) hypotheekhouder op de hoogte te stellen.

\section{$\S 6$. Enkele concluderende woorden tot besluit}

Het aan de opstaller toekomende eigendomsrecht verschilt zodanig van de in $\S 903$ BGB, art. 5:1 BW en art. 544 BBW opgenomen eigendomsdefinities dat de vraagt rijst of de bevoegdheden die aan de opstaller toekomen ten aanzien van de opstallen eigenlijk wel als eigendom kunnen worden aangemerkt. De aan de opstaller toekomende bevoegdheden ten aanzien van de opstallen kunnen krachtens de in de vestigingsovereenkomst opgenomen bedingen dusdanig worden beperkt dat de aan de opstaller toekomende bevoegdheden minder verstrekkend van aard zijn dan de bevoegdheden die de erfpachter heeft ten aanzien van de opstallen ten behoeve waarvan hij 'enkel' een gebruiksbevoegdheid heeft. Terwijl de aan de erfpachter toekomende bevoegdheden ruimer van aard kunnen zijn dan de aan de opstaller toekomende bevoegdheden, worden de aan de erfpachter toekomende bevoegdheden niet als eigendom gekwalificeerd. ${ }^{1330}$

Als al van eigendom kan worden gesproken, dan verkrijgt de opstaller dit eigendomsrecht doordat ten gevolge van de vestiging de natrekking ten aanzien van de 'oude' opstallen wordt doorbroken en de (eigendom van de) opstallen in de vestigingsakte aan hem wordt toegewezen. Of dit eigendomsrecht krachtens derivatieve of originaire wijze wordt verkregen is onduidelijk. ${ }^{1331}$ Het eigendomsrecht op de 'nieuwe' opstallen is -althans volgens de mij aan de heersende keer toe te kennen uitleg- geen eigendomsrecht dat voortvloeit uit de vestiging van het opstalrecht. Door de vestiging van het opstalrecht wordt de natrekking ten aanzien van de 'nieuwe' opstallen terzijde geschoven, waardoor het eigendomsrecht niet ontstaat door de vestiging van het opstalrecht maar blijft voortbestaan.

Mijns inziens dient te worden overwogen het recht van opstal te benaderen als een 'gewoon' beperkt zakelijk recht waarbij de aan de opstaller toekomende bevoegdheden ten aanzien van het grondstuk èn de opstallen voortvloeien uit het recht dat met het opstalrecht is bezwaard. De vestiging van het recht van opstal leidt dan, evenals bij de 'andere' zakelijke gebruiksrechten, tot een overdracht van bevoegdheden aan de opstaller. Hierdoor kan het opstalrecht niet langer worden angemerkt als een bijzondere wijze waarop eigendom kan worden verkregen en leidt vestiging 
niet langer tot doorbreking of het terzijde schuiven van de natrekking. Of het naast elkaar bestaan van opstal- en erfpachtrecht binnen een rechtsstelsel dan nog langer wenselijk of noodzakelijk is, valt te betwisten. ${ }^{1332}$

Niet alleen door het vestigen van een recht van opstal kan de natrekking worden doorbroken maar eveneens door het object dat duurzaam met het grondstuk is verenigd feitelijk van het grondstuk af te scheiden. Door het object feitelijk van het grondstuk af te scheiden komt aan het object een eigen goederenrechtelijke identiteit toe en gaat het object toebehoren aan diegene die bevoegd is tot wegname. Het recht objecten die duurzaam met het grondstuk zijn verenigd weg te nemen, kan in beginsel toekomen aan diegene die ten aanzien van het grondstuk waarmee het object is verenigd een gebruiksrecht heeft. Onder het Schotse recht leidt enkel fysieke afscheiding van het object van het grondstuk tot doorbreking van de natrekking; het Schotse recht is niet bekend met een rechtsfiguur die overeenkomt met het recht van opstal. Het Schotse rechtsstelsel is wel bekend met de rechtsfiguur lease, een zakenrechtelijke rechtsfiguur die grote gelijkenissen vertoont met huur en pacht. Uit de jurisprudentie volgt dat de tenant bevoegd is bepaalde objecten, fixtures, weg te nemen die duurzaam met het grondstuk zijn verenigd. Wanneer een fixture gekwalificeerd kan worden als een trade, agricultural, ornamental of domestic fixture komt aan de tenant de bevoegdheid toe de fixture van het grondstuk af te scheiden. Krachtens effectuering van het wegneemrecht verkrijgt de tenant de eigendom van de fixture. Het wegneemrecht kan dan ook als een bijzondere wijze van eigendomsverkriiging worden aangemerkt. ${ }^{1333}$

Er bestaan grote onzekerheden omtrent het wegneemrecht. Dient een wegneemrecht altijd accessoir te zijn aan een gebruiksrecht of kan het wegneemrecht ook worden overeengekomen ten behoeve van een derde ten gunste van de door hem geleverde objecten die ten tijde van de duurzame vereniging met het grondstuk nog niet zijn betaald? Kan de huurder zijn wegneemrecht uitoefenen ten aanzien van de door hem aangebrachte objecten wanneer het grondstuk reeds vóór de huurovereenkomst is verhypothekeerd en de hypotheekhouder op grond van de wettelijke regeling eveneens de objecten die nà vestiging van het hypotheekrecht zijn aangebracht mag uitwinnen? En wat als de huurovereenkomst van een eerdere datum is dan het gevestigde recht van hypotheek en de hypotheekhouder van het bestaan van het wegneemrecht niet op de hoogte

1332 Voor de in dit proefschrift onderzochte rechtsstelsels dient deze vraag zowel ten aanzien van het Nederlandse als ten aanzien van het Belgische recht te worden gesteld.

1333 Hoofdstuk 6 §5.1. 
is? Deze en vele andere vragen worden noch door de wet noch door de jurisprudentie van de verschillende rechtsstelsels beantwoord. ${ }^{1334}$

Doorbreking van de natrekking is, een enkele wettelijke uitzondering ten gunste van een specifiek object daargelaten, enkel mogelijk door middel van het feitelijk wegnemen van het duurzaam met het grondstuk verenigde object. Het Romeinsrechtelijke superficies solo cedit-beginsel is na 2000 jaar dan ook nog steeds onverkort van toepassing op de huidige in dit proefschrift onderzochte rechtsstelsels. 



\section{Chapter 7. Summary and conclusions}

\section{$\S 1$. Introduction}

The leased construction shed installed on the land for the duration of a construction project, the bronze statue bought under retention of title and placed in the garden, and the electrical cables buried underground are all examples of objects that are directly or indirectly united with the land. This attachment may significantly impact the proprietary rights that rest on the object that is united with the land when the attachment between the object and land is considered permanent according to objective standards. When the permanent attachment criterion is met, the object and land form a juridical unity by which the proprietary rights that rest on the land extend to the object that is united with the land and the proprietary rights that rested on the object before the accession are extinguished as a result of the accession to the land. ${ }^{1335}$ The object also forms a proprietary unity with the land. As a result of the formation of a juridical unity, the object 'follows' the proprietary qualification of the land: just like the land, the object becomes qualified as immovable.

Although all the legal systems studied here ${ }^{1336}$ are familiar with the permanent attachment criterion, they apply different objective standards. ${ }^{1337}$ These standards create differences in the outcome of the permanent attachment criterion: the object attached to the land may form a juridical unity with the land in one legal system, but not in another.

The reason a proprietary unity is adopted between a piece of land and an object that is united with that land is found in the preservation of the value added by the unification, and legal certainty. According to common opinion, objects that together form a composite property have a certain added value. While the value of a single brick is almost nil, a brick building is assigned a value above the combined value of all the individual bricks that were used to build it. A brick building that forms a proprietary unity with the land increases the land's value. Merging the different independent objects into

1335 The Roman legal principle of superficies solo cedit suggests beyond doubt that the land should be regarded as the primary object regardless of the object that is connected with it. A 110-story building or a gold-plated fountain will both become a component of the land on which they were built. The superficies solo cedit principle underlies all the legal systems studied in this thesis.

1336 This thesis discusses accession and the prevention and termination of accession according to German (Chapter 2), Dutch (Chapter 3), Belgian (Chapter 4) and Scottish law (Chapter 5). The legal system applicable to a concrete situation is the legal system that applies in the country where the property is located.

1337 Chapter 7: $\$ 2.2$ for the German legal system, $\$ 2.3$ for the Dutch legal system, $\$ 2.2 .1$ for the Belgian legal system and $§ 3.3$ for the Scottish legal system. 
one composite property increases the social value of each of the merged objects and, thus, the economic value of the whole. Because of this higher economic value, the owner of the composite property is less likely to separate objects that are part of the composite property. Allowing separate real rights on parts of the composite property would increase the risk of the unity being taken apart and the added value being destroyed.

Legal certainty is another reason for the assumption of a proprietary unity. When an object is deemed to be permanently united with the land, the object and land form a single juridical unity with, in principle, a single proprietary identity. In principle, third parties should be able to deduce from the observable situation which objects conform to the permanent attachment criterion and can therefore be regarded as part of the ownership of the land. This is, for instance, important for the mortgagee who, on the bases of the value of the land, determines the amount of the loan to be granted to the mortgagor.

Legal certainty is at stake when, based on the actual situation, third parties conclude that an object unified with the land is intended to be permanently united with that land, but that the permanent attachment criterion is set aside by statutory provisions or by agreement between parties. If the permanent attachment criterion cannot be satisfied because the criterion does not apply to this specific situation, the object must be qualified as a moveable. ${ }^{1338}$ However, it is equally possible that the permanent attachment criterion is not set aside, but that the legal consequence (i.e. the accession of ownership) does not occur when the permanent attachment criterion is satisfied. Accession may be prevented through statutory provisions ${ }^{1339}$ and through the creation of a limited real right of superficies. The objects that are permanently united with the land but do not form a juridical unity with it, are governed by the legal rules that apply to immovable property.

Legal uncertainty may also exist in respect to objects that form a juridical unity with the land, but which have been united with the land by someone other than the landowner. This third party may receive the power to remove these objects under the right of removal. The legal uncertainty is caused by the fact that third parties, such as the buyer or the mortgagee who rely on the factual circumstances when determining the purchase price or the amount of the loan, can be confronted by another party who has the authority to remove objects from the land. The exercise of a right of removal leads to

1338 The German, Belgian and Scottish legal systems have statutory provisions and legal structures under which the permanent attachment criterion is or can be excluded. See Chapter $7 \S 3$.

1339 Under Dutch law pursuant to article 32a Wet op de lijkbezorging (freely translated as: the law on funerals), tombstones are owned by the relatives who are responsible for installing the tombstone, notwithstanding the fact that the tombstones are permanently united with the land. 
physical separation of the object that was unified with the land. As a result of this physical separation, the object is no longer permanently united with the land and it becomes a moveable thing belonging to the party who removed it.

This chapter discusses situations that create legal uncertainty, such as the situations described above. In section 3 we further examine the means by which an object, which according to the factual situation is permanently united with the land, may be prevented from forming a juridical unity with the land. With regard to dissolving the juridical unity, a distinction may be made between cases in which the object is separated and cases in which it is not separated from the land. In the discussion of cases in which accession is dissolved without separating the object the main emphasis will be on the limited right of superficies. With regard to the right of superficies especially, the question is answered whether the powers granted by this right regarding the objects for which the right is created can be regarded as ownership. A negative answer to this question means that the creation of a right of superficies does not lead to a dissolution or prevention of accession and the landowner retains ownership of the objects united with the land. ${ }^{1340}$ Section 5 reviews the dissolution of accession in combination with the physical separation of the object pursuant to the right of removal.

Before looking into the ways by which the permanent attachment criterion and accession may be set aside, the next chapter discusses the objective standards that underlie the permanent attachment criterion. These objective standards differ between the legal systems, as a result of which the outcome of the permanent attachment criterion also differs. ${ }^{1341}$

\section{$\S 2$. Further interpretation of the permanent attachment criterion}

For a proper understanding of this and the following paragraphs, we will first focus on the qualifications that may be granted to an object standing on the land. An object located on a piece of land may be regarded as a separate thing, a component or an accessory. Not all legal systems studied in this thesis have a special category named 'accessories'; since the introduction of the Dutch Civil Code in 1992, the Dutch legal system no longer has a term for accessories.

The proprietary concept of a 'thing' refers to a physically tangible object susceptible to human control and over which a person is able to exercise power. Although the moon is a tangible object, the moon is not a thing in a proprietary sense because it is impossible to dispose of the moon. A thing

$1340 \quad$ Chapter $7 \$ 4$.

1341 Chapter $7 \S 2$. 
has its own identity within the law of property, which means that the object may be subject to proprietary rights such as ownership.

A thing may have a solid body, like a precious stone, but a thing may also be composed of several objects, as in the case of a car or machinery. It is not always clear whether objects connected with each other are part of a single thing or are independent things. The pedals, saddle and handlebars are all part of a bicycle, but how should we classify bicycle lights that can be snapped on and off a bicycle and can be used for other purposes? Are these lights part of the bicycle and can they be regarded as bicycle components or do they remain independent things? This question should be answered on the basis of common opinion. If the lights can be considered part of the bicycle, this implies that the lights do not have a proprietary identity; if the bicycle is then transferred or encumbered, the lights will be transferred or encumbered with it.

A building that is unified with the land can be considered to be a component of the land when the building and land constitute a juridical unity. A juridical unity exists when the unity of the building with the land is permanent according to objective standards. ${ }^{1342}$ According to the Roman superficies solo cedit principle, the land has to be considered the principal thing in relation to the building; therefore, it can only be concluded that the building is a component of the land according to the legal systems which are being compared in this thesis and which are all familiar with the above principle. ${ }^{1343}$ The legal effect of accession is caused by the formation of a juridical unity: proprietary rights that rested on the building prior to the permanent attachment will become extinct whereas the proprietary rights that rest on the land extend to the building. The building will no longer have its 'own' proprietary identity. The real rights to a transmission mast that exist before the accession will lapse as a result of the accession and the real right on the land will extend to the transmission mast.

Aside from the concepts of 'thing' and 'component', moveables that have a certain relationship to the land may be regarded as an 'accessory' under German, Belgian and Scottish law. ${ }^{1344}$ A moveable thing may be regarded

1342 Plants and trees can be also considered components of the land if united with the land. Depending on the legal system that considers plantings a component, the unification may or may not need to be permanent.

1343 In Dutch literature there is discussion about whether or not a building that is permanently united with the land has to be regarded as a component of that land. See Chapter $3 \$ 3$.

1344 Under Belgian law, these objects are referred to as 'properties that are immoveable by destination' (onroerend door bestemming) (see Chapter 4 \$2.2.2). In German law, these moveables are called 'Zubehör' (accessories) (see Chapter 2 \$2.5). In Scottish law, these objects are referred to as 'constructive 
as an accessory when it serves the land. The detailed interpretation of this 'serving the land' criterion varies per legal system: whereas Belgian and German law interpret this criterion broadly (e.g. a truck can be considered an accessory when the truck is transporting products grown on the land), under Scottish law a moveable thing may only qualify as an accessory if there is a constructive alignment with the land. ${ }^{1345}$ Under Belgian law, a moveable thing can also be regarded as an accessory when it serves to embellish the land or the building that is permanently united with the land. For a thing that is moveable by nature to qualify as an accessory, Belgian and Scottish law also require that the moveable thing should belong to the landowner.

An object that can be classified as an accessory retains its own proprietary identity; the proprietary rights that rest on the object continue. Thus, the right of pledge or usufruct resting on an object survives despite the qualification of the object as an accessory. When ownership of the land is transferred, the ownership of the accessory is transferred with it.

\section{§2.1 The German legal system: wesentliche Bestandteile}

German law distinguishes between objects that are 'Sachen' (things), 'wesentliche Bestandteile' (essential components), 'unwesentliche Bestandteile' (inessential components), 'Scheinbestandteile' (apparent components) and 'Zubehör' (accessories). The term essential component is used to refer to objects that have a relationship with the land in some form; there need not be a juridical unity. Only in the case of a essential component do the object and land form a juridical unity.

Buildings and plants and trees may be seen as essential components of the land when they are united with the land in a fixed way ${ }^{1346}$ and cannot be qualified as apparent components. ${ }^{1347}$ According to common opinion, the permanent attachment criterion is met when the separation of a building or plants or trees would damage the land or the object united with the land, or when the separation attached to would incur disproportionately high costs. ${ }^{1348}$ It is assumed that the permanent attachment criterion is also fulfilled when the building, on the basis of its weight, is difficult or impossible to move. ${ }^{1349}$ If the permanent attachment criterion is fulfilled, the object can

1345

1346

1347

1348

1349 fixtures' (see Chapter 5 \$2.1).

Chapter 5 \$2.1.

\$94 Abs. 1 BGB.

§ 95 BGB. See Chapter 7 §3.

The sustainability of the attachment lies in the required far-reaching manner in which an object must be connected with the land in order to qualify as an essential component.

BFH 4 October 1978, NJW 1979, 392; LG Berlin 10 November 2003, NJW-RR 2004, 635. 
be regarded as an essential component. As a result of the accession the object is no longer moveable but becomes immoveable in nature.

Objects that are indirectly united with the land, that is, an object that is united with an essential component of the land, can also be regarded as essential components. ${ }^{1350}$ An indirect unity of an object with the land does not require a permanent attachment; however, it is required that the applied object is viewed in common opinion to be necessary for the building to be complete. Shutters, applied carpeting and an easily removable boiler are all essential components of a building. ${ }^{1351}$

\section{§2.2 The Dutch legal system: two grounds for characterising an object as a component}

In the Dutch legal system an object may form a juridical unity with the land in two ways: 1) pursuant to article 3:4 read with article 5:3 of the Dutch Civil Code (BW) and 2) according to article 5:20 subparagraph 1, read with article $3: 3 \mathrm{BW}$. Regardless of the manner in which the juridical unity is created, the legal effects that are assigned to the formation of the unity are identical: the object becomes a component of the land. ${ }^{1352}$

The first method for forming a juridical unity is found in article 3:4 BW. Article 3:4 BW gives two criteria: common opinion and the attachment criterion. The keys of a bicycle lock, a roof tile blown off the roof and the spare parts of a machine are all part of the bicycle, house and machine according to common opinion ${ }^{1353}$ and can be considered components. The attachment criterion is laid out in the second paragraph of article 3:4 BW. Based on this criterion, a juridical unity is formed when the object cannot be separated without significant damage. The separation of an object without damage to either object can also be grouped under the attachment criterion when the separation is attached to disproportionate costs or labour. The attachment criterion should be seen as an elaboration of common opinion. ${ }^{1354}$

On account of the criteria in article 3:4 BW, a building may not be viewed as a component of the land: according to common opinion, the building is not part of the land and the building can be separated from the land without essential damage. As the Dutch legal system follows the Roman principle of

1351 Chapter $2 \S 2.2$.

1352 According to article 5:3 BW, the owner of a thing is owner of everything that according to art. 3:4 BW qualifies as a component. Buildings, plants and trees that form a juridical unity with the land according to art. 3:3 BW are subject to the right of ownership of the land according to art. 5:20 para $1 \mathrm{BW}$.

1353 Chapter 3 \$2.2.1.

1354 Chapter $3 \$ 2.2 .2$. 
superficies solo cedit ${ }^{1355}$, under which all objects that are permanently united with the land are considered to be a component of the land, there must be a second principle in Dutch civil law under which an object forms a juridical unity with the land. This second rule is found in article 5:20 paragraph $1 \mathrm{BW}$ in conjunction with article 3:3 BW. ${ }^{1356}$ Article 5:20 paragraph $1 \mathrm{BW}$ lists the objects that are considered components of that land, at least "as far as the law does not provides otherwise". 1357 The enumeration of article 5:20 paragraph $1 \mathrm{BW}$ is largely consistent with the objects that, pursuant to article 3:3 paragraph $1 \mathrm{BW}$, can be characterised as immovable.

According to article 3:3 $\mathrm{BW}$, a building can be considered immoveable when it is permanently united with the land, either directly or by attachment to other buildings. In the leading 'Portacabin' judgment, the Dutch Supreme Court further developed the notion of 'permanently united with the land': "A building can be united in a permanent manner with the land in the sense of article $3: 3 \mathrm{BW}$ when through nature and construction it is intended to permanently remain in place". ${ }^{1358}$ A permanent attachment exists when the builder of the object intends for the object to be permanently united with the land. This intention of permanence must be derived objectively from the attachment of the building to the land. The existence of a foundation is not required for a unity to be qualified as permanent ${ }^{1359}$; an object may also be united with the land by other means in such a way that it is clear to any third party that the attachment is of a permanent nature. Objects that can move on the land, such as cranes ${ }^{1360}$, can also be labelled as immoveable pursuant to article 3:3 BW if third parties can derive from the circumstances of the annexation that it is of a permanent nature. According to article 5:20 paragraph 1, in conjunction with article $3: 3$ paragraph $1 \mathrm{BW}^{1361}$, the aforementioned crane forms a juridical as well as a proprietary unity with the land.

It may not be concluded that article 3:4 BW plays no role in the accession of buildings. The question which parts attached to a building can be considered as components of the building is answered by the criteria laid down in article 3:4 BW. Article 5:20 paragraph $1 \mathrm{BW}$ cannot help here, since this article 'only' enumerates those objects that can be considered a component of the land. Article 3:4 BW refers to the delimitation of the size of the building. ${ }^{1362}$

1355 In the Dutch legal system the superficies solo cedit principle is expressed in art. 5:20 paragraph $1 \mathrm{BW}$.

1356 Chapter $3 \$ 3.1$.

1357 Article 5:20 paragraph 1 BW.

1358 HR 31 October 1997, NJ 1998, 97.

1359 HR 25 October 2002, NJ 2003, 241.

1360 HR 24 December 2010, LJN BO3644.

1361 Chapter $3 \$ 2.3$.

1362 Chapter $3 \S 3$. 


\section{$\S 2.3$ The Belgian legal system: immoveable by nature}

The Belgian legal system divides immoveable things into two categories: things that are immoveable by their nature ${ }^{1363}$ and things that are immoveable by their destination ${ }^{1364}$. Objects that are immoveable by their nature can furthermore be divided into land and objects regarded as immoveable through the incorporation criterion. Only the objects that are immoveable under the incorporation criterion form a juridical unity with the land. The incorporation criterion is met when there is a permanent connection between a building and the land, either directly or through another building, or when the building is fixed to the land. ${ }^{1365}$ The intention of the building to remain in place may be derived from the existence of a close physical connection between the land and the building but may also be derived from other circumstances when such a physical connection is missing. Thus, a harbour crane ${ }^{1366}$ moving on the land may be immoveable by nature when, from the circumstances, it can be concluded that the relationship between the crane and the land is permanent. When an object is classified as immoveable by its nature, it follows from article 552 of the Belgian Civil Code (BBW) that the ownership of the land includes the ownership of the immoveable object. ${ }^{1367}$

\section{§2.4 The Scottish legal system: fixtures}

In contrast to the German, Dutch and Belgian legal systems, there is no distinction between juridical and proprietary unification under the Scottish legal system. The requirement that an object be physically and permanently united with the land is the foundation of accession and, therefore, of proprietary unification. The literature lists three requirements for accession: physical attachment, functional subordination and permanency. Accession requires that the immoveable thing and the object in or on the immovable thing should be physically united with each other and that the attachment may be regarded as permanent. The permanency may be inferred from different factors: from the manner in which the object is united with the land or the extent of this unification. It may also be inferred from the fact that modifications to an object and/or the land are made prior to their attachment. Common opinion may play a role in determining whether the attachment is permanent; will the object that is united with the immoveable

1363 Article 518 in conjunction with 525 paragraph 1 BBW. See Chapter 4 §2.2.1.

1364 A thing that is immoveable by its destination can be considered an accessory. See Chapter 4 \$2.2.2 and Chapter 7 \$2.

1365 Cass. 15 September 1998, T.B.B.R. 1990, 211.

1366 Cass. 14 February 2008, R.W. 2008-2009, pp. 456-459; hof Gent 11 February 2011, T.F.R. 2011/42, p. 603.

1367 In the Belgian legal system, the superficies solo cedit principle is expressed in article $552 \mathrm{BBW}$. See Chapter 4 §3. 
thing normally be left behind or taken away when the immoveable thing changes hands? The final aspect concerns the time span needed for the object to be united with the immoveable thing or removed from the land. Objects for which the application or removal takes a longer time are presumed to be permanently attached to the land.

To meet the functional subordination requirement, the unification of the object with the land must be for the benefit of the immoveable thing. This requirement only plays a role in an indirect unification of an object with the land because the application of the functional subordination requirement to a direct unification may conflict with the physical attachment requirement. The unification of a factory building with the land is not made for the benefit of the land but for the benefit of the factory building. ${ }^{1368}$

Due to accession, the object that is attached to the land is considered to be a component and loses its independence, and the rights that exist on the immoveable thing will now also cover the object. ${ }^{1369}$ Since the object is no longer independent in nature, it should be considered as a fixture.

\section{$\S 2.5$ The permanent attachment criterion in comparative perspective}

The essential component, the component, the thing that is immovable by nature and the fixture all form a juridical unity with the land due to their permanent attachment to the land. As previous paragraphs have shown, each of the legal systems studied here have their own interpretation of the permanent attachment criterion. ${ }^{1370}$ The objective standards that must be met to create a permanent attachment are based on common opinion about when a unity is deemed to exist between an object and the land. As these criteria differ between legal systems, there are differences in the scope of the permanent attachment criterion in the legal systems. Thus, an object may (under certain circumstances) form a juridical unity with the land in one legal system, but not in another legal system. In the Dutch and Belgian legal systems, a harbour crane moving on rails can form a juridical unity with the land with which the crane is united, whereas under German and Scottish law the same harbour crane will be qualified as an independent thing, since these legal systems do not view the unification of the land and crane as 'permanent'. ${ }^{1371}$

1368 Chapter $5 \$ 3.3$.

1369 Chapter $5 \$ 3.4$.

1370 Chapter $7 \S 2.1$ to $\$ 2.4$.

1371 The Dutch Supreme Court (HR 24 December 2010, LJN: BO3644) and the Belgian Court of Cassation (Cass. 14 February 2008, R.W. 2008-09, 456) are of the opinion that the mobility of an object does not obstruct a durable 
Moreover, common opinion is not static, but develop with the changing social needs of society. This means that the objective standards that should be met to create a permanent attachment are also subject to change. A changing common opinion is usually reflected in case law, which can lead to the reformulation of existing standards, the formulation of new standards or simply a different decision based on the same standards. An example of this changing common opinion in case law is to be found in 'prefabricated' structures, such as a log cabin or a portable building, that are united with the land. The attachment of such an 'off-the-shelf building with the land is generally characterised by the absence of a foundation, so the attachment of the building with the land is achieved through sheer weight of the construction on the land. While the German ${ }^{1372}$, Dutch ${ }^{1373}$ and Belgian ${ }^{1374}$ legal systems have long assumed that a permanent attachment required the existence of a foundation, the German, Dutch and Belgian courts have come to the conclusion that changing building techniques mean that even prefabricated structures can be considered components of the land, despite the absence of a foundation. ${ }^{1375}$

In principle, the permanency of the attachment must be inferred from the circumstances relating to the attachment itself. In a recent judgment, the Dutch Supreme Court confirmed that only the nature and construction of the object that is united with the land should be considered when determining whether an object is intended to be permanently united with the land. ${ }^{1376}$ The case that underlies this judgment involved a houseboat that could only be placed in a residential area by temporarily demolishing part of a dike. After placement, the houseboat was surrounded by low bridges and could not in its entirety pass under these bridges to another location. ${ }^{1377}$ The Dutch Supreme Court held that only the nature and construction of the houseboat itself should be considered when determining whether there was a permanent unification. Neither the connection between the houseboat and the soil beneath the houseboat ${ }^{1378}$ nor the connection between the houseboat and the banks ${ }^{1379}$ led to the qualification that the houseboat was \$2.2.1 (Belgian legal system).

1372 BFH 4 October 1978, NJW 1979, 392; LG Berlin 10 November 2003, NJW-RR 2004, 635 .

1373 HR 31 October 1997, NJ 1998, 97.

1374 Hof Gent 16 March 2000, T.F.R. 2000, 650.

1375 It is uncertain whether Scottish law considers a prefabricated structure to be a component of the land.

1376 HR 15 January 2010, LJN: BK9136. See Chapter 3 \$2.3.1.

1377 Para. 4.4.1 in HR 15 January 2010, LJN: BK9136.

1378 Para. 4.2 in HR 15 January 2010, LJN: BK9136.

1379 Para. 4.6 in Hof's-Hertogenbosch 30 December 2010, LJN: BQ0443. 
permanently united with the land. ${ }^{1380}$ According to Belgian literature, all circumstances in a case should be taken into account when determining whether or not an object qualifies as permanently united with the land. It is likely that under Belgian law such a houseboat would be regarded as being permanently united with the land.

Under Dutch law, when an object is united with the land in a direct way and we are asked to determine whether the object forms a juridical unity with the land, only those circumstances concerning the attachment between the object and the land itself are taken into account. ${ }^{1381}$ This is different when an object is united with the land in an indirect manner: in cases of indirect attachment we have to determine whether the object can be considered a component of a building. This determination is based on common opinion in which all circumstances in a case are taken into account. ${ }^{1382}$

A comparison of the application of the permanent attachment criterion in different legal systems shows a decreasing scale. The German legal system considers the fewest number of objects to be permanently united with the land. This is not only caused by stricter standards relating to 'the permanent attachment criterion' in comparison with the other jurisdictions, but also by the apparent component classification. ${ }^{1383}$

Similarly to German law, Scottish law recognises a relatively small group of objects as forming a juridical unity with the land. Unlike German law, Scottish law gives common opinion a larger role in interpreting the permanency criterion. In comparison to German and Scottish law, Dutch and Belgian law identify a larger group of objects that form a juridical unity with the land. They also find that objects that are able to move on land may form a juridical unity with that land. This broad interpretation of the permanent attachment criterion can lead to legal uncertainty: does the object that moves on land form a juridical unity with the land or should it be considered as moveable? The qualification of the object depends on the specific circumstances of the case.

Another source of legal uncertainty under Dutch law is the double criterion that it uses to form a juridical unity between an object and the land. Apart from the permanent attachment criterion that applies to those cases where a

1380 In the sense of article 3:3 paragraph $1 \mathrm{BW}$.

1381 Chapter $3 \$ 2.3$.

1382 Later on, this section discusses the qualification of an object as a component under the common opinion as per article 3:4 BW.

1383 When an object may be classified as an apparent component, it implies that the object can be considered a moveable thing despite the permanent attachment to the land. $\S 3$ of this chapter deals with the exceptions that the different legal systems discussed in this thesis make towards the permanent attachment criterion. The apparent component is discussed further in $\S 3.1$ of this chapter. 
building is united with the land either directly or through another building, an object that is not a building may form a juridical unity with the land when, according to common opinion, that object is part of the building; the object may then be regarded as a component of the land. ${ }^{1384}$ This second manner of forming juridical unity relates to the definition of the dimension of the building. ${ }^{1385}$ The civil code ${ }^{1386}$ and case law indicate what, according to common opinion, should be considered part of a building. The Dutch Supreme Court in its 'Dépex/Curatoren Bergel c.s.' judgment ${ }^{1387}$ provided two criteria for answering the question when equipment may be considered part of a factory building: the equipment form part of the building if 1) the building is incomplete without the equipment or if 2) the building and equipment are adapted to each other from a constructive perspective. ${ }^{1388}$ The assessment of whether an object can be designated as a component of a building is therefore not purely based on the connection between the building and the object. Since the details of common opinion are less welldefined in comparison to the permanent attachment criterion $^{1389}$, this can lead to a situation where an object that is united with a building forms a juridical unity with the land under one legal system but not under another system.

\section{§3. Exceptions to the permanent attachment criterion}

Not every object that is permanently united with the land forms a juridical unity with that land. The German ${ }^{1390}$, Belgian ${ }^{1391}$ and Scottish legal systems ${ }^{1392}$ are familiar with concepts which set aside the permanent attachment criterion. Where these concepts apply, the objects to which these legal concepts relate should be regarded as moveables despite their permanent unification with the land..

\section{§3.1 The Scheinbestandteil}

Under German law an object that is permanently united with the land ${ }^{1393}$ has its own proprietary identity when the object can be qualified as an

1384 Art. 3:4 paragraph $1 \mathrm{BW}$.

1385 Chapter $3 \S 3$.

1386 According to article 3:4 paragraph 2 BW an object can be regarded as a component of a building when separation leads to substantial damage to either.

1387 HR 15 November 1991, NJ 1993, 316.

1388 Chapter $3 \$ 2.2 .1$.

1389 Except as discussed above in the case of equipment in a factory building.

1390 Chapter 7 \$3.1.

1391 Chapter $7 \$ 3.2$.

1392 Chapter $7 \$ 3.3$.

1393 Objects that are indirectly united with the land, for instance via attachment to a 
apparent component. ${ }^{1394}$ An object serves as an apparent component when it is permanently united with the land in the exercise of a limited right in rem or when it can be inferred, from the factual circumstances of a case, that the permanent attachment of the object with the land was only intended to be temporary. ${ }^{1395}$

If, on the basis of common opinion, it can be argued that the object was intended to be united with the land only temporarily, the object has to be qualified as an apparent component, and is therefore not deemed to form a juridical unity with the land. For instance, when a grandstand is permanently united with the land to offer the visitors of a summer festival a place to sit, it is clear to everyone that the builder intends to unite the object only temporarily with the land. In contrast, when an object is united with the land by a tenant, it will not often be as easy to determine whether the object should be seen as an essential component or as an apparent component. If the temporariness of the attachment cannot be derived from the circumstances of a case, then the object forms a juridical unity with the land and it can be considered an essential component. The tenant may, however, have the right to remove the objects that she installed and that have become part of the land because of the unification.

Objects that are united with the land by the holder of a real right are presumed to be united with the land for the purpose of exercising the real right. By consulting the Grundbuch (land register), third parties may learn of the existence of the real right and thus about the possible existence of apparent components. However, the land register cannot specify which objects may be regarded as apparent components. The intention to unite the object with the land for the duration of the real right need not be derived from the factual circumstances for identifying the object as an apparent component.

\section{$\S 3.2$ Moveable by anticipation}

Under Belgian law, it is possible to qualify an object as a moveable thing by anticipation ${ }^{1396}$ even though it is still permanently united with the land. ${ }^{1397}$ An object is considered to be a moveable thing when the object is the subject of a juridical act to transfer the ownership of the object without it being physically separated from the land. Since the transfer relates to moveable

building, can also be considered an apparent component

1396 Objects that are indirectly permanently united with the land may also be classified as moveable as a result of early anticipation. See Chapter $4 \$ 2.2 .1$.

1397 The literature also uses the term 'moveable by anticipation'. 
property, there is no requirement to register the transfer or the agreement relating to the determination of the object as moveable by anticipation in the land register. For example, fruit on a tree, the raw materials contained in the ground and construction materials derived from a building on the land may be transferred in ownership to a third party without physical separation having taken place. Objects that are the subject of a juridical act performed in anticipation of separation are no longer burdened with a mortgage on the land. However, the mortgagee can exercise her rights of enforcement on the purchase price of the things sold. ${ }^{1398}$

\section{$\S 3.3$ Industrial fruits}

Under Scottish law fruits that are permanently united with the land may be considered moveables when these fruits are grown for the purpose of conducting trade. ${ }^{1399}$ These fruits, described by the term 'industrial fruits', are moveable by nature from the moment that the seeds or the plants are united with the land or fruit starts to develop on the trees. ${ }^{1400}$ Because these fruits have their own identity in property law, they may be transferred to another person during their attachment to the land. Since the objects are moveable by nature, there is no requirement to register the transfer of ownership.

The seeds and plants planted by the tenant another's land for the purpose of conducting commercial trade are also moveable by nature; the plants and seeds belong to the tenant in spite of their permanent attachment to the land. While the plants and seeds are owned by the tenant, machinery that is permanently united with the land and necessary for manufacturing products for the conduct of trade (known as 'trade fixtures') does form a juridical unity with the land. ${ }^{1401}$ In principle, the tenant is entitled to separate these trade fixtures from the land. Scottish literature does not explain the different approach that property law takes in regard to industrial fruits on one hand and trade fixtures on the other hand.

\section{$\S 4$. Exceptions to accession}

Not every object that is permanently united with the land can be regarded as a component of the land. When society feels that the accession of a certain

1398 Article 45 paragraph 3 Hypotheekwet (Hyp.W.).

1399 Chapter $5 \$ 2.1$.

1400 The tree that grows the fruits cannot be regarded as an industrial fruit, but it is part of the land. It is noteworthy that trees grown with a view to exploitation cannot be classified as industrial fruits. See Paul v Cuthbertson (1840) 2 D 1286.

1401 Chapter $5 \$ 4$. 
object with the land is undesirable, the legislature may decide to exclude accession by statute. Such a statutory provision may lead, depending on the legal system and the object, to the creation of a statutory right of superficies. ${ }^{1402}$ In addition to statutory provisions as instruments for social intervention, the landowner is entitled to create a real right of superficies. The creation of this real right means that the party entitled to the right of superficies owns one or more objects that are permanently united with the land. Under German, Dutch and Belgian law, accession may be terminated or prevented by creating a right of superficies. ${ }^{1403}$

\section{$\$ 4.1$ The right of superficies}

The limited real right of superficies gives its holder, the superficiary, the right to own or acquire one or more objects in or on another person's land. According to both Dutch and Belgian law, these objects can include buildings, works and plants and trees. ${ }^{1404}$ Under German law a right of superficies may only be created for buildings and works. ${ }^{1405}$ The contract of creation lists the objects for which the right of superficies is created; these objects can be qualified as 'superficies'. A right of superficies can be created for the benefit of one or more objects that are permanently unified with the land at the time of creation, known as 'old' superficies, as well as for the benefit of one or more objects that are to be created by the superficiary during the right of superficies, the 'new' superficies. ${ }^{1406}$ Since according to the prevailing doctrine ${ }^{1407}$, the superficiary owns the superficies as a result of her right of superficies, it must be presumed that the creation of a right of superficies leads to a dissolution of the accession with regard to the 'old' superficies. With regard to the 'new' superficies, the accession is not dissolved but prevented.

1402 The party installing an electrical grid in Belgian soil for general use owns the grid pursuant to a statutory right of superficies, i.e. a right of superficies automatically created by law. See article 15 Law of 10 March 1925 elektriciteitsvoorziening and Chapter $4 \$ 4.1$. The entitled installer of an electrical grid on Dutch soil also owns the grid but, different from Belgian law, the exclusion of accession does not take place by way of a statutory right of superficies. Dutch law has no provisions for the statutory right of superficies. Pursuant to article 5:20 paragraph $2 \mathrm{BW}$, the installer of the grid is the owner. See Chapter $3 \S 4.2$.

1403 The right of superficies is discussed in Chapter $2 \$ 3$ (German law), Chapter 3 $\S 4$ (Dutch law) and Chapter 4 \$4 (Belgian law).

1404 Chapter $3 \$ 4.2$ (Dutch law) and Chapter $4 \$ 4.4 .1$ (Belgian law).

1405 Chapter $2 \S 3.3$.

1406 Objects that are permanently united with the land by the superficiary but are not included in the contract of creation will, in principle, belong to the landowner during the lifetime of the right of superficies.

1407 Chapter $2 \S 3.3 .2$ (German law); Chapter $3 \S 4.3 .1$ (Dutch law); Chapter 4 $\S 4.4 .2$ (Belgian law). 
In both Dutch and Belgian law the relationship between the right of superficies and ownership of the superficies can be considered dependent or accessory. It is impossible to transfer ownership of the superficies separately from the right of superficies; alienation of the right of superficies automatically leads to alienation of the superficies. Under Dutch law, encumbrance and lease of the right of superficies also leads to encumbrance and lease of the superficies. ${ }^{1408}$ Unlike Dutch law, it is possible under Belgian law to encumber and lease the superficies separately from the right of superficies; however, it is not possible to alienate the superficies separately from the right of superficies. ${ }^{1409}$ The relationship between the right of superficies and the superficies for which benefit the right is created can therefore be referred to as 'limited accessory' under Belgian law. ${ }^{1410}$

Under German law the object for which the right of superficies is created is considered to be an essential component of the right of superficies, which is possible because the 'Gesetz über das Erbbaurecht'1411 (statute about the right of superficies) considers the right of superficies to be similar to the right of ownership of the land ('grundeigentumsgleiches Recht'). ${ }^{1412}$ As an essential component of the right of superficies, the superficies follows the right of superficies. The superficies cannot be alienated or encumbered separately from the right of superficies. ${ }^{1413}$ In relation to the land, the superficies is considered to be an apparent component. ${ }^{1414}$

\section{\$4.1.1 Does the superficiary have the right of ownership over the superficies?}

Except for Scots law the legal systems compared in this thesis are familiar with the limited real right of superficies and agree that a right of ownership rests on the superficies as part of the prevailing doctrine. From paragraph $903 \mathrm{BGB}$ and articles 5:1 BW and 544 BBW it follows that this right of ownership can in principle be exercised to the exclusion of all other persons. The owner has the right to use the thing on which the right of ownership rests as she wishes, unless such use is contrary to statutory provisions or rights of others. The use of the thing includes acts that result in transfer, encumbrance and the destruction of the thing. The right of ownership, as defined in the aforementioned provisions, can be regarded as the most

1408 Chapter $3 \S 4.6$.

1409 Chapter 4 \$4.4.

1410 For the transfer and encumbrance of the right of superficies, the superficies and approval by the person providing the right of superficies can be required when parties have agreed so in the contract of creation.

1411 Further ErbbauRG.

$1412 \S 11$ ErbbauRG jo. $§ 96$ BGB. See Chapter 2 \$2.2.2 and §3.3.2.

1413 Chapter $2 \S 3.5$.

1414 Chapter $2 \S 3.3 .2$. 
comprehensive right that a person can have in respect to an object. I doubt, however, if the right that rests on the superficies as a result of the creation of the right of superficies can be considered as ownership.

The scope of the right of ownership that rests on the superficies is not only limited by the dependent or accessory relationship between the right of superficies and the right of ownership resting on the superficies, as described in the above paragraph. It is also limited by laws relating to the right of superficies and to the contract, which is the basis for the deed of creation for the right of superficies. It is remarkable that the scope of the right of ownership may be limited by the aforementioned contract of creation, because this possibility is not mentioned in the provisions of paragraph 903 BGB, article 5:1 BW or article 544 BBW mentioned above. The parties are free to agree on the use ${ }^{1415}$ of the right of superficies, the land and the superficies united with the land. By making provisions in the contract of creation about the use of the superficies, the contents of the right of ownership resting on the superficies is contractually stipulated by the parties. As the parties may in principle shape the right of ownership in their contract, the right of ownership can be given virtually any arbitrary content, which, in my opinion, is contrary to the numerus clausus principle. In both the Dutch and Belgian legal systems, it is possible to limit the rights of the superficiary regarding 'ownership' of the superficies to such an extent that a person who has a right of emphyteusis (and who therefore 'only' has a right to use the land and the superficies united with it) has more powers than the superficiary who has the 'ownership' of the superficies. Although the powers of the person with a right of emphyteusis may be more far reaching, they will not be classified as ownership. ${ }^{1416}$

While the existence of the right of ownership ${ }^{1417}$ resting on a thing depends on the existence of the thing, the existence of the 'right of ownership' resting on the superficies does not only depend on the (continued) existence of the superficies, but also depends on the duration of the right of superficies. In principle, the destruction of the superficies has no effect on the survival of the right of superficies. Depending on the legal system, the right of superficies can be temporary or perpetual. While the right of ownership set forth in paragraph $903 \mathrm{BGB}$, article 5:1 BW and article $544 \mathrm{BBW}$ is, in principle, perpetual, it is impossible under Belgian law to create a perpetual independent right of superficies. An independent right of superficies in Belgium may be created for a maximum of 50 years. ${ }^{1418}$

1415 The term 'use' refers to the actual use as well as to juridical acts.

1416 Chapter $3 \$ 4.3 .1$ (Dutch); Chapter $4 \$ 4.2 .2$ (Belgian).

1417 As stipulated in $\S 903 \mathrm{BGB}$, article 5:1 BW and article 544 BBW.

1418 The Belgian law of superficies (Opstalwet) allows parties to extend the right of 
According to Dutch law, it is impossible to transfer property for a certain limited period of time into the patrimony of another. Article 3:85 paragraph $1 \mathrm{BW}$ states that an obligation intended to transfer property for a certain specific period is deemed to be an obligation to create a right of usufruct. Since the prevailing doctrine holds that the creation of a right of superficies leads to acquisition of ownership, I conclude that the creation of a temporary right of superficies violates article 3:85 $\mathrm{BW}$ and that the creation of a right of superficies does not lead to acquisition of ownership. As article 3:85 BW lacks any phrase like 'unless otherwise provided by law' and as it is possible to create a temporary right of superficies, this confirms my presumption that the creation of a right of superficies does not provide ownership to the superficiary. ${ }^{1419}$

Since according to the prevailing doctrine, the superficiary owns the superficies for which the right of superficies is created, the creation of a right of superficies cannot be dismissed as being 'merely' a creation of a limited real right of use: the creation of a right of superficies must also be seen as a means by which ownership can be obtained. It is uncertain whether the right of ownership that is acquired through the creation of the right of superficies is a form of original or derivative acquisition. According to the prevailing doctrine, the creation of a limited right has to be considered as a form of derivative acquisition. Although a new right is created when a limited right is created, the powers that the person entitled to the limited right can derive from the existing 'motherright' are transferred to that person as a result of the creation. The unusual aspect of the right of superficies in comparison with other limited rights is that the superficiary not only has rights of use but also has ownership of the superficies in favour of which the right has been created. Concerning the question of acquisition, a distinction must be made between a situation in which the superficies is already present when the right of superficies is created and a situation in which the superficies is built after the creation.

According to the prevailing doctrine, the creation of the right of superficies also has to be considered as a means of acquiring ownership with regard to the 'old' superficies. Together with the creation of the right of superficies, a right of ownership with regard to the 'old' superficies is created as an accessory to the right of superficies. ${ }^{1420}$ It is uncertain if the right of

superficies (art. 4 Opstalwet). See Chapter $4 \$ 4$.2.4. A right of superficies that is an accessory of the right of emphyteusis can, on the other hand, be perennial. See Chapter $5 \S 4$.5.2.3. The temporariness of the right of ownership does not derive from the character of the right of ownership that rests on the superficies, but from the limitation set by article 4 Opstalwet, which is an imperative statutory provision. See Chapter $4 \$ 4.2 .4$.

1419 Chapter 3 \$4.3.1.

1420 Creating a right of superficies results in dissolution of the accession. 
ownership of the 'old' superficies is created in an original or a derivative manner. An identifying mark of original acquisition is that, in principle, a limited right resting on the acquired thing will lapse. This would mean that a limited right resting on the 'motherright' before the creation of the right of superficies no longer rests on the superficies owned by the superficiary. But such a description would be misleading: a limited right that is created before the creation of the right of superficies can clearly influence the right of ownership. Pursuant to the priority principle, the person entitled to an 'older' right (e.g. the right of mortgage or servitude) is entitled to exercise her right without having to take into account a right that is created later. When the right of superficies is created on land that is already encumbered with a right of mortgage, the mortgagee may sell the land in a forced sale free from the right of superficies. The forced sale includes the superficies in favour of which the right of superficies was created. The question whether the superficiary acquired ownership in an original or derivative way is of no practical significance here.

The right of ownership over the 'new' superficies is also an accessory to the right of superficies, but in my opinion does not derive from the limited right of superficies. The right of ownership already resting on a superficies will survive because the superficies cannot be regarded as a component of the land. The superficiary does not acquire a right of ownership but keeps the right of ownership that is already resting on the superficies; in my opinion, the accession is excluded as a result of the creation of the right of superficies. The question whether there is an original or derivative acquisition need not be raised.

There can be no new or existing 'right of ownership' if based on the arguments discussed in this paragraph, it can be alleged that the powers of the superficiary with regard to the superficies may not be considered as ownership but that, as is the case with other limited real rights, they derive from the more comprehensive 'motherright'. ${ }^{1421}$ With regard to 'old' and 'new' superficies, we can speak of a derivative acquisition of the right of superficies. According to that interpretation, no right of ownership rests on 'new' or 'old' superficies. The superficies is a component of the land and is owned by the landowner; pursuant to the right of superficies, the superficiary acquires the powers agreed to in the contract.

In paragraph 2 of this chapter, it is noted that a component does not have its own proprietary identity. ${ }^{1422}$ It is remarkable that under German law a right of ownership rests on the superficies that must be considered a component

1421 The creation of the right of superficies can then be considered a transfer of powers.

1422 Chapter $7 \S 2$. 
of the right of superficies. Since the German legislature qualifies the right of ownership that will rest on the superficies as 'Sondereigentum' ${ }^{1423}$, the German legislature seems fully aware that the right that will rest on the superficies cannot be equated to the right of ownership as defined in paragraph 903 $\mathrm{BGB}$. The question thus arises whether a second private form of ownership exists in addition to the ownership concept in paragraph 903 BGB. ${ }^{1424}$

On the above-mentioned grounds, I believe that it is preferable to regard the creation of a right of superficies in the same way as the creation of any other limited real right. As a result of the creation the superficiary receives a bundle of powers that relate to a superficies and to the land encumbered with the right of superficies. Depending on what is agreed in the contract that created the right of superficies, powers related to the superficies can largely be equated to the right of ownership as defined in paragraph 903 $\mathrm{BGB}$, article 5:1 BW and article $544 \mathrm{BBW}$. However, no right of ownership would rest on the superficies and none would accrue to the superficiary.

\section{$\S 4.1 .2$ The creation of a right of superficies as a disguised method of transfer}

Under German law, burdening an existing right of superficies held by A with another right of superficies in favour of $\mathrm{B}$ is not considered as the creation of a right of superficies in favour of B when the superficiary A, no longer has the power to have a building on the landowner's land. The creation of the right of superficies in favour of $B$ should then be considered to be a transfer of A's right of superficies to B. ${ }^{1425}$ This transfer not only applies to the superficies for which the right of superficies is created (since the superficiary, according to the prevailing doctrine, already owns the superficies pursuant to the created right of superficies), but it also applies to the right of use on the land, and the objects permanently united with it, as granted by law or by the deed of creation.

The assumption of transfer of land can, in my opinion, exist when according to the contract of creation of the right of superficies the powers accruing to the superficiary ${ }^{1426}$ are so far reaching that the creation of a perpetual right

1423 § 3 WEG. See Chapter 2 \$3.3.2.

1424 In addition to the civil law ownership concept set out in $\S 903$ BGB, the German legal system has a public ownership provision (§ 14 German Constitution). See Chapter 2 \$3.3.2.

1425 Chapter $2 \$ 3.5 .1 .1$.

1426 We should note here that the superficiary derives these powers from the right of superficies. 
of superficies ${ }^{1427}$ entails that the landowner retains little or no power over the land now or in the future. ${ }^{1428}$ Apart from the duration and the scope of the content of the right of superficies, I believe the following elements also play a role in labelling a perpetual right of superficies as a clear or disguised method of transfer: 1) the possibility that the right of superficies can revert to the landowner ${ }^{1429}$ and 2) the duty resting on the superficiary to pay or not to pay a recurring monetary consideration. ${ }^{1430}$

When the right of superficies is subjected to certain resolutive conditions, there is a possibility that the superficiary's powers could, at some point, return to the landowner. Thus, the right of superficies may be subject to the resolutive condition that the superficies is used only to a particular purpose. If according to common opinion there is a real risk that the superficiary's powers will revert to the landowner or her successor ${ }^{1431}$, then it is unlikely to regard the created right of superficies as a transfer of land.

In addition to the real or perceived chance of relapse of the perpetual right of superficies to the landowner, the payment or non-payment of an initial fee by the superficiary for the creation of the right of superficies also plays a role when deciding whether the creation of the right of superficies should be regarded as a transfer of land. ${ }^{1432} \mathrm{~A}$ perpetual right of superficies created gratuitously and the creation of a perpetual right of superficies with a stipulated initial fee can both lead to transfer. When parties agree to a recurring fee in the contract of creation, then the existence of the right of ownership of the grantor is confirmed with the recurring payment; there is no transfer. The amount of the fee does not, in my opinion, play a decisive role in designating the creation as a means of transfer, but it can confirm the presumption of transfer. An agreed one-time fee that approximates the value of the property confirms the presumption of transfer.

1427 Concerning the legal systems compared in this thesis, it is only possible to create a perpetual right of superficies under German and Dutch law.

1428 Chapter $2 \S 3.4 .1$.

1429 See Chapter $2 \S 3.2 .1$ note 214 (German law), Chapter $3 \$ 4.5$ (Dutch law) and Chapter 4 \$4.6 (Belgian law).

1430 The obligation of the superficiary to pay a fee for the acquired right of superficies, the Erbbauzins, should not be confused with the Reallast ( $\$ 1105$ BGB). Although $§ 9$ ErbbauRG declares that the provisions regarding the Reallast to the Erbbauzins is applicable, the existence of the Erbbauzins in comparison with the Reallast depends on the existence of the right of superficies. See Chapter 2 §3.2.2.

1431 This may be the landowner who is responsible for the creation of the right of superficies or her successor.

1432 Agreeing to a payment obligation on the part of the superficiary in 'exchange' for the acquired right of superficies is not required for the creation of a right of superficies. Chapter $2 \S 3.2 .2$ (German law); Chapter $3 § 4.4$ (Dutch law); Chapter $4 \S 4.3$ (Belgian law). 
By qualifying the creation of a perpetual right of superficies in some cases as equivalent to the transfer of the land, there is an approximation of the actual situation. ${ }^{1433}$ Following the creation of a perpetual right of superficies where the chance of relapse is very small or absent and where the superficiary has no obligation to pay a fee or is under a duty to pay a one-time fee only, the land's value decreases in such a way that (as with the extinction of the feudal legal concept of dominium directum) it may be assumed that the landowner loses her right of ownership.

\section{$\S 5$. The right of removal}

The person entitled to the right of removal ${ }^{1434}$ has the power to separate one or more physical objects from the land. By granting the land user a right of removal, the user is free to exercise her rightful power of use. In addition to the right of removal, parties may include a compensation regulation in the contract to create a right of superficies, meaning that the user has the right to receive a fee for the superficies she has applied during the right of superficies or which has been compensated to the landowner at the start of the right of superficies. ${ }^{1435}$ This section will only address the right of removal. By simply exercising the right of removal, accession is dissolved.

\section{§5.1 The competent remover under the right of removal}

The right of removal can be given to all German, Dutch and Belgian owners of a real right of use. This means that under the German, Dutch and Belgian law, the superficiary may have the power to remove the superficies she attached to the land. ${ }^{1436}$ By physically separating the object that is permanently united with the land, the object obtains its own proprietary identity. The right of removal relates in principle to those objects that the user has permanently united with the land. In addition, Dutch and Belgian law state that a right of removal may be given to the user in relation to an 'old' superficies, the value of which has been paid by the user to the landowner when the right of use was created. Regarding the objects that the entitled person is bound to attach

1433 This has already been done on a wider scale with the transfer tax.

1434 The term 'ius tollendi' is also used in the literature.

1435 Chapter $2 \S 3.5 .2$ (German law); Chapter $3 \S 4.5$ (Dutch law); Chapter $4 \S 4.6$ (Belgian law). The right to compensation may also exist in some legal systems with respect to the superficies that have been reimbursed by the user to the landowner when a right of use first started.

1436 The owner of a right of emphyteusis, servitude or usufruct may also be entitled to remove the objects she attached. As this section will show, the right of removal may also be granted to the tenant. The list given here of rights to which a right of removal can be linked is certainly not exhaustive. 
under the contract to create a right of superficies, a right of removal does not in principle exist unless it has been agreed otherwise; the parties are often free to include or exclude the right of removal. When no clause is incorporated in the contract of creation, the statutory provisions regarding the right to use and connected to the right of removal then become conclusive.

Under Dutch and Belgian law, the superficiary has a legal right of removal, which has a real effect and is included in the statutory provisions regarding the right of superficies. This legal right of removal can be explicitly excluded in the contract. ${ }^{1437}$ It should be noted that under the legal provisions of the German statute about the right of superficies, the superficiary has no right of removal. According to German law, the superficiary merely has the power to remove the superficies attached by him if this is agreed in the contract. The contractual right of removal only creates a contractual right and singular successors are not bound. ${ }^{1438}$

Under Dutch, Belgian and German law, the right of removal can also be granted to the lessee. Under Dutch law, the right of removal is included in the statutory provisions regarding lease. ${ }^{1439}$ By granting right of removal to the lessee, an obligatory right can have a real effect under the rule 'sale does not break lease'. ${ }^{1440}$ The Dutch Supreme Court ruled in the 'Christenhusz/ Brunsveld' judgment that the tenant is entitled to effectuate the right of removal despite the fact that this right has arisen after the creation of the right of mortgage and the lease is in breach of the lease clause recorded in the mortgage deed. ${ }^{1441}$ Under German law the tenant also has a right of removal, ${ }^{1442}$ but this right is only needed when an object that was attached by the tenant is considered to be permanently united with the land. When it is clear to third parties that the permanent unification of the object with the land is temporary, the object can be regarded as an apparent component and the object remains moveable; with regard to objects that can be considered apparent components, the permanent unification principle is excluded. ${ }^{1443}$ The right of removal given to Belgian tenants stems from the accessory real

1437 Chapter $3 \S 4.5$ (Dutch law) and Chapter 4 §4.6 (Belgian law).

1438 Under the legal provisions of the ErbbauRG, the superficiary is not entitled to exercise a right of removal. The fact that under German law the superficiary does not have a right to remove the objects she attached unless the parties have expressly agreed to it in the contract of creation confirms my view that the powers of the superficiary in respect to the superficies cannot be considered ownership. See Chapter $7 \S 4.1 .1$ and Chapter 2 33.3.2 and §3.5.2. Article 7:216 BW (lease), article 7:349 BW (agricultural tenancy).

1440 Chapter $3 \S 4.5$ and $\$ 4.6 .3$

1441 HR 2 June 1989, NJ 1990, 253. See Chapter 3 \$4.6.3.

$1442 \S 539$ Abs. 2 BGB.

1443 Chapters $2 \$ 2.4$ and 7 \$3.1. 
right of superficies. In principle, it is assumed that an object attached by the tenant is owned by him. ${ }^{1444}$

It follows from Scottish literature that a right of removal can be linked to the lease $^{1445}$ as well as the liferent. ${ }^{1446}$ However, a right of removal may also exist with respect to other relationships and/or users. ${ }^{1447}$ A right of removal that is linked to a right of use relates 'only' to those objects that are permanently united with the land by the tenant and can be qualified as a trade, agricultural, ornamental or domestic 'fixture'. It is believed that the right of removal under Scottish law does not necessarily have to be dependent on another right (of use). It is possible to enter into an agreement with a right of removal as the principal commitment; however, it is uncertain to what extent this agreement has third-party effect and if it is possible to register this agreement in the land registry. A right of removal that has been expressly stipulated by the parties is not limited to the aforementioned fixtures but may be agreed for the benefit of any object that is permanently united with the land. ${ }^{1448}$

\section{$\S 5.2$ Uncertainties regarding the right of removal ${ }^{1449}$}

In principle, the right of removal may be exercised during the existence of the right of use to which it is linked. The right of removal does indeed depend on the right of use. It is noteworthy that according to Dutch law, the right of removal may be exercised during as well as a certain time after the end of the right of use. ${ }^{1450}$ In my opinion, this can lead to great legal uncertainty when the land is transferred to a third party after termination of the right of use. ${ }^{1451}$

If the new landowner has not been informed of the ongoing right of removal, she may assume that all objects permanently united with the land belong to her by accession. However, the holder of the still-to-be-effectuated right of removal will believe that she may not be harmed by a juridical act

\footnotetext{
1444 Chapters $4 \S 4.5$ and $\S 4.5 .2 .3$.

1445 Chapter $5 \$ 4.1 .1$.

1446 Chapter $5 \$ 4.1 .2$.

1447 Chapter $5 \$ 4$.

1448 Chapter $5 \$ 4.2$.

1449 Everything in this section on the right of removal relates not only to the right of superficies, but also to other rights such as the rights of emphyteusis, lease and agricultural tenancies.

1450 Chapter $3 \S 4.5$. Under Scottish law, a lease attached to a right of removal can be exercised as long as the tenant has possession of the property, even after the expiration of the lease term. See Chapter 5 \$4.1.1.

1451 As the right of removal can persist even after the right of superficies has been extinguished, it seems likely that the right of removal in relation to the right of superficies does not arise, according to the prevailing doctrine, from the right of ownership of the superficiary. See Chapter $3 \S 4.5$.
} 
(namely the land transfer) performed by the land owner. The transferor of the land is obliged to notify the land purchaser of the existence of the stillto-be-effectuated right of removal. If the transferor omits to do so, she has to compensate for damages suffered by the purchaser or the owner of the right of removal. ${ }^{1452}$ Whether the owner of the right of removal is actually authorised to remove the superficies she has attached should, in my view, be approached on the basis of the type of object that the holder of the right of removal has attached to the land. If it concerns an authentic, non-replaceable object, it seems plausible that the interests of the holder of the right of removal would take preference over those of the purchaser of the land. The purchaser of the land can normally recover her damage, consisting of the value of the removed object, from the transferor of the land. ${ }^{1453}$

A mortgagee who obtains her right of mortgage after termination of the right of use may also be disadvantaged if the former holder of the right of use of the land, now encumbered with a right of mortgage, turns out to have the authority to remove objects that are permanently united with the land. In principle, the right of mortgage extends over all objects that are united with the land. When the holder of the right of removal decides to exercise her right, this will mean a decrease in the value of the object of the mortgage. The mortgagee can then request that the mortgagor should provide additional security for the loan. If the mortgagor fails to accept the request, the mortgagee may be free to terminate the credit granted, depending on the loan contract. ${ }^{1454}$

In all legal systems investigated in this thesis, the following situation may occur and may lead to legal uncertainty: a property already encumbered with a right of mortgage is burdened with a right of use, ${ }^{1455}$ whereby the user of the land has a right of removal. It is beyond doubt that the right of mortgage extends to the objects that are permanently united with the land, whether attached by the landowner or by the user and whether or not the objects were attached before or after the creation of the right of mortgage. This means that if the right of mortgage is enforced, the objects attached by the user can also be sold in a forced sale, while the user has a right to remove the objects she attached. It is unclear whether the user can set up the right of removal against the mortgagee and the buyer in the forced sale. If the mortgage predates the right of use, the attachment of the objects and the right of removal an argument in favour of the erga omnes effect of the power of removal could be that the right of mortgage is created without

1452 This is a problem pertaining to the law of obligations and can be solved by the doctrine of non-performance.

1453 Again, the provisions regarding the doctrine of non-performance apply.

1454 Chapter 3 \$4.6.3 (Dutch law).

1455 This right of use may be a contractual right or a real right. 
the presence of the objects that were attached at a later date and that the mortgagee is therefore not disadvantaged when the objects are removed by the user. On the other hand, it could be said that the user can inform herself of the right of mortgage by consulting the land register and that the user only has a right of removal if the mortgagee has authorised the right of use on the land, and thus the right of removal.

It is also possible that first a right of use was created on the land and that afterwards the right of mortgage was created. Even if the right of use is a real right, the landowner continues to be entitled to mortgage her land. If the right of use is a real right, the mortgagee can inform herself of its existence by consulting the land register. Based on this knowledge, the current or future mortgagee can investigate the objects that are united with the land, study the contract of the right of use and possibly ask the holder of the right of use which objects have been attached by her; she can then decide whether to adapt the amount of the loan to be provided to the mortgagor. In my view, the priority principle already entails that the owner of a real right reinforced with a right of removal is free at all times to remove the superficies that she has attached. When the right of removal depends on an contractual right of use, it will not always help to consult the land register, as in many jurisdictions contractual rights of use cannot be entered onto the land register. In that case, it is up to the mortgagor to notify the current or future mortgagee.

\section{$\S 6$. Some concluding words}

The right of ownership attributed to the superficiary differs from the ownership definition in paragraph $903 \mathrm{BGB}$, article 5:1 BW and article $544 \mathrm{BBW}$ in such a way that it is unclear whether the superficiary's powers may actually be regarded as ownership. The powers of the superficiary over the superficies can be restricted by contract; these restriction may entail that the powers of that superficiary are less far reaching than the powers which the holder of a right of emphyteusis has in respect to the superficies, whereas the right of emphyteusis is a mere right of use that does not give its holder ownership. Although the powers of the person holding a right of emphyteusis can be broader than those of the superficiary, these broader powers are not qualified as ownership. ${ }^{1456}$

Even if we can speak of ownership, the superficiary acquires this right of ownership because the accession related to the 'old' superficies is dissolved as a result of the creation and the ownership is granted to her by the right of superficies. As said before, it is unclear whether this ownership is acquired in an original or derivative way. In my opinion, the right of ownership of the 'new' superficies does not result from the creation of the right of superficies. 
With the creation of the right of superficies, the accession related to the 'new' superficies is prevented, and the right of ownership does not arise due to the creation of the right of superficies, but the pre-existing right of ownership continues to exist.

In my opinion consideration should be given to regarding the right of superficies as a 'normal' limited real right whereby the powers of the superficiary in relation to the land and the superficies derive from the right that is encumbered with the right of superficies. Like the 'other' real rights of use, the creation of the right of superficies then leads to a transfer of powers to the superficiary. In this view the right of superficies can no longer be considered as a special way of acquiring ownership and the creation no longer leads to dissolving or preventing accession. As a consequence, it is debatable whether the coexistence of the right of superficies and the right of emphyteusis within a legal system remains desirable or necessary. ${ }^{1457}$

Apart from creating a right of superficies, accession can also be dissolved by actually separating the object that is permanently united with the land from that land. The actual separation of the object from the land gives the object its own proprietary identity and it will belong to the person who is entitled to the removal. The right to remove objects that are permanently united with the land can, in principle, belong to the holder of a right of use of the land to which the objects have been attached. Under Scottish law, only physical separation of the object from the land results in dissolving the accession; Scottish law has no legal concept that corresponds with the right of superficies. However, Scottish law does contain the legal concept of a lease. From case law it follows that the tenant is entitled to separate certain objects from the land that are permanently united with the land, the so-called fixtures. When a fixture can be qualified as a trade, agricultural, ornamental or domestic fixture, the tenant has the power to separate that fixture from the land. Pursuant to the exercise of the right of removal, the tenant obtains ownership of the fixture. The right of removal can therefore be considered to be a particular mode of acquisition of ownership. ${ }^{1458}$

There are major uncertainties about the right of removal. Should a right of removal always be accessory to a right of use or can a right of removal also be stipulated by the unpaid seller who sells objects under a retention of title clause with the effect that objects delivered by her and permanently attached to the land can be removed by her if the purchase price remains unpaid? Can the tenant exercise her right of removal in respect to the objects she attached when the land is mortgaged prior to the lease and the mortgagee, under the legislation, can include in the forced sale objects that have been attached

1457 This question needs to be asked about both Dutch and Belgian law.

1458 Chapter 7 \$5.1. 
after the creation of the right of mortgage? What happens if the lease agreement predates the right of mortgage and the mortgagee is unaware of the existence of the right of removal? These and many other questions are neither answered by law nor by case law of the different legal systems discussed. ${ }^{1459}$

Apart from a single statutory exception for specific objects, dissolving accession is only possible by actually removing the object that is permanently united with the land. Therefore, after 2000 years, the Roman legal principle of superficies solo cedit remains fully applicable to the current legal systems studied in this thesis. 


\section{Lijst van aangehaalde literatuur}

A

Amos \& Ferard 1827

A. Amos en J. Ferard, A treatise on the Law of Fixtures and other property, partaking both of a real and personal nature. Comprising the law relating to annexations to the freehold in general, London: Joseph Butterworth and Son 1827.

\section{Apers 2011}

A. Apers, 'Afgrenzing van onroerende goederen uit hun aard', Tijdschrift voor Fiscaal Recht 2011/42, pp. 605-609.

\section{Asser/Hartkamp \& Sieburgh 6-IV 2011}

A. Hartkamp en C. Sieburgh, Mr. C. Asser's Handleiding tot de beoefening van het Nederlands Burgerlijk Recht. 6. Verbintenissenrecht. Deel IV. De Verbintenis uit de wet, Deventer: Kluwer 2011.

\section{Asser/Van Heusde 1890}

C. Asser en Ph. van Heusde, Handleiding tot de beoefening van het Nederlandsch Burgerlijk Recht door Mr. C. Asser. Tweede deel, Zwolle: W.E.J. Tjeenk Willink 1890.

\section{Asser/Mijnssen-Van Dam-Van Velten 2002}

F. Mijnssen, C. van Dam en A. van Velten, Mr. C. Asser's Handleiding tot de beoefening van het Nederlands Burgerlijk Recht. 3. Goederenrecht. Deel II. Zakelijke rechten, Deventer: Kluwer 2002.

\section{Asser/Mijnssen-De Haan 1992}

F. Mijnssen en P. de Haan, Mr. C. Asser's Handleiding tot de beoefening van het Nederlands Burgerlijk Recht. 3. Zakenrecht. Deel I. Algemeen Goederenrecht, Zwolle: W.E.J. Tjeenk Willink 1992.

\section{Asser/Van Mierlo \& Van Velten 3-VI` 2010}

A. van Mierlo en A. Van Velten, Mr. C. Asser's Handleiding tot de beoefening van het Nederlands Burgerlijk Recht. 3. Vermogensrecht Algemeen. Deel VI. Vermogensrechten algemeen, Deventer: Kluwer 2010. 


\section{Asser/Mijnssen, Van Velten \& Bartels 5^ 2008}

F. Mijnssen, A. van Velten en S. Bartels, Mr. C. Asser's Handleiding tot de beoefening van het Nederlands Burgerlijk Recht. 5. Zakenrecht. Eigendom en beperkte rechten, Deventer: Kluwer 2008.

\section{Asser/Snijders 7-III^ 2009}

G. Snijders, Mr. C. Asser's Handleiding tot de beoefening van het Nederlands burgerlijk recht. 7. Bijzondere overeenkomsten. Deel II. Pacht, Deventer: Kluwer 2009.

\section{B}

\section{Bankton 1751}

A. Bankton, An institute of the Law of Scotland in civil rights. With observations upon the agreement of diversity between them and the laws of England in four books, Edinburgh: R. Fleming 1751.

\section{Baur \& Stürner 2009}

J. Baur en R. Stürner, Sachenrecht, München: Verlag C.H. Beck 2009.

\section{Beekhuis 1940}

J. Beekhuis, Horizontale eigendom (overdruk uit het Correspondentie-Blad van de 'Broederschap der Notarissen in Nederland'), Amsterdam: Van Mantgem 1940.

\section{Bell 1839}

G. Bell, Principles of the Law of Scotland, Edinburgh: T. Clark 1839.

\section{Berger 2001}

K. Berger, Burenrecht, mandeligheid en erfdienstbaarheden, Deventer: Kluwer 2001.

\section{Blockx, Lens \& Wynant 2006}

G. Blockx, F. Lens en L. Wynant, Erfpacht, opstal en erfdienstbaarheden, Mechelen: Wolters Kluwer Belgium NV 2006.

\section{De Boeck 2009}

A. De Boeck, 'De duur van de woninghuurovereenkomst, de beëindiging door opzegging en de verlenging wegens buitengewone omstandigheden. Afdeling 2. De uitzonderingen op de negenjarige huur', in: A. Van Oevelen (red.), Woninghuur, Brugge: die Keure 2009, pp. 151-165. 


\section{Bork 2006}

R. Bork, Allgemeiner Teil des Bürgerlichen Gesetzbuch, Tübingen: Mohr Siebeck 2006.

\section{Van den Bos 2004}

J. van den Bos, 'Niet gesplitst, maar toch gescheiden: de zelfstandigheid van grond en opstal', Bouwrecht 2004/7, pp. 584-591.

\section{Böttcher 2005}

R.Böttcher, ZVG, GesetzüberdieZwangversteigerungunddieZwangverwaltung, München: Verlag C.H. Beck 2005.

\section{Bracke 2007}

D. Bracke, 'Schoppenboer jagen in het recht van opstal ... Over de vroegtijdige beëindiging van het recht van opstal en enkele valkuilen', Tijdschrift voor Belgisch Burgerlijk Recht 2007, pp. 541-553.

\section{Brehm \& Berger 2006}

W. Brehm en C. Berger, Sachenrecht, Tübingen: Mohr Siebeck 2006.

\section{Bronson 1904}

H. Bronson, A treatise on the Law of Fixtures, St. Paul: Keefe-Davidson Co. 1904.

\section{Byttebier}

K. Byttebier, Voorrechten en hypotheken, Antwerpen/Apeldoorn: Maklu 2005.

\section{C}

\section{Carey Miller 1986}

D. Carey Miller, The acquisition and protection of ownership, Cape Town: Juta \& Co. LTD 1986.

\section{Carey Miller 2000}

D. Carey Miller, 'Transfer of Ownership', in: K. Reid \& R. Zimmermann (red.), A History of Private Law in Scotland.Volume 1. Introduction and Property, Oxford: Oxford University Press 2000, pp. 269-304.

\section{Carey Miller \& Irvine 2005}

D. Carey Miller en D. Irvine, Corporeal Moveables in Scots Law, Edinburgh: Thomson W. Green 2005. 


\section{Chambers 1823}

C. Chambers, A treatise on the Law of Landlord and Tenant. Compiled in part from the notes of the late Sir William David Evans, London: Joseph Butterworth and Son 1823.

\section{Coing 1953}

H. Coing, 'Zur Eigentumslehre des Bartolus', Zeitschrift der Savigny-Stiftung für Rechtsgeschichte, 70 (1953), pp. 348-371.

\section{De Corte \& de Groote 2005}

R. de Corte en B. de Groote, Overzicht van het Burgerlijk Recht, Mechelen: Kluwer 2005.

\section{Cusine \& Paisley 1998}

D. Cusine en R. Paisley, Servitudes and Rights of Way, Edinburgh: W. Green 1998.

\section{D}

\section{Dambre 2006}

M. Dambre, 'Rechten en verbintenissen van de huurder', in: M. Dambre, B. Hubeau en S. Stijns (red.), Handboek algemeen huurrecht, Brugge: die Keure 2006.

\section{Danau, Dom \& Roodhooft 2010}

C. Danau, P. Dom en J. Roodhooft, Praktisch Burgerlijk Recht uitgediept, Antwerpen: De Boeck 2010.

\section{Dankers-Hagenaars 2000}

D. Dankers-Hagenaars, Op het spoor van de concessie. Een onderzoek naar het rechtskarakter van de concessie in Nederland en in Frankrijk, Den Haag: Boom Juridische uitgevers 2000.

\section{Dekkers/Dirix 2005}

R. Dekkers en E. Dirix, Handboek Burgerlijk Recht. Deel II. ZakenrechtZekerheden-Verjaring, Antwerpen: Intersentia 2005.

\section{Deli 1998}

D. Deli, 'Erfpacht en opstal: burgerlijke aspecten', in: D. Meulemans (red.), Vruchtgebruik, erfpacht en opstal, Antwerpen-Apeldoorn: Maklu 1998, pp. 37-74. 


\section{Delva 1973}

W. Delva, Voorrechten en hypotheken, Gent: Wetenschappelijke Uitgeverij E. Story-Scientia 1973.

\section{Delva 1982}

W. Delva, Overzicht van het Belgisch burgerlijk recht en burgerlijk procesrecht, Gent: Wetenschappelijke Uitgeverij E. Story-Scientia 1982.

Derine, Van Neste \& Vandenberghe 1984a

R. Derine, F. van Neste en H. Vandenberghe, Zakenrecht. Deel IIA, Brussel: E.Story-Scientia 1984.

\section{Derine, Van Neste \& Vandenberghe 1984b}

R. Derine, F. van Neste en H. Vandenberghe, Zakenrecht. Deel IIB, Brussel: E.Story-Scientia 1984.

\section{Diephuis 1857}

G. Diephuis, Het Nederlandsch Burgerlijk Regt naar de volgorde van het Burgerlijk Wetboek. Tweede deel, Groningen: J.B. Wolters 1857.

\section{Dobie 1941}

W. Dobie, Manual of the Law of Liferent en Fee in Scotland, Edinburgh: W. Green \& Son Limited Law Publishers 1941.

\section{E}

\section{Erskine 1773}

J. Erskine of Carnock, An Institute of the Law of Scotland. In four books. In the order of Sir George MacKenzie's Institute of law, Edinburgh: John Bell 1773.

\section{Ewell 1905}

M. Ewell, A treatise on the Law of Fixtures, Chicago: Callaghan \& company 1905.

\section{G}

\section{Ganshof 1996}

F. Ganshof, Feudalism, Toronto: University of Toronto Press in assoc. with the Medieval Academy of America 1996.

\section{Gerver 2001}

P. Gerver, Het recht van hypotheek, Deventer: W.E.J. Tjeenk Willink 2001. 


\section{Van Gessel-de Roo 1991}

M. van Gessel-de Roo, Bronnen van de Nederlandse Codificatie sinds 1798. Zakenrecht 1798-1820, Zutphen: Walburg Pers 1991.

\section{Gits \& Devos}

A. Gits en B. Devos, 'Verzaking aan het recht van natrekking getoetst aan de landpachtwet: begrippen en misvattingen', Tijdschrift voor Notarissen 2007, pp. 205-227.

\section{Goedertier 1953-1954}

J. Goedertier, 'Het regiem der ondergrondse waters. Wettelijkheid van de Besluit-Wet van 18 december 1946 en van het Koninklijk besluit van 12 juni 1947’, Rechtskundig Weekblad 1953-54, pp. 1657-1672.

\section{Goeminne 2007}

S. Goeminne, 'De praktijk van vruchtgebruik, erfpacht en opstal', in: Het onroerend goed in de praktijk. XV.B, Mechelen: Kluwer 2007.

\section{Gordon 1999}

W. Gordon, Scottish Land Law, Edinburgh: W. Green \& Son Ltd 1999.

\section{Gordon \& De Waal 2004}

W. Gordon en M. de Waal, 'Servitudes and Real Burdens', in: R. Zimmermann, D. Visser \& K. Reid (red.), Mixed Legal Systems in Comparative Perspective: Property and Obligations in Scotland and South Africa, Oxford: Oxford University Press 2004, pp. 735-757.

\section{Gordon \& Wortley 2009}

W. Gordon en S. Wortley, Scottish Land Law, London: W. Green/Thomson Reuters (Legal) Limited 2009.

\section{Gretton \& Steven 2009}

G. Gretton en A. Steven, Property, Trusts and Succession, West Sussex: Tottel Publishing 2009.

\section{Guthrie 2005}

T. Guthrie, Scottish Property Law, West Sussex: Tottel Publishing 2005.

\section{$\mathbf{H}$}

\section{Harpum, Bridge \& Dixon 2008}

C. Harpum, S. Bridge en M. Dixon, The Law of Real Property, London: Thomas Reuters (Legal) Ltd. 2008. 


\section{Heirbaut 1999}

D. Heirbaut, Romeins recht vroeger en nu, Antwerpen: Maklu 1999.

\section{Hemmer \& Wüst 2011}

K. Hemmer en A.Wüst, Sachenrecht III, Hemmer/Wüst Verlagsgesellschaft 2011.

\section{Heyman 1999}

H. Heyman, 'Kan een opstalrecht worden gevestigd door een erfpachter of een appartementseigenaar?', Weekblad voor Privaatrecht, Notariaat en Registratie 6342 (1999), pp. 52-56.

\section{Heyman 2000a}

H. Heyman, 'Wanneer is een gebouw of werk 'duurzaam met de grond verenigd'? Een kritische noot bij het Portacabin-arrest (HR 31 oktober 1997, NJ 1998, 97)', in: S. Bartels \& J. Milo (red.), Open normen in het goederenrecht, Den Haag: Boom Juridische Uitgevers 2000, pp. 91-122.

\section{Heyman 2000b}

H. Heyman, 'Zijn zeecontainers onroerend?', Nederlands Tijdschrift voor Burgerlijk Recht 2000/5, pp. 197-200.

\section{Heyman 2003}

H.Heyman, 'Vestigingvanerfpachtenopstaldooreenappartementseigenaar', in: J. Struiksma e.a. (red.), Vast en goed. Bundel opstellen aangeboden aan prof. mr. A.A. van Velten ter gelegenheid van zijn vijfenzestigste verjaardag en zijn defungeren als notaris, Deventer: Kluwer 2003, pp. 77-92.

\section{Heyman 2005}

H. Heyman, 'Het mysterie van het eigendomsrecht van de opstaller', in: W. Huijgen (red.), 2000 jaar eigendom en beperkte rechten (Pleysier-bundel), Deventer: Kluwer 2005, pp. 19-31.

\section{Heyman \& Bartels 2006}

H. Heyman en S. Bartels, 'Is een huis een bestanddeel van de grond? Een rechtsgeleerde dialoog tussen H.W. Heyman en S.E. Bartels', Nederlands Tijdschrift voor Burgerlijk Recht 2006/40, pp. 271-275.

\section{Heyman \& Bartels 2012}

H. Heyman en S. Bartels, Vastgoedtransacties. Koop, Den Haag: Boom Juridische uitgevers 2012. 


\section{Hk-BGB/Dörner 2012}

H. Dörner, 'Vor §§ 1-20, 1-240; Vor Art 3-6 EGBGB, Art 3-10 EGBGB; Vor Art 38-24 EGBGB, Art 38-46a EGBGB; Rom II-VO', Bürgerliches Gesetzbuch. Handkommentar, Baden-Baden: Nomos Verlagsgesellschaft 2012.

\section{HK-BGB/Staudinger 2012}

A. Staudinger, ' $§ \S 481-487$; $§ \S 765-782$, Vor $\S \S 823-853,823-853$; Vor $\S \S$ 873-928, 873-902; Vor §§ 906-924, 906-928; §§ 1012-1029; §§ 1090-1203; Anh I u II zu Art 7 EBGBG, Art 11-12 EGBGB; Vor Art 25, 26 EGBGB, Art 25-26 EGBGB; Art 46 b-46 c EGBGB; Rom I-VO', Bürgerliches Gesetzbuch. Handkommentar, Baden-Baden: Nomos Verlagsgesellschaft 2012.

\section{Hofmann 1944}

L. Hofmann, Het Nederlandsch Zakenrecht, Groningen: J.B. Wolter's Uitgevers-Maatschappij n.v. 1944.

\section{Hoofs 2011}

K. Hoofs, 'Leidt wijziging van de canon tot een nieuw erfpachtsrecht?', Nederlands Tijdschrift voor Burgerlijk Recht 2011/4, pp. 158-162.

\section{Hügel 2009}

S. Hügel, Grundbuchordnung, München: Verlag C.H. Beck 2009.

\section{I}

\section{Ingenstau 1987}

J. Ingenstau, Kommentar zum Erbbaurecht, Düsseldorf: Werner-Verlag GmbH 1987.

\section{J}

\section{Janssen 2006}

J. Janssen, 'De uitleg die wordt gegeven aan de artt. 3:3 lid 1 en 5:20 sub e BW, ontregelt de zaak', Weekblad voor Privaatrecht, Notariaat en Registratie 6691 (2006), pp. 855-867.

\section{De Jong 2006}

Th. de Jong, Destructuur van het goederenrecht. Over het afschaffen van het begrip van de onlichamelijke zaak, het onderscheid tussen rechten en hun voorwerpen en een opening in het systeem, Deventer: Kluwer 2006. 
Kleyn 1997

W. Kleyn, 'Hoever strekt een opstalrecht uitgegeven door een beperkt gerechtigde', Juridische Berichten voor het Notariaat 1997, p. 14.

\section{Kluyskens 1940}

A. Kluyskens, Beginselen van Burgerlijk Recht, Antwerpen: N.V. StandaardBoekhandel 1940.

\section{Kokelenberg 2009a}

J. Kokelenberg, 'Onroerend uit zijn aard: de beperkingen van de notie beperkt', Tijdschrift voor Belgisch Burgerlijk Recht 2009/7, pp. 337-347.

\section{Kokelenberg 2009b}

J. Kokelenberg, 'Deel III. Eigendom, natrekking en burenhinder. Hoofdstuk 1. Eigendom. Natrekking', Tijdschrift voor Privaatrecht 2009, pp. 1148-1168.

\section{Kokelenberg, Van Sinay \& Vuye 1989}

J. Kokelenberg, Th. Van Sinay en H. Vuye, 'Overzicht van rechtspraak zakenrecht (1980-1988)', Tijdschrift voor Privaatrecht 1989, pp. 1689-1875.

\section{Kortmann 1990}

S. Kortmann, 'Hulpzaak exit?', Weekblad voor Privaatrecht, Notariaat en Registratie 5855 (1990), pp. 710-715.

\section{Kortmann 1997}

S. Kortmann, 'Het object van leasing', in: J. van Hees, R. Hermans en S. Kortmann, Vermogensrechtelijke aspecten van leasing, Lelystad: Koninklijke Vermande 1997, pp. 16-41.

\section{Kortmann 1998}

S. Kortmann, ‘De portacabin', Ars Aequi 1998, vol. 47/2, pp. 101-105.

\section{L}

\section{Land 1901}

N. Land, Verklaring van het Burgerlijk Wetboek. Tweede Deel, Haarlem: De erven F. Bohn 1901.

\section{Laurant 1878}

F.Laurant, Principesde Droit Civil.Vol8, Bruxelles: Bruylant-Christophe1878. 


\section{Van der Linden/de Smidt 1967}

J. van der Linden en J. de Smidt, Ontwerp Burgerlijk Wetboek 1807/1808, Amsterdam: Graphic 1967.

\section{M}

\section{Van Maanen 1998}

G. van Maanen, 'Ondergrondse en bovengrondse gebouwen', Weekblad voor Privaatrecht, Notariaat en Registratie 6326 (1998), pp. 553-557.

\section{Van Maanen 2006}

G. Van Maanen, 'Is een gebouw bestanddeel van de grond?', Nederlands Tijdschrift voor Burgerlijk Recht 2006/6, pp. 228-230.

\section{McAllister 2002}

A. McAllister, Scottish Law of Leases, Edinburgh: Butterworths LexisNexis 2002.

\section{Meijers 1910}

E. Meijers, 'Tijdschriften overzicht', Weekblad voor Privaatrecht, Notarisambt en Registratie 2104 (1910), pp. 204-206.

\section{Meijers 1955}

E. Meijers, Ontwerp voor een nieuw Burgerlijk Wetboek. Tekst Tweede gedeelte (Boek 5), 's-Gravenhage: Staatsdrukkerij- en uitgeverijbedrijf 1955.

\section{Memelink 2005}

P. Memelink, 'Rechtseenheid en het onderscheid tussen roerende en onroerende zaken', in: E. Hoogervorst e.a. (red.), Rechtseenheid en vermogensrecht, Deventer: Kluwer 2005, pp. 65-96.

\section{Van der Merwe 2000}

C. van der Merwe, 'Accession by building', in: K. Reid \& R. Zimmermann (red.), A History of Private Law in Scotland.Volume 1. Introduction and Property, Oxford: Oxford University Press 2000, pp. 245-268.

\section{Meston 1993}

M. Meston, The Succession (Scotland) Act 1964, Edinburgh: W. Green/Sweet \& Maxwell 1993.

\section{Meulemans 1998}

D. Meulemans, 'Vruchtgebruik, erfpacht en opstal als alternatief voor huur', in: D. Meulemans (red.), Vruchtgebruik, erfpacht en opstal, AntwerpenApeldoorn: Maklu 1998, pp. 181-201. 


\section{Michiels 2007}

D. Michiels, 'Het accessoir opstalrecht', Tijdschrift voor Notarissen 2007, pp. 213-227.

\section{Miller \& Robson 1991}

K. Miller en P. Robson, Property. Green's Concise Scots Law, Edinburgh: W. Green/Sweet \& Maxwell 1991.

\section{Milo 2007}

J. Milo, 'Timeshare in het Nederlandse recht', in: A. Hartkamp e.a., De invloed van het Europese recht op het Nederlandse privaatrecht, Deventer: Kluwer 2007, pp. 193-216.

\section{Mon. BW B12b (Huijgen)}

W. Huijgen, Hypotheek. Monografieën BW, Deventer: Kluwer 2007.

\section{Mon. BW B27 (Wibbens-De Jong)}

A. Wibbens-De Jong, Mandeligheid en erfdienstbaarheden. Monografieën BW, Deventer: Kluwer 2006.

\section{Mon. BW B28 (De Jong/Ploeger)}

J. de Jong en H. Ploeger, Erfpacht en opstal. Monografieën BW, Deventer: Kluwer 2008.

\section{Mon. BW B29 (Mertens)}

R. Mertens, Appartementen. Monografieën BW, Deventer: Kluwer 2006.

\section{De Monté Ver Loren \& Spruit 1982}

J. De Monté Ver Loren en J. Spruit, Hoofdlijnen uit de ontwikkeling der rechterlijke organisatie in de Noordelijke Nederlanden tot de Bataafse omwenteling, Deventer: Kluwer 1982.

\section{MünchKommBGB/Commichau 2009}

M. Commichau, '§§ 1-15, 59-64 WEG', in: R. Gaier (red.), Münchener Kommentar zum Bürgerlichen Gesetzbuch. Band 6. Sachenrecht. §§ 854-1296. Wohnungseigentumsgesetz - Erbbaurechtsgesetz, München: Verlag C.H. Beck 2009.

\section{MünchKommBGB/Säcker 2009}

F. Säcker, '§§ 903-924 BGB', R. Gaier (red.), Münchener Kommentar zum Bürgerlichen Gesetzbuch. Band 6. Sachenrecht. \$§ 854-1296. Wohnungsgesetz Erbbaurechtsgesetz, München: Verlag C.H. Beck 2009. 


\section{MünchKommBGB/Stresemann 2012}

C. Stresemann, Münchener Kommentar zum Bürgerlichen Gesetzbuch. Band 1. Allgemeiner Teil. §\$1-240, München: Verlag C.H. Beck 2012.

\section{MünchKommBGB/Von Oefele 2009}

H. von Oefele, '\$\$ 903-924 BGB', R. Gaier (red.), Münchener Kommentar zum Bürgerlichen Gesetzbuch. Band 6. Sachenrecht. \$\$ 854-1296. WohnungsgesetzErbbaurechtsgesetz, München: Verlag C.H. Beck 2009.

\section{Van Muylder \& Verstappen 1992}

A. van Muylder en J. Verstappen, 'Actuele problemen inzake het recht van natrekking, de verzaking daaraan, en het recht van opstal', Tijdschrift voor Notarissen 1992, pp. 281-339.

\section{Muylle 2012}

M. Muylle, De duur en de beëindiging van zakelijke rechten, AntwerpenCambridge: Intersentia 2012.

\section{$\mathbf{N}$}

\section{Van Neste 1990}

F. Van Neste, Beginselen van Belgisch Privaatrecht. V. Zakenrecht. Boek 1. Goederen, Bezit en Eigendom, Brussel: E.Story-Scientia 1990.

\section{Neut 2000}

M. Neut, 'Vergoedingsrecht van de huurder op het einde van de huur voor niet-wegneembare (verbeterings)werken', Rechtskundig Weekblad 19992000, pp. 1026-1032.

\section{$\mathbf{O}$}

\section{Von Oefele \& Winkler 2008}

H. von Oefele en K. Winkler, Handbuch des Erbbaurechts, München: Verlag C.H. Beck 2008.

\section{Van Oevelen 1991}

A. van Oevelen, 'Recente ontwikkelingen inzake het recht van erfpacht, het recht van opstal en de onroerende leasing', in: A. Casman, M. Boes. A. van Oevelen (red.), Notariële actualiteit. Zaken- en contractenrecht, Brugge: die Keure 1991, pp. 55-84. 


\section{Van Oevelen 1992}

A. van Oevelen, 'Actuele ontwikkelingen inzake het recht van erfpacht en het recht van opstal', in: H. Casman, E. Dirix, R. de Corte, Het zakenrecht: absoluut niet een rustig bezit, Antwerpen: Kluwer 1992.

\section{Van Oevelen 2003}

A. van Oevelen, 'Knelpunten gemene huur', in: A. Verbeke (red.), Knelpunten huur, Antwerpen: Intersentia 2003, pp. 1-20.

\section{Van Oevelen 2009}

A. van Oevelen, Woninghuur, Brugge: die Keure 2009.

\section{Van Oevelen, Van Poucke \& Van de Velde 1989}

A. Van Oevelen, P. Van Poucke en J. van de Velde, Oude en nieuwe rechtsfiguren: erfpacht, opstal, onroerende leasing, time-sharing, Antwerpen: Kluwer rechtswetenschappen 1989.

\section{Opzoomer 1876}

C. Opzoomer, Het Burgerlijke Wetboek. Derde deel. Art. 555-783, Amsterdam: J.H. Gebhard \& Comp. 1876.

\section{$\mathbf{P}$}

\section{De Page 1942}

H. de Page, Traité élémentaire de droit civil Belge. Tome VI les biens - les sûretés, Bruxelles: Bruylant 1942.

\section{Paisley 2000}

R. Paisley, Land Law, Edinburgh: W. Green/Sweet \& Maxwell 2000.

\section{Paisley 2005}

R. Paisley, 'Real Rights: Practical Problems and Dogmatic Rigidity', Edinburgh Law Review 8 (2005), pp. 267-297.

\section{Parl. Gesch. Boek 3 (1981)}

Van Zeben, J. Du Pon en M. Olthof, Parlementaire Geschiedenis van het nieuwe Burgerlijk Wetboek. Boek 3. Vermogensrecht in het Algemeen, Deventer: Kluwer 1981.

\section{Parl. Gesch. Boek 5 (1981)}

Van Zeben, J. Du Pon en M. Olthof, Parlementaire Geschiedenis van het nieuwe Burgerlijk Wetboek. Boek 5. Zakelijke Rechten, Deventer: Kluwer 1981. 


\section{Parl. Gesch. Boek 5 (Inv. 3, 5 en 6) (1990)}

W. Reehuis en E. Slob, Parlementaire Geschiedenis van het nieuwe Burgerlijk Wetboek. Invoering Boeken 3, 5 en 6. Boek 5. Zakelijke rechten, Deventer: Kluwer 1990.

\section{Parl. Gesch. Kadasterwet (1990)}

W. Reehuis en E. Slob, Parlementaire Geschiedenis van het nieuwe Burgerlijk Wetboek. Invoering Boeken 3, 5 en 6. Kadasterwet (Wet houdende regelen met betrekking tot de Openbare Registers voor registergoederen, alsmede met betrekking tot het Kadaster), Deventer: Kluwer 1990.

Parl. Gesch. Wijziging Rv e.a.w. (Inv. 3, 5 en 6) (1992)

W. Reehuis en E. Slob, Parlementaire Geschiedenis van het nieuwe Burgerlijk Wetboek. Invoering Boeken 3, 5 en 6. Wijziging van Burgerlijke Rechtsvordering, de Wet op de Rechterlijke Organisatie en de Faillissementswet, Deventer: Kluwer 1992.

Pitlo/Reehuis \& Heisterkamp 2012, Goederenrecht

W. Reehuis e.a., Pitlo. Het Nederlands burgerlijk recht. Deel 3. Goederenrecht, Deventer: Kluwer 2012.

\section{Van der Plank 2010}

P. van der Plank, 'Is een woonark onroerend? Noot bij HR 15 januari 2010, nr. 07/13305', Nederlands Tijdschrift voor Burgerlijk Recht 2010/4, pp. 130140.

\section{Van der Plank 2011}

P. van der Plank, 'Havenkranen onroerend? Over het verschil tussen rijden en drijven', Nederlands Tijdschrift voor Burgerlijk Recht 2011/5, pp. 202-206.

\section{Pleysier 1990}

A. Pleysier, 'Time-sharing', De Notarisklerk (1990) 1263, pp. 2-4.

\section{Ploeger \& Stolker 1994}

H. Ploeger en C. Stolker, 'Van grond en aarde', Weekblad voor Privaatrecht, Notariaat en Registratie 6151 (1994), pp. 641-643.

\section{Ploeger 1997}

H. Ploeger, Horizontale splitsing van eigendom, Deventer: Kluwer 1997.

\section{Ploeger 1998}

H. Ploeger, 'Een mobiele onroerende zaak? Over de grens tussen roerend en onroerend, n.a.v. Hoge Raad 8 juli 1997, BNB 1997/294', Weekblad voor Privaatrecht, Notariaat en Registratie 6321 (1998), pp. 470-472. 


\section{Ploeger 1999}

H. Ploeger, 'De eigendom van grafmonumenten', Weekblad voor Privaatrecht, Notariaat en Registratie 6359 (1999), pp. 423-425.

\section{Ploeger 2002}

H. Ploeger, 'Onroerende stacarvans: hoe lang is duurzaam?', Weekblad voor Privaatrecht, Notariaat en Registratie 6497 (2002), pp. 519-522.

\section{$\mathbf{R}$}

\section{Rankine 1891}

J. Rankine, The Law of Land-ownership in Scotland. A Treatise on the rights and burdens incident to the ownership of lands and other heritages in Scotland, Edinburgh: Bell \& Bradfute 1891.

\section{Reepmakers 1931}

A. Reepmakers, Het recht van erfpacht, Leiden: S.CC. van Doesburgh 1931.

\section{Reid 1996}

K. Reid, The Law of Property in Scotland, Edinburgh: The Law Society of Scotland Butterworths 1996.

\section{Reid 2000}

K. Reid, Property Law: Sources and Doctrine, in: K. Reid \& R. Zimmermann (red.), A History of Private Law in Scotland.Volume 1. Introduction and Property, Oxford: Oxford University Press 2000, pp. 185-219.

\section{Reid 2003}

K. Reid, The Abolition of Feudal Tenure in Scotland, Edinburgh: Butterworths Scotland 2003.

\section{Reid \& Van der Merwe 2004}

K. Reid en C. van der Merwe, 'Property Law: some Themes and Some Variations', in: R. Zimmermann, D. Visser \& K. Reid (red.), Mixed Legal Systems in Comparative Perspective: Property and Obligations in Scotland and South Africa, Oxford: Oxford University Press 2004, pp. 637-670.

\section{Rodrigues Lopes 2007}

D. Rodrigues Lopes, Pacht, Deventer: Kluwer 2007.

\section{Roggenkamp 2006}

M. Roggenkamp, 'De winning van delfstoffen en de aanleg van mijnbouwwerken onder de (nieuwe) Mijnbouwwet', Bouwrecht 2006/3, pp. 213-225. 


\section{Rogmans 2007}

B. Rogmans, Verkeersopvattingen, Deventer: Kluwer 2007.

\section{Rossel 2007}

H. Rossel, Huurrecht algemeen, Deventer: Kluwer 2007.

\section{Rüfner 2010}

T. Rüfner, 'The Roman Concept of Ownership and the Medieval Doctrine of Dominium Utile', in: J. Cairns \& P. Plessis (red.), The Creation of the Ius Commune, From Casus to Regula, Edinburgh: Edinburgh University Press 2010, pp. 127-142.

\section{S}

\section{Sagaert 2003}

V. Sagaert, Zakelijke Subrogatie, Antwerpen: Intersentia 2003.

\section{Sagaert 2004}

V. Sagaert, 'Oude zakenrechtelijke figuren met nut voor een moderne familiale vermogensplanning: knelpunten van tontine, vruchtgebruik, erfpacht en opstal', in: Levenslang en verder: familiale vermogensplanning in de 21ste eeuw, 30ste postuniversitaire Cyclus Willy Delva 2003-2004, Mechelen: Kluwer 2004.

\section{Sagaert 2005}

V. Sagaert, 'Het goederenrecht als open systeem van verbintenissen? Poging tot een nieuwe kwalificatie van de vermogensrechten', Tijdschrift voor Privaatrecht 2005, pp. 983-1086.

\section{Sagaert 2008}

V. Sagaert, 'Verticale eigendomsgrenzen en verticaal beperkte onteigening', in: J. Ghysels, V. Sagaert en R. Palmans (red.), Onteigeningen en eigendomsbeperkingen onder de grond en in de lucht, Antwerpen: Intersentia 2008, pp. 1-32.

\section{Sagaert 2008-2009a}

V. Sagaert, 'Actuele ontwikkelingen vastgoedrecht', in: V. Sagaert en A. Verbeke (red.) Goederenrecht, Brugge: die Keure 2008-2009, pp. 23-42.

\section{Sagaert 2008-2009b}

V. Sagaert, 'Onroerendmaking door incorporatie: over het verschil tussen beweegbaarheid en verplaatsbaarheid', Rechtskundig Weekblad 2008-09, pp. 457-459. 


\section{Sagaert 2010-2011}

V. Sagaert, 'Kroniek privaatrecht vastgoedrecht, met inbegrip van het nieuwe appartementsrecht', in: V. Sagaert en A. Verbeke (red.), Goederenrecht, Brugge: die Keure 2010-2011, pp. 1-22.

\section{Sagaert 2011-2012}

V. Sagaert, 'Het eigendomsvereiste bij onroerende goederen door bestemming noot bij Cass. 12 april 2010', Rechtskundig Weekblad 2011-12, pp. $177-180$.

\section{Sagaert, Tilleman \& Verbeke 2010}

V. Sagaert, B. Tilleman en A. Verbeke, Vermogensrecht in kort bestek. Goederen- en bijzondere overeenkomstenrecht, Antwerpen: Intersentia 2010.

\section{Scheltema 2003}

A. Scheltema, De goederenrechtelijke werking van de ontbindende voorwaarde, Alphen aan den Rijn: Kluwer 2003.

\section{Schöner \& Stöber 2008}

H. Schöner en K. Stöber, Handbuch der Rechtspraxis. Band 4. Grundbuchrecht, München: Verlag C.H. Beck 2008.

\section{Schoordijk 1992}

H. Schoordijk, 'Over de scheidslijn tussen goederen- en verbintenissenrecht (recensie dissertatie E.B. Rank-Berenschot)', Nederlands Juristenblad 1992/37, pp. 1202-1206.

\section{Prütting 2010}

H. Prütting, Sachenrecht: ein Studienbuch, München: Verlag C.H. Beck München 2010.

\section{Van Sinay 1996}

Th. Van Sinay, 'Bouwen op andermans grond - in het algemeen en in enkele bijzondere gevallen - vergoedingsregeling - enkele bedenkingen', in: $\mathrm{H}$. Vuye e.a. (red.), Eigendom-Propriété, Brugge: die Keure 1996, pp. 312-371.

\section{Slaski 2009}

A. Slaski, 'Stapeling van beperkte rechten op onroerende zaken', Weekblad voor Privaatrecht, Notariaat en Registratie 6789 (2009), pp. 200-207.

\section{SLC 1998a}

Scottish Law Commission, Discussion Paper on Real Burdens, 1998. 


\section{SLC 1998b}

Scottish Law Commission, Report on the Law of the Tenement, 1998.

\section{SLC 1999}

Scottish Law Commission, Report on abolition of the Feudal System, 1999.

\section{SLC 2000}

Scottish Law Commission, Report on Real Burdens, 2000.

\section{Smith 2011}

R. Smith, Property Law, Harlow: Longman 2011.

\section{Spyridakis 1966}

J. Spyridakis, Zur Problematik der Sachbestandteile, Tübingen: J.C.B. Mohr (Paul Siebeck) 1966.

\section{Stair 1693}

J. Viscount of Stair, The Institutions of the Law of Scotland. In IV books, Edinburgh: Heir of Andrew Anderson1693.

\section{Stassijns 1998}

E. Stassijns, Pacht, Antwerpen: Kluwer Rechtswetenschappen België 1998.

\section{Staudinger/Jickeli/Stieper 2012}

J. Jickeli en M. Stieper, '\$§ 90-103 BGB', in: N. Habermann (red.), J. von Staudingers Kommentar zum Bürgerlichen Gesetzbuch mit Einführungsgesetz und Nebengesetzen. Buch 1. Allgemeiner Teil. §§ 90-124; 130-133, Berlin: Sellier-de Gruyter 2012.

\section{Staudinger/Mayer 2009}

J. Mayer, '§§ 1018-1112', in: W. Wiegand (red.), J.von Staudingers Kommentar zum Bürgerlichen Gesetzbuch mit Einführungsgesetz und Nebengesetzen. Buch 3. Sachenrecht. ErbbauRG. $\$ \S ~ 1018-1112$ (Erbbaurecht, Dienstbarkeiten, Vorkausrecht, Reallasten), Berlin: Sellier-de Gruyter 2009.

\section{Staudinger/Pfeifer 2011}

A.Pfeifer, '§§925-928BGB’, in:K. Gursky(red.),J.vonStaudingersKommentar zum Bürgerlichen Gesetzbuch mit Einführungsgesetz und Nebengesetzen, Buch 3. Sachenrecht. §§ 925-984, Berlin: Sellier-de Gruyter 2011.

\section{Staudinger/Rapp 2009}

M. Rapp, 'ErbbauRG', in: W. Wiegand (red.), J. von Staudingers Kommentar zum Bürgerlichen Gesetzbuch mit Einführungsgesetz und Nebengesetzen. Buch 
3. Sachenrecht. ErbbauRG. §§ 1018-1112 (Erbbaurecht, Dienstbarkeiten, Vorkausrecht, Reallasten), Berlin: Sellier-de Gruyter 2009.

\section{Staudinger/Roth 2009}

H. Roth, J. von Staudingers Kommentar zum Bürgerlichen Gesetzbuch mit Einführungsgesetz und Nebengesetzen. Buch 3. Sachenrecht. \$§ 905-924, Berlin: Sellier-de Gruyter 2009.

\section{Staudinger/Wiegand 2011}

W. Wiegand, '\$§ 929-950 BGB', in: K. Gursky (red.), J. von Staudingers Kommentar zum Bürgerlichen Gesetzbuch mit Einführungsgesetz und Nebengesetzen. Buch 3. Sachenrecht. $\$ \S 925-984$, Berlin: Sellier-de Gruyter 2011.

\section{Stein 1991}

P. Stein, 'Bij- en hulpzaken', Weekblad voor Privaatrecht, Notariaat en Registratie 6030 (1991), pp. 880-882.

\section{Stein 2004}

P. Stein, Zekerheidsrechten. Hypotheek, Deventer: Kluwer 2004.

\section{Van der Steur 2003}

J. van der Steur, Grenzen van rechtsobjecten. Een onderzoek naar de grenzen van objecten van eigendomsrechten en intellectuele eigendomsrechten, Deventer: Kluwer 2003.

\section{Storme 2010-2011}

M. Storme, Erfpacht en opstalrecht. Syllabus ten behoeve van het vak notarieel zaken- en contractenrecht, onuitgegeven syllabus 2010-2011.

\section{Struycken 2007}

T. Struycken, De numerus clausus in het goederenrecht, Deventer: Kluwer 2007.

\section{Suijling 1940}

J. Suijling, Inleiding tot het Burgerlijk Recht. Deel V. Zakenrecht, Haarlem: De erven F. Bohn N.V. 1940.

\section{$\mathrm{T}$}

\section{Tilleman 2005}

B. Tilleman, 'De notie roerend en onroerend goed', in: P. Lecocq, B. Tilleman en A. Verbeke (red.), Zakenrecht - Droit des Biens, Brugge: die Keure 2005, pp. 3-42. 


\section{Tilleman \& Verbeke 2005}

B. Tilleman en A. Verbeke, Bijzondere overeenkomsten in kort bestek, Antwerpen: Intersentia 2005.

\section{Timme 2009}

M. Timme, WEG, München: Verlag C.H. Beck 2009.

Timmermans 2003a

R. Timmermans, 'De hoofdlijnen van het appartementsrecht in Frankrijk, België en Nederland (I)', Weekblad voor Privaatrecht, Notariaat en Registratie 6538 (2003), pp. 501-508.

\section{Timmermans 2003b}

R. Timmermans, 'De hoofdlijnen van het appartementsrecht in Frankrijk, België en Nederland (II)', Weekblad voor Privaatrecht, Notariaat en Registratie 6539 (2003), pp. 525-530.

\section{Timmermans 2008a}

R. Timmermans, 'Is opstal een geldig surrogaat voor splitsing van etagegebouwen in appartementseigendom?', Tijdschrift voor appartementsen immorecht 2008, pp. 3-6.

\section{Timmermans 2008b}

R. Timmermans, Appartementsrecht, Mechelen: Kluwer 2008.

\section{Timmermans 2009}

R. Timmermans, 'Enkele bedenkingen over horizontale splitsing van eigendom, het zelfstandige recht van opstal, de tijdelijkheid en het verlangen naar de eeuwigheid', Notariaat: notarieel en fiscaal maandblad 2009 1-2, pp. $35-48$.

\section{Truyen 2009}

P. Truyen, 'De fiscale gevolgen van de zakenrechtelijke natrekking', Algemeen Fiscaal Tijdschrift 2009, pp. 6-41.

\section{V}

\section{Vandenberghe 2005}

H. Vandenberghe, Goederenrecht, Leuven: Acco 2005.

\section{Vandenberghe \& Viaene 2006}

$\mathrm{H}$. Vandenberghe, 'Actuele ontwikkelingen inzake erfpacht en opstal', Tijdschrift voor Bouwrecht en Onroerend goed 2006, pp. 34-55. 


\section{Vanhove 2009}

K. Vanhove, 'Algemene situering van de woninghuurwet in het huurrecht. Afdeling 5. Totstandkoming en vorm', in: Van Oevelen (red.), Woninghuur, Brugge: die Keure 2009, pp. 36-42.

\section{Vanhove 2012}

K. Vanhove, Handelshuur. Rechtsvergelijkend onderzoek naar een evenwichtige regeling, Antwerpen: Intersentia 2012.

\section{Van Velten 1995}

A. van Velten e.a., Erfpacht, Preadvies KNB, Lelystad: Koninklijke Vermande B.V. 1995.

\section{Van Velten 2005}

A. Van Velten, 'Opstal en onderopstal', Weekblad voor Privaatrecht, Notariaat en Registratie 6616 (2005), pp. 283-286.

\section{Van Velten 2012}

A. van Velten, Privaatrechtelijke aspecten van onroerend goed, Deventer: Kluwer 2012.

\section{Venemans 1997}

C. Venemans, 'Erfpacht en opstal', in: R. Mertens, C. Venemans en G. Verdoes Kleijn, Naar een vernieuwd appartementsrecht. Preadvies KNB, Lelystad: Koninklijke Vermande 1997, pp. 43-56.

\section{Venemans 1999}

C. Venemans, 'Reactie op het artikel "Kan een opstalrecht worden gevestigd door een erfpachter of een appartmentseigenaar" van prof. mr. H.W. Heyman in WPNR (1999) 6342', Weekblad voor Privaatrecht, Notariaat en Registratie (1999) 6357, p. 387.

\section{Verbeke \& Snaet 2007}

A. Verbeke en S. Snaet, 'Meccano-goederenrecht', in: W. Pintens e.a. (red.), Vigilantibus ius scriptum. Feestbundel voor Hugo Vandenberghe, Brugge: die Keure 2007, pp. 365-393.

\section{Verbeke \& Vanhove 2005}

A. Verbeke en K. Vanhove, 'Spelen met het voorwerp van vruchtgebruik', in: P. Lecocq, B. Tilleman en A. Verbeke (red.), Zakenrecht - Droit des Biens, Brugge: die Keure 2005, pp. 172-217. 


\section{Verschelden e.a. 2007}

G. Verschelden, 'Overzicht van rechtspraak. Familierecht (2001-2006)', Tijdschrift voor Privaatrecht. 2007, pp. 141-789.

\section{Vonck 2007}

F. Vonck, 'De zakelijke werking van de erfpachtsvoorwaarden', Weekblad voor Privaatrecht, Notariaat en Registratie (2007) 6717, pp. 598-603.

\section{W}

\section{Watkin 1999}

T. Watkin, An Historical Introduction to Modern Civil Law, Aldershot: Ashgate Dartmouth 1999.

\section{Werdefroy 1994}

F. Werdefroy, 'Beëindiging van de erfpacht', Notariaat: notarieel en fiscaal maandblad 1994, pp. 1-12.

\section{Wichers 2002}

J. Wichers, Natrekking, vermenging en zaaksvorming. Opmerkingen bij de algemene regeling voor roerende zaken in het Burgerlijk Wetboek, Deventer: Kluwer 2002.

\section{Wicke 2006}

H. Wicke, 'Umwandlung wesentlicher Bestandteile in Scheinbestandteile - Anmerkung zum Urt. Des BGH v. 2.12.2005 - V ZR 35/05', Deutsche Notar-Zeitschrift 2006 (4), pp. 252-266.

\section{Wieling 2006}

H. Wieling, Sachenrecht. Band 1. Sachen, Besitz und Rechte an beweglichen Sachen, Berlin: Springer-Verlag 2006.

\section{Wolfert 2003a}

E. Wolfert, 'Bestanddeel of zaak? Over het onderscheid en de samenhang tussen de artikelen 3:4 en 5:20 BW', Weekblad voor Privaatrecht, Notariaat en Registratie 6523 (2003), pp. 191-197.

\section{Wolfert 2003b}

E. Wolfert, 'Bestanddeel of zaak? Over het onderscheid en de samenhang tussen de artikelen 3:4 en 5:20 BW. (II. Slot)', Weekblad voor Privaatrecht, Notariaat en Registratie 6525 (2003), pp. 279-285. 


\section{Rechtspraakregister}

\section{Belgische jurisprudentie}

\section{Hof van Cassatie}

Cass. 28 november 1969, Arr. Cass. 1969-1970, 314

Cass. 22 januari 1970, Arr. Cass. 1970, 460

Cass. 11 september 1980, R.W. 1980-1981, 1663

Cass. 19 mei 1988, R.W. 1988-1989, 572

Cass. 15 september 1988, T.B.B.R. 1990, 211

Cass. 18 april 1991, Arr. Cass. 1990-91, 839

Cass. 15 december 2006, R.W. 2007-08, 104

Cass. 18 mei 2007, R.W. 2007-2008, 736

Cass. 14 februari 2008, R.W. 2008-2009, 456

Cass. 31 mei 2012, c.10.0647.n.

\section{Hoven van Beroep}

Hof Brussel 20 juli 1900, Pas. 1901, II, 142 Hof Gent 22 oktober 1958, R.W. 1956-1960, 1951

Hof Gent 17 mei 1966, Rev. Fisc. 1967, 322

Hof Gent 21 april 1977, Res. Jur. Imm. 1978, nr. 5658

Hof Bergen 27 juli 1988, Bull. Bel. 1989, 2171

Hof Luik 13 november 1990, Rec. gén. enr. not. 1991, nr. 24050

Hof Antwerpen 2 juni 1994, Bull. Bel. 1996, 1090

Hof Gent 21 december 1999, F.J.F. 2000/166, 440

Hof Gent 16 maart 2000, T.F.R. 2000, 650

Hof Antwerpen 5 februari 2002, T.F.R. 2002, 889

Hof Antwerpen 6 maart 2002, NjW 2002/1, 25

Hof Gent 12 mei 2005, T.B.B.R. 2007, 541

Hof Gent 19 december 2006, T.F.R. 2007, 321

Hof Gent 25 april 2007, T. App. 2008, 16

Hof Gent 11 januari 2011, T.F.R. 2011/42, 603

\section{Rechtbanken}

Rb. Leuven 16 februari 1982, T. Not. 1982, 143

Rb. Bergen 22 maart 1989, T.B.B.R. 1990, 331

Rb. Brussel 1 september 1998, R.W. 1999-2000, 1026

Rb. Brugge 8 maart 1999, R.W. 2001-2002, 248

Rb. Brussel 26 oktober 2001, T.F.R. 2002, 421

Rb. Leuven 14 februari 2003, F.J.F. 2003, 251 
Rb. Brussel 14 mei 2004, trv 2004, 612

Rb. Ieper 18 februari 2005, R.A.B.G. 2006, 756

Rb. Leuven 13 januari 2006, R.A.B.G. 2007/8, 520

Rb. Gent 30 april 2009, F.J.F. 2010, 635

Rb. Brugge 26 mei 2010, T. App. 2010, 28

Vred. Eeklo 19 april 1973, R.W. 1973-74, 1830

\section{Duitse jurisprudentie}

\section{Bundesfinanzhof}

BFH 4 oktober 1978, N/W 1979, 392

\section{Bundesgerichtshof}

BGH 9 juli 1954, NJW 1954, 1444

BGH 8 oktober 1955, NJW 1955, 1793

BGH 3 maart 1956, N/W 1956, 945

BGH 27 mei 1959, N/W 1959, 1487

BGH 11 juli 1962, N/W 1962, 1817

BGH 27 juni 1973, NJW 1973, 1454

BGH 12 mei 1976, N/W 1976, 1539

BGH 26 november 1999, N/W 2000, 1031

BGH 2 december 2005, NJW 2006, 990

BGH 15 februari 2008, NJW 2008, 1810

BGH 23 januari 2009, N/W 2009, 1791

\section{Reichsgericht}

RG 26 januari 1901, RGZ 47, 197, 200

RG 17 januari 1903, RGZ 53, 307, 312

RG 15 september 1903, RGZ 55, 281, 285

RG 14 november 1938, RGZ 158, 362, 369

RG 7 december 1939, RGZ 162, 209, 222

\section{Landesgericht}

LG Köln v. 15 juni 1979-11 S 385/78

LG Berlin 10 november 2003, NJW-RR 2004, 635 
Nederlandse jurisprudentie

\section{Hoge Raad}

HR 8 februari $1878, W .4207$

HR 16 mei 1884,W. 5035

HR 18 februari 1898, W. 7086

HR 4 december 1903, W. 8004

HR 14 november 1904, W. 8142

HR 22 december 1911, W. 9290

HR 11 april 1913, W. 9499

HR 29 mei 1925, NJ 1925, 750

HR 26 maart 1936, NJ 1936, 757

HR 10 december 1937, NJ 1938, 335

HR 11 december 1953, NJ 1954, 115

HR 3 maart 1954, NJ 1954, 247

HR 8 juni 1956, NJ 1957, 67

HR 6 december 1963, NJ 1965, 9

HR 13 juni 1975, NJ 1975, 509

HR 7 maart 1979, NJ 1980, 116

HR 16 maart 1979, NJ 1980, 600

HR 11 maart 1981, NJ 1982, 76

HR 25 maart 1981, NJ 1982, 58

HR 22 juli 1988, NJ 1989, 257

HR 2 juni 1989, NJ 1990, 253

HR 15 november 1991, NJ 1993, 316

HR 27 november 1992, NJ 1993, 317

HR 14 september 1994, BNB 1994, 322

HR 19 mei 1995, NJ 1996, 119

HR 28 juni 1996, NJ 1997, 397

HR 8 juli 1997, BNB 1997, 294

HR 31 oktober 1997, NJ 1998, 97

HR 4 december 1998, NJ 1999, 594

HR 5 januari 2000, BNB 2000, 83

HR 20 september 2002, BNB 2002, 374

HR 25 oktober 2002, NJ 2003, 241

HR 13 mei 2005, BNB 2005, 211

HR 25 november 2005, NJ 2006, 338

HR 17 november 2006, BNB 2007/50

HR 15 januari 2010, LJN: BK9136

HR 5 februari 2010, BNB 2010, 106

HR 8 oktober 2010, RN 2011, 2

HR 17 december 2010, NJ 2012, 155

HR 24 december 2010, LJN: BO3644

HR 9 maart 2012, LJN: BV8198 


\section{Gerechtshoven}

Hof Arnhem 1877 (datum zitting is niet opgegeven), W. 4081

Hof Arnhem 20 februari 1878, W. 4221

Hof Arnhem 2 november 1881,W. 4746

Hof 's-Hertogenbosch 4 december 1888, W. 5650.

Hof Arnhem 14 juli 1903, W. 7973

Hof's-Hertogenbosch 26 mei 1997, NJ 1998, 93

Hof 's-Hertogenbosch 5 december 2000, NJ 2001, 626

Hof 's-Hertogenbosch 15 augustus 2002, SES 2003, 56

Hof's-Hertogenbosch 16 november 2004, NJF 2005, 355

Hof's-Hertogenbosch 3 maart 2009, NJF 2010, 343.

Hof's-Hertogenbosch 30 december 2010, LJN: BQ0443

\section{Rechtbanken}

Rb Middelburg 11 oktober 1882, W. 4833

Rb Leeuwarden 20 december 1994, KG 1995, 61

Rb Maastricht 13 juni 1996, NJ 1997, 299

Rb Maastricht 6 april 2000, LJN: AA5402

Rb Maastricht 21 januari 2004, VR 2005, 35.

Rb 's-Hertogenbosch 8 april 2009, RVR 2009, 76

\section{Schotse jurisprudentie}

Alexander v Butchart (1875) 3R 156

Botham v TSB Bank plc (1996) 73 P\&CR D1

Brand's Trs v Brand's Trs (1874) 2 R 258

Brand's Trs v Brand's Trs (1876) 3 R 16

Burghead Harbour Co. v George (1906) 8 F 982

Cf. Spafford v Bryden (1991) SLT 49

Christie v Smith's Exrx (1949) SC 572

Cliffpland Ltd v Kinnaird (1981) SC 9

Crichton v Turnbull (1946) SC 52

Dyce v Hay (1852) 1 Macq 304

Ellis v Glover and Hobson (1908) 1 KB 388

Elwes v Maw (1802) 3 East 38

Fairlie's Trustees v Fairlie's Curator Bonis (1932) SC 216

Fisher v Dixon (1843) 5 D 775

Girdwood v Paterson (1873) 11 M 647

Glasgow City and District Rly Co v Macbrayne (1883) 10 R 894

Graham v Duke of Hamilton (1871) 9 M 98

Hobson v Gorringe (1897) 1 Ch 182

Houldsworth v Brand's Trs (1877) 4 R 369 
Howie's Trs v MacLay (1902) 5 F 214

Jamieson v Welsh (1900) 3 F 176

Johnston v White (1877) 4 R 721

Leigh v Taylor (1902) AC 157

Luigi Romano v Standard Commercial Property Securities Ltd and Atlas Investments Ltd (2008) SLT 859

McArly v French's Trs (1883) 10 R 574

McLellan v Hunter (1987) GWD 21-799

Miller v Muirhead (1894) 21 R 658

North British Rly Co v Park Yard Co Ltd (1898) 25 R 47

Paul v Cuthbertson (1840) 2 D 1286

Reynolds v Ashby (1904) AC 466

Sanderson's Trs v Yule (1897) 25 R 211

Scottish Discount Co Ltd v Blin (1985) SC 216

Scottish Temperance Life Assurance Co. v Law Union and Rock Insurance Co. (1917) SC 175

Shetland Islands Council v BP Petroleum Development Ltd (1990) SLT 82

Shilliday v Smith 1998 SC 725, 1998 SLT 976

Stirling v Bartlett (1993) SLT 763

Syme v Harvey (1861) 24 D 202

Taylor v Dunlop (1872) 11 M 25

Todd v Scoular (1988) GWD 24-1041

TSB Scotland plc v James Mills (Montrose) Ltd 1991 GWD 39-2406

Watt v Burgess' Tr (1891) 18 R 766

Ward v Countess of Dudley (1887) 57 LT 20 



\section{Curriculum vitae}

Kim Josef Henriette Hoofs werd op 23 augustus 1980 geboren te Geleen. Ze bezocht het Bisschoppelijk College te Sittard (1992-1997) waarna ze Technische Bedrijfskunde aan Hogeschool Zuyd (1997-2001) studeerde. $\mathrm{Na}$ het behalen van haar ingenieurstitel is Kim ruim een jaar werkzaam geweest bij DSM (2001-2002). In 2002 begon Kim met de studie Nederlands recht aan Maastricht University, waar zij na het voltooien van de bachelor Nederlands recht (2006) de master Nederlands privaatrecht in 2007 afrondde. Sinds februari 2008 is Kim als junior onderzoeker werkzaam bij Maastricht University. Naast het schrijven van het proefschrift is Kim betrokken bij het bachelor en master onderwijs en heeft ze verschillende artikelen, zowel Engels- als Nederlandstalig, gepubliceerd. 